FERNANDA MORAES

O processo de escolarização pública na Vila de Cotia no contexto cultural caipira (1870-1885) 
FERNANDA MORAES

\title{
O processo de escolarização pública na Vila de Cotia no contexto cultural caipira (1870-1885)
}

\author{
Dissertação apresentada à Faculdade de Educação da \\ Universidade de São Paulo para obtenção do título \\ de Mestra em Educação \\ Área de Concentração: História da Educação e \\ Historiografia
}

Orientadora: Prof ${ }^{\mathrm{a}}$. Dr ${ }^{\mathrm{a}}$. Diana Gonçalves Vidal

\section{São Paulo}


Autorizo a reprodução e divulgação total ou parcial deste trabalho, por qualquer meio convencional ou eletrônico, para fins de estudo e pesquisa, desde que citada a fonte.

Catalogação da Publicação

Serviço de Biblioteca e Documentação

Faculdade de Educação da Universidade de São Paulo

MORAES, Fernanda.

O processo de escolarização pública na Vila de Cotia no contexto cultural caipira (1870-1885) / Fernanda Moraes; Orientadora Prof ${ }^{\mathrm{a}}$. Dr ${ }^{\mathrm{a}}$. Diana Gonçalves Vidal. São Paulo, 2015 258f. : il.

Dissertação (Mestrado ) - Programa de Pós-Graduação em Educação. Área de Concentração: História da Educação e Historiografia. Faculdade de Educação da Universidade de São Paulo, 2015 .

1. Escolarização 2. Cotia - SP 3. História local 4. Século XIX 
MORAES, Fernanda. O processo de escolarização pública na Vila de Cotia no contexto cultural caipira (1870-1885). Dissertação apresentada à Faculdade de Educação da Universidade de São Paulo para obtenção do título de Mestra em Educação.

Aprovada em:

$$
\text { Banca Examinadora }
$$

$$
\begin{gathered}
\text { Prof }^{a} \text {. Dr }{ }^{\mathrm{a}} \text {. Diana Gonçalves Vidal } \\
\text { Universidade de São Paulo }
\end{gathered}
$$

Julgamento: Assinatura:

$$
\begin{gathered}
\text { Prof }^{a} \text {. Dr }{ }^{\mathrm{a}} \text {. Adriana Maria Paulo da Silva } \\
\text { Universidade de Pernambuco }
\end{gathered}
$$

Julgamento: Assinatura:

$$
\begin{gathered}
\text { Prof }^{\mathrm{a}} \text {. Dr }{ }^{\mathrm{a}} \text {. Rita de Cássia Gallego } \\
\text { Universidade de São Paulo }
\end{gathered}
$$

Julgamento: Assinatura: 
Para minha poesia: Clara.

E para a segunda poesia que em breve chegará a este mundo. 


\section{Agradecimentos}

Agradeço à população do estado de São Paulo, mantenedora desta universidade, local em que me graduei e cursei o mestrado. Ao governo federal por meio do Conselho Nacional de Desenvolvimento Científico e Tecnológico (CNPq), pela bolsa de pesquisa.

Aos funcionários da secretaria de Pós-Graduação da Faculdade de Educação da USP, especialmente ao Marcelo e à Claudia. Aos funcionários dos acervos textual e cartográfico do Arquivo do Estado de São Paulo. Aos funcionários da Biblioteca do Instituto de Estudos Brasileiros e da Biblioteca Mindlin, ambas da USP.

Aos professores do Departamento de História e da Pós-Graduação da Faculdade de Educação com os quais cursei disciplinas desde minha entrada na universidade, em especial a Nicolau Sevcenko (in memorian), Jorge Grespan, Carlos Zeron, Monica Dantas, Bruno Bontempi Júnior. Também agradeço ao Professor Fausto Nogueira do Instituto Federal de São Paulo.

Agradeço muito à minha orientadora Diana Gonçalves Vidal que, ao longo do processo, fez-me encantar pela pessoa generosa que é, além da profissional admirável, séria e competente. Sua valiosa orientação e nossas conversas ficarão para sempre comigo.

Às professoras que compuseram minhas bancas de qualificação e de defesa, Adriana Paulo da Silva, Rita Gallego, Maria Lucia Hilsdorf e Natália Gil, pela seriedade, leitura atenta e apontamentos valiosíssimos.

Aos membros do Núcleo Interdisciplinar de Estudos e Pesquisas em História da Educação (NIEPHE-USP) pelas contribuições para o desenvolvimento deste trabalho, sobretudo às professoras Maria Angela Salvadori, Maurilane Biccas e Ana Luiza da Costa, aos pesquisadores Sandra Caldeira, Rafaela Rabelo, Felipe Moraes e Fernanda Resende. À Surya Barros, amiga desde a graduação e que também faz parte do NIEPHE, muito obrigada. Às amigas que o NIEPHE me presenteou e levarei por toda a vida: Angelica Borges, Fernanda Franchini e Ariadne Ecar. Gratidão.

À Fabiana Garcia Munhoz (também do NIEPHE), amiga querida que me acompanha desde a graduação e que teve grande responsabilidade por eu ter entrado no campo da história da educação. Pelas conversas, pelas reflexões, pelo apoio, pelas indicações de leitura, pela revisão dos textos, pela amizade. Gratidão eterna e toda minha admiração.

Agradeço muito às grandes amigas que estão sempre juntas comigo na caminhada da vida: Adriana Madeira, Vanessa Gravino, Talitha Lessa. À Fortunata e à Vó Maria. Aos meus amigos próximos, de um modo geral. 
Ao Professor Langenbuch, pela conversa ao telefone e coordenadas para que eu encontrasse a réplica da capela de Itaqui. Aos moradores de Itapevi que me orientaram sobre o local de construção dessa réplica, especialmente ao Senhor Ramiro. Aos moradores de São Roque e Ibiúna, por informações sobre o antigo Bairro de Sorocamirim. Aos meus tios Francisco e Liberata e ao Senhor Benedito (o Dito de Cotia, criador da Congada local), pelas conversas sobre como era Cotia nos anos de 1940 e 1950.

Aos meus familiares, especialmente a meu irmão Eduardo, Lucila, Tales, Tomáz e Beatriz. Muito obrigada pela ajuda com a mudança e a reforma da nossa casa e pelos cuidados com minha filha.

Aos meus pais, por tudo o que me ensinaram: Claro Moraes, que já partiu deste mundo, e Maria Vitória Moraes, por todo o amor dedicado a mim e à sua neta - pela ajuda imensurável durante o mestrado cuidando da Clarinha para que eu estudasse. Mãe, minha eterna gratidão.

Ao meu companheiro Rafael Dall'Olio. Grata pelas conversas sobre a pesquisa, pela leitura atenta com a lente de um historiador de outra área, pela ajuda com as "coisas do computador", pelo amor de todo dia. É um privilégio compartilhar a vida com você e ver nossa família crescer. Muito obrigada.

À minha pequena Clarinha, que me faz viver com mais alegria e dar ainda mais sentido à vida. Durante a pesquisa você foi gestada, nasceu, começou a andar e a falar. Agora está "quase" independente. Suas obras de arte nos papéis das versões preliminares desta pesquisa ficarão guardadas para a posteridade. Agradeço também a outrx filhx que chegará em breve e que quase não fez a mamãe sentir enjoos durante a escrita final deste trabalho. A vocês, meu eterno amor e muito obrigada. 


\section{RESUMO}

MORAES, Fernanda. O processo de escolarização pública na Vila de Cotia no contexto cultural caipira (1870-1885). 2015. 258f. Dissertação (Mestrado em Educação) - Faculdade de Educação, Universidade de São Paulo, São Paulo, 2015.

Objetivei investigar o processo de escolarização pública na Vila de Cotia, município rural com características culturais caipiras do entorno da Capital paulista, entre 1870 e 1885 . No período houve uma retração econômica, porém a oferta de cadeiras públicas foi aumentada. Utilizei-me de variadas fontes, como livros de matrícula, relatórios de inspetores e professores e de governo, legislação, dados estatísticos, periódicos, registros de batismo e casamento, mapas, fotos, crônica, poesias, peça teatral etc., que foram entrecruzadas e interpretadas a partir, sobretudo, dos conceitos de cultura caipira (CANDIDO, 2001a), lar docente (MUNHOZ; VIDAL, 2014), estratégia e tática (CERTEAU), além dos apontamentos de Thompson (1998) quanto à lei da praxis se sobrepondo à do governo. No primeiro capítulo tratei da história local enfatizando o contexto do recorte. O local tinha a economia voltada para o tropeirismo, a subsistência e o abastecimento da Capital. A população era formada sobretudo por roceiros e sitiantes e os bairros eram dispersos e com características comuns, porém com algumas particularidades. No segundo capítulo, para visualizar o processo de escolarização, apresentei mapas com a localização dos bairros de instalação das escolas, possibilitando verificar a interiorização da escolarização e os problemas devidos às dificuldades em demarcações de fronteiras com os municípios vizinhos. No terceiro capítulo dei destaque aos professores. O casal Maria Joanna do Sacramento e João José Coelho morava num lar docente, onde algumas práticas do magistério eram compartilhadas. As fontes confirmaram que os professores das cadeiras da Vila tinham a permanência estável; os professores dos bairros, contrariamente, permaneceram por pouco tempo frente às cadeiras, evidenciando o caráter restritivo da vida nos bairros rurais. Em geral, não exerceram outros cargos antes do magistério, mas depois alguns exerceram outras funções em setores públicos. Apresentei ainda as precárias condições materiais de trabalho vivenciada pelos docentes, que implicaram nos resultados da aprendizagem dos alunos. O quarto capítulo versou sobre os alunos cotianos. A falta de frequência era motivada principalmente pelo trabalho na lavoura, evidenciando a ruralidade local e o não cumprimento da lei de obrigatoriedade de ensino (1874). Todavia, os dados mostraram um aumento de $407 \%$ de alunos e que muitas meninas frequentavam escolas particulares em 1872. A análise da composição das turmas de quatro cadeiras mostrou que a média de matrícula no bairro era maior que na Vila, e que esta tinha um fluxo maior de alunos, evidenciando seu caráter dinâmico em comparação ao bairro. Muitos alunos eram eliminados por motivo de mudança (principalmente para o sítio) ou por ausentar-se por mais de três meses. Metade dos alunos estudava com outro membro da família, evidenciando que seus pais/tutores preferiam que fossem juntos às aulas. A maioria dos professores qualificava os alunos e seus pais, o que permitiu a confirmação de quatro alunos "ingênuos" nas turmas, dos quais dois estudavam com os filhos do senhor de sua mãe, comprovando a hipótese de que nesse contexto os senhores e escravos tinham uma relação mais próxima que em lugares mais ricos da Província e que a vida fora da escola se refletia dentro dela. 


\begin{abstract}
MORAES, Fernanda. The public schooling process in the Village of Cotia in the caipira cultural context (1870-1885). 2015. 258f. Dissertation - Faculdade de Educação, Universidade de São Paulo, São Paulo, 2015.
\end{abstract}

I aimed to investigate the public schooling process in the Village of Cotia, rural municipality with the caipira cultural characteristics in the Capital paulista surrondings, between 1870 and 1885. In the period was an economic retraction, but the offer of public chairs was increased.

I used several sources, such as enrollment books, inspectors, teachers and government reports, legislation, statistic data, journals, baptism and matrimony registers, maps, photos, chronicles, poetry, theatrical play etc., that were interlaced and interpreted, mainly, from the concepts of caipira culture (CANDIDO, 2001a), teacher family (MUNHOZ; VIDAL, 2014), strategy and tactics (CERTEAU), besides Thompson notes (1998) about the law of praxis overlapping the government. In the first chapter I treated the local history emphasizing the delimited context. The local had the economy focused to the tropeirismo, subsistence and the Capital supply. The population was formed mainly by small farmers and ranchers and the districts were dispersed and with common characteristics, but with some particularities. In the second chapter, to visualize the schooling process, I presented maps with the localization of the school installing districts, enabling to verify the schooling internalization and the problems due the difficulties in borders demarcation with the surrounding municipalities. In the third chapter I gave prominence to the teachers. The couple Maria Joanna do Sacramento and João José Coelho lived in a teaching home, where some teaching practices were shared. The sources confirmed that the teachers of the Village chairs had stable permanence; the district teachers, in contrast, remained briefly in the chairs, evidencing the restricted nature of life in rural districts. In general, they didn't exercise other positions prior to teaching, but after some exercise other functions in public sectors. I've presented the precarious material conditions of work lived by the teachers, which resulted in the student's learning outcomes. The forth chapter expounded the cotiano students. The lack of frequency was mainly motivated by working in the fields, evidencing the local rurality and the non-compliance of the teaching obligatory law (1874). Nevertheless, the data showed an increase of $407 \%$ of students and that many girls attended private colleges in 1872. The analyses of the class composition of four chairs showed that the average of enrollments on the district was higher than the Village, and that this had a higher flow of students, evidencing its dynamic character comparing to the district. Many students were eliminated by moving reasons (mainly to small farms) or by being away for more than three months. Half of students studied with other family members, evidencing that their parents/tutors preferred that they went together to the classes. Most of teachers qualified their students and parents, allowing the confirmation of four students "ingênuos" in the classes, of which two studied with the children of their Lord's mother, proving the hypothesis that in this context lords and slaves had a nearest relation than in richer places of the Province and that the life outside school reflected inside it.

Keywords: Schooling, Cotia - SP, Local History, 19th Century. 


\section{ÍNDICE DE ILUSTRAÇÕES}

Ilustração 1 - Mapa d'O cinturão caipira de São Paulo e os aldeamentos - Século XIX........ 30

Ilustração 2 - Mapa das localizações de Rio Bonito (Bofete), Tatuí e Cotia em 1884 .............33

Ilustração 3 - Mapa da área da Vila de Cotia entre 1870-1885 ................................................ 40

Ilustração 4 - Quadro da população segundo a cor e população escravizada - 1872 e 1886 ..52

Ilustração 5 - Foto da Parada Cotia em 1877 atribuída a Julio W. Durski. ............................. 56

Ilustração 6 - Foto da Estação São João em 1877 atribuída a Julio W. Durski. ........................57

Ilustração 7 - Croqui das coordenadas geográficas de Cotia, maio de 1941. ........................... 63

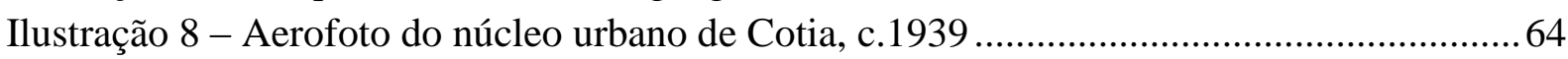

Ilustração 9 - Aerofoto da Estação de Cotia e Vila de Itapevi...............................................65

Ilustração 10 - Mapa da localização das cadeiras públicas de Cotia - 1838-1871 .................. 73

Ilustração 11 - Mapa da localização das cadeiras públicas de Cotia - 1871-1877 .................. 75

Ilustração 12 - Foto da réplica da capela original de Bom Jesus do Itaqui, 1971..................... 78

Ilustração 13 - Mapa da localização das cadeiras públicas de Cotia - 1878-1882 .................. 89

Ilustração 14 - Mapa da localização das cadeiras públicas de Cotia - 1882-1883 .................. 92

Ilustração 15 - Mapa da localização das cadeiras públicas de Cotia - 1884-1886 ...................94

Ilustração 16 - Mapa da localização das cadeiras públicas de Cotia - 1886 ............................98

Ilustração 17 - Mapa da localização das cadeiras públicas de Cotia - 1838-1871 .................. 99

Ilustração 18 - Mapa da localização das cadeiras públicas de Cotia - 1871-1877 ................. 100

Ilustração 19 - Mapa da localização das cadeiras públicas de Cotia - 1878-1882 ................. 101

Ilustração 20 - Mapa da localização das cadeiras públicas de Cotia - 1882-1883 ................ 102

Ilustração 21 - Mapa da localização das cadeiras públicas de Cotia - 1884-1886 ................. 103

Ilustração 22 - Mapa da localização das cadeiras públicas de Cotia - 1886. ........................ 104

Ilustração 23 - Quadro das cadeiras e dos respectivos professores públicos de Cotia entre

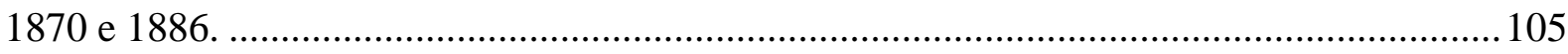

Ilustração 24 - Recorte do registro de casamento de Maria Joanna do Sacramento e João José

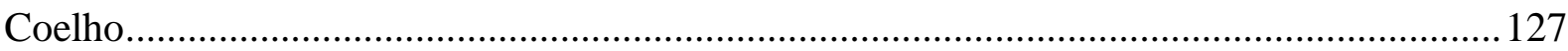

Ilustração 25 - Relatório do Prof. João José Coelho de 1 nov. 1882 ..................................... 132

Ilustração 26 - Relatório da Prof ${ }^{a}$. Maria Joanna do Sacramento de 1 nov. 1882 ................. 133

Ilustração 27 - Publicação de “A moralidade” contra João José Coelho ................................. 139

Ilustração 28 - Publicação de “G. J. P” contra João José Coelho ............................................ 140

Ilustração 29 - Quadro da população de Cotia de acordo com a instrução - 1872 ................. 156

Ilustração 30 - Quadro da população escolar de Cotia - de 6 a 15 anos - 1872 ..................... 156

Ilustração 31 - Quadro da população segundo o grau de instrução - 1886 ............................. 157

Ilustração 32 - Quadro do número de alunas/os matriculadas/os entre 1870 e 1885 nas cadeiras públicas de Cotia ............................................................................................. 159

Ilustração 33 - Gráfico do número de alunas da Cadeira Feminina da Vila (1870-1885).... 169 Ilustração 34 - Gráfico dos motivos das eliminações - Cadeira Feminina da Vila (1870-1885).

Ilustração 35 - Gráfico do número de novas matrículas - Cadeira Feminina da Vila (18701885). 
Ilustração 36 - Gráfico do número de alunos da $1^{\text {a }}$ Cadeira Masculina da Vila (1870-1885).

Ilustração 37 - Gráfico dos motivos das eliminações - $1^{\text {a }}$ Cadeira Masculina da Vila (18701885).

Ilustração 38 - Gráfico do número de novas matrículas - $1^{a}$ Cadeira Masculina da Vila (18701885).

Ilustração 39 - Gráfico do número de alunos da $2^{\text {a }}$ Cadeira da Vila de Cotia (1875-1882). . 174 Ilustração 40 - Gráfico dos motivos das eliminações - 2 ${ }^{\mathrm{a}}$ Cadeira da Vila de Cotia (18751882).

Ilustração 41 - Gráfico do número de novas matrículas - 2 ${ }^{a}$ Cadeira da Vila de Cotia (18751882).

Ilustração 42 - Gráfico do número de alunos matriculados - Cadeira do Bairro de Capitão Jerônimo (1879-1885).

Ilustração 43 - Gráfico dos motivos das eliminações - Cadeira do Bairro de Capitão Jerônimo (1879-1885)

Ilustração 44 - Gráfico do número de novas matrículas - Cadeira do Bairro de Capitão

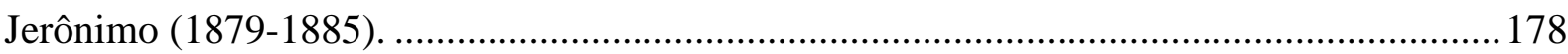

Ilustração 45 - Gráfico das idades das alunas - Cadeira Feminina da Vila (1870-1885). .... 179 Ilustração 46 - Gráfico dos responsáveis pelas alunas - Cadeira Feminina da Vila (18701885)

Ilustração 47 - Gráfico dos vínculos familiares - Cadeira Feminina da Vila (1870-1885).... 181 Ilustração 48 - Gráfico das idades dos alunos - $1^{\text {a }}$ Cadeira Masculina da Vila (1870-1885). 181 Ilustração 49 - Gráfico dos responsáveis pelos alunos - $1^{\text {a }}$ Cadeira Masculina da Vila (18701885)

Ilustração 50 - Recorte do registro de matrícula José Vicente da Silva de 7 jan. de 1881 ... 182

Ilustração 51 - Recorte do registro de matrícula Porfírio Rocha de 3 nov. de 1882 .............. 183

Ilustração 52 - Recorte do registro de batismo de José Vicente da Silva ............................... 183

Ilustração 53 - Recorte do registro de matrícula José Pedroso de 4 jul. de 1881 ................... 184

Ilustração 54 - Recorte do registro de batismo de José Pedroso............................................ 184

Ilustração 55 - Gráfico dos vínculos familiares - 1ª Cadeira Masculina da Vila (1870-1885).

Ilustração 56 - Gráfico das idades dos alunos - $2^{\mathrm{a}}$ Cadeira Masculina da Vila (1875-1882). 186 Ilustração 57 - Gráfico dos responsáveis pelos meninos - 2a Cadeira Masculina da Vila (1875-

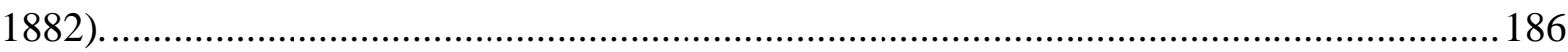

Ilustração 58 - Recorte do registro de matrícula de José Pedroso de 7 jan. 1881 .................. 187 Ilustração 59 - Gráfico dos vínculos familiares - $2^{\text {a }}$ Cadeira Masculina da Vila (1875-1882).

Ilustração 60 - Gráfico das idades dos alunos - Cadeira do Bairro de Capitão Jerônimo (18791885).

Ilustração 61 - Gráfico dos responsáveis pelos meninos - Cadeira do Bairro de Capitão Jerônimo (1879-1885).

Ilustração 62 - Recorte do registro de matrícula de Feliciano Pinto d'Oliveira de 28 mar. 1884

Ilustração 63 - Recorte do registro de batismo de Feliciano Pinto d'Oliveira. 
Ilustração 64 - Gráfico dos vínculos familiares - Cadeira do Bairro de Capitão Jerônimo

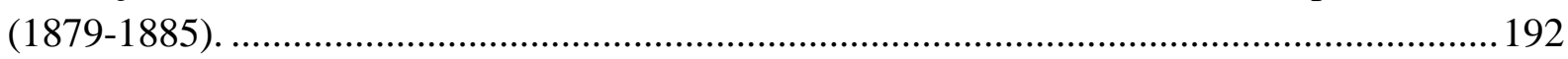

Ilustração 65 - Quadro da população total de Cotia segundo a cor - 1872 e 1886 ................. 194 


\section{SUMÁRIO}

INTRODUÇÃO

CAPÍTULO 1. NÃO ANDAVA METIDO NUMA CASACA DE PANO PRETO: NOTAS SOBRE A HISTÓRIA DE COTIA E O CONTEXTO CAIPIRA NO SÉCULO XIX

1.1. O local e seus antecedentes 33

1.2. Cotia entre 1870 e 1885 39

CAPÍTULO 2. A GEOGRAFIA DAS CADEIRAS PÚBLICAS NA VILA DE COTIA (18701885)

2.1. A legislação vigente e as maneiras para que uma cadeira fosse criada 68

2.2. A localização das escolas 71

CAPÍTULO 3. MAS DEIXEMOS AS JABUTICABAS E FALEMOS DOS PROFESSORES DE COTIA.

3. 1. Os sujeitos professores

3. 2. Professores das primeiras cadeiras na vida pública e casal na vida privada: Maria Joanna do Sacramento e João José Coelho. 123

3. 3. As condições materiais de trabalho 144

CAPÍTULO 4. A ALMA DO POVO, USANÇAS E COSTUMES: OS ALUNOS, AS INFLUÊNCIAS DO COTIDIANO LOCAL NA VIDA ESCOLAR E A COMPOSIÇÃO DAS TURMAS 153

4.1. A composição das turmas a partir dos livros de matrícula ....................................167

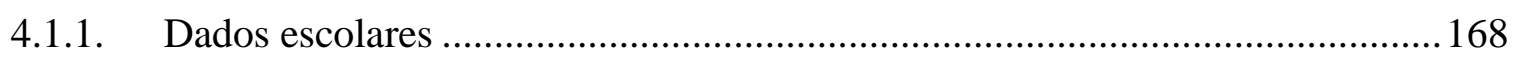

4.1.2. Dados pessoais e reflexões sobre a presença de "ingênuos", a diversidade social e de cor 179

CONCLUSÃO 201

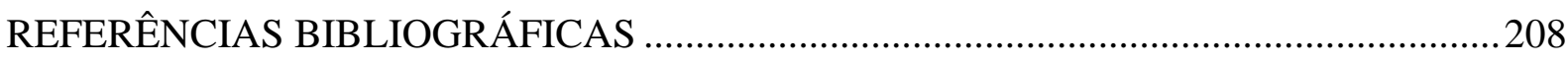

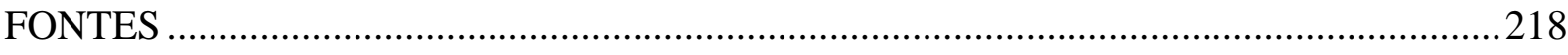

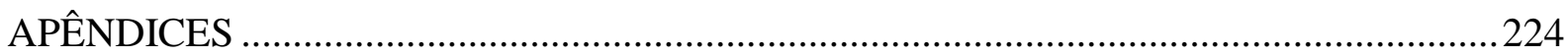




\section{INTRODUÇÃO}

A presente pesquisa tem como objeto de investigação a escolarização pública e como objetivo compreender o processo de escolarização na Vila de Cotia, Província de São Paulo, uma área rural de economia diminuta do entorno da Capital com características culturais caipiras, entre os anos de 1870 e 1885.

Tal economia se refletia também nas precárias condições materiais dos alunos e dos pais, que ficaram evidenciadas em alguns dos relatórios semestrais que acompanhavam os mapas de frequência elaborados por professores e endereçados ao Inspetor Geral da Instrução Pública disponíveis no Arquivo do Estado de São Paulo (AESP). Algumas das frases dos professores retratavam a situação das pessoas e dos bairros, e até mesmo da Vila, onde estavam lecionando. Escreveu o professor Marcolino da Cadeira Masculina do Bairro de Itaqui, em 1874, que seus alunos eram "pobres"; no mesmo ano o professor Severiano da Cadeira Masculina de Várzea-Grande informou da "pobreza" dos pais e de seus alunos; também em 1874, Antonio Manoel Vieira, da Cadeira Masculina do Bairro de Sorocamirim, informou que fornecia material a seus alunos, pois eram "pobres" e o bairro era "remoto"; em 1881, o professor Marcolino, então frente à $2^{\mathrm{a}}$ Cadeira Masculina da Vila, relatou que usava seu ordenado para comprar materiais escolares, pois estava "attento à pobreza dos alumnos que frequentão a escola"; na mesma direção, afirmou a professora Analia Franco da $1^{\text {a }}$ Cadeira Feminina da Vila, em 1885, que ofereceu às alunas "todos os livros e materiais indispensáveis, visto serem os paes paupérrimos"1.

O campo da história da educação paulista carece de pesquisas sobre a escolarização do entorno da Capital. A partir de meados do século XIX, período em que começou a se intensificar o processo de escolarização em São Paulo e no Brasil, a Capital paulista se destacava no cenário político e econômico brasileiro, enquanto que os municípios dos arredores, em geral, tiveram um papel de subsidiários às demandas da futura metrópole. Todavia, os municípios do entorno - que outrora também fizeram parte de São Paulo e depois se tornaram independentes, sobretudo no século XIX - apresentavam características peculiares, que refletiram também no processo de escolarização. Dessa maneira, a presente pesquisa pode contribuir para preencher tal lacuna e ampliar o leque de conhecimentos proporcionados pelas investigações relacionadas à história da educação da região

\footnotetext{
1 Todos esses relatórios encontram-se no AESP, Série Instrução Pública - Manuscritos, na lata de Ofícios Diversos da Instrução Pública de Cotia e de outros municípios, número de referência CO5044.
} 
metropolitana de São Paulo, região de importância histórica e econômica no estado, colaborando para o conhecimento de características da escolarização da Província de São Paulo, assim como para reflexão sobre a sociedade da época.

Nesta investigação busco traçar os contornos da escolarização pública em Cotia inserida no cenário da história local por meio do diálogo entre a formação das cadeiras e as mudanças ocorridas no município ao longo de 15 anos. O período da pesquisa abarca algumas importantes peças legais, como o Regulamento da Instrução Provincial de 1869, a Lei de obrigatoriedade do ensino (1874) e a Lei do Ventre Livre (1871).

O recorte temporal delimitado entre 1870 e 1885 foi desenhado de acordo com as fontes localizadas e também porque nesses 15 anos houve a intensificação do processo de escolarização pública no local, no qual de duas cadeiras existentes até o início dos anos de 1870, outras 10 foram criadas e 9 providas até 1885. A partir de 1870, evidenciava-se a difusão dos ideais republicanos que começavam a emergir na legislação referente à educação: “desde 1870, a diacronia republicana pode ser percebida coexistindo, cooperando e conflitando com a monárquica" (HILSDORF, 2003a, p. 57). O ano final do recorte, 1885, foi o ano em que se aposentaram dois professores, Maria Joanna do Sacramento, da $1^{\text {a }}$ Cadeira Feminina da Vila, e João José Coelho, da $1^{\text {a }}$ Masculina da Vila, que lecionaram por 27 e 25 anos, respectivamente, nas mesmas cadeiras, e também formaram um casal na vida privada. Portanto, a história da atuação desse casal como um dos guias para o recorte se configurou profícua para esta pesquisa, pelo longo tempo de atuação de ambos nas mesmas cadeiras, por serem casados, propiciando discutir as influências do âmbito privado no desenvolvimento da escolarização em Cotia.

Do período da presente pesquisa estão disponíveis no AESP alguns livros de matrícula. São seis livros ao todo, referentes a quatro cadeiras:

- $\quad 1^{\mathrm{a}}$ Cadeira Feminina da Vila: dois livros que contemplam o período de 1870 1885, referências EO2230 e EO3182.

- $\quad 1^{\mathrm{a}}$ Cadeira Masculina da Vila: dois livros que contemplam o período de 18701885, referências EO2234 e EO3030.

- $\quad 2^{a}$ Cadeira Masculina da Vila: um livro que contempla o período de 18751882, referência EO2918.

- Cadeira do Bairro de Capitão Jerônymo: um livro que contempla o período de 1879-1885, referência EO3116.

Tendo como uma das principais intenções do presente estudo a investigação dos alunos cotianos, a principal fonte que trazia informações sobre eles - os livros de matrícula - 
auxiliou para determinar o recorte temporal. Esses livros apresentaram-se como um núcleo consistente de fontes contemporâneas entre si.

A origem desta pesquisa se deu a partir da minha experiência como professora pública de História da rede estadual em Cotia, local onde morei por muitos anos e fui estudante de escolas públicas durante todo meu percurso escolar básico (da pré-escola ao ensino médio). Os anos como professora da rede estadual, além de me proporcionarem valiosa experiência sobre a prática docente e conhecimento administrativo escolar, despertaram em mim algumas indagações sobre a história da escolarização da cidade, como: quem eram os alunos cotianos no início da escolarização? Como foi o processo de escolarização desde seu início? Contudo, não encontrei nenhuma pesquisa feita sobre a gênese da escolarização local e muito poucas sobre a história de Cotia.

Então, a partir dessas questões, percorri o caminho investigativo baseando-me na história e historiografia local, regional e nacional e na história e historiografia da educação brasileira, além de uma gama diversificada de fontes e de valiosa orientação, que me proporcionaram verificar que o espaço escolhido apresentava particularidades interessantes para o estudo da história da educação. Apresentava características de uma sociedade rústica de costumes caipiras, vivenciava uma retração na economia devido ao declínio do tropeirismo (tendo sua modesta participação na economia paulista por vezes ridicularizada na Assembleia Provincial), mas em contrapartida, recebia duas estações de trem e mais de uma dezena de escolas. Assim, a pergunta central da pesquisa passou a ser: como foi o processo de escolarização na Vila de Cotia, município vizinho de São Paulo com características culturais caipiras, num momento de retração econômica e que, a despeito disso, teve a oferta de cadeiras públicas aumentada?

O município de Cotia está localizado na zona oeste da região metropolitana de São Paulo, tem área territorial de $324 \mathrm{~km}^{2}$, e possui pouco mais de 200 mil habitantes, de acordo com dados do IBGE referentes ao Censo 2010. A região pertenceu ao município de São Paulo até $1856^{2}$. Sua dimensão geográfica após a emancipação possuía por volta de $500 \mathrm{~km} 2$ e compreendia o que hoje são os municípios de Cotia, Itapevi, Jandira, Vargem Grande Paulista, parte de Carapicuíba e de Embu (INSTITUTO GEOGRÁFICO E CARTOGRÁFICO - IGC-SP, 1995) e também da Capital, pois fazia divisa com esta na

\footnotetext{
${ }^{2}$ Em 1723, sob o nome de Nossa Senhora do Monte Serrat da Cutia, foi elevada à categoria de freguesia e, em 1856, após sua emancipação, elevou-se à categoria de vila (Lei Provincial $\mathrm{n}^{\circ} 7 / 1856$ ), possuindo seu próprio corpo de vereadores. Passou a se chamar Cotia a partir de sua elevação à condição de cidade, em 1906 (Lei Estadual no1.038/1906).
} 
região do córrego Jaguarahé, hoje localizado no distrito paulistano de Jaguaré (Relatório apresentado ao Exmo. Presidente da Próvíncia de São Paulo,1888; PINTO, 1900).

Em 1928, ao discutir o método da História Comparada, o historiador Marc Bloch apontou que na sua prática, o historiador deve trabalhar a partir dos estudos pormenorizados, críticos e solidamente documentados, e evidenciou a importância de monografias locais, que podem conduzir a uma melhor compreensão da história através da comparação entre elas (1998, p. 143).

No campo da história da educação, Chapoulie e Briand (1994), autores que analisaram a escolarização na França entre 1830 e 1960, apontaram que as especificidades locais, como espaço e gestão, interferem na escolaridade e vice-versa: "cada estabelecimento está submetido às exigências de uma localidade, que ele mesmo contribui, aliás, para definir, e que possui, ao mesmo tempo, uma dimensão demográfica, econômica, política, assim como uma dimensão institucional" (p. 18).

Os contextos local e regional são necessários no estudo da história da educação. Dessa maneira, ressalto as reflexões de Faria Filho (2009) sobre o estudo da história regional:

Se entendermos que a ideia de região faz parte de estratégias de mobilização política, de homogeneização, de produção de identidades e, por fim, de classificação social, é preciso que nós pesquisadores, nos aproximemos com mais cautela da mesma. Ou, dizendo de outra forma, quando todo o léxico mobilizado para adjetivar (e, geralmente, contrapor) as distintas "regiões", tais como arcaicas/modernas, rurais/urbanas, centrais/periféricas, atrasadas/adiantadas, dentre outras, é, ele mesmo, objeto das nossas mais apaixonadas discussões, então, o substantivo que elas adjetivam não podem ficar de fora de nossa inquirição. (FARIA FILHO, 2009, p. 63).

Considerando que toda história diz respeito a um período e a um lugar/região, por que estudar apenas os centros políticos e econômicos, em detrimento de outras regiões do cenário nacional? Isso se refere ao fim e ao cabo à uma questão metodológica. É necessário, como mencionou Faria Filho, que os pesquisadores se aproximem com mais cautela da ideia de região. Para ele, região é

[...] uma representação e uma prática cultural por meio das quais (e nas quais) determinados fenômenos e posições são produzidos, os sujeitos são identificados e ganham visibilidade e as nossas instituições são criadas e mobilizadas para a ação social e política. Ou seja, a região é, de certo modo, uma invenção. (FARIA FILHO, 2009, p. 63).

Para o autor, podemos tratar a região como unidade de análise, e dessa maneira, a questão que todo pesquisador deve fazer a si é: “o que torna possível falar de uma história 
regional de um objeto particular, seja ele uma instituição, uma disciplina escolar, um movimento social ou uma política educacional?" (2009, p. 63). Para o autor:

\begin{abstract}
O objeto, a sua produção teórico-metodológica, as suas temporalidades e dinâmicas próprias, as suas relações com os demais fenômenos sociais e, por fim, as fontes mobilizadas deveriam comparecer ao tribunal da história, como diria E. P. Thompson, para produzir a justificativa da possibilidade de uma tal história regional. Como vocês vêem, também aqui o regional é o produto da operação historiográfica, e não o seu pressuposto. (FARIA FILHO, 2009, p. 64, grifo do autor).
\end{abstract}

Segundo Faria Filho, além de unidade de análise, também podemos tratar a região como lugar epistemólogico, e ainda ressalta que é possível operar com os dois. Na presente pesquisa, todavia, procuro apenas tratar a região que estudo como unidade de análise, analisando o caso da Vila de Cotia nos moldes propostos por Amália Dias (2012) ao estudar o município de Nova Iguaçu (RJ):

[...] procuramos evidenciar, na delimitação do objeto, a compreensão de Nova Iguaçu para além de um território geográfico circunscrito, mas de um espaço socialmente construído. Isto significa conhecer a história de constituição desta região, as dinâmicas econômicas, populacionais, sociais e políticas que configuram este território no período estudado [...]. (DIAS, 2012, p. 14).

No presente estudo, apresento a história da constituição da Vila de Cotia e suas dinâmicas sociais, políticas, econômicas e populacionais. Apresento também a história dos bairros onde as cadeiras foram criadas, sobretudo suas dinâmicas sociais e econômicas, a fim de compreender como as especificidades dos bairros interferiram na escolarização. Para a compreensão do processo de escolarização de Cotia, busco desvendar como foram distribuídas as escolas, geograficamente, refletir sobre essas distribuições, pensando quais sujeitos e vozes compunham esses espaços de interlocução.

O conceito de escolarização aqui compreendido baseia-se nos apontamentos de alguns autores: Chapoulie e Briand (1994), Faria Filho (2002) e Vidal e Biccas (2008), além do que Vincent, Lahire e Thin (2001) chamaram de forma escolar.

Chapoulie e Briand (1994) consideram a escolarização como "fato institucional" e a “instituição escolar como uma organização cujo imperativo primeiro de funcionamento é a análise dos fluxos dos alunos dentro das redes de estabelecimentos" (p. 11), sendo assim,

A construção de um conjunto coerente de categorias de análise, destinadas à compreensão do funcionamento da instituição e de suas relações com o contexto, significa uma etapa essencial para o estudo rigoroso da escolarização, com destaque 
especial à escolha da ordem em que as diferentes determinações são introduzidas na análise. (CHAPOULIE; BRIAND, 1994, p. 12).

Para tanto, é necessário também atentar aos dados e categorias impostos nos documentos institucionais, pois não estão ali "naturalmente", mas com intencionalidade. Para os autores as categorias implicadas no processo de escolarização são: famílias, movimentos sociais, grupos de interesses, igrejas, comunidades locais, administradores de estabelecimentos ou de parte do sistema escolar, políticos etc. Assim, a escolarização é "o produto da interação entre a instituição - isto é, no caso dos estabelecimentos escolares - e uma população diferenciada conforme diferentes princípios exteriores à instituição (como sexo, idade, classe social, religião etc.)" (CHAPOULIE; BRIAND, 1994, p. 16).

Segundo Faria Filho (2002), duas acepções do termo escolarização estão “intimamente relacionadas":

\begin{abstract}
Num primeiro, escolarização pretende designar o estabelecimento de processos e políticas concernentes à "organização" de uma rede, ou redes, de instituições, mais ou menos formais, responsáveis seja pelo ensino elementar da leitura, da escrita, do cálculo e, no mais das vezes, da moral e da religião, seja pelo atendimento em níveis posteriores e mais aprofundados.

Em outra acepção, estamos entendendo por escolarização o processo e a paulatina produção de referências sociais tendo a escola, ou a forma escolar de socialização e transmissão de conhecimentos, como eixo articulador de seus sentidos e significados. Neste caso, nossa atenção está voltada para o que temos chamado de "consequências" sociais, culturais e políticas da escolarização, abrangendo questões relacionadas ao letramento, ao reconhecimento ou não de competências culturais e políticas dos diversos sujeitos sociais e à emergência da profissão docente no Brasil. (FARIA FILHO, 2002, p. 16).
\end{abstract}

A segunda definição assinalada por Faria Filho remete ao que Vincent, Lahire e Thin (2001) chamaram de forma escolar, uma forma de socialização peculiar que ultrapassa a escola e tem como um de seus objetivos finais a "pedagogização das relações sociais", compreendidas através de normas, sendo a escola "o lugar da aprendizagem de formas de exercício do poder" (VINCENT; LAHINE; THIN, 2001, p. 30, grifo dos autores). Em outro artigo de Faria Filho, em parceira com Bertucci (2009), baseando-se também na concepção de forma escolar, os autores asseveraram:

[...] a escola não age apenas intra-muros, e sim tem uma ampliada atuação social na medida em que funciona como uma instituição que produz, divulga e legitima identidades, competências e modos de vida, ao mesmo tempo em que deslegitima outros. (FARIA FILHO; BERTUCCI, 2009, p. 14). 
[...] referência simbólica, o que implica o jogo tenso de reinvenção das identidades sociais e das representações sobre o lugar social da escola". [Articulada à cultura escolar, a escolarização é] "uma estratégia instaurada pelo Estado, mas não apenas. Para nós, evidencia-se como importante atentar para os vários projetos educativos colocados em jogo por movimentos ou grupos sociais [...]. (VIDAL; BICCAS, 2008, p. 28, adendos meus).

Assim, procuro compreender como, num período de 15 anos, desenvolveu-se o processo de escolarização em Cotia, considerando não apenas a criação de escolas, o número de alunos matriculados e frequentes, os estabelecimentos, mas o significado da escolarização nesse local, sua implicação no cotidiano, dialogando com o contexto, reconhecendo os vários sujeitos envolvidos, compreendendo as consequências sociais, culturais e políticas da escolarização, as relações que se estabeleceram entre o modo de vida local e a institucionalização do ensino.

Para o desenvolvimento desta pesquisa, mobilizei um grande conjunto de fontes diferentes entre si e de diferentes bases documentais (físicas ou digitalizadas). No AESP, além dos livros de matrícula já mencionados (com referências EO2230, EO3182, EO2234, EO3030, EO2918, EO3116), os relatórios de inspetores locais e, sobretudo, de professores, que originalmente acompanhavam os mapas de frequência (estes não estavam arquivados), tornaram-se também uma das principais fontes de pesquisa.

Todos os relatórios ${ }^{3}$ dos professores usados estão disponíveis na lata de referência $\mathrm{CO}_{0} 44^{4}$, que contém documentos de vários municípios, dentre eles, Cotia (deste há documentos de 1838 a 1896). Além de relatórios que acompanhavam os mapas de frequência das cadeiras de Cotia, essa lata também conta com ofícios e petições de inspetores locais, professores e do Conselho de Instrução Pública, além de ofícios de governo.

Nela há 75 relatórios de professores referentes ao período de 1870 a 1885 . Mas além desses relatórios, consultei alguns do período anterior (desde 1838, data da criação da primeira cadeira pública), e posterior (até 1886, data em que houve transferência de cadeiras). Os relatórios cumpriam o papel de anunciar ao Inspetor Geral que o mapa de frequência estava sendo remetido e informar sobre o "adiantamento dos alunos" e o estado geral da escola.

O mapa de frequência era um dispositivo de governo elaborado com o objetivo de comprovar o exercício efetivo, condição para que os professores recebessem seus salários e

\footnotetext{
${ }^{3}$ Há autores que não usam o termo relatório, mas ofício ou, ainda, comunicação de professores. No AESP também chamam genericamente esses documentos de ofício, mas como os professores de Cotia, autores do documento, usavam o termo relatório, e a legislação vigente também, optei por usar o mesmo termo.

${ }^{4}$ AESP, Série Instrução Pública - Manuscritos, Ofícios de Instrução Pública.
} 
para viabilizar o funcionamento da escola (VIDAL, 2008). Entretanto, como mencionado, os mapas referentes ao recorte desta pesquisa não foram localizados no AESP e utilizo apenas os relatórios para a análise ${ }^{5}$. Os artigos que se relacionavam à feitura dos mapas presentes na legislação que vigorou antes do Regulamento de 1869 não mencionavam a elaboração de relatórios de professores. Em 1851, a lei asseverava que cabiam aos inspetores de distrito, entre outras coisas,

Art. 12. $\S 11^{\circ}$ Enviar ao inspector geral no fim de cada trimestre um relatorio sobre o estado das aulas e escolas do seu districto, capacidade, comportamento civil, e moral dos professores reformas e melhoramentos de que carecer a instrucção publica, acompanhado de um mappa contendo o numero das aulas e escolas, e dos alumnos que as frequentam com observação sobre seu comportamento. (Capítulo III do Regulamento de 8 de novembro de 1851 - Para a Instrucção Publica).

Nesse regulamento havia a necessidade da elaboração de relatórios por inspetores locais. Segundo Hilsdorf (2003b), o governo provincial organizou uma estrutura administrativa a partir de 1851:

[...] composta de uma Inspetoria Geral da Instrução e várias inspetorias distritais, com funções de fiscalização sobre as escolas públicas e particulares da província. A Inspetoria fazia anualmente a estatística da instrução. Informação tem, então, à época, uma outra face: controle (HILSDORF, 2003b, s/p).

Uma das formas de ação do Estado no processo de institucionalização do ensino no XIX se dava a partir de estatísticas e um auxiliar no levantamento das estatísticas era o mapa de frequência, documento que os professores deveriam elaborar, entregar ao inspetor local que, por sua vez, enviava ao Inspetor Geral de Instrução Pública. Para Diana Vidal (2008), essa prática escriturística "nomeava, classificava e hierarquizava os sujeitos e a realidade social" (p. 43), da qual o Governo articulava práticas heterogêneas, colocadas como homogêneas, lineares e sistêmicas (p. 47), corroborando com o discurso do Estado. Entretanto, os professores incluíam um pouco de si, de seus saberes pedagógicos, ou omitiam fatos para cumprirem as medidas legais e manterem seu oficio no local.

No Regulamento de 18 de abril de 1869 ficou determinado que os professores deveriam enviar ao Inspetor Geral da Instrução Pública "em $1^{\circ}$ de junho e de novembro um relatorio sobre o estado de sua escola, o adiantamento de seus discipulos, acompanhado de um mappa conforme o modelo que lhe fôr dado pelo mesmo Inspector Geral” ( 111 do Art. 110).

\footnotetext{
${ }^{5}$ Aliás, o fato de ter apenas os relatórios, mas não os mapas, é uma questão importante a se considerar, e passa pela discussão de gestão de arquivo, todavia, como não é o foco desta pesquisa, fica apenas registrada essa incongruência.
} 
No caso de Cotia, os relatórios localizados foram feitos pelos inspetores até 1870, mas a partir dessa data, a maioria é de professores. Contudo, em 1874 houve uma nova legislação que continha informações sobre a elaboração e envio dos mapas de frequência. Na lei da obrigatoriedade do ensino de 1874, o artigo 13 asseverava:

Art. $1^{\circ}$. Os Professores Publicos apresentarão, no fim de cada mêz, ao Inspector de Districto, um mappa dos alumnos matriculados em suas escolas, com declaração dos frequentes, suas idades, filiações, numero e faltas e a razão dellas, e só á vista deste mappa e abaixo delle, verificada a frequencia de vinte alumnos, deverá o Inspector de Districto passar o respectivo attestado. (Lei ${ }^{\circ} 9$, de 22 de março de 1874).

Na legislação de 1874 não há menção sobre a feitura dos relatórios pelos professores, apenas dos mapas de frequência, portanto, continuou vigorando o que determinava o Regulamento de 1869. No corpo do texto dos relatórios coligidos para esta pesquisa havia a quantidade de alunos matriculados e frequentes de cada cadeira, mas além dessa informação, inspetores locais e, sobretudo, os professores apresentavam dados sobre a cultura escolar, o cotidiano, as demandas e as dificuldades enfrentadas por eles e por seus alunos no processo de escolarização.

Esses relatórios trazem consigo um pouco do dia a dia da escola na lente do professor e um pouco do professor como sujeito histórico. Apresentam dados sobre a cultura escolar, o cotidiano, as demandas e as dificuldades enfrentadas pelos professores e alunos, assim como suas conquistas, tendo o professor como porta-voz. Demonstram, ainda, as demandas locais, como as condições dos bairros e dos pais e alunos, seus tipos de trabalho e a ausência de estrutura para o ensino.

Também disponíveis no AESP, há as petições locais de criação de escolas ${ }^{6}$. Pesquisei nas latas da Série de Instrução Pública (Manuscritos) do período da pesquisa e também do período anterior, desde a criação de uma cadeira em Cotia, em $1838^{7}$, latas que têm fontes de diversos municípios, cabendo ao pesquisador ter a "sorte" de encontrar algum documento que lhe interesse. Localizei apenas quatro mapas de frequência feitos pelo primeiro professor, Antonio Bandeira Barreto, referentes aos anos de $1840^{8}$, portanto, fora do meu recorte de pesquisa. Todavia, havia os nomes dos professores João José Coelho e Manoel de Moraes Pinto entre os alunos de Barreto, então essas fontes auxiliaram para desvelar parte de suas trajetórias.

\footnotetext{
${ }^{6}$ AESP, Série Ofícios Diversos, Ofício Diversos de Cotia, ref. CO1008.

${ }^{7}$ AESP, Série Instrução Pública - Manuscritos, ref. CO4914, CO4915, CO4916 e CO4917.

${ }^{8}$ Os mapas estavam em uma das latas consultadas: AESP, Série Instrução Pública - Manuscritos, ref. CO4915.
} 
Dados oficiais sobre a Instrução Pública constantes nos Relatórios e mapas estatísticos de governo (Relatórios de Presidente de Província e Relatórios da Instrução Pública de São Paulo) foram consultados no site do Center for Research Libraries da Universidade de Chicago.

As fontes de legislação utilizadas foram muitas, com destaque para as referentes à Instrução da Província: o Regulamento de 18 de abril de 1869 e a Lei número 9 de 22 de março de 1874, que instituiu a obrigatoriedade do ensino na Província de São Paulo, e para a Lei do Ventre Livre (Lei $\mathrm{n}^{\circ} 2.040$ de 28 de Setembro de 1871). Além de leis, decretos e resoluções referentes à criação, supressão ou transferência das cadeiras, aposentadorias, aos artigos de posturas da Câmara Municipal, demarcação de fronteiras, alteração de comarca, construção da estrada Sorocabana e do ramal para Cotia etc. Algumas dessas fontes estão no site do Acervo Histórico da Assembleia Legislativa de São Paulo, onde também localizei Atas de Assembléia e petições e ofícios em geral relativos à escolarização cotiana.

Periódicos foram outras fontes muito usadas neste trabalho. Algumas informações e fontes referentes à Cadeira Feminina de Cotia e à Professora Maria Joanna foram consultadas no trabalho de Hilsdorf (1999). Além dessas, no site da Hemeroteca Digital Brasileira da Biblioteca $\mathrm{Nacional}^{9}$, busquei os nomes dos professores e dados relativos à vida pública de cada um, além de notícias que traziam alguma informação sobre Cotia, para que eu compreendesse melhor o contexto do meu recorte, pois poucos trabalhos sobre Cotia se debruçaram sobre a Vila na segunda metade do XIX.

Coloquei no campo de busca a palavra "Cotia". A pesquisa foi feita por períodos determinados pelo site (período de 10 anos), de acordo com o recorte temporal da pesquisa (1870-1885): para o período de 1870 a 1879 houve 3.885 ocorrências em periódicos de todo o Brasil; para o período 1880 a 1889 houve 7.017 ocorrências. Como que para o decênio de 1880 a 1889 eu consultei apenas até 31 de dezembro de 1885, trabalho com a hipótese bem generalizante de que usei $50 \%$ do total do decênio, portanto, em torno de 3.500 ocorrências. Todavia, apesar de digitar "Cotia", o sistema também buscou e colocou entre as ocorrências palavras como "costa", "cota", "colla" etc., e também "Cotia" referindo-se ao animal e ao sobrenome de algumas pessoas, especialmente do Rio de Janeiro. Esta busca “ampliada” fez somar muitas ocorrências, mas efetivamente as que se referia à Vila de Cotia foram em torno de $10 \%$ nos jornais de outras províncias (do total) e em torno de $70 \%$ dos jornais de São Paulo

\footnotetext{
9 Site da Fundação Biblioteca Nacional que oferece ao público um portal de periódicos nacionais que proporciona consulta via internet ao acervo dessa instituição, como jornais, revistas, anuários, boletins etc., além de publicações seriadas.
} 
(do total). Dos periódicos paulistas, foram consultadas em torno de 1.300 ocorrências, que se tornaram imprescindíveis para a compreensão do contexto local, ao menos pelos olhos da imprensa e do governo, que sempre publicava informes de despachos, ordens de pagamento, deferimento e indeferimentos de petições, atas, projetos etc.

Percorri o fio do nome dos sujeitos (GINZBURG; PONI, 1991) para investigá-los, tendo como base a imprensa a partir da Hemeroteca Digital e eliminando os falsos cognatos. Também utilizei registros de casamento e batismo, disponíveis no site FamilySearch ${ }^{10}$, para obter informações sobre o nascimento e/ou casamento de alguns sujeitos, como professores e alunos, e suas árvores genealógicas. Listas de vereadores da época e de presidentes da Câmara Municipal também foram consultadas, além do Almanak da Província de São Paulo para 1873, que trouxe vários nomes de sujeitos que compunham os setores públicos, o comércio e a agricultura de Cotia.

Foram utilizados dados estatísticos, como o Censo imperial de 1872 e o recenseamento provincial de 1886 presente no Relatório apresentado ao Exmo. Sr. Presidente da Província de S. Paulo (1888), assim como os dados da Estatistica Agricola e Zootechnica de Cotia no anno agricola de 1904-1905. Além de fontes oficiais e da imprensa, utilizo mapas geográficos, fotos e aerofotos, croqui e ainda poesias, crônica, texto de peça teatral e relatos de viajantes - ainda que em menor quantidade devido à sua escassez em comparação aos dados oficiais, procuro "dar voz" a documentos não-oficiais.

O trabalho de entrecruzar os documentos, "encaixar" as fontes mobilizadas em lugares que adquirissem maior inteligibilidade, foi ganhando forma ao longo da pesquisa, na medida em que consultava a bibliografia. Para facilitar a análise, elaborei quadros e gráficos sobre a escolarização de Cotia a partir dos documentos coligidos, além dos mapas geográficos com a localização das escolas. Para uma leitura um pouco mais fluida das palavras escritas pelos professores com a grafia da época, optei por atualizar os nomes da Vila e dos bairros, com exceção de Sorocamirim, Várzea-Grande, São João, Lavapés e Bairro das Graças, que permaneceram os mesmos. Assim, abaixo estão as grafias usadas na época pelos professores e, em seguida, as usadas ao longo deste trabalho:

- Villa da Cutia: Vila de Cotia;

- Itaquy: Itaqui;

${ }^{10}$ FamilySearch é uma organização de pesquisa genealógica mantida pela Igreja de Jesus Cristo dos Santos dos Últimos Dias (popularmente conhecida como Igreja dos Mórmons), que reúne registros de nascimento, casamento e óbito de "3 bilhões de nomes" de diversos países, incluindo o Brasil. Há livros digitalizados da Igreja Católica Apostólica Romana de batismo, casamento e óbito de muitas localidades do Brasil (dentre elas, Cotia), além de árvores genealógicas de brasileiros nascidos desde o século XVII em seu acervo digital https://familysearch.org/. 
- Carapucuhyba/ Carapocuhyba: Carapicuíba;

- Capitão Jerônymo: Capitão Jerônimo;

- $\quad$ Rio da Cutia: Rio Cotia;

- Caocaia: Caucaia.

Para a discussão da profissão docente, busquei analisar meus documentos à luz do estudo de Vidal (2010) que compreende a docência como uma experiência coletiva. Valendose do conceito de experiência de E. P. Thompson, a autora apresentou e analisou quatro elementos constitutivos da experiência docente, mas para esta pesquisa, me respaldo em três elementos. O primeiro é a trajetória escolar dos professores que, segundo a autora é o "conjunto da experiência acumulada pelo sujeito professor ao longo de sua vida" (p. 712). Além da sua experiência estritamente como professor, importa investigar suas vivências como aluno desde o início de sua escolarização, que, segundo Vidal "envolve modelos formadores e saberes" (p. 712), que podem permitir que o pesquisador compreenda a "configuração dos repertórios docentes" (p. 713).

Como segundo elemento, Vidal (2010) aponta que a relação intersubjetiva estabelecida com diferentes atores sociais (e escolares) nos vários níveis influencia na construção da experiência docente: "o que inclui atentar para as dimensões de etnia, gênero, classe e geração, além de se interrogar sobre as expectativas familiares dos sujeitos” (p. 718719). Já o terceiro elemento assinalado pela autora é a confrontação dos sujeitos com as condições materiais da existência e do trabalho docente:

\footnotetext{
A materialidade da escola (objetos com os quais o professor lida cotidianamente como livros, cartazes, globos dentre outros), espaço escolar (sala de aula, tamanho da escola, trabalho em uma ou duas escolas), tempo escolar (da aula, da permanência diária, semanal, anual na escola, da permanência na carreira, tempo histórico), carreira (salário, projetos individuais, expectativas de ascensão, participação em associações sindicais) e urgências da classe (síntese e negociações). (VIDAL, 2010, p. 721).
}

A análise dos elementos constitutivos da experiência docente proposta por Vidal converge de forma fecunda para a pesquisa, pois localizei professores que outrora foram alunos de outros professores cotianos e procuro discorrer sobre as relações intersubjetivas entre os sujeitos e as condições materiais às quais estavam submetidos.

Para instrumentalizar a análise das condições materiais também utilizo os conceitos de estratégia e tática de Michel de Certeau (1994). Segundo este autor, estratégia é: 
[...] o cálculo (ou a manipulação) das relações de forças que se torna possível a partir do momento em que um sujeito de querer e poder (uma empresa, um exército, uma cidade, uma instituição científica) pode ser isolado. A estratégia postula um lugar suscetível de ser circunscrito como algo próprio e ser a base de onde se podem gerir as relações com uma exterioridade de alvos ou ameaças (CERTEAU, 1994, p. 99, grifos do autor).

Enquanto que a tática para Certeau se configura como:

[...] a ação calculada que é determinada pela ausência de um próprio. Então nenhuma delimitação de fora lhe fornece a condição de autonomia. A tática não tem por lugar senão o do outro. E por isso deve jogar com o terreno que lhe é imposto tal como organiza a lei de uma força estranha. [...] É astúcia. Em suma, a tática é a arte do fraco. (CERTEAU, 1994, p. 100-101).

À luz desses conceitos, interpreto as leis e os dispositivos de governo como estratégias do Estado, enquanto que os relatórios dos professores com as solicitações de móveis, "utensis" entre outras coisas, enaltecendo a figura do Inspetor Geral de Instrução Pública, interpreto como táticas.

Os apontamentos de Edward Palmer Thompson em Costume, lei e direito comum, capítulo que faz parte do livro Costumes em Comum: estudos sobre a cultura popular tradicional (1998), são utilizados para interpretar a importância dos costumes em detrimento da assimilação das leis do Governo pelo povo - no caso aqui tratado, da lei de obrigatoriedade do ensino de 1874. Considerando a teoria thompsoniana, Faria Filho (2011) assinalou que o historiador da educação pode interpretar a lei como prática ordenadora das relações sociais, ressaltando o caráter político da lei, da ação do Estado "e/ou das classes ilustradas sobre o heterogêneo povo brasileiro, no sentido de civilizá-lo e prepará-lo para contribuir com o progresso da nação" (FARIA FILHO, 2011, p. 260, grifo do autor).

Por fim, destaco o uso do estudo de Antonio Candido em Os parceiros do Rio Bonito: estudo sobre o caipira paulista e a transformação dos seus meios de vida (2001a) como guia principal para ajudar a compreender e a justificar a sociedade de Cotia inserida na cultura rústica paulista, a caipira. Além das fundamentações dos estudos de Petrone (1995) e Langenbuch (1971) sobre a região de São Paulo e arredores.

Para desenvolver tal proposta, a pesquisa foi dividida em quatro capítulos. No primeiro, apresento a história política, econômica e social local desde sua fundação, enfatizando o período do recorte da pesquisa (1870-1885), a partir de uma gama diversificada de fontes e de bibliografia sobre Cotia e a Província de São Paulo.

No segundo capítulo exponho, cronologicamente, dados sobre as aberturas, deslocamentos e fechamentos das cadeiras públicas, buscando dialogar com a história dos 
bairros para, com isso, compreender a lógica das escolhas dos lugares de instalação das cadeiras, pensando quais sujeitos e vozes compunham esses espaços de interlocução. Nele, apresento um conjunto de mapas cartográficos com as localizações das escolas para que o leitor perceba a geografia das cadeiras, facilitando a compreensão do processo de escolarização também no campo visual.

O terceiro capítulo aborda os professores públicos de Cotia, sujeitos com características muito diferentes entre si, e aponta os campos de atuação de cada um, antes, durante e depois do período da pesquisa, atuando como professores públicos e/ou em outros setores da sociedade. O capítulo enfatiza a trajetória do casal de professores da Vila, Maria Joanna do Sacramento e João José Coelho, buscando desvelar a influência da vida do casal na prática escolar e usando o conceito de lar docente de Munhoz e Vidal (2014). Nesse capítulo também foram abordadas as condições materiais de trabalho dos sujeitos envolvidos no processo de escolarização, principalmente dos professores, baseando-se essencialmente no relatórios que acompanhavam os mapas de frequência.

$\mathrm{O}$ quarto e último capítulo versa sobre algumas características dos alunos e as influências do cotidiano local na vida escolar. Num primeiro momento, discuto o aumento de alunos matriculados ao longo dos 15 anos, a falta de frequência dos alunos que, segundo a maioria dos professores, era motivada principalmente pelo trabalho, sobretudo na lavoura, e discuto a questão de tempo e espaço sociais x tempo e espaço escolares. Na segunda parte, apresento os dados dos alunos e de seus responsáveis retirados de livros de matrícula de quatro cadeiras ( $1^{\mathrm{a}}$ Feminina da Vila, $1^{\mathrm{a}}$ e $2^{\mathrm{a}}$ Masculinas da Vila e a do Bairro de Capitão Jerônimo), no qual foram identificados alunos filhos de escravas. Procuro refletir sobre a composição social presente nas turmas e se a presença dos filhos de escravas refletia as características da sociedade, de parca condição econômica, onde os senhores e seus escravos conviviam a partir de relações mais estreitas do que em lugares mais abastados da Província e do Brasil. 


\section{CAPÍtUlO 1. NÃO ANDAVA METIDO NUMA CASACA DE PANO PRETO: NOTAS SOBRE A HISTÓRIA DE COTIA E O CONTEXTO CAIPIRA NO SÉCULO XIX}

Personagem caricato criado por França Junior ${ }^{11}$ em 1862 para a peça Tipos da atualidade, o Barão da Cotia é o protagonista da obra. É um fazendeiro rico e viúvo, que vai passar um tempo na Capital imperial, e apresenta características de um "caipira bronco e desajeitado, completamente inadaptado à vida da corte" (FARIA, 1998, p. 58). A história é uma comédia que se passa no Rio de Janeiro e trata, entre outras coisas, do interesse de uma mãe em casar sua filha com um homem de posses, no caso, o Barão da Cotia. A comédia ficou popularmente conhecida como $O$ Barão da Cotia em virtude da notoriedade do personagem.

Segundo anúncios de jornais da época coligidos no site da Hemeroteca Digital, a peça estreou no Rio de Janeiro no mesmo ano e foi apresentada em alguns municípios do Brasil, o que pode indicar relativo sucesso ${ }^{12}$. Para o crítico paranaense Aristhaco, o Barão da Cotia "é honrado, porém rude, homem do centro, que mesmo nos bailes lembra-se de sua Ignez [sua falecida esposa] e da bella garapa que preparava", e passa um tempo na Corte, local "onde se julga sempre peor que na fazenda da Cutia" ${ }^{13}$.

Trata-se de uma obra fictícia, com atributos exagerados em cada personagem, mas, embora haja caricatura, há passagens na peça do teatrólogo carioca com elementos da história e da sociedade da Vila de Nossa Senhora do Monte Serrat da Cotia, Província de São Paulo, da segunda metade do século XIX, que podem corroborar para vislumbrar o que Cotia representava para algumas pessoas:

GASPARINO - Pois quando Vossa Excelência quiser utilizar-se da minha égua de Meklemburgo, está muito a seu dispor.

BARÃO - Eu prefiro uma boa besta. Em São Paulo tenho uma burra branca que é uma rede; foi um presente que deu-me no dia de meus anos o Juiz de Paz da Cutia: custou-lhe na feira de Sorocaba 500\$000 réis. Oh! que lindo animal! É meter-se-lhe as esporas, e a mulinha sai pela estrada que é um regalo.

D. ANA - Vossa Excelência é a primeira vez que vem ao Rio?

BARÃO - É verdade, minha senhora.

\footnotetext{
11 Joaquim José da França Junior (1838-1890) foi um jornalista e teatrólogo carioca, membro da Academia Brasileira de Letras, bacharel em letras pelo Colégio D. Pedro II e direito pela Faculdade de Direito no Largo São Francisco. Quando ainda era aluno de direito, lançou Tipos da atualidade, estreando a peça no Ginásio Dramático (RJ). Mais informações, consultar: Silva (2010), Freitas (2002) e site da Academia Brasileira de Letras (ABL) "França Júnior: biografia". Disponível em <http://www.academia.org.br/abl/cgi/cgilua.exe/sys/start.htm?infoid=857\&sid=161> Acesso em: 12 jan. 2015. 12 A pesquisa feita na base de dados da Hemeroteca Digital da Biblioteca Nacional do período de 1862, ano de lançamento da peça, até 1885, ano final do recorte temporal desta pesquisa, mostrou temporadas ou apresentações únicas da peça Tipos da atualidade no Rio de Janeiro, São Paulo, Campinas e Curitiba.

13 Jornal Dezenove de Dezembro (PR) de 20 jun. 1877, p. 3, adendo meu.
} 
GASPARINO - E como tem achado Vossa Excelência o Rio de Janeiro?

BARÃO - Para falar com franqueza prefiro viver em São Paulo. Aqui vive um homem constrangido, e constantemente a suar: olhe, ontem mudei três camisas, e assim mesmo ainda suava como um alambique de engenho! Lá no meu sítio da Cutia, aquilo sim, é que era viver; não andava metido numa casaca de pano preto, como estou agora: com o meu chapéu de palha, o meu paletó branco, e as minhas calças de enfiar, percorria aquilo tudo, como se estivesse em minha casa. Não há nada que pague a minha comodidade. Não tinha distrações, é verdade; mas quando queria divertir-me, montava na minha burra branca, e ia a São Paulo. [...]

D. ANA (à parte) - Um Barão... Viúvo e um dos mais ricos fazendeiros da Província... (Alto) A fazenda de Vossa Excelência é mesmo na Cutia?

BARÃO - Tenho duas, minha senhora, uma em Itu, e outra em Porto-Feliz, e além do sítio da Cutia, tenho outra no Senhor Bom-Jesus de Pirapora, onde vou todos os anos passar a festa. O lugar da minha residência é na Cutia, onde sou o eleitor mais votado, e prefiro-o por ser mais perto de São Paulo. (FRANÇA JUNIOR in MENDES, 2014, p. 353-354).

O Barão representa um homem abastado e influente de um lugar simples, rústico. Prefere uma besta a uma égua de raça nobre ${ }^{14}$, prefere roupas simples, de roça, a roupas formais comuns na Corte. O personagem retrata o rico, representa um segmento da sociedade, mas, apesar de haver na real Vila de Cotia indivíduos como o Barão, com posses e influência política, dados que vou apresentar ao longo deste trabalho mostram que na sociedade cotiana daquele período, caracterizada pela ruralidade, predominavam pequenos roceiros com produção agrícola voltada para a subsistência, para o mercado interno e, em menor quantidade, para o abastecimento da Capital.

Considerando essas características e refletindo sobre a história da educação, cabe assinalar que compreender o processo de escolarização brasileira no século XIX necessariamente requer do pesquisador um olhar plural sobre o significado do que viria a ser escola pública e quais as condições para seu estabelecimento nos diversos rincões do Brasil. No caso de São Paulo, particularmente na segunda metade do Oitocentos, a Província apresentava características de uma urbanidade incipiente na Capital, porém na sua maior parte - incluindo regiões da própria Capital - a sociedade era rural. Entretanto, essa ruralidade tinha feições diferenciadas dependendo das regiões e/ou municípios.

O geógrafo Pasquale Petrone $\left(1995^{15}\right)$ denominou de cinturão caipira a área ao redor da Capital de São Paulo, formada especialmente a partir da segunda metade do século XIX. Utilizando-se de uma extensa quantidade de documentos históricos, sua tese foi de que esse cinturão pode ser explicado pela presença dos aldeamentos localizados na região na época colonial, sendo os caipiras formados, em grande parte, por mestiços com ascendência

\footnotetext{
${ }^{14}$ Os muares eram mais usados pelos caipiras e tropeiros do que os equinos devido à sua força.

${ }^{15}$ Publicação em livro da tese de livre-docência apresentada no Departamento de Geografia da Universidade de São Paulo em 1964.
} 
indígena (p. 374). Segundo o autor, desenvolveu-se um "cinturão de terras pobres dos arredores do aglomerado" da Capital com "uma agricultura dominante de subsistência, caracterizada pelo sistema de roças" (p. 371) e com "muitos elementos que em grande parte poderiam ser explicados pela presença pretérita dos aldeamentos” (p. 16). Para Petrone:

Durante um século, caipiras marcaram a paisagem cultural dos arredores de São Paulo, seus contatos com a metrópole sendo feitos à custa de uma atividade comercial modesta: utilizando cargueiros isolados, tropas pequenas, ou carros de boi, levaram suas mercadorias para a cidade e contribuíram para criar um capítulo pitoresco que então caracterizou alguns ângulos metropolitanos [...]. (PETRONE, 1995, p. 375, grifo do autor).

Em mapa relativo ao século XIX desenvolvido pelo autor, assinalou Cotia e Caucaia (naquele momento, um bairro de Cotia) como dois dos principais núcleos caipiras dos arredores de São Paulo. Carapicuíba, que nesse período pertencia a Cotia, foi registrada no mapa como um aldeamento ${ }^{16}$, no entanto, também apresentava características caipiras, segundo o autor. Abaixo, segue o mapa com círculos em azul feitos por mim ao redor da localização de Cotia, Caucaia e Carapicuíba:

\footnotetext{
${ }^{16}$ Carapicuíba, inclusive, faz parte do recorte espacial da pesquisa de Petrone, junto com Pinheiros, São Miguel, Barueri, Guarulhos, Embu, Escada, Itaquaquecetuba, Itapecerica, São José, Peruíbe e Queluz.
} 


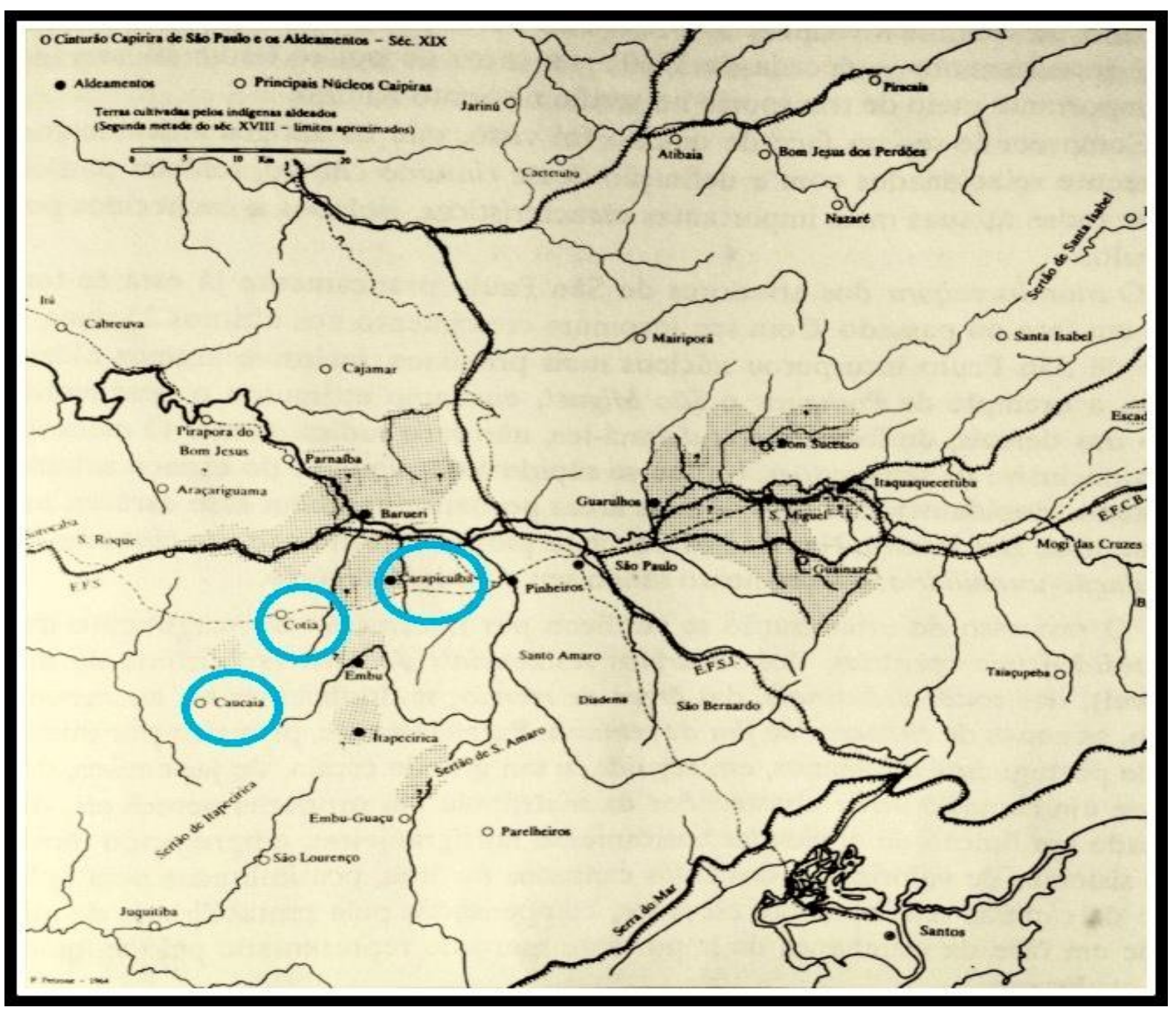

Ilustração 1 - Mapa d'O cinturão caipira de São Paulo e os aldeamentos - Século XIX (Fonte: Petrone, 1995, p. 377).

Ao estudar a formação da Grande São Paulo, Langenbuch (1971) apontou quatro categorias que caracterizaram a produção econômica dos municípios do cinturão caipira, identificadas a partir dos "destinos da produção": 1) havia aqueles cujos destinos da produção eram para exportação; 2) outros para o autoconsumo dos produtores ("culturas de subsistência”), 3) para o abastecimento da cidade de São Paulo e 4) para a manutenção e abastecimento das tropas em animais e gêneros alimentícios (1971, p. 21-22).

As economias caracterizadas, sobretudo nos itens 2, 3 e 4 acima citados, faziam parte da cultura caipira. Antonio Candido em Os parceiros do Rio Bonito: estudo sobre o caipira paulista e a transformação dos seus meios de vida (2001a) ${ }^{17}$ assinalou que a expressão cultura (e sociedade) rústica se distingue pelo "universo das culturas tradicionais do homem

\footnotetext{
${ }^{17}$ Publicação em livro da tese de doutorado apresentada no Departamento de Sociologia da Universidade de São Paulo em 1954.
} 
do campo; as que resultaram do ajustamento do colonizador português ao Novo Mundo", o que implica "em constante incorporação e reinterpretação de traços, que vão se alterando ao longo do contínuo rural-urbano" (CANDIDO, 2001a, p. 26); e a cultura (e sociedade) caipira engloba essa característica da cultura rústica, mas se restringe ao universo particular paulista ${ }^{18}$ (p. 28).

O homem caipira "é o morador do campo que vive numa sociedade relativamente homogênea, com valores tradicionais muito marcados, fruto da evolução histórica do grupo social radicado em São Paulo" (CANDIDO, 2001b ${ }^{19}$ ), mistura do branco com índio posteriormente com a assimilação do negro, que se "acaipirou". Esse homem miscigenado, o caboclo, adquiriu características de nomadismo e isolamento do bandeirante, além de hábitos indígenas ligados à alimentação, por exemplo.

Para traçar um panorama histórico da cultura caipira, Candido (2001a) utilizou como fontes documentos de viajantes do século XVIII e início do XIX que apresentavam dados sobre a vida caipira e também fez longas entrevistas entre os anos de 1940 e 1950 com "velhos caipiras de lugares isolados, a fim de alcançar por meio deles como era o "tempo dos antigos" (p. 23). Assim, "combinando ambos, foi possível em muitos casos obter coincidências que asseguram a validade da reconstituição" (p. 23). Os anos a que se referem os entrevistados de Candido ao remontar o passado de seus ancestrais se ancoram no século XIX, sobretudo na segunda metade, período que abordo nesta pesquisa.

A principal base territorial dos caipiras eram os bairros. Para compreender o significado do termo bairro no período estudado, Candido (2001a) apoiou-se em variados dicionários de época, além das fontes já citadas no parágrafo anterior. Dessa forma, para abranger a diferença entre vila e bairro numa sociedade caipira, o autor apresentou as seguintes definições, as quais uso neste trabalho: enquanto a vila era a "sede da administração e da paróquia e cabeça de todo o território, quase sempre vasto" (p. 81), o bairro era a:

\footnotetext{
estrutura fundamental da sociabilidade caipira, consistindo no agrupamento de algumas ou muitas famílias, mais ou menos vinculadas pelo sentimento de localidade, pela convivência, pelas práticas de auxílio mútuo e pelas atividades lúdico-religiosas. As habitações podem estar próximas umas das outras, sugerindo por vezes, um esboço de povoado ralo; e podem estar de tal modo afastadas que o observador muitas vezes não discerne, nas casas isoladas que topa a certos intervalos, a unidade que as congrega (CANDIDO, 2001a, p. 81).
}

\footnotetext{
18 Segundo Candido (2001a e 2001b), o território paulista nesse caso abrange, aproximadamente, a região chamada de Paulistânia pelo historiador Alfredo Ellis Junior, composta pela extensa área de influência bandeirista: São Paulo, parte de Minas Gerais, Paraná, Goiás e Mato Grosso, com a área afim do Rio de Janeiro rural e do Espírito Santo.

${ }^{19}$ Entrevista concedida por Antonio Candido, Vídeo Intérpretes do Brasil (2001b).
} 
Economicamente, era um sistema autossuficiente (2001a, p. 75), e socialmente, indicava formas de sociabilidade como solidariedade, cooperação, mutirões de trabalho, festas religiosas etc., desenvolvidas em função das formas dispersas de povoamento (p. 77). O bairro rural se constituía de uma "porção de terra a que os moradores têm [tinham] consciência de pertencer, formando uma certa unidade diferente das outras" (p. 84, adendo meu). Para um caipira perguntado por Candido: "bairro é uma naçãozinha” (p. 84).

Antonio Candido (2001a, p. 81) assinalou que em São Paulo os grupos rurais de vizinhança eram chamados de bairro e que entre os moradores dos bairros havia os proprietários de terras (sitiantes e fazendeiros, que eram os moradores permanentes) e os que não eram proprietários de terras (cultivadores nômades, agregados ou posseiros, portanto moradores transitórios). Sitiantes, posseiros e agregados determinavam "a economia paulista de subsistência e a vida caracterizada pela sociabilidade dos bairros" (p. 104), na qual o fazendeiro era em geral participante, mas nem sempre integrante. Esse muitas vezes era do mesmo tronco familiar dos menos abastados que, segundo o autor, diferenciava-se também por ter escravos, já os sitiantes trabalhavam por si nas terras. Todavia, no caso de Cotia, havia a ocorrência de roceiros e sitiantes donos de escravos, que com estes trabalhavam na terra (WISSENBACH, 1998; SCHLEUMER, 1999).

Candido (2001a) estudou a cultura caipira da região do município de Bofete (antes denominado Rio Bonito), localizado na região Centro-Oeste de São Paulo e alguns municípios ao redor. Bofete se desenvolveu demograficamente a partir do século XIX e, como Cotia, também era caminho de tropeiros. Apesar de Cotia não fazer parte da área estudada por Candido, também fazia parte da expansão a Oeste, era um dos "postos avançados da Vila de São Paulo de Piratininga, no rumo de Oeste e de Sudoeste” (COSTA, 1958, p. 132). Além disso, nas listas de matrícula localizadas, havia indivíduos com relação próxima a Tatuí (há uma estreita relação entre Bofete e Tatuí ${ }^{20}$ ) e dados coligidos pela pesquisa apresentam características semelhantes entre os moradores dos bairros de Bofete e de Cotia, as características caipiras, apontadas ao longo desta dissertação, sobretudo neste capítulo e no próximo.

Abaixo, segue mapa de 1884 com traçados em azul feitos por mim ao redor da localização de Rio Bonito (Bofete), Tatuí e Cotia, para melhor visualização das regiões em

\footnotetext{
${ }^{20}$ Antes de tornar-se município, parte de Bofete integrava-se a Tatuí. Uma das hipóteses da pesquisa de Candido era de que Bofete compreendia "um município de certo modo marginal, participando da tradição caipira representada por Tatuí, bem como de algumas características das áreas do café, representadas por Botucatu" (CANDIDO, 2001a, p. 127).
} 
questão. A distância atual entre Cotia e Bofete é de um pouco mais de 170 quilômetros, e entre Cotia e Tatuí, um pouco mais de 120 quilômetros.

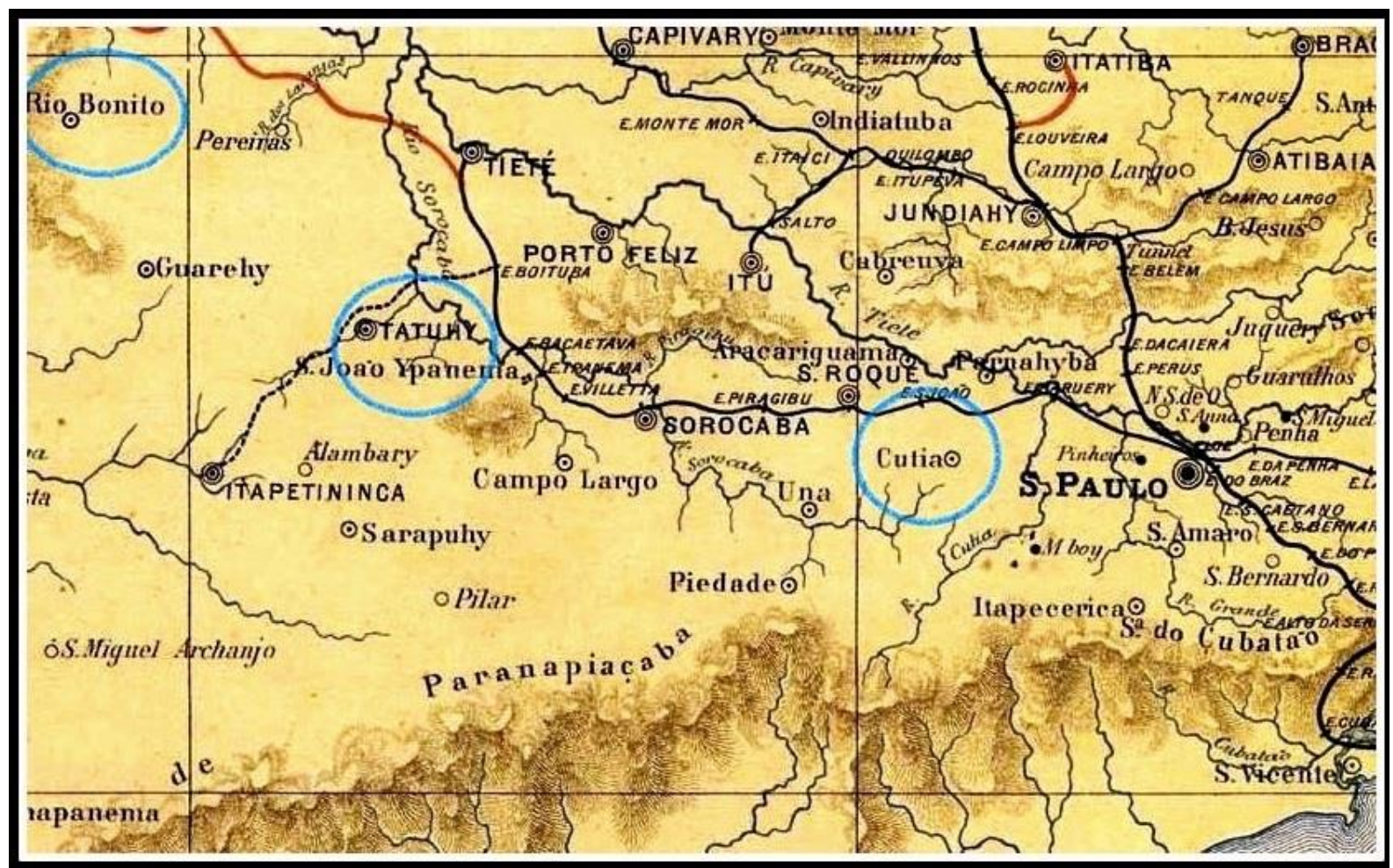

Ilustração 2 - Mapa das localizações de Rio Bonito (Bofete), Tatuí e Cotia em 1884 (Fonte: LISBOA, 1884. Traçados circulares em azul feitos por mim).

A partir dessas considerações, neste capítulo procuro trazer dados da história de Cotia desde sua fundação durante o período colonial, mas sobretudo do período a que se refere esta pesquisa, de 1870 a 1885, haja vista que a compreensão da configuração local proporcionará subsídios para o entendimento do processo de escolarização da Vila de Cotia.

\subsection{O local e seus antecedentes}

De acordo com Candido (2001a), as cidades paulistas via de regra se formaram passando pelas seguintes fases de "evolução": 1. Existência de moradores segregados em determinado local, 2. Ereção de capela e atração de casas por perto, 3. Elevação a freguesia, 4. Elevação a vila, 5. Elevação a cidade. "A população rural ia-se ampliando na periferia, onde apareciam novos bairros, que passavam a vila, e assim sucessivamente, sertão adentro.” (p. 
100). Como veremos a seguir, apesar da capela inicial ter sido transferida de lugar, Cotia fez parte dessa "regra".

Há diferentes versões sobre a origem do nome do município. Derivado do guarani Koty, significa ponto de encontro, em decorrência de sua localização estratégica no encontro de caminhos indígenas (BARCELLOS, 2011, p. 14); outras versões ligam seu nome ao tupi Akuti, Kuti, significando desde morada, casa; barco, canoa (por ser uma região com rios, riachos e ribeirões). Mas a versão mais conhecida remete o nome do município às cutias, mamíferos roedores da família dos dasiproctídeos, muito presentes no local na época da colonização. Acredita-se que o nome esteja ligado à sinuosidade característica da estrada à margem de onde o povoado foi fundado, "lembrando os rastros que o animalzinho cutia costuma deixar atrás de si” (SQUEFF; FERREIRA, 2003, p. 94).

Segundo Emilia Viotti da Costa (1958, p. 132), no princípio da colonização, Cotia era habitada pelos índios Guaianás. Os colonizadores portugueses começaram a se estabelecer nessa região a partir do final do século XVI e no século XVII os jesuítas fundaram aldeamentos indígenas (COSTA, 1958, p. 132; PRADO; CAMPOS; DUARTE, 2004, p. 252). Localizados próximos de Cotia estavam os grandes aldeamentos de Pinheiros, Barueri, Carapicuíba e Embu ${ }^{21}$, e para Cotia seguiam índios fugidos dessas aldeias (SILVA, 1995, p. 114).

A fundação do povoado de Cotia deu-se no século XVII ${ }^{22}$ na capela dedicada a Nossa Senhora do Monte Serrat, num local chamado Caiapiá, no sertão carapicuibano. Seus fundadores foram Fernão Dias Paes e Gaspar de Godói Moreira, proprietários de terras na época (sesmeiros). Nesse século, Cotia fazia parte da zona de produção de trigo (HOLANDA, 2000, p. 175; MONTEIRO, 1994, p. 142), utilizando mão de obra indígena. Segundo John Monteiro (1994, p. 142-143), protestos de colonos locais em 1633 contra o monopólio jesuítico sobre terras de Cotia e de Carapicuíba e sobre os cativos indígenas tiveram grande influência na expulsão desses padres de São Paulo em 1640.

O traçado geográfico de Cotia favorecia o trânsito dos índios e posteriormente dos bandeirantes $^{23}$, pois por ali passava o Caminho de Peabiru (COSTA, 1958, p. 132-133), posteriormente chamado pelos jesuítas de Caminho de São Tomé. A via de passagem para

\footnotetext{
${ }^{21}$ Sobre eles ver Petrone (1995) e Monteiro (1994).

${ }^{22}$ Não há consenso sobre a data de fundação devido à ausência de documentação, mas deu-se entre 1640 e 1670.

${ }^{23}$ Do período colonial, há exemplares de casas bandeiristas tombadas pelo Instituto de Patrimônio Histórico e Artístico Nacional (IPHAN): o sítio do Padre Inácio (morada primeira de Roque Soares de Medela, juiz de órfãos), localizado no Bairro da Graça, e o Sitio do Mandu, no Caiapiá, próximo ao local da primitiva capela de Cotia. Atualmente essas casas estão abertas para visitação. Sobre elas, ver Brasil-IPHAN/MinC (1996); BrasilIPHAN/MinC (1997); Galvão (2010).
} 
outras localidades foi uma das gêneses da expansão territorial e demográfica brasileira. Segundo Sérgio Buarque de Holanda,

De São Paulo, ou melhor, dos antigos bairros paulistanos de Parnaíba, Pinheiros e Cotia, saiu a maior parte dos povoadores antigos de Sorocaba, assim como de Sorocaba (e de Itu) provém o principal contingente dos habitantes do arraial de Bom Jesus do Cuiabá [...] (HOLANDA, 1994, p. 255).

Em $1703^{24}$ foi aberta a segunda capela ${ }^{25}$ de Cotia, fundada pelo Coronel Estevão Lopes de Camargo ${ }^{26}$ e pelo padre Matheus de Laya ${ }^{27}$ Leão (SILVA, 1937, p. 45-47), transferida do local original "por conveniência de seus moradores" 28 para um lugar situado mais próximo do caminho de Peabiru/São Tomé. Para Costa (1958), “compreenderam os homens do tempo que maiores possibilidades de desenvolvimento encontrariam o povoado junto ao Caminho de São Tomé. E assim aconteceu, pois ali passavam as tropas de burros que procediam de Sorocaba e do Sul do país” (p. 140). Dessa forma, a partir do século XVIII, Cotia passou a desempenhar a função de pouso de tropeiros durante o chamado ciclo do muar (ELLIS JUNIOR, 1950). As tropas de muares e equinos advindas da região Sul do Brasil, do Uruguai e da Argentina dirigiam-se a Sorocaba, onde aconteciam as feiras de animais e de onde saíam os tropeiros e as tropas rumo a São Paulo, Rio de Janeiro e Minas Gerais, principalmente. Os tropeiros, além de animais, transportavam produtos diversos.

Segundo Lemos (1972), em decorrência da função de pouso de tropeiros, criou-se em Cotia um comércio de prestação de serviços a essa população flutuante: "venda e aluguel de animais de carga ou de montaria, hospedagem para pernoite de viajantes, fornecimento de

\footnotetext{
${ }^{24}$ Utilizo esta data, apesar de muitos autores mencionarem 1713. Segundo Silva (1937, p. 45-47) foi um equívoco de Azevedo Marques colocar em seus Apontamentos o ano de 1713 (que provovou a reprodução dessa data por outros estudiosos), pois no documento original da Igreja Católica, o Termo de posse do Pe. Matheus de Laya, está o ano de 1703.

${ }^{25}$ Distante uma légua, mais ou menos seis quilômetros da primeira capela, onde hoje está situada a Igreja Matriz, no Centro da cidade.

${ }^{26}$ Membro da família Camargo, família castelhana que dominava o cenário político e econômico de São Paulo nos séculos XVII e XVIII e que protagonizou uma guerra contra os Pires, portugueses, desde meados do século XVII: "A ascensão dos Camargo para uma posição hegemônica [no controle da maior parte da população indígena do termo de São Paulo] foi certamente um dos eventos de maior significado na São Paulo seiscentista. A luta contra os Pires trouxe à luz uma série de conflitos e pontos de pressão que afligiam o Planalto em meados do século, entre as quais predominaram a questão da mão-de-obra indígena, a expulsão dos jesuítas e o problema do controle social sobre uma vasta população cativa. De fato, a produção comercial de trigo e o crescimento de grandes posses de índios cativos haviam concentrado parte desproporcional da riqueza nas mãos de poucas famílias, sobretudo os Pires e Camargo, que se digladiaram por boa parte do século XVII" (MONTEIRO, 1994, p. 200, adendo meu). As famílias Pires e Camargo tiveram e ainda têm uma grande importância no cenário político e econômico de Cotia, juntamente com as famílias Pedroso e Leite.

${ }^{27}$ Lara, para alguns autores. Silva (1937, p. 45-47) também apontou o equívoco de muitos autores, pois, segundo ele, a grafia que está no documento é Laya.

${ }^{28}$ Segundo o Termo de posse do Pe. Matheus de Laya de 9 set. 1703 (documento integral transcrito do original). In: Silva (1937, p. 96).
} 
víveres e alimentação para os animais, e ainda, recrutamento de população para tropeiros", assinalando a autora ser muito possível a existência de oficinas e fábricas artesanais para ferrar os animais e consertar arreios (LEMOS, 1972, p. 41). Ranchos e casas de pousos serviam de hospedagem para tropeiros e seus animais. Segundo Candido (2001a), os caipiras também costumavam chamar suas casas de ranchos:

A sua casa (significativamente chamada rancho por ele próprio, como querendo exprimir o seu caráter de pouso) é um abrigo de palha, sobre paredes de pau-a-pique, ou mesmo varas não bareadas, levemente pousado no solo (CANDIDO, 2001a, p. 48).

Em 1723, Cotia foi elevada à categoria de Freguesia, tornou-se um dos locais mais populosos de São Paulo (BLAJ, 2002, p. 264) e de moradia de alguns comerciantes influentes, como membros da então poderosa família Camargo, segundo dados do artigo Laços familiares e aspectos materiais da dinâmica mercantil na cidade de São Paulo (séculos XVIII e XIX) de Maria Borrego (2010). Em 1766, Cotia tinha 1.735 habitantes enquanto que a cidade de São Paulo tinha 3.828:

Sobrepujando, nesse particular, muitas outras localidades, como Santo Amaro, São Vicente, Iguape, Ubatuba, Mogi das Cruzes, Guarulhos, Jundiaí, Bragança e Juqueri. A região continuava a produzir cereais e lenha, contava com algumas cabeças de gado e dispunha de engenhos de açúcar, farinha de mandioca e fubá (COSTA, 1958, p. 133).

O aumento populacional muito possivelmente teve relação com o tropeirismo, que foi intensamente presente até pouco depois da metade do século XIX. Ao longo do século XVIII também foram criadas irmandades católicas ${ }^{29}$.

Contudo, dentro de um cenário no qual a Capital paulista ainda não possuía muita importância econômica para o Brasil, segundo o relato do viajante Manuel Cardoso de Abreu, em 1783, "[eram] muito miseráveis os moradores das freguesias da Cutia, S. Roque, Santo Amaro e outras aldeias dos subúrbios desta cidade" (ABREU apud MOTA, 1941, p. 174). Corrobora esta afirmação a pesquisa de Fabiana Schleumer (1999) que, investigando a vida familiar de escravos e libertos em Cotia colonial entre 1790 e 1810, a partir de listas

\footnotetext{
${ }^{29}$ Segundo Pe. Daniel Balzan (s/d) em pesquisa em documentos da Cúria Metropolitana (Tombo de Cotia dos séculos XVIII e XIX) havia a Irmandade do Santíssimo Sacramento, a Irmandade de Nossa Senhora do Rosário dos Pretos e a Irmandade de Nossa Senhora da Conceição dos homens pardos. Disponível em <http://www.portalviva.com.br/index.php?option=com_content\&view=article\&id=4644\%3Aartigo-asirmandades-da-freguesia-de-cotia\&catid=46\%3Amarcos-martinez\&Itemid=31> Acesso em: 15 fev. 2015 e <http://www.cotiatododia.com.br/igreja-300-anos-sepultamentos-e-protetores/> Acesso em: 5 mai. 2015; Também ver Souza (s/d, p. 35 e 42).
} 
nominativas e registros paroquiais, verificou que em 1798 a economia local se caracterizava pela pobreza e era basicamente rural,

[...] voltada para o mercado interno e para o consumo de subsistência. A produção concentrava-se na produção de milho, feijão, mandioca, algodão, fumo, açúcar, bem como na fabricação de aguardente e na criação de potros, bestas e rezes, animais de condução. (SCHLEUMER, 1999, p.140).

Enfim, baseava-se na economia de policultura de subsistência (SCHLEUMER, 1999, p. 44). No século XVIII a produção de trigo não fazia parte da lavoura cotiana como fez no século XVII. Dados apresentados por Schleumer vão ao encontro do que Antonio Candido apontou como base da produção agrícola e alimentação do paulista rural, no qual o feijão, o milho, a mandioca "constituíam o triângulo básico da alimentação caipira, alterado mais tarde com a substituição da última pelo arroz" (CANDIDO, 2001a, p. 68).

Com relação à organização social, Schleumer (1999) apontou que apesar da economia cotiana não estar voltada para o mercado externo, favoreceu a existência de famílias de pessoas escravizadas e libertas. A posse de escravos era difundida entre a população, com destaque para religiosos, militares, mulheres e roceiros, todavia, era "uma sociedade não polarizada entre senhores e escravos" (p. 50), isto é, marcada principalmente pela inexistência de um intermediário na relação escravo-senhor. Os maços de população analisados por Schleumer apontaram que em 1808 os moradores de Cotia executavam diferentes atividades, eram agricultores, lavradores, gente que vivia de seus negócios, tropeiros, jornaleiros. Os tropeiros eram formados majoritariamente por brancos, já os jornaleiros e músicos, em sua maioria, por pardos e pretos. A autora verificou haver roceiros pardos,

[...] negros recém-egressos da escravidão vivendo em famílias, alguns gerenciando suas escravarias, outros imersos na vadiagem. (SCHLEUMER, 1999, p. 50).

$[\ldots]$

Dados indicam que a sociedade cotiana de fins do século XVIII permitia aos mulatos galgar a ascensão social não só pelo exercício da música, mas também como soldados. (SCHLEUMER, 1999, p. 280)

Em Cotia do início do século XIX, roceiros mantinham famílias de pessoas escravizadas em seus fogos, que indicariam a hipótese de "a família escrava [...] ser utilizada como uma forma de reprodução natural dos cativos", evidenciando "a pobreza em que viviam os proprietários rurais paulistas, detentores em sua maioria de poucos escravos, quando estes não eram inexistentes" (SCHLEUMER, 1999, p. 293). Assim, era possível "compreender a família escrava não somente como uma forma de resistência dos cativos perante os senhores, 
mas também como uma estratégia de dominação e de lucro dos segundos sobre os primeiros" (p. 305).

Maria Cristina Wissenbach (1998), ao estudar a vida de pessoas escravizadas e forras na Primeira Comarca de São Paulo (Cotia, inclusive) na segunda metade do XIX, também apontou que na zona rural e pobre dos arredores de São Paulo "a família escrava pode ter sido, em alguns momentos e para alguns senhores, uma forma de reprodução natural dos escravos" (p. 131).

Para Fabiana Schleumer,

A pobreza reinante em Cotia foi um fator de mobilidade tanto para a população branca quanto para a negra. No caso das famílias de libertos, estes estavam condicionados a outras variantes, distintas das referentes à família escrava, as dificuldades econômicas e a morte natural interferiram de forma significativa nas possibilidades de manutenção e reprodução destas famílias. [...]

A terra, ainda mais quando situada no ambiente rural, onde a pobreza era dominante, não deixou de ser um fator de mobilidade social (SCHLEUMER, 1999, p. 309-310).

A autora considerou que por Cotia estar "na contramão da História", pois a maior parte dos estudos volta-se para regiões de grande lavoura e exportadoras (e eu acrescentaria também as capitais), o estudo dessa sociedade possibilitou perceber que a família de pessoas escravizadas achava-se em todos os contextos socioeconômicos. Evidenciou ainda que as famílias pardas gerenciavam suas roças, havendo uma relativa mobilidade socioeconômica.

O universo socioeconômico cotiano era rico, detentor de elementos importantes para a compreensão do contexto colonial: havia músicos e soldados milicianos pardos, famílias escravas e forras estáveis, vadios que galgaram socialmente, mulheres brancas e pardas como proprietárias de cativos. Enfim, a especificidade de Cotia demonstra-se pela sua particularidade e pela diversidade de questões que suscita um estudo a região (SCHLEUMER, 1999, p. 305-306).

No que se refere à paisagem geográfica local, em meados do Oitocentos, José Bonifácio de Andrada e Silva e seu irmão Martim Francisco passaram por Cotia no final da primeira metade do XIX e relataram que ali o cenário se fazia em parte com capoeiras e outra com matas virgens, onde se viam algumas casas espalhadas (SILVA; ANDRADA,1846, p. 31-32). Ainda nesse século, mais precisamente no ano de 1842, Cotia serviu de abrigo para 
acampamento das tropas lideradas por Diogo Feijó ${ }^{30}$ e pelo brigadeiro Tobias de Aguiar durante a Revolução Liberal, além da tropa de Caxias no Bairro de Várzea-Grande ${ }^{31}$.

No século XIX, Cotia entrou num processo de relativa decadência (relativa, pois, sua economia tinha uma modesta participação comercial na Província) devido ao que tudo indica à diminuição do tráfego de tropeiros, sobretudo a partir da construção das vias férreas na segunda metade do século: "O último lampejo de seus melhores dias teve lugar na década de 1850-60, pois em abril de 1856, Cotia foi elevada à categoria de vila ${ }^{32}$. Depois disso, regrediu sempre e assim continuou até a primeira vintena do século atual [XX]" (COSTA, 1958, p. 141, nota e adendo meus). Curiosamente, Cotia teve duas estações (Estação São João e Parada/Estação Cotia) inauguradas em 1875, mas localizadas distantes da Vila, que são objeto de análise no próximo item.

\subsection{Cotia entre 1870 e 1885}

O período no qual Cotia apresentava linear declínio econômico coincide com a intensificação da criação de escolas e do processo de escolarização, em expansão em todo o território provincial ${ }^{33}$.

Como mencionado na introdução, no recorte temporal desta pesquisa, a Vila de Cotia compreendia os territórios dos atuais municípios de Cotia, Itapevi, Vargem Grande Paulista, Jandira e parte de Embu das Artes e de Carapicuíba (IGC-SP, 1995), todos pertencentes hoje em dia à Região Metropolitana de São Paulo; e também da Capital, pois fazia divisa com esta na região do córrego Jaguarahé, hoje localizado no distrito paulistano de Jaguaré (Relatório apresentado ao Exmo. Presidente da Próvíncia de São Paulo,1888; PINTO, 1900). Abaixo, segue o detalhe do mapa da Província de São Paulo de $1884^{34}$ com o traçado aproximado do que correspondia à área territorial da Vila de Cotia entre 1870 e $1885^{35}$.

\footnotetext{
${ }^{30}$ Há alguns biógrafos que atribuíram à Cotia o local de nascimento e de parte inicial da vida de Feijó. Ver Daunt (1945); Talassi (1949); Fleury (1967); Ver estudo sobre Feijó que assinala haver biógrafos que atribuem à Cotia local de parte inicial de sua vida: Ricci (2001).

${ }^{31}$ Jornal Correio Paulistano de 17 jun. 1882, p. 1: Nota do lembrou que o Barão de Caxias acampou em Vargem Grande em 1842, "entre a villa da Cutia e a cidade de S. Roque".

${ }^{32}$ Sua emancipação data de 2 de abril de 1856 (Lei Provincial nº7/1856).

${ }^{33}$ Hilsdorf (1977 e 2002), Almeida (2000), Giglio (2001), Bontempi Jr (2004), Marcilio (2005), Barra (2005), Gallego (2008).

${ }^{34}$ Devido à dificuldade em encontrar um mapa do local referente ao período estudado, utilizo o mapa de LISBOA, Joaquim Miguel Ribeiro. Mappa da província de São Paulo: Organisado no Escriptorio Tecnico da Companhia Mogyana sob a direcção do engenheiro em chefe. Rio de Janeiro: Lith. Paulo Robin, 1884. 1 mapa, col., 51,5 


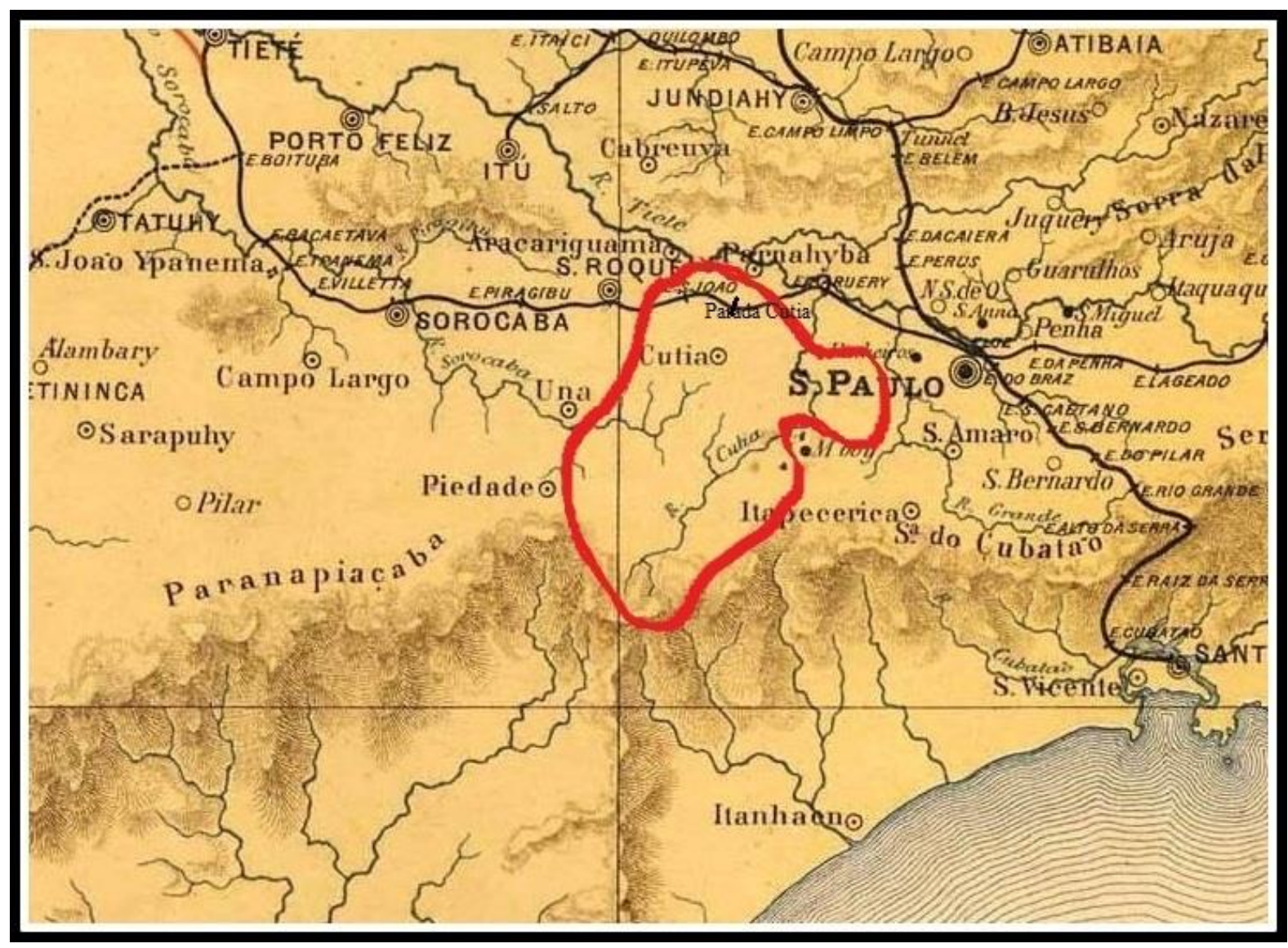

Ilustração 3 - Mapa da área da Vila de Cotia entre 1870-1885 (Fonte: LISBOA, 1884; SEADE, s/d. Traçado e indicação do local da Parada Cotia feitos por mim).

Até 1873, Cotia pertencia ao termo da Capital $^{36}$, mas em abril desse ano, a administração pública do município apresentou à Assembleia um pedido para fazer parte do termo de São Roque, visto que este município ficava mais próximo da Vila em comparação à

<http://objdigital.bn.br/objdigital2/acervo_digital/div_cartografia/cart515157/cart515157.jpg>. Acesso em: 8 abr. 2015. Este foi o mapa que mais se aproximou de nossas expectativas e que trouxe mais detalhes da região estudada, além disso, refere-se ao ano de 1884, portanto, dentro do recorte temporal desta pesquisa. Para traçar (em vermelho) o limite geográfico da Vila de Cotia referente a 1870-1885, respaldei-me no mapa Fundação Sistema Estadual de Análise de Dados (SEADE). Memória das Estatísticas Demográficas - Mapas: Divisão Político administrativa $1900 . \quad$ S/d. $\quad$ Disponível em: <http://www.seade.gov.br/produtos/500anos/index.php?tip=esta>. Acesso em: 29 abr. 2015. Também tracei no mapa (em preto) a localização da Parada/Estação Cotia, criada em 1875.

${ }^{35}$ Segundo o Relatório apresentado ao Exmo. Presidente da Próvíncia de São Paulo de 1888, as divisas de Cotia se estabeleciam da seguinte forma: "Ao norte confina este município com os de Parnahyba e Araçariguama, correndo as divisas pela antiga estrada de Ytú; a leste e sul com a Freguesia de Santa Iphigenia, capital, e com os municípios de Santo Amaro e Itapecerica, correndo as divisas pelos ribeirões Jaguarahe e Pirajussara, ribeirão da Ressaca e estrada do mesmo nome; a oeste com o município de São Roque, confinando também a sul e a oeste com os de Una, pelo rio Sorocamirim (vide leis provinciaes de $1^{\circ}$ de abril de 1865 e 10 de abril de 1872)" (1888, p. 361-362, grifos dos autores). Até 1888 as demarcações permaneceram as mesmas do recorte desta pesquisa.

${ }^{36}$ Jornal Diário de São Paulo de 28 mar. 1872, p. 2: Cotia pertence ao termo da Capital, $3^{\circ}$ distrito juntamente com a Paróquia Nossa Sra da Consolação, Santo Amaro e Itapecerica. 
Capital $^{37}$. No Almanak da Província de São Paulo para 1873, Cotia ainda consta como pertencente ao termo da Capital. Em junho, sob a Lei número 62, Cotia passou a pertencer ao termo de São Roque ${ }^{38}$, no entanto, desde o início dos anos de 1880, representantes de moradores de Cotia e da Câmara municipal passaram a requerer novamente o pertencimento de Cotia ao termo da Capital $^{39}$. Em 1885 ainda tramitava na Assembleia a discussão sobre seu retorno ao termo de São Paulo ${ }^{40}$, voltando efetivamente para este termo apenas em $1889^{41}$.

Por ser um município paulista e por não ter um destaque de âmbito nacional, a maior parte das notícias referentes à Vila de Cotia estava presente nos periódicos da mesma Província $^{42}$. As notícias de jornais de outras Províncias como Rio de Janeiro, Pernambuco, Maranhão, entre outras, diziam respeito principalmente à construção da Sorocabana no trecho de Cotia (estações e ramal até a Vila), incluindo a passagem do Imperador em visita às obras, ou assuntos relacionados a tragédias ou curiosidades ${ }^{43}$. Pelo conteúdo das notícias nos jornais de outras Províncias, e principalmente por serem bem esporádicas, ficou evidente a parca importância da Vila no cenário nacional.

\footnotetext{
37 Jornal Diário de São Paulo de 20 abr. 1873, p. 1: representação de um pedido de Cotia na Assembléia Provincial para fazer parte do termo de São Roque, alegando esta estar mais próxima a Cotia em comparação à Capital.

${ }^{38}$ Cotia passa a pertencer ao termo e comarca de São Roque, junto com Una e Piedade. Lei $\mathrm{n}^{\circ} 62$ de criação da Comarca de São Roque. Disponível em <http://www.al.sp.gov.br/repositorio/legislacao/lei/1873/lei-6215.04.1873.html> Acesso em: 20 out. 2014.

${ }^{39}$ Correio Paulistano de 27 jan. 1882, p. 2: discussão na Assembleia Provincial de 24 de janeiro do projeto 208 de 1881 sobre desanexação de Cotia a São Roque.

40 Correio Paulistano de 24 mar. 1885, p. 2: Primeira discussão do Projeto número 211 na Assembleia Provincial de 24 de março, referente à passagem da Vila de Cotia para a Comarca da Capital.

${ }^{41}$ Lei provincial no 91 de 1889. Disponível em <http://www.al.sp.gov.br/repositorio/legislacao/lei/1889/lei-9103.04.1889.html>, Acesso em: 20 abr. 2015.

${ }^{42}$ Como mencionado na Introdução deste trabalho, no levantamento realizado no banco de dados da Hemeroteca Digital da Biblioteca Nacional, cerca de 70\% dos jornais consultados eram de São Paulo, o restante de outras Províncias. Foi consultado algo em torno de 1.300 páginas com a palavra "Cotia" nos periódicos paulistas.

${ }^{43}$ Sobre política e economia: $O$ Globo (RJ) de setembro de 1875: visita do imperador a São Paulo, na qual foi às obras da Sorocabana e passou por Cotia; dezembro de 1875: notícia do cancelamento da construção do ramal de Cotia pela Sorocabana; Jornal de Recife de outubro de 1872: sobre matriculas de escravos, mencionava a Capital, Paranaíba e Cotia; março de 1874: notícia sobre a substituição do ramal pela estrada de rodagem em Cotia; outubro de 1874: Conde d'Eu, Conde de Barral, Presidente da Província e outros foram da Estação da Luz de trem até ponte da Cutia ver as obras da Sorocabana; janeiro de 1878: visita do reverendo Bispo diocesano às igrejas de Cotia, Una e S Roque; agosto de 1878: vitória dos conservadores em algumas paróquias, entre elas, Cotia; Diário do Rio de Janeiro de setembro de 1872: fornecimento de dormentes da Sorocabana para construção da linha entre São João e Rio Cotia; janeiro de 1878: visita de bispo paulistano a Cotia; entre outras.

Sobre o cotidiano (tragédias ou curiosidades): Jornal de Recife de janeiro de 1880: na Vila de Cotia se matou um pássaro enorme que não sabiam o nome; Gazeta de Notícias (RJ) de fevereiro de 1881: falecimento do exprofessor Antonio Bandeira Barreto; Gazeta de Notícias (RJ), Diário do Brasil (RJ) e Jornal de Recife de outubro de 1882: assassinato de um homem na Vila de Cotia por sua esposa no Bairro da Graça; Gazeta de Notícias (RJ) e Gazeta da Tarde (RJ) de dezembro de 1883: suicídio de um órfão de Araçariguama cujo tutor estava em Cotia e o pediu para que fosse até lá, mas o menino se matou antes de ir; Diário de Belém e Pacotilha (MA) de agosto de 1885: mulher curandeira no Bairro do Caputera, em Cotia, é ridicularizada pelos jornais por sua "medicina"; Jornal de Recife de novembro de 1885: assassinado um homem chamado Manoel Nunes de Almeida em Vendinha, no Bairro dos Pereiras, em Cotia; entre outras.
} 
Nos periódicos paulistas, ao longo desses 15 anos, eram comuns notas sobre os dias em que se fechavam as malas de expedição de correio para Cotia e outros municípios, sobre o envio de verba para reforma, manutenção da estrada da Capital a Sorocaba no trecho entre Cotia e São Paulo e para o pagamento de funcionários que trabalhavam na estrada. Apesar de algumas reformas, eram comuns notas de particulares reclamando do estado da estrada e dos responsáveis por sua manutenção ${ }^{44}$. Com menor frequência nos jornais, notas indicavam também as condições precárias do trecho da estrada que ligava Sorocaba a Cotia, principalmente na década de $1870^{45}$. A estrada que ligava a Capital à Sorocaba (com percurso próximo ao da atual Rodovia Raposo Tavares, cuja chegada a São Paulo tinha uma parada em Pinheiros ${ }^{46}$ ) era a principal via que cortava a Vila de Cotia, mas havia outra importante via de ligação que fazia parte do ciclo do muar: a que vinha de Una (atual Ibiúna) e se entroncava com a estrada para Sorocaba (hoje é a Rodovia Bunjiro Nakao, que se liga à Raposo Tavares na altura do $\mathrm{km} \mathrm{45).}$

Passavam pela estrada entre Cotia e São Paulo pessoas a pé, sobre animais, em carroças, tropeiros e suas tropas de muares e equinos, troiys ${ }^{47}$ que saíam da Capital para Sorocaba. Havia ainda outras estradas entre Cotia e outros lugares, como a que a ligava São Bernardo, passando por Santo Amaro ${ }^{48}$.

As demarcações das fronteiras com o município de Una eram às vezes veiculadas pelos jornais ${ }^{49}$, indicando alterações. Os reparos e/ou construção da cadeia, das pontes, da Igreja Matriz e da Igreja de Nossa Senhora da Penha, localizada na Vila e muito próxima à

\footnotetext{
${ }^{44}$ Jornal Correio Paulistano de 15 jan. 1873, p. 2: "Flauta Desafinada em Ré" questiona o inspetor de estrada José Joaquim Pedroso Junior sobre as condições da estrada Cotia; em 18 jan. 1873, p. 3: J. J. Pedroso Jr responde às ironias da "Flauta Desafinada em Ré" e diz que não tinha verba nem ordem para fazer a reforma; em 31 out. 1873, p. 3: reclamação de anônimo sobre as péssimas condições da estrada da Capital à Cotia.

7 jun. 1879, p. 3: nota apontando que a estrada de Cotia estava em péssimo estado; em 17 mar. 1880, p. 2: em Ata de Assembléia, requerimento de vários lavradores da Capital e de Cotia pedindo consignação de quota para consertos na estrada da Freguesia da Consolação até a Vila de Cotia.

${ }^{45}$ Jornal Diário de São Paulo de 4 mai. 1873, p. 3: nota particular sobre necessários reparos à estrada de São Roque a Cotia devido ao estrago por grande número de carros que por ali passavam.

46 A história do ponto comercial do Mercado e do Largo de Pinheiros está relacionada com a história da passagem de tropas pela estrada Cotia-São Paulo, pois esse ponto era lugar de parada dos tropeiros.

${ }^{47}$ Tipo de carroça/carro de cocheira; Jornal Correio Paulistano de 20 mar. 1873, p. 3: propaganda de viagem de troiys de São Paulo para Sorocaba, passando por Cotia (valor da Capital a Cotia: 10\$000).

48 Jornal Correio Paulistano de 1 mar. 1878, p. 2: rua de Santo Amaro, "muito povoada", é meio de comunicação para Cotia, Itapecerica e São Paulo; Jornal Diário de São Paulo de 7 ago. 1873, p. 1: reparo na estrada de São Bernardo a Cotia, que passava por Santo Amaro.

${ }^{49}$ Jornal Diário de São Paulo de 5 mai. 1872, p. 2: novas demarcações entre Cotia e Una (lei no 51 ); em 26 abr. 1874, p. 1: representação enviada à Assembléia Provincial dos moradores de Cotia pedindo alteração da divisa com Una; Jornal Correio Paulistano de 17 fev. 1883, p. 2: requerimento à Assembleia dos moradores de Sorocamirim e da Câmara de Cotia pedindo revogação da lei $\mathrm{n}^{\circ} 54$ de 1877 quanto à demarcação de fronteira entre Cotia e Una.
} 
Matriz, também eram noticiados esporadicamente ${ }^{50}$. As condições ruins da estrada e das pontes ocasionavam acidentes diversos, como por exemplo, o ocorrido em fevereiro de 1879, quando a ponte sobre o Rio Cotia caiu, distante uma légua (em torno de seis quilômetros) da Vila, causando a morte de um tropeiro ${ }^{51}$.

Durante o século XIX, a economia cotiana voltava-se para subsistência, mas também para atender a Capital e para a manutenção e passagem de tropeiros, conforme características apontadas por Langenbuch (1971) ao descrever as atividades do cinturão caipira. Com base nos jornais, as principais produções de Cotia eram de cereais para a Capital e plantações diversas para consumo local $^{52}$, realizadas principalmente em sítios, e a criação de animais em fazendas de criar $^{53}$.

Segundo o Almanak da Província de São Paulo para 1873 (p. 145), as principais fazendas de Cotia produziam milho e feijão e criavam gado vacum e cavalar; segundo o Relatório apresentado ao Exmo. Sr. Presidente da Província de São Paulo de 1888 (p. 363), produzia-se milho, feijão, arroz, café, fumo e cana de açúcar, sendo a produção de café "diminuta", e "com a introdução de imigrantes italianos deu-se o início ao plantio de uva, de que já se fabrica algum vinho"; quanto à pecuária, mencionava-se a criação de gado bovino. Segundo o relatório da Estatistica Agricola e Zootechnica de Cotia no anno agricola de 19041905 (SÃO PAULO, 1907) plantava-se, sobretudo, milho, feijão, batata e marmelo, e um pouco de café, e criava-se gado cavalar, muar, lanígero, caprino, suíno e, principalmente, o vacum, e aves ${ }^{54}$. Além das informações de documentos estatísticos, os professores em seus relatórios mencionaram o trabalho rural muito presente no cotidiano dos pais e alunos.

Em 1873, o Almanak não informou o número de fazendas, estabelecimentos comerciais, de artes e indústria, mas os nomes das pessoas que estavam à frente desses afazeres, tendo, portanto, seis fazendeiros, duas em lojas de fazendas, oito negociantes de

\footnotetext{
50 Jornal Correio Paulistano de 17 fev. 1883, p. 2: Câmara de Cotia pedindo verba ao Presidente da Província pra construção de nova cadeia; em 13 jan. 1883, p. 1: aprovada pelo Presidente da Província verba para a obra da matriz; em 15 mar. 1883, p. 4: obras na Igreja Matriz foram financiadas com o dinheiro arrecadado na loteria provincial. A verba financiou também obras na Santa Casa de Misericórdia da Capital; 4 set. 1884, p. 4: loteria provincial em prol da reforma da Matriz de Cotia e Ubatuba.

${ }^{51}$ Jornal Correio Paulistano de 7 e 8 fev. 1879, p. 2.

${ }^{52}$ Nas Atas de Assembléia ao longo de 1871 a 1876 os deputados discutiram a importância da economia local e a viabilidade do gasto de dinheiro público para a construção do ramal que ligaria a Estação Cotia à Vila e comentaram da produção agrícola de Cotia.

53 Jornal Correio Paulistano de 4 out. 1870: furto de porcos da fazenda de criar de Barão de Iguape em Carapicuíba, Cotia; em 13 ago. 1873, p. 4: propaganda de cabras criadas em Cotia e vendidas na Capital; Jornal Diário de São Paulo de 5 out. 1870, p. 2: furto de porcos da fazenda de criar de Barão de Iguape, registrado na subdelegacia de Cotia em 29 de setembro.

${ }^{54}$ Esse documento, apesar de dizer respeito a um período posterior ao desta pesquisa, início do século XX, está sendo usado para ilustrar que os mesmos produtos eram cultivados em 30 anos, sendo incluída a batata e o marmelo. Este, entretanto, foi mencionado nas atas de Assembleia Provincial na primeira metade dos anos de 1870 como um dos produtos que Cotia cultivava e vendia a São Paulo, conforme relatado adiante neste capítulo.
} 
secos e molhados, oito em afazeres ligados a artes e indústria (alfaiates, carpinteiros, ferreiros, pedreiros, mestre de música e dono de padaria); já segundo Relatório de 1888, havia cinco fazendas, 15 comércios de secos e molhados e quatro engenhos. Estes últimos estabelecimentos não foram mencionados no Almanak.

Numa primeira análise, percebe-se uma diminuição de estabelecimentos, que pode estar atrelada ao relativo declínio econômico local, mas os documentos são de naturezas diferentes e os critérios de nomenclatura diversos, podendo ser falha a comparação entre os dois com relação a esses dados. Entretanto, é notório o número pequeno de fazendas/fazendeiros, para uma extensão grande de terras (por volta de $500 \mathrm{~km}^{2}$ ), principalmente se confrontados com outros estudos (WISSENBACH, 1998; SCHLEUMER, 1999) e outras fontes como atas de Assembléia Provincial, recenseamento provincial de 1886 e relatórios de professores e inspetores apresentados nos próximos capítulos, que assinalaram a ocorrência de grande número de roceiros.

Outros dados corroboram para essa afirmação. Segundo o Censo de 1872 da população total de 5.024 habitantes, 31,9\% (1.602 habitantes) eram lavradores, 23,7\% (1.096) realizavam serviços domésticos e 33,9\% (1.701) não tinham profissão (dados que devem ser usados com cautela devido aos erros e incongruências com os dados das paróquias, segundo RODARTE e SANTOS JÚNIOR, 2008). Cabe ponderar que números parecidos com os de Cotia eram comuns em vários municípios da Província em 1872, pois São Paulo e o Brasil caracterizavam-se pela ruralidade. No Censo não há distinção entre um município rural com a produção de monocultura voltada para o mercado externo e um com características de policultura voltada para o mercado interno e relativo abastecimento da Capital, porém, esses dados novamente combinados com outras fontes, além de estudos já mencionados acima, confirmam a ruralidade cotiana relacionada a pequenos roçados.

Infelizmente não há dados sobre as profissões no recenseamento provincial com dados coletados até 30 de setembro de 1886, presente no Relatório apresentado ao Exmo. Sr. Presidente da Província de São Paulo em 1888, mas o grande número de proprietários das casas que moravam indicam serem sobretudo roceiros. Nesse documento, havia 1.043 fogos ${ }^{55}$ em Cotia, sendo 92,7\% (967 fogos) com “Chefes de Família Proprietários da Casa que

\footnotetext{
${ }^{55}$ Segundo Fonseca (2007) é uma designação usada no século XIX próxima ao que chamamos de domicílio, mas "Diferentemente da ideia que tendemos a ter de domicílio, como espaço de moradia que comporta um grupo familiar, o fogo era um tipo de espaço de moradia que correspondia a um padrão específico de organização. No fogo podemos encontrar uma família ou várias e muitas vezes indivíduos que viviam juntos, mas não aparentavam possuir nenhuma relação de parentesco.

Neste espaço, sempre havia um indivíduo que era classificado como chefe e que vivia acompanhado de um conjunto de membros que podiam ser da sua família, mas também escravos e agregados; todo o conjunto destes indivíduos era contabilizado como pertencente ao fogo" (p. 62).
} 
Habitam" e 7,3\% (76 fogos) com chefes não proprietários, com média de 7,21 pessoas para cada fogo de uma população total de 7.517 habitantes (Relatório apresentado ao Exmo. Pres. da Província, 1888, p. 25; BASSANEZI et al., 1999, p. 55). Ainda, segundo o mesmo relatório, havia na Vila de Cotia 115 casas (p. 362), isto é, considerando que havia 1.043 fogos em Cotia, podemos afirmar que a maioria das casas situava-se fora da Vila. Portanto, a imensa maioria era propritária de terra e morava nos bairros, confirmando a característica roceira dos cotianos.

Os sítios dos roceiros eram pequenas propriedades, porções de terra que não necessariamente estavam distantes das vilas, mas que sobretudo se localizavam nos bairros. Os roceiros caipiras tinham o hábito de plantar a partir de queimadas e não aravam a terra. Colocavam fogo nas matas para plantar e depois de esgotar todos os recursos da terra, geralmente, plantavam em outro local.

O poeta Manuel Baptista Cepellos, cotiano que na infância foi aluno em três cadeiras públicas locais, escreveu um poema sobre essa técnica dos lavradores caipiras, intitulado $A$ derrubada (1896). Nele, o autor apresenta em seis partes a derrubada da mata até o nascer da plantação, conforme trechos abaixo:

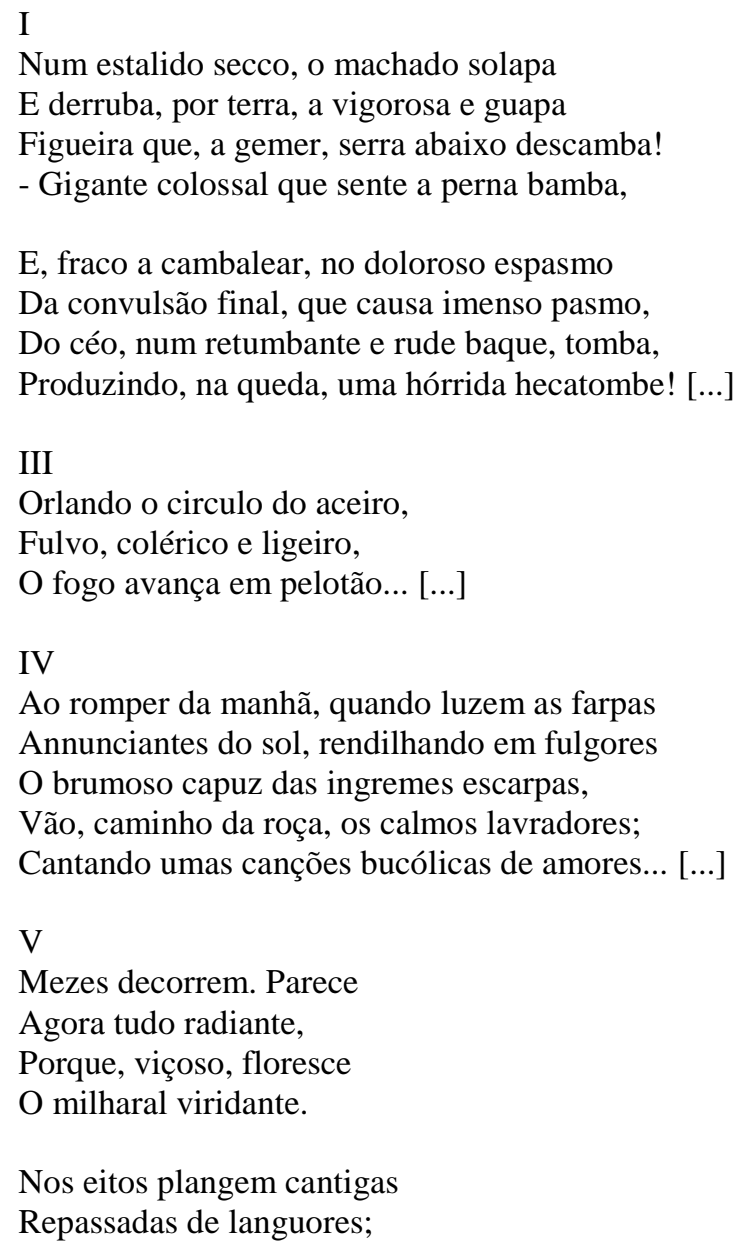




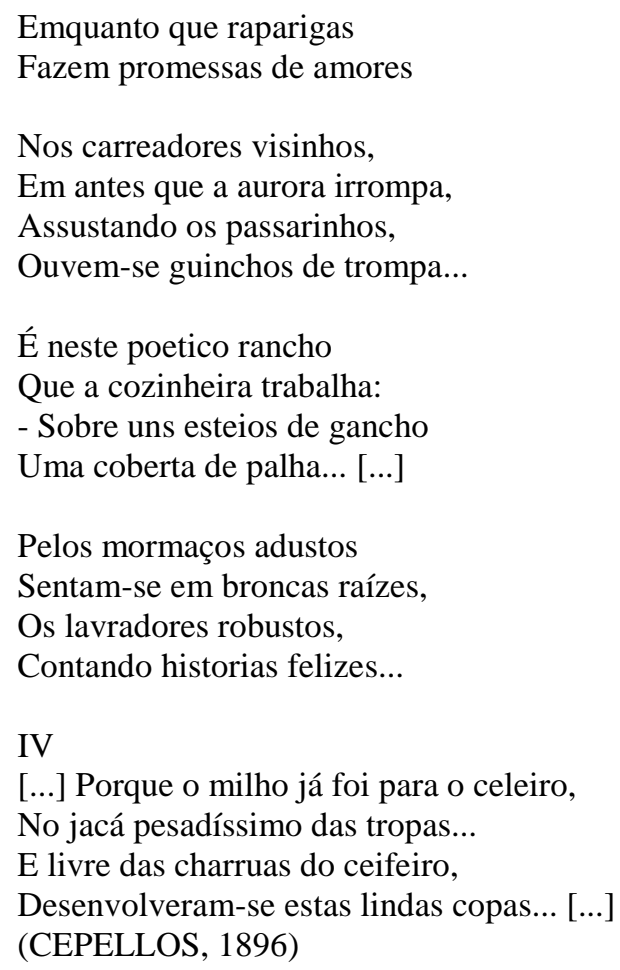

No poema há elementos da cultura caipira: o autor, com sua lente, além de descrever a derrubada da mata, queimada, plantação e colheita do milho (principal alimento produzido em Cotia), apresenta os personagens caipiras no dia a dia (lavradores, raparigas, cozinheira) e a presença das tropas. $\mathrm{O}$ poeta traz traços da sociedade caipira cotiana.

Dados do relatório da Estatistica Agricola e Zootechnica de Cotia no anno agricola de 1904-1905 (SÃO PAULO, 1907) mostraram que não havia nenhum arado empregado na lavoura, mas neste documento não há menção sobre as queimadas.

O modo do caipira trabalhar na terra foi alvo de críticas dos japoneses que foram morar em Cotia no início do século XX e criaram a Cooperativa Agrícola de Cotia (CAC) ${ }^{56}$. Em livro comemorativo pelos 30 anos da CAC, o sociólogo Zempati Ando escreveu:

[...] as terras da zona haviam sido cultivadas há muito tempo, nelas se praticava a lavoura cabocla, plantava-se feijão, milho, mandioca etc. sem lavrar o solo, apenas derrubando a floresta, cortando matagais e queimando-os. Em consequência dessa lavoura predatória exauriu-se a fertilidade do solo e, nas terras abandonadas, crescia a barba de bode ${ }^{57}$ (ANDO, 1961, p. 21, nota minha).

Essa forma de plantio do caipira também foi abordada por Candido (2001a). Segundo ele, era um tipo de agricultura itinerante, possibilitada pelo sistema de sesmarias e posses. Foi

\footnotetext{
56 A Cooperativa Agrícola de Cotia foi criada em 1927 por lavradores japoneses - inicialmente produtores de batata - que foram morar em Cotia, e se tornou uma das maiores cooperativas agrícolas do Brasil. Encerrou suas atividades em 1994. Sobre sua história, ver Ando (1961); Marcovitch (1989); Seabra (1977).

${ }^{57}$ Barba de bode é um capim comumente considerado uma "praga" na agricultura.
} 
um recurso usado pelo caipira "para estabelecer o equilíbrio ecológico", pois ajustava as necessidades de sobrevivência à falta de técnicas agrícolas, ocasionando uma economia fechada, "fator de preservação de uma sociedade estável e pouco dinâmica" (p. 59). Desse modo, devido ao isolamento, a vida do caipira distinguia-se pelo "alheamento a mudanças sociais" (p. 60). Tal característica pareceu ser refletida na escolarização nos bairros, tratada no quarto capítulo desta dissertação.

Contribuindo para a compreensão do contexto cotiano no período da presente pesquisa, Maria Cristina Wissenbach $(1998)^{58}$, ao analisar processos criminais na tentativa de reconstruir a vida de pessoas escravizadas e forras na primeira Comarca de São Paulo (da qual Cotia fazia parte) na segunda metade do Oitocentos, observou que nas áreas rurais do entorno da Capital a pobreza era a "questão maior a ser enfrentada" (p. 103) tanto por senhores quanto por escravos. Os autos mostraram que os senhores não possuíam grande quantidade de escravos e trabalhavam juntos na roça (como mencionado anteriormente), sem nenhum outro indivíduo moderando a relação, como acontecia em outras regiões mais ricas. Também sinalizaram que os escravos nesse contexto não se organizavam coletivamente contra o regime de trabalho. De fato, notas da imprensa referentes ao período da pesquisa apontaram que escravos cotianos fugidos (encontrados ou não) pareciam fazer isso sozinhos ${ }^{59}$, mas estes são dados escassos para afirmar que não havia nenhuma forma de organização. Apesar disso, dadas as condições da sociedade caipira (isolamento, economia fechada e parcas condições econômicas dos sujeitos), poucas eram as condições para uma organização coletiva de escravos contra o regime de trabalho.

Para Wissenbach (1998), o cenário dos arredores da Capital na segunda metade do XIX, característico do universo caipira, relativizava o caráter urbano paulistano e trazia elementos que demonstravam que os escravos locais incorporavam "a ética da valentia e a troca de favores como regras de conduta, [e] afirmavam-se não só como simples assimilados, mas como agentes de fato" (p. 260, adendo meu). A pesquisa de Schleumer (1999) foi feita posteriomente à de Wissenbach e, apesar de ser de um recorte temporal anterior (Cotia

\footnotetext{
${ }^{58}$ Fruto de pesquisa de mestrado finalizada em 1989 e única dissertação entre algumas teses publicada na Série Teses do Programa de Pós-Graduação da Faculdade de Filosofia, Letras e Ciências Humanas da Universidade de São Paulo em 1998, devido à qualidade da pesquisa.

${ }^{59}$ Jornal da Tarde (SP) de 12 abr. 1881, p. 2: escravo fugido estava no calabouço, vindo de Cotia; Jornal Diário de São Paulo de 6 nov. 1870, p. 2: em 04/11, fuga do escravo Firmino da Fazenda do Retiro, de Francisco Rodrigues Cezar que estava com camisa de chita, chapéu baixo de pelo de lebre e paletó de alpaca preta; Jornal Correio Paulistano de nov. e dez. 1870, jan. e fev. 1871 (várias notas ao longo desses meses): Francisco Rodrigues Cesar anunciou fuga de seu escravo, indicando seu endereço na Capital (rua do trem, número 8, atualmente situa-se a Rua Anita Garibladi no Centro da Capital) e caracterizando seu escravo como tendo cabelo liso e oferecendo gratificação a quem o encontrasse.
} 
colonial), demonstrou que a localidade já apresentava a assimilação da população não-branca à organização socioeconômica dos livres. É importante sinalizar que ambos os estudos não são recentes (1989 e 1999) e atualmente há muitos outros que comprovam a existência de mobilidade social dos negros, pardos, libertos ou não, na sociedade escravista brasileira ${ }^{60}$. Entretanto, considerando as condições econômicas do local, parece plausível que a mobilidade e a presença desses sujeitos em diversos segmentos da sociedade fossem bem representativas.

A ética da valentia mencionada por Wissenbach é apontada por Candido como uma característica do caipira: "Os costumes na área estudada eram rudes; os homens eram irascíveis e valentes, matando uns aos outros com frequência atestada pelas cruzes e 'capelinhas' votivas, desconfiando do estranho, mas prontos à hospitalidade desde que não surgissem dúvidas" (CANDIDO, 2001a, p. 52, grifo do autor). Algumas notícias de assassinatos em Cotia parecem confirmar essa característica ${ }^{61}$, entretanto, é de conhecimento geral que o quesito violência esteve muito marcado em toda a sociedade imperial.

Na pesquisa de Wissenbach (1998) há dois autos com mortes envolvendo moradores de Cotia que indicaram a ruralidade e a pobreza local, ambos de período pouco anterior ao recorte do presente trabalho. O primeiro caso aconteceu em 1850 e se referia ao assassinato de um senhor chamado Francisco pelo seu escravo Benedicto, crime que deu indícios importantes para que a autora refletisse sobre as relações entre roceiros e seus poucos escravos. O proprietário, Francisco Ferreira Dias, tinha quatro escravos que revezavam no trabalho doméstico e no trabalho na lavoura em seu sítio, no bairro do Tijuco Preto (p. 98). Eram eles: Catarina, crioula, Manuela, africana de Moçambique, e seus filhos, Benedicto e Miguel, de pai falecido e escravo do mesmo senhor.

Quando foi feita a reconstituição do crime, encontraram os escravos trabalhando em uma roça de milhos pertencente a eles. De acordo com o auto, o roceiro assassinado e seus filhos trabalhavam com os escravos na colheita e debulha dos grãos. $\mathrm{O}$ dia do crime era de trabalho, segundo os filhos de Francisco em depoimento. No dia do crime, ao andarem por uma estrada, um possível comprador do milho perguntou à escrava Manuela (mãe de Benedicto) se a mesma queria vender "a metade de um capado", então o roceiro e proprietário

\footnotetext{
${ }^{60}$ Ver Grinberg (2002), Guedes (2006, 2007 e 2008), entre outros. A pesquisa de Mattos (1998), realizada em seu doutorado defendido em 1993, também demonstrou essa mobilidade social.

${ }^{61}$ Jornal Correio Paulistano de 3 mai. 1873, p. 2: Francisco Gonçalves Figueiró matou seu cunhado, Alexandre Dias, e depois se entregou na subdelegacia local, entregando a espingarda e a foice usadas no crime; Jornal de Recife de 7 nov. 1882, p. 1: no Bairro da Graça, Vila de Cotia, São Paulo, Roque Agostinho de Brito foi assassinado "a pancadas de mão de pilão" por sua mulher; Jornal de Recife de 17 nov. 1885, p. 1: assassinado um homem chamado Manoel Nunes de Almeida em Vendinha, no Bairro dos Pereiras, em Cotia; entre outras.
} 
dos escravos se zangou, questionou-a como poderia vender o "capado" sem seu consentimento e bateu em Manuela. Ao ver a cena, Benedicto bateu em Francisco com um "pau" até quase sua morte. A autora apontou que nessa história "transparecia a intimidade da pobreza, a divisão dos parcos meios de sobrevivência e questões relativas às posses cativas" (p. 104). A temática da punição injusta, segundo Wissenbach (1999), esteve presente em quase todos os autos por ela analisados, mas no caso dos proprietários pobres, a estreiteza do convívio entre os dois lados atrapalhava a "consecução da lógica paternalista" (p. 105).

Em outro caso, em 1858, "Rita Pedrosa, viúva de um sitiante de Cotia assassinado por um ex-escravo, viu-se obrigada a desistir da autoria do processo por sua condição de pobreza" (p. 99). O marido de Rita era Benedicto Gonçalves Nunes, e o escravo, Firmino Teixeira. Muito possivelmente a pobreza impedia sua ida a São Paulo, pois despenderia dinheiro para a viagem e teria que deixar um dia de trabalho para resolver essa questão na Capital. Essa passagem mostrou a carência material de uma proprietária cotiana.

Analisando os fatos nesse contexto caipira, a autora apontou que os homens escravizados apresentavam padrões de comportamento comuns a homens livres pobres (p. 100-101), porém, apesar de esses crimes confirmarem a proximidade entre senhor e escravo, a relação entre os envolvidos não afastava os castigos físicos e as retaliações (p. 102-103). Sua tese é que, pelo contrário, essa relação tão próxima:

[...] contribuía para acentuar determinados conflitos que nas grandes propriedades seriam eventualmente neutralizados pela presença de intermediários. Além disso, as condições de trabalho poderiam atingir dimensões mais amplas, descortinando, sobretudo, nas freguesias mais pobres, os esforços conjuntos de senhores e de seus cativos em garantir o sustento. (WISSENBACH, 1998, p. 103).

Um outro elemento que a autora apontou como comum nos bairros rurais, segundo os autos, foi a prática de mutirões de trabalho, que eram uma das formas do auxílio vicinal, constitutivo da cultura caipira, segundo Candido (2001a). Justamente nas interrupções da rotina (nos domingos e dias festas, ou em mutirões de trabalho) eclodiam desavenças, muitas vezes misturando-se com o consumo de bebidas alcoólicas. Nas roças e nos sítios de pequenas proporções, segundo os autos, plantavam-se mandioca, milho, feijão e cana, e fabricavam-se farinha e aguardente em pequenas engenhocas movidas a mão ou a água, destinados tanto ao consumo próprio quanto ao abastecimento de mercados locais (WISSENBACH, 1998, p. 97). 
A autora apresentou os dois casos de Cotia acima descritos e mencionou outro ${ }^{62}$ sem entrar em detalhes, ocorrido - assim como o caso de Francisco e Benedicto - no bairro de Tijuco Preto ${ }^{63}$. Dessa maneira, não foram muitas as ocorrências em Cotia se comparadas a outras tratadas pela autora ao longo de seu trabalho. Entretanto, são casos que demonstram a precária condição financeira dos senhores de escravos locais.

As condições de pobreza compartilhada com os amos favoreciam outros aspectos da organização de suas vidas, servindo ao menos para distanciá-los de uma disciplina rígida, aproximando-os dos homens livres pobres. Nessas regiões, misturados a uma mão-de-obra de caráter híbrido, não chegavam a compor uma comunidade própria, no mais das vezes integrados às expressões socioculturais da população pobre livre, do que em manifestações especificas de uma cultura escrava. (WISSENBACH, 1998, p. 126).

Essa afirmação permite pensar em que contexto e de que maneira a escolarização de Cotia possibilitou ser mais uma via de convivência entre livres e cativos, ou filhos de livres e filhos de cativos. Dados mostraram a presença de "ingênuos" (filhos livres de mães escravizadas) nos livros de matrícula a partir de 1881, analisados no quarto capítulo. A hipótese da presente pesquisa é que o convívio desses alunos no ambiente escolar refletia a relação escravo-senhor, na qual havia vínculos mais próximos de convivência no ambiente fora da escola do que em outras regiões mais ricas.

Segundo o Censo de 1872, Cotia tinha 505 pessoas escravizadas para um total de 5.024 habitantes. Dados levantados pela Comissão de Estatística da Província ${ }^{64}$ em 1886 identificam 7.517 habitantes em Cotia, sendo 144 escravizados e 156 ingênuos (até 30 de março de $1887^{65}$ ).

Faz-se necessário um breve apontamento a partir de estudiosos do assunto quanto às dificuldades na feitura do Censo de 1872 e, consequentemente, dos cuidados ao utilizar esses dados como fontes, implicando destacar:

\footnotetext{
${ }^{62}$ Auto contra Domingos, escravo de Ignacio Godoy Castanho, de 1886 (nota de rodapé número 48 da p. 124 do livro de Wissenbach).

${ }^{63}$ A autora mencionou que no bairro de Tijuco Preto se desenvolveu um povoado devido à existência de um rancho de tropeiros. O bairro de Tijuco Preto atualmente está localizado em Vargem Grande Paulista e faz divisa com Caucaia do Alto, atual distrito de Cotia. No século XIX, possivelmente ficava muito próximo ao bairro de Capitão Jerônimo, local onde foi criada uma escola.

${ }^{64}$ Presentes no Relatório apresentado ao Exmo. Sr. Presidente da Província de S. Paulo pela Comissão Central de Estatística em 1888.

${ }^{65}$ Os dados referentes à população escravizada foram arrolados até 1887 , e o recenseamento até 30 de setembro de 1886 (dados levantados pelas paróquias entre 1883 e 1886, segundo BASSANEZI et al., 1999), portanto, há incompatibilidade de datas e consequentemente de dados, mas ainda assim, podem indicar algumas considerações acerca da sociedade estudada.
} 
O fato de se ter um questionário de difícil transcrição e apuração, acrescido à da questão da baixa escolarização da população contribuíram, provavelmente, para o agravamento dos erros de planejamento logístico para a execução do Censo. Estes derivaram, sobretudo, da subestimação dos problemas inerentes ao desafio de se recensear um país de proporções continentais, com a infraestrutura de meios de transporte e comunicação daquela época (PAIVA et al., 2012, p. 21-22).

Em relatório de 1876 (Directoria Geral de Estatística - Relatório e Trabalhos Estatísticos apresentados ao Ilmo. E Exmo. Snr Conselheiro Dr. José Bento da Cunha e Figueiredo, Ministro e Secretário de Estado dos Negócios do Império pelo Diretor Conselheiro Manoel Francisco Correia em 31 de dezembro de 1876), a Diretoria Geral de Estatística encerrou os trabalhos do Censo de 1872 e destacou "problemas na sua realização, que geraram lacunas e incorreções” (BASSANEZI et al., 1999, p. 17). Segundo o relatório:

O recenseamento determinado para o dia $1^{\circ}$ de Agosto de 1872 não se realisou esse dia em todo o império.

Circunstâncias imperiosas fizerão com que só mais tarde se effectuasse nas províncias de Minas Geraes, S. Paulo ${ }^{66}$ e Matto Grosso. (Relatório da DGE de 1876 apud BASSANEZI et al., 1999, p. 17).

As adversidades também estiveram muito presentes na execução do recenseamento provincial de 1886, apresentadas na própria redação do documento oficial:

\begin{abstract}
Assoberbada, porém, por difficuldades de todo genero, sem o auxílio de corporação technica, de caráter scientífico ou administrativo, que pudesse encaminhar-lhe o passo ou explanar-lhe os acidentes do caminho, obrigada a esclarecer-se por si, a juntar peça por peça todo o material necessário á construcção e urdidura do trabalho de que se tinha incumbido, a Commissão provavelmente teria desanimado se não fôra a inexcedível e perceverante dedicação de um de seus membros, o illustrado Sr. Dr. Adolpho Augusto Pinto, a cujos excepcionaes esforços deve ella o ter superado mil difficuldades que se lhe autolhavam invencíveis. (Relatório apresentado ao Exmo. Sr. Presidente da Província de S. Paulo, 1888, p. III).
\end{abstract}

Salvaguardando as dificuldades na contagem e elaboração do Censo imperial e do recenseamento provincial, as intenções dos órgãos governamentais para a elaboração das estatísticas, e levando em consideração os erros ou diferença entre as formas de questionamentos feitas pelas comissões durante a coleta das informações, é notável que o

\footnotetext{
${ }^{66}$ No Jornal Diário de São Paulo de 20 dez. 1873 (um ano após à data do Censo, ou seja, Cotia estava entre as paróquias de São Paulo em que o recenseamento foi efetuado depois de 1872), p. 2, constava a Comissão Censitária de Cotia era formada pelo Vigário Manoel das Dores Rocha, Joaquim Jose Pedroso, Capitão Antonio Bandeira Barreto (professor aposentado), Capitão Agostinho de Oliveira Barros, José Joaquim Pedroso Junior. Em 4 jul. 1872 os membros da comissão Antonio Barreto e Manoel das Dores Rocha enviaram um ofício ao Presidente da Província informando que tinham dúvidas para começar os trabalhos, assim comunicaram que ficariam aguardando o retorno (AESP, Série Ofícios Diversos, Ofícios Diversos de Cotia, ref. CO1008); no Jornal Correio Paulistano de 19 dez. 1874, p. 2, há uma nota anônima e cômica sobre sumiço de dinheiro da comissão do recenseamento.
} 
número de escravos decresceu mais de $70 \%$ entre 1872 e 1886. Se considerarmos a proporção entre o número total de habitantes para o número de escravizados, temos que quase $10 \%$ da população era escravizada em 1872, enquanto que em 1886 não chegava a 2\%. Em 1872 havia 505 escravos em Cotia e, segundo notas de jornal, até novembro de 1876, havia $471^{67}$ escravos e, em 1882, havia $393^{68}$, o que mostra relativa diminuição de escravizados num período de 10 anos, mas que se intensificou até 1886, ano em que teve 144 escravos.

\begin{tabular}{|c|c|c|c|c|c|c|c|}
\hline \multicolumn{7}{|c|}{ População segundo a cor e população escravizada - 1872 e 1886 } \\
\hline & Brancos & Pardos & Pretos & Caboclos & $\begin{array}{c}\text { População } \\
\text { total }\end{array}$ & $\begin{array}{c}\text { Total de } \\
\text { pardos e } \\
\text { pretos }\end{array}$ & $\begin{array}{c}\text { População } \\
\text { escravizada }\end{array}$ \\
\hline 1872 & 2.646 & 1.505 & 574 & 299 & $\mathbf{5 . 0 2 4}$ & 2.079 & 505 \\
\hline 1886 & 5.891 & 964 & 436 & 226 & $\mathbf{7 . 5 1 7}$ & 1.400 & 144 \\
\hline
\end{tabular}

Ilustração 4 - Quadro da população segundo a cor e população escravizada - 1872 e 1886 (Fontes: Censo de 1872; Relatório apresentado ao Exmo. Sr. Presidente da Província de S. Paulo, 1888; BASSANEZI et al., 1999)

Se considerarmos apenas a população de pretos e pardos, população mais comum entre os escravos no período imperial, Cotia contava com 2.079 indivíduos em 1872, portanto, possivelmente mais de $75 \%$ dessa população era livre. Já os apontamentos da comissão provincial demonstraram que entre pretos e pardos havia 1.400 moradores em Cotia, ou seja, possivelmente $90 \%$ deles eram livres. Essas informações contribuem para pensar na composição social do local e que isso provavelmente refletiu também na composição das turmas de alunos.

Na resolução número 57 de 28 de abril de 1874, decretada pela Assembleia Legislativa Provincial sobre a proposta da Câmara Municipal da Vila de Cotia $^{69}$ (os chamados artigos de posturas), há mais elementos que ajudam a compreender o cotidiano local e confirmam a característica caipira, com economia inserida no ciclo do muar e hábitos nada salutares.

Entre os 118 artigos, há a proibição de armas aos moradores, exceto no desempenho de suas profissões, como tropeiros, carreiros, lenheiros, oficiais mecânicos, caçadores,

\footnotetext{
${ }^{67}$ Jornal Diário de São Paulo de 24 nov. 1876, p. 1: em publicação da presidência da Província referente ao fundo de emancipação de escravos, Cotia tinha 471 escravos e recebeu $1.236 \$ 486$.

68 Jornal Correio Paulistano de 7 set. 1882, p. 2: em publicação da presidência da Província referente ao fundo de emancipação de escravos, Cotia tinha 393 escravos e recebeu $691 \$ 528$.

${ }^{69}$ Disponível em <http://www.al.sp.gov.br/repositorio/legislacao/resolucao/1874/resolucao-57-28.04.1874.html> Acesso em: 1 mai. 2015.
} 
viandantes, mas os cotianos que viessem dos bairros, apesar de não serem da Vila, não poderiam portar armas também. Essa passagem coloca em evidência a violência latente da sociedade em questão. A resolução também proibia animais soltos pelas ruas ou amarrados do lado de fora das casas. Estas deveriam ser cobertas com telhas, rebocadas e caiadas, com muros fechando a frente delas para a rua, além de outros padrões de construção, senão seriam multadas. Era proibido jogar objetos na rua, como louças e vidros quebrados, deixar correr pelos canos "águas servidas e immundas" e "enxugar couros ou outros quaesquer generos humedecidos" (Art. 19). Pelo documento, não parecia incomum também a presença de animais mortos pelas ruas da Vila, cabendo ao dono do animal arcar com as despesas para retirada e enterramento.

Em 1886, outra resolução como a de 1874 foi $\operatorname{aprovada}^{70}$, na qual muitos artigos permaneciam os mesmos, indicando a necessidade de ratificar as posturas que os munícipes deveriam ter e indicando que algumas pessoas continuavam a fazer o que era proibido. Dos artigos inseridos neste ano e que não estavam presentes em 1874, alguns se relacionam à proibição de carros e animais (estes exaustivamente mencionados ao longo do documento de 167 artigos) parados nas ruas "de algum modo [que] possa estorvar o transito publico" (Art. 24). Nessa resolução também ficou designado o largo da Matriz como o local onde as quitandas de doces e outros gêneros pudessem ser vendidos.

Entre aqueles que pudessem estar munidos de armas estavam os empregados no serviço de carros, os tropeiros, boiadeiros e porqueiros, os lenhadores, os caçadores, os trabalhadores de lavoura e os oficiais mecânicos. Em 1886 mais profissionais puderam fazer uso de armas sem estarem fora da lei em comparação com 1874.

Quanto ao lazer, tanto em 1874 como em 1886, havia um artigo sobre a proibição de escravos ou menores jogando jogos lícitos, mas na última resolução houve mais artigos com relação às formas de entretenimento dos munícipes. Proibiu-se rifas, loterias, "jogos de paradas, ou sejam, de cartas, buzios, dados, dedaes, ou de qualquer outra especie ou denominação, nas casas de pasto, tavernas, botequins ou em qualquer lugar publico" (Art. 49), além de "jogos de baralhos, como carimbo, trinta e um, pacáu, lasquenet, estrada de ferro e outros desta especie não carteados" (Art. 50), sendo permitidos apenas "os jogos de baralho denominados bisca, manilha, solo, voltarete e outros carteados desta ordem, vispora e bilhar" (Art. 51). Ademais, nenhum "espectaculo ou divertimento publico de qualquer natureza ou

\footnotetext{
70 Resolução $\mathrm{n}^{\mathrm{o}} 136$, de 08 de junho de 1886. Disponível em <http://www.al.sp.gov.br/repositorio/legislacao/resolucao/1886/resolucao-136-08.06.1886.html> Acesso em: 7 jul. 2015.
} 
especie que seja, do qual se aufira lucros, poderá ter lugar, sem licença da camara" e pagamento de impostos (Art. 53). O tolhimento à diversão dos munícipes teve lugar cativo nessa resolução. Outro tema que apareceu apenas em 1886 foi a vacina, ficando estabelecida a obrigatoriedade da vacinação a todas as pessoas que residissem no município (Art. 67).

Também na resolução desse ano, o serviço de aferidor (que fiscalizaria as balanças, pesos e medidas) podia ser feito por professor púbico, diferente de 1874, onde não havia menção de quem especificamente iria fazê-1o ${ }^{71}$. O serviço consistia em durante o mês de julho de cada ano elaborar uma guia declarando os objetos aferidos com os nomes dos envolvidos e um recibo de pagamento. Encerrado o prazo de aferição, o aferidor era "obrigado a apresentar á camara, um relatorio ácerca dos trabalhos da mesma, no qual, alem de mencionar os nomes dos que pagarão e não a aferição, proporá as providencias que julgar precisas para melhorar o serviço" (Art. 78). Ele recebia 4\% do total da arrecadação do imposto da aferição e ela deveria ser feita "nos dias uteis, das 9 horas da manhã ás 3 da tarde, quando for feita por pessoa habilitada, e das 2 às 4 da tarde, quando feita por professor publico, excepto nos dias feriados" (Art. 81). O aparecimento da figura do professor como aferidor estava ligado à escassez de mão de obra qualificada para esse trabalho, pois em ofício da Câmara de Cotia ao Presidente da Província de 1875, o presidente da Câmara José Joaquim Pedroso Junior pediu que fosse permitido que um professor público cumprisse a função de aferidor, pois não havia na Vila quem fosse "habilitado com systema metrico"72.

Nos dois documentos de artigos de posturas há normas para aqueles que tinham pastos de aluguel e também para aqueles que faziam queimadas de áreas, indicando ser muito comum a já referida forma de plantio do caipira. Segundo os documentos, não se poderia queimar as roçadas que estivessem próximas a terrenos de outros proprietários, e que para fazê-la em terreno próximo ao do vizinho, deveria haver um desbate para não atingir o terreno alheio (de 30 palmos em 1874, e de 6,6 metros de largura em 1886), devendo o lavrador que fizesse a queimada avisar seu vizinho para assistir à queima.

Quanto à religiosidade, o estudo de Langenbuch (1971) considerou ser a função religiosa uma das funções de certas localidades do entorno da Capital (p. 52-53). Amália Lemos (1972), em seu trabalho sobre a participação de Cotia na periferia da metrópole paulistana, assinalou que Cotia tinha representativa função religiosa (p. 41), pois angariava populações vizinhas para as missas de domingo ou festas religiosas. Registros da imprensa

\footnotetext{
71 “Art. 72. A aferição será feita por pessoa habilitada nos termos do decreto n. 5089 e do regulamento n. 5169 de 11 de Dezembro de 1872, ou em sua falta por um professor publico nomeado pelo presidente da camara" (Resolução no 136, de 8 de junho de 1886, link citado).

${ }^{72}$ Ofício de 1 jul. 1875. AESP, Série Ofícios Diversos, Ofícios Diversos de Cotia, CO1008.
} 
apontaram que em 1870 a população de M'boy (Embu) tinha o costume de ir às missas em Cotia $^{73}$ e também que no recorte da pesquisa algumas publicações registravam as festas católicas que contavam com a presença de muitas pessoas, desde moradores locais adjetivados como festeiros, que se enfeitavam com máscaras e enfeitavam a igreja - a padres, vigários e cônegos de outros lugares ${ }^{74}$.

Dando indícios de sua relativa importância como local de encontro religioso, em 1870 o cônego da Capital, Monte Carmelo, foi a Cotia para fazer um sermão na Matriz em que apontava o lugar da Igreja no Estado ${ }^{75}$, além da visita do bispo de São Paulo Dom Lino Dedodato em 16 de janeiro de 1878. Detalhes noticiados pela imprensa da visita episcopal em Cotia relatam que o bispo considerou que "o povo desse lugar é bom, morigerado, pacífico, e sobretudo, religioso"76. A intenção aqui não é entrar no mérito ou demérito da fé e religiosidade católica da população, comum no Brasil do século XIX, mas apontar como esses dados sustentam a afirmação que Cotia tinha uma representativa função religiosa e, consequentemente, social na região.

Em 1875, foi inaugurado o segundo trecho da Estrada de Ferro Sorocabana, o tropeirismo entrou em decadência e a vida econômica de Cotia sofreu reflexos, apesar de Cotia também receber uma estação ferroviária (a Estação São João, no Bairro de São João, atualmente pertencente a São Roque) e uma parada (a Parada Cotia, em seguida Estação Cotia, atualmente é Estação Itapevi, localizada no município de mesmo nome). Essas estações foram construídas nessas regiões devido à topografia favorável (LANGENBUCH, 1971) e possivelmente ao fácil abastecimento de lenha para as máquinas, pois ali havia uma vegetação abundante. No entanto, ficavam distantes da Vila e não despertaram grande desenvolvimento comercial ao redor, em comparação a outras cidades paulistas. Um ramal de ligação entre a

\footnotetext{
${ }^{73}$ Jornal Diário de São Paulo de 15 mar. 1870, p. 1: na Ata da Assembleia Provincial, população da aldeia de M'boy (um "arraial de cerca de 30 a 40 casas miseráveis") costumava ir à missa em Cotia e Itapecerica.

${ }^{74}$ Jornal Diário de São Paulo de 10 jun. 1870, p. 2: notícia sobre a Festa do Divino ocorrida em 4 de junho na Vila de Cotia, trazendo características do local; povo festeiro/máscaras; igreja enfeitada; presença de padre, vigário e cônego de outros lugares (a publicação na íntegra está nos anexos desta dissertação); Jornal Correio Paulistano de 1 jun. 1870, p. 1: sobre a festa de São João em uma fazenda, na qual "o alferes Francisco Rodrigues Cesar, por occasiao da festa de S. João em sua fazenda, no districto da Cutia, deu liberdade, na pia, a uma mulatinha sua escrava, de 3 anos de edade. Consta-nos que este senhor já outras alforrias ha feito de escravos seus, manifestando a adhesão generosa que presta ao pensamento da emancipação"; em 16 set. 1884, p. 3: notícia sobre a festa de Monte Serrat ocorrida no dia 8, com a presença de muitas pessoas.

75 Jornal Correio Paulistano de 28 jul. 1870, p. 1, e Jornal Diário de São Paulo de 29 jul. 1870: os jornais agradecem o recebimento da cópia do sermão de Monte Carmelo dado em Cotia. O sermão foi publicado no livro A Igreja e o Estado: sermão pregado na Matriz da Villa da Cutia, Termo da Cidade de São Paulo, Em 28 de maio do corrente anno pelo Dr. Joaquim de Monte Carmelo, Cônego da Sé da dita cidade. Rio de Janeiro: Typ. De Pinheiro \& C., 1871. Consta na publicação que foi gratuitamente distribuído no Rio de Janeiro.

${ }^{76}$ Jornal de Recife de 30 jan. 1878, p. 1, e do Diário Rio de Janeiro de 26 jan. 1878, p. 2: visita do reverendo Bispo diocesano às igrejas de Cotia, Una e São Roque; O Apostolo (RJ) de 6 fev. 1878, p. 2: A visita foi bem detalhada nesse jornal. O bispo crismou mais de duas mil pessoas.
} 
Estação Cotia e a Vila chegou a ter sua construção aprovada em 1872, porém a lei foi revogada em 1876.

A seguir seguem as fotos das duas construções, ambas de 1877:

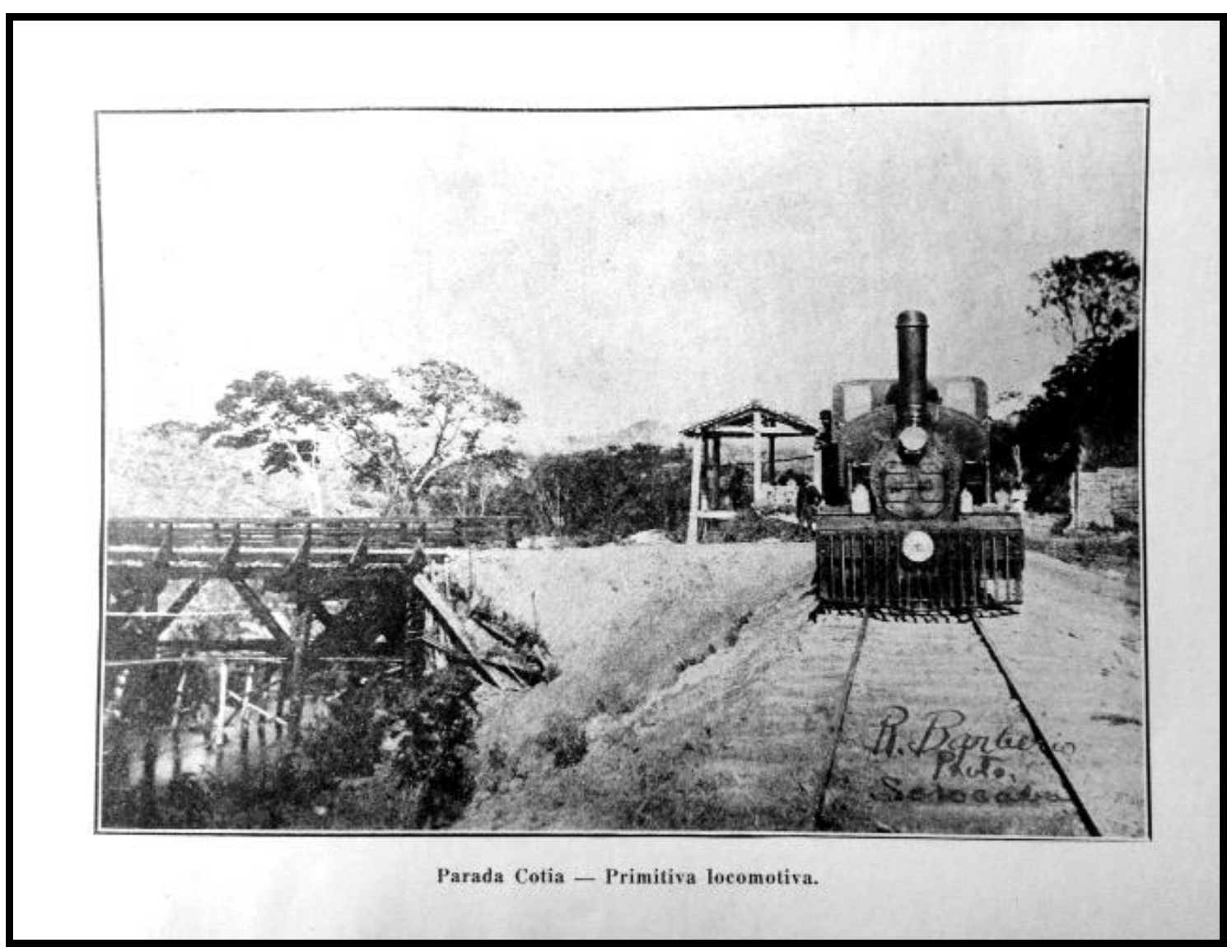

Ilustração 5 - Foto da Parada Cotia em 1877 atribuída a Julio W. Durski (Fonte: GASPAR, 1930). 


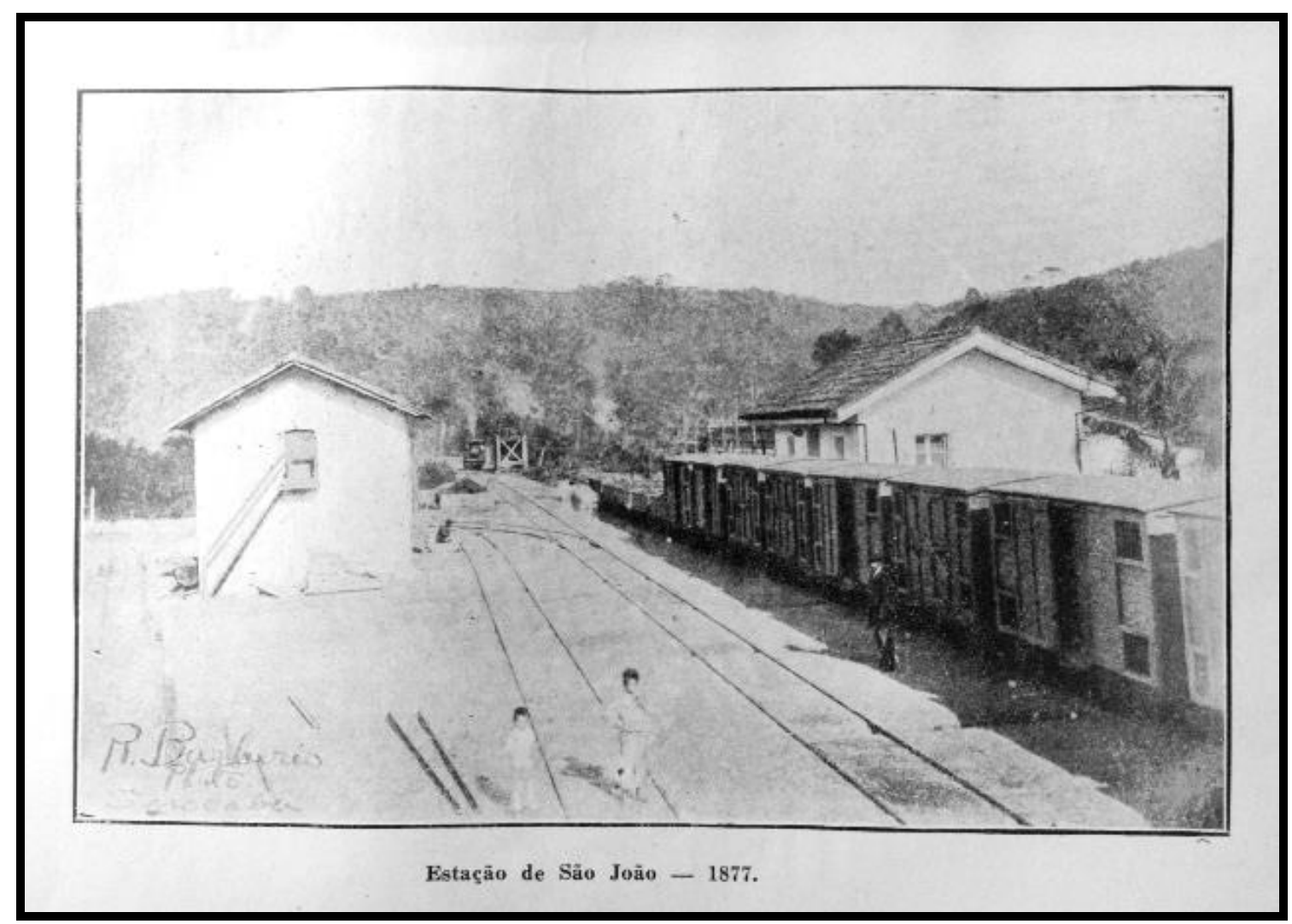

Ilustração 6 - Foto da Estação São João em 1877 atribuída a Julio W. Durski (Fonte: GASPAR, 1930).

Percebe-se que ao redor das construções havia uma mata densa e pelo ângulo das câmeras há poucas construções em torno da estação ou da parada. Na primeira foto, a Parada Cotia está entre uma ponte e aparentemente uma construção de tijolos, que possivelmente pertencia à Sorocabana, devido à proximidade com a Parada. Na foto da Estação São João há duas crianças que posam para o fotógrafo, isso permite pensar que havia pessoas morando próximas à construção da Sorocabana, mas também poderiam ser crianças que acompanhavam o fotógrafo, entre outras possibilidades.

Os jornais mostraram que, ao longo dos anos de 1870, Cotia esteve muito presente nas discussões políticas, especialmente nas Atas da Assembléia Provincial, por conta da construção do ramal entre a Estação de Cotia e a Vila. Segundo relatório da Sorocabana de julho de 1872, o ramal foi solicitado pelos moradores do município ${ }^{77}$. Não localizei a petição do ramal, mas uma petição da Câmara de Cotia ao Presidente da Província, 24 de outubro de 1871, solicitando que a estrada de ferro passasse pela Vila de Cotia, pois um dos engenheiros

77 Jornal Correio Paulistano de 7 jul. 1872, p. 2: Publicação do relatório apresentado pela Companhia Sorocabana na Assembleia dos Acionistas em 2 de julho do mesmo ano. 
do projeto havia opinado favoravelmente que fosse ali construída, e porque Cotia "sustenta[va]" a Capital com gêneros alimentícios ${ }^{78}$.

Nas $\operatorname{atas}^{79}$, deputados contrários à construção do ramal comentavam que Cotia não tinha nenhum destaque econômico que justificasse tal obra e despesa, já que sua economia era basicamente de subsistência, com tímido abastecimento da Capital com cereais, principalmente milho. Este, segundo os deputados contrários, era produzido em pequenas quantidades por roceiros pobres e dispersos, condição que favorecia a chegada desses produtos à Capital por meio das tropas de muares e não justificaria o transporte por trem. Para alguns parlamentares (os mais incisivos contra o ramal), Cotia produzia marmelos (quando mencionavam os marmelos, alguns deputados riam, conforme descrição das atas), não tinha importância econômica, era insignificante. Atribuíam a construção à política a fim de valorizar a região de São Roque. Argumentavam que a produção de milho que abastecia a Capital poderia ser suprida pela produção que viria do interior da Província nos trens; que eram escassas a produção e a renda de Cotia, enfatizando a esterilidade dos terrenos e a desimportância agrícola, industrial e comercial dos arredores da Capital (as terras ao redor de São Paulo eram consideradas estéreis devido à sua escassa produção agrícola, se comparadas a outros municípios da Província, mas isto estava diretamente relacionado ao modo de plantio, à já mencionada ausência de técnica do caipira para a produção agrícola ${ }^{80}$ ).

Por outro lado, os deputados favoráveis opinavam que Cotia mandava gêneros de primeiras necessidades e cereais para São Paulo, e que apesar de não ser uma região economicamente muito importante, o ramal deveria ser feito, posto que locais pobres também deveriam ter direitos. Além disso justificavam a construção porque, depois de aberta a estação, haveria desenvolvimento local. Enfim, os dados apontados por essas fontes também confirmam a condição rural e pobre de Cotia e demonstram as tensões e negociações entre as

\footnotetext{
78 AESP, Série Ofícios Diversos, Ofícios Diversos de Cotia, ref. CO1008.

79 Discussão sobre a construção registradas nas sessões de março e abril de 1872 no Anaes da Assembleia Legislativa de São Paulo (1872). Disponível em <http://www.al.sp.gov.br/acervo-historico/base-dedados/imperio/anais/imperio_1872.pdf> Acesso em: 18 dez. 2014. No Jornal Correio Paulistano também foram publicadas essas Atas de Assembleia, ao longo dos meses de março a julho de 1872; No Jornal Diário de São Paulo as atas foram publicadas entre os dias 24 de março e 20 de junho de 1872.

${ }^{80}$ Segundo Emilia Viotti da Costa (1958), comentando sobre a produção agrícola do caipira em comparação aos japoneses que imigraram para os arredores de São Paulo: "É profundamente triste constatar que sua ignorância, seu fatalismo, sua inércia, falta de ambição e desconhecimento da técnica mais rudimentar refletem-se nas propriedades em que trabalham por conta própria. O caipira não sabe aproveitar convenientemente o solo, nem consegue auferir lucros com o que produz. Alega com freqüência que a terra não presta ou está cansada, mesmo quando, ao lado, exista uma bem organizada e próspera comunidade de japoneses. Via de regra, suas lavouras não chagam para atender às necessidades da própria subsistência; em canteiros assimétricos e desalinhados, plantam pequena roça de milho, exíguo mandiocal, umas poucas verduras e flores; no mais apenas algumas laranjeiras, limoeiros e bananeiras. Sua técnica de cultivo é praticamente inexistente, pois, em regra, não emprega adubos, não utiliza o arado, desconhece remédios contra pragas, não se preocupa em selecionar as sementes. Quando muito, pratica a rega" (p. 122-123).
} 
municipalidades e o governo provincial e diferentes perspectivas administrativas, algumas que visavam os supostos benefícios mais imediatos e outras que pensavas mais em longo prazo e levavam em consideração a melhoria das condições de vida da população.

Nas discussões, houve deputado que afirmou que "Cotia só serve[ia] para dar votos" 81 . A pesquisa feita na imprensa da época indicou Cotia como um município conservador, contribuindo para eleger deputados do Partido Conservador. Os professores públicos eleitores de Cotia, segundo as listas da imprensa noticiadas periodicamente, eram conservadores e muitos se tornaram membros do Partido Republicano ${ }^{82}$.

Também houve uma movimentação de particulares contra a construção do ramal por meio de publicações nos jornais desse período ${ }^{83}$. Apesar de opiniões contrárias à construção do ramal, o projeto foi aprovado pela assembléia e posteriormente assinado pelo Presidente da Província José Fernandes da Costa Pereira Junior, sob a lei número 34 de $1872^{84}$.

Como a construção da malha ferroviária envolvia muito dinheiro e aprovações de leis, pessoas de altos cargos públicos visitavam com certa frequência as obras. Visitas presidenciais ocorreram, como em 1872, cuja notícia da excursão no jornal também informava as precárias condições da estrada entre São Paulo e Cotia e as dificuldades de locomoção ${ }^{85}$. Também visitaram as obras o Conde d'Eu, o Conde de Barral, o Presidente da

81 Sessão de 16 março de 1872, p. 437. Disponível em <http://www.al.sp.gov.br/acervo-historico/base-dedados/imperio/anais/imperio_1872.pdf> Acesso em: 18 dez. 2014.

${ }^{82}$ Politicamente, os representantes de Cotia se destacavam pelo conservadorismo (os professores públicos eleitos eram todos eleitores conservadores - João José Coelho, Marcolino Pinto de Queiroz, Antonio Barreto) e membros do Partido Republicano. Estranhamente, no Congresso do Partido Republicano de 1873, o representante de Cotia foi um agricultor de Amparo (Jornal Correio Paulistano de 5 jul. 1873, p. 1). No Jornal Correio Paulistano de 31 mai. 1885, p. 2: nota da morte de José Joaquim Pedroso, pai de José Joaquim Pedroso $\mathrm{Jr}$, segundo nota, com sua morte "perde o partido conservador um amigo de todos os tempos".

${ }^{83}$ Jornal Correio Paulistano de 1 set. 1872, p. 1: carta particular irônica sobre a Sorocabana, São Roque e Cotia (que produz marmelos); Jornal da Tarde (RJ) de 10 abr. 1872, p. 2: publicação de "um paulista" reclamando que há projetos de estradas de ferro pra várias localidades de São Paulo, inclusive para os "marmelos" de Cotia, mas não para Piracicaba.

84 "Faço saber a todos os seus habitantes que a Assembléa Legislativa Provincial decretou, e eu sanccionei, a seguinte Lei:

Art. $1 .^{\circ}$ - O Governo é autorisado a augmentar o capital garantido da companhia Sorocabana, até 1,800:000\$000, á vista do projecto definitivo da estrada, quando este for-lhe apresentado, na conformidade da condição $6^{\mathrm{a}}$ do contrato de 8 de Julho de 1871, se reconhecer que tal augmento é necessario para conclusão della ; devendo a companhia construir um ramal para a Villa da Cutia, se a mencionada estrada afastar-se desta localidade.

Art. 2. ${ }^{\circ}$ - Ficão revogadas as disposições em contrario.

Mando, portanto, a todas as autoridades, a quem o conhecimento e execução da referida Lei pertencer, que a cumprão e facão cumprir tão inteiramente como nella se contém.

O Secretario desta Provincia a faça imprimir, publicar e correr.

Dada no Palacio do Governo de S. Paulo, aos cinco dias do mez de Abril do anno de 1872.

José Fernandes da Costa Pereira Junior." (Lei $\mathrm{n}^{\mathrm{o}} 34$ de 5 de abril de 1872. Disponivel em <http://www.al.sp.gov.br/repositorio/legislacao/lei/1872/lei-34-05.04.1872.html> Acesso em: 21 set. 2015.

${ }^{85}$ Jornal Correio Paulistano de 19 jun. 1872, p. 1: passagem do Presidente da Província Costa Pereira por Cotia, o mesmo que assinou a lei para a construção do ramal, para inauguração dos trabalhos da Sorocabana; Jornal Diário de São Paulo de 4 dez. 1872, p. 1: Excursão presidencial em novembro feita pelo Conselheiro Pinto Lima - nesta publicação é citada a hospedaria dos Viajantes de Eduardo José Pedroso. O Conselheiro Pinto Lima, com 
Província e outros, que foram de trem da Estação da Luz até a Ponte do Rio Cotia ${ }^{86}$ ver as obras da Sorocabana ${ }^{87}$. Há registro de que houve ainda a passagem do Imperador por Cotia, a bordo de um vagão de trem da Estrada de Ferro Sorocabana no percurso de São Paulo a Sorocaba em 20 de agosto de $1875^{88}$.

Em 1874, dois anos após a aprovação da lei de construção de ramal, término do prazo dado à Sorocabana, novas discussões acerca desse tema estiveram presentes nas sessões da Assembléia, que se seguiram em 1875 e 1876, tendo interpretado como a melhor saída a construção de uma estrada de rodagem no lugar do ramal ferroviário ${ }^{89}$. Concomitante a isso, novamente foram publicados artigos de autores anônimos ou não que ressaltavam a produção estéril de São Roque e Cotia e o mau emprego do dinheiro público ${ }^{90}$.

Deputados contrários ao ramal conseguiram aprovar a revogação da lei tendo como principal justificativa os abusos dos gastos da Sorocabana. Em relatório de 2 de fevereiro de 1876, o então Presidente da Província Sebastião José Pereira assinalou que a pequena produção agrícola de Cotia poderia ser escoada por meio de estrada de rodagem, sendo desnecessário o ramal ${ }^{91}$, e em 3 de abril assinou a lei provincial número 83 que desonerou a Sorocabana da construção do ramal de Cotia ${ }^{92}$. Segundo o Relatório apresentado ao Exmo. Sr. Presidente da Província de S. Paulo em 1888, no território de Cotia, além da estrada que ligava a Capital a Sorocaba e a de Una que se entroncava à estrada Capital-Sorocaba, havia uma outra estrada importante que passava pelo município, considerada provincial e chamada Capitão Vieira, que “da Vila procura[va] o ponto da linha férrea Sorocabana” (1888, p.

capitão João José Pedroso e o vigário, visitam a igreja de Nossa Senhora da Penha. A viagem demora 5 horas de São Roque a Cotia, com terreno montanhoso e em "sofrível" estado de conservação e 4 horas pra chegar em São Paulo, cujos "terrenos [são] accidentados sobre campos e pequenas matas de acanhada vegetação"; em 27 e 31 dez. 1872, p. 1: relatório de Pinto Lima para o novo Presidente João Theodoro Xavier: consta que mandou reparar a estrada de Cotia próxima a Pinheiros, e que visitou a construção da E. F. Sorocabana, mencionando a Vila de Cotia.

${ }^{86}$ Esta ponte passa sobre o Rio Cotia e localiza-se no atual município de Barueri.

${ }^{87}$ Jornal de Recife de 30 out. 1874, p. 3.

${ }^{88}$ Jornal $O$ Globo $(\mathrm{RJ})$ de 9 set. 1875 , p. 2.

${ }^{89}$ As atas referentes a 1874 e 1875 não estão disponíveis no site do Acervo Histórico da Assembleia Legislativa como as de 1873, portanto, utilizei apenas as publicadas na imprensa: Jornal Diário de São Paulo de 6 e 25 mar. 1874, p. 1-2; 31 mar. 1875, p. 1-2; Jornal Correio Paulistano de 6 mar. 1874, p. 1-2.

${ }^{90}$ Jornal Diário de São Paulo de 11 fev. 1875, p. 2-3: publicação extensa assinada por "Veritas" sobre os abusos dos custos da estação Sorocabana e é mencionado o ramal de Cotia; Jornal Correio Paulistano de 12 mar. 1874 , p. 2: artigo assinado por "A Justiça" elevando a importância de Bragança Paulista e criticando a Sorocabana, menciona São Roque e Cotia como municípios que sempre foram "estéreis".

${ }^{91}$ Relatorio apresentado á Assembléa Legislativa Provincial de S. Paulo pelo Presidente da Provincia, Exmo. Sr. Dr. Sebastião José Pereira em 2 de fevereiro de 1876, publicado no Jornal Correio Paulistano de 11 fev. 1876, p. 1.

${ }_{92}$ Disponível em <http://www.al.sp.gov.br/repositorio/legislacao/lei/1876/lei-83-03.04.1876.html> Acesso em: 20 fev. 2015. 
$362)^{93}$. Ao que parece, deveria ser a estrada de rodagem que foi construída no lugar do ramal ferroviário.

Essa decisão contribuiu de forma significativa para o declínio econômico de Cotia, sentido principalmente a partir da segunda metade dos anos de 1880. Autores como Antonio Penteado (1958), Emilia Viotti da Costa (1958) consideraram Cotia como subúrbio agrícola da Capital.

Segundo Langenbuch (1971, p. 100-130), a topografia das passagens de tropeiros não favorecia a construção e passagem de trens, que requeriam uma topografia menos acidentada. Dessa forma, a maior parte das vias de circulação de tropas ficou distante das vias férreas, decorrendo que:

\begin{abstract}
As ferrovias provocaram uma valorização de terras por elas percorridas, em detrimento daquelas que ladeavam estradas de tropa, anteriormente privilegiadas. Assim sendo, os estabelecimentos e os aglomerados que encerravam a função de prestação de serviços à circulação não foram prejudicados apenas pela mudança do meio de transporte, mas também pela mudança dos itinerários, que os deixava à margem da circulação extra-regional. Os aglomerados prejudicados, sem nunca serem muito progressistas, viram as suas possibilidades de desenvolvimento bastante tolhidas. (LANGENBUCH, 1971, p. 101).
\end{abstract}

Esse autor apresentou dois motivos para explicar o porquê de Embu e Itapecerica não sofrerem negativamente as consequências da instalação das vias férreas tanto quanto Cotia, Parnaíba, Juqueri, São Miguel, Itaquaquecetuba e São Bernardo: 1. Os dois primeiros não tiveram redução de travessias nas estradas locais como os demais, e 2. Por estarem longe da ferrovia, não tiveram seu "modesto papel de núcleo polarizador local suplantado por alguma estação férrea" (p. 122).

A população de Cotia, que estava em expansão até a década de 1880 passou a diminuir. Em $1874^{94}$ eram 5.024 habitantes; em $1886^{95}$ eram 7.517 habitantes e em $1900^{96}$, eram 4.892. Langenbuch (1971, p. 125) atribuiu essa diminuição demográfica ao êxodo rural relacionado com o crescimento de São Paulo. A ferrovia funcionou como instrumento de reorganização dos arredores da Capital:

[...] antes de mais nada provocou o colapso do antigo sistema de transporte e das atividades a ele relacionadas. Por seguir trajetos diferentes das antigas estradas "ordinárias" provocou uma relativa desvalorização de áreas beneficiadas por

\footnotetext{
${ }^{93}$ Possivelmente é a atual Estrada Velha de Itapevi II. Cotianos antigos chamam de Estrada Velha de Itapevi.

${ }^{94}$ Censo de 1872.

${ }^{95}$ Relatório apresentado ao Exmo. Sr. Presidente da Província de S. Paulo pela Comissão Central de Estatística, 1888.

${ }^{96}$ Censo de 1900.
} 
aquelas, desvalorização esta que abrangeu grande número dos aglomerados preexistentes. Pelo mesmo motivo, a ferrovia ocasionou um desvio de rotas, valorizando estradas "ordinárias" transversais. Valorizou as áreas que passou a servir. Os "povoados-estação" [aqueles que se situavam e se desenvolveram onde estações de trem foram criadas] cresciam, enquanto os aglomerados apartados da linha, de um modo geral, estagnavam”. (LANGENBUCH, 1971, p. 129, adendo meu).

Segundo Lemos (1972), “Cotia perdeu seu título de 'pacata vila' setecentista só a partir do momento [segunda metade do século XX] em que foi alcançada pela metrópole e envolvida pelo círculo de suas relações" (p. 3, adendo meu), incluída no cinturão periférico metropolitano. Para a geógrafa,

Foram, sem dúvida, as repercussões do crescimento rápido e sem igual da cidade de São Paulo que, em contato com o caipira decadente, acentuou mais a sua pobreza e ao mesmo tempo, incentivou a necessidade de uma nova organização do espaço em função da metrópole. (LEMOS, 1972, p. 46).

Até metade do século XX, a Vila compunha-se de uma rua principal, a Senador Feijó, e outras três, a Lopes Camargo, a Dez de Janeiro e Dois de Abril. Abaixo está o croqui do núcleo urbano em 1941, que dá a dimensão visual de uma região que pareceu "parar no tempo", se comparada à Capital e a outras localidades de São Paulo desse período. Este croqui, entretanto, coloca a rua Dez de Janeiro como Dez de Abril e não nomeia a Dois de Abril, que corta a Dez de Janeiro: 


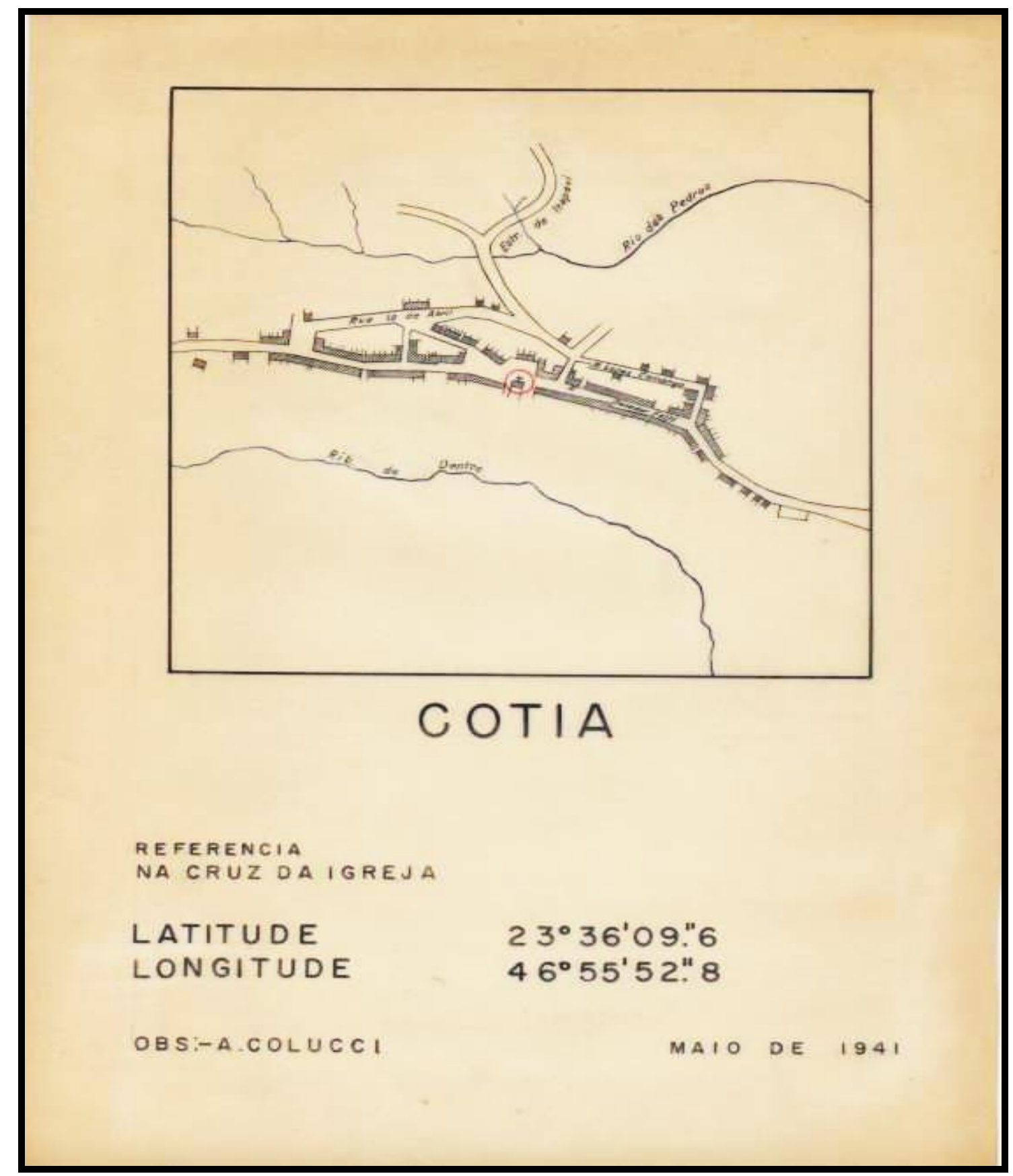

Ilustração 7 - Croqui das coordenadas geográficas de Cotia, maio de 1941 (Fonte: IGC-SP, 1941).

Abaixo segue a aerofoto do núcleo urbano de Cotia do acervo do Instituto Geográfico e Cartográfico, possivelmente do início de 1939, levando em consideração o número de tombo das fotos: 


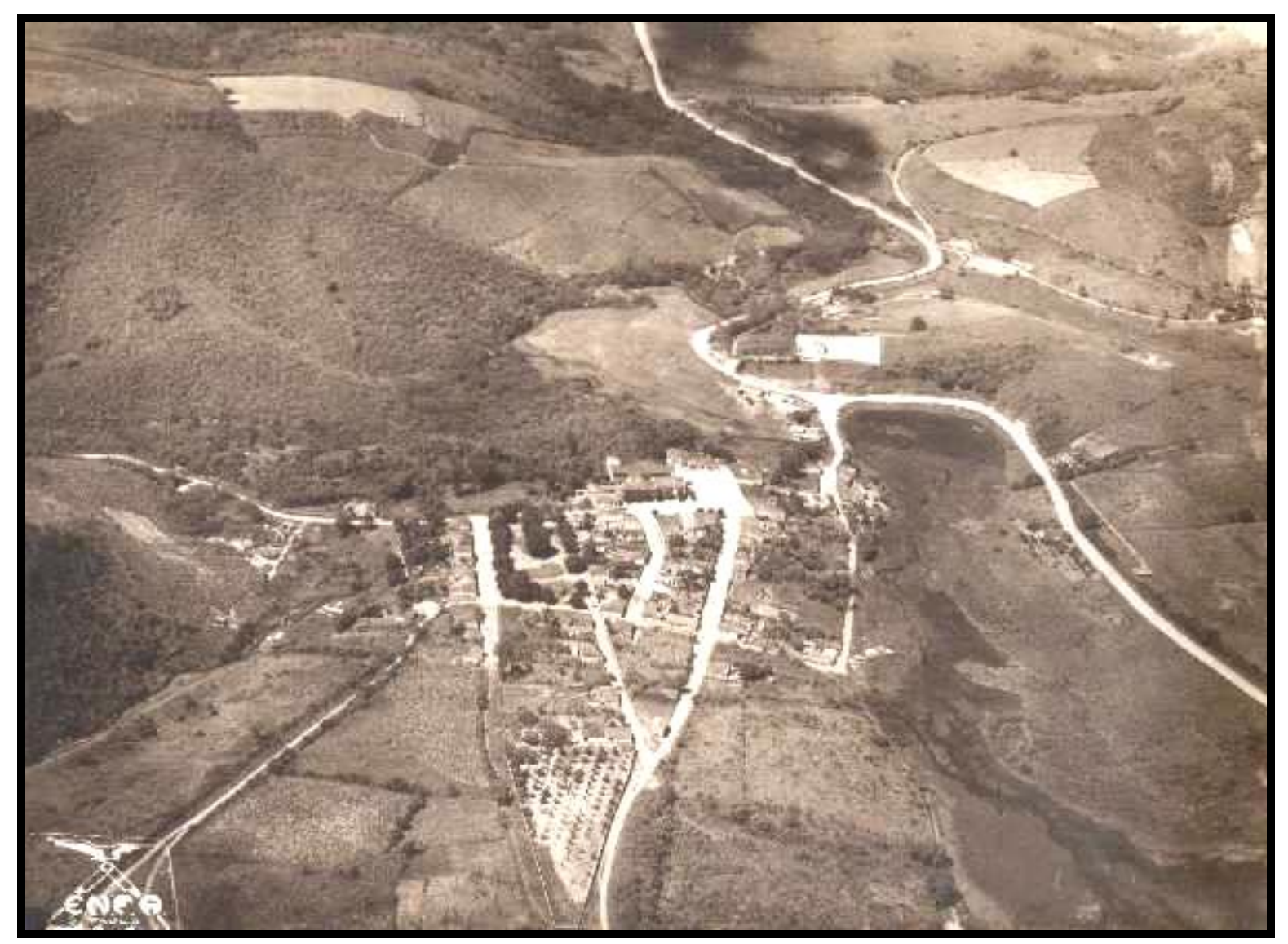

Ilustração 8 - Aerofoto do núcleo urbano de Cotia, c.1939 (Fonte: IGC-SP, 1939/194097).

O núcleo urbano era formado pelas ruas citadas anteriormente. Na foto observa-se a longa estrada à direita que corta a área, ela é a Rodovia Raposo Tavares, antiga estrada das tropas (Capital-Sorocaba). Ao alto, seguindo caminho para São Roque, abaixo, para São Paulo. Mesmo próximo ao Centro, havia grandes áreas sem construção, mas grande parte com vegetação rasteira, indicando plantações ou campos inertes.

A seguir está a imagem da região da Estação Cotia (Itapevi) em aerofoto de 1940, com características de uma urbanização semelhante ao núcleo urbano do município, só que desenvolvida em função da estação de trem. Itapevi foi um exemplo de povoado-estação, segundo Langenbuch (1971).

\footnotetext{
${ }^{97}$ Faz parte da Coleção de Aerofotos Oblíquas 1939 / 1940: "Série composta por aerofotos tomadas em ângulo de $45^{\circ}$ retratando núcleos urbanos, instalações fabris, estabelecimentos rurais e acidentes naturais referentes a 369 municípios paulistas. O trabalho foi realizado a mando do Governo Federal, sob a supervisão do IGG (Fundo IGG), pela empresa ENFA (Empresa Nacional de Fotos Aéreas) como etapa da entrega dos Mapas Municipais elaborados em cumprimento do Decreto Federal 311 de 1938". Disponíveis em <www.igc.sp.gov.br/produtos/galeria_aerofotos.aspx> Acesso em: 8 mai. 2015.
} 


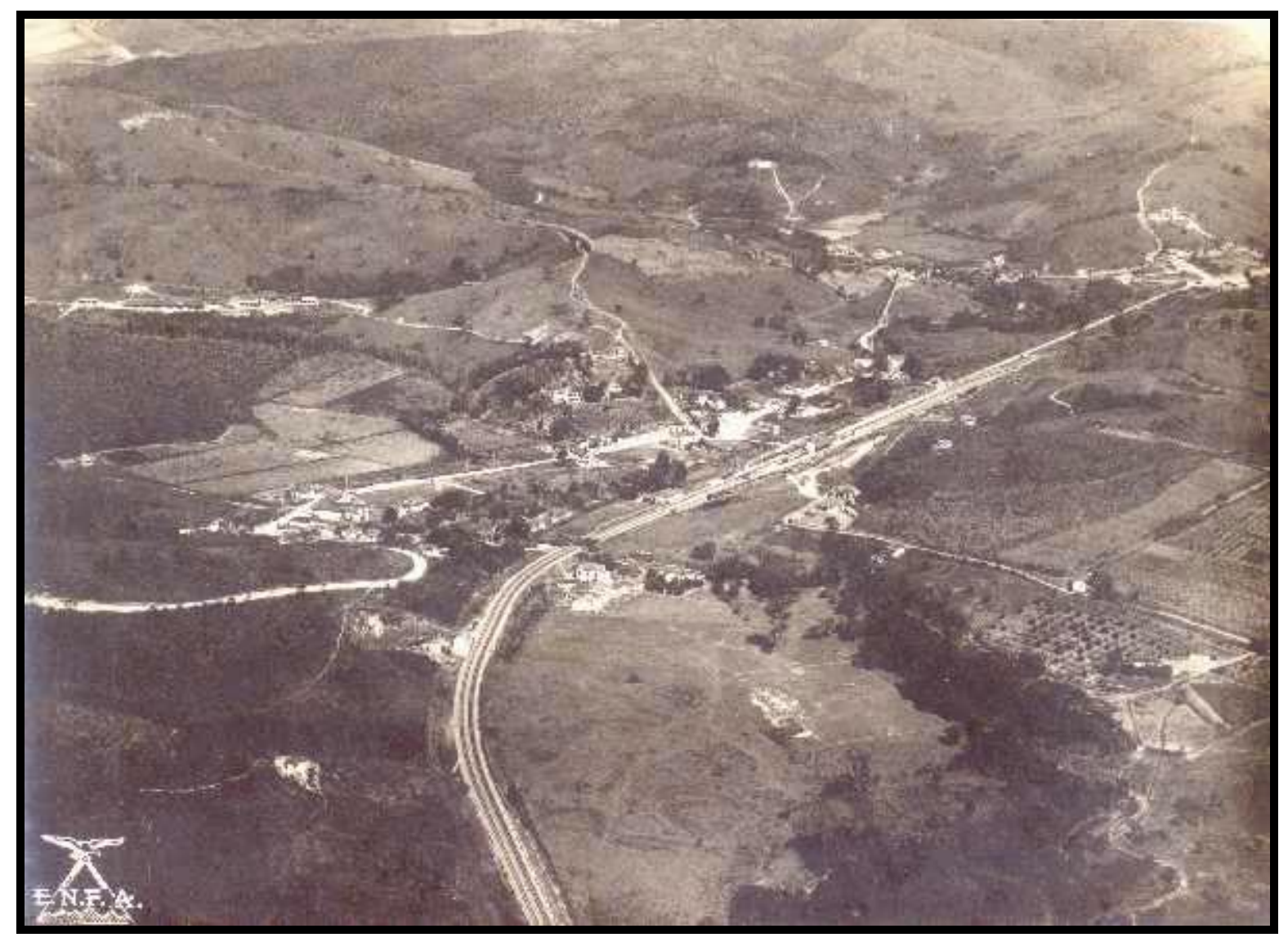

Ilustração 9 - Aerofoto da Estação de Cotia e Vila de Itapevi (Fonte: ICG-SP, 1939/1940).

Ambas as imagens, embora de um período posterior ao da presente pesquisa, permitem dar visibilidade à área territorial ocupada e ajudam a fundamentar a relação entre crescimento das cidades e vias de transporte próximas (antiga estrada de tropeiros e linha férrea) e indiciam como a materialidade cria possibilidades e impõe restrições.

A mencionada diminuição demográfica nos últimos 20 anos do século XIX, segundo Lemos (1972, p. 42), decorreu da falta de incentivo econômico local, e da busca de trabalho de parte da população em regiões pelas quais passavam o café e as ferrovias. Esse processo ocorreu concomitantemente em municípios vizinhos à Capital paulista:

São Miguel, Guarulhos, Embu, Itapecerica, Carapicuíba e outros municípios, entre os quais estava Cotia, formavam um cinturão de cidades históricas bastante próximas a São Paulo, que marcavam um enorme abismo entre o dinamismo desta e a estagnação total em que haviam ficado no passado. (LEMOS, 1972, p. 44-45).

Cotia, doravante, passou a ter uma função subsidiária à cidade de São Paulo que permanece até a atualidade. Segundo Penteado (1958, p. 7), foi “inegavelmente o desenvolvimento industrial da cidade de São Paulo que veio dar importância às áreas hoje ocupadas pelos subúrbios”, entre as quais está Cotia, que mantinha no início do século XX 
sua função agrícola para abastecimento da Capital e hoje em dia, podemos constatar que se destaca pela função residencial e de serviços.

Discorrendo sobre o desenvolvimento da cidade de São Paulo em 1935, Caio Prado Junior (1935) asseverou:

Todas as pequenas cidades ou vilas que a rodeiam não passam de povoados miseráveis e decadentes: São Miguel, Guarulhos, Barueri, Cotia, M’Boi, Itapecerica etc. É este um fenômeno curioso e quiçá único no mundo, num raio de dezenas de quilômetros, a região de São Paulo é das mais primitivas e miseráveis do Estado. (PRADO JUNIOR, 1935, p. 239).

A análise de Prado Junior está fundamentada numa apropriação marxista que, de maneira sintética, buscou enfatizar a extrema pobreza decorrente do sistema capitalista, o que acabou reduzindo muito a história dos lugares por ele citados. Contudo, por meio de uma análise mais localizada, apesar de constatar que a pobreza e a decadência no fím do século XIX faziam parte do cotidiano cotiano, tive a pretensão de enfatizar o que acontecia (e não as ausências) na "pacata" Vila de Cotia.

A presente pesquisa verificou que não houve uma estagnação pós-Estrada de Ferro Sorocabana, mas um declínio econômico e social, haja vista o elevado êxodo demográfico entre 1886 e 1900. No entanto, o foco aqui está entre os anos de 1870 e 1885, período em que não houve regressão demográfica, mas podemos afirmar, pelo exposto, que já se sentiam as mudanças advindas da ferrovia e declínio do tropeirismo, mudanças que também se relacionaram com a escolarização local, pois o processo de escolarização emergiu neste cenário de condições materiais desfavoráveis. Considerando tais mudanças, no próximo capítulo, privilegio a história dos bairros juntamente com a descrição e análise sobre a criação das cadeiras públicas. 


\section{CAPÍtulo 2. A geOgrafia dAS CADEIRAS PÚBliCAS NA VILA DE COTIA (1870-1885)}

Ancorada nas características locais abordadas no primeiro capítulo, procuro localizar onde as primeiras cadeiras públicas foram instaladas a partir dos mapas geográficos apresentados no decorrer deste capítulo. Dessa maneira, inicialmente, pretendo dar uma visão geral do processo de criação das cadeiras e agregar mais elementos que possam desvelar a escolarização local em consonância com as áreas mais povoadas, refletindo sobre as distâncias entre as escolas e entre os bairros e a Vila, sobre a relação da criação e manutenção da escola com a história do bairro em que se estabeleceu, sobre a participação dos sujeitos na criação e transferência das cadeiras. Pretendo também conjeturar sobre as dificuldades dos professores em se estabelecerem em bairros que faziam limite com outro município e indagar se houve algum planejamento para o estabelecimento das cadeiras em Cotia.

Como não há fontes que permitam a localização exata das escolas, o termo geografia das cadeiras utilizado aqui é abrangente, referindo-se à localização dos bairros em que cadeiras foram criadas. No caso de Cotia, e da maioria das localidades do Brasil durante o Oitocentos, esse tipo de precisão do local onde se estabeleceram as aulas públicas é praticamente impossível.

Em sua tese, Angelica Borges (2014) investigou os diversos níveis de aproximação entre a escola e a sociedade e seus desdobramentos, tendo como fio condutor a trajetória de um professor público do município da Corte, Candido Matheus de Faria Pardal. Nela, a autora conseguiu identificar a localização exata das escolas a partir de dados de algumas edições do Almanak Laemmert e também a localização das moradias dos alunos, pois essa informação estava nos mapas de aulas. Por tratar-se do município da Corte, documentos mais específicos eram circunstanciados, mas para minha pesquisa não possuo esses tipos de informações. Não há almanaques ou outros documentos que sinalizem o local das escolas, além disso, os professores de Cotia não indicavam o local exato das casas ou capelas onde lecionavam, e ao indicarem qual era a moradia dos alunos, colocavam simplesmente "com seu pai", "com sua mãe", "com seu avô", "com o Vigário", entre outros. Portanto, como mencionei, trabalho apenas com a localização dos bairros, pensando o processo de escolarização num ambiente ruralizado, num local onde muitas pessoas moravam em pequenos sítios e roças. Assim, todas as referências que tenho se relacionam aos bairros como um todo. Devido à falta de um mapa 
de época com a localização dos bairros, há inclusive bairros que não pude saber precisamente onde se situavam, assim, indiquei apenas a hipótese de sua localização.

\subsection{A legislação vigente e as maneiras para que uma cadeira fosse criada}

A lei paulista que regulava a criação e supressão de cadeiras vigentes no período inicial a que se refere esta pesquisa é a de número 310 de 1846. Segundo ela:

Art. $3^{\circ}$. O governo estabelecerá escolas publicas de instrucção primaria em todas as cidades e villas; e nas outras povoações que, attento o numero da população reunida, julgar em circumstancias apropriadas, sugeitando à approvação da Assembléa.

Art $4^{\circ}$. Nas povoações em que as escolas do sexo masculino forem freqüentadas por mais de sessenta alumnos, poderá haver mais de uma escola; e n'este caso serão addicionadas á instrucção primaria designada no artigo primeiro na segunda aula as seguintes matérias: noções geraes de historia e geographia, especialmente da historia e geographia do Brazil; noções das sciencias físicas applicaveis aos usos da vida. Naquellas em que as do sexo feminino forem frequientadas por mais de quarenta, também poderá haver mais de uma, addicionando-se noções geraes de historia, e geographia, e musica. (Lei número 310 de 16 de março de 1846).

O regulamento de $1851^{98}$ também dispunha sobre a criação de escolas, ficando a cargo do Inspetor Geral da Instrução Pública sua aprovação: “Art. 4. Competem ao inspector geral as seguintes atribuições gerais: $\S 7^{\circ}$ Propôr a creação, remoção, reunião, supressão, e divisão das escolas primarias e secundarias".

Segundo estudo de Mauriceia Ananias (2005), até 1868 eram frequentes as aprovações de leis de criação de escolas na Província de São Paulo, o que se pode apreender pelos pedidos recebidos pela Assembleia Legislativa das Câmaras Municipais, deputados e até professores (p. 64-65). No entanto, de acordo com Ananias, "ao mesmo tempo que se criavam cadeiras, havia um posicionamento de crítica [do governo provincial de um modo geral] em relação a tais criações, pois muitas delas não eram preenchidas pelos professores" (p. 135, adendo meu).

Em decorrência de grande número de cadeiras vagas na Província, a Lei número 54 de 1868 determinou os critérios para supressão de cadeiras vigente no período inicial a que se refere esta pesquisa. Segundo ela,

Art. $8^{\circ}$. Fica o governo autorisado:

$\S 1^{\circ}$. A supprimir todas as escholas publicas que não tiverem vinte alumnos frequentes.

98 Regulamento Provincial de 8 de novembro de 1851. Disponível em <http://www.usp.br/niephe/bancos/legis_detalhe.asp?blg_id=385> Acesso em: 5 mai. 2015. 
$\S 2^{\circ}$. A supprimir uma das cadeiras nos logares onde houverem duas, quando os alumnos de ambas, reunidos, não excederem de cincoenta. Egual proporção se observará na suppressão de cadeiras nos logares onde houver mais de duas.

Art. $9^{\circ}$. Na suppressão de cadeiras observar-se-hão as regras seguintes:

$\S 1^{\circ}$. As cadeiras menos frequentadas serão supprimidas de preferencia

$\S 2^{\circ}$. Em egualdade de circumstancias quanto á frequencia de alumnos, será supprimida a cadeira regida pelo professor menos antigo no exercicio do cargo.

Art. $10^{\circ}$. Os professores, cujas cadeiras forem supprimidas por virtude do artigo nono, serão removidos para outras cadeiras vagas, que não deverem ser supprimidas. (Lei número 54 de 15 de abril de 1868).

Com o objetivo "de esquadrinhar as estratégias mobilizadas pelas famílias e de demonstrar que, mesmo quando a oferta escolar é reduzida, as famílias e grupos sociais participam ativamente na seleção e hierarquização da oferta e na orientação da demanda por escolas públicas" (2014, p. 1), o artigo de Borges e Vidal (2014) apontou e analisou as relações entre escola, cidade e família em São Paulo e Rio de Janeiro no século XIX em situações variáveis de acordo com o contexto local.

Segundo as autoras, as transferências e criações das escolas eram realizadas a partir de estatísticas, elaboradas pelo governo, mas também de demandas dos sujeitos locais:

O trabalho de gerar dados estatísticos, executado a partir de uma determinada intencionalidade, nesse caso em torno da escolarização, pode ser feito tanto pelo governo quanto pelos professores, pelos habitantes de uma região ou pela polícia, por diversos motivos que não apenas para justificar a abertura, manutenção ou subvenção das escolas em determinada região. (BORGES; VIDAL, 2014, p. 4).

Assim, “o entrecruzamento entre espaço e tempo (escolar e social) desponta como problemática no tratamento dos desafios enfrentados na distribuição das escolas, incitando a tomar os dois eixos como indissociáveis nas análises sobre a escolarização” (2014, p. 12). As autoras operaram na pesquisa "com três ordens de problemas que recortam três momentos da relação entre escola e cidade: a instalação, a manutenção e a consolidação da escola em uma localidade" (p. 4), refletindo sobre os "jogos de poder que envolvem esses três momentos" (p. 5) e assinalaram alguns exemplos: problema quanto ao local de instalação de escola que atenderia grupos que residiam muito distantes uns dos outros na Corte (Rio de Janeiro) e, em função disso, o Inspetor Geral viu um internato como solução; a petição de uma população por escola, também na Corte, porém o espaço não era adequado/conveniente, mas não havia um melhor no local para sua instalação; o caso da Freguesia do Ó (São Paulo), que teve uma escola criada e com espaço adequado, mas longe das pessoas, e para solucionar esse obstáculo, alterou-se seu período de funcionamento; do delegado da Instrução da Corte que 
pediu uma escola e conseguiu, fato que indicou jogo de poder, pois ele morava muito próximo à escola recém-criada; entre outros exemplos descritos pelas autoras.

Pesquisas realizadas sobre outras Províncias no Oitocentos trazem considerações semelhantes. É o caso de Adriana Silva (2007), ao investigar a escolarização de Pernambuco entre o final do século XVIII e a primeira metade do século XIX. A autora assinalou que além de esforços governamentais, a população pernambucana entre 1822 e 1851 fez diversas petições por aulas públicas, sendo a maioria enviada ao governo por intermédio das Câmaras Municipais (p. 193). Segundo ela, os potentados locais tinham muito poder sobre a criação ou supressão das cadeiras públicas em Pernambuco.

Os dados coligidos pela presente pesquisa corroboram com os achados dos trabalhos acima mencionados. Algumas escolas foram criadas e transferidas em Cotia a partir de petições locais, das quais tive acesso a quatro ${ }^{99}$. Duas foram assinadas apenas pelos inspetores de distrito e duas pelo inspetor de distrito juntamente com o presidente interino da Câmara Municipal. Elas são apresentadas no decorrer deste capítulo.

Em 1874 foi implementada a lei de obrigatoriedade de ensino na Província de São Paulo, que vigorou até 1886. Portanto, é com base na lei de 1874 que decorre a maior parte do recorte temporal desta pesquisa. Ela determinava a idade dos alunos que deveriam obrigatoriamente estudar nas escolas, o critério para o aluno deixar de frequentá-la e o lugar onde ela funcionaria, conforme a seguir:

\footnotetext{
Art. $1^{\circ}$. O ensino primário é obrigatório para todos os menores de 7 a 14 annos do sexo masculino, e 7 a 11 do sexo feminino, que residem dentro de Cidade ou Villa em que houver escola publica ou particular subsidiada, não tendo elles impossibilidade physica ou moral.

Art. $2^{\circ}$. Antes da idade determinada nesta Lei, só poderão os menores deixar a escola se forem julgados habilitados em exame publico. [...]

Art. 11. O Presidente da Província, na Capital, e os Inspectores de Districto, no interior, designarão os lugares em que os Professores Publicos funccionarão com suas escolas. (Lei Provincial número 9 de 22 de março de 1874).
}

Essa lei determinava que vinte alunos frequentes era o número mínimo para o funcionamento das escolas (1874, Art. 13), que deveria ser comprovado pelos professores por meio dos mapas de frequência. A comprovação da frequência por meio deste dispositivo de governo (VIDAL, 2008) também era exigida na legislação anterior.

\footnotetext{
${ }^{99}$ Disponíveis no site do Acervo Histórico da Assembleia Legislativa de São Paulo e no AESP, Ofícios Diversos de Cotia, ref. CO1008.
} 


\subsection{A localização das escolas}

No período de 1870 a 1885 Cotia teve 12 cadeiras criadas, das quais 11 funcionaram efetivamente. Quatro se localizaram na Vila e oito nos bairros. Levando em consideração a definição de bairro na sociedade caipira dada por Candido (2001a), o fato das oito escolas se localizarem nos bairros se caracterizou como um elemento essencial para compreender o processo de escolarização.

Segundo Candido (2001a), o bairro "é a unidade em que se ordenam as relações básicas da vida caipira, rudimentares como ele. É um mínimo social, equivalente no plano das relações ao mínimo vital, representado pela dieta ${ }^{100 "}$ (p. 98, grifo do autor). A relação com a Vila podia ser mais próxima, dependendo do bairro, ou mais afastada, mas, mesmo o que estivesse mais afastado, o morador do bairro "ligava-se, ainda que esporadicamente, ao centro provedor de sal, administração e ministério religioso; e, por meio dele, conservava sempre vivos, mesmo quando tênues, os ligamentos com a civilização" (p. 100). Assim, partindo desse ponto de vista de bases territoriais (Vila e bairros) e suas implicações sociais, políticas e econômicas, procuro refletir sobre a história local e a geografia das cadeiras públicas.

Apesar de a pesquisa tratar especificamente da escolarização em Cotia entre 1870 e 1885, convém mencionar a implantação de suas primeiras escolas. A primeira escola pública de Cotia data de 1838, quando ainda era uma freguesia da Capital, a Freguesia de Nossa Senhora do Monte Serrat da Cutia. O primeiro professor foi Antonio Bandeira Barreto de Gouvêa ${ }^{101}$, que lecionou até 1858 , ano de sua aposentadoria ${ }^{102}$. A Escola de Primeiras Letras do Sexo Masculino funcionava na Vila, hoje, Centro do município, e sua inspeção ficou a cargo do vigário José Manoel d'Oliveira ${ }^{103}$. Por muitos anos foi a única escola pública de

\footnotetext{
${ }^{100}$ Em sua pesquisa sobre a cultura caipira, Candido dispende um capítulo inteiro para a temática da dieta do homem caipira e o quanto essa dieta estava relacionada com a forma de (sobre)vivência e com cultura desses indivíduos.

101 Apesar de ser este o nome completo do professor, o mesmo costumava assinar apenas como Antonio Bandeira Barreto ou Antonio Barreto.

${ }^{102}$ Lei $\mathrm{n}^{\mathrm{o}} 39$ de 4 de maio de 1858. Disponível em <http://www.al.sp.gov.br/repositorio/legislacao/lei/1858/lei39-04.05.1858.html> Acesso em: 5 mai. 2015.

${ }^{103}$ Borges e Vidal (2014) apontaram que acionar um membro da igreja para assumir o cargo de fiscalização era comum na época da institucionalização do ensino, pois essa relação "favorecia o estabelecimento de relações diferenciadas envolvendo igreja, escola e habitantes" (p. 12). Não à toa, o inspetor de escola de Cotia era o Vigário, que exerceu essa função até 1871, segundo seu pedido de demissão de 1 jun. 1871 (AESP, ref. CO1008). Também por não haver muitas pessoas alfabetizadas, os padres assumiam certos cargos e posições sociais.
} 
Cotia, local que passou um processo de escolarização efetivo apenas no início dos anos de 1870.

Após passar o ano de 1859 sem um professor fixo, essa Cadeira da Vila foi assumida pelo Professor João José Coelho ${ }^{104}$ em 1860, que nela permaneceu até 1885 , quando de sua aposentadoria. João José Coelho nasceu em Cotia e foi aluno de Antonio Barreto, pois aparece entre os alunos nos mapas de 1839, 1843, 1844, 1845 e $1846^{105}$. Além de professor da $1^{a}$ Cadeira pública masculina dessa Vila de 1860 a 1885, atuou em outros setores do município, como a segurança e a justiça, assunto tratado no próximo capítulo. Casou-se com a professora Maria Joanna do Sacramento em $1873^{106}$, e lecionaram na mesma casa, ficando a turma de Coelho numa sala do lado de fora da residência e a turma de Maria Joanna numa sala do lado de dentro.

Apenas em 1858 foi criada outra cadeira, a Escola de Primeiras Letras do sexo feminino da Vila de Cotia ${ }^{107}$, para qual foi nomeada primeiramente a educanda Rosa Josefa de Jesus como professora vitalícia ${ }^{108}$, mas que não chegou a assumir, pois preferiu lecionar em Una. Quem assumiu a cadeira foi Maria Joanna, com nomeação em $1^{\circ}$ de junho do mesmo ano e juramento prestado perante a Câmara Municipal em 30 desse mês. Maria Joanna lecionou por 27 anos na mesma cadeira e infelizmente não consegui informações sobre sua vida fora da escola, com exceção de que se casou com João José Coelho em 1873 e não tiveram filhos. Contudo, mais dados e a discussão sobre a atuação do casal na escolarização de Cotia são abordados no terceiro capítulo.

A seguir, apresento o mapa de Cotia com a localização da Vila, ponto onde se estabeleceram as duas primeiras cadeiras (a masculina e a feminina):

\footnotetext{
${ }^{104}$ Em julho de 1859, Coelho foi aprovado em exame como opositor a essa cadeira (publicação do Jornal Correio Paulistano de 23 jul. 1859, p. 1), e seu nome apareceu como professor da Cadeira Masculina da Vila de Cotia em Relatório de Presidente de Província de 1860. Antes de Coelho assumir, Manoel de Moraes Pinto foi contratado para reger essa cadeira, e lecionou desde 26 de outubro (quase seis meses após Antonio Barreto se aposentar), segundo publicação oficial do Presidente da Província no Jornal Correio Paulistano 14 de nov. de 1858 , p. 2. Nela, o Presidente pediu explicações ao Inspetor Geral de Instrução Pública, pois outro professor Antonio Benedicto Gonçalves Gomide - havia sido removido de Piedade para Cotia em seis de novembro. No Relatório de Presidente de Província referente a 1859, consta como professor interino da cadeira Antonio Benedicto Gonçalves Gomide. Não encontrei mais fontes sobre esse caso.

${ }^{105}$ Estes são os mapas localizados no AESP feitos pelo Professor Antonio Barreto, além do de 1849, no qual João José Coelho não aparece. AESP, Série Instrução Pública - Manuscritos, ref. CO4915 e CO5044.

${ }^{106}$ Disponível em <https://familysearch.org/pal:/MM9.1.1/V2KW-T22> Acesso em: 6 mai. 2014.

${ }^{107}$ Lei $\mathrm{n}^{\circ} 9$ de 11 de março de 1858. Disponível em <http://www.al.sp.gov.br/repositorio/legislacao/lei/1858/lei9-11.03.1858.html> Acesso em: 2 fev. 2014.

108 Jornal O Publicador Paulistano de 3 mar. 1858, Seção Expediente da Presidência. In: Hilsdorf (1999). As datas não estão batendo, pois a professora é nomeada antes da lei de criação da cadeira, segundo a data publicada no livro de Maria Lucia Hilsdorf. Todavia, é necessário destacar que não eram incomuns erros de informações e de impressão presentes nos jornais da época.
} 


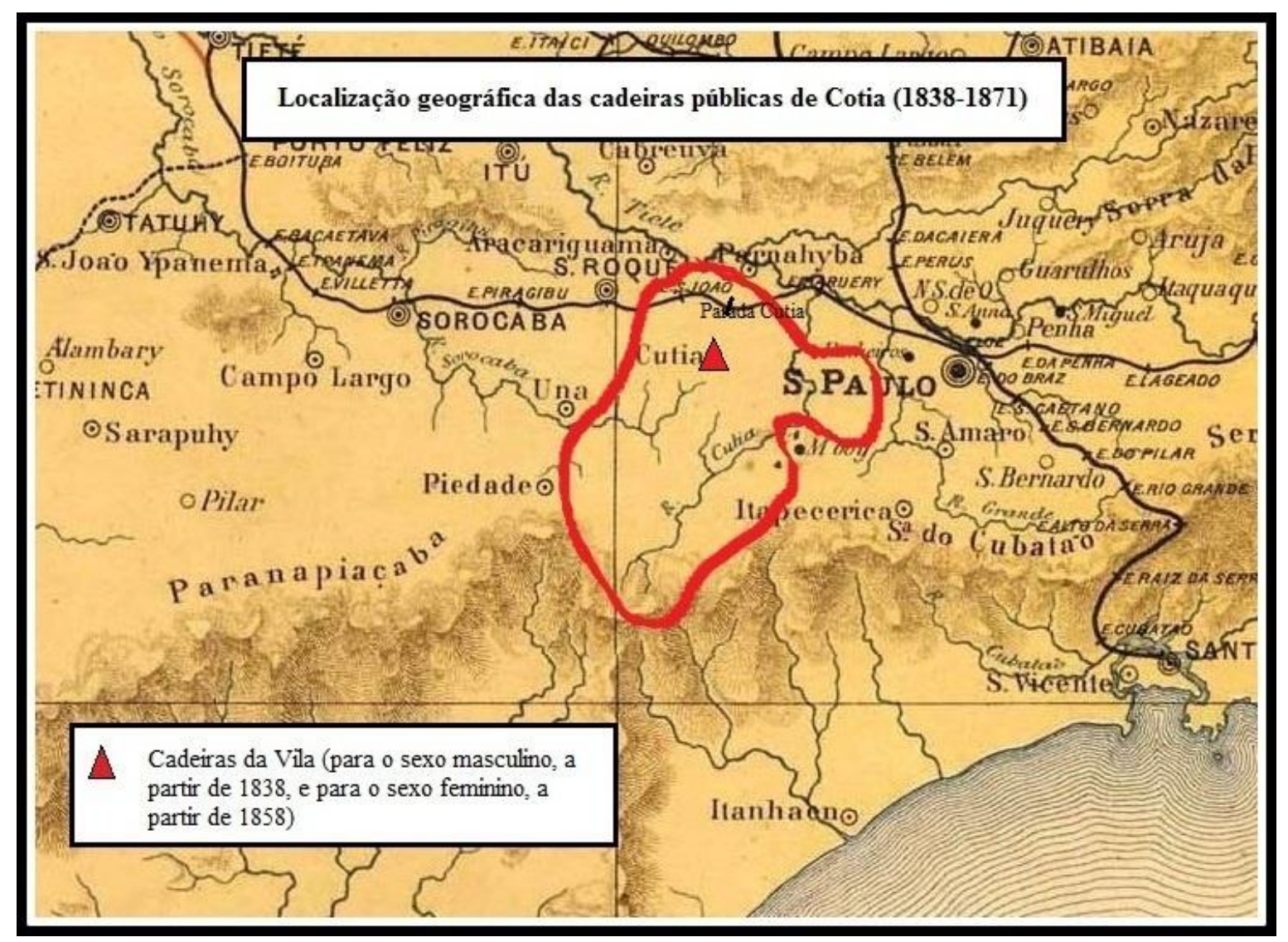

Ilustração 10 - Mapa da localização das cadeiras públicas de Cotia - 1838-1871 (Fontes: LISBOA, 1884; SEADE, s/d. Traçados, título e legenda feitos por mim).

Em julho de 1871 foi nomeado para inspetor de distrito o professor aposentado Antonio Barreto ${ }^{109}$. Corroborando com os apontamentos de Borges e Vidal (2014), que assinalaram ser comum que professores tivessem outras funções ligadas à escolarização após se aposentarem, o primeiro professor de Cotia, que lecionou por 20 anos, tornou-se inspetor de distrito.

Até esse ano, eram apenas duas as cadeiras públicas em Cotia ${ }^{110}$, ainda que em 1870 tenha havido um requerimento do Inspetor de Instrução Pública para criação de uma cadeira masculina no Bairro de Itaqui, indeferida pelo Presidente de Província ${ }^{111}$.

\footnotetext{
109 Jornal Correio Paulistano de 3 ago. 1871, p. 2: em 1 de agosto Antonio Barreto foi nomeado inspetor de instrução pública de Cotia.

${ }^{110}$ Em um relatório do inspetor local referente ao ano de 1862 (AESP, Série Instrução Pública - Manuscritos, CO5044), foi apontada a existência de uma escola privada, a do professor Antonio, com dois alunos (não há mais informações sobre ela, nem mesmo o sobrenome do professor). Como não temos mapas de matrícula ou frequência, ou relatórios escritos pelos professores, as informações até esse período se encontram apenas nos relatórios do inspetor e nos relatórios de governo, não havendo como tentar se aprofundar nessa questão. Também por não ser esse o objetivo desta pesquisa, que se ancora apenas na instrução pública.

111 Jornal Correio Paulistano de 22 out. 1870, p. 1, e Jornal Diário de São Paulo de 25 out. 1870, p. 1: indeferimento da criação de uma cadeira masculina em Itaqui pelo Presidente despachado ao Inspetor de Instrução Pública. Segundo nota, por não estar "em conformidade" com o regulamento de 1869, não havendo informação sobre qual artigo se referia. A cadeira nesse bairro foi criada um ano depois.
} 
Em 1871, foram criadas mais três cadeiras no município: no Bairro de Várzea-Grande e no Bairro de Itaqui, ambas sob a mesma lei $^{112}$, e no Bairro de Sorocamirim ${ }^{113}$. O professor Marcolino Pinto de Queiroz assumiu a cadeira de Itaqui, removido da cadeira de Pirapora, no município de Parnaíba ${ }^{114}$; para a de Várzea-Grande, chegou o professor Severiano José de Ramos $^{115}$; e para a cadeira de Sorocamirim, o professor José Custódio de Queiroz ${ }^{116}$. O concurso para Sorocamirim foi noticiado algumas vezes nos jornais paulistas, dado que indica dificuldade para o preenchimento de vaga, já que não havia procura ${ }^{117}$. O professor que a assumiu, José Custódio de Queiroz, não passou por concurso ou exame, sendo apenas nomeado para o cargo.

Quando o professor Severiano José de Ramos chegou à Várzea-Grande, o inspetor Antonio Barreto informou, em agosto de 1871, em ofício ao Inspetor Geral da Instrução Pública, que "por melhor comodidade [o professor] abrio a eschola no districto de São Roque, no mesmo bairro, por ter ahi achado casa sufficiente [?]"118. A resposta colocada no canto esquerdo, ao alto, está pouco legível, mas o inspetor pediu que a escola ficasse estabelecida em São Roque. No mesmo ofício, no verso, assinado por João Aureliano de Toledo, "Official, servindo de Secretario", consta que a lei de criação da escola indicava que Várzea-Grande ficava entre Cotia e São Roque e que "o empregado que fez as minutas ou participações, de que falla o despacho retro, não o cumpriu em sua totalidade, deixando de prestar esta informação e de tomar a nota da abertura da eschola", indicando que o oficial não sabia do que estava acontecendo. João Aureliano, então, esclareceu que a escola deveria ser estabelecida em Cotia. Após essa confusão, no ano seguinte foi criada a Lei $n^{\circ} 37^{119}$, na qual o Artigo $4^{\circ}$ assinalava: “A escola da Várzea-Grande, nos limites de São Roque e Cotia, será estabelecida em território deste último município". Esse caso demonstra as dificuldades

112 Lei $\mathrm{n}^{\text {o }} 13$ de 9 de março de $1871 . \quad$ Disponível em <http://www.usp.br/niephe/bancos/legis_detalhe.asp?blg_id=66> Acesso em: 13 ago. 2014

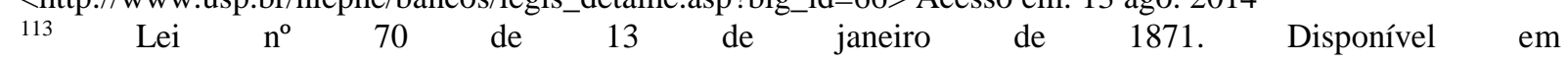
<http://www.usp.br/niephe/bancos/legis_detalhe.asp?blg_id=67> Acesso em: 13 ago. 2014. A Cadeira de Sorocamirim aparece nos jornais ora como pertencente ao município de Cotia, ora como São Roque. Como o bairro localizava-se no limite de Cotia com São Roque, havia essa confusão. No AESP, os documentos referentes a esta cadeira estão entre os documentos pertencentes à Cotia, ref. CO5044.

${ }^{114}$ Conta sua remoção no Relatório de Presidente de Província referente a 1871.

${ }^{115}$ No Jornal Diário de São Paulo de 8 jul. 1871, p. 3, consta seu na relação de aprovados no exame para exercer o cargo de professor de primeiras letras, mas não havia a menção da cadeira que assumiria. Todavia, o professor assinou os relatórios da Cadeira de Várzea-Grande desde 1871.

116 Jornal Diário de São Paulo de 21 dez. 1871, p. 1.

117 Jornal Diário de São Paulo de 28 de abr. 1871: edital de abertura do de concurso para a cadeira de Sorocamirim, Cotia, entre outras. Em agosto e setembro o jornal ainda publicava que a cadeira estava vaga. José Custódio assumiu em dezembro desse ano.

118 Ofício ao Inspetor Geral da Instrução Pública. AESP, Série Instrução Pública - Manuscritos, ref. CO5044.

${ }^{119}$ Lei $\mathrm{n}^{\circ} 37$ de 6 de abril de 1872. Disponível em <http://www.al.sp.gov.br/repositorio/legislacao/lei/1872/lei37-06.04.1872.html> Acesso em: 18 jun. 2015. 
enfrentadas pelos professores ao se estabeleceram em regiões afastadas para trabalhar e a difícil comunicação entre os professores que lecionavam em bairros afastados e os agentes da instrução pública.

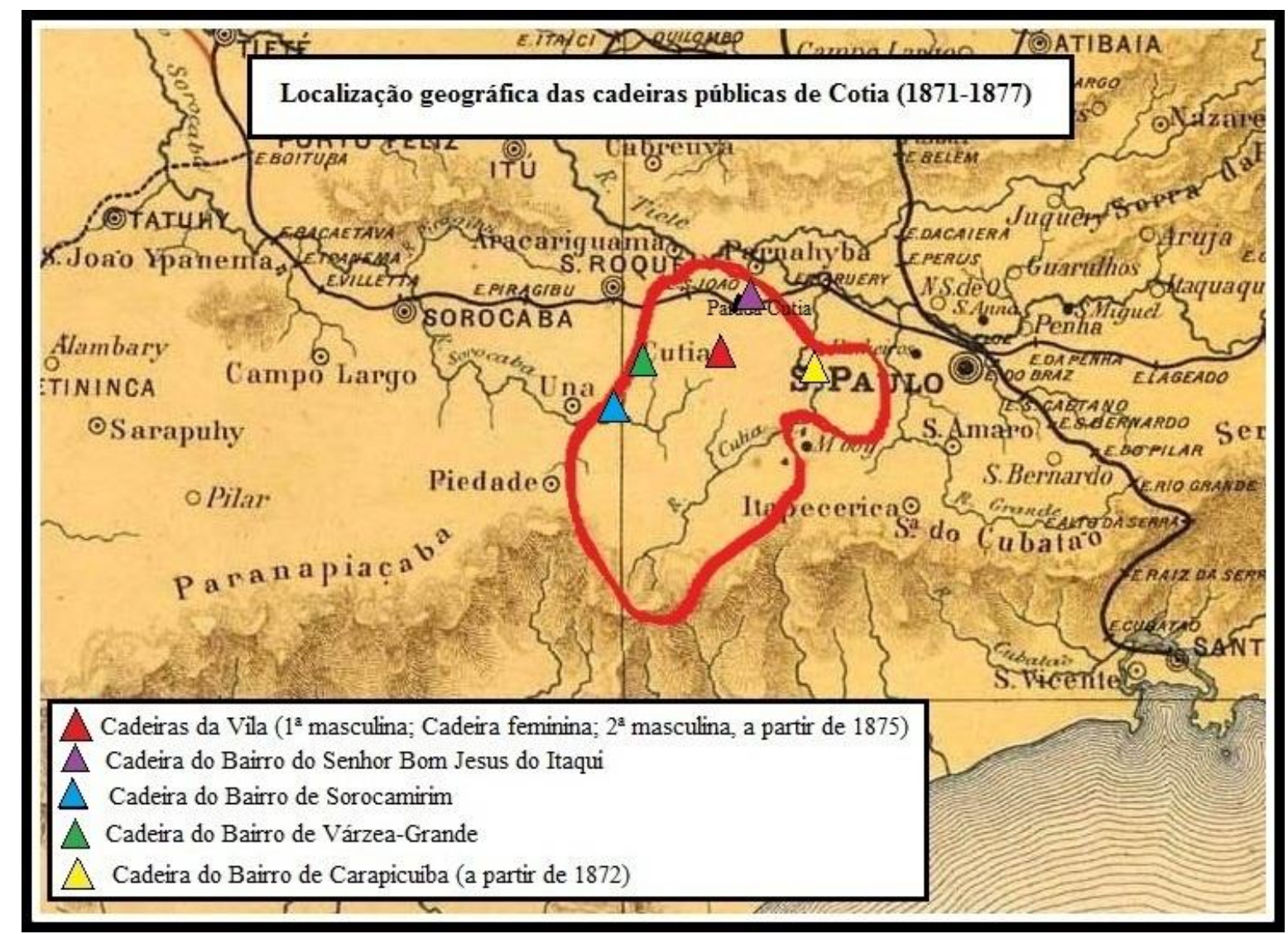

Ilustração 11 - Mapa da localização das cadeiras públicas de Cotia - 1871-1877 (Fontes: LISBOA, 1884; SEADE, s/d. Traçados, título e legenda feitos por mim).

A história do bairro de Várzea-Grande está associada ao tropeirismo, pois no local havia um rancho para pouso de tropeiros, e por essa característica abrigou a tropa de Caxias durante a Revolução Liberal de 1842. Azevedo Marques dedicou um verbete em seus Apontamentos de 1876 ao bairro de Várzea-Grande, porém o situou em São Roque (equívoco ocasionado devido à fronteira do bairro com este município): "bairro situado no município de São Roque, onde existe criada uma cadeira de instrução pública primária para o sexo masculino" (AZEVEDO MARQUES, 1954, tomo 2, p. 297).

O antigo bairro é hoje em dia o município de Vargem Grande Paulista. O estudo de Manuel Seabra (1971) sobre a região de Vargem Grande e sua participação no cinturão-verde paulistano, apontou que a área era habitada no século XIX por caipiras, roceiros e sitiantes (p. 7-12) e a situou entre as que compunham o cinturão caipira tratado por Petrone (1995). Nela habitavam sitiantes com grande influência política, que "além de suas propriedades agrícolas, 
geralmente eram donos de venda, tropa e carros de boi. Na lavoura empregavam os agregados; e os tropeiros e carreiros... eram agregados ou membros das próprias famílias" (SAITO, 1964 apud SEABRA, 1971, p. 12).

Langenbuch (1971) mencionou que acreditava que o núcleo aglomerado de VárzeaGrande se fez recentemente à data de sua tese de doutorado, 1971. Para ele, a existência de um bairro rural não está diretamente relacionada à formação de um núcleo aglomerado, assim, o autor colocou em dúvida as informações de Azevedo Marques referentes à existência ou não de núcleos aglomerados nos bairros citados em Apontamentos históricos, geográficos, biográficos, estatísticos e noticiosos da Província de São Paulo, pois Marques não utilizou esses termos (LANGENBUCH, 1971, p. 44). Não consigo afirmar com exatidão a existência ou não de núcleos aglomerados nos bairros rurais de Cotia nos anos correspondentes ao período da pesquisa, todavia, opero com a hipótese de que esses bairros se caracterizavam com o que Candido (2001a) definiu como bairro caipira, com habitações dispersas, mas com formas de sociabilidade. Enfim, se a cadeira de Várzea-Grande foi criada e funcionou por pelo menos nove anos dos 14 analisados nesta pesquisa, havia uma demanda para isso e, portanto, mesmo que não houvesse núcleo aglomerado, existia uma população ali fixada que tinha a escola como espaço de convivência. A presença de proprietários com influência política juntamente com a característica de passagem de tropas - que possivelmente havia gerado um comércio para atender às necessidades dos tropeiros -, além de uma demanda de alunos, ajudam a explicar a criação da cadeira nesse bairro.

O bairro de Itaqui, de onde se originou o atual município de Itapevi, também passou a ter uma cadeira em 1871, cujas aulas eram dadas na Capela de Bom Jesus do Itaqui. Era o momento de construção da Estrada de Ferro Sorocabana ${ }^{120}$ e opero com a hipótese de que a criação e o funcionamento da escola estiveram associados à demanda gerada a partir do aglomerado humano que se formou ao redor daquela construção. As fontes sobre a cadeira sugerem que havia esse núcleo, pois após a construção da Sorocabana, houve uma diminuição no número de alunos frequentes, atribuída, segundo o professor Marcolino ${ }^{121}$, à mudança dos pais após o término dos trabalhos, à distância de mais de uma légua entre a escola e a moradia de parte dos alunos e aos pais que preferiam que os filhos fossem trabalhar a estudar.

Saint-Hilaire em sua viagem de São Paulo a Itu, em 1819, pernoitou em Itaqui e sinalizou em seus escritos que aquele local dependia da paróquia de Cotia. Descreveu, entre

\footnotetext{
${ }^{120}$ Em 1875 foi inaugurado o trecho da Estrada de Ferro Sorocabana, ligando Sorocaba a São Paulo, para o escoamento da produção de café e outros produtos.

${ }^{121}$ Relatório (que acompanhava mapa de frequência) de 1 nov. 1874 ao Inspetor Geral da I.P. AESP, Série Instrução Pública - Manuscritos, ref. CO5044.
} 
outras coisas, a paisagem - composta por plantação de milho e mata virgem -, o trabalho do sitiante, o modo de vida, a pobreza dos moradores e mencionou a construção da capela. Segundo ele:

O sitio de Itaque (415), onde me detive, é situado à margem dum ribeirão, além do qual eleva-se uma pequena montanha coberta, ao tempo de minha viagem, em parte de milho e em parte de mata virgem. Uma grande capela existe perto da residência do proprietário. Enquanto eu trabalhava, esse homem indivíduo de sangue mesclado, veio conversar comigo, dirigindo-me, perguntas frequentemente muito tolas, e notei que evitava responder as perguntas que eu lhe fazia sobre a região. Perguntei-lhe várias vezes quanto rendia o milho; acabou por me indicar um número tão baixo, que duvidei de sua informação, e, no mesmo instante, fez-me êle a enumeração dos impostos que pagava e dos serviços que prestava ao Estado, julgando, segundo penso que eu estivesse encarregado de colher informes dos quais pudesse decorrer algum aumento nos impostos.

Esse digno homem, e vários de seus vizinhos, como êle pouco abonados, só possuíam pastagens, cultivavam apenas para satisfação da subsistência das próprias famílias. Compravam muares que, internados em seus pastos, alugavam aos proprietários dos engenhos de açúcar, ou os empregavam diretamente no transporte de açúcar, sob pagamento previamente ajustado. Ao que parece, nunca houve razão de queixa relativamente à probidade das pessoas que exercem esta espécie de ocupação.

A mãe do proprietário de Itaqué foi quem, apesar de muito pobre, fez construir a grande capela existente perto dessa fazenda, e à qual já me referi. Essa senhora, querendo assegurar, tanto quanto possível, a duração da capela, fez, ao morrer, o legado de uma pastagem, para com o seu rendimento garantir a conservação e manutenção da mesma. Construir igrejas era, na época, a obra reputada como de mais agrado a Deus, a que, em tal sentido, sobrepunha-se a todas as outras (416). Parece que atualmente não podem ser censurados os brasileiros pelos abusos dessa espécie; é de esperar que eles jamais negligenciem o que é indispensável, substituindo por atos de caridade o que seus antepassados exageravam ou em que os mesmos nem sempre pensavam.

(Saint-Hilaire, 1940, p. 221-222, notas do autor ${ }^{122}$ ).

No relato de Saint-Hilaire, Itaqui apresentava características de um povoamento disperso, próprias de bairro rural, havendo cultivo para subsistência, plantação de milho, pobreza dos moradores, capela votiva (mandada construir pela mãe do homem "de sangue mesclado" que recebeu Saint-Hilaire e que anos depois seria sede da primeira cadeira de instrução pública do bairro), e apontava o aluguel de animais criados por alguns moradores era um meio de renda comum entre eles. Sua viagem aconteceu num período bem anterior ao recorte desta pesquisa e, até a época da criação da Cadeira de Itaqui, mudanças devem ter acontecido com relação à ocupação das terras e ao trabalho dos roceiros, mas é importante considerar as características de bairros rurais apresentadas por Candido (2001a) - com um certo alheamento a mudanças sociais devido ao isolamento -, assim, as informações e características assinaladas por Saint-Hilaire podem dar subsídios para a interpretação do local

\footnotetext{
${ }^{122}$ Notas do texto feitas pelo autor: “(415) Do guarani itaquí - pedra de amolar. (416) V. minhas narrações
} anteriores". 
estudado. Todavia, a configuração do bairro também sofreu alterações com a construção da estação, que coincide com o período da implantação da cadeira pública.

Langenbuch (1971) apresentou uma foto da réplica da Capela de Bom Jesus do Itaqui e atribuiu o local a Jandira, mas ao visitar o Bairro de Itaqui para localizá-la, fui informada por um antigo morador (Senhor Ramiro, vendedor de doces da Estrada do Itaqui) que a capela foi destruída na década de 1990 para construção de uma empresa, ainda existente. A réplica estava na Estrada do Itaqui, altura dos números 711 e $715^{123}$, no município de Itapevi, ao lado da atual sede da Guarda Municipal. Abaixo segue a foto de Langenbuch da réplica do local onde muito provavelmente os alunos tinham aula no século XIX:

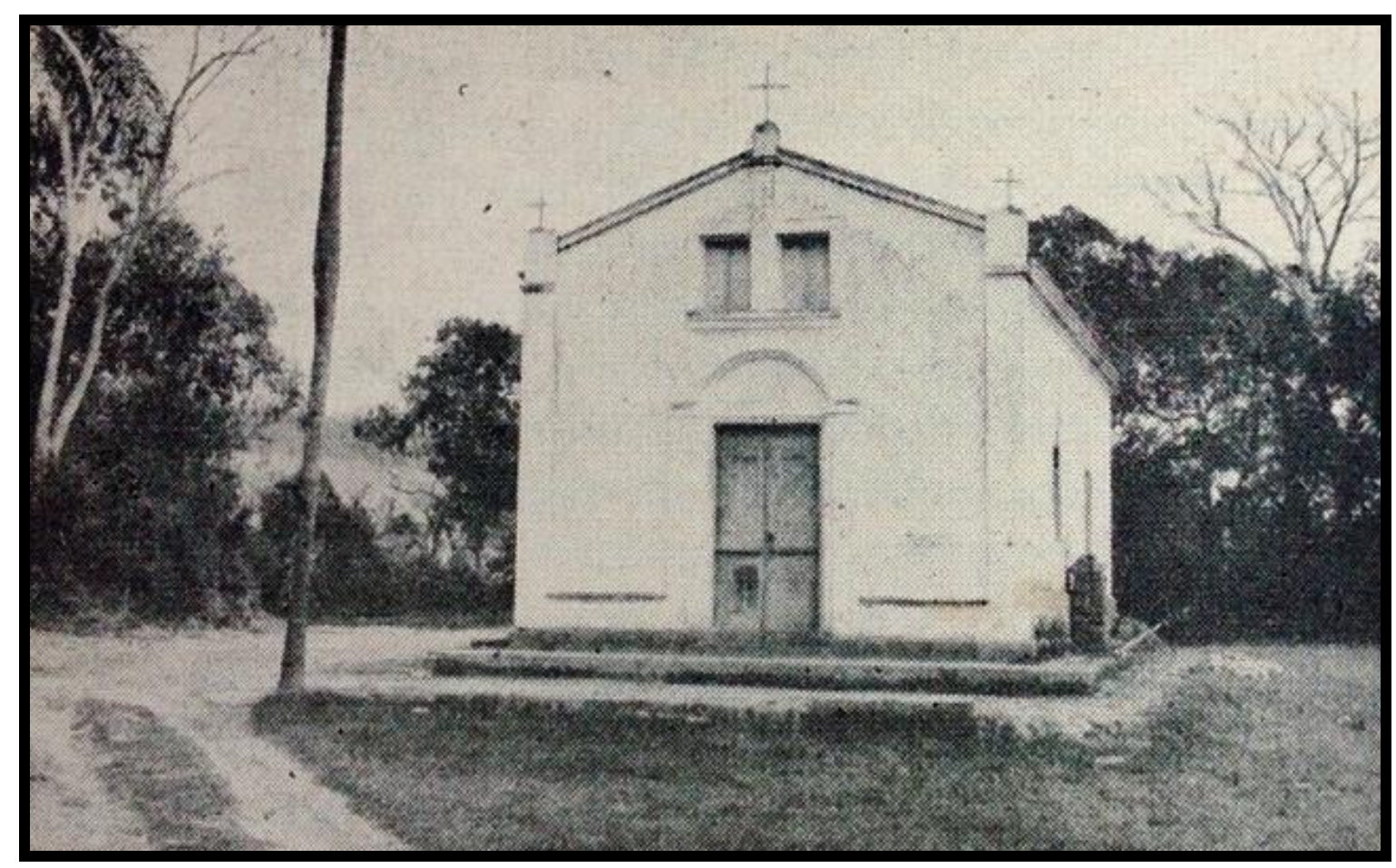

Ilustração 12 - Foto da réplica da capela original de Bom Jesus do Itaqui, 1971 (Fonte: LANGENBUCH, 1971, p. 46).

A terceira cadeira pública criada em 1871 foi a do Bairro de Sorocamirim. O bairro localizava-se no limite entre Cotia, São Roque e Una, de modo que ora essa cadeira aparecia nos documentos oficiais ou jornais como pertencente à Cotia, ora à São Roque. Segundo Azevedo Marques, esse bairro pertencia ao município de Cotia, estava situado à margem do ribeirão Sorocamirim (rio situado entre Cotia, São Roque e Una) e tinha uma cadeira pública primária masculina (1954, tomo 2, p. 274). Atualmente existem dois bairros chamados Sorocamirim, um em São Roque e outro em Ibiúna, relativamente próximos, mas, segundo

${ }^{123}$ Tentei contato com essa empresa, mas não fui atendida. 
moradores locais, no passado esses bairros eram muito grandes, havendo a possibilidade de ser um só naquela época. Trabalho com a hipótese de que a escola de Sorocamirim tenha funcionado na área entre os atuais bairros de Aguassaí (Cotia), Canguera (São Roque) e Patrimônio do Carmo (Ibiúna), que hoje permanecem como áreas rurais.

A história de Ibiúna se relaciona com o tropeirismo, assim como a de Cotia e São Roque. Havia uma estrada importante para o ciclo do muar entre Ibiúna e Cotia, a atual Rodovia Bunjiro Nakao, que se entroncava com a estrada da Capital a Sorocaba. Nela passavam tropeiros que saíam de Ibiúna e Piedade rumo à Sorocaba, e também ficava próxima ao rio Sorocamirim, nos limites de Cotia, São Roque e Ibiúna. Assim, ao que tudo indica, a cadeira de Sorocamirim se localizava num bairro de passagem de tropas e possivelmente possuidor de uma estrutura que um bairro de pouso exigia, ainda que rudimentar, mas também se caracterizava como um bairro rural. Pelas fontes, o local parecia não despertar o interesse de professores ensinarem ali, tendo o concurso anunciado algumas vezes nos jornais.

Em 1872, o professor José Custódio foi removido de Sorocamirim para a Cadeira do Bairro de Carapicuíba, criada provisoriamente em agosto $^{124}$ a partir duas petições locais datadas do mesmo mês, acompanhadas da relação de 34 crianças em idade escolar e assinadas pelo inspetor Antonio Barreto e pelo presidente interino da Câmara Municipal José Innocencio de Oliveira, que foram aprovadas pelo Presidente da Província e encaminhadas ao Inspetor Geral da Instrução Pública. Levando em consideração a morosidade intrínseca do poder público para efetivar projetos, a Cadeira de Carapicuíba foi criada com muita rapidez.

Ainda neste ano foi nomeado o professor Antonio Manoel Vieira ${ }^{125}$ para a Cadeira do Bairro de Sorocamirim ${ }^{126}$. Sobre ela, no Jornal Correio Paulistano de 2 de fevereiro de 1873 , houve a seguinte denúncia:

\footnotetext{
Nós, tendo cadeira creada para este bairro, estamos com nossos filhos sem aprenderem nada, visto a escola continuar a funccionar no bairro de Caucaia; por isso pedimos ao novo inspector geral que dê suas providências.

O sorocamiriano (Jornal Correio Paulistano de 2 fev. 1873, p. 3).
}

Localizei os relatórios do professor referentes a esse período reclamado pelo sorocamiriano e em nenhum deles o professor mencionou lecionar em outro bairro. Caucaia

\footnotetext{
124 Jornal Diário de São Paulo de 25 e 30 ago. 1872, p. 2: criada uma cadeira provisória em Carapicuíba, assumida pelo Professor Jose Custódio de Queiroz, removido da Cadeira de Sorocamirim.

125 Professor nomeado, segundo o Relatório de Presidente de Província de 1873, referente a 1872, p.24. Disponível em: <http://brazil.crl.edu/bsd/bsd/1014/000066.html> Acesso em: 18 abr. 2015.

126 Segundo ofício do inspetor Antonio Barreto de 6 dez. 1872 ao Insp. Geral de I. P., o Professor Antonio Manoel Vieira entrou em exercício nessa cadeira em 24 de novembro, tendo 15 alunos matriculados. AESP, Série Instrução Pública - Manuscritos, ref. CO5044.
} 
(atualmente distrito de Cotia) está em torno de nove quilômetros de distância do antigo Bairro de Sorocamirim. Se a escola de Sorocamirim chegou a funcionar em Caucaia é porque havia demanda nesse local, mas estranhamente, apenas em 1886 foi aberta uma cadeira ali.

Essa denúncia do sorocamiriano, se verdadeira, nos faz questionar sobre o motivo pelo qual o professor passou a lecionar em outro bairro e nos dá pistas sobre a falta de vistoria ou ainda da cumplicidade do inspetor em não denunciar o fato. É possível que não houvesse uma casa para a instalação de escola em Sorocamirim que cumprisse as necessidades do professor. O caso também permite considerar a atuação da população local, ou ao menos de um desafeto do professor, em relação à instrução pública. Desentendimentos entre professores e moradores (figuras públicas ligadas à política ou não) eram comuns durante a implementação da escolarização no Oitocentos. Esse tema é tratado no próximo capítulo.

Retomando a descrição da criação e funcionamento das cadeiras, a presente pesquisa verificou haver variadas informações sobre o Bairro de Carapicuíba: 1. A Aldeia de Carapicuíba ${ }^{127}$ fazia parte dele; 2. Parte do atual município de Carapicuíba, desmembrada de Cotia, pertencia ao bairro; 3. A localização da área da fazenda de criar que pertencia ao Barão de Iguape encontra-se entre Carapicuíba e Osasco (Quitaúna); 4. Segundo Barcellos (2011), na região que hoje compreende o bairro da Granja Viana, em Cotia, localizava-se a Fazenda Carapocuyba; e 5. Alfredo Moreira Pinto no livro A cidade de S. Paulo em 1900: impressões de viagem (1900) registrou que a Freguesia de Santa Ifigênia fazia divisa

[...] com a Freguezia da Cotia pelo córrego Jaguarahé ${ }^{128}$ na distancia de duas e meia a tres léguas cortando pelo lado direito da parte de áquem até o sitio de Jeronymo Pedroso inclusive, e pelo esquerdo até ode João José exclusive, pertencendo á Santa Ephigenia o territorio á quem do Jaguarahé. (PINTO, 1900, p. 18-19, nota minha).

Ao que parece, essa divisa referia-se ao antigo Bairro de Carapicuíba. Portanto, no período abrangido pela presente pesquisa, o bairro podia situar-se no local que contempla a atual Granja Viana (distrito de Cotia), a Aldeia de Carapicuíba e parte da atual Carapicuíba até próxima a Osasco, fazendo divisa com parte da área do atual Distrito do Jaguaré, pertencente à Capital. O povoamento local remonta ao aldeamento jesuíta.

Saint-Hilaire, em 1819, passou por Carapicuíba antes de chegar a Itaqui. Pela descrição, as características se aproximam do local comprado por Barão de Iguape:

Depois de uma caminhada de três léguas [partindo do rio Pinheiros], parei na fazenda de Carapicuva uma das que, na região, é denominada fazenda de criar,

\footnotetext{
127 Tombada como patrimônio histórico pelo IPHAN, hoje é um ponto turístico do município de Carapicuíba.
}

128 Jaguaré. 
porque na mesma são criados cavalos e gado vacum. Em Carapicuva existe unicamente uma construção, de muito mau aspecto e mal cuidada; mas parece que as terras que a constituem, têm grande extensão. Em meio das mesmas existe uma aldeiola habitada por indígenas e dependente da paróquia de Pinheiros (411), certamente um remanescente do primeiro estabelecimento que os indígenas formaram nesse local. O proprietário de Carapicuva lastimava-se amargamente de que seus vizinhos roubavam-lhe animais. A ideia do teu e do meu, como farei ver em a narração de minha viagem às missões do Uruguai, é uma das que os indígenas apreendem com mais dificuldade; e não é certamente com o exemplo dos brancos, usurpadores de suas propriedades, que os habitantes da paróquia de Pinheiros poderiam compreendê-la. Em Carapicuva e em todas as outras fazendas de criar das cercanias de São Paulo, só se dá sal às vacas e às éguas uma vez por mês. [...]

Entre Carapicuba e a fazenda Itaqué, onde pernoitei, a estrada passa quasi sempre por terrenos altos, de onde se descortinam, muitas vezes, vistas aprazíveis. Ondulações do solo assaz variadas, reunião de capões de mato e pastagens, rochedos, o Tietê que serpenteia ao fundo, algumas casinhas, a capela de Bariri todo esse conjunto, visto de diferentes pontos, apresenta lindíssimas paisagens. Nesse dia, passei a vau dois grandes ribeirões que desaguam no Tietê - o ribeirão da Cutia e o ribeirão de Berirí, Bariri ou Barueí (414), ribeirões cujos nomes são também os das igrejas vizinhas.

Toda a região que então percorri era antigamente habitada por numerosos indígenas. Foram aniquilados, e as denominações por eles dadas às terras em que moravam são os únicos vestígios que deixaram; assim o fogo, à proporção que avança, consome a erva das savanas. Nossa raça perversa só se utiliza da sua superioridade sobre as outras raças, para oprimi-las; reduzimos os africanos à escravidão e em espaço de tempo pouco apreciável, não restarão, provavelmente, da raça americana, mais do que obscuras lembranças. (Saint-Hilaire, 1940, p. 219-221, notas do autor ${ }^{129}$, adendo meu).

Azevedo Marques também criou um verbete para Carapicuíba, caracterizando-o como um pequeno arraial de cerca de 22,2 quilômetros da Capital, banhado pelo ribeirão Carapicuíba ${ }^{130}$, que "foi outrora uma das mais populosas aldeias de índios trazidos dos sertões por Afonso Sardinha” (1950, vol. 1, p. 170). O autor não mencionou a existência de uma cadeira pública, como nos bairros de Várzea-Grande e Sorocamirim. Devido à sua história colonial, Carapicuíba era o bairro mais antigo de Cotia, com população composta por indígenas e não-indígenas. Segundo Petrone (1995), a miscigenação resultou nos pardos

\footnotetext{
${ }^{129}$ Notas de Saint-Hilaire: “(409) Ampere, Hist, de la Littérature de la France avantle Xll e Siècle, II, 110. (410) Discurso pronunciado pelo Presidente Manuel da Fonseca Lima e Silva no dia 7 de janeiro de 1847. - O advogado dos indígenas de Carapicuíba e ao mesmo tempo diretor da respectiva aldeia, nomeado em 1846, foi Joaquim António Pinto Junior. Na mesma ocasião foi nomeado diretor geral dos indígenas da província o coronel José Joaquim Machado de Oliveira, cujas ideias filantrópicas fazem ter boas esperanças relativamente à sorte desses infelizes. (411) Os próprios habitantes da região informaram-me que a vila de Pinheiros constituía uma paróquia, e como tal é indicada no excelente mapa denominado Carta Topográfica da Província de São Paulo, editado no Rio de Janeiro, em 1847; mas devo dizer que Dan. Pedro Muller não a considera como paróquia da província, não fazendo mesmo qualquer menção a respeito. (414) Segundo Francisco José de Lacerda e Almeida, Barnerí ou Bariri significa o rio da planta chamada barirí, que tem flores vermelhas e sementes pretas (Diário da Viagem, 57)".

${ }^{130} \mathrm{O}$ ribeirão fica localizado próximo ao atual Rodoanel Mário Covas (SP-21), perto do km 20 dessa rodovia construída em torno do centro da Região Metropolitana de São Paulo.
} 
caipiras, compondo parte do número de pardos mencionados nos recenseamentos ${ }^{131}$ (p. 368370), e em 1896, dados oficiais ${ }^{132}$ apontaram que grande parte de Carapicuíba era formada por latifúndios improdutivos "e não raro as terras eram ocupadas por posseiros" (p. 371-372, grifo do autor).

Retomando a discussão sobre instrução pública, em conformidade com a lei de obrigatoriedade de ensino de 1874, foi formado o Conselho de Instrução Pública, composto pelo inspetor do distrito, presidente da Câmara Municipal e um cidadão nomeado pelo Presidente da Província e um substituto para esse cidadão ${ }^{133}$. O inspetor Antonio Barreto, em ofício datado de novembro ${ }^{134}$, pediu uma remessa do regulamento de ensino obrigatório, para que a "Comissão Inspectora" pudesse começar seus trabalhos (pedido feito em novembro, oito meses após a aprovação da lei). Entretanto, em um ofício endereçado ao Inspetor $\mathrm{Geral}^{135} \mathrm{em}$ dezembro, ficou evidente que no momento da criação do Conselho houve um contratempo entre o inspetor de distrito (Antonio Barreto) e o presidente do Conselho (José Novaes). No ofício, Antonio Barreto informou que o livro e as leis e instruções sobre o ensino obrigatório (que ele mesmo havia solicitado no mês anterior) estavam em posse do presidente do Conselho e não havia recebido comunicação nenhuma por parte dele, redimindo-se, assim, de qualquer responsabilidade. Ao invés desse simples problema ser resolvido entre Antonio Barreto e José Novaes, o primeiro mandou um documento oficial ao Inspetor Geral, o que nos faz pensar como as relações pessoais interferiam na institucionalização do ensino público e ainda nos dá indícios de que os sujeitos envolvidos com a escolarização disputavam posições de poder e se valiam das comunicações oficiais para estas negociações, acionando a legislação e os "superiores" em momentos de interesse.

Nesse mesmo ano, em julho, Antonio Barreto havia sido questionado junto com o professor de Itaqui, Marcolino Pinto de Queiroz, numa nota de jornal particular e anônima,

\footnotetext{
${ }^{131}$ Petrone, nessa passagem, se refere aos recenseamentos de 1813 e 1836: "Conforme é amplamente conhecido, sob a rubrica de pardos eram incluídos todos os mestiços, desde o mameluco até o mulato, passando pelo cafuzo" (1995, p. 368, grifo do autor).

${ }_{132}$ Dado retirado por Petrone de Documentos Interessantes para a História e Costumes de São Paulo, v. 22, nota de rodapé, p. 25.

133 O inspetor Antonio Barreto e o presidente da Câmara José Joaquim Pedroso Junior compuseram o Conselho, mas os cidadãos nomeados mudaram num curto período de tempo. No primeiro ofício (28 jul. 1874), assinado por Antonio Barreto, fariam parte do Conselho o cidadão José d'Araujo Novaes Junior e, como substituto, o cidadão Joaquim Lemos Leite. Em outro oficio (19 ago. 1874), assinado por José Joaquim Pedroso Junior, há a informação de que os membros são os cidadãos Joaquim José da Luz e Joaquim Francisco de Moraes Victor; em outros dois ofícios (7 e 9 dez. 1874) e assinaram como representantes do Conselho: José de Araujo Novaes (presidente), José Joaquim Pedroso Junior e Antonio Bandeira Barreto (secretário).

${ }_{134}$ Ofício do Inspetor de Distrito ao Inspetor Geral da I. P., 7 nov. 1874, AESP, Série Instrução Pública Manuscritos, ref. CO5044.

${ }^{135}$ Ofício do Inspetor de Distrito ao Inspetor Geral da I. P., 7 dez. 1874, AESP, Série Instrução Pública Manuscritos, ref. CO5044.
} 
que se referia ao fato de ambos serem pai e filho e considerando que em Itapecerica 136 "era incompatível servir o pai de inspector de districto e o filho de ser professor" ${ }^{\text {"137. Em }}$ novembro, o presidente da Câmara municipal, José Joaquim Pedroso Junior (que também era segundo suplente de subdelegado, inspetor de estrada e membro do Conselho de Instrução Pública, e que possivelmente estava ligado à nota questionadora de julho), criticou o professor de Itaqui, alegando que este não queria participar do Conselho de Classificação de Escravos ${ }^{138}$ e questionou se seria pelo fato de ele ser o filho do inspetor de distrito ${ }^{139}$.

Não obtive mais fontes que contribuíssem para o melhor entendimento desse caso, nem informações que confirmassem ser o professor Marcolino Pinto de Queiroz filho de Antonio Barreto. Não há na legislação educacional paulista vigente nada que impedisse que parentes pudessem exercer cargos concomitantes na instrução pública. A história culmina em novembro desse mesmo ano, quando o presidente da Câmara, J. J. Pedroso Junior, envia ao Presidente da Província uma representação contra Antonio Barreto, que despacha o documento ao Inspetor Geral da Instrução Pública ${ }^{140}$. Pareceu ter ficado insustentável a situação entre o inspetor de distrito e o presidente da Câmara e não localizei mais documentos assinados por Antonio Barreto como inspetor de distrito. Foi nomeado para esse cargo o cidadão Joaquim de Araujo Novaes ${ }^{141}$, irmão de José de Araujo Novaes (capitão, vereador, presidente do Conselho de Instrução Pública até o mês de outubro de 1875 e aparente desafeto de Antonio Barreto).

Em ofício localizado no AESP endereçado ao Presidente da Província pelo Inspetor Geral da Instrução Pública, Francisco Aurelio de Souza Carvalho, menciona-se que o inspetor local havia indicado o Capitão Agostinho de Oliveira Barros para seu cargo, e o presidente da Câmara indicado o cidadão Gabriel Jose Corrêa Bueno de Camargo ${ }^{142}$, mas, segundo o Inspetor Geral a partir de "informações de pessoas consideradas daquella Villa”, Joaquim de

\footnotetext{
${ }^{136}$ Município vizinho a Cotia.

137 Jornal Correio Paulistano de 10 jul. 1874, p. 2.

${ }^{138}$ Ou Junta de Classificação de Escravos, equipe encarregada de elaborar Listas de Classificação de Escravos em cumprimento do Decreto $n^{\circ} 5.135$ de 13 de novembro de 1872 que aprovou o regulamento para a execução da Lei n 2.040 de 28 de setembro de 1871, a Lei do Ventre Livre. Nesse decreto constava a criação do Fundo de Emancipação, com o propósito de haver uma gradual emancipação escrava no Brasil, seguindo uma ordem estabelecida (primeiro a emancipação das famílias escravas, depois dos indivíduos, havendo ainda critérios tanto para as famílias quanto para os indivíduos). Para isso, foram elaboradas as Listas de Classificação dos Escravos para Emancipação, entretanto, nem todos os cativos foram classificados. Cf. Marcondes e Motta (2000), Abreu (2002), Louzada (2011).

139 Jornal Correio Paulistano de 7 nov. 1874, p. 3.

140 Jornal Diário de São Paulo de 11 dez. 1874, p. 1.

141 Jornal Diário de São Paulo de 19 out. 1875, p. 2: em 10 de outubro foi nomeado para inspetor de distrito Joaquim de Araujo Novaes e exonerado do Conselho de Instrução Pública do município José de Araujo Novaes.

142 Jornal Diário de São Paulo de 10 set. 1875, p. 1: o Presidente da Província despachou ao Inspetor Geral de Instrução Pública um pedido do J. J. Pedroso Junior para que o cidadão fosse nomeado inspetor da instrução pública.
} 
Araujo Novaes era pessoa mais indicada para o cargo de inspetor de distrito, "por ser uma das pessoas mais importantes e consideradas daquella localidade e única capaz de reunir o Conselho de Instrucção, e á base do serviço publico sustento aquela minha proposta [enviada em 31 de agosto em outro ofício]"143. O Inspetor Geral acabou não cedendo a nenhum dos dois extremos da querela e indicou uma terceira pessoa, talvez não apenas por ser um sujeito mais influente e indicado para cargo, mas para evitar mais contratempos, amenizando a situação.

Com relação às cadeiras, e ainda tratando de possíveis desafetos, em 1875 foi criada a $2^{\text {a }}$ Cadeira Masculina da Vila de Cotia ${ }^{144}$ e quem a assumiu foi Marcolino Pinto de Queiroz, professor "perseguido" por José Joaquim Pedroso Junior. Interessante constatar que, a despeito da "perseguição" sofrida por um sujeito influente de Cotia, o professor assumiu uma cadeira na Vila. Assim, Marcolino deixou a Cadeira de Itaqui, com publicação de seu exercício de cargo na Vila em julho ${ }^{145}$. Como informado anteriormente, antes de sair de Itaqui, o professor apontou em seu relatório que muitos alunos tinham saído da escola porque seus pais se mudaram dali, já que as obras da Sorocabana haviam cessado ${ }^{146}$.

Com a saída de Marcolino foi aberto concurso para provimento de cargo de professor para Itaqui ${ }^{147}$, que seguiu aberto em 1876, 1877 e 1878. Outros concursos para cadeiras de Cotia foram abertos também: Sorocamirim e Várzea-Grande ${ }^{148}$. O concurso para a cadeira de Itaqui pareceu não ter procura e, somado ao fato de provavelmente não haver uma demanda local, ocasionou na transferência da cadeira de Itaqui para outro bairro, em 1878. É importante destacar que após a construção da parada ferroviária, a demanda decresceu e não se formou um aglomerado populacional mais denso ao redor dessa construção logo que ela foi efetuada. Pelo contrário, o aglomerado diminuiu, já que trabalhadores da Sorocabana foram embora dali.

Azevedo Marques citou o bairro de Itaqui em seus Apontamentos (1953, p. 358), referindo-se à segunda metade de 1870, que incluiu na descrição a existência da cadeira de instrução pública primária masculina. Entretanto, Langenbuch (1971) supôs - ainda que

\footnotetext{
${ }^{143}$ Ofício de 14 out. 1875, adendo meu. AESP, Série Ofícios Diversos, Ofícios Diversos de Cotia, ref. CO1008.

${ }^{144}$ Lei $\mathrm{n}^{\circ} 27$ de 14 abr. 1875. Disponível em <http://www.usp.br/niephe/bancos/legis_detalhe.asp?blg_id=75> Acesso em: 30 jan. 2014.

145 Jornal Correio Paulistano de 23 jul. 1875, p. 2.

${ }^{146}$ Relatório do professor (sem mapa) de 01 nov. 1874 ao Inspetor Geral de I. P. AESP, Série Instrução Pública Manuscritos, ref. CO5044.

147 Jornal Diário de São Paulo de 17 e 27 de jul. 1875, p. 3.

148 Jornal Diário de São Paulo de 24, 24, 25, 26 e 27 ago., 1, 8, 9 de set. de 1876, todos na p. 3: editais abertos concursos para várias cadeiras da Província, entre elas as de Itaqui, Sorocamirim e Várzea-Grande (esta consta "dito São Roque"); em 28 nov., 3, 4, 5 dez. 1877, 22, 28 mai. e 15 jun. 1878: editais abertos para várias cadeiras, entre elas, Itaqui e Sorocamirim.
} 
Azevedo Marques tenha mencionado o bairro em seu livro - não existir aglomerado humano naquele local naquele momento, haja vista que Saint-Hilaire não mencionou isso em seu relato de viagem e também porque o autor não visualizou construções antigas ao redor da réplica da capela de Itaqui (foto da página 78), quando visitou no início dos anos de 1970. Todavia, dados presentes nesta pesquisa confirmam a existência de povoamento naquela região, posto que havia demanda para a criação de uma cadeira (que durou de 1871 a 1875) e, ao que tudo indica, a criação e o funcionamento de uma cadeira pública estava diretamente ligada à população decorrente da construção da Parada/Estação Cotia.

No ano de 1875 houve uma epidemia de varíola entre os índios de Carapicuíba ${ }^{149}$, entretanto, como não localizei relatórios do professor ou de inspetor de distrito referentes a este ano, não tenho dados concretos para afirmar a influência dessa epidemia na vida escolar. Todavia, a aldeia se localizava dentro do bairro da escola, cujo professor havia entrado em exercício de cargo no mês de julho, segundo nota do Inspetor de Instrução Pública ${ }^{150}$. Se houve este comunicado, é possível que o professor tenha ficado afastado. O professor José Custódio de Queiroz assumiu esta cadeira em 1872, mas não há relatórios dele referentes a 1875 e 1876, além disso, nos jornais não há nenhuma nota de que a cadeira de Carapicuíba estivesse vaga ou com concurso para provimento de cargo. A informação sobre o exercício de cargo do professor de Carapicuíba sugere a possibilidade de uma licença do professor, talvez por conta da epidemia da varíola ou de alguma outra enfermidade.

Nos relatórios não há informações da existência de alunos indígenas matriculados nessa cadeira. Dados de jornais apontam que, em 1875, Cotia encontrava-se entre os municípios com epidemia da doença ${ }^{151}$, não especificando se se restringia apenas à aldeia de Carapicuíba. Talvez o fato de não localizar os relatórios do professor desses anos se refira a uma possível suspensão temporária da cadeira do bairro de Carapicuíba.

\footnotetext{
149 Jornal Correio Paulistano de 1 abr. 1875, p. 2;

Ofícios de março de 1875 disponíveis no site do Acervo Histórico da ALESP: "Encaminha cópia de ofício do subdelegado de Cotia, acompanhado de cópia de ofício do inspetor de quarteirão comunicando acerca da epidemia de varíola no aldeamento de Carapicuíba. Solicita providências". Disponíveis em: <http://200.144.6.120/upload/oficios/ODSP0095303005_001.jpg>,

<http://200.144.6.120/upload/oficios/ODSP0095303005_002.jpg>,

<http://200.144.6.120/upload/oficios/ODSP0095303005_003.jpg> Acesso em: 2 mai. 2015.

Em um deles o professor da primeira cadeira da Vila, João José Coelho, é escrivão de subdelegado;

Ofícios de abril de 1875 disponíveis no site do acervo histórico da ALESP. "Encaminha ofício do diretor do aldeamento de Carapicuíba solicitando providências acerca da epidemia de bexigas que vem afetando o aldeamento. Anexo A: Ofício do diretor do aldeamento de Carapicuíba". Disponíveis em: <http://200.144.6.120/upload/oficios/ODSP0095301036_001.jpg>,

<http://200.144.6.120/upload/oficios/ODSP0095301036_002.jpg> Acesso em: 2 mai. 2015.

150 Jornal Correio Paulistano de 1 jul. 1875, p. 2.

${ }^{151}$ Jornal Diário de São Paulo de 26 set. 1875, p. 1, e 28 out. 1875, p. 1: o governo declarou que mandaria verba caso tenha mais casos de varíola pra tratar os indigentes.
} 
Também em 1875, o professor Severiano, da cadeira de Várzea-Grande, matriculou-se como aluno-mestre da Escola Normal da Capital ${ }^{152}$. Ele se matriculou em novembro e em junho de 1876 foi removido para a Cadeira de Lageado, distrito da Freguesia da Penha de França, Capital ${ }^{153}$. Esta informação apresenta-se como exemplo do aperfeiçoamento docente por meio institucional, indicando quiçá uma melhoria salarial e/ou almejando vaga em alguma escola de seu interesse e/ou vontade de aprender cada vez mais, desejo comum aos sujeitos que escolheram a docência como ofício.

Entretanto, é sabido que a legislação vigente privilegiava os professores com formação escolar. Segundo a seção II da Lei $n^{\circ} 9$ de 1874, que tratava especificamente da criação da Escola Normal, os professores públicos poderiam se matricular como normalista, estabelecendo algumas vantagens:

Art. $8^{\circ}[\ldots]$

$\S$ 14. - Os Professores Publicos actuaes poderão matricular-se na Escola Normal, garantindo-lhes a Provincia os seus ordenados por dous annos.

Art. 9..$^{\circ}$ - Serão desde logo considerados vitalicios os alumnos da Escola Normal que, obtendo certificado de habilitação, forem providos nas cadeiras.

(Lei ${ }^{\circ}$ 9, de 22 de março de 1874, grifos meus).

Além da garantia de dois anos de ordenado e a vitaliciedade aos habilitados após terem cadeiras providas, segundo a norma, apenas os professores públicos e os alunos reconhecidamente pobres estudariam ali gratuitamente. Os demais deveriam pagar uma quantia à Província. Severiano, ao que tudo indica, foi o primeiro professor de Cotia que conseguiu tal feito, haja vista não ter localizado os nomes dos outros professores entre os normalistas. Posteriormente a ele, em 1885, outra professora que estudara na Escola Normal passou a exercer a função em Cotia: Analia Franco, professora da $1^{\text {a }}$ Cadeira Feminina da Vila de 1885 a 1887.

O ano de 1877 foi problemático para a instrução pública de Cotia, pois estavam vagas as cadeiras de Itaqui, Várzea-Grande e Sorocamirim, e em julho José Custódio de Queiroz pediu exoneração da cadeira de Carapicuíba ${ }^{154}$. Apesar de a legislação vigente determinar a obrigatoriedade escolar, efetivamente funcionaram apenas as três cadeiras da Vila o ano todo.

A cadeira de Itaqui foi transferida para o Bairro de Capitão Jerônimo em $1878^{155}$, que passou efetivamente a funcionar em setembro de 1879 , demorando mais de um ano para isso.

\footnotetext{
152 Jornal Diário de São Paulo de 30 nov. 1875, p. 3.

153 Jornal Diário de São Paulo de 19 ago. 1876, p. 1-2.

${ }^{154}$ Jornal Diário de São Paulo de 28 de jul. 1877, p. 2.

155 Lei $\mathrm{n}^{\circ} 9$ de 23 de março de 1878. Disponível em <http://www.usp.br/niephe/bancos/legis_detalhe.asp?blg_id=91> Acesso em: 10 mai. 2013.
} 
Não há nos arquivos pesquisados petição para a transferência dessa cadeira, contudo, os primeiros relatórios feitos pelo professor de Capitão Jerônimo apontaram contingente de alunos em ascensão: 23 alunos matriculados e 20 frequentes em 1879, 39 matriculados e 28 frequentes em 1880, chegando a 45 matriculados e 35 frequentes no primeiro semestre de 1881.

Esse bairro encontrava-se muito distante de Itaqui, possivelmente onde hoje em dia está o Bairro das Pedras, perto da atual Estrada de Caucaia do Alto ${ }^{156}$ e divisa com o atual município de Vargem Grande Paulista (antigo Bairro de Várzea-Grande). Capitão Jerônimo também estava próximo da estrada Ibiúna-Cotia, via de passagem de tropas. Pela relativa proximidade com Caucaia, talvez a cadeira do Bairro de Capitão Jerônimo tenha atendido também parte da daquela demanda. Essa hipótese considera o caso da denúncia do sorocamiriano, em 1873, de que crianças de Caucaia tinham aula com professor da cadeira do Bairro de Sorocamirim, pois este se estabelecera lá. Caucaia era um bairro caipira e possuía um povoado desde os tempos coloniais. Apresento mais dados sobre este bairro adiante.

Outro dado que pode contribuir para a compreensão da criação desta cadeira no Bairro de Capitão Jerônimo é que, segundo Wissenbach (1999), no Bairro de Tijuco Preto havia um rancho de pouso de tropeiros. Geograficamente o bairro de Tijuco Preto estava próximo de Capitão Jerônimo. Se pensarmos na definição de Candido (2001a) para bairro caipira, necessariamente inferimos que havia longas distâncias entre as casas e ainda maiores entre os bairros, porém, talvez a escola de Capitão Jerônimo estivesse localizada num local em que atendia as populações tanto do próprio bairro quanto de Tijuco Preto. Segundo Candido (2001a, p. 99), havia casos onde “o bairro não é[era] uma unidade rígida e exclusiva. Sob este ponto de vista situa[va]-se num determinado plano ecológico e social, definido pela interdependência das famílias, como estas se definem[niam] pela interdependência das pessoas" e onde, às vezes, havia uma interdependência entre os bairros.

Mas a principal hipótese para a criação dessa cadeira, além da demanda, é que havia um vereador que morava nesse bairro, Jesuíno Pereira Leite, com seis filhos matriculados ao longo de 1879 e $1885^{157}$ e que concedeu a casa para abrigar a escola, segundo o relatório do professor $^{158}$.

\footnotetext{
${ }^{156}$ Segundo antigos moradores de Vargem Grande Paulista, entrevistados por Teresinha Matos para seu estudo sobre o trânsito religioso de mulheres em Vargem Grande Paulista (2007), o Bairro das Pedras, nos arredores do Bairro de Tijuco Preto, antigamente chamava-se Capitão Jerônimo.

${ }^{157}$ AESP, Série Instrução Pública, livro de matrícula de Cotia, ref. EO3116.

${ }^{158}$ Relatório (sem mapa) de José Custódio de 25 set. 1879 ao Inspetor Geral da I. P. AESP, Série Instrução Pública - Manuscritos, ref. CO5044.
} 
Quem era o professor da cadeira de Capitão Jerônimo? José Custódio de Queiroz ${ }^{159}$, que, segundo Relatório de Presidente de Província de 1878, assumiu a cadeira na forma do parágrafo 3 do artigo 57 do Regulamento de 1869. O dispositivo permitia nomear, sem exame, professores que "houverem exercido o cargo de Professores públicos por mais de três annos, sem nota que os desabone" ${ }^{160}$. Outro professor havia sido nomeado em abril, João da Matta e Luz, mencionado no mesmo relatório de presidente de Província, mas em julho foi transferido para a Cadeira do Bairro de Canguára, em São Roque ${ }^{161}$. No Relatório de Presidente de Província referente a 1879, todavia, consta que se removeu de Capitão Jerônimo para a Cadeira do Bairro do Collegio (sem especificar o município) ${ }^{162}$.

O professor José Custódio de Queiroz parecia funcionar como um "coringa" na educação pública cotiana. Não era um professor concursado, seus cargos eram nomeados, evidenciando a falta de pessoas qualificadas em Cotia para o exercício do cargo e sugerindo uma provável rede clientelística com a elite local que ocupava cargos na Câmara. Passou por várias cadeiras dos bairros, cinco no total, mesmo que distantes um do outro.

\footnotetext{
159 Jornal da Tarde (SP) de 19 jul. 1879, p. 3.

${ }^{160}$ Regulamento de 18 de abril de 1869 - Para Instrução Pública e particular da Província. São Paulo: Tipografia Correio Paulistano, 1874.

${ }^{161}$ Jornal da Tarde (SP) de 30 abr. 1879, p. 3: nomeado João da Matta e Luz para a cadeira de Capitão Jerônimo; Jornal Correio Paulistano de 30 jul. 1879, p. 1: transferência do mesmo professor para a Cadeira do Bairro de Canguára, São Roque; Há atualmente o Bairro de Canguera, talvez seja este mesmo bairro no passado (bairro que, inclusive, tenho como hipótese que ficava próximo ao Bairro de Sorocamirim). Ele também ficava perto do bairro de Capitão Jerônimo.

${ }^{162}$ Disponível em <http://brazil.crl.edu/bsd/bsd/1024/000279.html> Acesso em: 5 ago. 2015.
} 


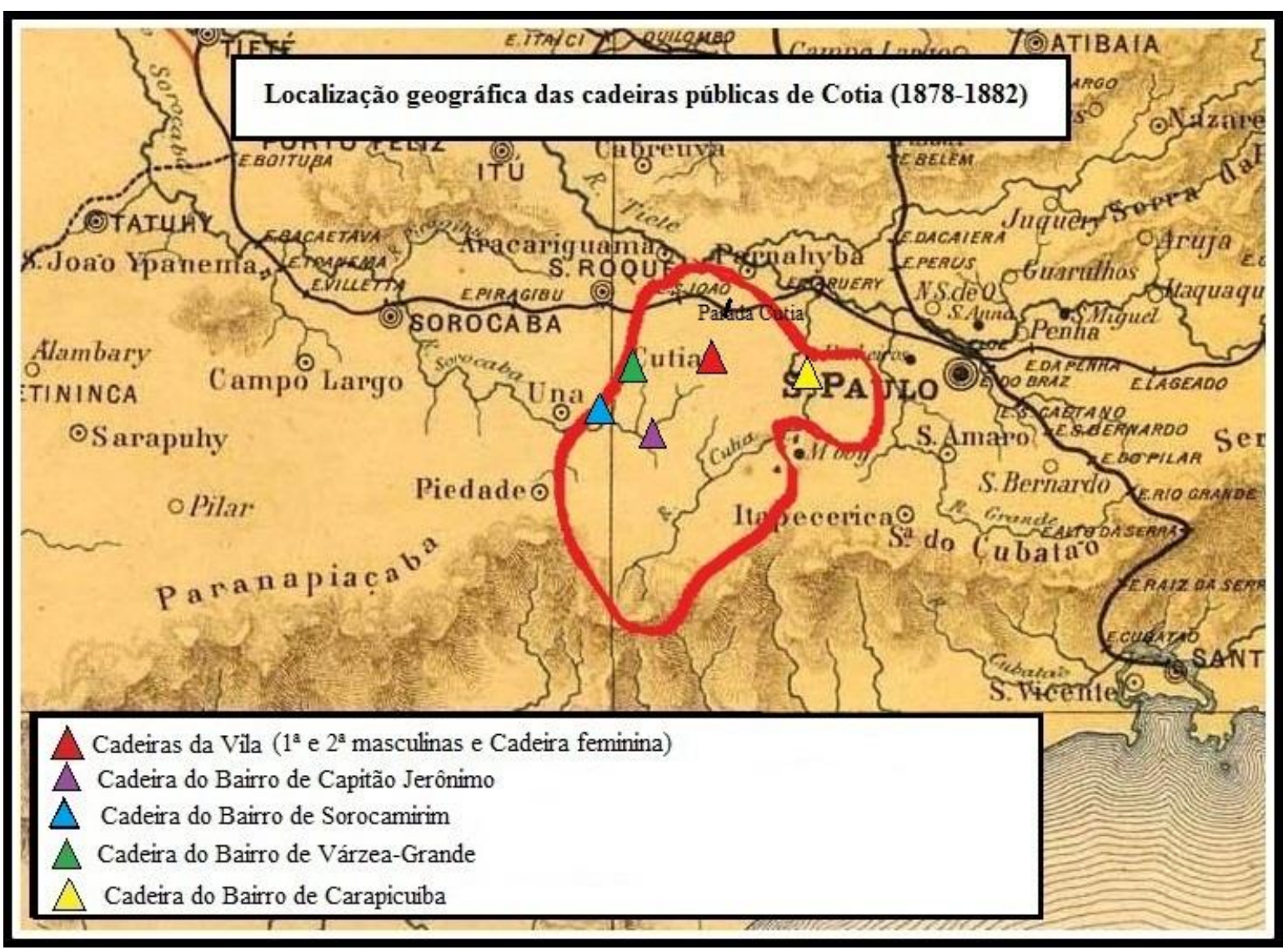

Ilustração 13 - Mapa da localização das cadeiras públicas de Cotia - 1878-1882 (Fontes: LISBOA, 1884; SEADE, s/d. Traçados, título e legenda feitos por mim).

De acordo com os dados compilados, algumas cadeiras foram ocupadas após exames de professores que se candidataram como opositores a elas (João José Coelho, Marcolino Pinto de Queiroz, Severiano José de Ramos, entre outros). Mas o nome de José Custódio não apareceu entre eles, pois não há publicações sobre exames por ele feitos, apesar de ter assumido várias cadeiras. As diferentes maneiras de vínculo com o serviço público, como os casos de João José Coelho, que lecionou na mesma cadeira por 25 anos, e de José Custódio de Queiroz, que assumiu cinco cadeiras em Cotia sem nunca passar por exame, são alguns dos modelos da vida do magistério no Oitocentos. E do Novecentos, e até dos dias atuais...

Também em 1878, a mesma lei que transferiu a cadeira de Itaqui para Capitão Jerônimo, mudou a cadeira de Carapicuíba para "as immediações da estação do Baruery, no município de Parnaíba, na estação Sorocabana, no logar mais conveniente, sendo o professor obrigado a ensinar os alumnos de ambos os districtos"163 $\left(\$ 1^{\circ}\right.$ do Art. $\left.2^{\circ}\right)$. O professor de Carapicuíba deveria se estabelecer em Barueri, município de Parnaíba, e atender aos alunos de dois municípios diferentes. É verossímil considerar que essa decisão tenha sido tomada

${ }^{163}$ Disponível em <http://www.usp.br/niephe/bancos/legis_detalhe.asp?blg_id=91> Acesso em: 3 jul. 2014. 
devido à epidemia de varíola na aldeia em 1875, pois a região de divisa entre Carapicuíba e Barueri está distante de onde se encontra a Aldeia de Carapicuíba.

José Custódio de Queiroz foi professor desta cadeira até meados de 1877, não sendo localizado relatório do final deste ano e nem de 1878. O relatório que consta nas latas consultadas no AESP após a mudança é datado de 19 de maio de 1879, assinado pelo então professor da cadeira de "Carapucuhyba, Vila da Cutia", João Rodrigues de Jesus, comunicando que desde aquele dia abriu a escola do sexo masculino, com 17 alunos frequentes. Este professor havia sido nomeado no mês de abril de 1879 para o exercício de cargo ${ }^{164}$. Pelo fato do professor colocar "Vila da Cutia", talvez a escola tenha se localizado mais próximo de Barueri, mas ainda dentro de Carapicuíba.

Segundo ofício do inspetor de distrito Joaquim de Araujo Novaes de janeiro de 1879 havia em Cotia oito escolas, sendo sete públicas e uma particular para o sexo feminino. Nesse relatório, informou apenas a quantidade de alunos frequentes nas cadeiras da Vila, $1^{\mathrm{a}}$ e $2^{\mathrm{a}}$ Masculinas e a Feminina, respectivamente, 20, 15 e $18^{165}$. Entretanto, no Relatório de Presidente de Província referente a 1879, a quantidade se altera para, respectivamente, 21, 18 e $20^{166}$. A escola particular feminina era da professora Presciliana Barbara de S. Pedro Crysolo, com 18 alunas matriculadas e 12 frequentes, segundo o mesmo relatório de governo. Nesse documento, as cadeiras de Várzea-Grande e Sorocamirim encontravam-se vagas. Ainda em 1879 houve alteração na inspeção do distrito, assumindo a função o Tenente Benedicto José de Oliveira $^{167}$.

Em 1880, a escola de Sorocamirim não teve aluno, apenas professor, João Cezar de Abreu ${ }^{168}$, segundo Relatório de Instrução Pública para o ano de $1880^{169}$. Já a cadeira de Várzea-Grande voltou a funcionar ${ }^{170}$. Removido da cadeira da Vila de Araçariguama, quem assumiu a cadeira de Várzea-Grande foi Manoel de Moraes Pinto, abrindo a escola com 10 alunos matriculados ${ }^{171}$. Manoel já havia lecionado na $1^{\text {a }}$ Cadeira da Vila da Cotia logo após

\footnotetext{
164 Jornal da Tarde (SP) de 19 d abr. 1879, p. 2.

165 Ofício do inspetor de distrito de Cotia ao Inspetor Geral da I. P. que acompanhava os termos de exames dos alunos (termos não arquivados) de 3 de janeiro de 1879. AESP, Série Instrução Pública - Manuscritos, CO5044. 166 Disponível em <http://brazil.crl.edu/bsd/bsd/1024/000255.html > e <http://brazil.crl.edu/bsd/bsd/1024/000266.html> Acesso em: 5 ago. 2015.

167 Relatório de P. Província de 1879. Disponível em <http://brazil.crl.edu/bsd/bsd/1024/000289.html> Acesso em: 5 ago. 2015.

168 Jornal Correio Paulistano de 12 out. 1880, p. 2.

${ }^{169}$ Disponível em <http://brazil.crl.edu/bsd/bsd/1025/000523.html> Acesso em: 5 ago. 2015.

${ }^{170}$ Disponível em <http://brazil.crl.edu/bsd/bsd/1025/000524.html> Acesso em: 5 ago. 2015.

${ }^{171}$ Relatório (sem mapa) do professor ao Inspetor Geral da I. P. de 1 jun. 1880. AESP. Série Instrução Pública Manuscritos, ref. CO5044.
} 
Antonio Barreto se aposentar. Ele também foi aluno de Antonio Barreto, aparecendo no mapa de frequência do ano de 1849.

Em relatório feito pelo então inspetor de distrito Benedicto José de Oliveira, em 1881 havia também duas aulas particulares, uma para cada sexo, mas não há informação dos nomes dos professores. Esse é o ano do falecimento de Antonio Barreto ${ }^{172}$. A nota de falecimento coligida da Hemeroteca Digital da Biblioteca Nacional é do jornal Gazeta de Notícias do Rio de Janeiro e não há, ao menos digitalizados pela Hemeroteca, outros jornais que noticiaram a morte.

Em 1882 houve algumas mudanças na composição das cadeiras públicas de Cotia: a cadeira de Sorocamirim voltou a funcionar, tendo como professor João Maria Thomaz, apesar disso, a cadeira de Carapicuíba não teve documentos localizados e não os encontrei desde esse ano até 1888. Em novembro houve a abertura de outra cadeira, a Escola da Estação São João na Estrada Sorocabana ${ }^{173}$, cujo professor foi Joaquim Chrispim de Oliveira. No ano de 1883, o preofessor Joaquim solicitou, por meio do relatório, o regulamento da instrução pública "para eu saber dirigir melhor a minha Escola".

172 Jornal Gazeta de Notícias (RJ) de 27 fev. 1881, p. 1.

173 Lei de criação $\mathrm{n}^{\circ} 37$ de 30 de março de 1882. Disponível em <http://www.usp.br/niephe/bancos/legis_detalhe.asp?blg_id=240> Acesso em: 4 jul.2014. Conhecida atualmente como São João Velho, a estação localiza-se em São Roque, perto da divisa com Itapevi. 


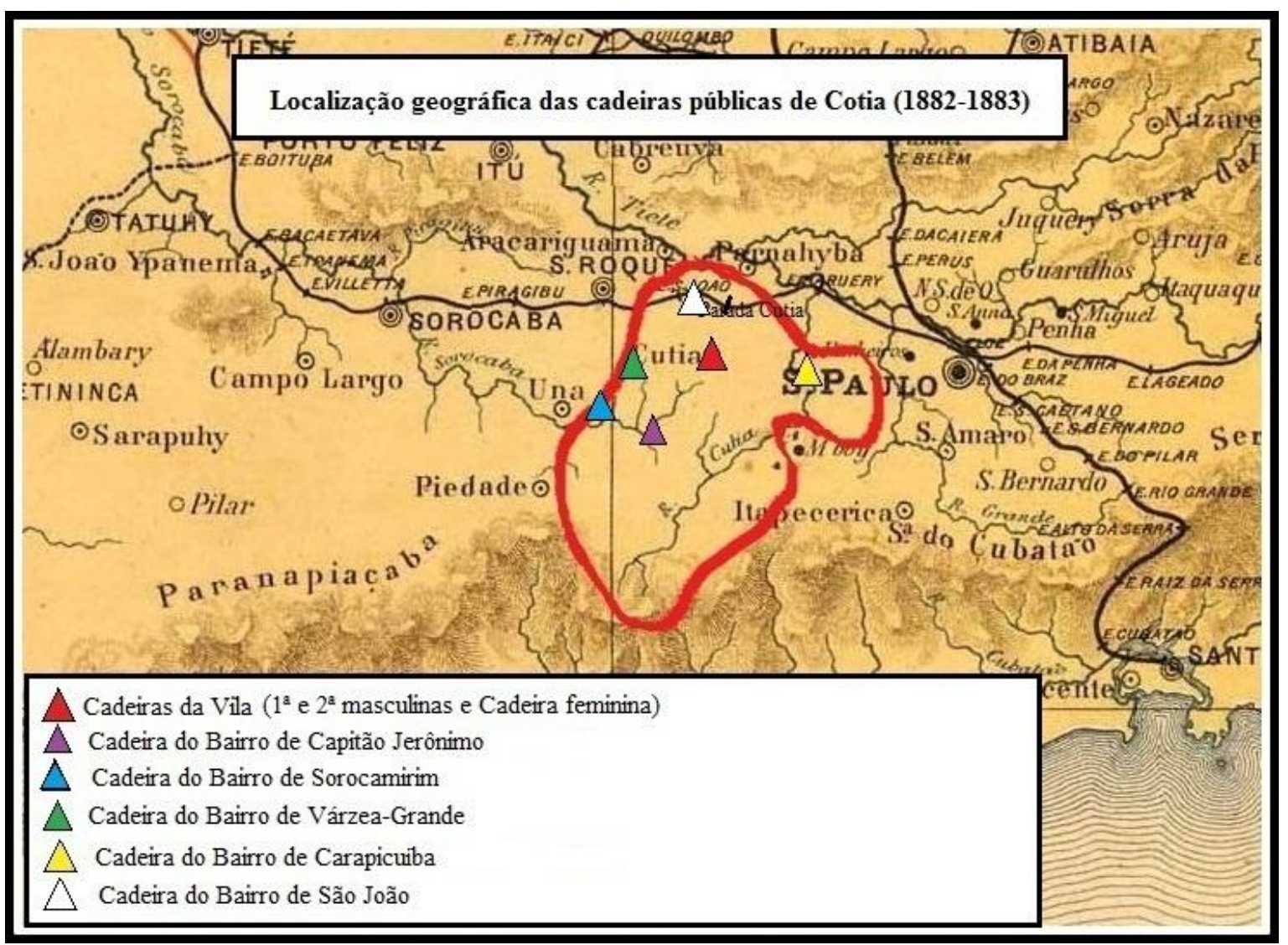

Ilustração 14 - Mapa da localização das cadeiras públicas de Cotia - 1882-1883 (Fontes: LISBOA, 1884; SEADE, s/d. Traçados, título e legenda feitos por mim).

A Escola da Estação São João localizava-se no Bairro de São João, muito próximo da divisa com São Roque. Atualmente a Estação São João Velho pertence ao território de São Roque. A despeito de este bairro ter recebido uma estação de trem que funcionava desde 1875, a cadeira pública foi criada apenas em 1882. Diferentemente do que aconteceu em Itaqui, onde a demanda por escola foi condicionada pelo aglomerado formado ao redor da construção da via férrea ainda no período das obras, em São João, a falta de escola pode ter sido ocasionada por falta de demanda. Também é possível que houvesse demanda, mas não tenha havido organização dos moradores e dos representantes políticos locais para solicitarem uma cadeira para o bairro. Outra possibilidade é de que tenha havido demanda e solicitação da cadeira, mas o pedido não tenha sido atendido. Essas hipóteses levam em conta, infelizmente, a ausência de fontes (entre tantas bases procuradas) que indicassem a tentativa de criação da cadeira naquele bairro.

Em março de 1884, o Correio Paulistano publicou a ata da $33^{\mathrm{a}}$ sessão ordinária da Assembleia Provincial que apontava criação da cadeira masculina do Bairro de São João, no 
lugar chamado Cruz Grande ${ }^{174}$. A primeira cadeira deste bairro, criada em 1882, passou a funcionar no mesmo ano, como mostram os relatórios do professor Joaquim Chrispim, porém não foi encontrado nenhum relatório do ano de 1884. Em nenhuma fonte localizada referente a 1883 ou 1885 há menção à supressão de cadeira no Bairro de São João, nem transferência de alunos para outra cadeira do mesmo bairro. Não há nenhuma lei no arquivo digital da Assembleia Legislativa de São Paulo de criação da cadeira no local chamado Cruz Grande e no relatório de Presidente de Província referente a 1885 consta apenas para esse bairro a cadeira da Estação São João, cujo professor era Joaquim Chrispim ${ }^{175}$.

Pela petição do então inspetor literário José Joaquim Pedroso Junior de $1886^{176}$, a Cadeira de Cruz Grande na Estação São João havia sido criada, mas a lei ainda não estava sancionada. $\mathrm{O}$ inspetor pediu que sancionasse, visto que havia mais de 30 alunos para se matricularem, mas este pedido não foi atendido e a causa é desconhecida pela pesquisa.

Em março de 1885 houve um requerimento do inspetor literário Benedicto de Oliveira pedindo criação de cadeira feminina para o Bairro de São João ${ }^{177}$, entretanto o pedido não foi atendido e também a causa é desconhecida pela pesquisa. De todo modo, cabe sinalizar que o bairro que teve uma escola só sete anos depois da criação da estação, poucos anos depois solicitou outras cadeiras, fato que reforça a hipótese de que esse local passou a ter o número de moradores aumentado. Contudo, hoje em dia a região é pouco povoada, tendo algumas empresas e bastante mata preservada. O Bairro de São João, apesar de receber uma das primeiras estações da Sorocabana, não se desenvolveu como Itaqui, este que posteriormente tornou-se Itapevi e emancipou-se de Cotia em 1959.

Em 1884, foram criadas três cadeiras, a $2^{\text {a }}$ Cadeira Feminina da Vila, e duas cadeiras masculinas, do Bairro do Lavapés e do Bairro do Rio Cotia ${ }^{178}$. O professor José Custódio de Queiroz foi removido para a cadeira de Lavapés, assumindo as aulas em 15 de março. Manoel

\footnotetext{
${ }^{174}$ Jornal Correio Paulistano de 30 mar. 1884, p. 1; Não existe um bairro atual com este nome, apenas uma estrada chamada Estrada da Cruz Grande localizado onde atualmente está o município de Itapevi, próxima à divisa com São Roque. A antiga estação São João localiza-se no atual município de São Roque. A atual estrada da Cruz Grande está distante em por volta de cinco quilômetros do local da antiga estação São João.

${ }^{175}$ Disponível em <http://brazil.crl.edu/bsd/bsd/1031/000227.html> Acesso em: 5 ago. 2015.

176 Petição de 20 de março de 1886 de José Joaquim Pedroso Junior ao Presidente da Assembleia Legislativa Provincial. Disponível em <http://www.al.sp.gov.br/repositorioAH/Acervo/Alesp/Imperio/Falp_439/IP86_055.pdf〉 Acesso em: 29 set. 2014.

${ }^{177}$ Petição de 9 de março de 1885 de Benedicto d'Oliveira ao Presidente da Assembleia Legislativa Provincial. Disponível em <http://www.al.sp.gov.br/repositorioAH/Acervo/Alesp/Imperio/Falp_437/IP85_002.pdf> Acesso em: 29 set. 2014.

178 Lei $\mathrm{n}^{\circ} 3$ de 5 de fevereiro de 1884. Disponível em <http://www.usp.br/niephe/bancos/legis_detalhe.asp?blg_id=295> Acesso em: 29 set. 2014.
} 
de Moraes Pinto, antes professor de Várzea-Grande, assumiu a cadeira de Capitão Jerônimo ${ }^{179}$. Para a cadeira feminina assumiu a professora Catharina Etelvina Pedroso.

Não foram localizadas fontes das cadeiras de Várzea-Grande, Sorocamirim e Carapicuíba, e também da recém-criada do Bairro do Rio Cotia, com exceção da lei de criação. De todas as cadeiras criadas em Cotia desde 1838, a do Bairro do Rio Cotia foi a única criada que não foi provida após a criação, ficando vaga desde sua abertura até a transferência de local.

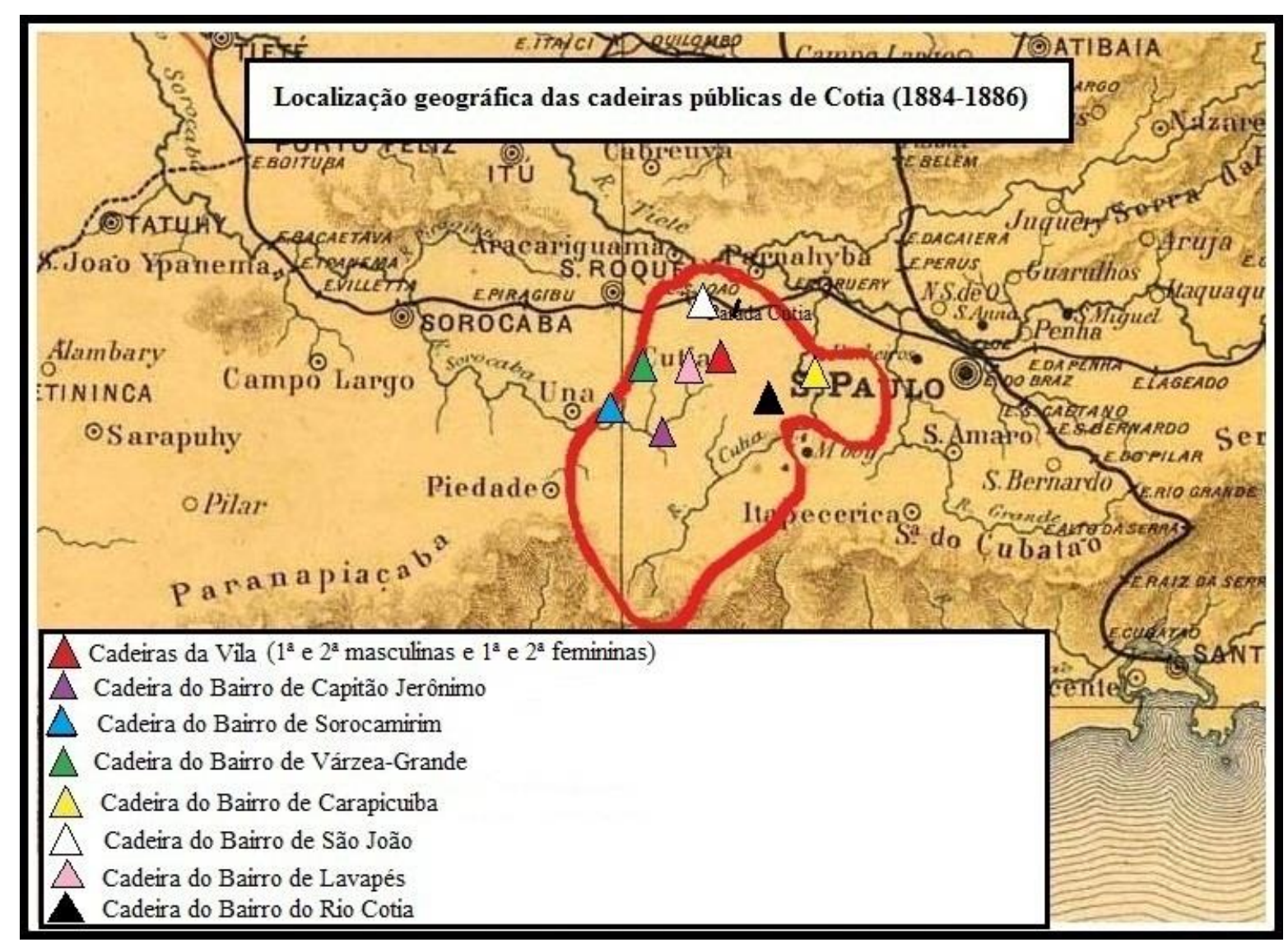

Ilustração 15 - Mapa da localização das cadeiras públicas de Cotia - 1884-1886 (Fontes: LISBOA, 1884; SEADE, s/d. Traçados, título e legenda feitos por mim).

Poucas são as informações dos bairros do Lavapés e do Rio Cotia, bairros situados nas "imediações da Villa" ". Ao que parece, o Bairro do Lavapés localizava-se bem próximo à Vila, com área correspondente ao atual Jardim Lavapés (ou parte dele). Nos artigos de

179 Jornal Correio Paulistano de 6 mar. 1884, p. 2.

180 Disponível em <http://www.al.sp.gov.br/repositorioAH/Acervo/Alesp/Imperio/Falp_439/IP86_055.pdf〉 Acesso em: 8 mai. 2015. 
posturas da Câmara Municipal da Vila de Cotia de 1874 e de $1886^{181}$, apontados no capítulo anterior, menciona-se que os moradores da Vila poderiam lavar roupa ou banhar-se no rio Lavapés, nas "servidões públicas" da Vila e num ofício da Câmara remetido em 1862 para o Presidente da Província pedindo consertos diversos em Cotia, menciona-se que Lavapés localizava-se "perto da Vila"182.

No caso do Bairro do Rio Cotia não foi possível saber sua localização exata, pois o rio que recebe este nome se estende por grande parte do município, desde o Morro Grande, em Cotia, passando por Barueri, até desaguar no Rio Tietê. Mas como em documento da época assinado pelo inspetor literário José Joaquim Pedroso Junior mencionava-se que se tratava de um bairro nas imediações da Vila, é possível que seja na área do atual Bairro do Rio Cotia, na altura do km 29 da Rodovia Raposo Tavares, relativamente próximo ao local onde foi instalada a primeira capela de Cotia (no Caiapiá).

O cargo de inspetor literário deixou de ser exercido pelo Tenente Benedito José de Oliveira, em setembro de 1885, e foi nomeado o Capitão José Joaquim Pedroso Junior ${ }^{183}$, que, segundo relatório do governo, exerceu essa função de 24 de setembro a 7 de dezembro de 1885, solicitando exoneração ${ }^{184}$. Mas há uma petição de escolas assinada por esse inspetor em 1886 sem se designar como "interino", mencionada anteriormente ${ }^{185}$. Entre os vários cargos desse sujeito já sinalizados nesta dissertação, também foi inspetor literário.

Em abril desse ano, os professores das primeiras cadeiras da Vila, Maria Joanna do Sacramento e João José Coelho, se aposentaram ${ }^{186}$. A solicitação de suas aposentadorias à Assembleia Provincial já havia sido feita em março de $1880^{187}$, mas foram concedidas apenas cinco anos depois. Para seus cargos assumiram, respectivamente, Analia Emilia Franco

\footnotetext{
181 Disponíveis em <http://www.al.sp.gov.br/repositorio/legislacao/resolucao/1874/resolucao-5728.04.1874.html> e <http://www.al.sp.gov.br/repositorio/legislacao/resolucao/1886/resolucao-13608.06.1886.html> Acesso em: 8 mai. 2015.

182 Ofício da Câmara Municipal de Cotia ao Presidente da Província de 19 fev. 1962. AESP, Série Ofícios Diversos, Ofícios Diversos de Cotia, ref. CO1008.

${ }^{183}$ Jornal Correio Paulistano de 26 set. 1885, p. 2: exonerado o inspetor literário Benedicto José de Oliveira e nomeado o capitão José Joaquim Pedroso Junior.

${ }^{184}$ Relatório sobre o estado da Intrução Pública de São Paulo, 1886 (com dados de 1885 e de 1886). Disponível em <http://brazil.crl.edu/bsd/bsd/1031/000258.html> Acesso em 6 ago. 2015.

185 Petição de 20 de março de 1886 de José Joaquim Pedroso Junior ao Presidente da Assembleia Legislativa Provincial. <http://www.al.sp.gov.br/repositorioAH/Acervo/Alesp/Imperio/Falp_439/IP86_055.pdf> Acesso em: 29 set. 2014.

${ }^{186}$ Jornal Correio Paulistano de 23 abr. 1885, p. 1.

187 Jornal A Constituinte de 10 mar. 1880, p.1.
} 
(removida da cadeira de Guaratinguetá) ${ }^{188}$ e José Custódio de Queiroz (removido da cadeira do Bairro de Lavapés, Cotia) ${ }^{189}$.

O último ano do recorte desta pesquisa apresenta o funcionamento efetivo de nove cadeiras, das 11 estabelecidas em Cotia. A cadeira de Várzea-Grande, antes sem professor, passou a ter como docente João Baptista Cepellos, removido da Cadeira do Bairro da Quadra, em Tatuí ${ }^{190}$. João era pai do poeta Manoel Baptista Cepellos e, em 1874, havia aberto uma escola particular no município sem informar o inspetor de distrito.

Destaca-se em 1885 o fato de o professor de Sorocamirim, João Maria Thomaz, não informar em seus relatórios o município de sua cadeira e no relatório do governo constar como cadeira de São Roque, apesar de no AESP o documento estar entre os pertencentes à Cotia. Fato que indica a dificuldade de certificação do pertencimento do bairro, tanto pelos sujeitos que ali viviam quanto pelo governo e também pelo arquivo, e é um caso exemplar de um dos problemas encarados pelos professores que lecionavam em regiões afastadas e de divisas.

Estendo aqui o período definido por esta pesquisa apenas a fim de ilustrar o que aconteceu com as cadeiras criadas em 1884, pois tiveram pouco tempo de existência, porém o recorte permanece até 1885 devido às fontes localizadas em maior quantidade, possibilitando melhor análise.

Como não havia alunos suficientes para o funcionamento das escolas de Lavapés e do Rio Cotia, ambas foram transferidas em julho de 1886 para, respectivamente, o Bairro das Graças e o Bairro de Caucaia. Em petição ${ }^{191}$, o inspetor José Joaquim Pedroso Junior, além de informar a falta de frequência dos alunos naquelas cadeiras, alegou que havia mais de 30 alunos para o preenchimento das últimas. Também nesse documento, como já tratado anteriormente, pediu que sancionasse a lei de criação de mais uma cadeira na Estação de São João, no lugar chamado Cruz Grande. Os pedidos de José Joaquim foram atendidos em parte, pois as escolas foram transferidas, mas não houve a criação de mais uma cadeira no Bairro da Estação de São João.

O Bairro de Caucaia, para onde foi transferida a cadeira do Rio Cotia, foi o local de funcionamento da escola do Bairro de Sorocamirim em 1873, segundo a reclamação de um

\footnotetext{
188 Jornal Correio Paulistano de 27 mai. 1885, p. 2.

189 Jornal Correio Paulistano de 27 mai. 1885, p. 2.

${ }^{190}$ Jornal Correio Paulistano de 22 out. 1885, p. 2.

${ }^{191}$ Petição de 20 de março de 1886 de José Joaquim Pedroso Junior ao Presidente da Assembleia Legislativa Provincial. Disponível em <http://www.al.sp.gov.br/repositorioAH/Acervo/Alesp/Imperio/Falp_439/IP86_055.pdf> Acesso em: 29 set. 2014.
} 
sorocamiriano no jornal da época. Somente após 13 anos desse fato, foi criada uma cadeira no bairro. Historicamente, Caucaia (hoje distrito de Cotia) se caracteriza por uma região de produção agrícola e, segundo Petrone (1995), no século XIX, era um dos principais núcleos caipiras dos arredores de São Paulo. Borrego (2010), em pesquisa sobre a trajetória de nove agentes comerciais de São Paulo Colonial a partir de laços familiares, na qual articula "o desenvolvimento urbano do centro da Capital com a atuação destes homens de negócio, concentrando as análises sobre aspectos da vida material relacionados às suas moradias e ao mobiliário existente no espaço doméstico" (p. 11), apontou Caucaia como área de sesmarias concedidas a duas famílias de portugueses. Uma das famílias cultivava milho e feijão, criava porcos e possuía "alguns poucos cavalos de carga para a condução dos mantimentos" (p. 17). O Bairro de Caucaia estava localizado relativamente próximo da estrada que liga Ibiúna a Cotia, antiga passagem de tropas. Como o Bairro de Sorocamirim, fez parte desse ciclo econômico de forma direta ou indireta.

Já o Bairro das Graças está localizado próximo da nascente do Rio Cotia e da casa bandeirista construída em fins do século XVII e tombada pelo IPHAN, no Sítio do Padre Inácio. Sua história remonta aos tempos coloniais e dados do processo de tombamento da casa feito pelo IPHAN esclarecem, segundo listas nominativas, que no século XIX funcionava uma fazenda de propriedade de uma mulher descendente do juiz de órfãos Roque Soares de Medela (o primeiro proprietário), onde se produzia milho e feijão (Brasil-IPHAN/MinC, 1996 e 1997). Era um bairro situado numa área de produção agrícola. 


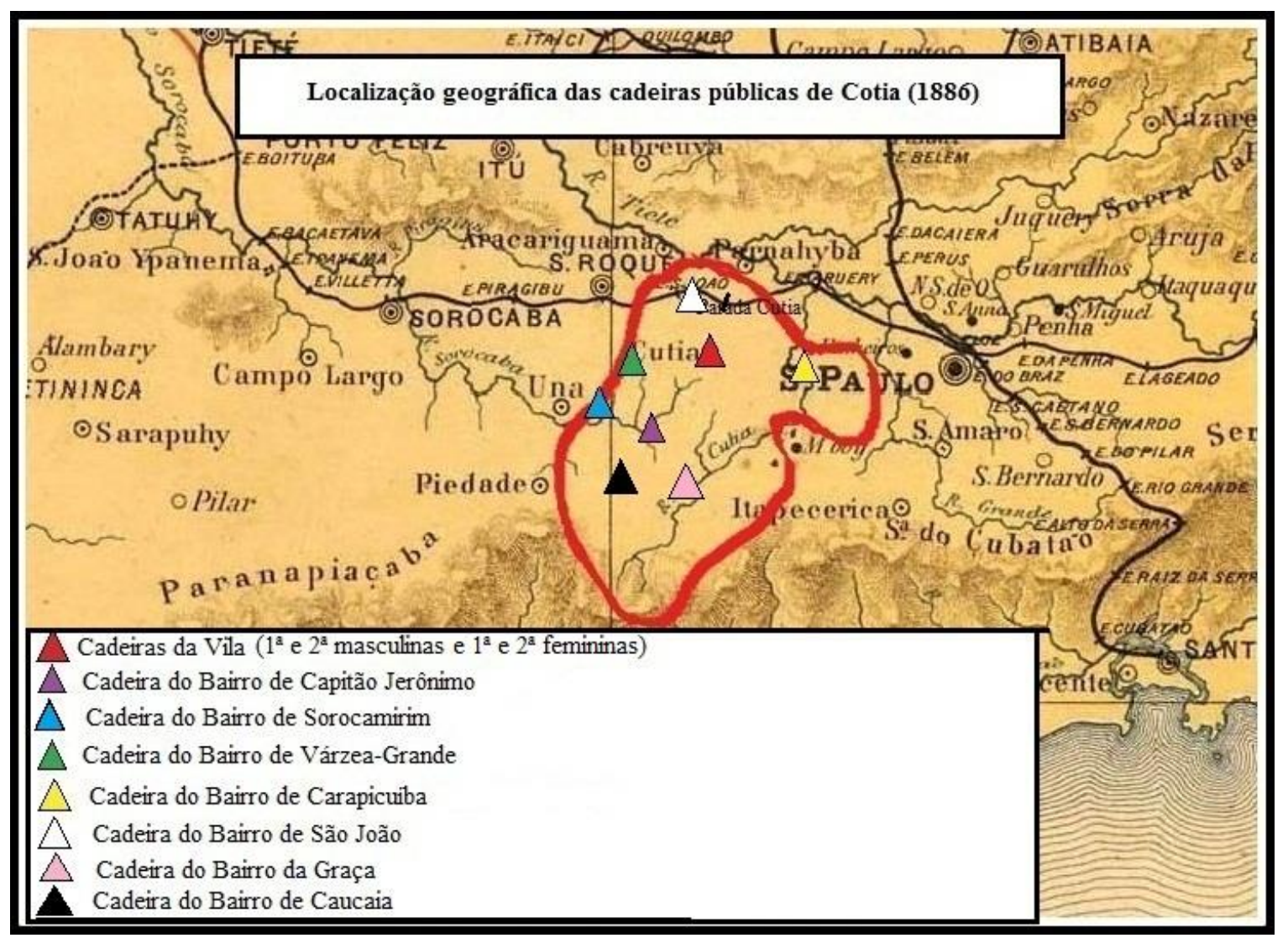

Ilustração 16 - Mapa da localização das cadeiras públicas de Cotia - 1886 (Fontes: LISBOA, 1884; SEADE, s/d. Traçados, título e legenda feitos por mim).

Elementos apresentados neste capítulo apontam que o processo de escolarização de Cotia se desenvolveu em bairros com povoamentos que se originaram de diferentes maneiras. Foram 12 cadeiras criadas - desde 1838, mas com o processo de escolarização intensificado a partir de 1871 - e 11 que efetivamente funcionaram, porém, não funcionaram em todos os anos, marca comum na escolarização do Oitocentos no Brasil. Segundo as fontes, descrevi as criações, as transferências, os momentos nos quais não havia alunos ou professor, indicando os sujeitos envolvidos.

A seguir está o conjunto dos mapas apresentados ao longo deste capítulo, mas agora me utilizando do recurso da sobreposição dos mesmos, impressos em folhas transparentes. Dessa maneira, pretendo oferecer com mais clareza a distribuição e a geografia das cadeiras de Cotia no período estudado. Posteriormente aos mapas, para visualizar melhor a dinâmica da composição do processo de escolarização local, segue um quadro elaborado de maneira sintética a partir das fontes citadas neste capítulo, onde sinalizo as lacunas existentes, os professores públicos de cada cadeira e o movimento de alguns deles pelas cadeiras públicas cotianas. 


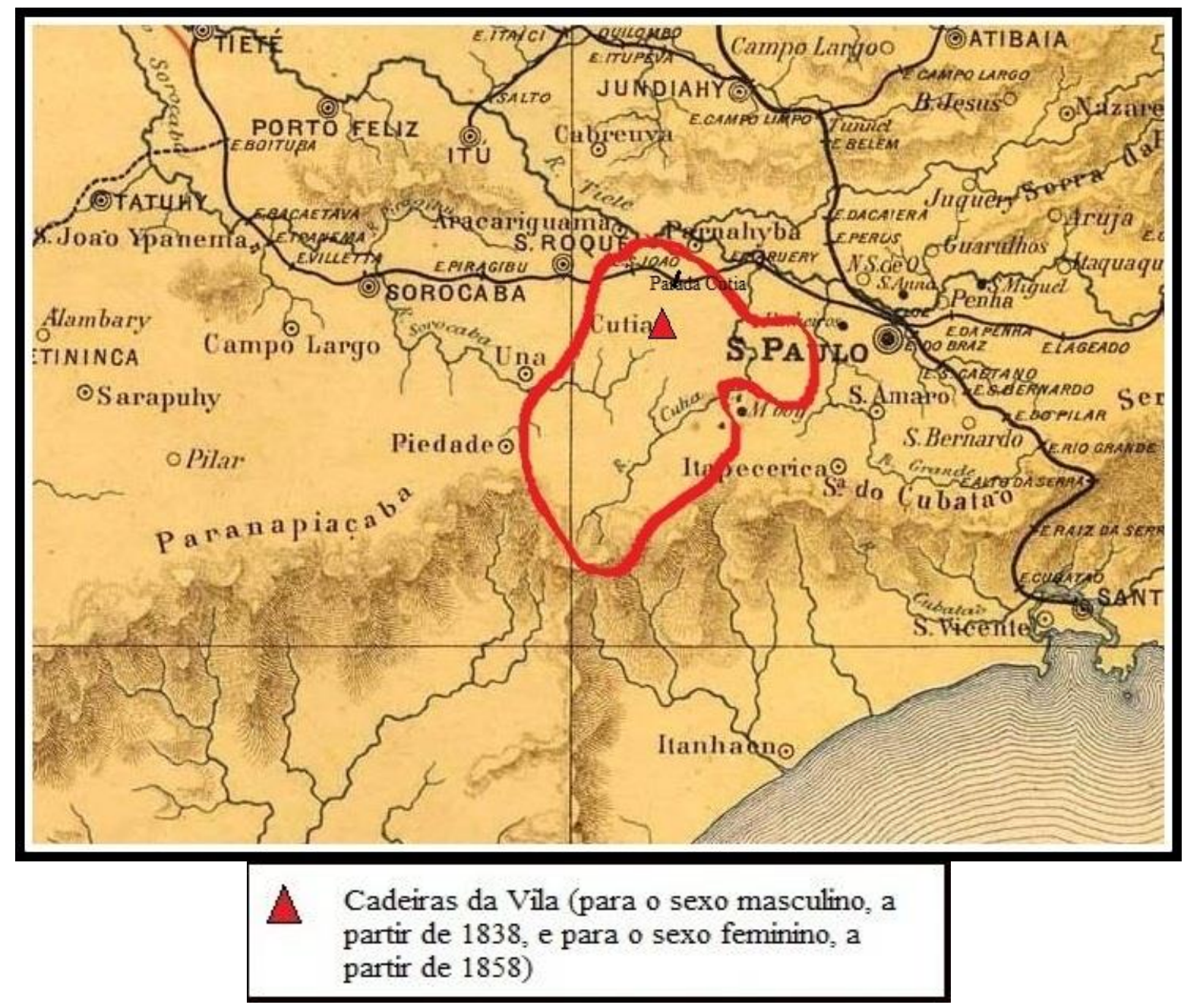

Ilustração 17 - Mapa da localização das cadeiras públicas de Cotia - 1838-1871 (Fontes: LISBOA, 1884; SEADE, s/d. Traçados, título e legenda feitos por mim). 


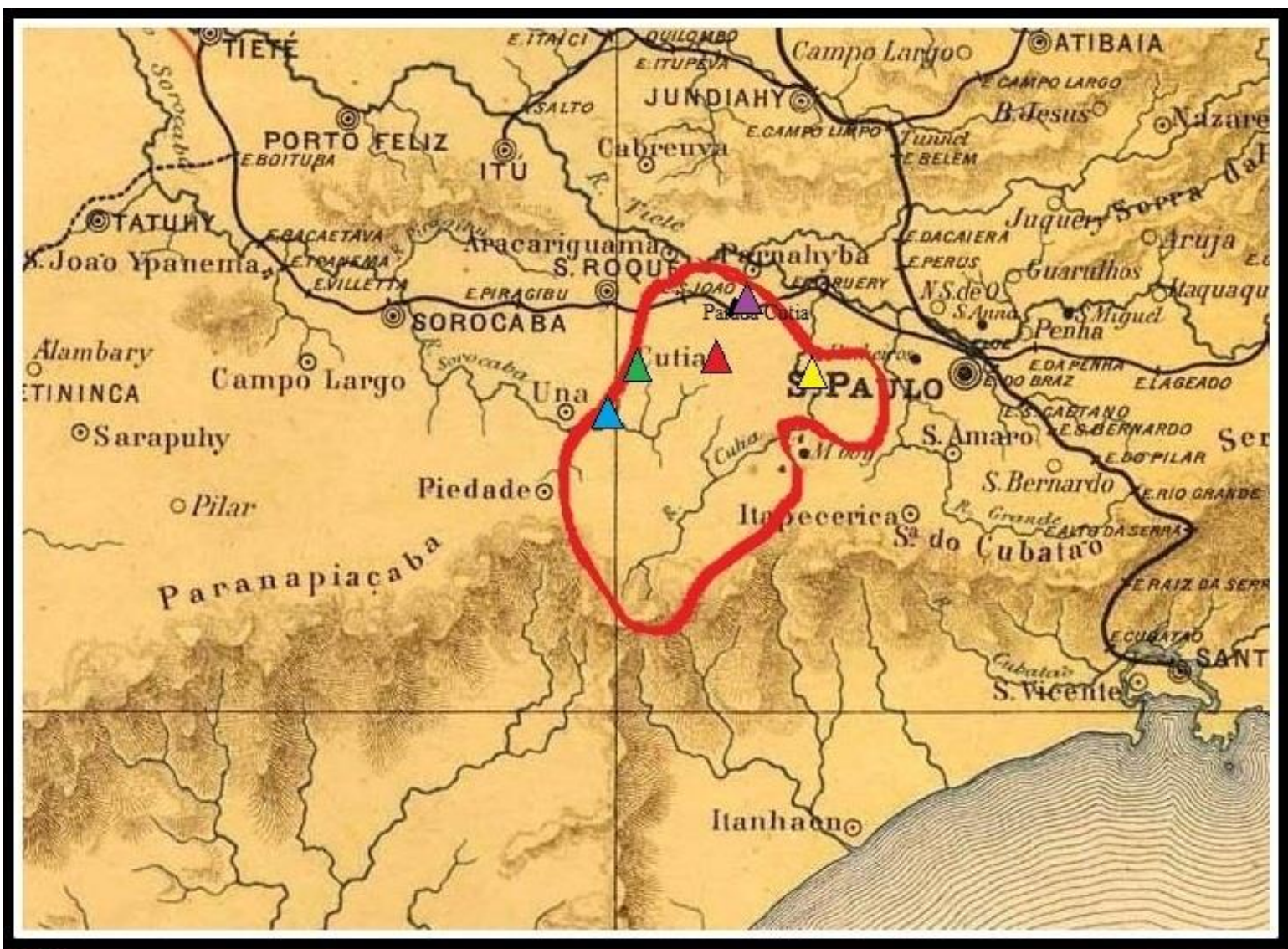

Cadeiras da Vila ( $1^{a}$ masculina; Cadeira feminina; $2^{a}$ masculina, a partir de 1875 ) Cadeira do Bairro do Senhor Bom Jesus do Itaqui

Cadeira do Bairro de Sorocamirim

Cadeira do Bairro de Várzea-Grande

Cadeira do Bairro de Carapicuiba (a partir de 1872)

Ilustração 18 - Mapa da localização das cadeiras públicas de Cotia - 1871-1877 (Fontes: LISBOA, 1884; SEADE, s/d. Traçados, título e legenda feitos por mim). 


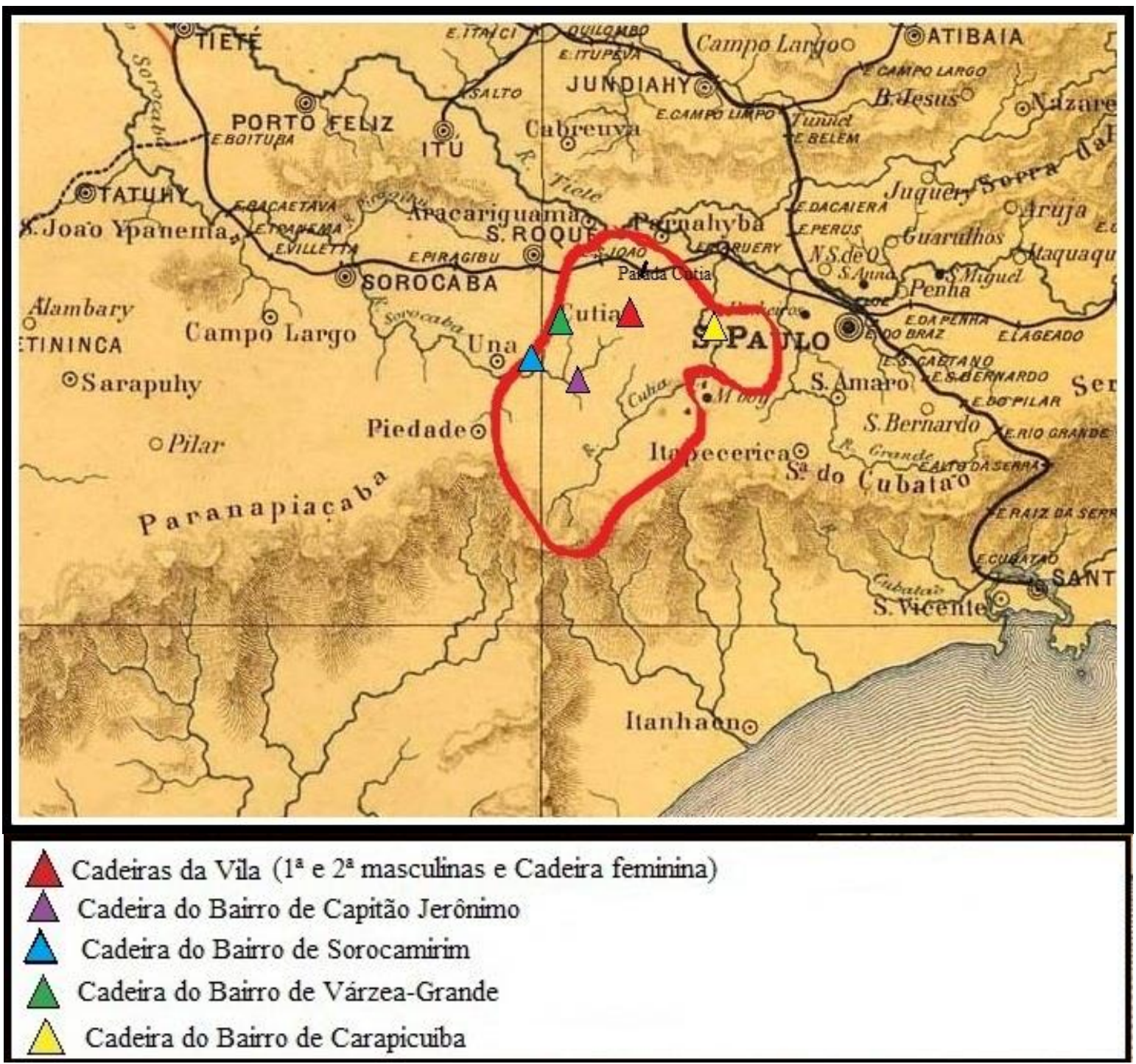

Ilustração 19 - Mapa da localização das cadeiras públicas de Cotia - 1878-1882 (Fontes: LISBOA, 1884; SEADE, s/d. Traçados, título e legenda feitos por mim). 


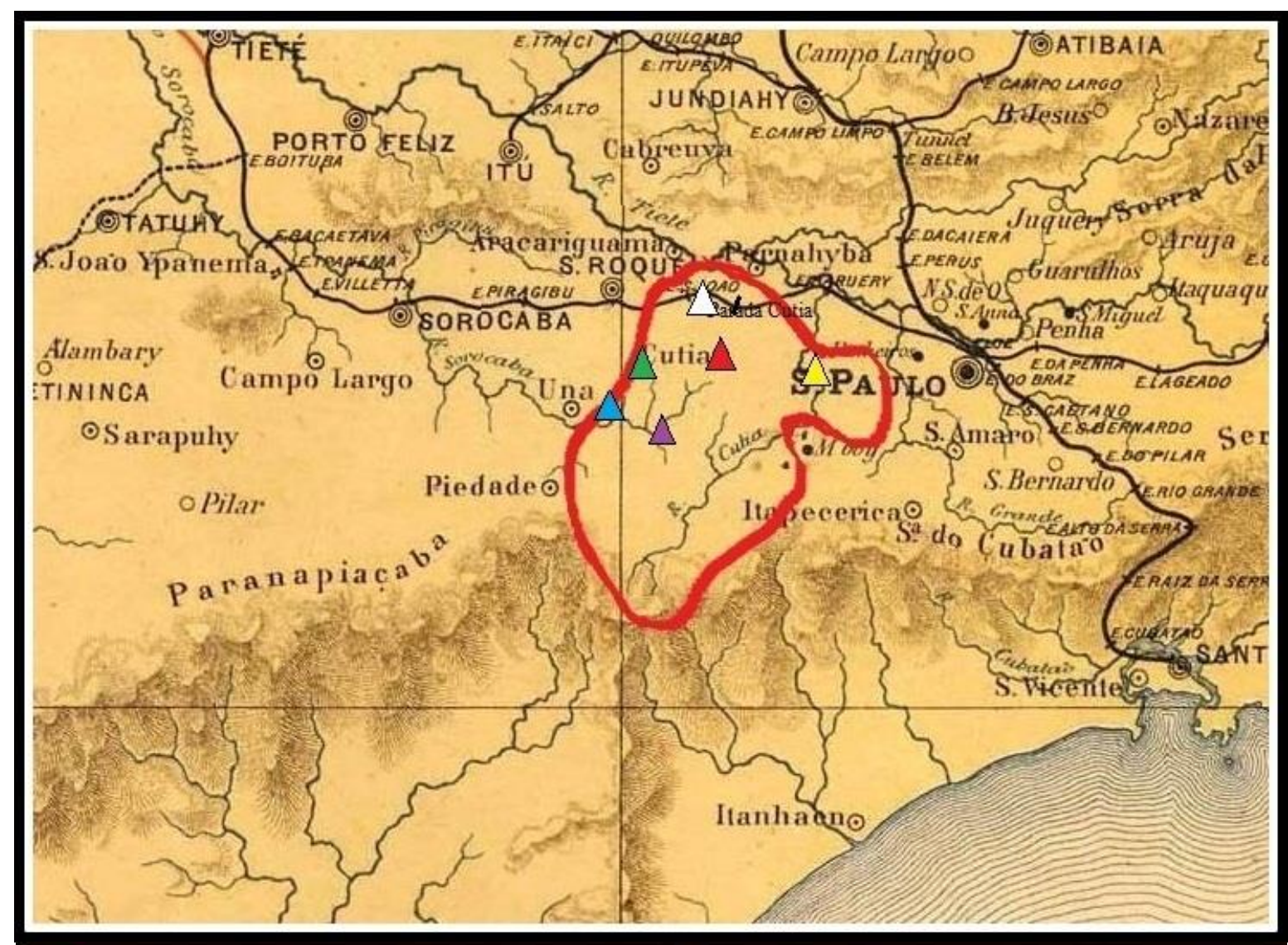

Cadeiras da Vila ( $1^{\mathrm{a}}$ e $2^{\mathrm{a}}$ masculinas e Cadeira feminina)

$\triangle$ Cadeira do Bairro de Capitão Jerônimo

$\triangle$ Cadeira do Bairro de Sorocamirim

$\triangle$ Cadeira do Bairro de Várzea-Grande

$\triangle$ Cadeira do Bairro de Carapicuiba

$\triangle$ Cadeira do Bairro de São João

Ilustração 20 - Mapa da localização das cadeiras públicas de Cotia - 1882-1883 (Fontes: LISBOA, 1884; SEADE, s/d. Traçados, título e legenda feitos por mim). 


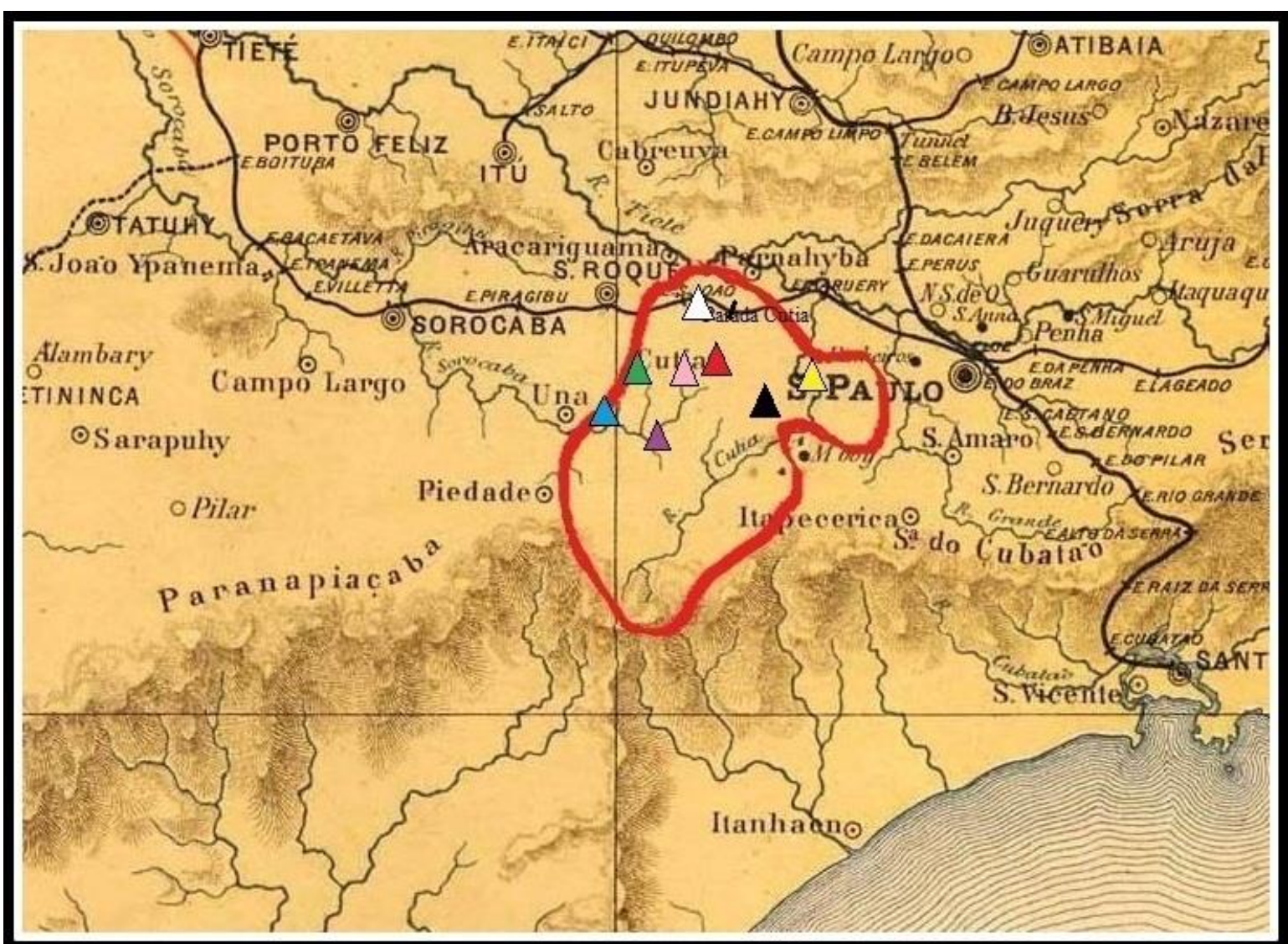

Cadeiras da Vila ( $1^{a}$ e $2^{a}$ masculinas e $1^{a}$ e $2^{a}$ femininas)

Cadeira do Bairro de Capitão Jerônimo

Cadeira do Bairro de Sorocamirim

$\triangle$ Cadeira do Bairro de Várzea-Grande

$\triangle$ Cadeira do Bairro de Carapicuiba

$\triangle$ Cadeira do Bairro de São João

$\triangle$ Cadeira do Bairro de Lavapés

Cadeira do Bairro do Rio Cotia

Ilustração 21 - Mapa da localização das cadeiras públicas de Cotia - 1884-1886 (Fontes: LISBOA, 1884; SEADE, s/d. Traçados, título e legenda feitos por mim). 


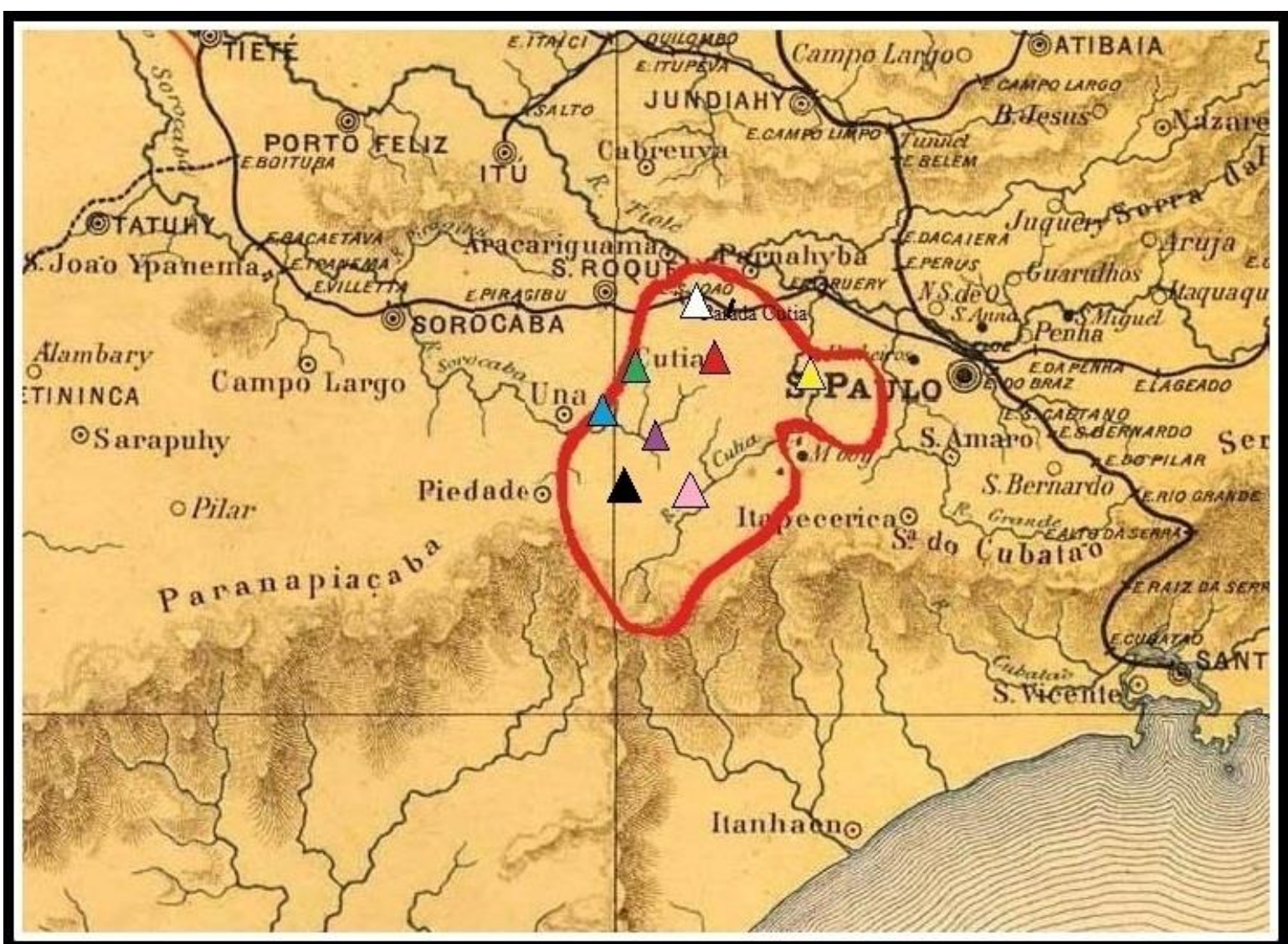

Cadeiras da Vila ( $1^{\mathrm{a}}$ e $2^{\mathrm{a}}$ masculinas e $1^{\mathrm{a}}$ e $2^{\mathrm{a}}$ femininas)

Cadeira do Bairro de Capitão Jerônimo

Cadeira do Bairro de Sorocamirim

Cadeira do Bairro de Várzea-Grande

$\triangle$ Cadeira do Bairro de Carapicuiba

$\triangle$ Cadeira do Bairro de São João

Cadeira do Bairro da Graça

Cadeira do Bairro de Caucaia

Ilustração 22 - Mapa da localização das cadeiras públicas de Cotia - 1886 (Fontes: LISBOA, 1884; SEADE, s/d. Traçados, título e legenda feitos por mim). 


\begin{tabular}{|c|c|c|c|c|c|c|c|c|c|c|c|}
\hline \multicolumn{12}{|c|}{ Cadeiras e professores públicos de Cotia entre 1870 e 1886} \\
\hline Ano & $\begin{array}{c}\text { 1a Masculina da } \\
\text { Vila }\end{array}$ & $\begin{array}{c}\text { 19 Feminina da } \\
\text { Vila }\end{array}$ & $\begin{array}{l}\text { Itaqui /Capitão } \\
\text { Jerônimo }\end{array}$ & $\begin{array}{l}\text { Várzea- } \\
\text { Grande }\end{array}$ & Sorocamirim & Carapicuíba & $\begin{array}{l}\text { 2a Masculina } \\
\text { da Vila }\end{array}$ & $\begin{array}{l}\text { Estação de São } \\
\text { João }\end{array}$ & $\begin{array}{l}\text { 2a Feminina } \\
\text { da Vila }\end{array}$ & $\begin{array}{l}\text { Lavapés/ } \\
\text { Graças }\end{array}$ & $\begin{array}{l}\text { Rio Cotia/ } \\
\text { Caucaia }\end{array}$ \\
\hline 1870 & $\begin{array}{l}\text { João José } \\
\text { Coelho }\end{array}$ & $\begin{array}{c}\text { M. J. do } \\
\text { Sacramento }\end{array}$ & & & & & & & & & \\
\hline 1871 & J. J. Coelho & $\begin{array}{c}\text { M. J. do } \\
\text { Sacramento }\end{array}$ & $\begin{array}{c}\text { Marcolino Pinto de } \\
\text { Queiroz }\end{array}$ & $\begin{array}{c}\text { Severiano José } \\
\text { de Ramos }\end{array}$ & $\begin{array}{c}\text { José Custódio de } \\
\text { Queiroz }\end{array}$ & & & & & & \\
\hline $\begin{array}{l}1872- \\
1874\end{array}$ & J. J. Coelho & $\begin{array}{c}\text { M. J. do } \\
\text { Sacramento }\end{array}$ & M. P. de Queiroz & S. J. de Ramos & $\begin{array}{c}\text { 1872: } \\
\text { J. C. de Queiroz; } \\
\text { 1872-74: Antonio } \\
\text { Manoel Vieira }\end{array}$ & J. C. de Queiroz & & & & & \\
\hline 1875 & J. J. Coelho & $\begin{array}{c}\text { M. J. do } \\
\text { Sacramento }\end{array}$ & $\begin{array}{l}\text { (M. P. de } \\
\text { Queiroz) }^{192}\end{array}$ & S. J. de Ramos & A. M. Vieira & (J.C. de Queiroz) & $\begin{array}{l}\text { Marcolino P. } \\
\text { de Queiroz }\end{array}$ & & & & \\
\hline $\begin{array}{l}1876- \\
1877\end{array}$ & J. J. Coelho & $\begin{array}{c}\text { M. J. do } \\
\text { Sacramento }\end{array}$ & Vaga & $\begin{array}{l}\text { S. J. de Ramos; } \\
\text { Meados de } 76 \\
\text { e 77: Vaga }\end{array}$ & $\begin{array}{c}\text { Meados de } 76 \text { e 77: } \\
\text { Vaga }\end{array}$ & $\begin{array}{c}\text { 1876: } \\
\text { (J.C. de Queiroz); } \\
\text { até meados de 77: } \\
\text { J.C. de Queiroz }\end{array}$ & $\begin{array}{l}\text { M.P.de } \\
\text { Queiroz }\end{array}$ & & & & \\
\hline 1878 & J. J. Coelho & $\begin{array}{c}\text { M. J. do } \\
\text { Sacramento }\end{array}$ & $\begin{array}{c}\text { Vaga; } \\
\text { Transferida para o } \\
\text { B. de Capitão } \\
\text { Jerônimo }\end{array}$ & Vaga & Vaga & $\begin{array}{c}\text { Transferida para } \\
\text { Barueri, mas atendia } \\
\text { também Carapicuíba } \\
\text { ? }{ }^{193} \\
\end{array}$ & $\begin{array}{l}\text { M.P.de } \\
\text { Queiroz }\end{array}$ & & & & \\
\hline 1879 & J. J. Coelho & $\begin{array}{c}\text { M. J. do } \\
\text { Sacramento }\end{array}$ & $\begin{array}{l}\text { João da Matta Luz/ } \\
\text { J. C. de Queiroz }\end{array}$ & Vaga & Vaga & $\begin{array}{c}\text { João Rodrigues de } \\
\text { Jesus }\end{array}$ & $\begin{array}{l}\text { M.P. de } \\
\text { Queiroz }\end{array}$ & & & & \\
\hline $\begin{array}{l}1880- \\
1881\end{array}$ & J. J. Coelho & $\begin{array}{c}\text { M. J. do } \\
\text { Sacramento }\end{array}$ & J. C. de Queiroz & $\begin{array}{l}\text { Manoel de } \\
\text { Moraes Pinto }\end{array}$ & $\begin{array}{c}\text { 1880: João Cezar de } \\
\text { Abreu e Silva - sem } \\
\text { alunos } \\
\text { 1881: ? }\end{array}$ & João R. de Jesus & $\begin{array}{l}\text { M.P. de } \\
\text { Queiroz }\end{array}$ & & & & \\
\hline 1882 & J. J. Coelho & $\begin{array}{c}\text { M. J. do } \\
\text { Sacramento }\end{array}$ & J. C. de Queiroz & M. M. Pinto & João Maria Thomaz & $?$ & $\begin{array}{l}\text { M.P. de } \\
\text { Queiroz }\end{array}$ & $\begin{array}{l}\text { Joaquim } \\
\text { Chrispim de } \\
\text { Oliveira }\end{array}$ & & & \\
\hline 1883 & J. J. Coelho & $\begin{array}{c}\text { M. J. do } \\
\text { Sacramento }\end{array}$ & J. C. de Queiroz & M. M. Pinto & (João M.Thomaz) & $?$ & $\begin{array}{l}\text { (M.P. de } \\
\text { Queiroz) }\end{array}$ & J. C. de Oliveira & & & \\
\hline 1884 & J. J. Coelho & $\begin{array}{c}\text { M. J. do } \\
\text { Sacramento }\end{array}$ & $\begin{array}{c}\text { Manoel de Moraes } \\
\text { Pinto }\end{array}$ & $?$ & (João M.Thomaz) & $?$ & $\begin{array}{l}\text { (M. P. de } \\
\text { Queiroz) }\end{array}$ & J. C. de Oliveira & $\begin{array}{l}\text { Catharina E. } \\
\text { Pedroso }\end{array}$ & $\begin{array}{l}\text { J.C. de } \\
\text { Queiroz }\end{array}$ & Vaga \\
\hline 1885 & $\begin{array}{l}\text { J. J. Coelho / } \\
\text { José Custodio } \\
\text { de Queiroz }\end{array}$ & $\begin{array}{c}\text { M. J. do } \\
\text { Sacramento/ } \\
\text { AnaliaEmilia } \\
\text { Franco } \\
\end{array}$ & M. M. Pinto & $\begin{array}{l}\text { João Baptista } \\
\text { Cepellos }\end{array}$ & João M.Thomaz & $?$ & $\begin{array}{l}\text { M.P. de } \\
\text { Queiroz }\end{array}$ & J. C. de Oliveira & $\begin{array}{l}\text { Catharina E. } \\
\text { Pedroso }\end{array}$ & $\begin{array}{l}\text { J.C. de } \\
\text { Queiroz/ } \\
\text { Vaga }\end{array}$ & Vaga \\
\hline 1886 & J. C. de Queiroz & $\begin{array}{l}\text { Analia E. Franco } \\
\text { (Leonilbes C. de } \\
\text { Souza Gouvêa) }\end{array}$ & M. M. Pinto & $\begin{array}{l}\text { João Baptista } \\
\text { Cepellos }\end{array}$ & João M. Thomaz & $?$ & $\begin{array}{l}\text { M.P. de } \\
\text { Queiroz }\end{array}$ & J. C. de Oliveira & $\begin{array}{l}\text { Catharina E. } \\
\text { Pedroso }\end{array}$ & $\begin{array}{c}\text { Vaga; } \\
\text { Transferida } \\
\text { para o Bairro } \\
\text { das Graças }\end{array}$ & $\begin{array}{c}\text { Vaga; } \\
\text { Transferida } \\
\text { para o Bairro } \\
\text { de Caucaia }\end{array}$ \\
\hline
\end{tabular}

Ilustração 23 - Quadro das cadeiras e dos respectivos professores públicos de Cotia entre 1870 e 1886.

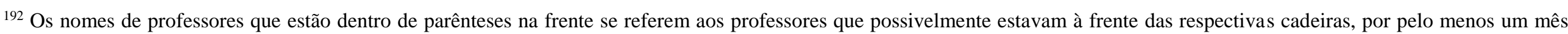
durante o ano, mas que por não localizar nenhuma fonte referente ao professor e sua cadeira, recorri a esse recurso.

$193 ?=$ não foram localizadas fontes. 
Retomando Chapoulie e Briand (1994), mencionados na introdução desta pesquisa, “cada estabelecimento está submetido às exigências de uma localidade, que ele mesmo contribui, aliás, para definir, e que possui, ao mesmo tempo, uma dimensão demográfica, econômica, política, assim como uma dimensão institucional" (p. 18). No caso de Cotia, as especificidades locais no Oitocentos durante o período estudado - sociedade caipira com economia modesta dentro do quadro provincial, participante do ciclo do muar e que vivenciou a construção de estações férreas em dois bairros rurais e o declínio de sua já modesta economia após a abertura da via férrea - foi importante para compreender o processo de criação de cadeiras. Ainda, numa visão mais pormenorizada, a pesquisa deu elementos para compreensão das especificidades de cada área que compunha o município, a Vila e os bairros (as "naçõezinhas", segundo o caipira entrevistado por Candido, 2001a), entretanto, algumas lacunas ainda ficaram por falta de documentação.

Como assinalaram Borges e Vidal (2014):

[...] os procedimentos estatísticos [de governo] com sua racionalidade nem sempre conseguem definir o lugar da escola. A cidade, sua organização e estruturas sociais, econômicas e políticas produzidas pelas especificidades dos espaços geográficos igualmente têm sua parcela de participação, pois também nem sempre onde é considerado mais adequado haver uma escola, há um prédio para instalá-la. Isso obriga o governo, o professor e seus alunos a se deslocarem para outro local, também de acordo com a oferta de espaço físico. Assim, muitas vezes as demandas tanto do governo quanto as da população se esbarram na estrutura política e econômica da cidade. (BORGES; VIDAL, 2014, p. 4, adendo meu).

A localização geográfica das cadeiras em Cotia ao longo do processo de escolarização partiu da Vila em direção aos bairros, indicando um processo de interiorização da escolarização, comum nos Oitocentos. A Vila nesse período passou a ter quatro cadeiras, duas femininas e duas masculinas, confirmando aumento populacional e da demanda. No período em que o tropeirismo entrou em decadência, e consequentemente a economia local também, duas escolas foram criadas e passaram a funcionar na Vila sem nenhuma interrupção ao longo dos 15 anos analisados.

As fontes permitiram compreender as características de alguns bairros e as demandas por escolas. Os primeiros bairros foram Itaqui, Várzea Grande, Sorocamirim. O primeiro, antes composto apenas por roceiros pobres, vivenciou a construção de uma parada/estação ferroviária, porém ao término da construção viu sua população diminuir. A falta de frequência de alunos nas aulas foi relatada pelo professor (que a relacionou também ao êxodo populacional local) e, concomitante a isso, o professor foi removido para outra cadeira. Apesar de haver concurso, não teve a vaga preenchida e a cadeira não voltou a funcionar, 
sendo transferida em 1878 para outro bairro. O Bairro de Itaqui, primitivo povoado que deu origem a Itapevi, não se desenvolveu imediatamente (mesmo que lentamente) após a construção da parada/estação de trem. Dessa forma, as fontes mostraram que a cadeira foi criada para atender a demanda de um misto composto por uma população flutuante formada pelas famílias de trabalhadores da construção da E. F. Sorocabana e uma população local roceira. Com a demanda diminuída e a ausência de professor para o preenchimento da vaga, a cadeira foi transferida.

A Cadeira de Várzea-Grande, bairro ligado ao tropeirismo, segundo as fontes, ficou vaga por alguns anos. Criada em 1871, funcionou ininterruptamente até 1876, ano da saída do primeiro professor (removido para a Capital) e um ano após a inauguração do trecho da E. F. Sorocabana. Porém, a partir daí, seu funcionamento oscilou, ficando vaga por, ao que as fontes indicam, quase quatro anos, possivelmente por falta de professor habilitado para o cargo, pois teve concurso aberto para ela por três anos. Parecido foi o caso da cadeira do Bairro de Sorocamirim. Este bairro esteve de forma direta ou indireta ligado ao tropeirismo, haja a vista a proximidade com a via de passagem de tropas entre Una e Cotia. Sua cadeira passou a funcionar em 1871, mas ficou vaga (tendo concurso aberto para ela por três anos consecutivos) ou sem alunos entre 1876 e 1881, retomando em 1882. Apesar de um período sem funcionar, ambas não foram suprimidas ou transferidas. A ausência de dados de alguns anos referentes ao período de análise impede compreender se houve algum ano em que tenha ficado vaga ou se o professor estava lecionando normalmente.

Já o Bairro de Carapicuíba, região historicamente ligada ao aldeamento indígena e com economia voltada para criação de animais, teve uma cadeira provisória que, ao que as fontes indicam, funcionou ali apenas de meados dos anos de 1870 e início dos anos de 1880. A varíola, epidemia na aldeia local, pode ter ocasionado a instabilidade de seu funcionamento. $\mathrm{O}$ fato de ter sido transferida para Barueri (mesmo que por lei a cadeira devesse atender também à demanda de Carapicuíba) pode explicar essa lacuna.

Apesar das mudanças econômicas, decadência do tropeirismo na Província a partir da criação das vias férreas, a cadeira do Bairro de Itaqui foi transferida para o Bairro de Capitão Jerônimo que, ao que tudo indica, estava muito próximo da passagem de tropeiros e, é muito possível, tinha sua economia voltada para essa função. A cadeira desse bairro funcionou ininterruptamente desde 1879 até o final do período desta pesquisa, apontando, inclusive, um aumento do número de alunos matriculados e frequentes desde os primeiros anos. Sua criação, ao que parece, além da demanda, também esteve ligada a um potentado local, um vereador que ali residia e matriculou seis filhos seus. 
Outro bairro que, como Itaqui, recebeu uma estação em 1875 foi São João, mas teve uma escola somente em 1882 e funcionou pelo menos até 1886. Pelas fontes a população do bairro cresceu e novas demandas por cadeiras surgiram, mas apesar dos requerimentos, a criação de novas cadeiras não foi deferida.

As cadeiras do Lavapés e do Rio Cotia, criadas em 1884 e localizadas próximas à Vila, logo foram transferidas. A de Lavapés chegou a funcionar, mas devido à escassez de alunos e a partir de uma petição do inspetor literário, foi transferida para outro bairro em 1886. A segunda ficou vaga desde sua criação e foi transferida a partir da mesma petição mencionada. Essa petição indicou a ausência de alunos dos bairros de Lavapés e Rio Cotia e a existência de demanda em dois bairros sem cadeira, Caucaia e Bairro das Graças. Em 1873, Caucaia havia sido lugar de funcionamento da cadeira de Sorocamirim, segundo um morador deste bairro, mas apenas em 1886 passou a ter uma cadeira ali.

Há que se considerar, principalmente no caso da criação das cadeiras de Rio Cotia e Lavapés, a influência política das pessoas estabelecidas nos bairros (ou vinculadas a eles de alguma forma), pois a demanda era escassa. Parece plausível que as duas cadeiras que mal funcionaram tenham sido criadas devido a algum potentado político local. Borges e Vidal (2014) apontaram a influência de potentados locais na criação e transferência das cadeiras públicas em São Paulo e no Rio de Janeiro, assim como Silva (2007), analisando as práticas da escolarização pública na Província de Pernambuco. Segundo essa autora, os potentados locais pernambucanos influenciavam tanto para promoção da escolarização quanto para limitar sua expansão, sinalizando que havia localidades com muita demanda de alunos e sem aula pública, enquanto que em outros lugares menos povoados havia mais que uma escola.

Das 11 cadeiras que efetivamente funcionaram entre 1870 e 1885, quatro estavam localizadas na Vila e sete nos bairros. Com características parecidas no que se refere à rusticidade e à ruralidade (com áreas de plantio para subsistência, comercio local e/ou com a Capital), elas se diferenciavam com relação à origem e função do povoamento. Quatro estavam na Vila, centro político, comercial (tendo a função de pouso de tropeiros incluída) e religioso do município. As principais características dos bairros que receberam cadeiras se relacionavam: ao tropeirismo (Várzea-Grande, Sorocamirim e Capitão Jerônimo); à via férrea Sorocabana (Itaqui e São João); à criação de animais e antiga área de aldeamento indígena (Carapicuíba); e bairros conectados à Vila, possivelmente atendendo parte de sua demanda de produtos (Lavapés e Rio Cotia).

Os locais de instalação das cadeiras confirmaram o período de mudanças na dinâmica socioeconômica de Cotia, pois se situavam em bairros ligados ao decadente tropeirismo e 
outros ligados à estação de trem. O velho e o novo transpareceram na composição geográfica das cadeiras. Destacando-se, todavia, o fato da retenção de demanda em bairro onde houve a construção de uma estação (Itaqui) e, em contrapartida, ainda que num momento de declínio do tropeirismo, houve uma grande demanda por escola num bairro ligado a passagem de tropeiros (Capitão Jerônimo).

Dados confirmaram que nas escolas dos bairros houve uma grande instabilidade de professores, permanecendo por pouco tempo frente às cadeiras. É possível que esse fato estivesse ligado à característica de bairros caipiras, marcados pela rusticidade, pelo mínimo social e mínimo vital (CANDIDO, 2001a). A influência das condições materiais no exercício do magistério, os professores e outros cargos que exerciam, a relação da comunidade com a escola e os professores, o cotidiano escolar, a composição das cadeiras pelos alunos, a influência do tempo social no tempo escolar, além de outros elementos, são analisados nos próximos capítulos. 


\section{CAPÍtULO 3. MAS DEIXEMOS AS JABUTICABAS E FALEMOS DOS PROFESSORES DE COTIA}

Um leitor que se identificava como Salambô remeteu longas cartas ao redator do jornal Diário de São Paulo em 1872, publicadas na seção Publicações Perdidas e intituladas Sobre o que vai pela Paulicéa. Nelas, com teor irônico, o autor relatava sobre assuntos diversos, impressões sobre São Paulo, fazendo denúncias do cotidiano através de sua lente. $\mathrm{Na}$ carta de número VII ${ }^{194}$, entre os variados assuntos, convidou o "amigo" redator a um "passeio ás jaboticabas". Segundo o autor, "o paulista passa sem comer, sem beber, sem dormir, mas não passa sem as jaboticabas", e quando ele fica “doente, muito doente; consulta ao médico que lhe receita tal remédio. - Tem dieta? - Tem. - Posso comer jaboticaba? - Não senhor. - Pois então, senhor doutor, eu só tomo o remédio depois de passado o tempo das jaboticabas". De acordo com Candido, "das frutas de mato, a jabuticaba é por antonomasia a fruta, sempre pronunciada fruita e preferida [pelo caipira] a todas as outras" (2001a, p. 72, adendo meu).

Salambô então assinalou que visitou Cotia acompanhando um amigo, ele à procura das jabuticabas e o amigo por causa de uma herança. O cronista expôs suas percepções sobre um professor público cotiano que conheceu quando da visita. De acordo com Salambô:

\footnotetext{
Um professor público (o $1^{\circ}$ ) dava a aula em mangas de camisa de algodãozinho, chinellos sem meias, chapéo de junco, oculos, um cigarro de dous palmos, que pareceu-me uma espiga de milho, e faca á cinta.

Do segundo professor contou-me Manoel Mulher cousas do arco da velha.

Diz elle que o dito professor atrapalhou-o de tal modo que já não sabe mais qual é a mão direita. A lição de conta principia de 6 em 6 até 36, noves fóra 0 , e é isso que cifra-se a explicação, que se resume em 0. O professor, é ainda o Manoel Mulher quem informa, não admitte o systema metrico por ser difficil, prefere os covados e alqueires, que, assegura elle, são mais commodos para o negociante: falla ex cathedra, como diz o vizinho Fulgencio.

Para pôr ordem à escola, propoz o homem ao governo a adopção de mucunan, para corrigir os meninos.

Havia de ser interessante o homem armado de mucunan! S. Lourenço ao lado da grelha, instrumento de seu supplicio.

Por isso bem faz o menino Joaquim Rodrigues, que abriu uma escola e já tem nove discípulos, mais prudente e menos esperto que o senhor professor de cupidaria, que quando esbarra em uma questão erotica logo a aprofunda.

Mas deixemos os negocios da Cotia e fallemos de jaboticabas.[...] (SALAMBÔ, 1872, p. 2, grifos da publicação).
}

O conteúdo se refere a "um professor público (o $\left.1^{\circ}\right)$ " de Cotia, podendo ser Antonio Barreto, o primeiro que passou a lecionar em 1838 e se aposentou em 1858, mas é mais

${ }^{194}$ Jornal Correio Paulistano de 27 out. 1872, p. 2. 
possível ser João José Coelho, o professor que em 1872 ocupava a $1^{\text {a }}$ Cadeira Masculina da Vila. O professor Coelho assumiu a $1^{\text {a }}$ Cadeira em 1860, como mencionado anteriormente. No primeiro parágrafo o tempo verbal usado incialmente pelo autor é do passado "dava aula" (por isso pode ser o professor Barreto), mas logo depois ele comenta que o cigarro "pareceu-me uma espiga de milho", ou seja, ele escreveu como se tivesse visto o cigarro que o professor fumava quando visitou Cotia. Posteriormente, usa tempos verbais do presente, indicando que mesmo que sua viagem não tenha sido no ano em que escreveu a carta, o professor ainda estava na ativa em 1872.

A forma bem à vontade do professor se vestir, segundo o autor da carta, mostra uma despreocupação com as vestimentas formais no exercício de seu cargo e sugere um professor em trajes caipiras. Também nos remete ao personagem fictício Barão da Cotia, mencionado no primeiro capítulo, que se vestia com seu chapéu de palha, paletó branco e calças de enfiar. Além dos trajes, fumava um cigarro longo. Destaca-se o fato do professor ter uma faca em sua cinta durante suas aulas, o que nos faz pensar que um professor com uma arma não devia ser muito aprazível aos alunos. Todavia, apesar de ser um dos apontamentos de Salambô - o que sugere que o autor tenha estranhado bastante o detalhe da faca - talvez fosse comum, naquele momento e contexto, o uso de faca na cintura, pois os códigos de posturas que proibiam o porte de armas para as pessoas que não as usassem para fins de trabalho datam de 1874 e 1886, apresentados no primeiro capítulo. Dessa maneira, pode ser que os alunos não se incomodassem com a arma do professor.

Outro sujeito aparece no relato de Salambô, o Manoel Mulher. Este havia sido aluno do professor, com o qual não havia aprendido muita coisa. Ou melhor, o professor "atrapalhou-o", não admitia o sistema métrico e preferia ensinar "os covados e alqueires", conteúdo "mais commodos para o negociante". Com muitas terras, sitiantes e roceiros, parece que o professor atribuía à vida prática o que deveria ser ensinado na escola.

Caso semelhante foi apontado na narrativa da trajetória de um professor de Paranaguá, Hildebrando, construída por Munhoz (2012). A autora demonstrou que ele mesmo adaptava os conteúdos ensinados ao contexto local e concluiu que esta adaptação contribuiu para a frequência dos alunos. Paranaguá, uma cidade portuária, era palco de várias transações comerciais, portanto os saberes matemáticos eram bastante usados. Munhoz, por meio dos mapas, verificou que "em 1834, o professor passa a informar os alunos com adiantamento em 'contabilidade", em "1841, informa que três alunos se despediram 'todos com suficiente adiantamento, e consta-me se acharem empregado'. E, em 1846, o professor explicita os conhecimentos de contabilidade: no commercio 'rateio, regra de três, juros, caixaria, contas 
próprias para o comércio"” (MUNHOZ, 2012, p. 87). Essa prática fez escola, e o padre-mestre Albino, anos depois, também passou a adaptar os conteúdos em suas aulas em uma cadeira pública de Paranaguá.

Para "corrigir" os alunos, o professor de Cotia narrado por Salambô, fazia uso de “mucunan", indicando seu uso ao governo. Mucunã, segundo o dicionário, é uma "erva leguminosa que produz vagens revestidas de pêlos que causam alergia e irritação" (BORBA, 2004, p. 945). Outro sujeito mencionado na carta foi Joaquim Rodrigues, um "menino" "mais prudente" do que o $1^{\circ}$ professor público, um concorrente (possivelmente um professor particular) que abriu outra escola e tinha 9 alunos.

As impressões de Salambô sobre o professor de Cotia revelam um sujeito aquém do que estabelecia a lei para desempenhar a função. Além de não cumprir o conteúdo preconizado, gostava de falar imoralidades, indo na contramão dos requisitos para ser professor. A maior parte dos documentos utilizados nesta pesquisa não foge ao lugar comum das pesquisas de história da educação, são documentos institucionais, elaborados com um discurso próprio e que, em geral, não revelam o cotidiano escolar, os sujeitos como seres humanos, mas como uma peça que constitui o todo, um número para a estatística governamental. Todavia, dados da carta do cronista Salambô, ajudam a ver um outro lado da história, um outro ponto de vista. O ponto de vista de um homem de outro lugar que chega ao município atrás de jabuticabas, mas que conhece um professor público com um estilo peculiar e revela suas impressões e dados relatados por um antigo aluno.

Este capítulo busca trazer dados dos professores compilados em bases diversas, sobretudo nos jornais de época, mas também dados dos mesmos sujeitos e um pouco do cotidiano escolar através da lente dos professores a partir dos relatórios semestrais enviados ao Inspetor Geral da Instrução Pública. Pretendo com isso desvelar minimamente quem eram esses trabalhadores, em quais outros setores exerciam funções, a relação entre eles, sobretudo do casal Maria Joanna e João José no fazer-se professor, e as condições materiais no exercício de suas funções.

\section{1. Os sujeitos professores}

Assim como em vários lugares do Brasil no Oitocentos, os dados relacionados à vida dos professores de Cotia apontaram a ocorrência de três movimentos constitutivos do quadro de docentes. Um mostrou que parte dos funcionários foi formada por pessoas que já atuavam 
em outros setores públicos locais, sobretudo na área da segurança/polícia, o segundo assinalou que o letramento da população de Cotia auxiliou na composição do conjunto de funcionários públicos, que passaram a atuar como professores antes mesmo de outra função e o terceiro demonstrou que professores passaram a atuar primeiramente como professores e não transitaram em outros setores públicos locais. Com relação às condições locais, às características da sociedade e a uma das consequências do letramento da população, Cotia se aproximava da região estudada por Fabiana Munhoz, a $5^{\text {a }}$ Comarca da Província da São Paulo: "trata-se de uma região pouco povoada à época e com uma reduzida população letrada, deste modo as escolas de primeiras letras ajudaram a compor desde o quadro de funcionários públicos, passando por cargos políticos, até artistas.” (MUNHOZ, 2012, p. 155).

A partir de um rastreamento da vida pública dos professores cotianos presentes em periódicos paulistas, eliminando falsos cognatos, pude saber de alguns dos espaços ocupados pelos 14 professores, entre cargos públicos, participações como eleitores ou em diretórios partidários, e em funções diversas. Esse levantamento indicou que alguns deles também tinham outras funções, concomitantes ou não ao exercício do cargo de professor. A intenção neste capítulo é dar destaque para João José Coelho e Maria Joanna do Sacaramento, professores que ficaram à frente das primeiras cadeiras da Vila por mais de 25 anos e formaram um casal na vida privada. No entanto, inicialmente, apresento os demais professores para depois apresentar e analisar um pouco das trajetórias do casal citado, compondo um subcapítulo.

Optei por apresentar os professores na ordem cronológica em que assumiram os cargos, visando ficar mais compreensível ao leitor, pois no capítulo anterior também apresentei a criação das cadeiras cronologicamente. Também optei por privilegiar apenas o período em que os professores atuaram em Cotia, ficando alguns deles com poucas informações devido ao pouco tempo que estiveram no município.

Após João José Coelho e Maria Joanna do Sacramento, o próximo professor a assumir uma cadeira pública em Cotia foi Marcolino Pinto de Queiroz, que trabalhou por 30 anos na função de professor nesse municipio à frente das Cadeiras de Itaqui (1871-1875) e da $2^{\mathrm{a}}$ Masculina da Vila (1875-1901), aposentando-se em 1901 ${ }^{195}$. Antes de lecionar em Cotia, lecionou em Mogi-Mirim e Pirapora ${ }^{196}$ e foi removido desta cadeira para Itaqui ${ }^{197}$. Em Cotia,

\footnotetext{
195 Disponível em <http://www.jusbrasil.com.br/diarios/3667749/pg-17-diario-oficial-diario-oficial-do-estadode-sao-paulo-dosp-de-04-01-1901> Acesso em: 7 ago. 2015.

196 Jornal Diário de São Paulo de 30 out. 1869, p. 3: convocado para escolha de cadeira de primeiras letras; Jornal Diário de São Paulo de 6 nov. 1869, p. 2: conclusão de exame como opositor de cadeiras de primeiras letras; Jornal Diário de São Paulo de 14 nov. 1869: nomeado professor público em Mogi-Mirim; Jornal Correio
} 
também foi eleitor ${ }^{198}$, mestre de música ${ }^{199}$, juiz de paz $^{200}$ e secretário do Partido Republicano (PR) do diretório de Cotia ${ }^{201}$. As funções, com exceção do cargo de secretário do PR de Cotia, foram exercidas concomitantemente à de professor público e todas assumidas após sua entrada no magistério público.

Marcolino, quando professor de Itaqui, foi nomeado, em 1874, adjunto de promotor na Comarca de São Roque, segundo ofício do inspetor de distrito Antonio Barreto ao Inspetor Geral de Instrução Pública ${ }^{202}$. Barreto apontou não saber se aceitaria tal afastamento, pois, segundo o regulamento de 1869, os professores não podiam exercer cargo público concomitantemente ao magistério. A resposta a Barreto está ilegível, mas segundo as fontes, Marcolino permaneceu no cargo de professor de Itaqui, pois continuou a enviar relatórios juntamente com os mapas de frequência posteriormente a essa caso.

Consta ainda nesse ofício de Barreto que o professor participaria da Junta Classificadora de Escravos, tema da querela com José Joaquim Pedroso Junior, já mencionada anteriormente. Nessa querela, Marcolino foi mencionado como filho de Antonio Barreto. $\mathrm{O}$ desenrolar desse episódio já foi tratado anteriormente, mas cabe destacar novamente que, apesar das desavenças com sujeitos politicamente importantes em Cotia, como José Joaquim Pedroso Junior, Marcolino conquistou o cargo de professor da $2^{\mathrm{a}}$ Cadeira Masculina da Vila, transferido da Cadeira de Itaqui. Além disso, durante o período em que foi professor da $2^{\mathrm{a}}$ Cadeira, e enquanto João José Coelho lecionava na $1^{\mathrm{a}}$ Cadeira, sempre teve mais alunos que João José, com exceção do ano de abertura da cadeira, em 1875, pois a escola começou a funcionar em maio. No ínicio de 1876, segundo o livro de matrícula dos alunos da $2^{\mathrm{a}}$ Cadeira $^{203}$, houve uma tranferência em massa de alunos de João José Coelho para a cadeira de Marcolino, sendo que entre os sete meninos transferidos estavam os filhos do ex-presidente da

Paulistano de 26 jul. de 1870, p. 2: como professor de Pirapora (município de Paranaíba), teve disponível um valor para compra de móveis para a escola; Jornal Correio Paulistano de 15 abr. 1871, p. 3: teve um requerimento deferido pelo Presidente da Província, sem detalhes do que se referia. A hipótese desta pesquisa é que o professor Marcolino tenha requerido remoção de cargo para a Cadeira de Itaqui, pois ele assumiu esta cadeira após essa data.

197 Conta sua remoção no Relatório de Presidente de Província referente a 1871.

198 Jornal Correio Paulistano de 23 ago. 1872, p. 2: eleito eleitor em Cotia; Almanak da Província de São Paulo para 1873, p. 144; Jornal Diário de São Paulo 9 ago. 1878, p. 1: eleito eleitor conservador.

${ }^{199}$ Almanak da Província de São Paulo para 1873, p. 145.

${ }^{200}$ Jornal Correio Paulistano de 25 nov. 1915, p. 5 e 26 nov. 1915, p. 4: nas notas de seu falecimento ocorrido em 24 de novembro, constam que era professor aposentado e primeiro juiz de paz. Na primeira nota também consta que era secretário de diretório republicano, que deixou 11 filhos e era viúvo.

${ }^{201}$ Jornal Correio Paulistano de 12 out. 1915.

202 Ofício do inspetor Antonio Barreto de 28 set. 1874 ao Inspetor Geral de I. P. AESP, Série Instrução Pública Manuscritos, ref. CO5044.

${ }^{203}$ AESP, Série Instrução Pública, livro de matrícula da 2a Cadeira Masculina da Vila de Cotia, 1875-1882, ref. EO2918. 
Câmara, juiz de paz e subdelegado Capitão José Joaquim Pedroso (pai de José Joaquim Pedroso Junior) e filhos de outros sujeitos politicamente influentes.

Ao analisar o documento, há possibilidade de que a transferência em massa tenha ocorrido para assegurar a permanência da cadeira, já que de maio a dezembro de 1875, ela contou com 14 alunos. Entretanto, após esse ano, a $2^{\mathrm{a}}$ Cadeira sempre teve mais alunos que a $1^{\text {a }}$, chegando a ocorrer 40 matrículas em 1881, enquanto que João José Coelho matriculou 22 alunos; mas, a diferença entre matriculados e frequentes era muito menor nas aulas de Coelho. Cabe destacar que, nos anos registrados no livro da $2^{\text {a }}$ Cadeira (1875-1882), houve uma maior ocorrência de matrículas de filhos ou de meninos tutelados por figuras politicamente importantes de Cotia, em comparação com a $1^{\text {a }}$ Cadeira, o que indica uma preferência desses sujeitos pelo Professor Marcolino. Também havia filhos/tutelados de pessoas influentes presentes nos registros de João José Coelho, mas nos de Marcolino havia mais, questão que é melhor discutida no capítulo quatro desta dissertação.

O professor Severiano José de Ramos ficou por cinco anos lecionando em Cotia (de 1871 a 76) na Cadeira de Várzea-Grande, transferindo-se posteriormente para a Capital, na Cadeira de Lageado, distrito da Freguesia da Penha de França ${ }^{204}$. Ficou por pouco tempo como professor público do município e se destacou como o primeiro professor de Cotia a frequentar a Escola Normal ${ }^{205}$, como mencionado e discutido no segundo capítulo.

Professor muito presente no processo de escolarização de Cotia no recorte desta pesquisa, José Custódio de Queiroz lecionou por um total de 25 anos nas cadeiras públicas do município. Segundo os jornais, exerceu outras funções principalmente após aposentar-se do cargo de professor público, em $1898^{206}$. Foi delegado de polícia ${ }^{207}$, capitão-assistente ${ }^{208}$ e capitão-ajudante de ordens da Guarda Nacional ${ }^{209}, 1^{\circ}$ suplente do juiz federal ${ }^{210}$ e membro do diretório do PR de Cotia ${ }^{211}$. Mas durante o período em que lecionava, em 1875, também foi aferidor de pesos e medidas ${ }^{212}$, função que segundo a resolução de posturas de 1886 mencionada no segundo capítulo desta dissertação, também devia ser exercida por professores públicos. Tornou-se professor vitalício em 1885, após assumir a $1^{\text {a }}$ Cadeira da Vila ${ }^{213}$. Em

\footnotetext{
204 Jornal Diário de São Paulo de 19 ago. 1876, p. 1-2.

205 Jornal Diário de São Paulo de 30 nov. 1875, p. 3.

206 Jornal Correio Paulistano de 17 nov. 1907, p. 1.

207 Jornal Correio Paulistano de 26 jan. 1903, p. 1.

${ }^{208}$ Jornal Correio Paulistano de 2 fev. 1903, p. 1.

${ }^{209}$ Jornal Correio Paulistano de 10 out. 1904, p. 2.

${ }^{210}$ Jornal Correio Paulistano de 7 nov. 1915, p. 7.

211 Jornal Correio Paulistano de 12 out. 1915, p. 4.

${ }^{212}$ Jornal Diário de São Paulo de 9 jul. 1875, p.1.

213 Jornal Correio Paulistano de 11 set. 1885, p. 1.
} 
nota sobre seu falecimento, aos 70 anos, não é mencionado outro cargo, apenas que Queiroz era "professor aposentado" 214 .

Ao longo dos 25 anos esteve interinamente à frente de cinco cadeiras (Sorocamirim ${ }^{215}$, Carapicuíba ${ }^{216}$, Capitão Jerônimo ${ }^{217}$, Lavapés ${ }^{218}$ e $1^{\text {a }}$ Cadeira da Vila ${ }^{219}$ ), das quais saiu por remoção, com exceção da Cadeira de Carapicuíba, que pediu exoneração ${ }^{220}$ e da Cadeira da Vila, quando se aposentou. Esse professor foi nomeado para todos os cargos e não passou por exames, assumindo características de um professor "coringa" nas escolas onde a vaga não se preenchia por professor concursado.

Antonio Manoel Vieira ingressou na carreira do magistério em agosto de 1872, quando foi aprovado simplesmente como opositor à cadeira de primeiras letras ${ }^{221}$. Nesse mesmo ano assumiu a Cadeira do Bairro de Sorocamirim, ficando até 1876, quando se removeu para a Cadeira de Campo Limpo, município de Santo Amaro ${ }^{222}$.

O Professor João Rodrigues de Jesus assumiu a cadeira de Carapicuíba em 1880 e há relatórios seus apenas até 1881 nas latas consultadas no AESP. Nos periódicos digitalizados na Hemeroteca Nacional há, em 1886, o nome de João Rodrigues de Jesus como professor da $2^{\text {a }}$ Cadeira da Vila de Parnaíba ${ }^{223}$. Em 1888, uma nota de jornal também informou que esse professor lecionava para a $2^{\text {a }}$ Cadeira Masculina de Parnaíba ${ }^{224}$. É importante lembrar que, em 1878, a Cadeira de Carapicuíba foi transferida para Barueri, bairro do município de Parnaíba, mas atendia também aos carapicuibanos ${ }^{225}$.

Manoel de Moraes Pinto lecionou em Cotia por volta de 10 a 15 anos. Em 1858 foi contratado para única cadeira pública de Cotia, a Cadeira Masculina ${ }^{226}$ - logo após a aposentadoria do professor Antonio Barreto -, mas ficou por poucos meses e depois lecionou

\footnotetext{
${ }^{214}$ Jornal Correio Paulistano de 8 nov. 1922, p. 5.

215 Jornal Diário de São Paulo de 21 dez. 1871, p. 1.

216 Jornal Diário de São Paulo de 28 ago. 1872, p. 2.

${ }^{217}$ Jornal da Tarde (SP) de 19 jul. 1879, p. 3.

218 Ofício do inspetor de distrito Benedicto José d'Oliveira de 20 mar. 1884 ao Inspetor Geral da Instrução Pública. AESP, Série Instrução Pública - Manuscritos, ref. CO5044.

219 Jornal Correio Paulistano de 27 mai. 1885, p. 2.

${ }^{220}$ Jornal Correio Paulistano de 28 jul. 1877, p. 2.

${ }^{221}$ Jornal Diário de São Paulo de 23 ago. 1872, p. 3.

222 Jornal Correio Paulistano de 4 mai. 1876, p. 2.

223 Almanach Provincia de São Paulo, 1886, p. $397 . \quad$ Disponível em <http://memoria.bn.br/DocReader/DocReader.aspx?bib=828858\&PagFis=407> Acesso em 13.jun.2015. Neste documento também consta que à frente da cadeira da Estação Barueri estava o professor João da Mattta e Luz, o mesmo que em 1879 havia sido nomeado para o cargo de professor de Capitão Jerônimo, mas não assumiu.

224 Jornal Correio Paulistano de 25 set. 1888, p. 1.

${ }^{225}$ Contudo, tive acesso a essas dados apenas no final da pesquisa. Documentos do Professor João Rodrigues de Jesus muito possivelmente estão na lata do AESP referente à instrução pública de Parnaíba, mas devido à falta de tempo não consegui pesquisar nesta lata.

${ }^{226}$ Jornal Correio Paulistano de 14 nov. de 1858, p. 2.
} 
em Itapecerica ${ }^{227}$ e em Araçariguama, municípios vizinhos de Cotia. Em 1864, foi capitão da Guarda Policial da Vila de Cotia ${ }^{228}$, mas o exercício de seu cargo de capitão foi interrompido quando se tornou professor público em Itapecerica, exonerando-se daquele cargo $^{229}$. Em Itapecerica também foi eleitor (do Partido Conservador) ${ }^{230}$. Voltou a trabalhar em Cotia como professor em 1880, removido de Araçariguama para a Cadeira de Várzea-Grande ${ }^{231}$. Nesta cadeira lecionou até 1884 , quando pediu remoção para a Cadeira de Capitão Jerônimo ${ }^{232}$, permanecendo ali até o início dos anos de $1890^{233}$. Tornou-se professor vitalício em $1887^{234}$.

Em 1880, o “cidadão" João Cezar de Abreu e Silva foi nomeado para o cargo de professor de primeiras letras da cadeira de Sorocamirim ${ }^{235}$, na qual não chegou a exercer seu cargo, pois no relatório de governo constou que essa cadeira estava "sem alunos" em $1880^{236}$. O rastramento do nome do professor em periódicos paulistas no site da Hemeroteca Nacional indicou que em Perus, bairro da Capital, havia um professor com o mesmo nome frente à cadeira masculina, tendo grande possibilidade de ser o mesmo professor que outrora assumiu a cadeira de Sorocamirim ${ }^{237}$.

Consta no Correio Paulistano de 1876 o nome de João Maria Thomaz como um dos candidatos aprovados simplesmente em exame dentre os candidatos às cadeiras vagas de primeiras letras no dia 7 de novembro ${ }^{238}$, e foi admitido em 16 de outubro ${ }^{239}$, mas não obtive informação sobre em quais escolas lecionou até 1880. A partir deste ano há registros de jornais que lecionava em Una, na Escola de Primeiras Letras do Bairro de Feital ${ }^{240}$. Assumiu a

\footnotetext{
227 Jornal Diário de São Paulo de 16 nov. 1867, p. 3.

228 Jornal Correio Paulistano 8 jul. 1864, p. 1.

${ }^{229}$ Jornal Diário de São Paulo de 18 set. 1868, p. 1.

230 Jornal Diário de São Paulo de 4 fev. 1869, p. 3.

${ }^{231}$ No Amanak da Província de São Paulo para 1873, p. 392, consta como professor público de Araçariguama. Sua remoção para a Cadeira de Várzea-Grande consta no Relatório sobre o estado da I. Pública no ano de 1880 , 1881. Disponível em <http://brazil.crl.edu/bsd/bsd/1025/000523.html> Acesso em: 5 ago. 2015.

232 Jornal Correio Paulistano de 6 mar. 1884, p. 2.

${ }^{233}$ A data não é precisa pela pesquisa, entretanto, pode-se afirmar que foi no início dos anos de 1890 porque em 1891 Manoel ainda lecionava em Capitão Jerônimo (Jornal Correio Paulistano de 25 mar. 1891, p. 2), em 1893 apareceu em publicação como professor aposentado de Cotia (Jornal Correio Paulistano de 19 jan. 1893, p. 2) e em 1894 despede-se com sua família de Cotia em nota, informando que se mudariam para Sorocaba (Jornal Correio Paulistano de 4 fev. 1894, p. 2).

234 Jornal Correio Paulistano de 10 jul. 1887, p. 1.

235 Jornal Correio Paulistano de 12 out. 1880, p. 2.

236 Relatório sobre o estado da I. Pública no ano de 1880, 1881. Disponível em <http://brazil.crl.edu/bsd/bsd/1025/000523.html> Acesso em: 5 ago. 2015.

${ }^{237}$ Almanach Administrativo, Comercial e Insdustrial da Provincia de São Paulo para o ano bissexto de 1884, p. 112. Disponivel em <http://memoria.bn.br/DocReader/DocReader.aspx?bib=829560\&PagFis=135> Acesso em 02.jul.2015

238 Jornal Correio Paulistano de 14 nov. 1876, p. 2.

${ }^{239}$ Jonral Diário de São Paulo de 20 out. 1876, p. 3.

${ }^{240}$ Jornal Correio Paulistano de 8 set. 1880, p. 2; Jornal da Tarde (SP) de 12 jul. 1881, p. 2.
} 
cadeira de Sorocamirim em 1882 e permaneceu até $1888^{241}$, não exercendo outro cargo público, ao menos segundo os jornais consultados.

O Professor Joaquim Chrispim de Oliveira esteve como professor público por pouco mais de trinta anos, aposentando-se em $1913^{242}$ frente à $2^{\text {a }}$ Cadeira da Vila de Cotia. Começou a lecionar no local assumindo a Cadeira do Bairro de São João em 1882, onde permaneceu até pelo menos 1887, data da última nota de jornal que consta seu nome vinculado a essa cadeira e que informa sobre uma licença de 40 dias para tratar de saúde ${ }^{243}$. No ano seguinte teve o exercício de cargo suspenso devido à suspensão do funcionamento da Escola do Bairro de Lavapés, onde era professor intermédio ${ }^{244}$. Em 1889 tentou ser provido para o cargo de professor na Cadeira de Boamirim, no município de Itapecerica, mas seu pedido foi negado pelo Presidente de Província ${ }^{245}$, sem maiores detalhes. Em 1909 estava frente à Cadeira do Bairro da Graça, em Cotia, quando foi removido por decreto para a $2^{\mathrm{a}}$ Cadeira do Sexo Masculino da Vila ${ }^{246}$. Faleceu repentinamente aos 69 anos em 1921, cujo "enterro esteve muito comovido" 247 . Na nota sobre a morte do professor consta apenas que era "professor aposentado", mas segundo notícia de 1918 , também foi nomeado a $1^{\circ}$ suplente de juiz federal em Cotia $^{248}$, cargo que talvez nunca tenha assumido de fato.

A professora Catharina Etelvina Pedroso assumiu a $2^{\text {a }}$ Cadeira Feminina da Vila assim que ela foi criada, em 1884. Não há mais informações em jornais sobre sua vida pública, apenas nota que assumiu a cadeira em 5 de março de $1884^{249}$. Sobre sua vida particular, no livro de matrícula da $1^{\text {a }}$ Cadeira Feminina da Vila ${ }^{250}$, quando era aluna, consta que seu pai se chamava José Joaquim Pedroso. Segundo as informações de registros de nascimentos da Vila de Cotia localizadas no site FamilySearch, uma pessoa chamada Catharina Pedrozo (não há Catharina Etelvina Pedroso) foi batizada em Cotia em 4 de dezembro de 1863. Era filha de Joze Joaquim Pedrozo e Maria Brandina de Araujo ${ }^{251}$, os mesmos pais de Joze Pedroso, cuja página do livro consta apenas como Joze, mas há grande possibilidade de ser José Joaquim Pedroso Junior, presidente da Câmara, inspetor de estrada, entre outras funções. O Capitão José Joaquim Pedroso foi presidente da Câmara entre 1865 e 1868, foi vereador, juiz de paz,

\footnotetext{
241 Jornal Correio Paulistano de 2 fev. 1888, p. 3.

242 Jornal O Commercio de São Paulo de 25 jul. 1913, p. 2.

243 Jornal Correio Paulistano de 20 set. 1887, p. 1.

244 Jornal Correio Paulistano de 30 jul. 1898, p. 1.

${ }^{245}$ Jornal Correio Paulistano de 7 abr. 1899, p. 2.

246 Jornal O Commercio de São Paulo de 18 mar. 1909, p. 2.

247 Jornal Correio Paulistano de 17 mai. 1921, p. 4.

248 Jornal Correio Paulistano de 23 jan. 1918, p. 4.

249 Jornal Correio Paulistano de 12 mar. 1884, p. 3.

${ }^{250}$ AESP, referência EO2230.

${ }^{251}$ Disponível em <https://familysearch.org/pal:/MM9.1.1/XJVR-NJ7> Acesso em: 6 jul. 2015.
} 
subdelegado e eleitor ${ }^{252}$. José, o filho, foi batizado em 30 de agosto de 1848 e teve como padrinho um comendador de São Paulo ${ }^{253}$. O livro de registro em que consta o nome de Catharina não está disponível no acervo on-line de FamilySearch. Ao que parece muito possível, Catharina era irmã e filha de figuras muito influentes da localidade.

O nome de Catharina aparece entre as alunas de Maria Joanna do Sacramento entre 1870 e 1877 nas listas de matrícula, fato que abre precedente para inferir que Catharina teve a Professora Maria Joanna como a maior ou uma de suas maiores referências como docente. Segundo Borges e Vidal:

\begin{abstract}
A longa trajetória desenvolvida em uma mesma escola pode ter contribuído para o desenvolvimento de experiências educativas que se tornaram referência entre os professores - sendo importante assinalar que também ajudaram a formar professores por meio da "formação pela prática", instituída pelo regulamento de 1854 - e a consolidar uma determinada posição na sociedade. (BORGES; VIDAL, 2014, p. 13).
\end{abstract}

Como apontado na introdução desta dissertação, segundo Vidal (2010), um dos elementos constitutivos da experiência docente é a trajetória escolar dos professores, o "conjunto da experiência acumulada pelo sujeito professor ao longo de sua vida" (VIDAL, 2010, p. 712), que engloba sua experiência como professor e também suas vivências como aluno desde o início de sua escolarização.

Em 1885, pela primeira vez apareceu nos jornais pesquisados o nome de João Baptista Cepellos, pois estava entre os professores que passaram em exame para assumir cadeiras públicas $^{254}$, sendo nomeado em seguida para a Cadeira do Bairro da Quadra, sem informação de qual município pertencia esse bairro ${ }^{255}$. Foi removido em outubro para Várzea-Grande, em Cotia, onde lecionou até 23 de outubro de 1887, pois veio a falecer um dia depois. Não obtive maiores informações sobre a causa da morte, que foi informada segundo o Inspetor Geral em relatório ao Presidente da Província ${ }^{256}$. Neste documento o Inspetor Geral informou ainda que sugeriu ao Conselho a supressão e a criação de escolas em Cotia, mas não citou as cadeiras

\footnotetext{
252 Informações presentes no Almanak da Província de São Paulo para 1873; a relação de veradores no site de um Jornal Local chamado Cotiatododia. Esse jornal disponibilizou a lista de vereadores que outrora estava no site da Câmara Municipal de Cotia, mas que em sua configuração atual retirou essa listagem. Disponível em <http://cotiatododia.com.br/retro/cotiatododia2007/guias_publicos/vereadores_guiasdecotia.htm> Acesso em 14 jul. 2015; a relação de presidentes da Câmara estão no site da Câmara dos Vereadores (site que não têm disponível a relação de vereadores desde 1856). Disponível em <http://www.camaradecotia.sp.gov.br/presidentes.php> Acesso em: 14 jul. 2015.

253 Disponível em <https:/familysearch.org/pal:/MM9.3.1/TH-1-14090-7587-5?cc=2177299\&wc=M5JCBZD:372228201,372228202,372314201> Acesso em: 06.jul.2015

254 Jornal Correio Paulistano de 5 mar. 1885, p. 3.

255 Jornal Correio Paulistano de 19 jun. 1885, p. 1.

${ }^{256}$ Relatório do Inspetor Geral para o Presidente da Província de 21 jan. 1888. AESP, Série Instrução Pública Manuscritos, CO5044.
} 
que seriam suprimidas nem os bairros das que poderiam ser criadas. Como mencionado, João Baptista Cepellos era pai de Manoel Baptista Cepellos, ex-aluno de Cotia e poeta.

Ele também abriu uma escola particular em Cotia em 1874, ano em que foi aprovada a lei de obrigatoriedade do ensino da Província de São Paulo. Em 19 janeiro de 1874, o inspetor de distrito informou que João Baptista Cepellos havia aberto uma escola particular "sem

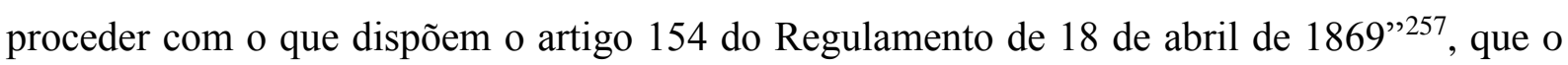
mesmo não possuía nenhuma habilitação para ensinar e pediu que Inspetor Geral fizesse o que achasse melhor. Segundo o mencionado artigo,

Art.154. Nenhuma escola ou collegio podem ser installados sem prévia participação do Inspector do Districto, do nome do seu proprietario, do lugar da escola ou collegio, programa do ensino, número de aulas, materias que nellas vão ser ensinadas, hora em que funccionaram, professores que as vão reger, e a pessoa a quem compete a direcção. (Regulamento de 18 de abril de 1869).

Não foram encontrados mais registros sobre o caso, portanto, ao que tudo indica, a escola foi fechada pelo inspetor de distrito. Embora não seja intenção da pesquisa discutir sobre a instrução particular, esse caso trouxe como protagonista o Professor João Baptista Cepellos, um dos professores públicos de Cotia.

A professora Analia Emilia Franco ${ }^{258}$ esteve à frente da $1^{\text {a }}$ Cadeira feminina da Vila de Cotia de 1885 a $1887^{259}$. Ao que indicam as fontes, Analia morava em São Carlos do Pinhal (São Carlos) antes de vir para Cotia, pois no Almanach Administrativo, Commercial $e$ Industrial para o ano de 1885, publicado no final de $1884^{260}$, consta que Analia era uma das docentes do Collegio Santa Cecília, colégio de instrução primária e secundária para meninas que, segundo a mesma publicação, foi fundado em 1882 pela própria Analia Franco. Durante o período que esteve como professora em Cotia foi contemplada com vantagens concedidas pela lei a professoras normalistas que continuavam a exercer o magistério público ${ }^{261}$, e também entrou em licença por pelo menos seis meses para cuidar de uma dispepsia (doença

\footnotetext{
257 Ofício de Antonio Barreto de 19 jan. 1874 ao Inspetor Geral da I. P. AESP, Série Instrução Pública Manuscritos, ref. CO5044.

258 Para mais informações sobre Analia Franco ver Monteiro (2004), Oliveira (2007), Lodi-Correa (2009), Chagas e Panizzolo (2014).

259 Jornal Correio Paulistano de 27 mai. 1885, p. 2.

260 Almanach Administrativo, Commercial e Industrial para o ano de 1885, p. 490. Disponível em <http://memoria.bn.br/DocReader/DocReader.aspx?bib=829161\&PagFis=506> Acesso em: 6 ago. 2015.

${ }^{261}$ Lei no78 de 6 de abril de 1885. Disponível em

<http://www.usp.br/niephe/bancos/legis_detalhe.asp?blg_id=328> Acesso em: 11 mai. 2015.
} 
ligada ao aparelho digestivo), segundo ofícios e relatórios de instrução pública assinados pelo Inspetor Geral $^{262}$.

No período da licença, duas professoras assumiram sua função (Leonilbes[?] C. de Souza Gouvêa e Maria José de Toledo Aymberé). Em agosto de 1887, Analia Franco conseguiu transferência para a Cadeira de Taubaté263, município que se localiza a mais de 220 quilômetros de Cotia. Não consegui informações com relação aos motivos pelos quais Analia veio lecionar em Cotia ou porque pediu remoção dois anos depois.

Professora desde 1872, Analia estava envolvida com a educação de crianças filhas de escravas e matriculou-se em 1877 na Escola Normal, formando-se em 1878. Lecionou em alguns municípios do interior de São Paulo, contudo, os trabalhos que tiveram a professora Analia Franco como sujeito e objeto de pesquisa não mencionaram a passagem dela por Cotia, alegando, inclusive, uma lacuna sobre sua atuação no magistério ${ }^{264}$. Trabalhos dão nota de que Analia lecionou em São Carlos e depois se mudou para Taubaté, portanto, a presente pesquisa contribui para desvelar parte da história da Professora Analia Franco. Sendo assim, entre sua morada em São Carlos e Taubaté, ela morou e atuou em Cotia como professora pública entre 1885 e 1887 (com períodos de tratamento de sua doença no município da Corte durante sua licença, segundo documentos de instrução pública ${ }^{265}$ ).

Após discorrer sobre as trajetórias dos professores de primeiras letras de Cotia, é possível afirmar que os dados demonstram que os professores públicos cotianos do sexo masculino transitavam em outros campos exercendo outras funções, ora ligados ao campo de segurança pública, ora da justiça, mas também no campo das artes ou integrando partido político. Comum para a época, Cotia não tinha muitas pessoas que soubessem ler até o início da década de 1870, conforme dados do Censo de 1872 (de 5.024 habitantes, 263 sabiam ler). Aqueles que possuíam esse saber conseguiam se inserir em outros segmentos do serviço público. Por outro lado, nenhum dos professores apresentados exercera um cargo público antes de se tornar professor público. O único que exerceu foi João José Coelho, que vou apresentar adiante.

Hilsdorf (1998), remetendo-se a Antonio Nóvoa, assinalou que os professores estavam no extrato de quem não era da burguesia, mas também não era da camada popular. Segundo Silva (2007), em sua pesquisa referente à Pernambuco, o magistério público funcionou como

\footnotetext{
262 Ofícios da Inspetoria Geral da I. P. de 4 ago. e 3 set. 1886 ao Presidente da Província. AESP, Série Instrução Pública - Manuscritos, ref. CO5044.

263 Jornal Correio Paulistano de 21 ago. 1887, p. 2.

${ }^{264}$ Cf. Monteiro (2004), Oliveira (2007), Lodi-Correa (2009).

${ }^{265}$ Ofícios da Inspetoria Geral da I. P. de 4 ago. e 3 set. 1886 ao Presidente da Província. AESP, Série Instrução Pública - Manuscritos, ref. CO5044.
} 
"um dos instrumentos componentes das redes de clientela e como uma porta de acesso individual à obtenção de benesses do Estado" (p. 125).

\begin{abstract}
Muito embora fosse majoritariamente exercido por homens pobres, o magistério público de primeiras letras - tarefa árdua inclusive nos dias atuais - permitia àqueles que a ele se dedicassem o desfrute de um cargo público vitalício, independente do comando de uma chefia direta (conforme ocorria com os funcionários de repartições, por exemplo); passível de ser exercido em toda a província; portador de um significativo prestígio social em meio às camadas mais modestas da sociedade, e significativamente valorizado para o ingresso nas redes locais de clientela. (SILVA, 2007, p. 173-174).
\end{abstract}

As variadas funções exercidas pelos professores públicos de Cotia podem sugerir que o trânsito deles em outros setores foi facilitado em virtude da rede de relações estabelecidas a partir do cargo de docente. Para compreender a relação da escola e seus sujeitos na dinâmica do município da Corte, Borges (2014) apontou os professores, por um lado, como agentes da administração (remetendo-se a Ilmar de Mattos) e,

\begin{abstract}
por outro, os professores sabiam que dispunham da possibilidade de exercer um poder, uma agência - propiciados pela autonomia da qual se faziam imbuir no exercício na profissão, mas também conferidos por sua condição de estarem em maior contato com o povo -, em favor de seus próprios interesses, fossem eles profissionais, econômicos, sociais ou políticos. (BORGES, 2014, p. 105).
\end{abstract}

Cabe destacar a questão das remoções dos professores. Em Cotia, com exceção de João José Coelho e Maria Joanna do Sacramento, todos os professores se removeram de escolas, uns com mais, outros com menos frequência. No município da Corte, segundo Borges,

\begin{abstract}
o trânsito por diversas regiões da cidade permitia ao professor ter conhecimento maior do terreno no qual operava e, de algum modo, fortalecer agências docentes e os laços de solidariedade entre os colegas, pois as questões reclamadas por um poderiam ser melhor compreendidas por outros que já teriam passado pela mesma região. $\mathrm{O}$ conhecimento adquirido pelo "rodízio das cadeiras" também poderia conferir ao professor uma experiência importante para atuação na vida social e política da cidade. (BORGES, 2014, p. 77-78).
\end{abstract}

Um dos professores cotianos, José Custódio de Queiroz, passou por cinco escolas locais, em diferentes bairros, e ainda exerceu variadas funções, entre elas delegado de polícia e juiz de paz. Devido a isso, o professor José Custódio deve ter adquirido grande conhecimento sobre o município em sua época.

Operando com o conceito de desconforto, Dayana Lima (2014) investigou os motivos de afastamentos dos professores públicos primários efetivos de Recife e Olinda entre 1860 e 
1880 tendo como questão basilar: “O ‘desconforto’ é um fenômeno individual ou constitutivo do ofício docente?" (p. 17). Lima entendeu como desconforto "as problemáticas práticas descritas pelos poderes públicos em relação às necessidades de afastamento do docente no exercício de seu trabalho" (p. 17-18), observando que as licenças médicas, as transferências de escola, faltas ao trabalho, substituições de professores e os casos de abandono eram corriqueiros na vida docente, de um modo geral. Assim, a pesquisa concluiu que o desconforto era um fenômeno comum nesses municípios de Pernambuco, sendo as remoções e licenças médicas (estas sobretudo de professoras mulheres) os principais motivos.

Segundo as fontes coligidas, em Cotia o fenômeno do desconforto também esteve presente entre os professores, em especial entre os professores dos bairros, que se transferiram, em geral, com menos de quatro anos de exercício do cargo. Houve também casos de afastamentos para cuidar de enfermidade, como no caso de Analia Franco, que posteriormente se transferiu para Taubaté, de Joaquim Chrispim que se afastou por 40 dias, além de outros professores que tiveram licenças curtas. Por outro lado, o casal das Primeiras Cadeiras da Vila parecia confortável com as escolas e o local de trabalho. Dessa maneira, dando continuidade à apresentação dos sujeitos e análise de suas atuações, o próximo subcapítulo discorre sobre o casal Maria Joanna do Sacramento e João José Coelho.

\section{2. Professores das primeiras cadeiras na vida pública e casal na vida privada: Maria Joanna do Sacramento e João José Coelho}

Trabalhos que privilegiam o estudo da história da educação por meio de trajetórias docentes possibilitam enxergar como esses sujeitos nos diversos rincões do Brasil tinham (e ainda têm, apesar de muito se generalizar sobre eles) características heterogêneas, e como a escolarização do Brasil se constituiu partindo de diversos e diferentes personagens. Entre os estudos sobre professores do Oitocentos, destaco as pesquisas de Hilsdorf (1998), Nascimento (2011), Munhoz (2012) e Borges (2014).

O trabalho de Hilsdorf (1998) trouxe a história da Mestra Benedita que ensinava na escola da Sé, na Capital Paulista, entre 1828 e 1858, uma professora que em sua época não dava aulas de prendas domésticas, conteúdo obrigatório. Munhoz (2012) investigou e analisou as trajetórias de quatro professores de Paranaguá e Curitiba entre 1826 e 1860: Hildebrando, Joana, Albino e João Baptista. Para a autora, “acompanhar o itinerário dos sujeitos permite interpretar elementos particulares, as relações daqueles sujeitos com as normas, as 
reciprocidades e valores específicos daqueles indivíduos e, simultaneamente, as condicionantes sociais e históricas que constituem, portanto, a docência” (MUNHOZ, 2012, p. 25).

A tese Nascimento (2011) percorreu a trajetória de 14 professoras de Sabará, Minas Gerais, durante o século XIX. Respaldada nos estudos de Giovanni Levi, apontou que "ora a experiência individual está subsumida pelos sistemas normativos gerais, exemplares de comportamentos que corroboram e validam leis e regras sociais, ora comportamentos individuais são entendidos como tendo dinâmica própria, independentes de sistemas normativos externos" (NASCIMENTO, 2011, p. 31) e que se deve considerar as instabilidades, incertezas, contradições próprias da vida das pessoas. Para Nascimento:

Estudar trajetórias implica "arrastar" o indivíduo estudado ao longo da história, como se fosse um ímã em uma limalha. Implica situá-lo nos campos possíveis onde o indivíduo se move e se constitui. Implica também falar de uma série de assuntos que, de forma direta ou tangencial, refletem em sua trajetória. (NASCIMENTO, 2011, p. 35).

Segundo a autora,

\begin{abstract}
Outra dimensão importante refere-se ao fato de estudos de trajetória ganharem sentido em um contexto denso, na ambiência, nas relações e nas sociabilidades. Não se deve perder de vista que os indivíduos se organizam em grupos que partilham certa sensibilidade diante das questões do seu tempo, por meio de trocas, articulações e contatos. São vinculações afetivas, sociais, religiosas e políticas, com níveis de formalização distintos e que indiciam elementos importantes da vida do indivíduo e o restitui nas redes de relações concretas que estabelece. (NASCIMENTO, 2011, p. 36).
\end{abstract}

Borges (2014) em sua tese percorreu a trajetória do professor Candido Pardal do município da Corte, funcionando como um fio condutor na investigação dos diversos níveis de aproximação entre a escola e a sociedade e seus desdobramentos. Sua pesquisa fez "quatro movimentos de análise". O primeiro se referiu aos professores públicos primários, privilegiando suas agências e relações com o governo. O segundo investigou as "vizinhanças" da escola, refletindo sobre as redes de relações e buscando compreender a dinâmica local e "seus efeitos na escolarização, por meio das relações e agências constituídas entre professores, alunos e habitantes, seus pertencimentos e o modo como se inseriam na cidade" (p. 36). O terceiro movimento de análise abrangeu a figura dos professores na dinâmica da cidade por meio de suas instituições sociais, culturais e políticas. E o quarto elegeu a discussão de história conectada ao investigar a apreensão pelo professor Candido Pardal de um modelo pedagógico francês. 
Ao discorrer sobre o espaço de trabalho dos professores oitocentistas, a autora asseverou, remetendo-se a Schueler:

\begin{abstract}
A casa, que na maioria das vezes também era a escola, foi palco de muitas relações conflituosas entre os próprios professores, suas respectivas famílias e o governo, apresentando um emaranhado de relações em que o público e o privado se confundiam, frequentemente de maneira tensa e heterogênea. (BORGES, 2014, p. 68).
\end{abstract}

A assertiva acima vai ao encontro do contexto da escolarização de Cotia, no que se refere aos espaços escolares no Oitocentos. Os espaços usados como escolas eram majoritariamente a casa dos professores cotianos, e às vezes casas de outros cidadãos ou capelas. Destaco a casa dos professores Maria Joanna e João José Coelho, a qual era palco de duas escolas, no mesmo horário, das 9 às 14 horas, sendo que as aulas das meninas aconteciam na sala da casa e as dos meninos numa sala do lado de fora; escolha dos professores que, possivelmente, estava relacionada com as dinâmicas sociais nas quais as mulheres deveriam permanecer em espaço privado.

Entre todos os sujeitos envolvidos na escolarização da Corte naquele período do século XIX, percorrer a trajetória do professor Candido Pardal foi o foco principal da autora, mas ela também verificou parte da trajetória de outros sujeitos a partir dos fios dos nomes. $\mathrm{O}$ trabalho de Borges mostrou que os indivíduos que pesquisou não eram

\begin{abstract}
apenas professores, alunos, pais e encarregados, mas sujeitos da cidade: votantes, eleitores, subdelegados de polícia, comerciantes, artesãos, militares, funcionários públicos, devotos, sócios, artistas, militantes, negociadores, enfim, agentes sociais que espalhados pela cidade se encontravam na escola de Santa Rita, presencialmente ou indiretamente, em razão da escolarização ou da figura de seu professor. Nesse sentido, os fazeres da escola e da cidade se mesclam, proporcionando aprendizagens diversas e produzindo formas de agir e pensar marcadas pelos seus pertencimentos sociais e pela escolarização. (BORGES, 2014, p. 275).
\end{abstract}

Percorrer as trajetórias não é o foco desta pesquisa, mas neste subcapítulo pretendo apresentar e discutir fragmentos das trajetórias docentes do casal Maria Joanna e João José, professores que lecionaram por mais de duas décadas na Vila de Cotia, frente às mesmas cadeiras públicas. Tinham "honesta conduta e regularidade de vida com os que são conhecidos, pública e particularmente", segundo o inspetor de distrito Manoel Joaquim da Luz em relatório de $1869^{266}$. Maria Joanna e João José se uniram matrimonialmente em novembro de $1873^{267}$.

\footnotetext{
${ }^{266}$ AESP, Ofícios da Instrução Pública de Cotia, Lata CO5044.

${ }^{267}$ Disponível em <https://familysearch.org/pal:/MM9.1.1/V2KW-T22> Acesso em: 5 jan. 2014.
} 
Quais foram as influências das aulas do casal na localidade e a atuação dos professores no desenvolvimento da escolarização em Cotia? Sem desconsiderar a vontade de estarem juntos, casados, será que os resultados dessa estreiteza de relação poderiam ser discutidos como tática na atuação como professores? Qual o nível de influência em suas formas de trabalhar? Entremeando a discussão dessas questões, faz-se necessário uma apresentação de dados sobre cada indivíduo contidos nos jornais de época e em outras fontes.

Maria Joanna do Sacramento lecionou por 27 anos frente à $1^{\text {a }}$ Escola do Sexo Feminino da Vila de Cotia. Foi nomeada no lugar da educanda Rosa Josefa de Jesus ${ }^{268}$, que não chegou a assumir porque preferiu lecionar em Una. Maria Joanna foi nomeada em $1^{\circ}$ de junho de 1858 e prestou juramento perante a Câmara Municipal no dia 30 desse mês ${ }^{269}$. Em maio de 1869 foi aprovada em exame para receber 200 mil reis anuais, além do ordenado, vantagem estabelecida pela legislação educacional aos professores aprovados ${ }^{270}$. Infelizmente não obtive informações sobre sua vida fora da escola, com exceção do nome de seus pais, de que se casou com João José Coelho em 1873 e não tiveram filhos. Abaixo está a imagem da anotação referente ao casamento dos professores assinado pelo Vigário Manoel das Dores Rocha.

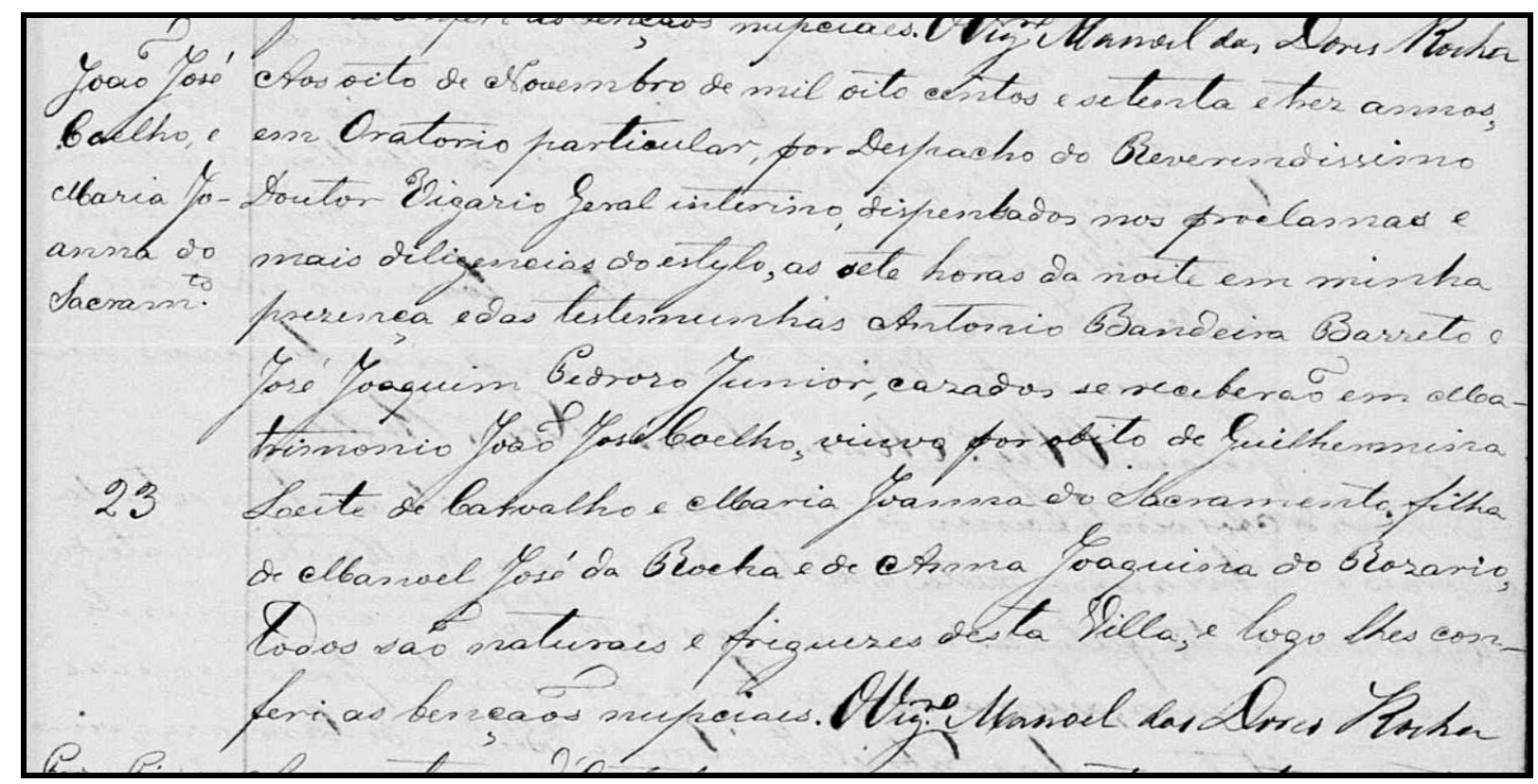

268 O Publicador Paulistano de 3 mar. 1858, Seção Expediente da Presidência. In: Hilsdorf (1999).

${ }^{269}$ Ofício da Câmara Municipal de 30 jun. 1858. AESP, Série Ofícios Diversos, Ofícios Diversos de Cotia, ref. CO1007.

270 Jornal Correio Paulistano de 15 mai. 1869. 
Ilustração 24 - Recorte do registro de casamento de Maria Joanna do Sacramento e João José Coelho (Fonte: Livro de Matrimônios de Cotia - 1818-1875, p. 225 ${ }^{271}$ )

Segundo o documento, Maria Joanna do Sacramento era natural de Cotia, filha de Manoel José da Rocha e de Anna Joaquina do Rosario. O casamento dos professores teve como testemunhas Antonio Barreto, ex-professor do noivo e nesse ano inspetor de distrito, e José Joaquim Pedroso Junior, inspetor de estrada e presidente da Câmara, personagem também já mencionado nesta pesquisa. A cerimônia aconteceu num oratório particular, o que pode indicar o desejo de privacidade para o sacramento, visto que ao longo das páginas do livro matrimonial encontrei apenas casamentos ocorridos na Igreja Matriz.

Enquanto apareceram em várias publicações de jornais os nomes dos professores homens ligados a outros setores da vida pública, não encontrei o de Maria Joanna, a não ser como professora da cadeira feminina de Cotia. Ela tinha sua vida pública muito provavelmente restrita à escola, fato diretamente relacionado à sociedade patriarcal em que vivia, pois era muito difícil conseguir um lugar de destaque na vida pública além da escola, ao menos na vida pública documentada nas fontes (talvez fosse muito ativa junto às famílias dos seus alunos, por exemplo).

Na contramão do que preconizava essa sociedade patriarcal estava a Mestra Benedita, protagonista do estudo de Hilsdorf (1998). O trabalho da autora nos convida a refletir sobre a conduta um tanto quanto desafiadora da dita mestra. Benedita da Trindade e Lado de Cristo ensinava na escola da Sé, cargo que assumiu em 1828 após concurso. Destacava-se o fato de que Benedita não ensinava prendas domésticas a suas alunas, conteúdo obrigatório nas aulas de meninas.

Apesar disso, Benedita ganhava mais que muitas professoras, sendo inclusive alvo de reclamação de uma colega de ofício que, segundo esta, ganhava bem menos e ensinava todas as matérias exigidas às alunas, inclusive prendas domésticas, além de administrar a instituição em que trabalhava. E por que Benedita escolheu esse ofício? Se aparentemente não se enquadrava (ou não queria se enquadrar) no "sistema"? A hipótese de Hilsdorf é de que pertencia a "uma família de 'devotos"” (1998, p. 523), cujo irmão possivelmente era professor particular e a irmã, anos depois, diretora do Seminário das Educandas.

Outras professoras como Benedita também foram denunciadas devido à ausência do ensino de "prendas femininas". O controle dos conteúdos ensinados passou a ser rigoroso com

271 Disponível em <https://familysearch.org/pal:/MM9.3.1/TH-1-14090-15177-51?cc=2177299\&wc=M5JZMNL:372228201,372228202,372397201> Acesso em: 7 jul. 2015. 
a inspeção dos funcionários do governo, que exigiu que as professoras soubessem costurar. Mas Benedita continuou a não ensinar as prendas a suas alunas ao que indicam as fontes analisadas por Hilsdorf, pois nelas não havia referência às prendas domésticas no conjunto de habilidades que suas alunas haviam aprendido em suas aulas ou o que deveriam aprender (1998, p. 523-525). Hilsdorf apontou, inclusive, que a mestra Benedita fez ao menos uma discípula, pois uma de suas alunas tornou-se professora e apenas ensinava as prendas domésticas no fim do horário escolar, quando as alunas ficavam esperando seus pais irem buscá-las.

Cabe fazer algumas considerações quanto à existência de cadeiras femininas e aos objetivos dessa escolarização. Analisando a presença feminina na instrução pública mineira, Gouvêa (2003) indicou que no século XIX, e em especial na primeira metade do Oitocentos (período da lei de obrigatoriedade de ensino na Província de Minas Gerais - 1835):

\footnotetext{
O ideário da educação feminina ao longo dos oitocentos, mesmo não correspondendo a experiência de vida de grande parte das mulheres, buscava dar sentido aos projetos de sua escolarização. Tais projetos tinham em vista a produção de um feminino capaz de ordenar a família de acordo com o modelo europeu de uma sociedade civilizada e ordeira. Principalmente na primeira metade do século XIX é o papel da mulher na formação das novas gerações de acordo com os princípios civilizatórios que fundamentava os discursos educacionais. (GOUVÊA, 2003, p. 7).
}

Faria Filho e Rosa (2001) enfatizaram que em Minas Gerais houve um grande crescimento da presença de meninas na escola se comparada a segunda metade do Oitocentos à primeira metade. Em Cotia, até 1884 tinha apenas uma escola pública feminina e, ao que as fontes indicaram e que menciono no próximo capítulo, algumas particulares. Gouvêa (2003) assinalou que a presença de meninas na escola se confrontava com os valores tradicionais e com a resistência dos pais em permitirem que suas filhas fossem para outra residência estudar, muitas vezes lá estavam meninos e homens, como esposos das professoras. Como mencionado, Maria Joanna do Sacramento e João José Coelho a partir de 1873 davam aula na casa do casal no mesmo horário, mas em salas separadas. A turma de Maria Joanna sempre teve alunas frequentes, nunca em número menor que o exigido pelo governo (vinte), o que sugere que a maioria dos pais das alunas não se incomodava tanto com a presença dos meninos ao mesmo tempo em que as meninas na residência dos professores a ponto de tirá-las da escola.

Valdeniza Barra (2005), tendo como fontes principais os processos judiciais que incidiram sobre professores primários da instrução pública paulista entre 1853 e 1889, 
objetivou verificar a escola a partir da institucionalização da inspeção escolar, dos mecanismos de controle e penalizações, da relação entre a escola e seus sujeitos (professores, alunos, pais, vizinhos da escola, autoridades locais, autoridades da instrução pública). Para tal tarefa, cruzou dados de 25 conjuntos de peças de processos judiciais com leis e regulamentos da instrução pública, informações contidas nas atas de Assembleia da Província - para averiguar quais debates relacionados à instrução pública ocorriam antes das publicações dos textos normativos, pois não eram raros discursos contrários entre si -, além de mapas de frequência, jornais, entre outros.

Ao longo do trabalho apresentou variados casos que deram origem aos processos movidos sobretudo por moradores e inspetores locais contra professores. Entre os processos analisados, um foi movido em 1864 por um pai contra um professor acusando-o de roubar a mesa da escola e levá-la para casa (2005, p. 82-84). O professor era João Maria de Toledo, casado com a professora Elisa Carolina de Toledo Dantas, ambos eram professores públicos da Vila da Penha de França, Capital paulista. Entre os vários dados informados pelo pai no processo, relatou que as escolas funcionavam em casas diferentes, mas que o professor tinha o hábito lecinonar para seus alunos em sua casa (local onde funcionava a escola feminina), uma prática não autorizada pela legislação da época, segundo Barra. O professor reuniu atestados de dez testemunhas a seu favor, principalmente dos responsáveis por seus alunos, informando que tinham boa aprendizagem. O professor permaneceu no cargo após essa contenda.

Como citado, as fontes mostram que o casal de professores de Cotia continuou lecionando na mesma casa, desde seu casamento em 1873 até a aposentadoria do casal, em 1885. Fica a questão de como devem ter sido os intervalos de aula, se os alunos se juntavam numa área comum ou não, ou se os intervalos eram realizados em horários diferentes, já que infelizmente não há fontes que confirmem isso.

Hilsdorf (1999, 2003b) apontou a presença/ausência da mulher no ambiente escolar no século XIX em São Paulo a partir de dados contidos em "312 títulos de jornais avulsos, almanaques, anuários, revistas e outras publicações culturais e de variedade da época" (1999, p. 8), seja como "a mulher-professora, a mulher-proprietária de escolas, e a estudante" (p. 10). Para a autora, "a mulher professora, diretora ou proprietária de escola é uma figura recorrente da sociedade brasileira entre as décadas de 1850 e 1900: na maior parte deste intervalo de tempo ela está presente compondo o cotidiano da educação escolar elementar e secundária do período" (2003b, s/p). 


\begin{abstract}
De qualquer modo, as mulheres estão aí, em ação, educando e sendo educadas muito antes da Escola Normal pública lhes abrir as portas em 1876: no caso das professoras públicas, sendo aprovadas para o magistério em "exames de palácio" ou junto das Câmaras municipais, ou sendo às vezes simplesmente nomeadas por interferência de padrinhos políticos; e no das particulares, pedindo registro na Inspetoria, como prescrevia a lei, ou ensinando na própria casa, sem interferência das autoridades. (HILSDORF, 2003b, s/p).
\end{abstract}

Maria Joanna esteve entre as professoras apontadas por Hilsdorf em seus trabalhos. No primeiro, intitulado Tempos de escola: fontes para a presença feminina na educação (1999), foi mencionada na página 52, sendo informado que assumiu a cadeira feminina em Cotia e os documentos de onde foram retiradas essas informações (jornal $O$ Publicador Paulistano de junho e julho de 1858 e Almanak da Província de São Paulo para 1873), e no segundo, apresentado no XXV ISCHE, International Standing Conference for the History of Education de 2003, intitulado À Sombra da Escola Normal: achegas para uma outra história da profissão docente, Maria Joanna foi citada, com mais 12 professoras, como exemplo de mulher que ficou um longo período no cargo da docência: de 1858 a 1873, segundo as fontes de Hilsdorf. Entretanto, a presente pesquisa conseguiu informações de que essa professora exerceu sua função até 1885 , por um tempo ainda maior.

Ao encontro do que propõe Hilsdorf, Nascimento (2011) buscou compreender e refletir sobre a inserção na docência de um grupo de mulheres em Sabará, Minas Gerais, durante o século XIX. Verificou diferentes formas de ingresso - convidadas, por meio de exames - e em diferentes idades (até com 65 anos). A autora mostrou as influências das redes de sociabilidade e valores patrimonialistas, mas também a ocorrência de valores meritocráticos. Sabará teve uma presença grande de mulheres atuando no magistério: "Foi possível contabilizar mais de uma centena delas no ensino público elementar entre as décadas de 1830 e 1900, conforme documentação da Instrução Pública” (2011, p. 78).

Segundo a autora, a inserção das mulheres na docência muitas vezes está atrelada à sua formação na Escola Normal, entretanto, as trajetórias de 14 professoras de Sabará mostrou a diversidade de elementos constitutivos de cada história e um movimento de inserção muito complexo. No resultado de seu trabalho apontou que "no decorrer do século XIX, uma trama de relações que construíram uma ambiência favorável à inserção de um grupo de mulheres no magistério" (NASCIMENTO, 2011, p. 184), algumas com melhores condições de vida ou com muita dificuldade em manterem-se professoras, algumas que vinham de família de professores, outras não; que ficaram muito tempo frente à mesma cadeira, outras que lecionaram em algumas cidades até se estabelecer em Sabará. Entre as conclusões de Nascimento, quanto à ambiência do trabalho: 
[...] o magistério, ao contrário do que é comumente difundido pelos estudos da temática, em que pese a ter significado importante espaço de atuação possível às mulheres, não significou a remissão delas, mulheres que, na perspectiva de alguns estudos, estiveram condenadas à reclusão doméstica.

Outra ambiência favorável à docência percebida no grupo de professoras estudado parece estar nas redes de sociabilidade vivenciadas por essas mulheres. A tradição patrimonialista que aos poucos se arraigou na cultura brasileira, herança portuguesa, foi mobilizada em favor de algumas dessas mulheres. Muitas delas se valeram de relações pessoais, de compadrio, para obterem indicações que endossavam a ocupação de cadeiras públicas, respaldada em aspectos que ultrapassavam questões de domínio de determinados saberes. (NASCIMENTO, 2011, p. 185).

A Igreja e as irmandades também constituíram ambiência favorável para a inserção e atuação da mulher docente, mas foi no ambiente familiar que a autora observou as condições mais favoráveis:

A família figura-se como elemento desencadeador da docência, na medida em que parte significativa das professoras pesquisadas tinha em sua família algum membro, ou muitos, atuando no magistério. [...] A ambiência familiar, que, em algum nível, associava-se às ambiências anunciadas anteriormente, parece ter, na confluência desses elementos, construído as condições que possibilitaram a docência, tornando-a mais que possível, autorizada, legitimada e percebida quase na ordem da natureza como uma herança familiar. (NASCIMENTO, 2011, p. 186)

Utilizando o conceito de herança imaterial emprestado de Giovanni Levi, Nascimento discorreu sobre a herança do magistério apreendida no ambiente familiar. Hilsdorf (1998) já assinalava essa herança do magistério ao mencionar que Mestra Benedita pertencia a uma família, cujos irmãos eram ligados de alguma forma à educação. Seguindo esse raciocínio, cabe discutir a relação entre os docentes Maria Joanna e João José Coelho e a influência (ou não) da vida privada na vida pública dos professores, principalmente na prática docente. Assinalo ainda que Analia Franco também tinha ao menos uma professora em sua família, sua mãe, e que teve direta influência em sua carreira, pois foi sua assistente em Guaratinguetá antes de tornar-se professora pública.

Vidal (2010) elencou como o segundo elemento constitutivo da experiência docente a relação intersubjetiva estabelecida com diferentes atores sociais (e escolares) nos vários níveis. No interior de diferentes espaços de sociabilidade, destacou "a interpenetração entre vida profissional e vida pessoal” (p. 720). Corroborando para essa análise, encontrei dois relatórios, um de Maria Joanna e outro de João José Coelho, escritos de forma igual com frases idênticas ${ }^{272}$, que estão a seguir. Outros relatórios do casal de professores são também muito parecidos, mas os colocados abaixo se destacaram, pois parecem cópia um do outro,

${ }^{272}$ Outros professores de Cotia tinham maneiras parecidas de elaborar as frases - talvez houvesse um relatóriomodelo que circulasse localmente -, mas também havia os relatórios que não se assemelhavam a nenhum outro. 
apesar das caligrafias diferentes - que coincidem com as letras de cada professor em seus respectivos livros de matrículas de alunos:

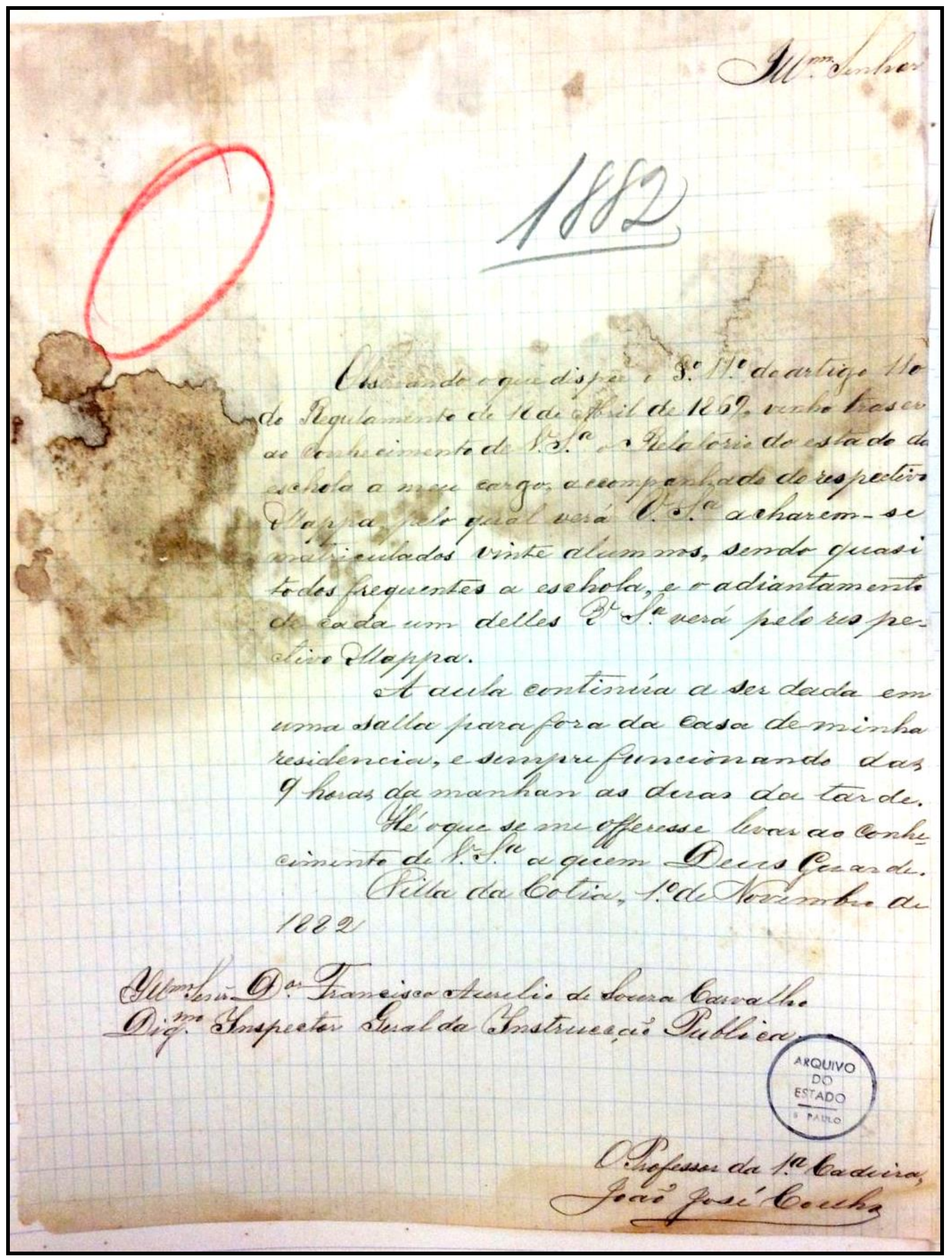

Ilustração 25 - Relatório do Prof. João José Coelho de 1 nov. 1882 (AESP, Série Instrução Pública Manuscritos, ref. CO5044). 


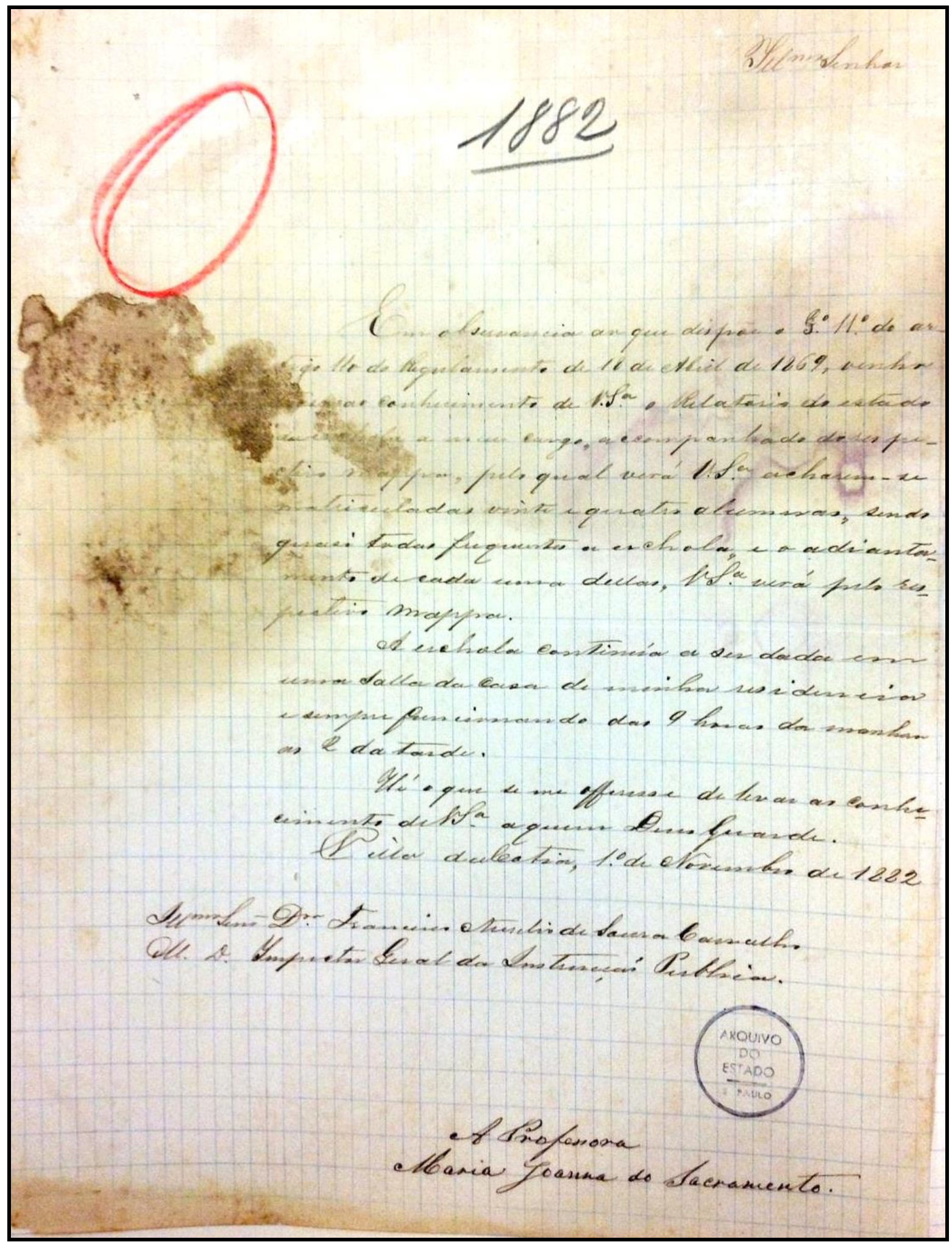

Ilustração 26 - Relatório da Prof ${ }^{a}$. Maria Joanna do Sacramento de 1 nov. 1882 (AESP, Série Instrução Pública Manuscritos, ref. CO5044). 
Segue a transcrição dos documentos anteriores:

Ilustração 25:

“Observando o que dispõe o §o 11 이 do artigo 110 do Regulamento de 18 de abril de 1869 , venho traser ao conhecimento de V.Sa o Relatório do estado da eschola a meu cargo, accompanhado do respectivo Mappa pelo qual verá V.Sa acharem-se matriculados vinte alumnos, sendo quase todos frequentes a eschola, e o adiantamento de cada um delles V.Sa verá pelo respectivo Mappa.

A aula continúa a ser dada em uma salla para fora da casa de minha residencia, e sempre funcionando das 9 horas da manhan as duas da tarde.

Hé o que se me offeresse levar ao conhecimento de V.Sa a quem Deus Guarde.

Villa da Cotia, 1ㅇ de Novembro de 1882.

Illmo. [?] Dor Francisco Aurelio de Souza Carvalho

Digmo. Inspector Geral da Instrucção Publica.

O Professor da 1a Cadeira João José Coelho"
Ilustração 26:

“Observando o que dispõe o §o 11 으 do artigo 110 do Regulamento de 18 de abril de 1869 , venho traser ao conhecimento de V.Sa o Relatório do estado da eschola a meu cargo, accompanhado do respectivo mappa pelo qual verá V.Sa acharem-se matriculadas vinte e quatro alumnas, sendo quase todas frequentes a eschola, e o adiantamento de cada uma dellas, V.Sa verá pelo respectivo mappa.

A eschola continúa a ser dada em uma salla da casa de minha residencia e sempre funcionando das 9 horas da manhan as 2 da tarde.

Hé o que se me offeresse levar ao conhecimento de V.Sa a quem Deus Guarde.

Villa da Cotia, 1ㅇ de Novembro de 1882.

Illmo. [?] Dor Francisco Aurelio de Souza Carvalho

M. D. Inspector Geral da Instrucção Publica.

A Professora

Maria Joanna do Sacramento" 
É possível, nesse caso, utilizar o conceito de lares docentes desenvolvido por Munhoz e Vidal (2014, p. 2) "para a interpretação sobre as experiências de professores com relações parentais, exercidas em espaços domésticos que se abriam ao público para a realização das aulas". No artigo, as autoras investigaram a trajetória de professores da $5^{\mathrm{a}}$ Comarca de São Paulo, posteriormente Paraná, da primeira metade do século XIX, no exercício da docência e suas redes de parentesco. Assinalaram como tais redes influenciaram no exercício da docência, tendo como fontes principais os mapas de frequência remetidos pelos professores à inspetoria da instrução pública.

Para explicar o conceito de lares docentes, as autoras enveredaram a discussão para a noção de família, remetendo-se a Giovanni Levi e Cecília Nascimento: "a noção de família não coincide com a unidade residencial, mas uma noção alargada de interesses entre grupos consanguíneos ou alianças de parentesco fictício em que o que importa são as alianças e as solidariedades" (NASCIMENTO, 2011, p. 116-117). Assim, Munhoz e Vidal (2014) apontaram que essa "senda de interpretação é profícua quando observamos relações muito similares no Brasil Oitocentista de predomínio da parentalidade na organização do tecido social” (p. 15). Analisando a feitura dos mapas de professores irmãos ou pais e filhos, interpretaram-na como um "saber-fazer compartilhado e transmitido de professor para professor ou executado por apenas um deles nos casos dos lares docentes, como uma tarefa atribuída a um dos sujeitos que trabalhavam juntos divindo socialmente o trabalho" (p. 13).

As trajetórias conectadas de João José Coelho e Maria Joanna do Sacramento no ambiente privado se projetam como exemplo de experiência de lar docente, materializado nos documentos de instrução pública elaborado por eles, que se constituem como "fragmentos de práticas escolares" (MUNHOZ; VIDAL, 2014, p. 10).

Laços de parentesco e inserção nos ofícios se entreteciam na sociedade paulista do
século XIX, particularmente para as camadas livres da população, como era o caso
de professores. Considerar o magistério como um ofício, nos incita a perquirir este
amálgama da parentalidade, urdida no interior de grupos sociais e responsável pela
constituição de modos docentes, organizando relações de saber e poder e produzindo
subjetividades, que se expressam nas práticas profissionais e permanecem como
experiência de uma determinada corporação, mesmo quando esta corporação
formalmente já não existe mais. (MUNHOZ; VIDAL, 2014, p. 15-16)

Nessa perspectiva, é possível pensar o interior da família composta por João José e Maria Joanna: a despeito de já exercerem a função antes de se unirem matrimonialmente, a herança imaterial está na prática da docência, na absorção de elementos e, ao se casarem, na 
partilha de saberes. No entanto, apesar de haver uma aproximação do fazer-se professor presentes nos relatórios, o casal difere no ato de qualificar seus alunos nas listas de matrícula.

Nesta pesquisa analiso seis livros de quatro cadeiras, sendo dois da $1^{\text {a }}$ Cadeira Masculina da Vila, dois da $1^{\text {a }}$ Cadeira Feminina da Vila, um da $2^{\text {a }}$ Cadeira Masculina da Vila e um da Cadeira de Capitão Jerônimo ${ }^{273}$, datados entre 1870 e 1885. A análise mais pormenorizada está no próximo capítulo, mas por ora, cabe trazer para este o uso ou não de qualificativos aos alunos e pais, pois se insere na discussão do lar docente do casal de professores. Em cada página dos livros havia informações obrigatórias que deveriam ser preenchidas pelos professores, segundo o Regulamento de 1869. Ao comparar as informações dadas por Maria Joanna e João José sobre os alunos e seus pais, há uma significativa diferença. A professora não atribuía qualidades aos alunos e pais, ela registrava apenas os dados necessários (os nomes) sem qualificá-los, com exceção se o pai ou a mãe houvesse falecido, aí seguiam os qualificativos "fallecido" ou "fallecida". Já o professor colocava na frente dos nomes de alguns de seus alunos a palavra "ingênuo", ou na frente do nome de algumas mães o adjetivo "escrava" ou "solteira".

Num período onde a ordem escravocrata e patriarcal imperavam, a ausência de qualificativos nos livros de Maria Joanna e a presença deles no livro de João José mostra-se como um ponto importante. Os outros dois professores das cadeiras com livros coligidos também qualificavam os alunos. Se a legislação não exigia que se qualificasse os alunos, a professora cumpria a lei, enquanto os demais acrescentavam a informação por algum motivo.

Ainda que vivessem como casal e compartilhassem saberes docentes no dia a dia, Maria Joanna não fazia questão de registrar atributos que naquele período pudessem “desqualificar" os sujeitos. Ao ler sua lista há apenas nomes de meninas e de pai e mães ou de outro responsável pela criança, algumas com sobrenome, outras sem. Não teria nenhuma filha de escrava ou mãe solteira? Seria um ato intencional e político ou apenas um esquecimento da professora que preenchia a lista somente com os dados obrigatórios? Acredito que era um ato intencional não qualificar, pois os relatórios apontam que ambos os professores compartilhavam saberes, desse modo, parece que Maria Joanna e João José discordavam quanto ao uso dessa forma de diferenciação, ao menos nos livros de matrícula.

Nos livros de Maria Joanna havia meninas cujas responsáveis eram as mães e não os pais, sendo bastante plausível que ao menos uma delas não fosse casada. Todavia, não há

\footnotetext{
${ }^{273}$ AESP, Série Instrução Pública, Livros de matrícula de alunos de Cotia. $1^{\text {a }}$ Cadeira Masculina, ref. EO2234 e EO3030; $1^{\text {a }}$ Cadeira Feminina, ref. EO2230 e EO3182; $2^{\text {a }}$ Cadeira Masculina, ref. EO2918; Cadeira de Capitão Jerônimo, ref. EO3116.
} 
como saber se a professora era contra a escravidão e a sociedade patriarcal com as fontes compiladas. Por outro lado, João José tinha ao menos dois escravos, Caetano ${ }^{274}$ e Vicencia ${ }^{275}$, era, portanto, senhor de escravo, o que ajuda a compreender o porquê qualificava seus alunos e mães como "ingênuos" e "escravas", respectivamente. Dado que complexifica a interpretação, pois, se Maria Joanna e João José eram casados, ela provavelmente se valia dos serviços desses escravos.

As carreiras docentes de Maria Joanna do Sacramento e João José Coelho têm outra característica comum: permaneceram na mesma cadeira desde que se tornaram professores públicos, aposentando-se no mesmo ano, $1885^{276}$, ela com 27 anos de magistério e ele com 25. Ambas as escolas funcionaram ininterruptamente desde suas criações, portanto, enquadram-se entre as escolas que, segundo Borges e Vidal (2014), tiveram suas permanências asseguradas, apesar de no século XIX isso não ser muito comum:

\begin{abstract}
Uma vez que a escola tinha sua permanência assegurada ou que sua existência encontrava-se de certo modo entranhada nas malhas sociais da localidade, emergiam outras questões somente possíveis nessas condições e que colocam o espaço como produtor de tensões e de estratégias, em meio a redes constituídas na relação entre escola e localidade. (BORGES; VIDAL, 2014, p. 12).
\end{abstract}

Para as autoras, "o tempo de atuação dos sujeitos envolvidos com o processo de escolarização [...] permite o estabelecimento de relações mais duradouras com o espaço de inserção da escola" (p. 12). No caso do casal de professores, importa ressaltar o fato de ambos serem de Cotia e estarem à frente das primeiras cadeiras da Vila, portanto pareciam estar numa situação bem confortável, se comparados aos outros professores locais, não havendo porquê se removerem.

Como não foram achados documentos sobre a vida pública além da docência de Maria Joanna, não posso tecer considerações se a professora "usufruiu" do fato de ser professora pública alcançando outros cargos e estabelecendo uma rede de relações significativa para sua manutenção como docente na mesma cadeira desde 1858. Entretanto, as fontes mostraram que João José Coelho adquiriu outras funções após ser professor, o que implica considerar que pudesse ter estabelecido uma rede de relações com o exercício do cargo de docente. Por outro

\footnotetext{
${ }^{274}$ Jornal Diário de São Paulo de 5 jul. 1871, p. 2: em uma relação com nomes de homens que trabalharam no conserto e manutenção da estrada Cotia à Capital, constava o escravo de J. J. Coelho chamado Caetano.

${ }^{275}$ AESP, Série Instrução Pública, livro de matrícula, ref. EO3030. Nele, Vicencia era mãe de dois alunos de João José que também moravam com ele. Nos registros de batismo dos filhos de Vicencia consta que ela era solteira e escrava de João José Coelho.

276 Jornal Correio Paulistano de 23 abr. 1885, p. 1.
} 
lado, antes de ser professor foi capitão da Guarda Municipal em $1855^{277}$, cargo de que se exonerou apenas em $1864^{278}$, fato que pode sugerir que sua inserção no exercício do magistério teve uma "ajuda" dos potentados locais. Era um homem com carreira nas áreas da segurança e da instrução públicas.

Nasceu em 1833 em Cotia ${ }^{279}$, filho de Luiz Antonio Coelho e Joaquina Maria Soares. Foi aluno de Antonio Barreto, professor da única cadeira pública de Cotia, quando ainda era Freguesia de São Paulo, pois seu nome aparece entre os alunos nos mapas de 1839, 1843, 1844,1845 e $1846^{280}$. Antonio Barreto possivelmente tenha sido sua maior influência na prática docente, e a amizade dos dois parece que seguiu ao longo dos anos, segundo as fontes. Ingressou no magistério em 1860 sendo aprovado em exame ${ }^{281}$, ano em que assumiu a Cadeira Masculina da Vila de Cotia ${ }^{282}$ permanecendo nela até 1885 , quando se aposentou. Após tornar-se docente, foi eleitor na ala do Partido Conservador (às vezes suplente de eleitor) ${ }^{283}$, agente do correio $^{284}$ e escrivão interino do juiz de paz $^{285}$ e escrivão de juiz de paz $^{286}$. Nos documentos de instrução pública posteriores à sua aposentadoria, seu nome também apareceu em atas de Conselho Municipal ao longo da década de 1890, como secretário $^{287}$. Antes de se casar com Maria Joanna, casou-se em 1853 com Guilhermina Leite de Carvalho, com quem teve cinco filhos e foram seus alunos e alunas de Maria Joanna, pois estão presentes em suas listas de matrícula. Também foi tutor de alguns meninos que moravam com ele e eram seus alunos, segundo as mesmas listas de matrícula.

Ao rastrear o fio do nome de João José Coelho na Hemeroteca Digital e eliminar os falsos cognatos, algumas notas e denúncias contra o professor de Cotia foram encontradas.

\footnotetext{
277 Jornal Correio Paulistano de 28 abr. 1855, p. 2.

278 Jornal Correio Paulistano de 8 jul. 1864, p. 1.

${ }^{279}$ Disponível em <https://familysearch.org/ark:/61903/1:1:XJPB-QXJ> Acesso em 9 jul. 2015.

${ }^{280}$ AESP, Série Instrução Pública - Manuscritos, ref. CO4915 e CO5044.

${ }^{281}$ Jornal Correio Paulistano de 23 jul. 1859, p. 1: aprovado em exame como opositor a cadeira de primeiras letras.

282 Seu nome apareceu como professor da Cadeira Masculina da Vila de Cotia em Discurso e Relatório de Presidente de Província de 1861, referente a $1860 . \quad$ Disponível em <http://brazil.crl.edu/bsd/bsd/998/000103.html>.

283 Jornal Correio Paulistano de 19 ago. 1863, p. 2: eleito eleitor - conservador.

Jornal Diário de São Paulo de 6 fev. 1867, p. 3: eleito eleitor suplente.

Jornal Correio Paulistano de 4 fev. 1869, p. 1: eleito eleitor.

Jornal Diário de São Paulo de 22 ago. 1872, p. 2: eleito eleitor suplente em Cotia.

Jornal Diário de São Paulo 9 ago. 1878, p. 1: eleito eleitor conservador (nesta lista pela primeira vez há os liberais eleitos no local).

${ }^{284}$ Jornal A Constituinte 6 dez. 1879, p. 1: nomeado agente de correio; Jornal Correio Paulistano de 6 jan. 1884, p. 1: a seu pedido, exonerado do cargo de agente do correio.

285 Ofício de 15 fev. 1861. AESP, Série Ofícios Diversos, Ofícios Diversos de Cotia, ref. CO1008.

286 Ofício de 2 nov. 1866. AESP, Série Ofícios Diversos, Ofícios Diversos de Cotia, ref. CO1008.

287 Ata de installação do Conselho Municipal da Villa de Cotia, 13 set. 1887; Ofício do presidente do Conselho Municipal de 20 jun. e 20 jul. 1890 ao Diretor de I. P. AESP, Série Instrução Pública - Manuscritos, ref. CO5044.
} 
Numa publicação assinada por "A moralidade" direcionada ao Inspetor Geral da Instrução Pública havia a acusação de que o professor exercia outros cargos e que isso era ilegal. O autor mencionou que outro artigo "contra certos abusos" já havia sido publicado e registrou os diversos cargos exercidos pelo professor da Vila de Cotia. Nem todos os cargos que o anônimo informou foram levantados por esta pesquisa, logo, cabe considerá-los como hipótese. João José além de professor, escrivão de juiz de paz (interino e efetivo) e agente do correio - já assinalados anteriormente a partir de notas oficiais de jornais e documentos oficiais assinados por ele -, segundo "A moralidade", também exercia os cargos de procurador da Câmara Municipal e agente da coletoria geral e provincial, conforme recorte do jornal que segue abaixo:

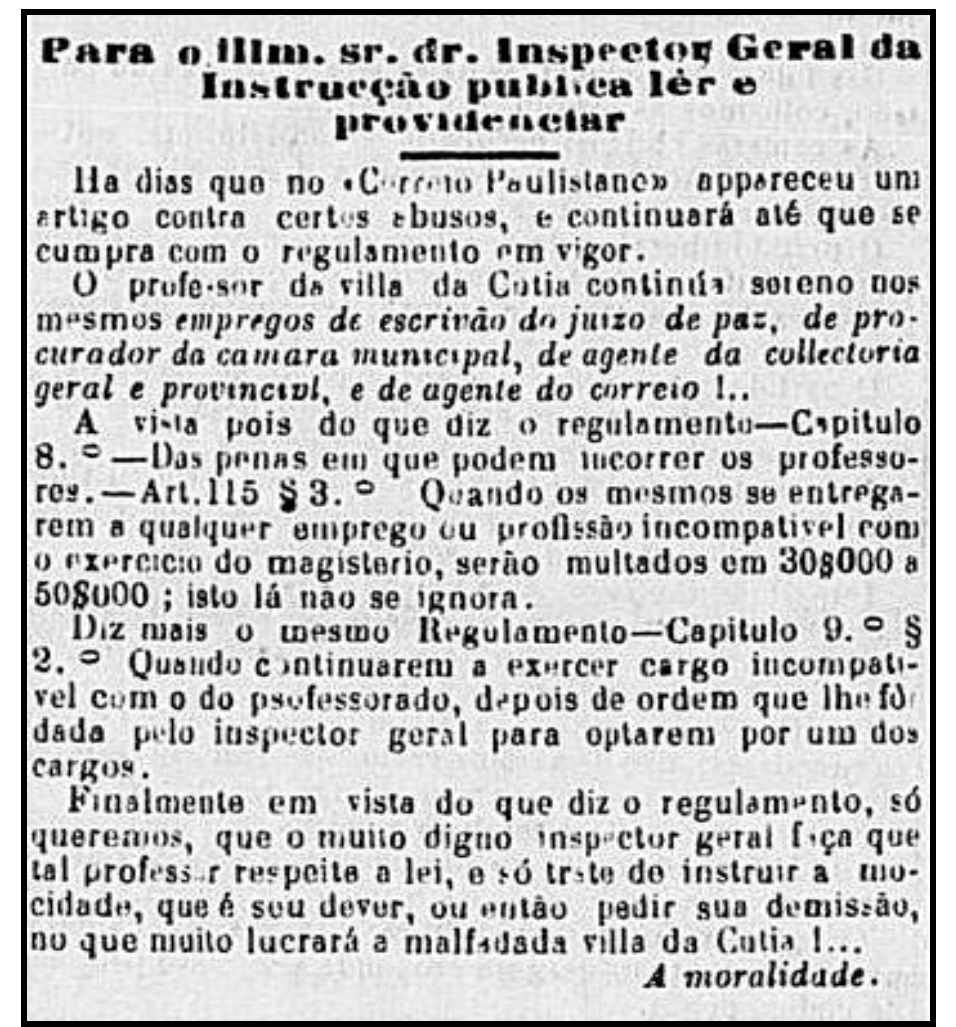

Ilustração 27 - Publicação de "A moralidade” contra João José Coelho (Fonte: Jornal Correio Paulistano de 20 dez. 1873, p. 2).

Além de denunciar, o autor também citou parte do Regulamento de 1869 que não permitia que professores públicos ocupassem outros cargos considerados "incompatíveis", sugerindo que ele pedisse demissão do cargo de professor, "no que muito lucrará a malfadada Villa da Cutia!...”. Todavia, no Regulamento não há menção de quais cargos eram considerados incompatíveis com a docência. Cabe destacar que a publicação ocorrera poucos dias após o casamento do professor João José com Maria Joanna. Talvez as denúncias e 
querelas relacionadas ao professor tenham influenciado para que o casal escolhesse fazer a cerimônia em um oratório particular.

Menos de dois meses depois dessa publicação, outra publicação envolvia o nome de João José Coelho, e, ao que tudo indica, relacionava-se à denúncia acima citada. A nota tinha como signatário “G. J. P.” e informava que em 31 de dezembro de 1873 o mesmo publicou um artigo também no Correio Paulistano no qual assinalava que "não duvidaria apresentar denuncia ou cousa que o valha contra o professor da villa da Cutia" (não localizei esta edição do jornal). Na publicação de 12 de fevereiro de 1874, informou que no dia 7 do mesmo mês entregou ao Presidente da Província uma representação contra o professor para que o regulamento fosse cumprido. Segundo o autor, "é só assim que teremos garantia, e que não se fará sómente aquillo que os régulos de aldeia determinam em sua alta prepotência e domínio nos logarejos", desejando que venha a público "os escândalos e patronatos que por ahi alem de praticam".

“G. J. P.” finalizou sua publicação informando que nunca se "curvou" desde a infância diante dos "regulos de aldeia". Esta passagem pode indicar que o autor tenha sido um dos alunos de João José Coelho e que não se curvara ao professor e às regras locais desde a época da escola. Abaixo está o recorte de jornal que contém a publicação:

\section{Ao publico}

Sempre flz timbre em cumprir aquillo que prometto.

No artigo ultimo inserto no Correio Paulistano de

31 de Drzembro do proximo passedo anno, disse que náo duvidaria opresentar denuncia ou cousa que o ra-

lha contra o professor da villa da Cutia, João José Cue-

lho; por isso me seria cousa desairosa deixor de o.fazer, visto ter publicado no mesmo Correio Pauliatano,

- qua acima levo dito.

No dia-7 di) corionte subiu ás mãos do exm. presidente da provincio a representaçào contra o dito pro-

fessor, e estou convencido de que s. exc. justiceiro como é, forá com que se cumpra a lei e o regulamento.

E' só assim, que teremos garantia, e que não se fará sómente aquillo que os regulos de aldeia deterrinam em sua alta prepotencia e doninio nos logarejos. Bem sei que os portos estāo tomodos; mas só 0 que anbiciono, é que o publico, a quem tributo muito respoito, conheca os escandalos e patronatos que por ahi além se pratican. Estou certo que contra força não ha resistencia 1 .....

Mos ainda me resta a imprensa, o tambem a gloria de ufanar-me, que nunca me curvei desde a infancia diante dos regulos de aldeia : $\theta$ aqui termino este artigo decla randu que os tempos mudam-se, eque algum dia conseguirei meus ensejos.

G. J. P.

Ilustração 28 - Publicação de “G. J. P” contra João José Coelho (Fonte: Jornal Correio Paulistano de 12 fev. 1874, p. 2). 
Infelizmente não tive acesso à representação citada na nota e não descobri qual o desdobramento do caso, mas é sabido que João José permaneceu no cargo de professor da $1^{\text {a }}$ Cadeira da Vila até 1885 e também no cargo de agente do correio até 1884, exonerando-se deste a seu pedido. Cabe relembrar que o inspetor de distrito Antonio Barreto enviou um ofício ao Inspetor Geral da Instrução Pública em 1874 porque não sabia se aceitaria o afastamento do professor Marcolino para exercer a função de adjunto de promotor na Comarca de São Roque, pois, segundo o próprio inspetor, no regulamento de 1869 os professores não podiam exercer cargo político concomitantemente ao magistério. Não há nenhum documento oficial com esse teor citando João José Coelho, apenas essas notas anônimas de jornal. Talvez o professor usufruísse de uma "blindagem" no município constituída por uma rede de relações derivada do clientelismo e de seu trânsito em outros espaços onde exercia outras funções.

Não obstante, esse episódio permite sinalizar quanto à conduta docente e à convivência entre professores e a população local, segundo apontamentos de Borges e Vidal sobre a participação dos atores locais na observação do funcionamento das escolas e da conduta moral dos professores, ou que de outras formas participavam do processo de escolarização (BORGES; VIDAL, 2014, p. 13). A pesquisa de Barra (2005) identificou alguns casos em que os sujeitos locais também denunciaram professores e participaram do processo de escolariação paulista no Oitocentos.

Levando em consideração a hipótese da "blindagem" de João José Coelho, pode-se dizer que isso não era incomum na instrução pública, como mostrou Barra (2005), analisando o caso da professora de São Sebastião, Francisca Augusta Cortez. Em 1859 a professora fez uma representação contra o inspetor local, alegando ser perseguida. Barra, ao analisar o fato, trouxe à tona que a professora era tutelada pelo Tenente Coronel local, um desafeto do inspetor de distrito (p. 70-73). Silva (2007), investigando a escolarização pernambucana, citou o caso do professor Francisco Briguel Cezar de Menezes de Nazaré do Cabo, que já havia cometido assassinato e "costumava declarar haver 20 alunos na sua aula, quando na verdade só havia oito" (p. 201), mas ele tinha proteção de Manoel do Rego Barros, um homem muito poderoso da localidade, e permanecia no cargo.

Silva (2007) ainda analisou alguns episódios em que professores públicos foram alvo de reclamações dos moradores da Província de Pernambuco, algumas ligadas à moralidade (caso do professor acusado de "deflorar" uma menina, p. 76), aos abusos de autoridade (caso do professor que pegava dinheiro dos meninos ou pedia queijos e vinhos e maltratava aqueles 
que não emprestassem ou levassem os produtos, p. 180-181), entre outros. Entretanto, a autora fez uma significativa consideração acerca das queixas contra os professores, referindose sobretudo aos professores da primeira metade do século XIX: as queixas contra os professores "tanto podiam partir dos agentes do governo, quanto das comunidades e das pessoas comuns. Mas podiam também se originar da cobiça de alguns à ocupação do cargo de professor público" (p. 187).

Caso semelhante ao de João José Coelho foi mencionado por Silva (2007), pois em 1853 um professor pernambucano ocupava muitos cargos ao mesmo tempo: vereador, juiz de paz, cuidador geral dos órfãos, advogado, suplente de subdelegado, ajudante do procurador fiscal, major da Guarda Nacional e agente consular de Sua Magestade Fidelíssima, segundo denúncia do Diretor Geral da Instrução contra Antonio da Silva Vital, professor de Rio Formoso. Para a autora:

Tamanha multiplicidade de cargos dificulta, inclusive, a minha crença na denúncia e me faz pensar na extrema vinculação existente entre aquele professor e os potentados locais, caso ele mesmo não fosse um deles. Aliás, esta é uma forte possibilidade. (SILVA, 2007, p. 191).

Ao que parece, o professor João José Coelho fazia parte como umas das peças principais das práticas políticas de Cotia, desfrutando de um status que permitia transitar em diversos setores. Seu status talvez seja também a explicação para o caso da transferência de sete alunos da cadeira do professor Marcolino ( $2^{\mathrm{a}}$ Cadeira da Vila) para a de João José Coelho em 1877, que pode significar a preferência dos alunos e/ou de seus pais a um docente em detrimento do outro, talvez pelo prestígio do professor João José Coelho, pelo tempo de serviço como docente. Todavia, a hipótese mais plausível é que a $1^{\text {a }}$ Cadeira, que sofrera uma saída de sete alunos em 1876 para a 2a Cadeira, em 1877 estava com 19 alunos matriculados, número inferior ao mínimo exigido para a permanência da cadeira, enquanto que a $2^{\text {a }}$ Cadeira estava com 30 alunos. Essa transferência pode indicar uma "parceria" entre esses sujeitos locais para não haver perigo de supressão da $1^{\mathrm{a}}$ Cadeira. Entre os pais/tutores que transferiram os meninos estavam Gregório de Almeida (negociante) e o Vigário Manoel das Dores Rocha, entretanto, a maior parte dos filhos e/ou tutelados de figuras locais importantes politicamente permaneceram na $2^{\mathrm{a}}$ Cadeira, fato que demonstra prestígio e influência do professor Marcolino, que ao que as fontes indicam, também pertencia ao núcleo de potentado local.

Outras autoras relataram a preferência dos alunos e/ou seus pais por determinados professores em detrimento de outro. Borges (2014) verificou que em 1855 o professor Candido Pardal na escola de Santa Rita, município da Corte, recebia vários meninos da 
freguesia, da região central da cidade e ainda de áreas mais afastadas, mesmo havendo mais cinco escolas públicas masculinas na mesma parte da cidade. Caso que, segundo a autora, poderia sinalizar a preferência dos pais pelo docente, mesmo que esse lecionasse longe. Essa prática foi apontada num relatório de instrução pública local de 1873, no qual afirmava que os pais matriculavam seus filhos "conforme as simpatias, as relações, ou a confiança que têm num ou n'outro professor" (Relatório da IGIPSC, anexo 7, 1873, p. 54 apud BORGES, p. 130-131). Em Paranaguá, Munhoz (2012) relacionou o alto número de discentes do professor Albino e a transferência de meninos da $1^{\text {a }}$ Cadeira para a sua com o fato de ele ser padre e pertencer a uma comunidade local muito ligada ao catolicismo, que associava a religião à qualidade de ensino (p. 122-123).

Retomando a crônica citada no início do capítulo, caso o professor que Salambô tenha se referido seja realmente João José Coelho, somando os elementos apresentados no decorrer deste subcapítulo sobre o docente, temos um sujeito muito aquém do que se preconizava como ideal de professor, ao menos com referência à lei.

No artigo 110 do Regulamento de 1869, “das obrigações dos professores", algumas das que o professor não cumpria: "trajar decentemente" dentro e fora da escola, "dar por palavras e obraz exemplos de polidez e moralidade" e não ocupar "qualquer cargo publico, ou [exercer] qualquer profissão ou industria, incompatíveis com o exercício do magistério". Os trajes do professor narrados por Salambô talvez não fossem indecentes (um julgamento anacrônico não pode ser feito, pois o que pode ser decente para nós não fosse em 1872), mas estavam aquém do que se esperava de um professor, haja vista que seu traje foi motivo de reparo do cronista. Além disso, usava uma faca em sua cinta durante suas aulas, que poderia ser um costume local, mas também foi motivo de observação de Salambô. O professor ainda gostava de falar imoralidades, contrariando a lei que exigia moral e polidez. Ensinava "os covados e alqueires", conteúdos "mais commodos para o negociante", ao invés do sistema métrico, opção que talvez estivesse locada na vida prática, já que em Cotia havia muitas terras, sitiantes e roceiros, como mencionado anteriormente.

João José Coelho transitava em vários setores da vida pública de Cotia e mesmo sendo denunciado, continuou atuando. Ao contrapor todas as fontes sobre o professor, construí a figura de um homem com poderes locais que o "blindavam", um sujeito de prestígio e pertencente ao núcleo do potentado político. O casamento com Maria Joanna proporcionou a criação de um lar docente, com algumas práticas comuns entre os dois, mas outras significativamente diferentes, e a ocorrência de aulas para meninos e meninas no mesmo lar pareceu não importar para muitos pais de meninos e meninas. Percorrer um pouco da 
trajetória desses professores mostrou-se uma eficiente forma de aproximação e compreensão das especificidades das práticas de escolarização de Cotia, um cenário de localidade caipira, geograficamente próxima à Capital paulista, mas distante do crescimento econômico que se assistia em outras regiões da Província.

\section{3. As condições materiais de trabalho}

As precárias condições de trabalho dos professores de primeiras letras da Província de São Paulo no Oitocentos foram apontadas por alguns estudos como os de Hilsdorf (1977 e 1886), Faria Filho e Vidal (2000), Giglio (2001), Barra (2005), Marcílio (2005), Gallego (2008) e Munhoz (2012). Receber baixos ordenados, lecionar em locais de trabalho longínquos e insatisfatórios para o exercício da profissão, trabalhar em sua própria residência, situação que gerava a "urgência de um espaço específico para o cumprimento do serviço público da instrução" (BARRA, 2005, p. 253), ou em lugar inadequado, ter falta de materiais e mobília apropriada e receber baixos salários eram características da docência pública paulista no século XIX. Para discutir essa temática, além de petições e relatórios do governo, opero com os relatórios semestrais que acompanhavam os mapas de frequência a partir, principalmente, da lente dos professores, já que a maior parte é da autoria deles ${ }^{288}$, e para instrumentalizar a análise ao longo deste subcapítulo, utilizo como referencial teórico os conceitos de estratégia e tática de Certeau (1994).

Vidal (2010) assinalou como um dos elementos constitutivos da experiência docente $a$ confrontação dos sujeitos com as condições materiais da existência e do trabalho docente. A condição material, o espaço escolar, tempo escolar, carreira e urgências da classe, enfim a confrontação dos sujeitos com as condições materiais da existência e do trabalho docente:

a materialidade da escola (objetos com os quais o professor lida cotidianamente como livros, cartazes, globos dentre outros), espaço escolar (sala de aula, tamanho da escola, trabalho em uma ou duas escolas), tempo escolar (da aula, da permanência diária, semanal, anual na escola, da permanência na carreira, tempo histórico), carreira (salário, projetos individuais, expectativas de ascensão, participação em associações sindicais) e urgências da classe (síntese e negociações). (VIDAL, 2010, p. 721).

\footnotetext{
288 Todos os trechos apresentados neste subcapítulo fazem parte dos relatórios dos professores disponíveis no
} AESP, Série Instrução Pública - Manuscritos de Cotia, refrência CO5044. 
Os sujeitos desta pesquisa demonstraram por meio dos relatórios quais eram essas condições. Neles, os professores apontavam como tais ausências implicavam na execução do trabalho e dessa forma utilizavam os relatórios como dispositivos de comunicação com os seus superiores, informando taticamente as ausências presentes no dia a dia docente.

Os dados referentes a 1870 foram retirados do relatório de inspetor de distrito e relatório de Presidente de Província. Nesse ano houve uma questão no processo de entrega de mapas feitos pelos professores de Cotia no período estipulado pelo governo, pois os professores não os enviaram à Inspeção Geral e foram multados em 30 mil réis, conforme o Regulamento de 1869. Em relatório do inspetor de distrito ao Inspetor Geral de 16 de agosto de 1870, foi apresentada a escusa de que os professores Maria Joanna do Sacramento e João José Coelho não fizeram os mapas porque não tinham o modelo do mapa para se basearem, e o inspetor, que também não sabia fazê-lo, no documento aproveitou para perguntar qual modelo usar.

Em outro relatório, datado de 12 de novembro de 1870, o inspetor Manoel Joaquim da Luz enviou, finalmente, os mapas de instrução e informou a quantidade de alunos matriculados e frequentes (30 matriculados e 25 frequentes na masculina e 25 matriculadas e 22 frequentes na feminina, a mesma quantidade informada no relatório de governo). Afirmou que foram feitos exames no ano anterior aos alunos das duas cadeiras e que os meninos não aprenderam o sistema métrico (conforme escreveu Salambô, teria Coelho ensinado covados e alqueires?); que os professores "goza[va]m de grande estima, são aptos para o ensino, cumpridores de seus deveres, e de conducta irreprehensivel tanto civil, como moral". Os meninos recebiam "a instrucção necessária com aproveitamento segundo a capacidade intelectual de cada um", e as meninas "a precisa instrucção, e com aproveitamento, aprendendo mais algumas prendas domésticas como bordar, [?], e costurar”.

Em 1871, foram criadas as cadeiras de Itaqui, Várzea-Grande e Sorocamirim. Como abordado no segundo capítulo, os três bairros estavam localizados em lugares distantes da Vila, e os bairros de Várzea-Grande e de Sorocamirim nos limites do município na época. Os professores tiveram dificuldade em se estabelecerem ali, tanto pela falta de recursos e casas que atendessem suas necessidades e as demandas dos alunos, quanto pela inexatidão das fronteiras.

Quando o professor Severiano José de Ramos chegou à Várzea-Grande, o inspetor Antonio Barreto informou em agosto de 1871, em ofício ao Inspetor Geral da Instrução Pública, que abriu a escola em São Roque, onde encontrou uma casa "sufficiente [?]"; solicitou saber se a cadeira permaneceria lotada em Cotia ou em São Roque e pediu 
"necessarios utensis" para a escola. A escola ao fim do caso ficou estabelecida em Cotia. Como abordado no segundo capítulo, essa história demonstra as dificuldades enfrentadas pelos professores ao se estabeleceram em regiões afastadas para trabalhar e a precária comunicação entre os professores que lecionavam em bairros afastados e os agentes da instrução pública.

Em 1872, José Custódio foi removido de Sorocamirim e registrou, em relatório de novembro deste ano, que a aula era dada das 8 às 13 horas na sacristia da capela, a qual "não oferece[ia] as commodidades necessarias para tal fim", porém os alunos tinham "boa vontade" para receberem o ensino. Ainda em 1872, o professor Marcolino Pinto de Queiroz, da Cadeira de Itaqui, informou em seus relatórios que suas aulas aconteciam das 9 às 14 horas na sacristia da Capela de Itaqui e pediu móveis e "utensis"; usava Cartilha de Pimentel para o ensino religioso. Neste ano, não foi possível ensinar o sistema métrico devido ao "pouco conhecimento dos alumnos para tal fim". Em junho de 1873, consta em seu relatório, que a aula era dada em sala de sua casa, que forneceu aos alunos a maior parte dos objetos (penas, papel, tinta e alguns livros) e que a "eschola [se encontrava] em lugar baldo de recursos".

No entanto, enquanto os professores dos bairros afastados reclamavam das condições impostas a eles, João José Coelho e Maria Joanna do Sacramento, em seus relatórios, seguiam mandando apenas informações quanto à conduta, à frequência ("quasi todos frequentes") e ao "adiantamento" dos alunos. Não havia reclamação de falta de material ou de local adequado para que ensinassem, talvez por ser uma opção não reclamar ou porque suas situações estavam em razoáveis ou boas condições.

Em 1874, com exceção dos professores das cadeiras da Vila, todos os professores reclamavam em seus relatórios da falta de móveis e "utensis" e de alguma condição imprópria para o trabalho. Marcolino, da Cadeira de Itaqui, também pediu compêndios. Citou que tinha alunos muito pobres e informou, como já mencionado, que muitos saíram da escola em 1874 porque os pais deixaram de trabalhar na Sorocabana e foram embora do local e que os pais do bairro não mandavam filhos para a escola porque achavam que os mesmos deviam trabalhar.

Severiano José de Ramos, o professor da cadeira de Várzea-Grande, citou em relatório de 1874, na contramão dos demais professores, que seus alunos moravam longe, mas os pais desejavam que frequentassem as aulas. Informou que os pais e alunos eram pobres, porém os alunos estavam "sempre limpos em seus trajes simples" e eram "morigerados", no entanto, três foram eliminados (um por abandono e dois porque os pais necessitaram de seus serviços). Apesar de elogios aos pais e aos alunos, confirmou a precariedade material de sua cadeira, pediu móveis e "utensis", ratificando que os pedia em todos os relatórios que enviava. Relatou 
em pormenores o que possuía para o exercício do cargo: “dois exemplares do Quadro Histórico, quatro [?] da Constituição e Ato Adicional, um Regulamento e 50 [?] extinctos”, e alguns móveis "emprestados", sendo que soube que outra cadeira de Cotia havia recebido materiais: "uma das cadeiras de Cotia tem recebido móveis e utensis". Apesar da distância e do isolamento dos moradores dos bairros caipiras, o professor recebeu a informação do material recebido pelo professor da vila e reclamou que também devia recebê-lo.

Corroboravam também, quanto à falta de material e à condição econômica precária dos alunos, os professores das cadeiras de Sorocamirim e de Carapicuíba. Em junho de 1874, Antonio Manoel Vieira, de Sorocamirim, informou que fornecia material a seus alunos, que eram "pobres" e o "bairro [era] remoto"; lecionava na casa "que servio o meu antecessor [José Custódio de Queiroz], cuja pertence a Antonio d'Oliveira Albuquerque, a quem estou pagando alugueis, onerando-me a qualquer [sic] concertos precisos”. O mesmo professor, em relatório de novembro, reclamou da falta de frequência dos alunos, mas apontou o quão “adiantados" estavam os frequentes. Pediu "cathecismos e compêndios próprios para o ensino, principalmente de princípios da moral, tendo muito em consideração é estado de pobreza deste bairro", reafirmando que seus alunos eram muito pobres.

Havia outras maneiras de professores informarem falta de material e o solicitarem a seus superiores, como petições aos inspetores locais. José Custódio de Queiroz, em 1874, frente à Cadeira de Carapicuíba, também ensejava que o Inspetor Geral atendesse a seu pedido de materiais. O professor fez uma petição ao inspetor de distrito, Antonio Barreto, para que móveis e "utensis" fossem remetidos à sua escola. O inspetor, por sua vez, mandou um ofício com a solicitação anexa ao Inspetor Geral em maio. Em seus relatórios, informou a falta dos tais materiais e apontou que muitos alunos não tinham mesa, assentos e objetos para receberem o ensino. Justificou que havia muitas faltas porque quase todos trabalhavam na lavoura. No canto esquerdo acima do relatório de novembro, tem uma anotação assinada pelo Inspetor Geral que está ilegível, mas com a observação legível, "tome-se nota", e abaixo a lápis tem a palavra "móveis" anotada.

Quando havia possibilidades de um local melhor para o ensino, existiam professores que não cumpriam o que determinava a inspetoria local, como o caso de, novamente, José Custódio de Queiroz. Em 1879, este professor à frente da Cadeira de Capitão Jerônimo, redigiu uma resposta ao Inspetor Geral (não foi localizado o documento enviado pelo Inspetor Geral). Datado de setembro, José Custódio explicou o que ocorreu com relação à abertura da escola para qual foi nomeado: disse que levou o papel de nomeação para que o inspetor de distrito o assinasse. Mas este não assinou e o professor tomou a iniciativa de ir ao bairro para 
ver a casa para lecionar e aproveitou para fixar o edital de abertura da escola. Abriu com 12 alunos, não na casa que o inspetor de distrito havia designado, mas em outra oferecida por um vereador e pai de cinco alunos ${ }^{289}$, que deu móveis para a sala. Já a que o inspetor ofereceu tinha "quarto esburacado", "sem feixo e sem móveis".

O professor fez mea-culpa dizendo que deveria ter informado ao inspetor da mudança, mas disse não o ter feito porque este foi a Rio Novo e voltou em 16 de agosto. Também relatou que a escola deveria ser aberta em 13 de agosto, mas ele abriu um dia antes, no dia 12, porque não tinha "na memória" a data correta. Terminou informando que a escola funcionava num lugar melhor para os alunos moradores das estradas de Una e Sorocaba. Esta resposta havia sido anteriormente enviada ao inspetor de distrito, mas o inspetor alegou, segundo o professor, que não era seu trabalho fazer isso e que o professor deveria enviar diretamente ao Inspetor Geral, devolvendo o documento a José Custódio de Queiroz.

Os relatórios que acompanhavam os mapas de frequência feitos no ano de 1880 não tinham muita alteração: as escolas dos bairros continuavam a não ter suas demandas materiais atendidas. Nesse ano ocorreu um episódio curioso ligado à Cadeira de Carapicuíba, na qual lecionava João Rodrigues de Jesus. Conforme relatório do inspetor Benedicto José d'Oliveira para Inspetor Geral com data de 3 de fevereiro, o professor mudou a escola para uma "casa do Alambique, imprópria para eschola pública, ficando aquém da Aldea, logar onde já funcionou o seu antecessor e onde o mesmo lecionou até dezembro, isto a seu bello prazer, sem sciencia minha", que a casa ficava longe dos alunos e em "local incomodo", e também que o professor deixava de dar aulas em dias úteis para caçar. Ainda, segundo o inspetor, o professor o respondeu que ele tinha direito de dar aula às quintas-feiras para faltar em qualquer dia útil e que deu aula na "casa do Alambique"290, mas que não o fazia mais. Porém, de acordo com o inspetor, o professor continuava lecionando nesse local. $\mathrm{O}$ inspetor perguntou ao Inspetor Geral se o professor podia fazer a mudança sem a ciência dele e se podia trocar as quintasfeiras com outros dias úteis. Há uma resposta no canto superior esquerdo, com letras um pouco apagadas e borradas, mas ao que tudo indica, o Inspetor Geral deu razão ao professor. Esse caso, entre outras coisas, sugere a participação de outras pessoas na fiscalização da escola, pois informaram ao inspetor o que estava acontecendo.

\footnotetext{
${ }^{289}$ O vereador era Jesuíno Pereira Leite, já mencionado no capítulo anterior, matriculou outro filho além dos cinco mencionados pelo professor nesse relatório, totalizando seis nessa cadeira.

${ }^{290}$ Não há mais informações se a casa tinha bebida ou não, apenas aparece no documento como "casa do Alambique" e que era "local incomodo" para o ensino. Todavia, sabe-se que havia grande produção de aguardente em Cotia.
} 
Cotia não possuía nenhum local que estivesse diretamente ligado à educação pública, com exceção das casas e capelas onde os professores lecionavam. Em 1881, segundo relatório de 24 de julho do inspetor de distrito ao Inspetor Geral em resposta à circular de 27 de junho que solicitava algumas informações sobre a educação local, afirmou, entre outras coisas, que não havia no distrito bibliotecas, museus ou gabinetes de leituras. Indício de que a cultura letrada era incipiente na localidade.

O professor José Custódio de Queiroz, da Cadeira de Capitão Jerônimo, em seus relatórios de 1881 prosseguiu pedindo móveis e "utensis", além de exemplares de Catecismos da Diocese para o ensino religioso (a partir desse ano é comum nos relatórios constar o requerimento desses exemplares. Os professores continuavam ensinando a doutrina religiosa pela Cartilha de Pimentel e justificavam que a utilizavam, "visto não ter Cathecismos da Diocese"). Também solicitou "utensis" o professor Manoel de Moraes Pinto, da Cadeira de Várzea-Grande, assim como João Rodrigues de Jesus, de Carapicuíba, que relatou ter se “esforçado" em ensinar "nos 5 méthodos de ensino do Dr. Freire que me forão fornecido por V. Exa., porém como por aqui não há mais compêndios, luto com grande difficuldade", deixando evidente a situação de adversidade para o exercício do cargo. Apesar da dificuldade dos alunos na escrita, esse professor conseguiu uma mesa para eles escreverem vinda de São Paulo. Não tinha "Cathechismo", então não se "adiantaram na doutrina cristã". "Sobre aritmética o mesmo acontece pois há grande falta de pedras", "as pedras e o Cathechismo são de uma necessidade espantoza para o adiantemento dos alumnos". As informações dadas pelos professores assinalam que a precariedade material era imensa.

Até a $2^{\text {a }}$ Cadeira Masculina da Vila tinha demandas materiais das mais básicas. $O$ professor Marcolino Pinto de Queiroz em seus relatórios disse estar "feliz" porque os alunos estavam aprendendo, pois havia poucas faltas e os pais estavam mandando os filhos para a escola. Apesar disso, lamentava: "lutamos com a acanhadez do lugar para a escola e com a falta de móveis e de tudo que é necessário para a sustentação do ensino". Ou, que do pouco de móveis que tinha, "continua a ser oferecido à custa da exiguidade de nosso ordenado, attento à pobreza dos alumnos que frequentão a escola"; "do nosso limitado ordenado pagamos o aluguel" (de onde morava e funcionava a escola) e outros materiais. Pediu ajuda ao Inspetor Geral e informou que o ensino religioso era dado pelo Catecismo da Diocese e para os que não o possuía, o professor o dava oralmente, repetindo aos alunos. Então pediu "meia dúzia deles".

Essas demandas continuavam a ser repetidas nos relatórios de 1882 de José Custódio (Capitão Jerônimo) e Marcolino ( $2^{\mathrm{a}}$ Cadeira Masculina da Vila). Este, para explicar o 
insatisfatório "desenvolvimento intelectual dos alumnos", informou que tinha "empregado os meios possíveis a alcançar tal desideratum, e se não o consigo, outras são as causas, que não a falta de cumprimento de meus deveres". Apontou que sentia

\begin{abstract}
a necessidade de uma pena capaz de corrigir, nas pessoas dos pais e tutores, a falta dos alumnos, e que ao mesmo tempo se desse aos mestres meios mais positivos para chamassem à boa ordem os seus alumnos, quando para esse fim tinhão esgotado os castigos Moraes, desculpando-se no entanto aos que, por falta de recursos, deixam de ser assíduos, o que alias considero em minha escola uma das principais causas de infrequencia. (Relatório de Marcolino Pinto de Queiroz ao Inspetor Geral da Instrução Pública de 31 out. 1882, AESP, Série Instrução Pública Manuscritos, ref. CO5044, grifos meus).
\end{abstract}

Do mesmo modo o professor João Maria Thomaz da Cadeira de Sorocamirim, em 1882, solicitava móveis e "utensis". Já em 1883, o professor da Escola da Estação São João na Estrada Sorocabana, Joaquim Chrispim de Oliveira, solicitou o regulamento da instrução pública "para eu saber dirigir melhor a minha Escola".

Em 1884, a então professora da $2^{a}$ Cadeira Feminina da Vila, Catharina Etelvina Pedroso requereu móveis e "utensis". O inspetor literário, confirmando o pedido da professora, enviou uma petição ao Inspetor Geral, solicitando tais materiais. José Custódio, da Cadeira de Lavapés, informou que lecionava na casa do cidadão João José da Luz e também pediu móveis e "utensis" para, segundo ele, "poder lecionar como desejo".

Sugerindo falta de material para o exercício da inspeção, em março de 1884, o inspetor literário Benedito José de Oliveira informou que os alunos das escolas do município fizeram exames, mas que deixou "de tomar por termo os exames por não haver livro para tal fim”. Há uma resposta do Inspetor Geral no canto esquerdo ao alto, mas está ilegível. Contraditoriamente, no Relatório de Presidente de Província para o ano de 1885, Cotia não está entre os municípios com cadeiras que solicitaram móveis, apesar de os relatórios dos professores informarem as ausências. A hipótese desta pesquisa é que por ter ficado sem inspetor literário por um tempo, tenha acontecido uma falta de comunicação.

Apesar dos primeiros professores das primeiras cadeiras da Vila, Maria Joanna e João José Coelho não informarem a falta de materiais em seus relatórios, os que vieram posteriormente à suas aposentadorias o fizeram. Em seus primeiros relatórios, Analia Franco e José Custódio de Queiroz apontavam a falta de móveis e "utensis". Analia Franco afirmou em documento de novembro que ofereceu às alunas "todos os livros e materiais indispensáveis, visto serem os paes paupérrimos". Nesse documento, no canto ao alto, assinado pelo Inspetor 
Geral, consta: “tomadas as notas necessárias, archiva-se". Anotações como essas são recorrentes nos cantos de grande parte dos relatórios coligidos.

A professora Catharina Pedroso, em 1885, continuava a pedir materiais para sua cadeira (móveis, "utensis" e livros). Em novembro, ao finalizar seu relatório após tais pedidos, apontou a "lacuna" [...] "que espero da intelligente e activa direcção de V. Sa.". Suas solicitações continuaram no ano de 1886.

Com relação ao espaço, é interessante pensar no indivíduo professor que não era da localidade e chegou para lecionar e teve de estruturar sua vida longe de seu lugar de origem e das pessoas que conhecia. No caso de Cotia, alguns lugares eram isolados. Os professores das cadeiras dos bairros comentavam em seus relatórios das dificuldades de se estabelecerem, como Severiano José de Ramos em Várzea-Grande, que, logo que chegou, preferiu abrir escola na área de Várzea-Grande pertencente a São Roque, "por melhor comodidade" e "por ter ali achado casa sufficiente", ou Antonio Manoel Vieira em Sorocamirim, cujo bairro qualificou como "remoto". Outro dado verificado foi o desconforto (LIMA, 2014), que estava também ligado às condições precárias para o exercício da docência. Como mencionado, por pouco tempo a maioria dos professores ficou frente às mesmas cadeiras, preferindo se remover para outros lugares, como Analia Franco, que lecionou por pouco mais de dois anos em Cotia, ou outros professores dos bairros que logo se removeram, especialmente para outros municípios.

Mesmo os que já moravam em Cotia, como o caso do professor José Custódio de Queiroz, passavam por dificuldades de acomodação. Após ter assumido a Cadeira de Capitão Jerônimo e constatado as precárias condições da casa que o inspetor havia indicado para o exercício do cargo, o professor mudou de endereço e abriu a escola em outra casa. Esse episódio confirmou a ocorrência de sujeitos professores que não atuaram segundo o protocolo no processo de escolarização, não cumprindo algumas determinações e agindo conforme o que julgasse melhor.

Sem desconsiderar de que se trata de uma perspectiva apenas, ainda assim pode-se afirmar que os documentos descreveram a situação em que se encontravam muitos professores para poderem exercer a função no Oitocentos na Província de São Paulo e também no Brasil. No caso de Cotia, o contexto de pobreza local acentuada parecia evidenciar ainda mais tais condições. Diante de muitas informações presentes nos relatórios, este trabalho interpretou-as na perspectiva certeauniana de táticas em contrapartida à estratégia do governo em exigir os relatórios que acompanhavam os mapas de frequência. Para reverter a situação imposta pelo estado vigente, inspetores e, sobretudo, professores denunciavam as 
condições precárias em que trabalhavam e solicitavam medidas. Dessa maneira, o documento obrigatório passou a exercer uma função tática aos professores.

A maioria dos professores pedia móveis, "utensis", livros etc., argumentava sobre a pobreza da população local, e no final de cada relatório, exaltava a "bondade", a "generosidade" e a "inteligência" do Inspetor Geral, o que parece também ser uma ação tática de alguns deles, ainda que não fosse incomum no Oitocentos despedir-se dirigindo loas a seu superior. Do mesmo modo pode-se considerar que taticamente o professor Severiano Ramos citou, em 1874, que soube que outro professor de Cotia recebeu móveis e "utensis" e que, então, lhe cabia o mesmo recebimento. Além de outras táticas relatadas: requerimento de espaço escolar adequado feito por vários professores; o professor João Rodrigues, de Carapicuíba, que informou a compra de uma mesa com seu ordenado; o professor José Custódio que abriu a escola do Bairro de Capitão Jerônimo em outra casa que não a indicada pelo inspetor.

A construção da docência e o processo de escolarização em Cotia estiveram intercalados à falta de condições materiais para o exercício da função (como mencionado, situação comum na maior parte da Província e mesmo no Brasil), e se agravavam com as condições precárias da sociedade local, imersa no trabalho rural baseado em pequenos roçados - trabalho no qual muitos pais inseriam seus filhos ainda crianças, também muito comum na época na maior parte do Brasil - e na pobreza dos moradores.

Apesar das táticas empreendidas, no período de 15 anos de escolarização, segundo os relatórios analisados, as demandas dos professores permaneceram quase intocadas: falta de móveis, "utensis", materiais como livros para leitura e catecismo, compêndios, entre outros, além da ausência de local adequado para o ensino. Condições materiais precárias que implicavam na execução do trabalho e, consequentemente, nos resultados da aprendizagem dos alunos.

Ao focar o processo de escolarização no dia a dia de seu fazer-se a partir de diversas fontes, o presente capítulo procurou identificar alguns de seus sujeitos e esboçar parte de suas trajetórias. A análise das fontes permitiu apreender os fazeres ordinários de professores até então anônimos e mesmo de professores consagrados durante períodos desconhecidos por uma historiografia da educação focada em figuras de maior visibilidade, como Analia Franco.

Cabe, por fim, no capítulo a seguir, discutir quem eram os destinatários dessa escolarização, os alunos. 
CAPÍtulo 4. A ALMA Do POVO, USANÇAS E COSTUMES: OS ALUNOS, AS INFLUÊNCIAS DO COTIDIANO LOCAL NA VIDA ESCOLAR E A COMPOSIÇÃO DAS TURMAS

\section{A procissão}

I

Oh! Noites de S. João, na minha terra! A alma do povo, uzanças e costumes, Tudo, em taes noites de festejo, encerra Assumptos para encher volumes e volumes!

Não é preciso recorrer á França

E consultar os livros de algum mestre:

A poesia aqui brota com pujança,

Cheirosa como a flor de uma planta sylvestre!

O poeta do sertão, o habil violeiro,

Canta e improvisa, lepido e casquilho;

Entretanto, esse rude brasileiro

Não traduz o francez, nem conhece Castilho ${ }^{291}$ !

Ó vós, que, encarcerados numa escola,

Fazeis questão de normas e systemas,

Vinde saber do tocador de viola

Em que moldes vasou suas canções e poemas! [...] (CEPELLOS, 1908a, p. 95-96, nota minha).

\section{Lição das cousas}

Sentemo-nos aqui, sob o docel frondente Desta velha figueira. $\mathrm{O}$ sol do meio dia Bafeja, lá por cima, o meu halito quente: Aqui em baixo, porém, corre uma aragem fria

Para reconfortar o espírito da gente,

Não ha como beber, na floresta sadia,

Esse alento vital que, poderosamente,

Circula pelo tronco e veste a ramaria.

Longe das ambições e do homem inimigo,

É assim, na solidão, em serena humildade,

Que eu invoco o meu Deus e converso commigo.

E, na folha que cai de uma fronde sylvestre,

Vejo resplandecer mais luz e mais verdade

291 Antonio Feliciano de Castilho (1800-1875) foi um escritor português e inventor do Método Castilho de leitura. 
Que num livro de sciencia ou na bocca de um mestre! (CEPELLOS, 1908b, $\mathrm{s} / \mathrm{n})$.

O poeta Manoel Baptista Cepellos, já mencionado nesta dissertação, foi aluno de João José Coelho em 1880 na $1^{\text {a }}$ Cadeira Masculina da Vila ${ }^{292}$, de Marcolino de Queiroz em 1881 e 1882 na $2^{\text {a }}$ Cadeira da Vila ${ }^{293}$ e de seu pai, João Baptista Cepellos, na Cadeira de VárzeaGrande $^{294}$. Os versos do poeta acima citados instigam o leitor a pensar que a vida fora da escola poderia ensinar mais e melhor do que dentro dela, presa a "normas e systemas" presentes em livros ou ensinados por um professor. Segundo ele, os violeiros faziam canções e poemas muito bem sem precisar recorrer a livros e o momento de solidão embaixo de uma árvore e a observação do comportamento da natureza traziam "mais luz e mais verdade que num livro de sciencia ou na bocca de um mestre".

Tendo esses versos como disparadores da discussão, inicio este capítulo, no qual discorro sobre as características dos alunos e as influências do cotidiano local na vida escolar segundo os professores e inspetores, a partir especialmente de relatórios que acompanhavam os mapas ${ }^{295}$, mas antes apresento o número de alunos cotianos de acordo com os mesmos relatórios, com livros de matrícula e com fontes estatísticas de governo. Na segunda parte apresento a composição de quatro turmas, as das cadeiras da Vila $\left(1^{\mathrm{a}}\right.$ e $2^{\mathrm{a}}$ Masculinas e $1^{\mathrm{a}}$ Feminina) e a da Cadeira do Bairro de Capitão Jerônimo, a partir de dados presentes nos livros de matrícula, entrecruzados a outras fontes que trouxeram mais informações sobre as pessoas ali registradas. São elas: registros de batismo, lista de vereadores da época, Almanak da Província de São Paulo (1873) etc. Com o expediente, pretendi coligir elementos para análise da composição social dos alunos das cadeiras, e consequentemente da sociedade em questão, sobretudo atentando para a presença de filhos de escravos nas escolas.

Em 1872, foram levantados os dados do recenseamento feito pelo governo imperial e nele constavam informações sobre a população de acordo com a instrução e a população em idade escolar (de seis a 15 anos). Quanto às dificuldades na feitura do Censo de 1872 e, consequentemente, dos cuidados ao utilizar esses dados como fontes, já discorri no primeiro capítulo, mas sobre os dados escolares, cabem algumas considerações. Segundo Paiva et.al. (2012), quando da coleta de dados, a informação sobre a frequência escolar de crianças no

\footnotetext{
292 AESP, Série Instrução Pública - Manuscritos, ref. EO3030.

293 AESP, Série Instrução Pública - Manuscritos, ref. EO2918.

294 Segundo biografos, Manoel Baptista Cepellos teve o pai como decurião quando estudou com outros professores, e quando o pai lecionou na Cadeira de Várzea-Grande, foi seu aluno e depois seu auxiliar. Cf. Nobrega (1937) e Germano (1962).

295 Para não repetir exaustivamente a mesma informação nas notas ao longo deste capítulo, assinalo que todos os relatórios de professores e inspetores utilizados aqui como fonte estão dispóníveis no AESP, Série Instrução Pública - Manuscritos, Ofícios de Instrução Pública de Cotia e outros municípios, ref. CO5044.
} 
Censo de 1872 deveria ser incluída no campo dedicado a observações (p. 21). Os autores assinalam que a informação sobre frequência escolar informada pela Diretoria Geral de Estatística (DGE) e pela soma dos dados recolhidos nas paróquias:

[...] apresenta números muito discrepantes entre as duas formas de mensuração. Segundo a DGE, havia 320,7 mil crianças nas escolas, ao passo que pela soma das paróquias esse número era de 251,7 mil. Os motivos pelos quais levaram a DGE divulgar um numero $27,4 \%$ maior que o apurado nas sub-unidades ainda devem ser investigados. Deve-se considerar, contudo, que esta questão era objeto de muita atenção por parte do governo, uma vez que a necessidade de números para se promover políticas públicas de educação era uma das justificativas explicitadas para se fazer censos demográficos. (PAIVA et al., 2012, p. 25).

A DGE foi criada em 1871 pelo governo imperial e, segundo Natália Gil (2009), "ainda que sua principal tarefa fosse a execução dos censos decenais, mencionava-se em seu regulamento explicitamente sua responsabilidade para com as estatísticas da instrução" (p. 348). Os dados eram entregues esporadicamente pelas províncias, mas estas não eram obrigadas a remetê-los (a remessa obrigatória dos dados deu-se apenas em 1908). De acordo com a autora,

\footnotetext{
Vale considerar, porém, que, a despeito da reclamação acerca da falta de colaboração das/dos províncias/estados, existisse, provavelmente, ao menos em alguns casos, a insuficiência de condições das administrações locais em atender aos pedidos da DGE. Ora, é de se supor que a escassez de funcionários se fizesse sentir nas repartições regionais, de modo a tornar difícil o preenchimento desse volume de requisições em meio a outras tantas tarefas que certamente lhes estavam atribuídas. Além disso, agravava a situação o fato de não serem obrigatórias as respostas que só seriam, portanto, dadas quando os questionários deparassem, nos órgãos regionais, com algum funcionário de boa vontade ou que, por acaso, considerasse pessoalmente importantes os trabalhos estatísticos (GIL, 2009, p. 349).
}

Cabe ainda relembrar, como mencionado no primeiro capítulo, que Cotia foi uma das paróquias que não entregou os dados do Censo na data preestabelecida, entregando apenas em 1874, porém, para poder efetuar a análise a seguir, trabalho com a hipótese de que os recenseadores locais usaram dados de 1872 referentes à instrução, pois os números de 1874 estão bem acima do informado no Censo e não foi possível reunir fontes de 1873. Assim, salvaguardando as dificuldades na contagem e na elaboração do Censo e das estatísticas relacionadas à educação, os dados sobre população de Cotia computavam 5.024 habitantes, sendo 4.519 livres e 505 escravos (estes, todos analfabetos). Sobre os livres, o Censo apontou os seguintes dados: 


\begin{tabular}{|l|c|c|}
\hline \multicolumn{3}{|c|}{ População de Cotia de acordo com a instrução - 1872 } \\
\hline & Homens & Mulheres \\
\hline Sabem ler & 162 & 101 \\
\hline Analfabetos & 2.124 & 2.132 \\
\hline
\end{tabular}

Ilustração 29 - Quadro da população de Cotia de acordo com a instrução - 1872 (Fonte: IBGE, Censo de 1872).

\begin{tabular}{|l|c|c|}
\hline \multicolumn{2}{|c|}{ População escolar de Cotia - de 6 a 15 anos - 1872} \\
\hline & Homens & Mulheres \\
\hline Frequentam escolas & 97 & 2.771 (271?) \\
\hline Não frequentam & 207 & $2.846(346 ?)$ \\
\hline Total & 304 & \\
\hline
\end{tabular}

Ilustração 30 - Quadro da população escolar de Cotia - de 6 a 15 anos - 1872 (Fonte: IBGE, Censo de 1872).

Quando entrei em contato com esse documento (disponível no site do IBGE - é o documento original da época, digitalizado), observei que o número de meninas de Cotia que não frequentavam a escola estava muito discrepante em comparação aos meninos: 207 meninos e 2.771 meninas não frequentavam as escolas. Também observei que número total de mulheres habitantes de Cotia era menor do que o número das meninas que não frequentavam a escola. Portanto, pode-se concluir que o dado estava errado e esse erro também alterou o número total da Província de São Paulo e, consequentemente, do Brasil. Possivelmente o número levantado pelos recenseadores de meninas que não frequentavam a escola foi 271 , somando, assim, um total de 346 meninas que habitavam Cotia em 1872.

Cotia só teve uma cadeira feminina e três masculinas por um bom tempo (de 1838 a 1870), apesar de possuir muitas meninas em idade escolar (segundo o Censo de 1872, 304 meninos e 346 ? meninas). Ao final do ano de 1872, as fontes de instrução pública informam que das cinco escolas masculinas existentes, haviam 76 meninos matriculados em quatro (faltando saber o número de alunos da cadeira de Várzea-Grande, pois desta não foi localizada nenhuma fonte com o número de alunos) e 22 na única escola feminina. Todavia, como colocado no quadro acima, o Censo de 1872 informou que 75 meninas frequentavam escola em Cotia, portanto, segundo as fontes, é possível considerar que mais de $70 \%$ das meninas frequentavam escolas particulares ou outros ambientes de letramento. Como asseveraram Faria Filho e Vidal (2000), discorrendo sobre as escolas entre os séculos XVIII e XIX: 
[...] não podemos desconsiderar que apenas aqueles, ou aquelas, que frequentavam uma escola tinham acesso às primeiras letras. Pelo contrário, têm-se indícios de que a rede de escolarização doméstica, ou seja, do ensino e da aprendizagem da leitura, da escrita e do cálculo, mas sobretudo daquela primeira, atendia um número de pessoas bem superior à rede pública. Essas escolas, às vezes chamadas de particulares, outras vezes de domésticas, ao que tudo indica, superavam em número, até bem avançado o século XIX, àquelas escolas cujos professores mantinham um vínculo direto com o Estado ${ }^{296}$. (FARIA FILHO; VIDAL, 2000, p. 21, nota dos autores).

A presente pesquisa não conseguiu dados de quais seriam essas escolas e professoras, mas importa sinalizar que a investição da instrução particular não se constituiu um dos objetivos deste trabalho.

Apesar da maoria das meninas que estudavam estarem em escolas particulares, 271 meninas ainda estavam fora da escola. Essa questão possivelmente se relaciona com o fato de famílias optarem por não enviar suas meninas às escolas por razões econômicas (participarem das atividades domésticas); morais (para evitar que percorressem o caminho ou que convivessem com outras pessoas na casa da professora, embora Maria Joanna ainda não houvesse se casado em 1872); dentre outras, como mencionado no capítulo anterior. E também pela cultura escrita não constituir uma necessidade para a vida cotidiana.

O recenseamento posterior datado de 1886 e feito pelo governo provincial, também traz dados referentes à instrução. Dos 7.517 habitantes de Cotia, dos quais 144 eram escravos, um número bem maior do que o apresentado em 1872 assinalava que a população estava se instruindo. Abaixo seguem os dados presentes nesse documento:

\begin{tabular}{|c|c|c|c|}
\hline \multicolumn{4}{|c|}{ População de Cotia segundo o grau de instrução - 1886} \\
\hline Primário & Secundário & Superior & Total \\
\hline 1.086 & 4 & 3 & 1.093 \\
\hline
\end{tabular}

Ilustração 31 - Quadro da população segundo o grau de instrução - 1886 (Fonte: BASSANEZI. et.al., 1998, p. $41)$.

São dados que precisam de muita cautela para ser comparados, pois em 1872 o critério usado era se a pessoa sabia ler, enquanto que em 1886 era o grau de instrução, além disso, houve inconsistência nos números coligidos pelos recenseamentos. No entanto, mesmo que tenham falhas, os dados ajudam a visualizar como o processo de escolarização de Cotia

\footnotetext{
${ }^{296}$ Nota dos autores: “A experiência meneira, que não parece ser única, bem o demonstra. Em 1827, Bernardo Pereira de Vasconcelos sustentava que, em Minas Gerais, havia 23 escolas públicas e 170 escolas privadas”.
} 
iniciado principalmente com a expansão do número de escolas públicas primárias a partir da década de 1870 foi responsável pela alteração do quadro local.

Para trazer mais dados numéricos do resultado do processo de escolarização, abaixo segue um quadro com a quantidade de alunos matriculados referente a todos os anos do recorte desta pesquisa (1870-1885): 


\begin{tabular}{|c|c|c|c|c|c|c|c|c|c|c|c|c|c|c|c|c|}
\hline \multicolumn{17}{|c|}{ Número de alunas/os matriculadas/os entre 1870 e 1885 nas cadeiras públicas de Cotia } \\
\hline Cadeiras Públicas de Cotia & 1870 & 1871 & 1872 & 1873 & 1874 & 1875 & 1876 & 1877 & 1878 & 1879 & 1880 & 1881 & 1882 & 1883 & 1884 & 1885 \\
\hline 19 Masculina da Vila & 30 & 24 & 24 & 32 & 23 & 29 & 24 & 19 & 34 & 21 & 20 & 20 & 20 & 20 & 22 & 22 \\
\hline 1a Feminina da Vila & 25 & 25 & 22 & 32 & 23 & 29 & 30 & 21 & 20 & 20 & 21 & 21 & 21 & 23 & 27 & 20 \\
\hline $\begin{array}{l}\text { Bairro de Itaqui/ Bairro de } \\
\text { Capitão Jerônimo }\end{array}$ & & 17 & 20 & 28 & 25 & $?$ & & & & 23 & 29 & 45 & 40 & 41 & 24 & 30 \\
\hline Bairro de Várzea-Grande & & $?^{297}$ & $?$ & $?$ & 28 & $?$ & $?$ & & & & 10 & 16 & 15 & $?$ & $?$ & 20 \\
\hline Bairro de Sorocamirim 298 & & $?$ & 22 & $?$ & 33 & $?$ & $?$ & & & & 0 & $?$ & 22 & $?$ & $?$ & 28 \\
\hline Bairro de Carapicuíba & & & 13 & $?$ & 26 & $?$ & $?$ & $?$ & ? & 17 & $?$ & 18 & & & & \\
\hline 2ª Masculina da Vila & & & & & & 14 & 31 & 30 & 22 & 23 & 24 & 35 & 33 & $?$ & $?$ & 26 \\
\hline Bairro de São João & & & & & & & & & & & & & 16 & 28 & $?$ & 30 \\
\hline 2a Feminina da Vila & & & & & & & & & & & & & & & 22 & 28 \\
\hline Bairro de Lavapés & & & & & & & & & & & & & & & 16 & 20 \\
\hline Total & 55 & $66 *$ & $101 *$ & $92^{*}$ & 158 & $72 *$ & $85^{*}$ & $70^{*}$ & $76^{*}$ & 101 & $104 *$ & $155^{*}$ & 167 & $112^{*}$ & 111* & 224 \\
\hline
\end{tabular}

Ilustração 32 - Quadro do número de alunas/os matriculadas/os entre 1870 e 1885 nas cadeiras públicas de Cotia (Fontes: Relatórios de governo referentes a 1870, 1871, 1879, 1880 e 1885, livros de

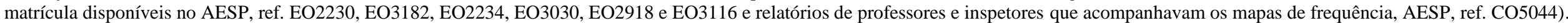

$297 ?$ = Não obtive fontes que informassem o número de alunos matriculados.

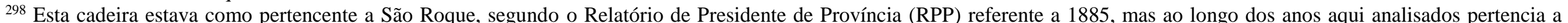

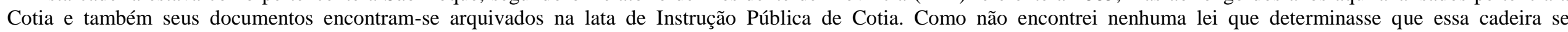
estabelecesse em São Roque, apenas assim consta no RPP, a incluí no quadro de cadeiras de Cotia.

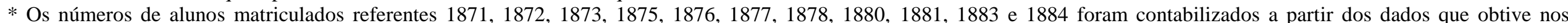
documentos e faltam informações de uma ou mais cadeiras em cada ano. Portanto, o número informado no quadro está abaixo do número de alunos matriculados. 
O quadro apresenta números referentes apenas a alunos matriculados, não informando os frequentes. As fontes em que constam os números de alunos frequentes são ainda em menor número, já que algumas delas apenas informavam dados de alunos matriculados. Em 1870, todas as cadeiras estavam localizadas na Vila e em 1885 observa-se que um pouco mais que a metade dos alunos (57\%) estudava em escolas de bairro, enquanto que $43 \%$ estudavam nas escolas da Vila. Houve um processo de interiorização das cadeiras públicas ao longo de 15 anos.

Para chegar a esse quadro usei três tipos de documentos: relatórios de governo, livros de matrícula e relatórios de professores e inspetores que acompanhavam os mapas de frequência. Quando houve dados diferentes referentes ao mesmo ano e à mesma cadeira, usei os números dos relatórios de governo, na ausência deles, os relatórios de professores e inspetores (como eram semestrais, optei por usar os relatórios de junho - que coligi em maior quantidade - e na ausência deles, os de novembro). Como terceira opção, caso não tivesse dados de relatórios de governo ou de professores e inspetores, utilizei o número de alunos matriculados nas listas de matrícula (no caso, apenas de quatro cadeiras: $1^{\mathrm{a}}$ e $2^{\mathrm{a}}$ Masculinas da Vila, $1^{\text {a }}$ Feminina da Vila e Cadeira de Capitão Jerônimo).

O Censo de 1872 informou que 97 meninos frequentavam escolas. Infelizmente para esse ano faltam informações no quadro no que se refere aos alunos da Cadeira de Várzea Grande. No entanto, diferentemente do número de meninas que frequentavam escola, pode-se avaliar que o número do Censo esteja próximo ao do quadro, que indicou 79 alunos matriculados, com exceção de uma turma, portanto, ou não havia escola particular para meninos ou se havia, atendia a um número muito reduzido de alunos.

Lamentavelmente, o recenseamento provincial não informou a população que frequentava a escola em 1886, apenas que a população entre seis e 15 anos totalizava 1901 meninos e meninas, portanto não há com comparar os dados como fiz referente a 1872. De qualquer forma, a contar pelo número de meninos e meninas nessa faixa etária, percebe-se ainda a grande defasagem de atendidos pela instrução pública em meados de 1880 .

Quanto ao quadro que elaborei a partir de números presentes em documentos de instrução pública, cabe sinalizar novamente que não era incomum haver casos em que professores forjavam o número de alunos, pois a partir deles recebiam seus salários (BARRA, 2005; SILVA, 2007; VIDAL, 2008), portanto deve-se usá-los com certa desconfiança. Segundo Vidal, 
enunciado pelo Estado. Mas é também desse lugar que se servem os professores ao preencherem os mapas de frequência, renovando, nas estratégias da escrita, táticas de sobrevivência profissional, como a manutenção das escolas e o recebimento de salários. Ao mesmo tempo, os mestres instalam práticas de classificação, ordenamento e hierarquização dos saberes e dos sujeitos escolares. Constroem identidades ao trabalho docente e à infância escolarizada, agindo de maneira que normatizem o exercício profissional e o aluno. Acumulam o passado e desenham o presente. E, no processo de escrituração dos mapas de frequência, produzem, os professores também, sistemas de inclusão e exclusão. (VIDAL, 2008, p. 47-48).

Todavia, ressalvando a desconfiança que se deve ter, os números do quadro são ilustrativos do processo de escolarização em crescimento ao longo dos 15 anos, que mostram um aumento de $407 \%$ de alunos matriculados. Entre 1870 e 1885 existiram gerações de alunos que estudaram em Cotia, sendo que alguns deles entraram e logo saíram da escola e outros estudaram por anos e até se tornaram professores, como o caso da Professora Catharina Etelvina Pedroso.

A construção da docência e o processo de escolarização em Cotia estiveram entremeados às precárias condições materiais para o exercício da função docente juntamente com a rusticidade da sociedade local, imersa no trabalho rural, no qual muitos pais roceiros inseriam seus filhos ainda crianças e dependiam deles para executar o serviço. As fontes demonstraram, a partir sobretudo da lente dos professores, as características dos alunos e a influência do cotidiano local na vida escolar, desse modo, dados sobre os motivos das faltas excessivas e do pouco "adiantamento" dos alunos denotam a característica de muitos deles: eram trabalhadores.

Anos antes do recorte desta pesquisa, os inspetores assinalavam o motivo das faltas dos alunos nas aulas. Informava o inspetor Vigário José Manoel de Oliveira em relatório ao Inspetor Geral de 30 de novembro de 1856 que os alunos não eram frequentes "devido aos pais que no tempo da lavoura os apartão para esse e outros serviços”. Dez anos depois, o inspetor de distrito Manoel Joaquim da Luz relatou que havia falta de alunos e soube que os pais "applicão os filhos à lavoura, e mais se demorão em seos Sítios levando-os em sua companhia". Ambas as informações se referiam aos alunos da Vila, a diferença é que em 1866 havia também a cadeira feminina.

Retomando o recorte, Marcolino Pinto de Queiroz em 1872, então professor da Cadeira de Itaqui, informou em seus relatórios a não frequência dos alunos, valendo-se de um certo sentimentalismo e buscando impressionar a autoridade. Neles mencionou que seus alunos tinham "bom comportamento" e "adiantamento" de ensino, mas que devido às faltas não mostravam mais "adiantamento". Segundo o professor, no bairro "abundão[vam]" alunos 
que poderiam estar frequentando a escola, mas que trabalhavam e por isso não iam, assim, via "meninos a poucos passos da eschola em vez de virem frequenta-las, pegarem na ferramenta e irem para o trabalho" e que para seus pais "antes da instrucção está o trabalho". Em 1874, o professor, ainda em Itaqui, asseverou: "é pena que a lei obrigatória não se entenda nos Bairros", sugerindo que nos bairros os pais infringiam mais a lei de obrigatoriedade do que os pais das vilas e cidades.

Um dos principais motivos para a cadeira de Itaqui ter sido tranferida para Capitão Jerônimo foi a falta de alunos após a saída das famílias dos trabalhadores da Companhia Sorocabana do local, como mencionado no capítulo dois, mas também a ausência dos alunos para irem trabalhar com seus pais. Assim, é plausível considerear que os alunos trabalhadores eram filhos dos moradores antigos da região. Mesmo em Capitão Jerônimo, para onde a cadeira de Itaqui foi transferida, o trabalho na lavoura impedia que seus alunos fossem frequentes, segundo o professor José Custódio, em 1880.

Em 1874, Antonio Manoel Vieira, de Sorocamirim, informou em relatório de novembro que dos 34 alunos matriculados, apenas 16 eram frequentes, sendo a "principal causa", "a legislação incompleta no sentido de não ter dado geralmente a precisa força ao professor para chamalos a cumprirem com seus deveres”. No mesmo ano, José Custódio de Queiroz, frente à Cadeira de Carapicuíba, justificou que havia muitas faltas porque quase todos trabalhavam na lavoura.

Em 1884, a cadeira do Bairro do Rio Cotia apresentou pouca frequência de alunos porque, segundo o professor José Custódio, os alunos “já” trabalhavam "com seus Pais na lavoura". Fato é que, em 1886, foi transferida para o Bairro das Graças por meio de uma petição local devido à falta de frequência dos alunos, como assinalado no segundo capítulo.

No geral, segundo os professores em relatórios semestrais, o principal motivo da não frequência dos alunos era ocasionado pelos pais que levavam seus filhos para trabalharem com eles. Os livros de matrícula são fontes que também trazem alguns dados que podem contribuir para essa discussão, mas no que se refere às eliminações - não necessariamente ligado à falta de frequência, pois um aluno que ia para a escola esporadicamente poderia ser considerado não frequente e não ser eliminado por esse motivo.

De acordo com os livros das cadeiras da Vila e da Cadeira de Capitão Jerônimo, muitas eliminações de alunos se davam em decorrência do $2^{\circ}$ parágrafo do artigo 97 do Regulamento de 1869 (“Os que sem causa participada faltarem á escola por tres mezes consecutivos, precedendo communicação ao pae, tutor, ou pessoa que os tenha em seu poder") e por mudança, principalmente para o sítio. Não há como ter dados concretos dos 
motivos, mas a indicação do $2^{\circ}$ parágrafo do Regulamento de 1869 feita pelos professores pode estar relacionada à ausência do aluno em decorrência de sua inserção no mundo do trabalho. Também não podemos desconsiderar que em virtude do município de Cotia ser composto por uma grande área constituída de roças, sítios, fazendas, distantes uns dos outros - conforme as características de bairros caipiras assinaladas por Candido (2001a) -, a escola poderia ficar situada longe da moradia das famílias, dificultando o envio das crianças.

Há alguns indícios da distância entre a escola e a casa dos alunos. O professor Severiano da Cadeira de Várzea-Grande, em 1874, como mencionado no capítulo anterior, informou que os alunos moravam longe, mas seus pais sempre os enviavam à escola, no entanto, três foram eliminados, um por abandono e dois porque os pais necessitaram de seus serviços. Em relatório, o inspetor Benedicto comunicou que a casa onde lecionava o professor João Rodrigues de Jesus, da Cadeira de Carapicuíba, estava “aquém da Aldea [...] onde fícava longe para a frequencia dos alunos".

Essas questões, sobretudo a não frequência dos alunos por conta do trabalho na lavoura, resvalam nas concepções de espaço/tempo social em conflito com as concepções de espaço/tempo da escola. As recorrentes faltas de alunos e a eliminações por abandono pareceram estar totalmente atreladas ao entrecruzamento desses tempos e espaços. Exemplo disso são o espaço da lavoura/trabalho e o tempo social "de trabalhar na lavoura" (época de plantar e época de colher), que se sobrepunham ao espaço e tempo escolares. Como mencionado por muitos professores dos bairros, os pais não viam importância no estudo dos filhos e davam mais importância ao trabalho, com exceção da turma do professor Severiano, da Cadeira de Várzea-Grande. Para este caso, outras questões podiam estar presentes, como o prestígio do professor.

Rita Gallego (2008) objetivou investigar a genealogia do tempo escolar na institucionalização do ensino em São Paulo entre 1846 e 1890. Gallego considera tempo escolar "uma temporalidade social e uma categoria ampla à instituição escolar que é composta de diversas temporalidades" (p. 25), o processo de sua naturalização na vida dos sujeitos e a articulação entre os tempos sociais (da família, do trabalho, da Igreja, do local) e escolares.

O recorte temporal da pesquisa de Gallego partiu de 1846 porque neste ano foi aprovada a primeira lei provincial de São Paulo que estabelecia, entre outras coisas, elementos referentes ao tempo escolar; e o marco final do recorte, 1890, deu-se porque em 1885 e 1887 foram publicados regulamentos provinciais que também levavam em conta o tempo escolar. Segundo a autora, nesse período os professores assumiram papel fundamental na estruturação do tempo. A autora também refletiu sobre a precariedade das condições de trabalho dos 
professores, como a falta de um espaço educativo próprio (lecionavam em suas próprias residências, como já mencionado anteriormente), a falta de materiais e mobília adequada, entre outros.

\begin{abstract}
O nível de desenvolvimento e os sentidos do tempo escolar foram assumidos diferentemente em cada lugar, inclusive nas diversas localidades da Província de São Paulo, por isso a importância de fontes como ofícios, circulares e sobretudo relatórios de inspetores e professores. (GALLEGO, 2008, p. 31).
\end{abstract}

Em sua trajetória de pesquisa, a autora debruçou-se sobre fontes de muitas vilas e municípios da Província e verificou diferentes processos de construção de tempos escolares e a resistência por parte dos sujeitos, até que se estabelecessem e se naturalizassem na vida escolar e, consequentemente, na vida social.

É importante deixar claro que o discurso dos professores de Cotia analisados no presente trabalho é generalizante, isto é, estende a todos os pais a mesma conduta e opinião quanto ao não envio dos filhos à escola. É importante ter consciência também de que o relatório representa uma voz (a do professor) entre tantas que estavam inseridas no contexto. Contudo, as informações apresentadas eram recorrentes no conteúdo relatado pelos professores, e elas podem levar à seguinte reflexão: aqueles pais que enviavam seus filhos à escola viam alguma importância na instrução, seja pelo estudo em si e/ou pela obrigatoriedade de mandar os filhos à escola, senão não enviariam. Porém, qual a duração do estudo que os pais acreditavam necessário? O embate entre as atividades da vida social e da vida escolar é um ponto a ser discutido com mais atenção.

No cerne da questão de tempo e espaço sociais x tempo e espaço escolares estão as características da sociedade local e o sentido que a população dava à escola, confirmando a pesquisa de Rita Gallego (2008) que assinalou que a assimilação do tempo escolar foi adotada de modo e em tempos diferentes em cada lugar (p. 31). Segundo Antonio Candido (2001a), na cultura caipira "os meninos desde cedo ajudavam os pais na faina da lavoura, mas apenas quando apresentavam certo vigor físico, aos treze ou quatorze anos, recebem o peso total do serviço do eito" (p. 315), ou seja, trabalhavam em idade escolar por necessidade.

Os apontamentos de Edward Palmer Thompson em Costume, lei e direito comum, capítulo que faz parte do livro Costumes em Comum: estudos sobre a cultura popular tradicional (1998) assinalam que mesmo com a lei, as mudanças efetivas na sociedade são lentas. Dessa maneira, traçando um paralelo com a legislação educacional, trabalhos apontaram que mesmo com a lei de obrigatoriedade escolar, ainda havia muita resistência de pais enviarem seus filhos à escola (GIGLIO, 2001; BARRA, 2005; GALLEGO, 2008). 
Antes de tudo, deve-se salientar o caráter político da obra de Thompson, construindo a história “vista de baixo". Segundo Faria Filho, há

uma dimensão política fundamental de sua obra que, no terreno mesmo de investigação, se desdobra numa exigência ética de comprometimento do historiador com seu tempo e numa sensibilidade para com os problemas dos esquecidos pela história, além da necessidade de um teor teórico-metodológico que leva constantemente da teoria a empiria e ao debate historiográfico (FARIA FILHO, 2011, p. 249).

No texto citado, Thompson (1998) discutiu a importância dos costumes na Inglaterra do século XVIII durante o processo de cercamento em relação à lei (instrumento do capitalismo agrário) do direito à propriedade agrária, e demonstrou como os processos históricos são construídos no campo dos conflitos e das negociações.

Segundo esse autor, o costume é local e mutável, e tem como fonte a práxis. Desse modo, podemos considerar o costume na Inglaterra agrária "como práxis e igualmente como lei” (1998, p. 86). Os costumes passam a valer como normas, muitas vezes não escritas, o que torna muito complexo o trabalho dos historiadores, principalmente quando o período a ser estudado é de um passado remoto.

Para o historiador inglês é necessário relacionar as leis e a prática legislativa com as relações sociais, com seus costumes, com a cultura. A respeito disso, Faria Filho (2011) elencou algumas maneiras em que o historiador da educação pode interpretar as leis segundo a teoria thompsoniana, entre elas, a lei como prática ordenadora das relações sociais.

No que concerne ao estudo da história da educação brasileira relacionado à legislação e aos dados e fontes oficiais, Faria Filho (2011) sinalizou o cuidado com o uso desses documentos, levando em consideração seus resultados otimistas, uma vez que também servem como propaganda político-administrativa do Estado, pois possuem um caráter discursivo (p. 258). Segundo o autor, uma análise simplista da legislação pode ocultar sua principal contribuição, que é compreender a lei como prática ordenadora das relações sociais. Por meio dessa abordagem, Faria Filho considerou ser possível analisar duas dimensões importantes e complementares: o caráter histórico e político das leis bem como os sujeitos responsáveis pela intervenção (p. 259). Durante o século XIX:

o caráter político da intervenção legal baseia-se num pressuposto fundamental: a intervenção era uma ação necessária das instituições estatais e/ou das classes ilustradas sobre o heterogêneo povo brasileiro, no sentido de civilizá-lo e prepará-lo para contribuir com o progresso da nação (2011, p. 260, grifo do autor). 
Desse modo, ao que indicam as fontes, apesar das leis educacionais que obrigavam os pais enviarem seus filhos à escola, as características culturais de Cotia, as "leis" estabelecidas pela praxis e pela necessidade da vida, estavam para muitos de seus habitantes se sobrepondo às leis do governo. Apesar dessa população mais resistente, o processo de escolarização ampliou o atendimento a alunos, em termos numéricos - como argumentado anteriormente a partir dos dados de recenseamento e de fontes de instrução pública.

Distante de São Paulo, a Província de Pernambuco passava por situação parecida quanto à falta de frequência dos alunos, tendo o trabalho como um dos principais motivos. Silva (2013) apontou, a partir de relatórios de instrução pública de meados do século XIX, que alguns pais não tinham condições para mandar seus filhos à escola e "mantê-los estudando, livres das obrigações do trabalho" (p. 217). Havia pouca frequência de alunos nas escolas públicas e, para tentar reverter essa situação, foi instituída a obrigatoriedade escolar em 1855, que nos primeiros 19 anos resultou em um grande aumento do número de escolas e de alunos em Pernambuco.

Um ponto a refletir se relaciona aos conteúdos ensinados pelos professores. Como o ensino de normas e sistemas reverberava na vida cotidiana dos alunos e seus pais? Segundo o Art. $3^{\circ}$ do Regulamento de 1869 , “O ensino primario nas escolas publicas comprehende a leitura, calligraphia, principios elementares de arithmetica, systema metrico de pesos e medidas, noções essenciaes da grammatica portugueza, doutrina da religião do Estado, e principios da moral christã”. Mas havia professores que preferiam ensinar outras coisas, como o professor de Cotia descrito por Salambô (possivelmente João José Coelho), que não via sentido em ensinar sistema métrico e ensinava "alqueires e covados".

Considerando as demandas do cotidiano local e as características da sociedade, do trabalho dos alunos na lavoura e das muitas eliminações em decorrência do $2^{\circ}$ parágrafo do artigo 197 do Regulamento de 1869 e de mudança de endereço (várias delas para sítios), talvez a falta de sentido dada à escola por alguns habitantes de Cotia, a falta de convergência entre o conteúdo ensinado e a vida prática, possam também justificar as eliminações. Manoel Baptista Cepellos, ex-aluno, expôs a falta de sentido das normas e dos sistemas da escola nos versos citados no início deste capítulo.

Por outro lado, houve relatórios em que os professores, muito satisfeitos, assinalavam o aproveitamento dos alunos durante as aulas. Em 1881, o professor da $2^{\mathrm{a}}$ Cadeira masculina da Vila, Marcolino Pinto de Queiroz, como já informado anteriormente, dizia-se "feliz" porque seus alunos estavam aprendendo e os pais enviavam os filhos para a escola. João Maria Thomaz da Cadeira de Carapicuíba explicou com detalhes os conteúdos ensinados, 
como a turma estava dividida e seus graus de "adiantamento". Essa precisão se repetiu nos relatórios dos anos seguintes. Em junho de 1885 o professor informou que:

[são 23 matriculados divididos em 3 classes; a 1 $1^{\mathrm{a}}$, com 7 alunos. Estes estão no] $2^{\circ}$ Livro de Hilário Ribeiro, escrevem bastardo, sabem de cor a Oração Dominical e saudação Angelical, somam, diminuem e multiplicam e estão em principio do sistema métrico; a segunda que consta de dez estão no terceiro livro de Hilário, escrevem cursivo, sabem várias orações de cor, estão na segunda parte do catheciscmo, fazem as quatro operações fundamentais e sabem de cor o valor das medidas lineares e de pesos; a terceira que consta de 6, estão no quarto livro de Hilário, escrevem cursivo, sabem várias orações de cor, estão na terceira parte do Catheciscmo, fazem as quatro operações decimais e ordinárias e regra de três direta e inversa, sabem de cor o valor das medidas métricas e estão em sintaxe da grammática portuguesa. (Relatório de J. M. Thomaz ao Inspetor Geral da Instrução Pública de 1 jun. 1885. AESP, Série Instrução Pública - Manuscritos, ref. CO5044).

Pude observar que filhos e tutelados de famílias mais abastadas e influentes estavam matriculados e frequentavam as escolas públicas. Nelas também estavam registrados filhos de escravos. Contrapondo-se à tese de Cynthia Greive Veiga (2004; 2008; 2010) de que a instrução pública era direcionada aos "filhos de uma sociedade mestiça e selvagem que, por ser portadora dessas características, precisaria ser escolarizada” (VEIGA, 2010, p. 263), em Cotia a instrução pública era para o povo e para os filhos dos cidadãos influentes (a elite). As cadeiras da Vila, tanto a feminina quanto as masculinas, tinham muitos alunos filhos destes cidadãos (ligados a setores da política e justiça locais), conforme dados das listas de matrícula. Segundo as fontes, o cenário da escolarização de Cotia na segunda metade do XIX estava montado com crianças pobres e crianças com melhores condições de vida, principalmente na Vila. A seguir, apresento dados mais detalhados da composição das turmas a partir dos livros de matrícula coligidos.

\subsection{A composição das turmas a partir dos livros de matrícula}

Os livros de matrícula coligidos e aqui analisados, como mencionado, foram seis, referentes a quatro cadeiras: $1^{\text {a }}$ Cadeira Feminina da Vila (1870-1885), $1^{\text {a }}$ Masculina da Vila (1870-1885), $2^{\text {a }}$ Cadeira Masculina da Vila (1875-1882) e Cadeira do Bairro de Capitão Jerônimo (1879-1885). Apesar de não serem todos exatamente do mesmo período, eles são contemporâneos entre si e foram abertos em consonância com o Artigo 94 do Regulamento de 
$1869^{299}$, como anotado pelos inspetores locais na primeira página dos mesmos. Cada um era composto com campos para o preenchimento do/a professor/a, e neles estão contidos: Nome da escola, Ano, Número e Nome do/a Aluno/a, Filiação, Moradia, Naturalidade, Nacionalidade, Idade, Matrícula e Observações. Ao final o/a professor/a datava e assinava. Os dados foram sistematizados e divididos em dois eixos para facilitar a análise (eixo 1: dados escolares e eixo 2: dados pessoais). No eixo dados pessoais também procuro refletir sobre a presença de alunos "ingênuos" nas escolas.

\subsubsection{Dados escolares}

Contemplando o recorte da pesquisa, da Escola de Primeiras Letras do Sexo Feminino da Vila de Cotia, onde a Professora Maria Joanna do Sacramento lecionava, há dois livros disponíveis no AESP, um com registros de 1870 a 1879 (AESP, referência EO2230) e outro de 1880 a 1885 (AESP, referência EO3182), que são a base documental de todos os gráficos relativos a essa cadeira. Ao todo, Maria Joanna registrou 94 nomes de meninas, pois muitos nomes se repetiam ao longo dos anos, visto que muitas alunas estudaram por até sete anos com Maria Joanna. A seguir está o gráfico com os números de alunas matriculadas em cada ano.

\footnotetext{
299 “Art.94. A matricula será feita pelo respectivo professor em livro proprio, aberto, numerado, rubricado e encerrado pelo Inspector de Districto, e segundo o modelo annexo com as seguintes declarações:

$\S 1^{\circ}$. Do nome do alumno.

$\S 2^{\circ}$. Da sua filiação, sendo conhecida.

$\S 3^{\circ}$. Do tutor, ou da pessoa que o tiver em seu poder.

$\S 4^{\circ}$. Da sua naturalidade e nacionalidade.

$\S 5^{\circ}$. Da sua idade, segundo declaração ou certidão que apresentar.

$\S 6^{\circ}$. Do dia, mez e anno em que se matricular". (Regulamento de 18 de abril de 1869 - Para Instrução Pública e particular da Província, 1874, p. 579-580).
} 


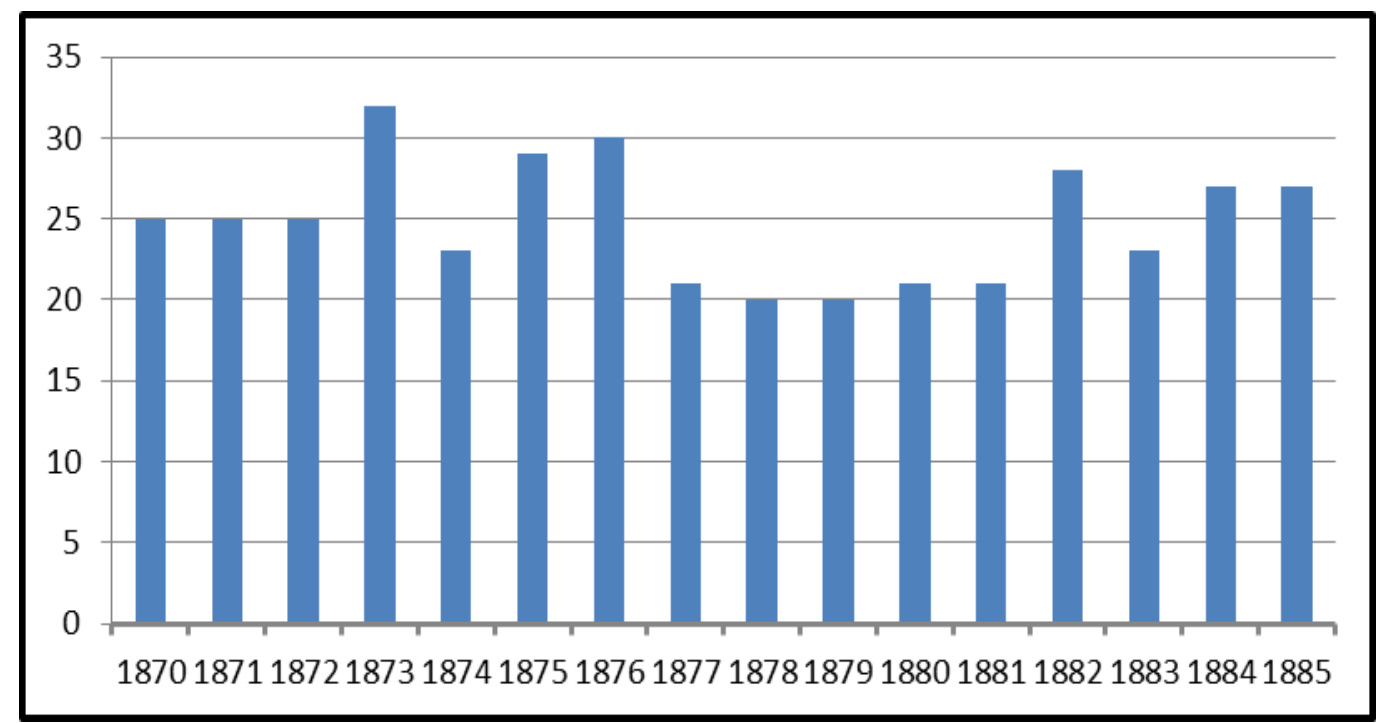

Ilustração 33 - Gráfico do número de alunas da Cadeira Feminina da Vila (1870-1885).

A média anual de alunas de Maria Joanna estava entre 20 e 30, apenas em 1873 houve 32 matrículas, mas em dezembro foram nove eliminações por terem passado no exame, indicando que não existiu relação direta com o casamento da professora com João José Coelho, que aconteceu também em dezembro de 1873, pois, a diferença no número de alunas entre 1873 e 1874, ao que indica a fonte, deu-se principalmente por causa do exame ao qual as alunas se submeteram e foram aprovadas.

No período registrado no livro de matrícula, houve anos em que o número de alunas eliminadas foi bastante elevado e outros em que não ocorreu saída de alunas. Dos motivos das eliminações, vários não foram informados pela professora, que apenas colocou no campo de observações: "Retirou-se da eschola em [citando a data]", sobretudo a partir de 1876. Das vezes que informou os motivos das saídas, elas aconteceram, em geral, por exame, mudança de endereço, responsável ter julgado a aluna pronta ou ter passado para a $2^{\mathrm{a}}$ Cadeira Feminina (criada em fevereiro de 1884), como se verifica abaixo: 


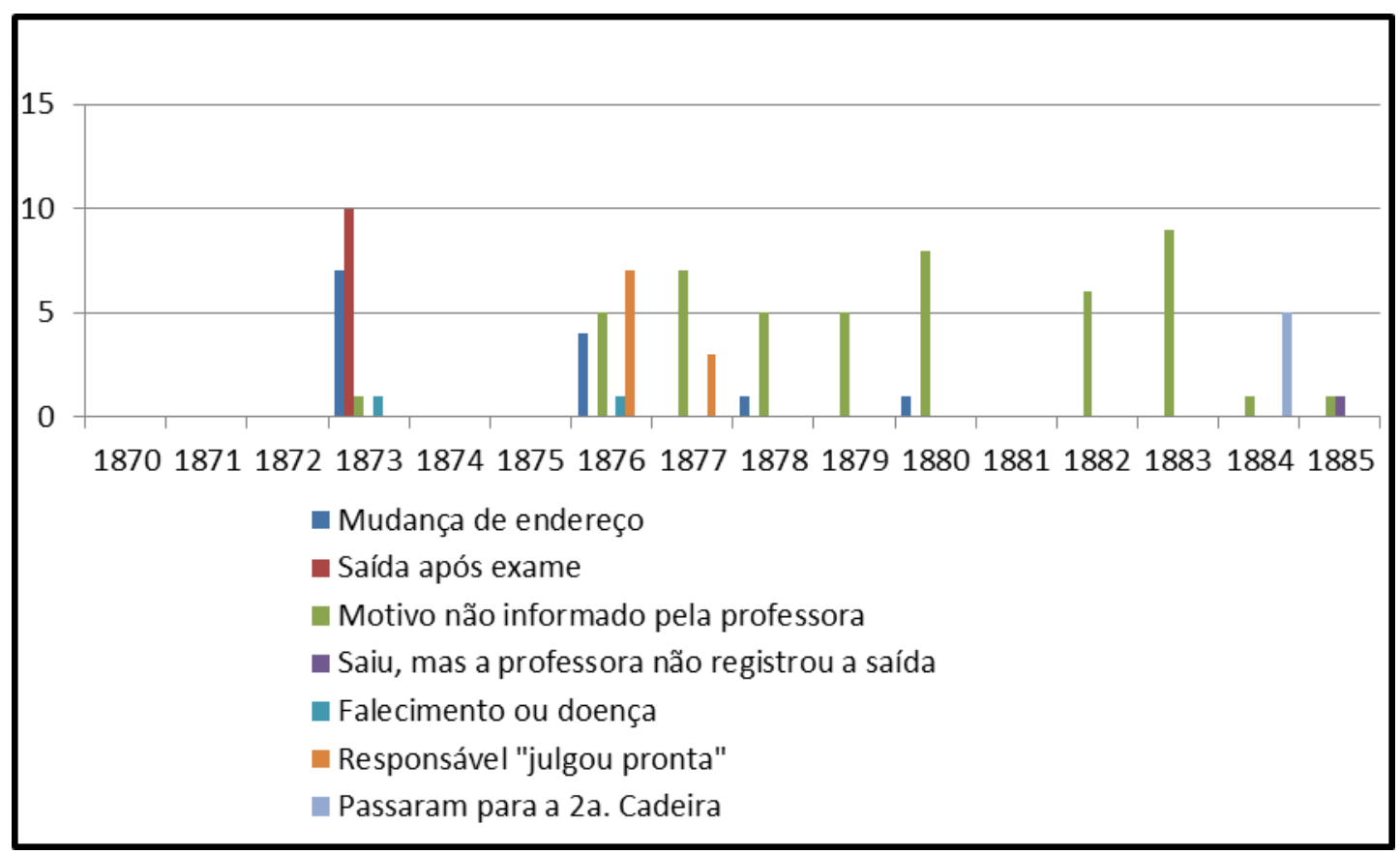

Ilustração 34 - Gráfico dos motivos das eliminações - Cadeira Feminina da Vila (1870-1885).

Quanto à mudança de endereço, 13 alunas saíram da escola ao longo dos anos por esse motivo, sendo oito para o sítio, duas para São Roque, duas para fora do distrito e uma para fora da Vila. A considerar que havia apenas uma cadeira feminina pública na Vila, as meninas que se mudavam para o sítio possivelmente paravam de estudar em escola, a não ser que houvesse alguma escola particular.

Muitas eram as eliminações, mas em contrapartida novas alunas se matriculavam, com exceção dos anos 1870, 1871, 1872 e 1885, que não houve novos registros, como mostra o gráfico a seguir:

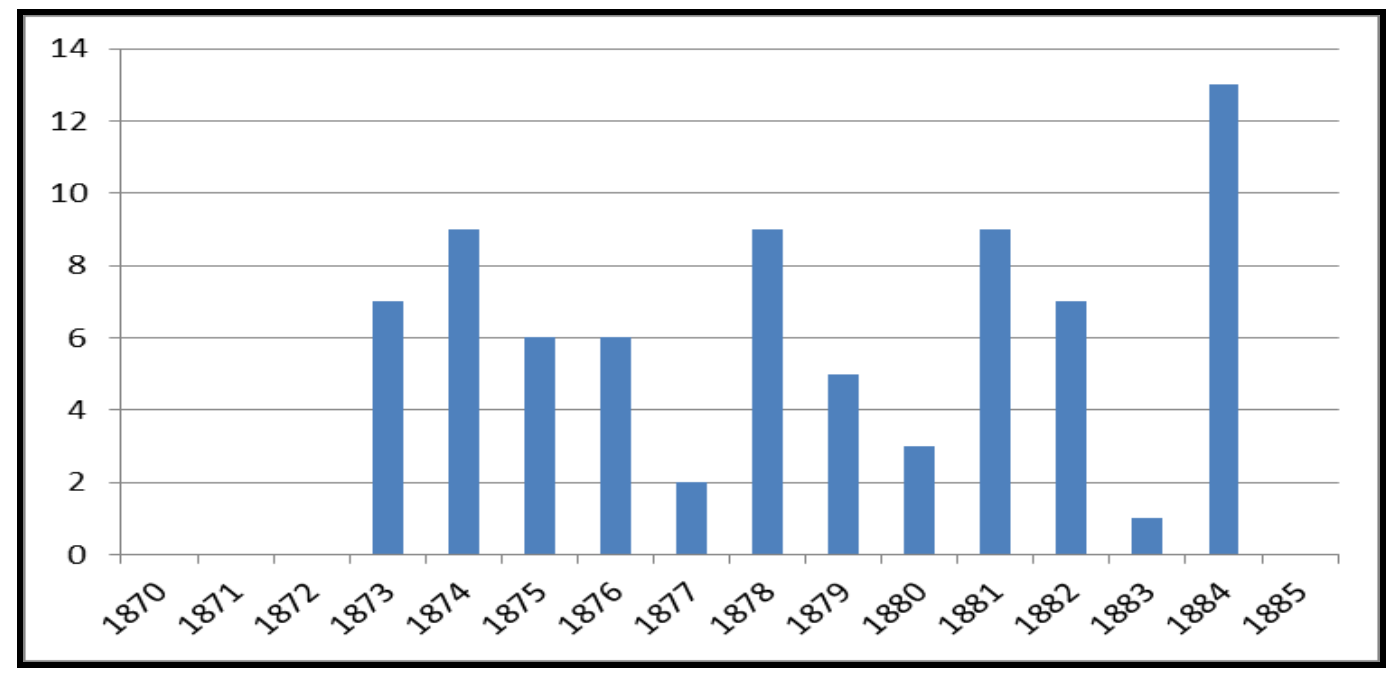

Ilustração 35 - Gráfico do número de novas matrículas - Cadeira Feminina da Vila (1870-1885). 
Em 1884, ano em que houve 13 matrículas novas (90\% do total de alunas que já estavam presentes na lista), três dessas alunas foram para a $2^{\mathrm{a}}$ Cadeira Feminina da Vila no meio do ano. Segundo relatório de $1^{\mathrm{o}}$ de junho de 1884 da professora Catharina Pedroso, a $2^{\mathrm{a}}$ Cadeira estava com 22 alunas matriculadas e 19 frequentes, e em $1^{\circ}$ de novembro do mesmo ano, com 24 matriculadas e 19 frequentes, logo, as alunas que se transferiram para a $2^{\mathrm{a}}$ Cadeira não foram "necessárias" para que ficasse com, no mínimo, vinte alunas. Esse caso demonstra uma preferência pela aula da Professora Catharina, todavia não há como saber por quais motivos.

A próxima cadeira a ter os dados apresentados é a $1^{\mathrm{a}}$ Cadeira Masculina da Vila, do Professor João José Coelho. Dela estão disponíveis no AESP dois livros referentes ao recorte desta pesquisa, um do período de 1870 a 1877 (referência EO2234) e outro de 1878 a 1885 (referência EO3030), ambos usados como base documental na elaboração dos gráficos relativos a essa cadeira. Ao longo dos 15 anos, o professor registrou 129 nomes diferentes de meninos, do mesmo modo que na Cadeira Feminina, houve repetições de nomes ao longo dos anos, e em cada ano teve entre 20 e 30 alunos matriculados, conforme gráfico abaixo:

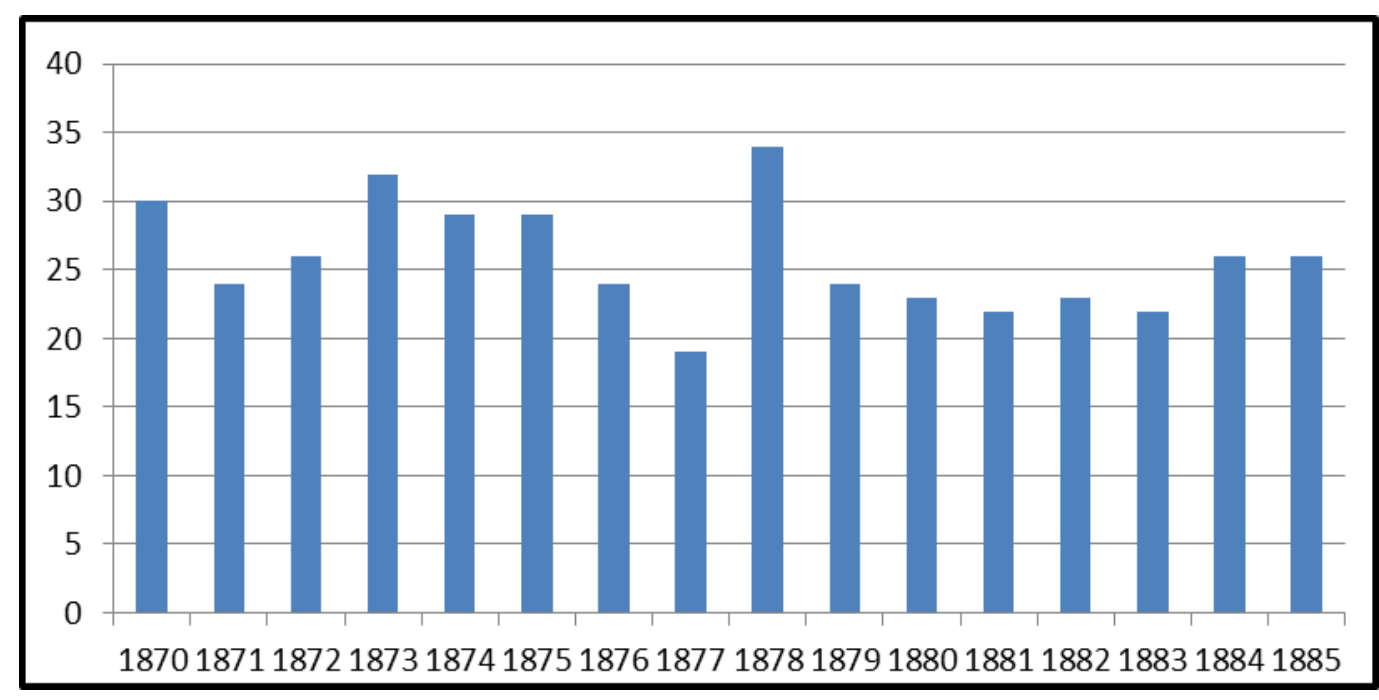

Ilustração 36 - Gráfico do número de alunos da $1^{\text {a }}$ Cadeira Masculina da Vila (1870-1885).

Houve um número significativo de eliminações em sete dos 15 anos de registros. Em 1875 e 1876 destaca-se o fato de vários alunos passarem para a $2^{\text {a }}$ Cadeira Masculina da Vila do Professor Marcolino Pinto de Queiroz. Estranhamente em 1874 também houve eliminações por esse motivo, mas a $2^{\mathrm{a}}$ Cadeira ainda não estava funcionando (ela funcionou 
apenas a partir de 1875). O professor não colocou a data exata da saída dos alunos. O quadro abaixo indica os motivos das eliminações:

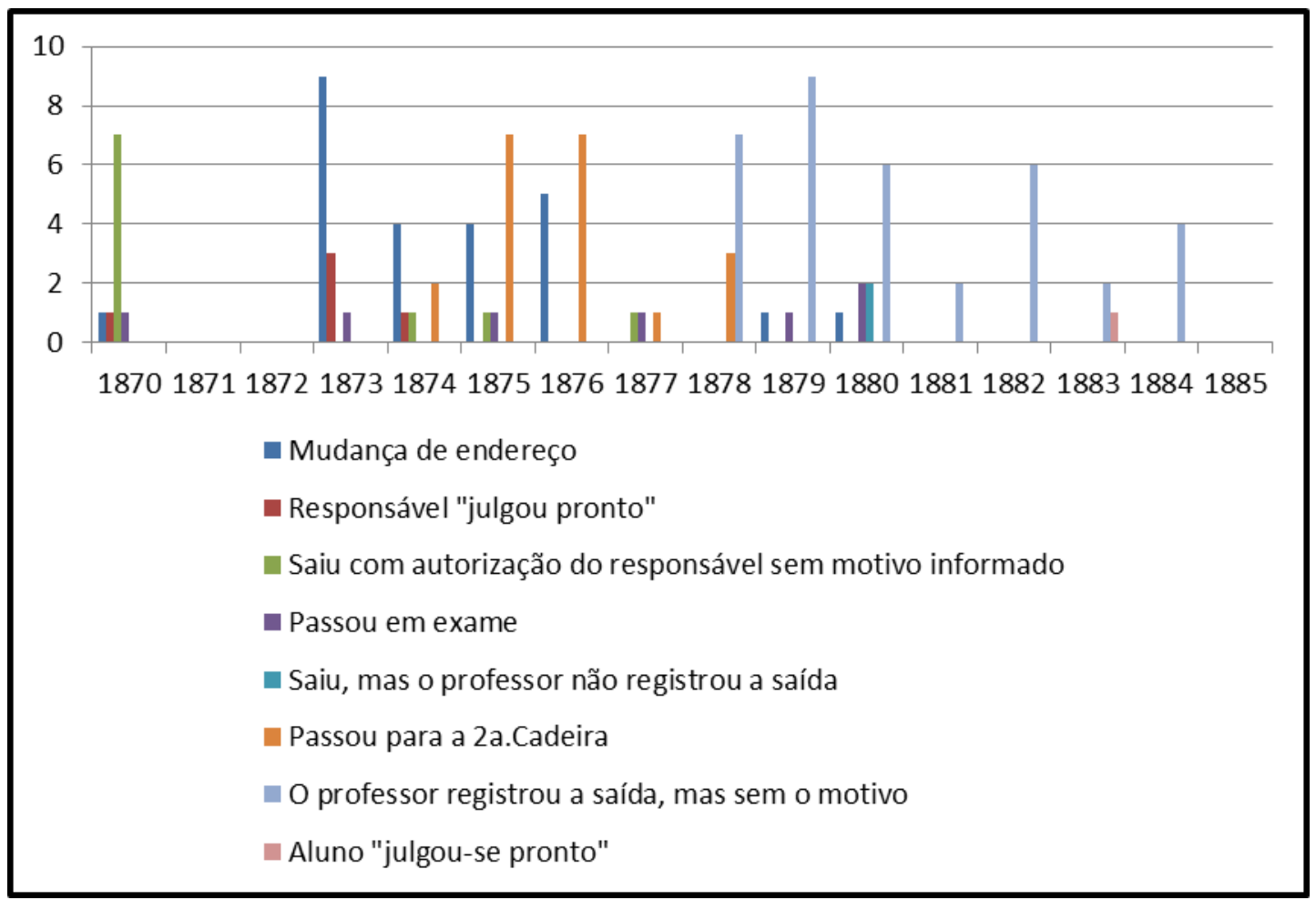

Ilustração 37 - Gráfico dos motivos das eliminações - $1^{\text {a }}$ Cadeira Masculina da Vila (1870-1885).

A partir de 1878, o Professor João José Coelho começou a não informar o motivo da eliminação de alguns de seus alunos, dado que também foi comum nos registros de Maria Joanna do Sacramento e que pode indicar mais um elemento compartilhado no lar docente (MUNHOZ; VIDAL, 2014). A grande maioria das eliminações sem o motivo registrado pelo professor não se relacionaram com a transfência para a $2^{\mathrm{a}}$ Cadeira da Vila, pois ao comparar os livros das duas cadeiras, os meninos eliminados, em geral, não haviam passado para a cadeira do Professor Marcolino.

$\mathrm{O}$ motivo relacionado à mudança de endereço referia-se principalmente à ida dos alunos para o sítio. Ao longo dos anos, 25 alunos saíram por mudança, sendo 16 para sítio, corroborando com os indícios de prática de trabalho rural. Esses alunos também podem ter sido matriculados em cadeiras dos bairros, caso tenham ido morar em bairros em que existisse uma cadeira pública masculina (ou em escolas particulares), o que a pesquisa não conseguiu apurar. Outros lugares para onde os alunos se mudaram: um foi para Tatuí, um para M'boy, um para Campinas, três para "outro distrito", um para "outro município", um para "outra vila" 
e um para "outro bairro". Este aluno também pode ter se matriculado em alguma cadeira dos bairros de Cotia.

Como a Cadeira Feminina, a $1^{\text {a }}$ Cadeira Masculina da Vila tinha um fluxo grande de saída e chegada de novos alunos, conforme o gráfico a seguir:

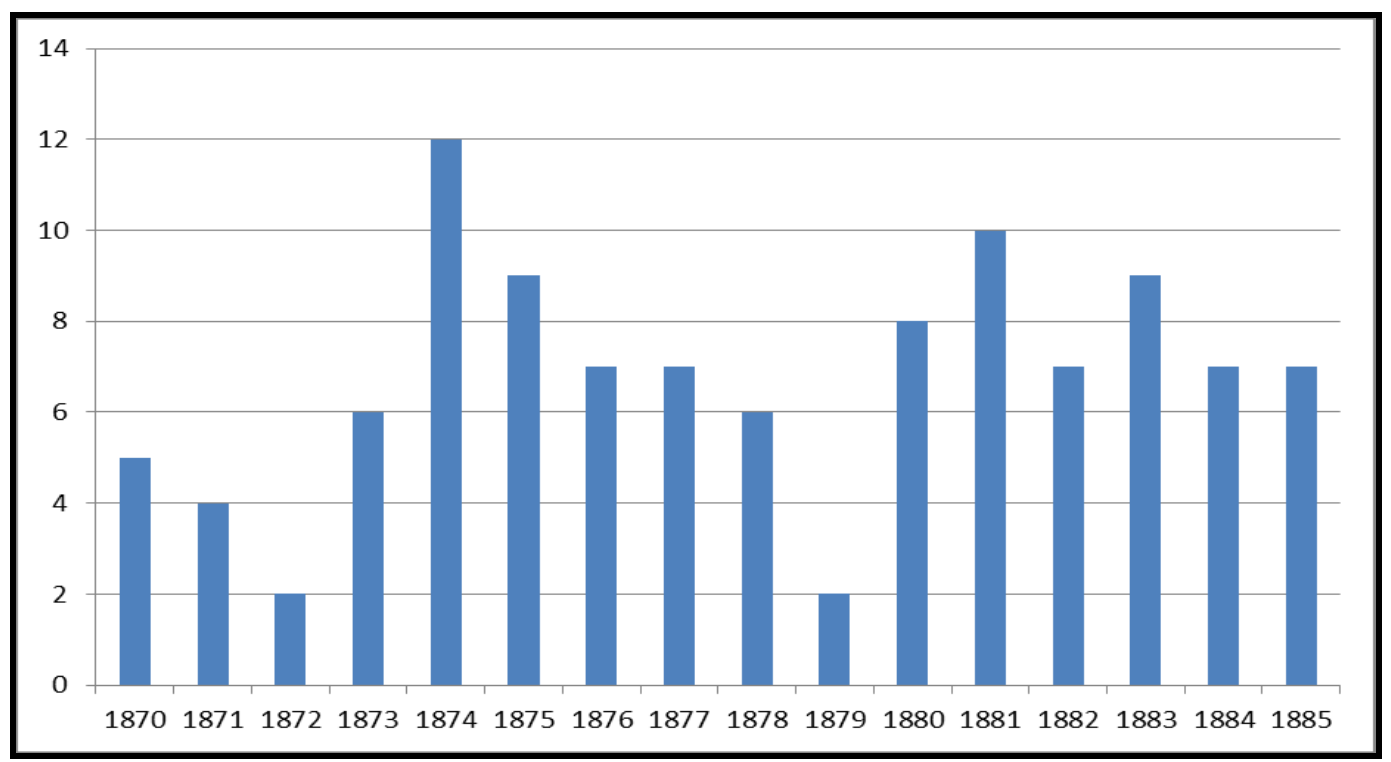

Ilustração 38 - Gráfico do número de novas matrículas - $1^{\text {a }}$ Cadeira Masculina da Vila (1870-1885).

Destacam-se os anos de 1874 e 1881 . No primeiro ocorreram 12 novas matrículas, tendo um total de $71 \%$ de aumento, pois em 1873 vários alunos saíram principalmente por mudança. Já em 1881, 80\% de novas matrículas: como em 1880 houve 11 eliminações (de 23 alunos matriculados), muitas delas sem motivo registrado, restaram 12 e em 1881 matricularam-se dez novos alunos, entre eles, dois "ingênuos". Segundo a Lei do Ventre Livre ( $n^{\circ} 2.040$ de 28 de Setembro de 1871), entre outras coisas, eram considerados livres os filhos de mulher escrava que nascessem a partir de 28 de setembro de 1871, indicando as providências quanto à criação e tratamento desses nascituros - comumente chamados de “ingênuos". A discussão sobre a presença de alunos "ingênuos" está no subcapítulo a seguir.

O livro de matrícula da $2^{\mathrm{a}}$ Cadeira Masculina de Cotia analisado se refere ao período de 1875 a 1882 (AESP, referência EO2918) e é base para a elaboração de todos os gráficos referentes a essa cadeira. O livro foi aberto em 27 de outubro de 1875 pelo então inspetor de distrito Joaquim de Araujo Novaes, mas a primeira matrícula data de 26 de maio desse ano, indicando que o professor lecionou durante meses sem ter livro de matrícula. Segundo o Artigo 95 do Regulamento de 1869, o livro deveria ser "fornecido a expensas do Professor". Nele, o Professor Marcolino Pinto de Queiroz registrou o total 74 nomes diferentes de 
meninos, pois muitos nomes também se repetiram ao longo dos anos. A distribuição de alunos por ano pode ser vista no gráfico abaixo:

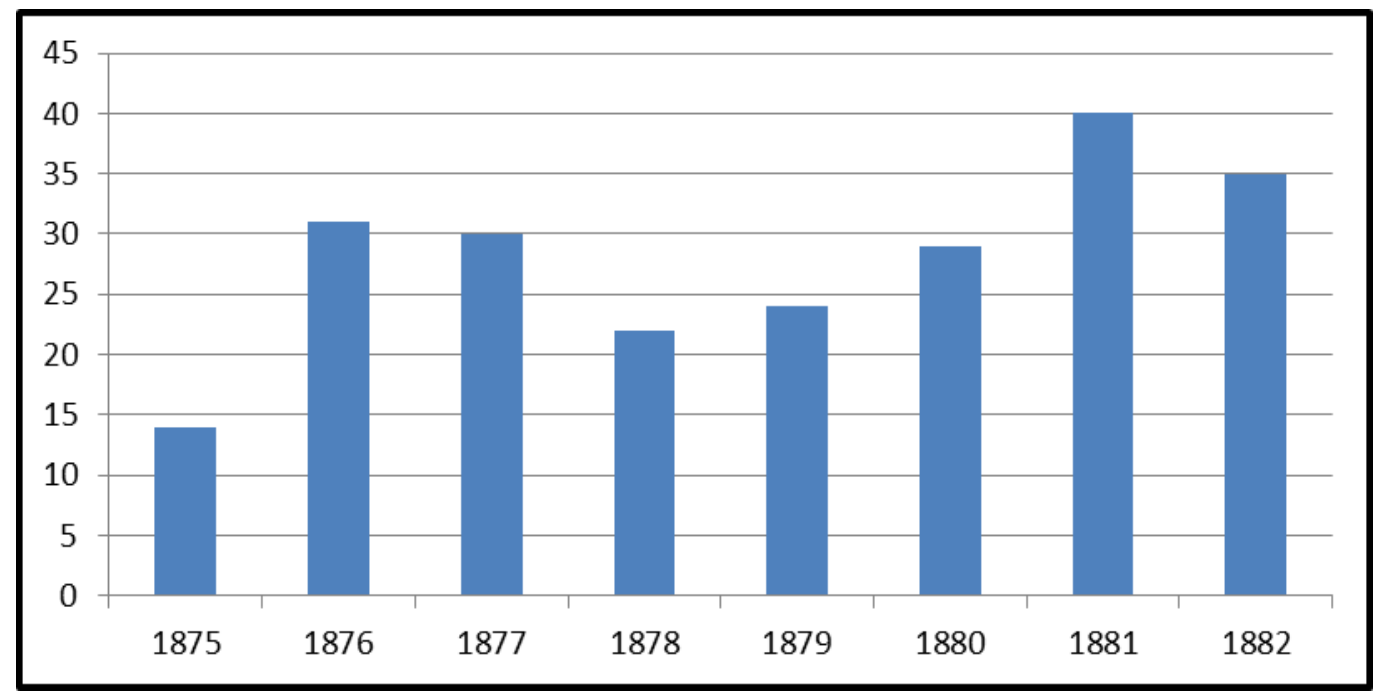

Ilustração 39 - Gráfico do número de alunos da 2ª Cadeira da Vila de Cotia (1875-1882).

A escola teve poucos alunos no ano em que foi criada, mas nos anos seguintes sempre teve mais que o mínimo exigido, destancando-se o ano de 1881 em que teve 40 alunos matriculados. Muitos deles vindos da $1^{\text {a }}$ Cadeira (vinte registrados pelo professor João José Coelho como motivo de saída para a $2^{\mathrm{a}}$ Cadeira e três não registrados por ele). Portanto, os sete primeiros anos da $2^{\mathrm{a}}$ Cadeira mostraram que houve uma preferência por ela em relação à $1^{\text {a }}$ Cadeira.

Entre os motivos das eliminações registrados pelo Professor Marcolino, destacam-se mudança de endereço, transferência para a $1^{\text {a }}$ Cadeira e a ausência por três meses consecutivos (Parágrafo $2^{\circ}$ do Artigo 97 do Regulamento de 1869). Curiosamente um aluno saiu pelo motivo de "se ter ajustado como camarada de Joaquim Nunes dos Santos". Este indivíduo não tinha filhos registrados nos livros coligidos, mas seu nome consta como vereador em várias gestões a partir de 1898, e em algumas delas como presidente da Câmara. Possivelmente o aluno deve ter começado a trabalhar para Joaquim Nunes dos Santos. 


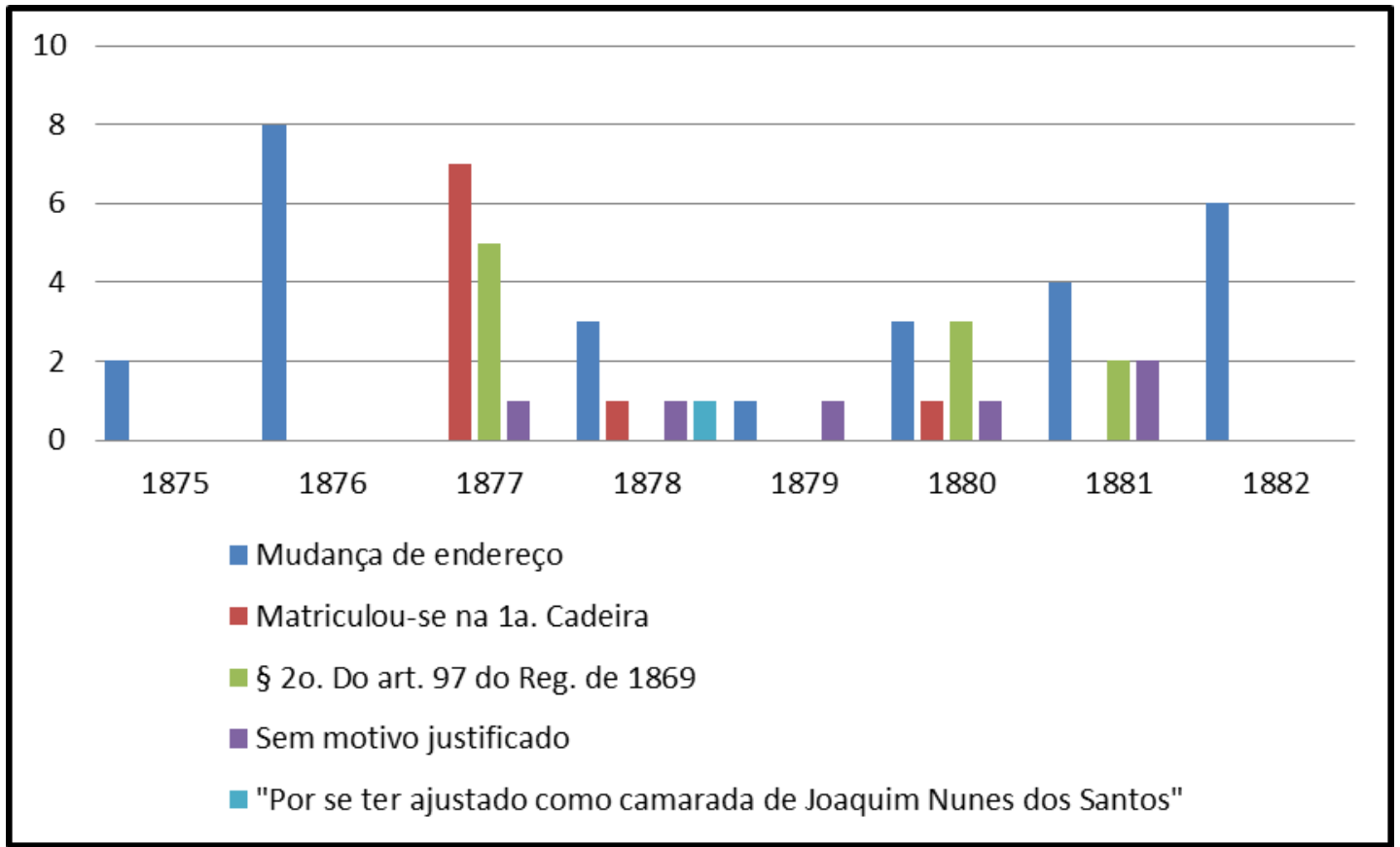

Ilustração 40 - Gráfico dos motivos das eliminações - 2ª Cadeira da Vila de Cotia (1875-1882).

Dos 27 alunos que saíram por motivo de mudança de endereço, dez foram para São Paulo, cinco para o sítio, cinco sem informação do local, dois para Tatuí, dois para Campinas e um para o Bairro de Várzea-Grande. Novamente nota-se a ocorrência de mudanças para o sítio, apesar de em menor número se comparado às primeiras cadeiras. Esse livro registra, entretanto, apenas sete anos, enquanto que os livros das primeiras cadeiras da Vila registram 15 anos no total.

As duas cadeiras masculinas da Vila assinalaram mudança de alunos para Tatuí, comprovando que alguns cotianos tinham relação com esse município, o mesmo que tinha extrema ligaçao com Bofete, local dos caipiras estudados por Candido (2001a). Dois dos alunos que foram para Tatuí eram Manoel Baptista Cepellos e Antonio Baptista Cepellos, filhos de João Baptista Cepellos, professor que viria a lecionar em Várzea-Grande em 1885, transferido de uma cadeira pública de Tatuí, como mencionado no segundo e terceiro capítulos.

A $2^{\text {a }}$ Cadeira apresentou um fluxo elevado de novos alunos, ressaltando os anos de 1876 e 1881. Como mencionado, alguns desses alunos foram transferidos da $1^{\mathrm{a}}$ Cadeira da Vila. Cabe destacar esse grande fluxo de novas matrículas e eliminações das cadeiras da Vila por motivo de mudança, o que indica que no local havia uma grande ocorrência de migrantes, característica de centros de municípios. 


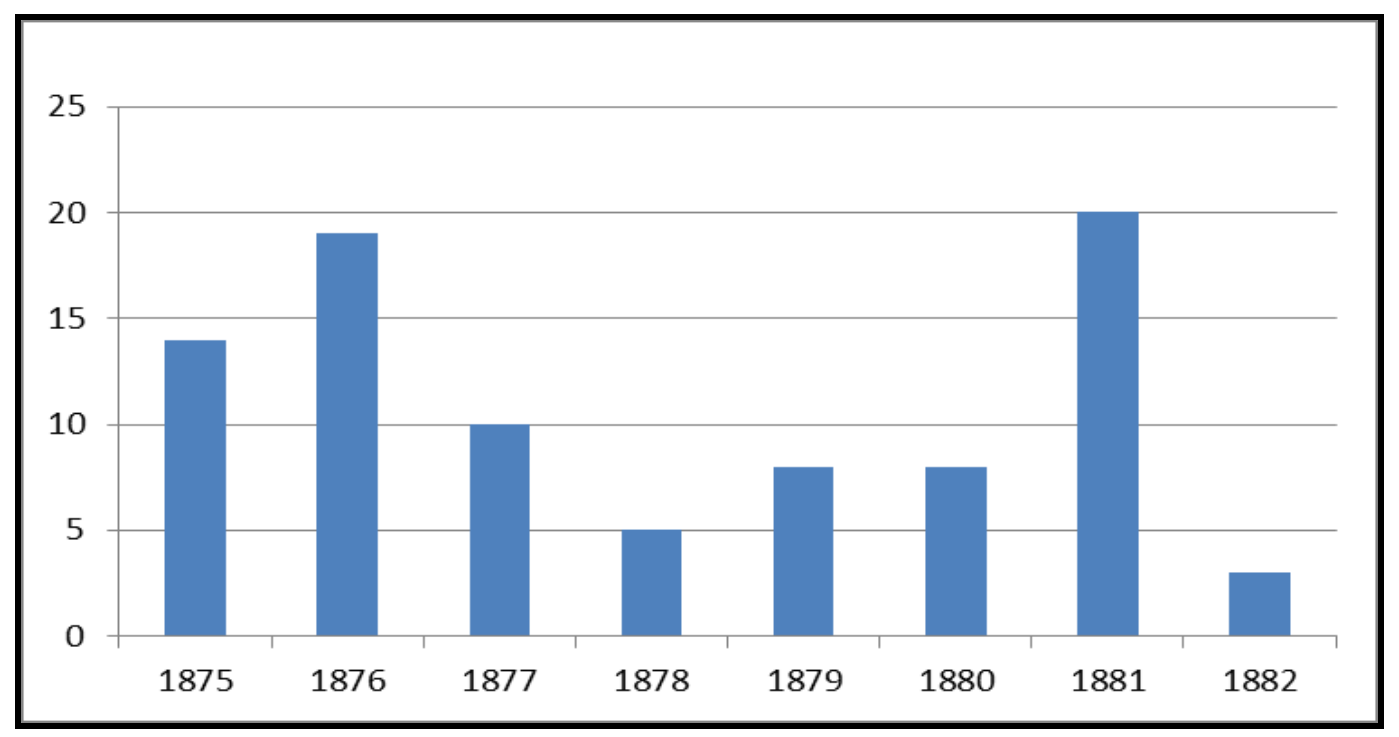

Ilustração 41 - Gráfico do número de novas matrículas - 2ª Cadeira da Vila de Cotia (1875-1882).

A quarta e última cadeira, com livro de matrículas que se refere ao recorte temporal desta pesquisa, é a Escola de Primeiras Letras da Cadeira do Sexo Masculino do Bairro de Capitão Jerônimo (AESP, referência EO3116). Esse livro foi usado como base documental para a elaboração dos gráficos relativos a essa cadeira e tem registros dos anos de 1879 (ano em que começou a funcionar) a 1885, com 61 meninos matriculados no total (o mesmo ocorrido nas outras cadeiras apresentadas, essa também teve nomes de meninos repetidos ao longo dos anos) pelos Professores José Custodio de Queiroz (1879-1884) e Manoel de Moraes Pinto (1884-1885). Em comparação às Cadeiras da Vila, o número de alunos matriculados na Cadeira de Capitão Jerônimo era maior.

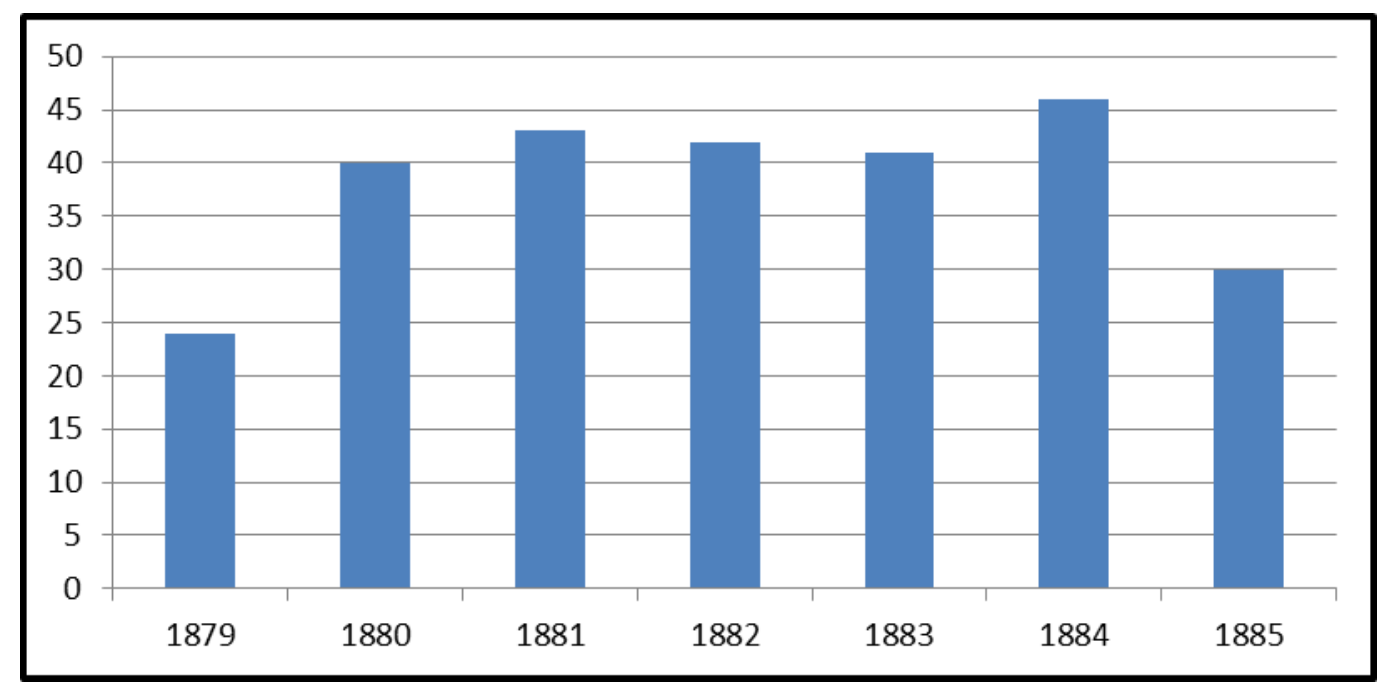

Ilustração 42 - Gráfico do número de alunos matriculados - Cadeira do Bairro de Capitão Jerônimo (1879-1885). 
Destaca-se o ano de 1884 em que a escola contou com 46 alunos matriculados. Nesse ano, por conta de mudança de professores, houve o registro de duas turmas, uma com 31 alunos registrados por José Custódio de Queiroz, e outra com 28 alunos, tendo Manoel de Moraes Pinto como professor, formada em março. Alguns dos alunos matriculados por José Custódio estavam também na lista de Manoel, outros não. O professor José Queiroz colocava o tempo de aprendizado no campo "Observações” de todos os alunos matriculados, enquanto que o professor Manoel não anotava essa informação e usava esse campo apenas para registrar as eliminações dos alunos.

O número de eliminações não era muito grande se comparado às escolas da Vila. Entre os motivos, nota-se maior incidência de falta dos alunos por três meses consecutivos, conforme abaixo:

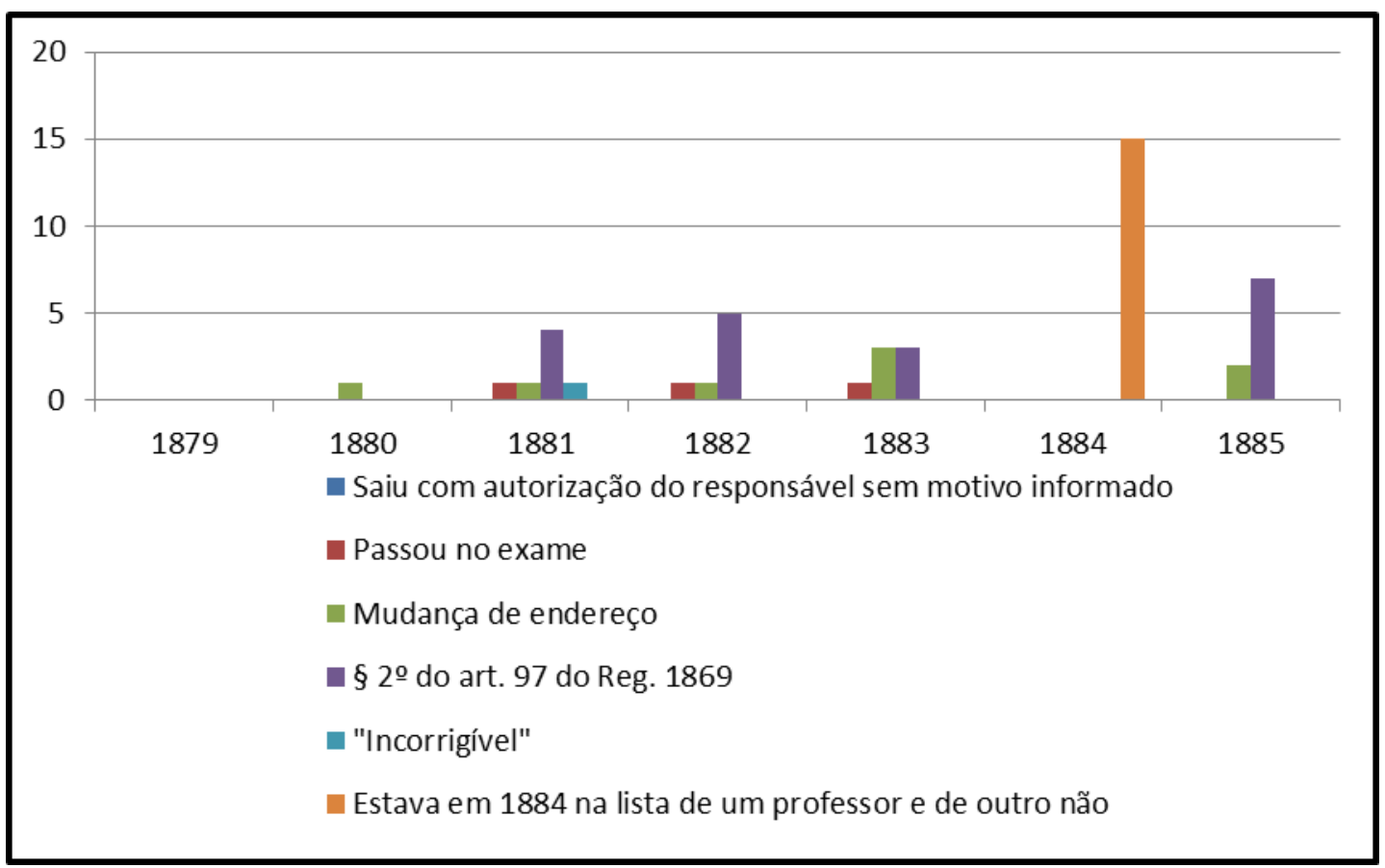

Ilustração 43 - Gráfico dos motivos das eliminações - Cadeira do Bairro de Capitão Jerônimo (1879-1885).

Quanto ao motivo de saída devido à mudança de endereço, ao longo dos anos, foram oito ocorrências: dois para morarem em Jundiaí e seis sem informação do local.

Em 1884, houve a mudança de professor. Saiu José Custódio de Queiroz e passou a lecionar Manoel de Moraes Pinto. Como mencionado, ao comparar as duas listas, houve alunos que se repetiram, porém 15 alunos que estavam na lista de José Custódio não apareceram na lista de Manoel de Moraes Pinto, não havendo mais informações sobre eles, que simplesmente "sumiram" dos registros. 
Existiu ainda um motivo que chamou a atenção: o aluno Indalecio Mendes Vaz de 1881 foi eliminado por ser "incorrigível". No Parágrafo 5 do Artigo 97 do Regulamento de 1869, era possível “expulsar" os alunos “ineptos ou incorrigiveis”. Indalecio era irmão de José Mendes Vaz, aluno que também saiu da escola, porém por se ausentar por mais de três meses consecutivos e estavam matriculados desde o ano anterior. Esses alunos tinham o pai falecido e moravam com a mãe, fato que pode indicar a necessidade de que trabalhassem.

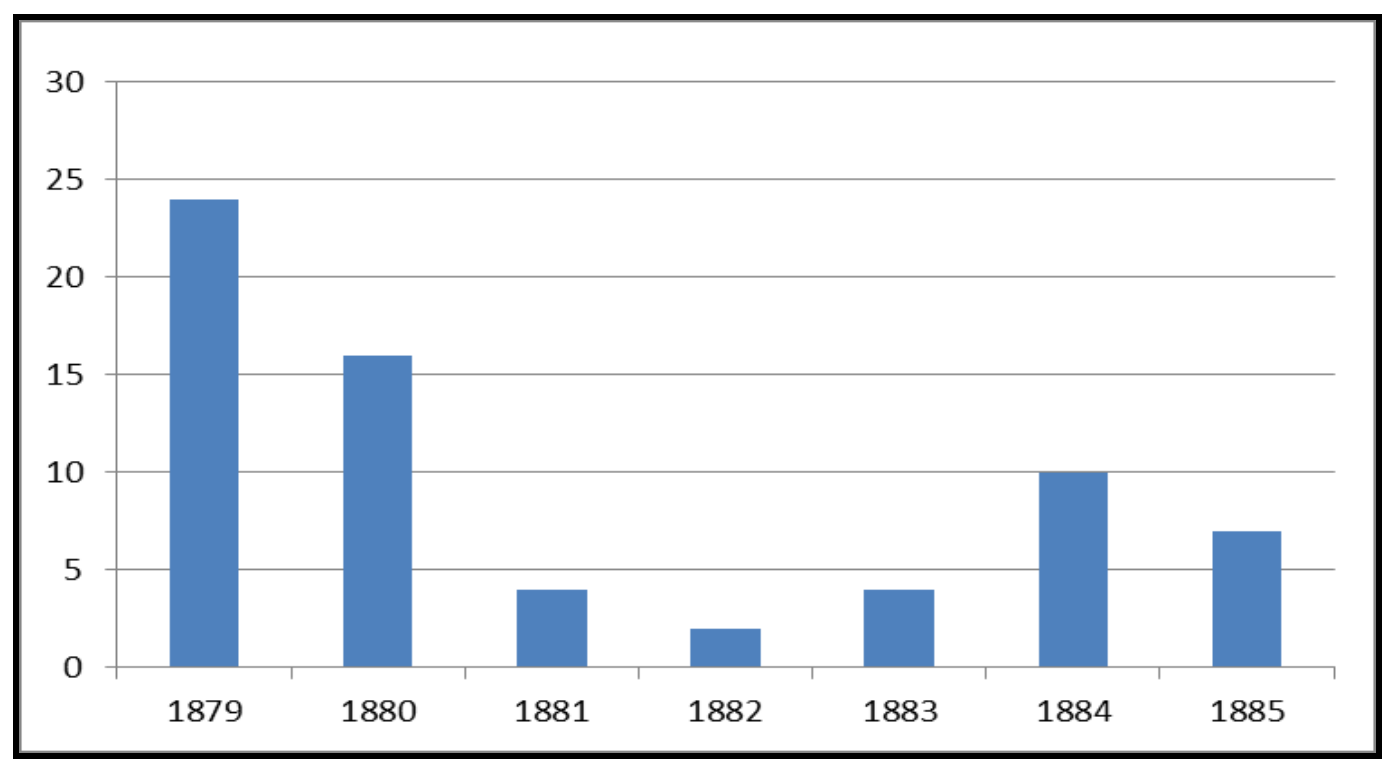

Ilustração 44 - Gráfico do número de novas matrículas - Cadeira do Bairro de Capitão Jerônimo (1879-1885).

Quanto às novas matrículas, o livro apontou uma grande quantidade nos dois primeiros anos e depois um período de poucas matrículas. $\mathrm{O}$ dado pode sugerir a pequena atração de moradores novos ao bairro, de forma que essa cadeira atendeu sobretudo a população que já residia ali. Portanto, tratava-se de um bairro com pouca migração, principalmente se comparado com a Vila.

Os dados apontados neste subtópico revelaram que, entre meninos e meninas matriculados nas quatro cadeiras, a média de matrículas era de 20 a 30 alunos nas escolas da Vila e 30 a 40 nas do bairro. O motivo mais recorrente das eliminações foi a mudança de endereço - especialmente da Vila para o sítio - seguido de ausência às aulas por mais de três meses. O fluxo de matrículas e eliminações era maior nas cadeiras da Vila. As informações apontaram o caráter dinâmico da Vila e mais estável do bairro e também a ruralidade cotidiana.

A seguir, a análise dos dados contidos nos livros tem como foco a compreensão das redes de relações estabelecidas em parte da sociedade cotiana entre 1870 e 1885, da 
diversidade social e de cor, enfim, das características de alguns dos sujeitos envolvidos no processo de escolarização de um dos diversos rincões do Brasil, a partir das informações pessoais dos alunos e de seus responsáveis.

\subsubsection{Dados pessoais e reflexões sobre a presença de "ingênuos", a diversidade social e de cor}

Todas as alunas da $1^{\text {a }}$ Cadeira Feminina da Vila eram naturais de Cotia e tinham em média aproximadamente dez anos de idade. No entanto, seguindo o que usualmente acontecia nas cadeiras públicas, a professora recebeu alunas de diversas idades, entre cinco e 16 anos. Abaixo está um gráfico referente à idade das alunas em cada ano letivo.

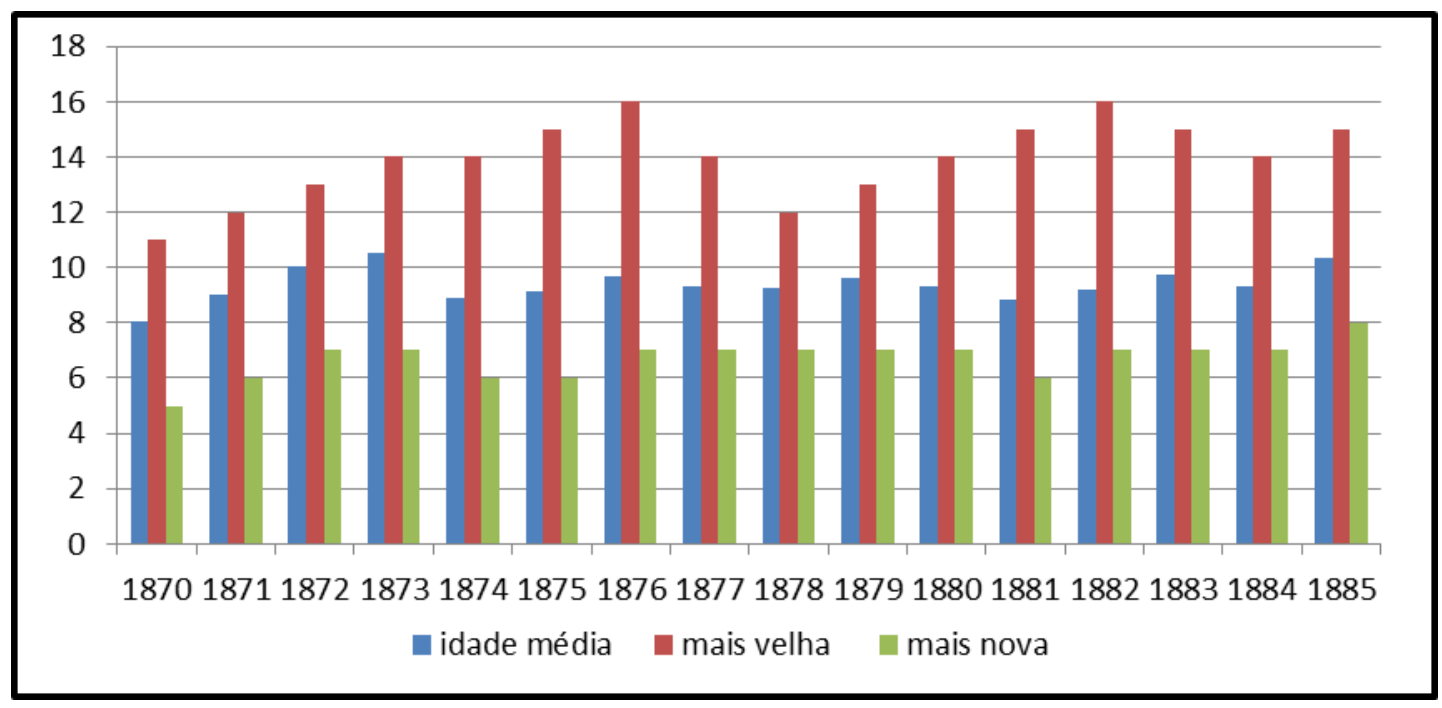

Ilustração 45 - Gráfico das idades das alunas - Cadeira Feminina da Vila (1870-1885).

Os responsáveis pelas alunas de Cadeira Feminina da Vila eram na maioria o pai, mas a mãe também aparecia como principal responsável em vários casos, seguidos de tutores/parente/outro ${ }^{300}$, conforme se verifica no gráfico abaixo:

\footnotetext{
300 "Outro" se refere ao registro apenas do nome da pessoa como responsável, não sendo possível saber se se tratava de parente ou tutor, ou ainda de um vínculo de outra natureza.
} 


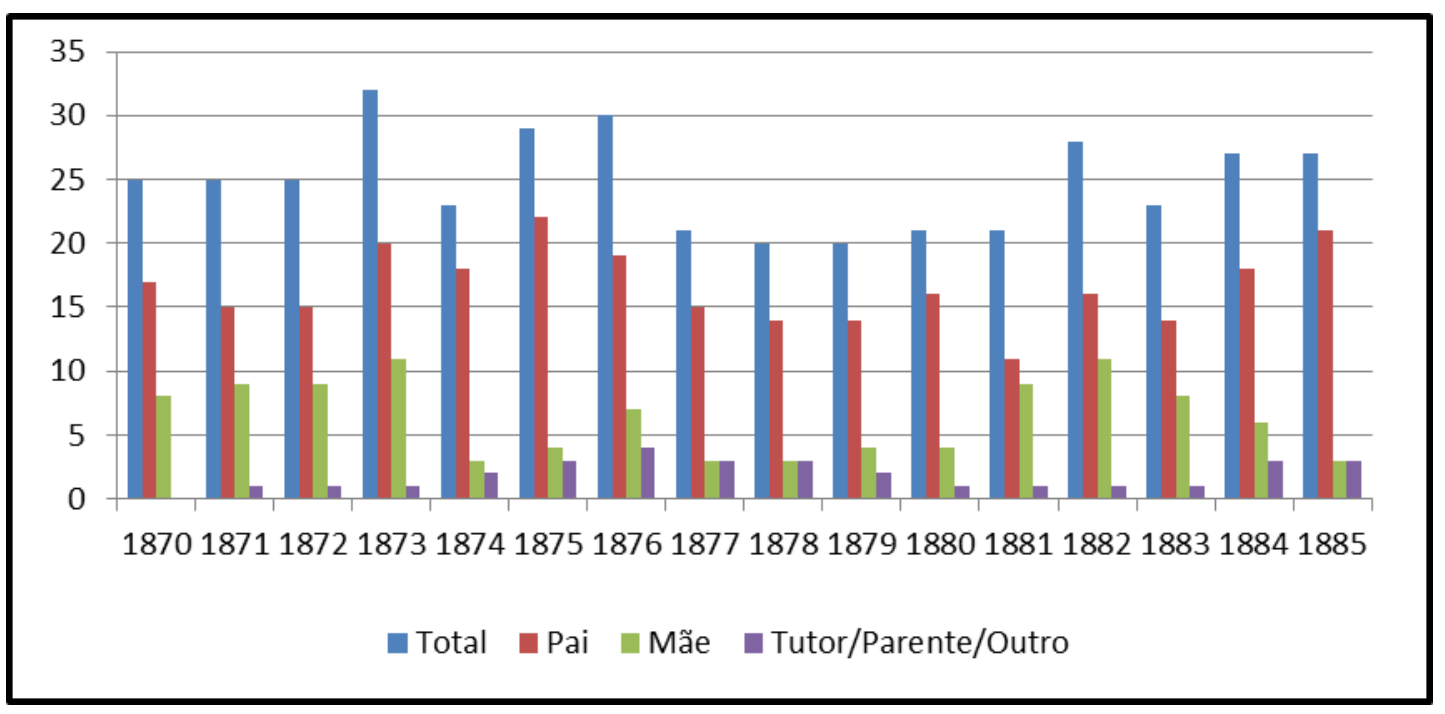

Ilustração 46 - Gráfico dos responsáveis pelas alunas - Cadeira Feminina da Vila (1870-1885).

Entre os responsáveis pelas meninas que estudavam com a Professora Maria Joanna do Sacramento estavam o ex-professor e inspetor de distrito Antonio Bandeira Barreto, o subdelegado e juiz de paz José Joaquim Pedroso (com quatro filhas, entre elas a futura professora Catharina Etelvina Pedroso), João José Coelho (com duas filhas e uma menina de que era tutor em decorrência de ter pais incógnitos), vereadores, tenente, alfaiate, sacristão, entre outros. Como mencionado anteriormente, Maria Joanna não qualificava suas alunas e seus responsáveis, por isso não houve possibilidade de saber se havia alunas "ingênuas".

Um dado levantado na sistematização das fontes é que muitas alunas iam estudar acompanhadas com outras do mesmo núcleo familiar, isto é, havia grande ocorrência de irmãs estudantes ou de meninas que moravam com o mesmo responsável (tutor, parente etc.). $\mathrm{O}$ ápice da ocorrência desses vínculos familiares na composição das turmas aconteceu em 1880, onde das 21 meninas matriculadas, 16 tinham vínculos com outras alunas, sendo irmãs ou morando sob a tutela do mesmo sujeito. Segundo o gráfico abaixo: 


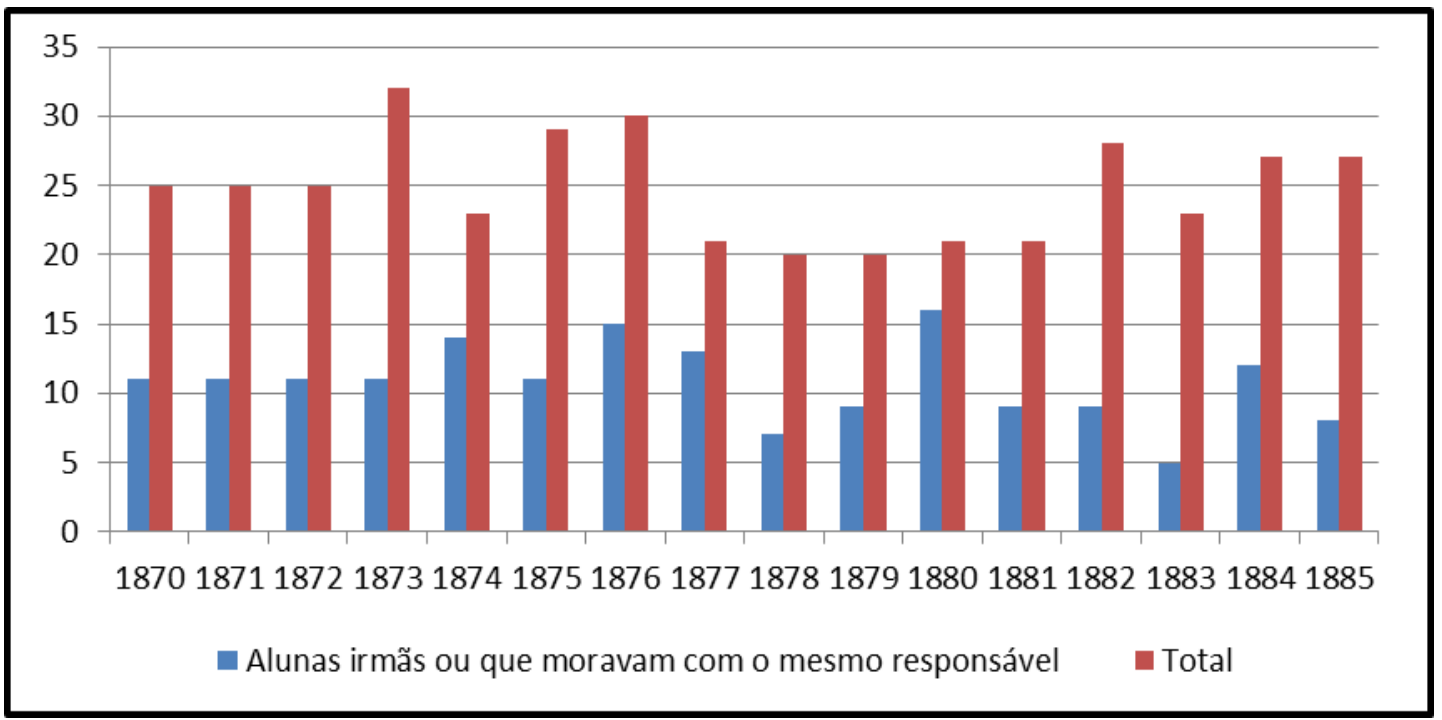

Ilustração 47 - Gráfico dos vínculos familiares - Cadeira Feminina da Vila (1870-1885).

Os meninos matriculados na $1^{\text {a }}$ Cadeira do Sexo Masculino da Vila de Cotia eram, em sua grande maioria, naturais de Cotia, mas houve a presença de alunos nascidos em M'boy, São Roque, São Paulo, Araçariguama, Tatuí e Nir Pereira (Portugal). Tinham entre seis e 17 anos de idade, e em média dez anos.

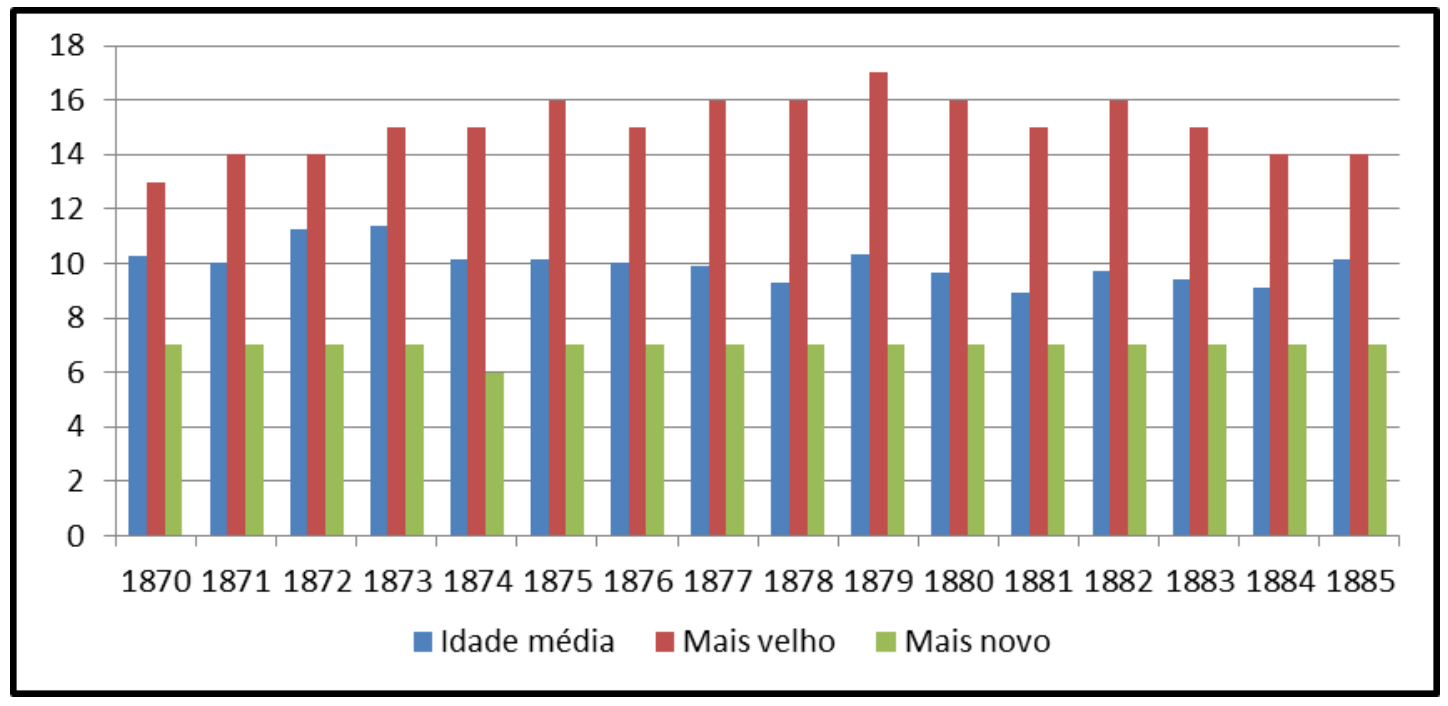

Ilustração 48 - Gráfico das idades dos alunos - $1^{\text {a }}$ Cadeira Masculina da Vila (1870-1885).

A maior parte dos responsáveis pelos meninos era os pais. Em alguns anos os tutores e parentes se destacaram entre os responsáveis em comparação com as mães, como mostra o gráfico abaixo: 


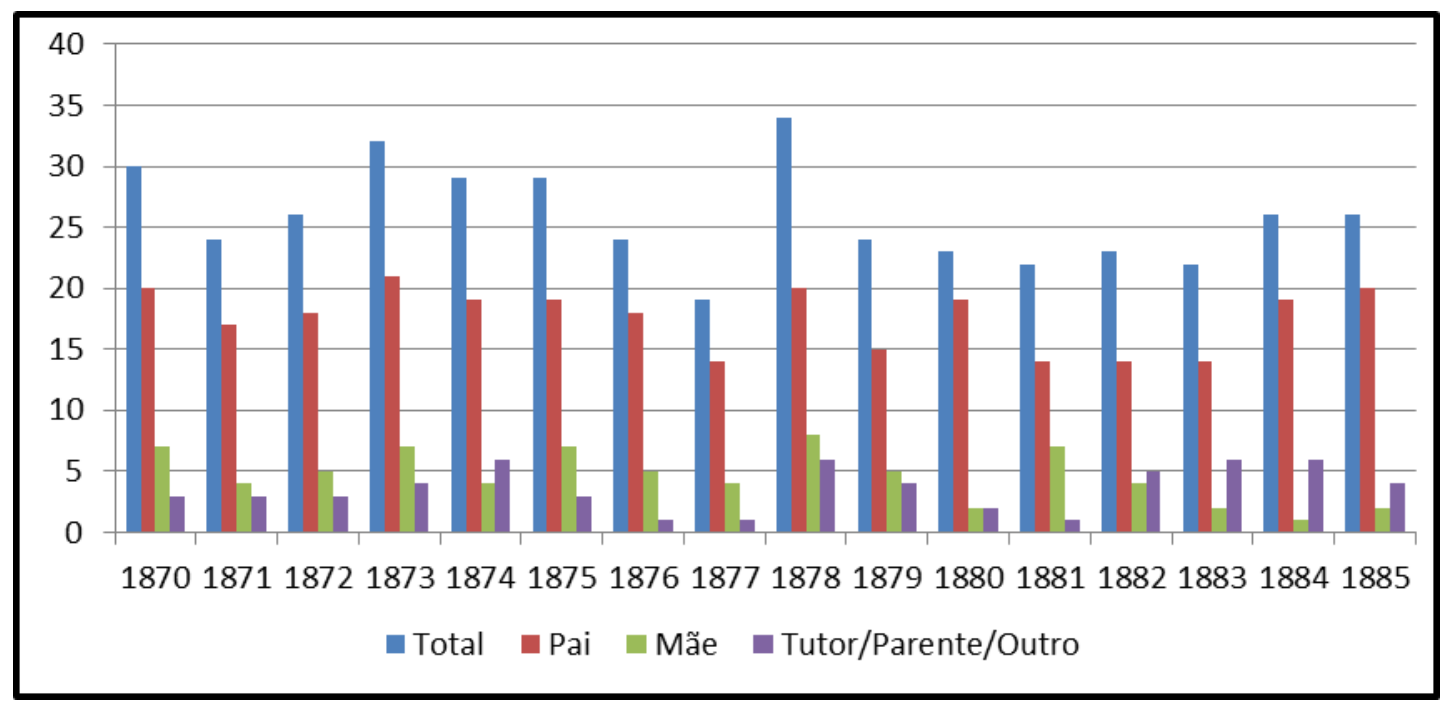

Ilustração 49 - Gráfico dos responsáveis pelos alunos - 1ª Cadeira Masculina da Vila (1870-1885)

Entre tutores de alunos estavam o próprio Professor João Jose Coelho (tutor de três meninos, dois filhos de sua escrava, e um filho de Antonio Barreto, que ele cuidou após a morte do pai em 1881) e o Vigário Manoel das Dores Rocha. O professor também teve ao longo dos 15 anos três filhos matriculados em sua cadeira, que contava ainda com filhos de vereadores, eleitores, ferreiro, alfaiate, negociantes, suplente de juiz de paz, do professor João Baptista Cepellos, do ex-professor e inspetor de distrito Antonio Barreto e do subdelegado e juiz de paz José Joaquim Pedroso (que em 1876 passou seu filho para a $2^{\text {a }}$ Cadeira junto com outros pais, como mencionado no terceiro capítulo).

Além de alunos com pais incógnitos havia também três meninos "ingênuos", registrados a partir de 1881. Dois eram José Vicente da Silva e Porfírio Rocha, filhos de Vicencia, escrava do próprio professor João José Coelho. O primeiro foi matriculado em 1881, aos sete anos, e o segundo em 1882, aos sete anos também.

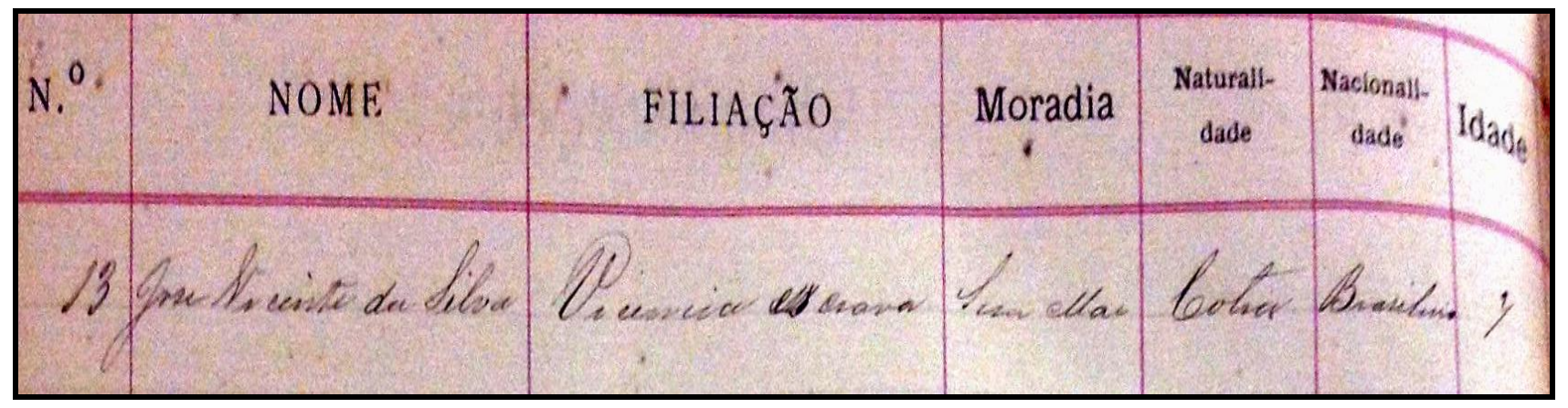

Ilustração 50 - Recorte do registro de matrícula José Vicente da Silva de 7 jan. de 1881 (Fonte: AESP, ref. EO3030, p. 18). 


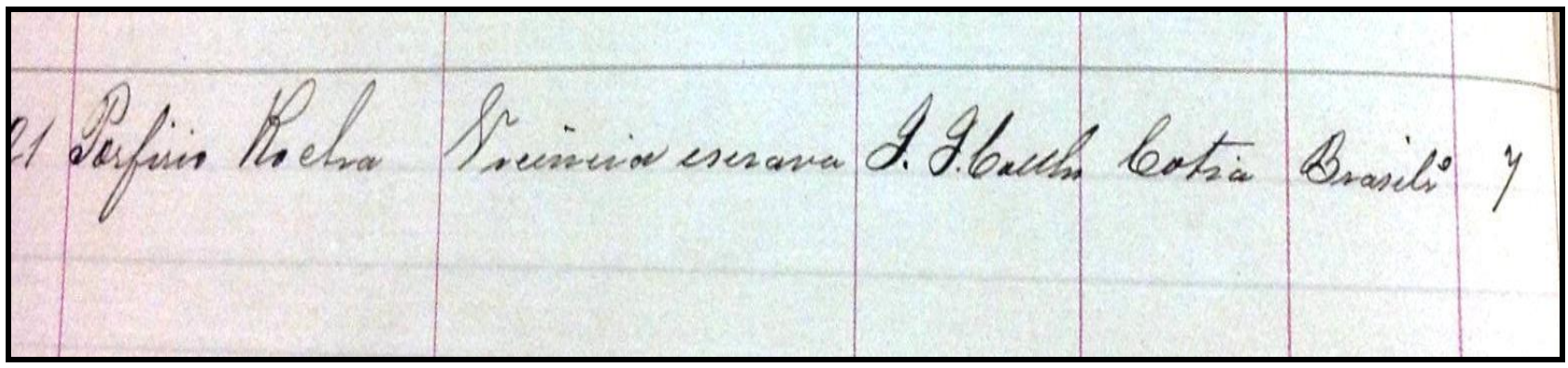

Ilustração 51 - Recorte do registro de matrícula Porfírio Rocha de 3 nov. de 1882 (Fonte: AESP, ref. EO3030, p. 33).

Como demonstra a ilustração 50, no livro de matrícula de 1881 não havia informação sobre de quem Vicencia era escrava, todavia no ano seguinte, constava que eles moravam com João José Coelho e, por meio de registro de batismo, consegui confirmá-lo como o senhor de Vicencia ${ }^{301}$. Não localizei o registro de batismo de Porfírio, mas o de José Vicente segue abaixo:

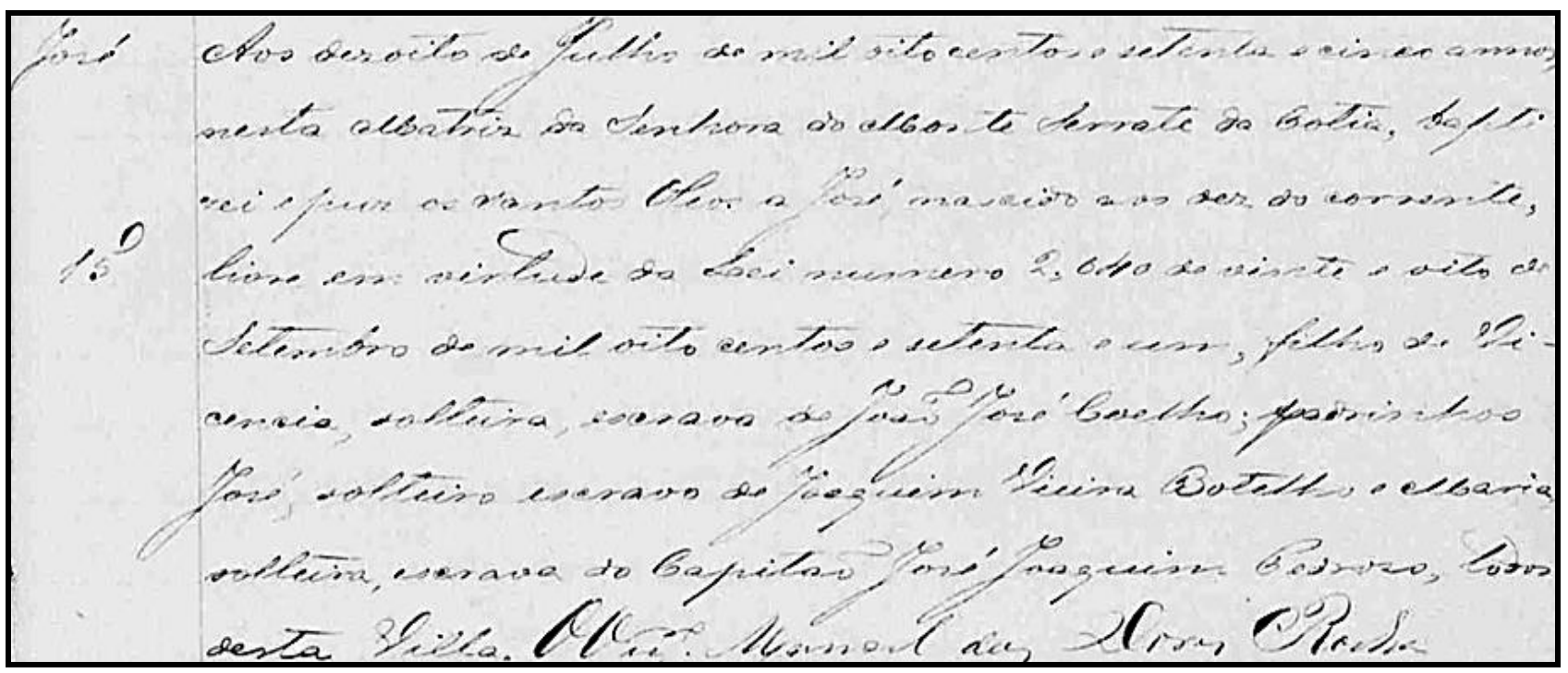

Ilustração 52 - Recorte do registro de batismo de José Vicente da Silva (Fonte: Livro de Baptisados de Livres e Captivos e Filhos de Escravos ${ }^{302}$ ).

O menino teve como padrinhos dois escravos de José Joaquim Pedroso. A madrinha Maria "solteira" pode ser a mãe do outro menino "ingênuo" matriculado em 1881 por João José Coelho na $1^{\text {a }}$ Cadeira Masculina da Vila. Era José Pedroso, com sete anos, filho de Maria "escrava", conforme o recorte do livro de matrícula:

\footnotetext{
${ }^{301}$ Além dos dois meninos, Vicencia tinha outra filha, nascida em 1881, também verificada no livro de batismos da Vila de Cotia. Disponível em <https://familysearch.org/pal:/MM9.3.1/TH-1-13507-26776951 ?cc $=2177299 \& w c=M 5 N B-82 Z: 372228201,372228202,372240001>$ Acesso em: 21 jul. 2015.

302 Disponível em <https://familysearch.org/pal:/MM9.3.1/TH-1-13507-269402-63?cc=2177299\&wc=M5NB82Z:372228201,372228202,372240001> Acesso em: 21 jul. 2015
} 


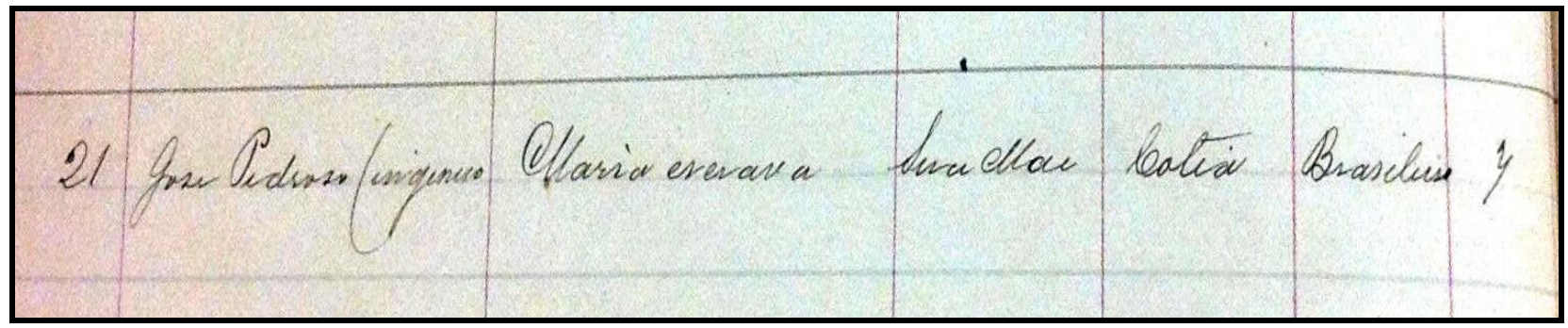

Ilustração 53 - Recorte do registro de matrícula José Pedroso de 4 jul. de 1881 (Fonte: AESP ref. EO3030, p. 19).

Uma mulher chamada Maria era escrava de José Joaquim Pedroso, como mostra o registro de batismo abaixo:

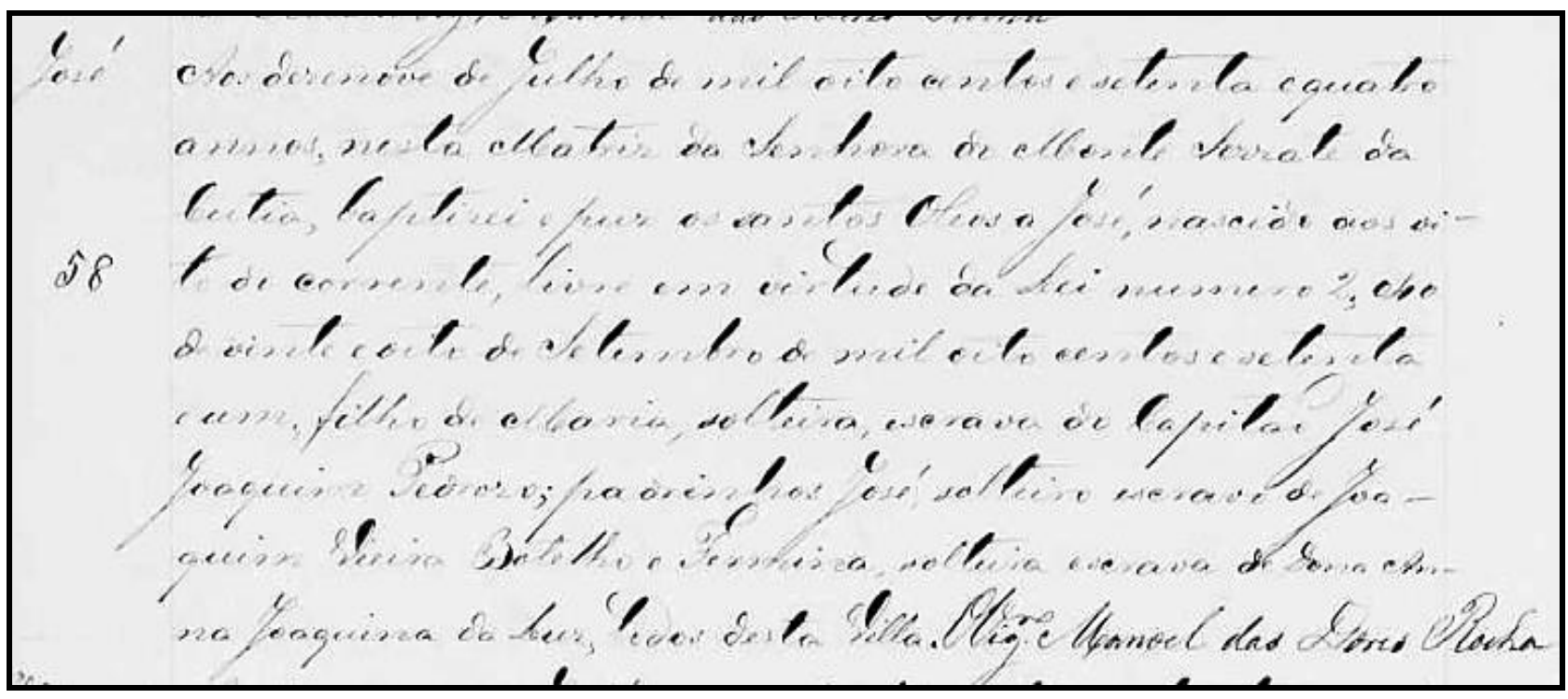

Ilustração 54 - Recorte do registro de batismo de José Pedroso (Fonte: Livro de Baptisados de Livres e Captivos e Filhos de Escravos ${ }^{303}$ ).

José estudou até 1884, sendo eliminado sem motivo informado, apenas que "retirou-se da eschola em 2 de julho de 1884". José adquiriu o sobrenome do senhor de sua mãe, José Jaoquim Pedroso. Ao procurar os nomes dos ingênuos a partir de 1871 no Livro de Baptisados de Livres e Captivos e Filhos de Escravos, da Vila de Cotia entre 1854 e $1888^{304}$, observei que há uma grande ocorrência de escravos de José Joaquim Pedroso, indicando que este era um grande senhor de escravos de Cotia, se não o maior, um dos maiores. Cabe

303 Disponível em <https://familysearch.org/pal:/MM9.3.1/TH-1-13507-269073-48?cc=2177299\&wc=M5NB82Z:372228201,372228202,372240001> Acesso em: 21 jul. 2015.

${ }^{304}$ Nele, há uma parte que se refere aos registros de batismos a partir da Lei do Ventre Livre, feitos entre 1871 e 1888. Disponível em <https://familysearch.org/pal:/MM9.3.1/TH-1-13507-26868134 ?cc=2177299\&wc=M5NB-82Z:372228201,372228202,372240001> Acesso em: 21 jul. 2015. 
ressaltar que a família Pedroso até hoje tem um forte domínio na política e na economia do município. Muitos alunos presentes nos livros de matrícula, especialmente da Vila, eram dessa família, mas não posso tirar conclusões sobre o pertencimento social de todos os alunos e pais de sobrenome Pedroso, pois, como o "ingênuo" José Pedroso, possivelmente outras famílias menos abastadas tivessem o mesmo sobrenome. Dentre os sobrenomes que se destacam pelo número de recorrências também estão Camargo, Pires, Leite e Oliveira.

Os registros de batismo mostram-se como documentos muito interessantes aos pesquisadores que tenham como sujeitos os filhos de escravas nascidos livres. De acordo com $5^{\circ}$ Parágrafo do Artigo $8^{\circ}$ da Lei do Ventre Livre: "Os párocos serão obrigados a ter livros especiais para o registro de nascimento e óbitos dos filhos das escravas, nascidos desde a data desta lei. Cada omissão sujeitará os párocos à multa de 100\$000”. Apesar de muito possivelmente não ter coberto a totalidade dos nascimentos de crianças "ingênuas", pois o batismo não era obrigatório, esses registros dão uma dimensão da quantidade de crianças filhas de escravas após a Lei do Ventre Livre. Em Cotia, apenas para ilustrar, contabilizei cinco batismos de "ingênuos" em 1871 (começaram em outubro), 20 em 1872, 16 em 1873, 22 em 1874, 20 em 1875 e 19 em 1876. No recenseamento de 1886, os filhos livres de mulheres escravas de Cotia matriculados e averbados até 30 de junho de 1886 totalizavam $156^{305}$.

Muitos alunos de João José Coelho eram irmãos ou tinham o mesmo responsável, como mostram os dados a seguir:

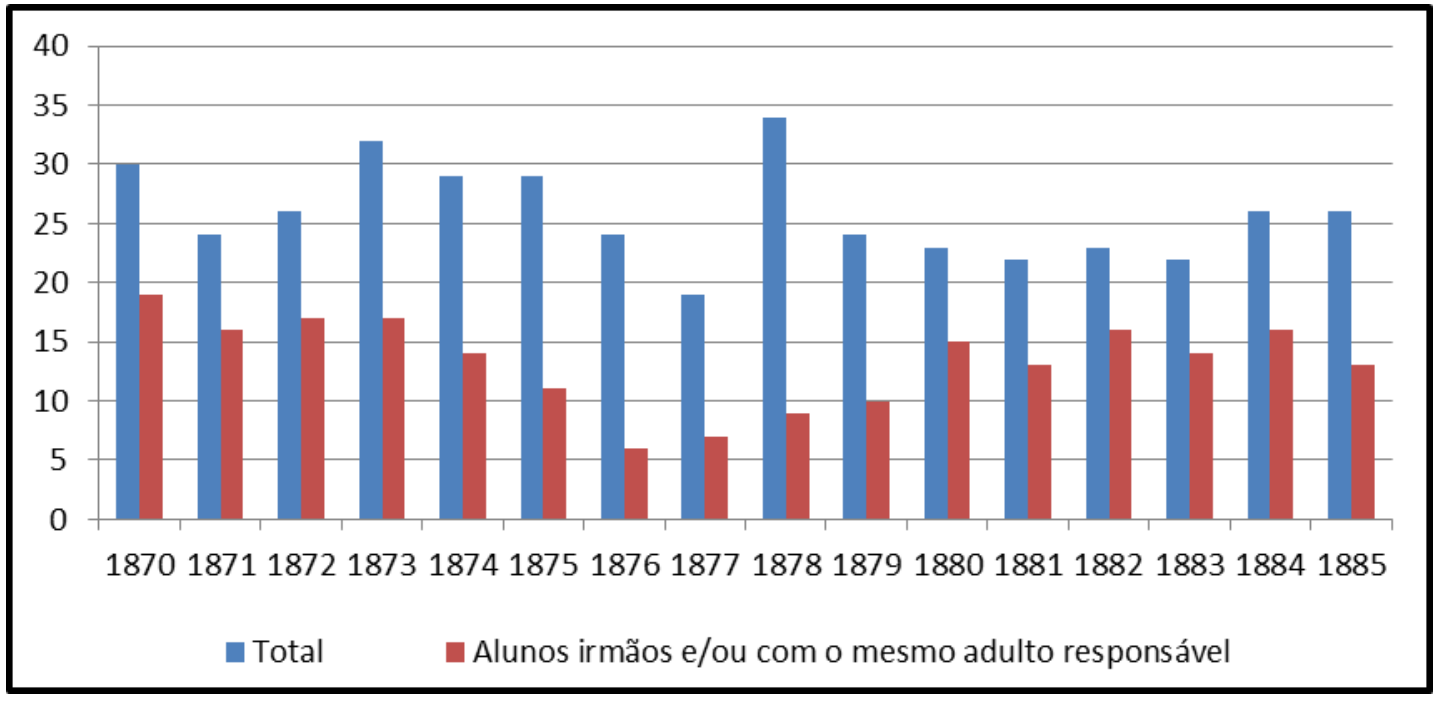

Ilustração 55 - Gráfico dos vínculos familiares - $1^{\text {a }}$ Cadeira Masculina da Vila (1870-1885).

${ }^{305}$ Relatório apresentado ao Exmo. Pres. da Província, 1888. 
Mais do que a Cadeira Feminina, a $1^{\text {a }}$ Masculina da Vila tinha sua turma composta por grande quantidade de alunos irmãos e/ou que eram tutelados pela mesma pessoa, indicando que iam e voltavam juntos da escola.

Os alunos da $2^{\text {a }}$ Cadeira do Sexo Masculino da Vila de Cotia de 1875 a 1882 eram todos naturais de Cotia e tinham em média dez anos, com idades oscilando entre cinco e 16 anos.

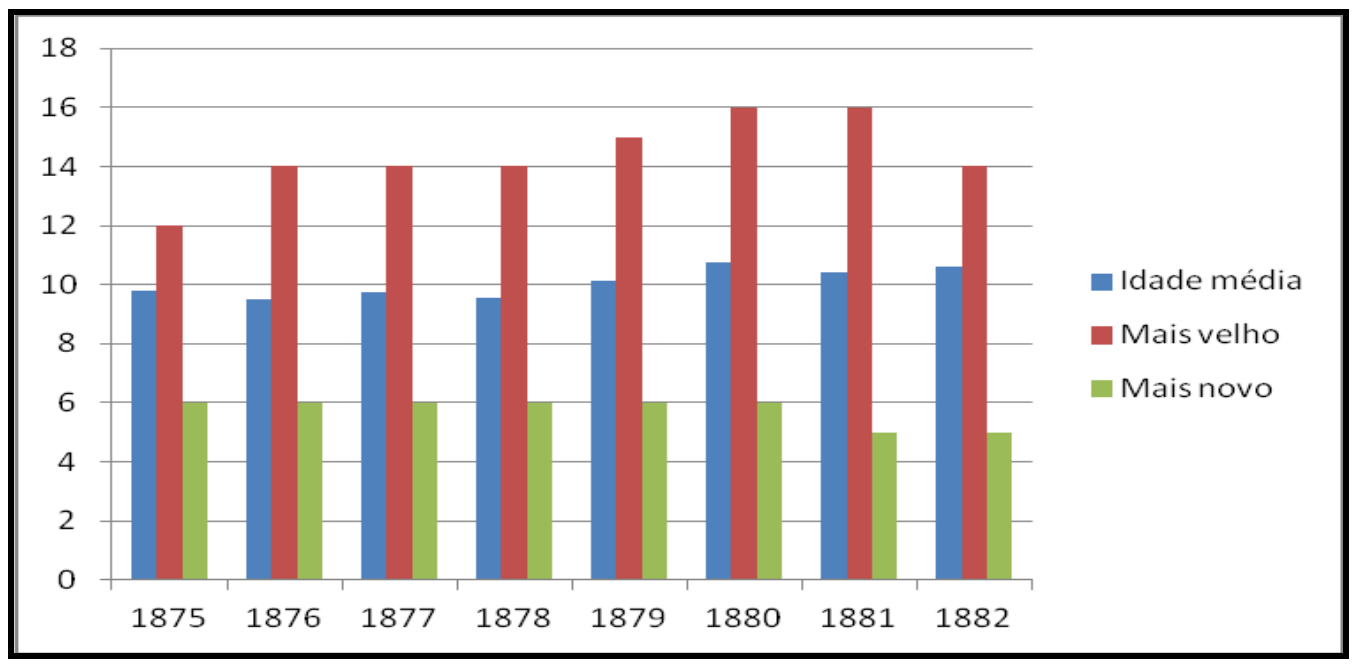

Ilustração 56 - Gráfico das idades dos alunos - 2 ${ }^{\mathrm{a}}$ Cadeira Masculina da Vila (1875-1882).

Os pais predominavam entre os responsáveis pelos meninos na maioria dos anos, mas em 1877 e em 1880 outros responsáveis como tutores e parentes se sobressaíram, indicando a grande quantidade de crianças que moravam com famílias que não seu pai e sua mãe. Veja o gráfico a seguir:

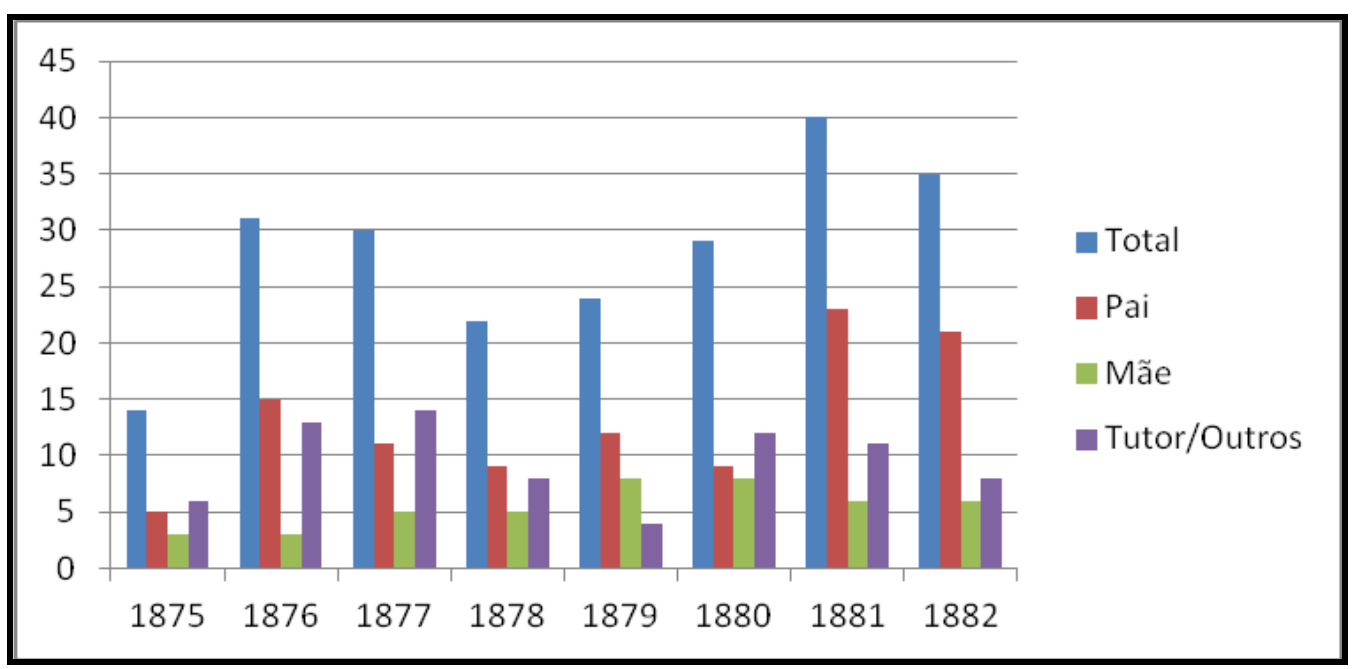

Ilustração 57 - Gráfico dos responsáveis pelos meninos - 2 Cadeira Masculina da Vila (1875-1882). 
Percentualmente, $47 \%$ tinham o pai como responsável, enquanto que $33 \%$ os tutores/parentes/outros e $20 \%$ as mães, indicando a diversidade na composição dos núcleos familiares. Entre os responsáveis pelos meninos havia o próprio Professor Marcolino, vereadores, eleitores, negociantes, o Vigário, o subdelegado e juiz de paz José Joaquim Pedroso, o inspetor de estrada e presidente da Câmara José Joaquim Pedroso Junior (com três meninos, dois filhos e um que morava com ele) e também os professores João Baptista Cepellos (que transferiu seus filhos da $1^{\mathrm{a}}$ para a $2^{\mathrm{a}}$ Cadeira) e José Custódio de Queiroz. Este professor era responsável por dois meninos, seu tutelado, matriculado em 1880, e um filho, matriculado em 1881, ambos permanecendo até 1882, último ano de registro do livro. Portanto, é impossível informar a data de suas eliminações. Nesse período, José Custódio era professor da Cadeira de Capitão Jerônimo, um bairro um pouco distante da Vila, onde ele lecionava na casa oferecida pelo vereador Jesuíno Pereira Leite. Como na lista de Marcolino os meninos moravam com José Custódio, há grande possibilidade de que esse professor fosse da Vila para Capitão Jerônimo lecionar nos dias letivos e morasse com os filhos na Vila.

A composição da $2^{a}$ Cadeira indicou haver mais filhos e/ou tutelados de pessoas influentes do que a $1^{\text {a }}$ Cadeira. Nela existiam alunos com pais incógnitos, com a mãe "liberta", com mães "solteiras", com pai "escravo" e mãe "livre” e com mãe "escrava", caso do aluno "ingênuo" José Pedroso, filho de Maria, escrava de José Joaquim Pedroso, já mencionado anteriormente, que passou da $2^{\mathrm{a}}$ para a $1^{\mathrm{a}}$ Cadeira em 1881 . A seguir está o recorte do registro de matrícula de José Pedroso na $2^{\text {a }}$ Cadeira:

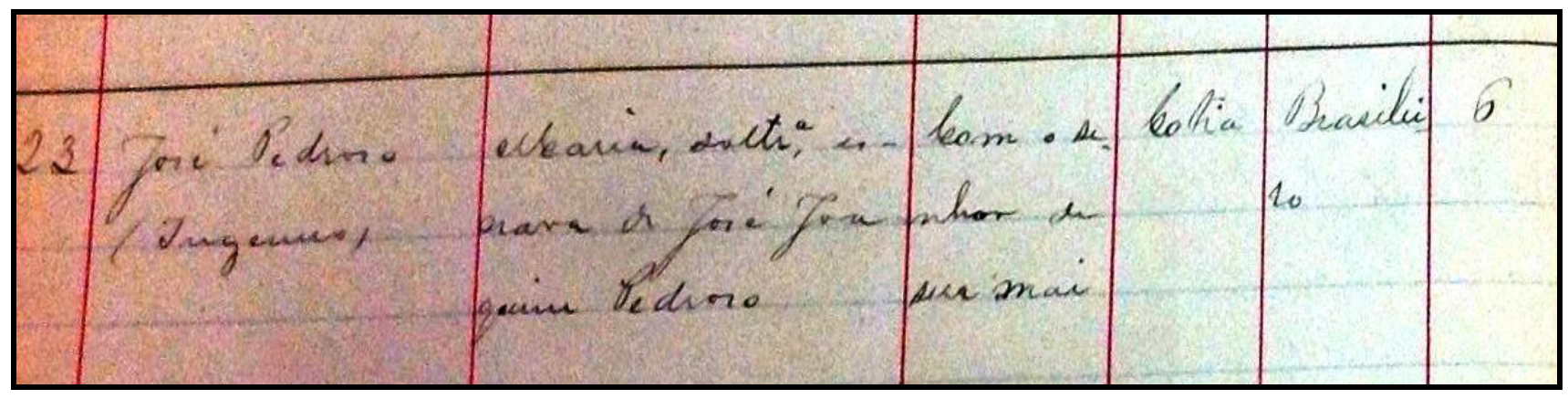

Ilustração 58 - Recorte do registro de matrícula de José Pedroso de 7 jan. 1881 (Fonte: AESP: EO2918, p. 34).

José Pedroso foi matriculado por Marcolino em 7 de janeiro de 1881, foi eliminado da $2^{\mathrm{a}}$ Cadeira sem nenhum motivo registrado, nem a data da saída, e foi matriculado na $1^{\mathrm{a}}$ Cadeira em 4 de julho do mesmo ano. Segundo a fonte, José Pedroso foi o único aluno 
“ingênuo" do Professor Marcolino. Será que sua presença incomodou o professor, os alunos e pais da $2^{\mathrm{a}}$ Cadeira a ponto de transferi-lo para a $1^{\mathrm{a}}$ ? Parece bem possível. Fato é que a cadeira de João José Coelho, naquele momento, contou com dois ingênuos, um filho de sua escrava (o outro filho de Vicencia foi matriculado por Coelho em 1882) e José Pedroso, transferido da cadeira de Marcolino. Todavia, os dois meninos filhos do mesmo casal "Galdino, escravo, e Ana Mendes Duarte, livre", matriculados em 17 de outubro de 1881, permaneceram na $2^{\mathrm{a}}$ cadeira em 1882, mas esses não eram "ingênuos", pois não eram filhos de mãe escrava, apenas o pai era escravo e a mãe livre.

A maioria dos meninos matriculados na $2^{\mathrm{a}}$ Cadeira ia sem irmão ou outro que morasse com ele na mesma casa, como mostra o gráfico abaixo:

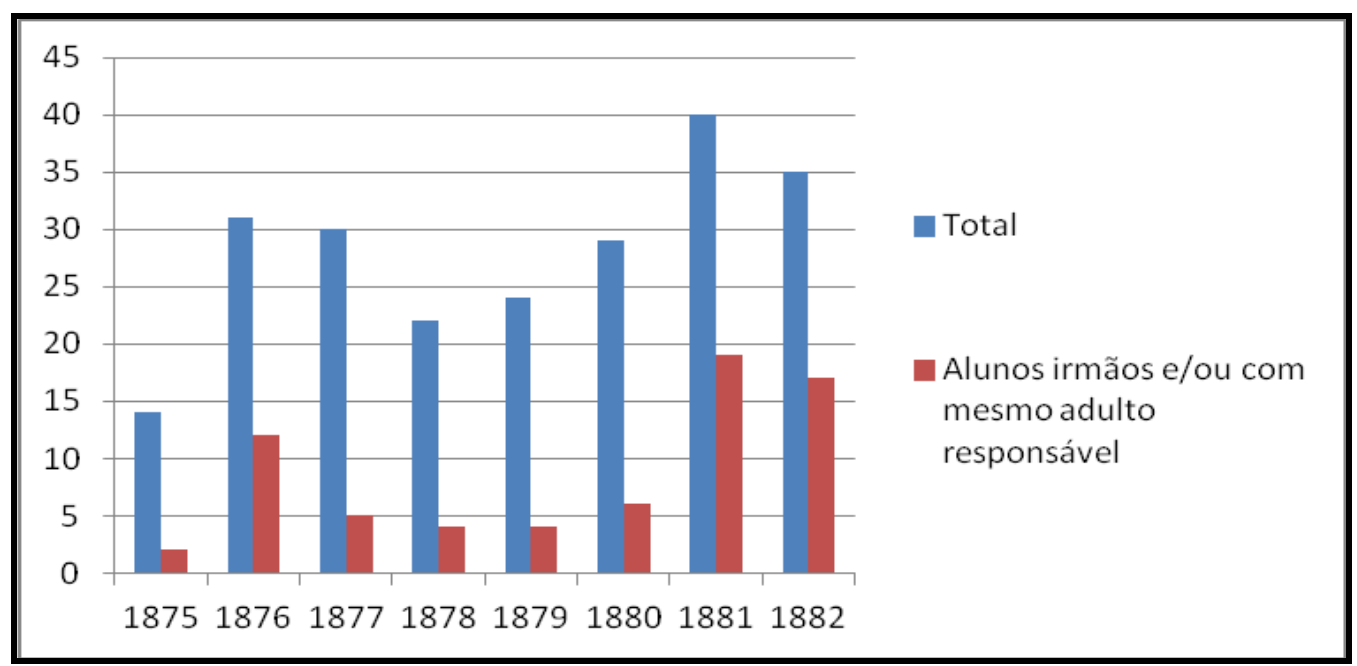

Ilustração 59 - Gráfico dos vínculos familiares - 2 ${ }^{\text {a }}$ Cadeira Masculina da Vila (1875-1882).

A última cadeira com livro coligido, a do Bairro de Capitão Jerônimo, apresentou uma média de alunos com idade de 11 anos, com destaque para a ocorrência de aluno com 20 anos de idade em 1884. 


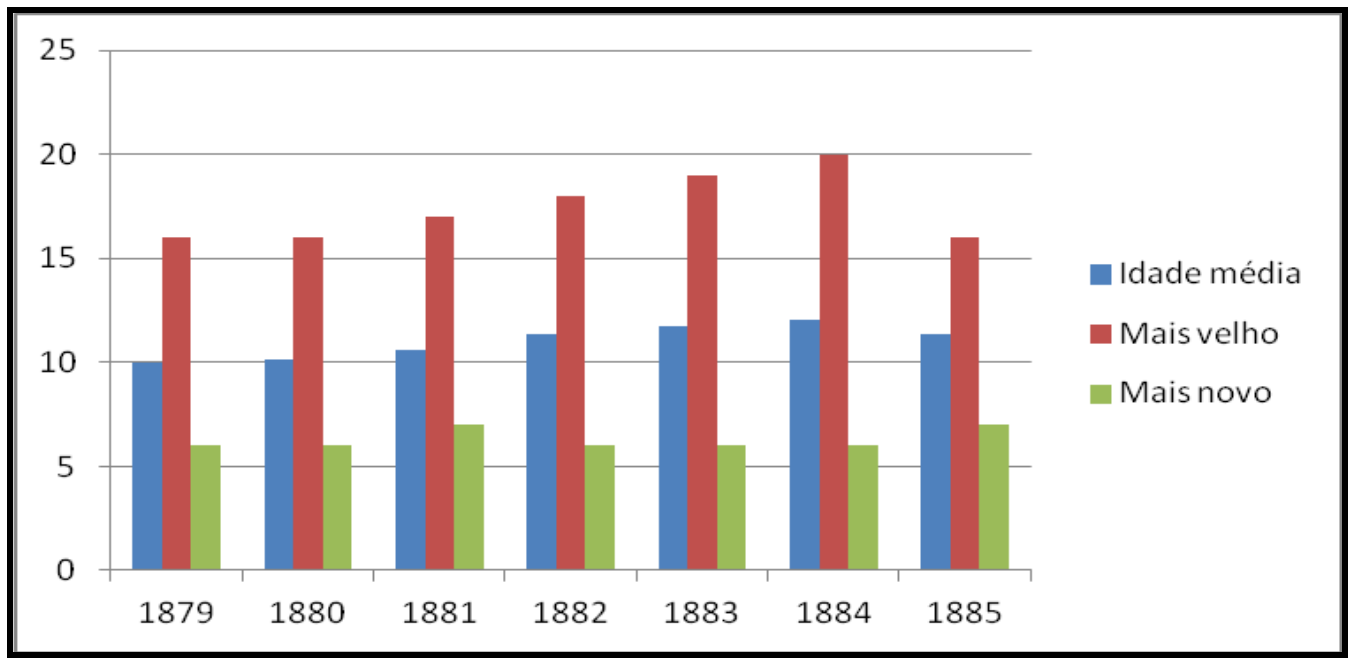

Ilustração 60 - Gráfico das idades dos alunos - Cadeira do Bairro de Capitão Jerônimo (1879-1885).

No bairro, poucos tinham como responsáveis tutores, parentes ou outros. A figura do pai se sobressaía, em seguida da mãe, ressaltando-se o fato de que em 1885, o número de mães como responsáveis estava próximo do número de pais. Dentre estes, destaca-se Jesuíno Pereira Leite, pai de seis alunos, vereador e quem cedeu a casa para José Custódio de Queiroz abrir a escola e poder lecionar. Como mencionado nos capítulos dois e três, era uma casa com melhores condições do que a indicada pelo inspetor de distrito.

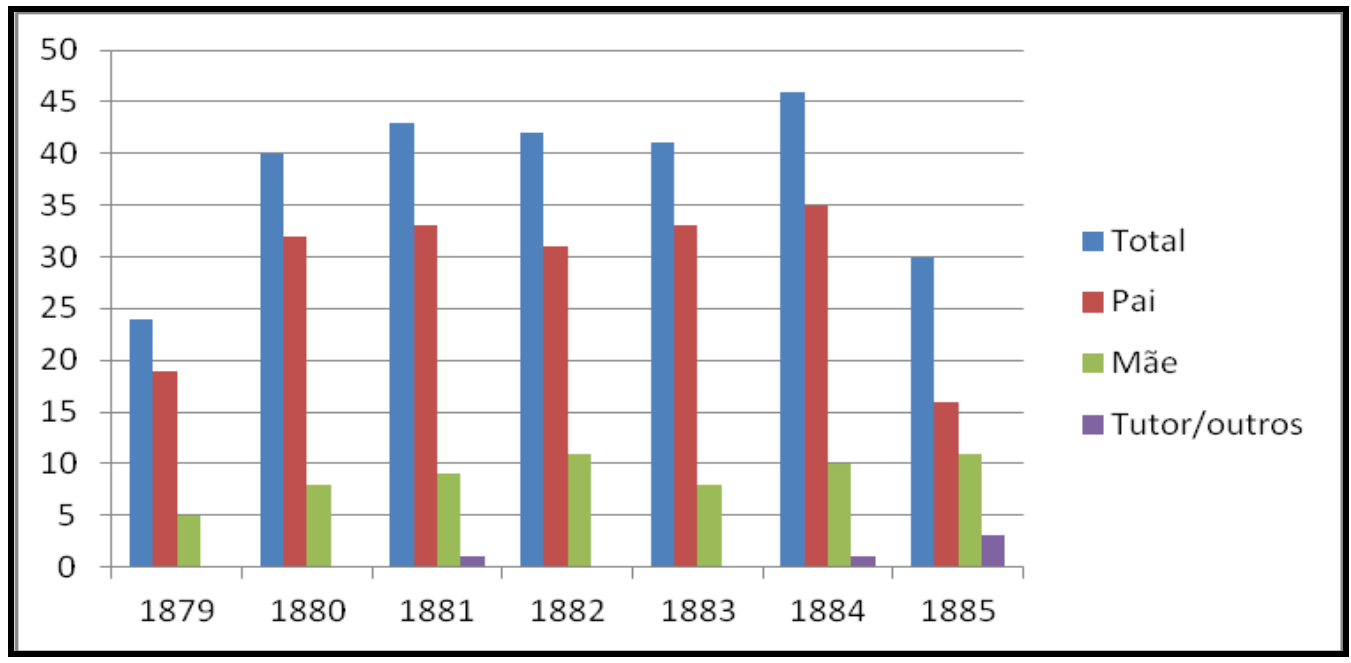

Ilustração 61 - Gráfico dos responsáveis pelos meninos - Cadeira do Bairro de Capitão Jerônimo (1879-1885).

Os dois professores dessa cadeira, José Custódio e Manoel de Moraes Pinto, assim como os professores das Cadeiras Masculinas da Vila, qualificavam os alunos e responsáveis. Chama a atenção o caso de Feliciano Pinto d'Oliveira, "pai incógnito", 12 anos, filho de 
Benedita "Escrava", e no campo "observações" registrou "Este ingenuo", conforme o recorte abaixo.

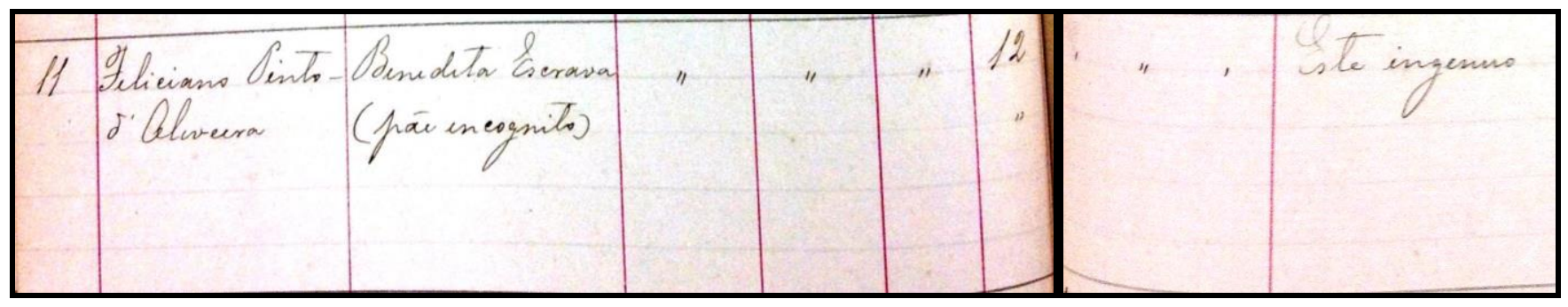

Ilustração 62 - Recorte do registro de matrícula de Feliciano Pinto d'Oliveira de 28 mar. 1884 (Fonte: AESP, EO3116, p. 41).

Feliciano morava com sua mãe e foi matriculado em 1884 por Manoel de Moraes Pinto, ficando até o ano seguinte, quando foi eliminado por ter incorrido no $2^{\circ}$ Parágrafo do Artigo 197 do Regulamento de 1869, registrado no campo “observações” pelo professor da seguinte maneira: "Ingênuo. Eliminado a 13 de junho de 1885, por não comparecer há três meses, sem causa participada, de que dei aviso a seu protetor". Benedita era escrava de Joaquim de Moraes Pinto, conforme excerto do registro de batismo de Feliciano inserido abaixo. Joaquim de Moraes Pinto consta na relação de vereadores entre 1887 e 1889, podendo ser a mesma pessoa. Todavia não tinha filhos ou tutelados na cadeira pública. Nota-se que Joaquim tinha o mesmo sobrenome do professor, mas não consegui dados para afirmar que fossem parentes em algum grau. 


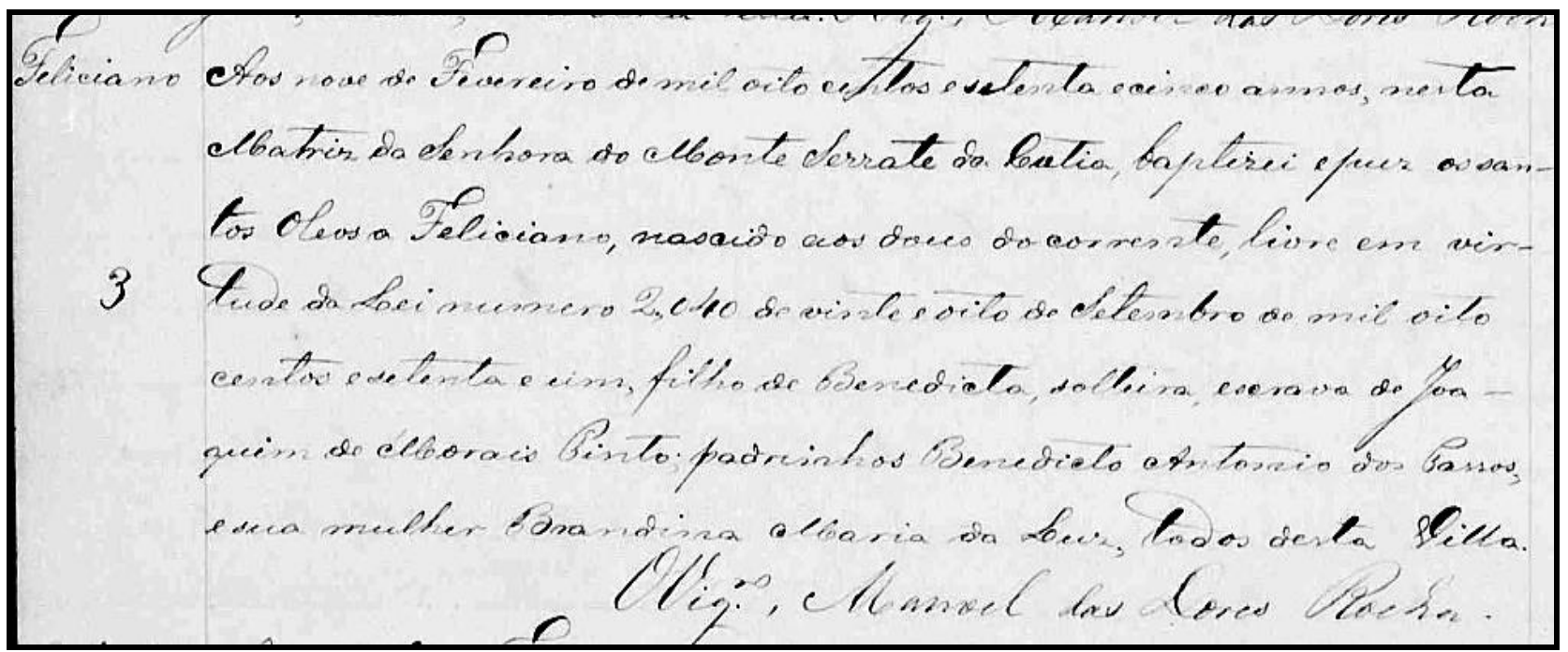

Ilustração 63 - Recorte do registro de batismo de Feliciano Pinto d'Oliveira (Fonte: Livro de Baptisados de Livres e Captivos e Filhos de Escravos $\left.{ }^{306}\right)$.

Como mencionado, o professor José Custódio tinha um filho e um menino que morava com ele estudando com Marcolino na $2^{\mathrm{a}}$ Cadeira da Vila. José Custódio lecionava numa casa de propriedade de um vereador que morava no bairro. Em contrapartida, quando o Professor Manoel de Moraes Pinto assumiu, em 1884, matriculou seus dois filhos nessa cadeira, que funcionava, segundo seus relatórios, numa sala do lado de fora de sua casa. E, em 1885, matriculou outro menino que morava em sua residência, portanto, o local onde funcionou a cadeira de Capitão Jerônimo na época do Professor Manoel não foi o mesmo da escola do Professor José Custódio.

Os números que dizem respeito à quantidade de alunos da Cadeira de Capitão Jerônimo com vínculos familiares entre si (sem contar primos) são bastante altos (68\%), isto é, aqueles que eram irmãos ou tinham o mesmo responsável, com destaque para o ano de 1880, no qual 31 alunos eram irmãos e/ou com o mesmo adulto responsável de um total de 40, conforme mostra o gráfico a seguir:

306 Disponível em <https://familysearch.org/pal:/MM9.3.1/TH-1-13507-268844-39?cc=2177299\&wc=M5NB82Z:372228201,372228202,372240001> Acesso em: 21 jul. 2015. 


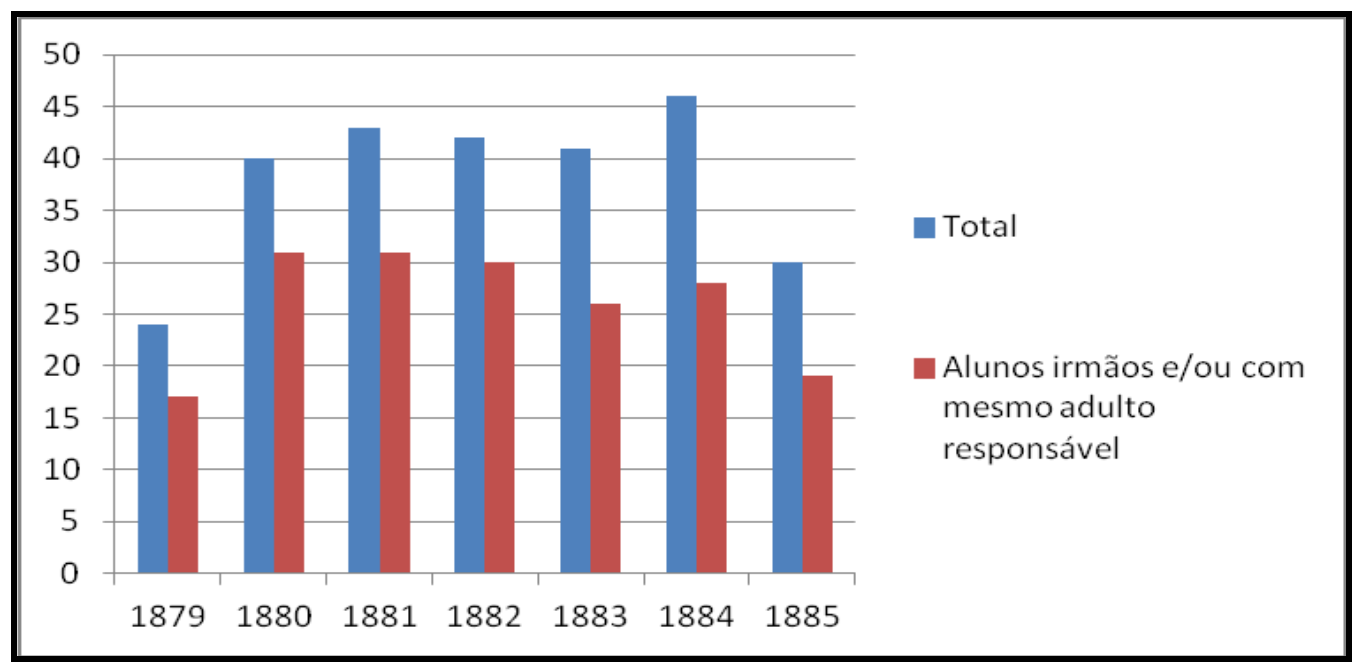

Ilustração 64 - Gráfico dos vínculos familiares - Cadeira do Bairro de Capitão Jerônimo (1879-1885).

Os dados sistematizados das quatro cadeiras demonstraram que os alunos tinham em média dez anos, a grande maioria era natural de Cotia e a maioria tinha o pai como responsável (65\%), mostrando que a família nuclear composta pelo pai como responsável era característica dessa sociedade. Do total, praticamente metade dos alunos ia para a escola acompanhada de irmã(o) ou outra criança que tivesse o mesmo responsável (49\%), enquanto que a outra metade não possuía esse tipo de vínculo (51\%), indicando que metade dos responsáveis optaram por enviar seus filhos e tutelados juntos, todavia o fato de que metade não ia acompanhado de outro membro da família pode indicar que a família não podia (talvez por razões econômicas) enviá-los todos para a escola. O entrecruzamento desses dados com outras fontes permitiu também desvelar que havia diversidade social na composição discente das cadeiras.

Dos cinco professores envolvidos na confecção dos registros dos livros de matrículas apresentados, quatro qualificavam alunos e pais com adjetivos que para a época poderiam soar como depreciativo. Com exceção de Maria Joanna do Sacramento, os professores usavam os termos "solteira", "escrava", "escravo", "ingênuo", sem que houvesse uma determinação na lei para que isso fosse revelado. Para as mães também houve o qualificativo "viúva", demarcando sempre uma referência às "ausências" da figura masculina na vida da mulher, sinal de uma sociedade patriarcal, pois "solteiro" e "viúvo" não eram usados para os homens.

Os professores não informavam as cores dos alunos, mas com os qualificativos “ingênuo" e dos pais "escravos", relacionados à condição jurídica dos indivíduos, alguns elementos sobre a diversidade de cor puderam ser desvelados, todavia, havia muitos livres e 
libertos entre negros e pardos em Cotia, além de caboclos, dado que impediu que esta pesquisa inferisse sobre a composição de cor na totalidade das turmas analisadas.

A historiadora Hebe Mattos (1998) investigou os significados de liberdade do Sudeste antigo $^{307}$ do Brasil, a partir principalmente de processos cíveis e criminais, e comprovou que a cor dos indivíduos influenciava nesses processos, servindo como um mecanismo de distinção social no Brasil colonial, se estendendo até a metade do século XIX. O dado "cor" estava ligado à condição jurídica do indivíduo.

Atrelar a cor à condição jurídica deixou de ser um dado evidente a partir da segunda metade do XIX, pois houve um aumento da população negra e mestiça e, dentro dela, um aumento de livres e libertos. Isso, segundo a autora, resultou na ausência da qualificação "cor" nos documentos da época.

Relacionando esse fato ao trabalho do historiador, Mattos apontou:

O sumiço do registro da cor consiste num dos processos mais intrigantes e irritantes, ocorridos no século XIX, do ponto de vista do pesquisador. Todos que tentaram trabalhar com a história do negro, após o fim do cativeiro, já se decepcionaram com a quase impossibilidade de alcançá-los, seja trabalhando com processos-crimes e até mesmo com registros civis. (MATTOS, 1998, p. 107).

Segundo sua pesquisa, a inexistência da menção sistemática da cor nos processos cíveis e criminais do antigo Sudeste ocorreu a partir de 1850 e 1860. A partir daí, não houve o desaparecimento total do quesito cor nas fontes, o que ocorreu, porém, foi seu aparecimento esporádico, registrado com a função a inferiorizar o indivíduo. Assim, os termos "pardo", "negro" e "preto" foram registrados como marcas, ainda, da escravidão. Diante desses apontamentos, mas considerando a condição jurídica e não a cor, os qualificativos "escrava", "escravo" e "ingênuo" dados pelos professores de Cotia aos pais e alunos matriculados mostram-se também com uma maneira de estabelecer fronteiras sociais, já que eles não eram obrigatórios nos documentos de instrução pública. Embora seja necessário considerar que os professores não tenham qualificado todos eles, complexificando ainda mais a análise e impossibilitando uma inferência mais precisa, não há como descartar totalmente a possibilidade de que esses qualificativos fossem colocados para inferiorizar os alunos e seus pais e mães. No entanto, a julgar pela sociedade escravista vigente, é bastante plausível que esse vestígio deixado pelos professores nos livros ratificasse uma fronteira jurídica e, consequentemente, social.

\footnotetext{
${ }^{307}$ Sul de Minas Gerais e Zona da Mata, Vale do Paraíba (fluminense e paulista) e Baixada e Norte Fluminense.
} 
A pesquisa em história da educação deve sempre considerar a sociedade racializada presente no Brasil desde sua colonização. Deixar a história da educação dos não-brancos à margem nas investigações da história educacional brasileira corrobora com a premissa de homogeneização cultural e racial, e de que no Brasil sempre houve uma democracia racial, de maneira que a racialização não influenciou a formação da instrução pública.

Não podemos esquecer que, no Brasil, a escravidão foi uma instituição que perdurou por quase quatro séculos e que se fez a partir da importação massiva de africanos e seus descendentes que penetraram em todas as dimensões da sociedade, estabelecendo influências que sempre caracterizaram o Brasil como nação. Desse modo, é praticamente impossível as narrativas históricas, entre elas a da educação, não levar em conta os negros. (FONSECA, 2007, p. 25).

Veiga e Rodrigues (2006) afirmaram a necessidade de

problematizar os múltiplos processos e lugares nos quais as identidades são constituídas e representadas. O entendimento das relações entre etnia e educação pressupõe, principalmente, a produção interrelacional de sujeitos, por meio dos códigos difusores dos modos civilizados de inserção social. Cabe-nos interrogar, dentre outras coisas, as dinâmicas de estigmatizações, de inclusão e exclusão propiciadas pela escolarização. (VEIGA; RODRIGUES, 2006, p. 34).

Como demonstrado, dentre os alunos das quatro cadeiras analisadas, no mínimo quatro eram "ingênuos", número bastante pequeno, sobretudo se levarmos em conta o número de batismos de "ingênuos" realizados em Cotia. Não tenho mais dados para apontar a composição "multicolorida" das cadeiras de Cotia, mas na medida em que houve a identificação de alguns alunos como "ingênuos", podemos afirmar que não eram apenas os brancos que estudavam. Cotia tinha em 1872 e 1886, segundo os recenseamentos, a presença expressiva de pessoas de várias cores:

\begin{tabular}{|l|l|l|l|l|l|}
\hline \multicolumn{7}{|c|}{ População total de Cotia segundo a cor - 1872 e 1886} \\
\hline & Brancos & Pardos & Pretos & Caboclos & Total \\
\hline 1872 & 2.646 & 1.505 & 574 & 299 & 5.024 \\
\hline 1886 & 5.891 & 964 & 436 & 226 & 7.517 \\
\hline
\end{tabular}

Ilustração 65 - Quadro da população total de Cotia segundo a cor - 1872 e 1886 (Fontes: Censo de 1872 e Relatório apresentado ao Exmo. Pres. da Província, 1888)

No Artigo 92 do Regulamento de 1869, não eram admitidos para matrícula: 
$\S 1^{\circ}$ As meninas nas escolas do sexo masculino, e os meninos nas escolas do sexo feminino.

$\S 2^{\circ}$ Os menores de cinco annos de idade.

$\S 3^{\circ}$ Os que padecem de molestia contagiosa.

$\S 4^{\circ}$ Os escravos.

$\$ 5^{\circ}$ Os que houverem sido expulsos por incorrigíveis. (Regulamento de 18 de abril de 1869 - Para Instrução Pública e particular da Província, 1874, p. 579).

A Lei $n^{\circ} 9$ de 22 de março de 1874, a que instituiu a obrigatoriedade de ensino para menores de 7 a 14 anos do sexo masculino, e 7 a 11 anos do feminino, não aludiu a essa questão, portanto, ficou valendo o Artigo 92 de 1869. Em Cotia, como mencionado no primeiro capítulo, em1872, havia 505 escravos entre pretos e pardos, constituindo um pouco mais da metade dessa população livre, já em 1886 eram 144 escravos, portanto, a grande maioria dos pretos e pardos era livre.

Esses dados corroboram para inferir que havia crianças pretas e pardas nas escolas, e também a população cabocla, principalmente se considerarmos a Cadeira de Carapicuíba, bairro onde havia uma aldeia. É muito possível que meninos caboclos estudassem ali. Cabe destacar que em 1874, o professor da Cadeira de Itaqui, Marcolino Pinto de Queiroz, registrou em seu relatório que acompanhava o mapa de frequência, que um de seus alunos fora eliminado devido à mudança para a Aldeia de Carapicuíba, dado que pode indicar que fosse indígena ou caboclo. Tomando ainda os apontamentos de Candido (2001a) e Petrone (1995), os caipiras se formaram basicamente pela mistura de branco com índio. Como Cotia participava da cultura caipira, é bastante plausível que meninos e meninas mestiças de índios e brancos estudassem nas escolas.

Em Cotia, antes da Lei do Ventre Livre, os professores João José Coelho e Maria Joanna do Sacramento registraram alunos libertos. Em dezembro de 1862, o inspetor Vigário José Manoel d'Oliveira informava em relatório ao Inspetor Geral da Instrução Pública que havia seis alunos libertos em cada cadeira pública da Vila (a masculina e a feminina), sendo 25 o total de alunos em cada cadeira. Dessa maneira, considerando que em cada cadeira, dos 25 alunos no total, seis eram ex-escravos (mais de $20 \%$ dos alunos), essas informações ajudam a desfazer "falsos pressupostos de proibição dos afrodescendentes de frequentar a escola no período imperial" (VEIGA; RODRIGUES, 2006, p. 40-41). Essa sinonímia entre escravo e negro, apontada por Veiga em seus trabalhos (2004, 2008 e 2010 e VEIGA; RODRIGUES, 2006), implica a consideração errônea de que nenhum negro no Brasil escravista frequentou a escola. Entretanto, no meio acadêmico, essa prerrogativa deixou de ser 
considerada há vários anos. Outros autores da área já assinalaram a presença de negros ${ }^{308}$ nas escolas, entre eles Silva (2000 e 2007) para o Rio de Janeiro e Pernambuco, Peres (2002) para o Rio Grande do Sul e Fonseca (2007) para de Minas Gerais.

Para São Paulo, Surya Barros (2005) abordou a presença (e ausência) de alunos negros nas escolas públicas da cidade de São Paulo entre 1870 e 1920, e verificou que antes da abolição dos escravos já havia negros (escravos e libertos) estudando nas escolas oficiais de São Paulo, submetidos a "sutis mecanismos de rejeição" (p. 168).

Em sua investigação, avaliou as estratégias relacionadas à educação dos negros articuladas pela elite branca, como política de modernizar a Província, civilizando o povo e condicionando-o à ordem do mundo do trabalho, mas apontou que na prática poucos negros frequentavam as escolas. Para Barros, o pequeno acesso desses alunos se dava pela tentativa das elites de manterem as hierarquias sociais presentes na escravidão, mesmo após sua abolição. Por outro lado, analisou o posicionamento da população negra e suas táticas. Segundo Barros, assim como as ações dos brancos, as ações dos negros eram entremeadas por embates e tensões. As táticas eram operadas por uma parcela da população negra ansiosa pelo direito de estudar. Porém, a pesquisadora localizou registros de casos de perseguição a alunos negros, malvistos pelos professores e colegas, o que considerou a decorrência da continuidade do pensamento escravista.

Apesar de 1871 ter sido o ano da aprovação da Lei do Ventre Livre, não houve menção à presença de alunos ingênuos ou da promulgação dessa lei em nenhum documento da instrução pública de Cotia, seja por parte de inspetor local, seja por professores. Dados sobre a frequência de alunos ingênuos aparecem apenas a partir de 1881 nas listas de matrícula. Considerando que os nascidos em 1871 estavam com sete anos em 1878, a entrada desses meninos na escola foi um pouco tardia, a não ser que os professores tenham passado a qualificar os alunos apenas em 1881, e que outros estivessem presentes antes desse ano.

A lei asseverava que:

$\S 1^{\circ}$ Os ditos filhos menores ficarão em poder o sob a autoridade dos senhores de suas mãis, os quaes terão obrigação de crial-os e tratal-os até a idade de oito annos completos. Chegando o filho da escrava a esta idade, o senhor da mãi terá opção, ou

\footnotetext{
${ }^{308}$ Utilizo esse termo, pois a maioria dos autores aqui apresentados o usou em seus trabalhos, a fim de generalizar as crianças mestiças, pardas, negras, enfim, as não-brancas, todavia, cabe assinalar que a maioria deles desenvolve em seus trabalhos uma discussão sobre as diferentes designações relacionadas à cor. Ainda que utilizem um termo genérico, a maior parte dos autores opta por utilizar, quando trata diretamente da fonte, o termo que nela aparece. Dessa forma, o termo "negro" é usado em quase todas as obras, como uma forma de generalização consciente, de maneira a facilitar a discussão.
} 
de receber do Estado a indemnização de $600 \$ 000$, ou de utilisar-se dos serviços do menor até a idade de 21 annos completos. (Lei no 2.040 de 28 de Setembro de 1871).

Dessa maneira, os "ingênuos" ficavam sob o poder do senhor de suas mães até os oito anos, com a obrigação de criá-los e tratá-los. A lei de obrigatoriedade escolar para crianças a partir de sete anos estava em vigor desde 1874, e tendo em vista o número de ingênuos nascidos em Cotia e os de matriculados, pelo menos em quatro cadeiras públicas, observa-se que a maioria dos senhores cotianos, de 1878 em diante, não cumpriu com suas obrigações, levando em consideração que a maior parte deles tenha ficado com o "ingênuo" após os oito anos completos. E é bastante possível que tenha ficado, baseando-se na pesquisa de Daniela Portela (2012).

Esta autora investigou o atendimento educacional à criança negra livre de 1871 a 1888 na Província de São Paulo, a partir de relatórios do Ministério da Agricultura, anais dos Congressos Agrícola do Recife e do Rio de Janeiro, ambos realizados no ano de 1878, registros de batismo de crianças "ingênuas", jornais da raça negra, entre outros.

Portela (2012) apresentou o processo de discussão da Lei do Ventre Livre e do futuro das crianças "ingênuas". Havia argumentos que ressaltavam a importância de os fazendeiros educarem essas crianças, possibilitando a geração de lucros - no congresso do Rio de Janeiro, alguns paulistas tinham um discurso de educar para formar mão de obra e prevenir a perturbação da ordem (p. 104). A maioria, porém, era favorável à imigração como forma de sanar a falta de braços. A autora constatou a carência de instituições voltadas para o seu atendimento em São Paulo e também averiguou que as crianças negras livres paulistas, em geral, não foram entregues ao Estado, mas permaneceram sob a tutela do escravocrata.

Como pesquisa de amostragem, a autora levantou os registros de batismo dos filhos de escravas nascidos livres da Freguesia do Ó (local de grande concentração de negros em São Paulo) a fim de "reconstruir, ainda que parcialmente, os aspectos privados da vida das crianças livres e de suas famílias escravizadas” (p. 131). A autora assinalou que os pais sabiam da importância da escolha dos padrinhos do filho "ingênuo", pois, de acordo com a lei, após oito anos completos, a criança poderia ser entregue ao Estado. "Sendo assim, tendo padrinhos com diferentes condições jurídicas, a criança livre estaria protegida em dois mundos distintos, dos quais ela acabava fazendo parte e nos quais podia transitar: o mundo escravizado e o mundo livre" (p. 143), ocorrência que ela verificou nos registros de batismo da Freguesia do Ó, pois a maioria dos padrinhos vivia em liberdade. 
Retomando a discussão do primeiro capítulo desta pesquisa sobre as parcas condições econômicas de Cotia - demonstradas a partir de uma grande quantidade de fontes - e sobre a precária condição financeira dos senhores de escravos locais - assinaladas especialmente por Wissenbach (1998) e Schleumer (1999), que afirmaram haver relações hierarquizadas, porém muito próximas entre senhores e escravos, chegando a primeira autora a aproximar os escravos a homens livres pobres -, indago: em que contexto e de que maneira a escolarização de Cotia possibilitou ser mais uma via de convivência entre livres e cativos, ou filhos de livres e filhos de cativos? O convívio desses alunos no ambiente escolar refletia a relação escravosenhor, na qual havia vínculos mais próximos de convivência no ambiente fora da escola do que em outras regiões mais ricas? Trabalhei com a hipótese de que sim, o convívio dos alunos "ingênuos" com os filhos de senhores no ambiente escolar refletia a relação escravo-senhor, com vínculos mais próximos de convivência no ambiente fora da escola do que em regiões mais ricas.

Ao analisar as fontes coligidas, observei que os professores em seus relatórios (que acompanhavam os mapas) não mencionaram a presenças de alunos filhos de escravos e não diferenciaram seus alunos pelas condições jurídicas, sociais ou por suas cores, mas mencioaram a pobreza presente entre os alunos e suas famílias de uma maneira geral, portanto, essas fontes não puderam desvelar se a escolarização de Cotia possibilitou ser mais uma via de convivência entre livres e cativos, ou filhos de livres e filhos de cativos. Porém, segundo os livros de matrícula, havia na mesma turma meninos filhos de escravos, filhos ou tutelados de negociantes, capitães, professores, ferreiros, Vigário, vereadores etc., confirmando a diversidade social e de cor da escola. Três professores diferenciaram os alunos, utilizando a designação “ingênuo". Quatro alunos assim identificados a partir de 1881 estiveram nas cadeiras da Vila e do Bairro de Capitão Jerônimo. Dois eram irmãos, José Vicente e Porfírio, e filhos da escrava do professor João José Coelho, que lecionava para vários meninos, entre eles três de seus filhos. Neste caso, muito possivelmente, a escolarização desses alunos funcionou também como a extensão da convivência desses meninos fora da escola. Mais do que isso, a casa deles era também a escola.

Outro "ingênuo" foi aluno de dois professores, primeiramente de Marcolino e depois de João José Coelho. José Pedroso, o menino, era filho da escrava de José Joaquim Pedroso, um dos homens mais poderosos de Cotia naquele momento. No ano de seu primeiro registro de matrícula, 1881, na cadeira de Marcolino havia muitos alunos filhos das pessoas mais influentes do local, inclusive havia netos de José Joaquim Pedroso. O menino José estudou pouco tempo na $2^{\mathrm{a}}$ Cadeira, não havendo nenhum registro de sua saída e aparencendo no livro 
de matrícula em julho de 1881 entre os alunos de João José Coelho, onde ficou até 1884. Neste caso, a convivência dentro da escola não contemplou a hipótese da pesquisa. O caso, inclusive, sugere uma segregação entre os alunos. Por outro lado, José Pedroso foi para uma turma onde havia um de seus "pares" (unidos propositalmente pelos professores e inspetor de distrito?) e onde o professor talvez não se incomodasse com sua presença.

É plausível também considerar que os professores que registraram os três meninos "ingênuos" acima citados, tenham feito porque eram filhos de escravas ou de sua propriedade (no caso de João José Coelho) ou de um dos sujeitos mais influentes da Vila (no caso, José Joaquim Pedroso), não eram filhos de escravas de pessoas que não faziam parte do núcleo de potentado local. Todavia, são apenas conjecturas, pois não há elementos concretos para afirmar que foram "abertas exceções" de matrícula para esses filhos de escravas, pois não tive acesso a mais livros de matrícula e não pude comprovar se filhos de escravos de roceiros e sitiantes pobres (como os verificados na pesquisa de Wissenbach, 1998) também frequentaram a escola. Além disso, como já mencionado, talvez outros meninos "ingênuos" foram matriculados e não foram assim qualificados pelos professores das cadeiras dos livros coligidos.

O quarto menino, Feliciano, aluno da Cadeira de Capitão Jerônimo, era filho da escrava de Joaquim de Moraes Pinto, possivelmente o homem que anos depois se tornaria vereador, mas não tinha filhos matriculados naquela cadeira. Sobre este caso não há muito o que inferir, apenas gostaria de ressaltar que estavam matriculados também seis filhos de Jesuíno Pereira Leite, vereador de Cotia naquele momento. Assim, cabe ressaltar a convivência na escola por cerca de um ano de Feliciano com alunos de vários estratos sociais, sendo eliminado em meados de 1885, devido à ausência de três meses consecutivos nas aulas, ausência que o professor "avisou" a seu "protetor".

Os relatórios de professores apontaram que muitos alunos eram trabalhadores, mas importa destacar a criança negra trabalhadora, que se apresenta como dado importante a se considerar. Não é difícil pensar que Feliciano, deixando de comparecer à escola, estivesse envolvido no mundo do trabalho. Se para muitos pais e mães das crianças brancas e livres, em Cotia, as condições eram precárias e as necessidades cotidianas como o trabalho vinham em primeiro plano, pode-se afirmar que eram ainda mais intensas para os pais e mãe negros e escravos.

Por fim, sinteticamente, podemos asseverar que este capítulo demonstrou um quadro geral dos números de alunos matriculados em escolas públicas de Cotia ao longo de 15 anos, com destaque para a grande quantidade de meninas que frequentaram escolas particulares no 
início dos anos de 1870. Também demonstrou os motivos da falta de frequência e das eliminações dos alunos segundo as especificidades locais, o cotidiano ruralizado, a partir da discussão do entrecruzamento dos tempos e espaços sociais e escolares.

Este capítulo ainda apresentou uma análise mais detalhada dos alunos e suas famílias a partir dos dados contidos nos livros de matrícula e em alguns registros de batismo. Dessa maneira, evidenciou as diferentes formas dos professores qualificarem (ou não) seus alunos nos livros de matrícula, segundo valores escravistas e patriarcais, e também demonstrou que as escolas públicas de primeiras letras de Cotia não eram um privilégio dos mais abastados e nem existiam estritamente com o propósito de educar os pobres, mas eram constituídas de meninos e meninas de diversos estratos sociais. Apesar da ordem escravocrata e de muito possíveis "sutis mecanismos de rejeição" (BARROS, 2005), ou talvez não muito sutis, a diversidade de cor e social estava presente nas cadeiras, característica comum da escolarização das Províncias, como a historiografia da educação assinalada ao longo deste trabalho tem apontado, ainda que existissem algumas particularidades locais. No caso de Cotia, destaquei a presença de alguns "ingênuos" e dos filhos do senhor da mãe desses meninos na mesma cadeira, indicando a aproximação do filho do senhor com o filho do cativo e os reflexos da vida cotidiana dessas crianças no ambiente escolar. 


\section{CONCLUSÃO}

Compreender o processo de escolarização brasileira no século XIX e as condições para seu estabelecimento nos diversos rincões do Brasil requer que o pesquisador da história da educação considere as especificidades de cada lugar. Entender as relações que se estabeleceram entre o modo de vida local e a institucionalização do ensino, as “consequências” sociais, culturais e políticas da escolarização (FARIA FILHO, 2002) foram as pretensões desta pesquisa, que investigou como foi o processo de escolarização num município situado nos arredores da Capital de São Paulo, com características de uma sociedade rústica nos moldes paulistas, a caipira. A Vila de Cotia, ao longo do século XIX, passou por um relativo "apogeu" econômico advindo do tropeirismo, mas a partir dos anos de 1870 sofreu um processo de retração econômica em decorrência do advento da cafeicultura e da instalação de ferrovias.

Com a pergunta central: como foi o processo de escolarização na Vila de Cotia, município vizinho de São Paulo com características culturais caipiras, num momento de retração econômica e que, a despeito disso, teve a oferta de cadeiras públicas aumentada? Salvaguardando o limite das fontes, a presente pesquisa trouxe documentos que auxiliaram na compreensão do contexto local (ora inserido e ora à margem da lógica econômica provincial e nacional) e da institucionalização do ensino, que puderam descortinar ao menos uma parte de seu processo de escolarização, de 1870 a 1885, além de estudos bibliográficos que auxiliaram nesse intento.

Os dados mostraram que a Vila de Cotia fez parte de uma importante rota de passagem para a expansão territorial e comercial em tempos coloniais, e que na segunda metade do século XIX sua economia se constituía em subsistência, abastecimento da Capital e manutenção e abastecimento de tropas. A composição social era representada principalmente por sitiantes e roceiros. As parcas condições materiais, características da sociedade caipira, ficaram evidentes na relação entre senhor e escravo, indicando a proximidade entre eles, sem a presença de um moderador nessa relação, como o feitor.

Ainda que pobreza e a decadência no fim do século XIX fizessem parte do cotidiano cotiano, acontecimentos economicamente importantes ocorreram no período estudado, como a construção de duas estações ferroviárias da Companhia Sorocabana. Todavia, na contramão do que aconteceu em muitos municípios de São Paulo, as estações não alavancaram a economia local, pelo contrário, a economia sofreu um impacto negativo. Segundo 
Langenbuch (analisando também outros municípios que tiveram retração econômica com a implantação das linhas férreas), Cotia sofreu por ter uma redução de travessias nas estradas locais e por estar relativamente perto da ferrovia, tendo seu "modesto papel de núcleo polarizador local suplantado" (1971, p. 122). Essas mudanças advindas da ferrovia e declínio do tropeirismo também se relacionaram com a escolarização local, pois a criação de algumas cadeiras estava diretamente atrelada a esses fatos.

No processo de instalação das escolas mostrado por meio de mapas cartográficos, verifiquei que a localização geográfica das cadeiras em Cotia, ao longo do recorte temporal pesquisado, partiu da Vila em direção aos bairros. A Vila nesse período teve quatro cadeiras, duas femininas e duas masculinas, confirmando o aumento populacional e da demanda. No momento de retração econômica, duas escolas foram criadas e passaram a funcionar na Vila sem nenhuma interrupção ao longo dos 15 anos analisados, além das duas que já funcionavam.

As caraterísticas econômicas dos bairros eram, basicamente, ligadas à produção agrícola, ao tropeirismo, às estações férreas e à criação de animais. Socialmente, predominavam trabalhadores agrícolas. Os elementos relacionados à história dos bairros permitiram refletir sobre suas demandas e a influência de potentados políticos na escolarização.

Das 11 cadeiras que efetivamente funcionaram entre 1870 e 1885, quatro estavam na Vila e sete nos bairros, figurando um processo de interiorização da escolarização, comum em todo o Brasil. Algumas delas foram criadas em decorrência da influência de potentados locais. Com características parecidas no que se refere à rusticidade e à ruralidade, elas se diferenciavam com relação à origem e função do povoamento. Os locais de instalação das cadeiras confirmaram o período de mudanças na dinâmica socioeconômica de Cotia, pois se situaram em bairros ligados ao decadente tropeirismo e outros ligados à estação de trem. Todavia, a pesquisa verificou que houve retenção de demanda em bairro onde houve a construção de uma estação (Itaqui) e, em contrapartida, ainda que num momento de declínio do tropeirismo, houve uma grande demanda por escola num bairro ligado a passagem de tropeiros (Capitão Jerônimo).

As fontes confirmaram que quase todos os professores que atuavam nas escolas da Vila tinham a permanência estável (com exceção apenas da Professora Analia Franco), não se removendo para outras cadeiras, já os das escolas dos bairros apresentaram instabilidade, pois permaneceram por pouco tempo frente a elas. O fato possivelmente teve relação com a característica de bairros caipiras, marcados pela rusticidade, pelo mínimo social e mínimo 
vital (CANDIDO, 2001a), dos quais os professores preferiam se transferir para outros municípios, para a Vila ou para bairros mais próximos dela. Destacou-se, entre os professores, José Custódio de Queiroz, professor que assumiu cinco cadeiras em 15 anos, todas em Cotia, mostrando-se como um personagem "coringa" na escolarização local.

Os dados demonstraram que passaram por Cotia 14 professores públicos com características diferentes entre si. Houve aqueles que, ao que tudo indica, sempre estiveram em cargos relacionados à instrução e outros que transitavam em diferentes setores exercendo outras funções, ora ligados ao campo de segurança pública, ora da justiça, mas também no campo das artes, da filantropia ou integrando partido político. Quase todos os professores que transitaram em outros segmentos, segundo o fio do nome (GINZBURG; PONI, 1991) percorrido por esta pesquisa, estiveram primeiramente atuando como professores para depois exercerem outras funções, enquanto apenas um professor apresentado (João José Coelho) exerceu outra função no mesmo município antes da atuação no magistério, fato que sugeriu que sua inserção na docência tenha sido favorecida por relações com os potentados locais.

Assim, as fontes mostraram que a maior parte dos professores era composta por sujeitos que não estavam em outros postos locais que facilitassem o acesso à docência. Contudo, as variadas funções exercidas por alguns professores públicos após a vida ligada ao magistério, sugeriram que o trânsito deles em outros setores foi facilitado em virtude da rede de relações estabelecidas a partir do cargo de docente. Essa rede de relações também pareceu ter grande influência na trajetória do Professor João José Coelho, que transitou em vários setores da vida pública de Cotia e, mesmo sendo denunciado pelo excesso de funções e por outras "peculiaridades", continuou atuando no magistério. As fontes coligidas proporcionaram construir a figura de um homem com poderes locais que o "blindavam", um sujeito de prestígio e pertencente ao núcleo do potentado político.

Também apresentei algumas práticas comuns entre os dois professores da Vila que também foram casados desde 1873, Maria Joanna do Sacramento e João José Coelho, corroborando com o conceito de lar docente (MUNHOZ; VIDAL, 2014) na partilha de seus saberes (nos relatórios que acompanhavam os mapas de frequência e no preenchimento dos livros de matrícula), entretanto, em uma das práticas foram significativamente diferentes (a de atribuir qualificativos a alunos e responsáveis). Ela, diferentemente de João José Coelho, teve a vida pública restrita à escola. Os dois nasceram em Cotia, foram professores com cargo definitivo e atuaram por mais de duas décadas em suas cadeiras. Destacou-se o fato de ambos darem aula na mesma casa desde 1873, das 9 às 14 horas, ele numa sala do lado de fora e ela numa sala interna e, apesar disso, não houve uma evasão significativa de meninas da Cadeira 
de Maria Joanna diretamente relacionada a esse fato. Percorrer minimamente a trajetória do casal de professores mostrou-se uma eficiente forma para compreender as práticas de escolarização de Cotia.

A pesquisa mostrou a situação em que se encontravam muitos professores brasileiros para desempenhar sua função no Oitocentos, apresentando as precárias condições materiais de trabalho e de espaço escolar em Cotia, que implicaram nos resultados da aprendizagem dos alunos. Nos relatórios, documentos onde os professores reclamavam da situação e pediam móveis e "utensis", observou-se que usavam de algumas táticas (CERTEAU, 1994) para persuadir o Inspetor Geral e conquistar o que pediam. Entretanto, os pedidos não pareciam ser atendidos, já que nos relatórios seguintes os professores continuavam a solicitar tais materiais e a reclamar dos espaços que atuavam (casas ou capelas).

Quanto aos alunos e suas características, e as influências do cotidiano local na vida escolar, um quadro com números de alunos matriculados ao longo dos 15 anos analisados, elaborado a partir de dados oficiais (usados com cautela), apontou um aumento de $407 \%$ de alunos de 1870 a 1885. Destacando-se que ainda havia uma grande defasagem de atendidos pela instrução pública em todo o período analisado e que, no início dos anos de 1870, das meninas que frequentavam escolas, a maior parte estudava em escolas particulares.

A falta de frequência dos alunos, segundo a maioria dos professores, era motivada principalmente pelo trabalho, sobretudo na lavoura. Intimamente ligada à falta de frequência dos alunos estava a questão de tempo e espaço sociais x tempo e espaço escolares, e apesar da lei de obrigatoriedade do ensino, a praxis se sobrepunha à lei do governo (THOMPSON, 1998). Segundo a historiografia consultada, o tempo e o espaço sociais se sobrepunham ao tempo e espaço escolares, assimilados de maneira lenta, em alguns locais mais, em outros menos. No caso de Cotia, até 1885 eram comuns as reclamações referentes a essa questão nos relatórios, e ao que as fontes indicaram, também esteve relacionada à sociedade rural composta sobretudo de famílias roceiras e sitiantes.

Por fim, foram analisados os dados de seis livros de matrícula referentes a quatro cadeiras públicas ( $1^{\mathrm{a}}$ Feminina da Vila, $1^{\mathrm{a}}$ e $2^{\mathrm{a}}$ Masculinas da Vila e a do Bairro de Capitão Jerônimo). Para isso, os dados foram sistematizados e divididos em dois eixos: 1. Dados escolares e 2. Dados pessoais. Sobre os dados escolares, os livros mostraram que, entre meninos e meninas, a média de matrículas era de 20 a 30 alunos nas escolas da Vila e 30 a 40 nas do bairro. Quanto às eliminações, o principal motivo se referia à mudança de endereço especialmente da Vila para o sítio - seguido de ausência às aulas por mais de três meses (incorrendo no Parágrafo $2^{\circ}$ do Artigo 97 do Regulamento de 1869). Os livros revelaram que 
o fluxo de matrículas e eliminações era maior nas cadeiras da Vila, apontando o caráter dinâmico da Vila, e mais estável do bairro, além da ruralidade cotidiana.

A análise dos dados pessoais revelou que os alunos tinham em média entre dez anos de idade, destacando-se a presença de um aluno de 20 anos em uma das cadeira, a grande maioria era natural de Cotia e a maioria tinha o pai como responsável, mas destacou-se em alguns momentos a ocorrência das mães e da categoria "tutores/parentes/outros" como responsáveis. Metade dos meninos e meninas ia para a escola acompanhada de irmã(o) ou outra criança que tivesse o mesmo responsável, podendo significar que, apesar de muitas serem crianças trabalhadoras e talvez a ausência delas fizesse diferença no resultado do trabalho familiar, algumas famílias preferiam que fossem juntas à escola, ao menos por algum tempo, pois muitas crianças eram eliminadas devido à ausência por mais de três meses, incluindo as crianças irmãs ou que tinham o mesmo responsável. Por outro lado, a ocorrência de que a outra metade ia à escola sem alguém do mesmo núcleo familiar, sugeriu principalmente que a família, talvez por questões econômicas, não conseguisse enviar todos os filhos à escola.

Os dados pessoais apresentados nos livros assinalaram que a maioria dos professores usava qualificativos que evidenciavam a sociedade escravista e patriarcal em que viviam. Nos livros houve a presença de quatro alunos "ingênuos" registrados por três professores em três cadeiras (todas as masculinas) a partir de 1881, comprovando que havia filhos de escravas entre eles. A professora Maria Joanna não qualificava suas alunas como "ingênuas", tampouco suas mães como escravas, portanto, a pesquisa não consiguiu afirmar a existência de filhas de escravas. O presente trabalho compartilhou da ideia de que, apesar de seu esposo qualificar alguns sujeitos nos registros de matrícula, a professora não qualificava suas alunas e mães considerando que isso não era necessário segundo o regulamento e, consequentemente, não vendo necessidade de apontar no documento tais elementos que ratificassem as diferenças sociais entre as alunas.

Os dados pessoais, entrecruzados com outras fontes, também permitiram desvelar que havia uma diversidade social e de cor na composição discente das cadeiras, de filhos de escravas até filho e netos de um dos maiores donos de escravos do local, subdelegado e juiz de paz, passando por filhos ou crianças tuteladas por professores, Vigário, vereadores, negociantes, ferreiros, entre outros. Ainda permitiram compreender as redes de relações estabelecidas em parte da sociedade cotiana entre 1870 e 1885 , revelando que, apesar de se considerar, segundo as fontes, o pertencimento do Professor João José Coelho à rede de potentado local, o Professor Marcolino de Moraes Pinto, da $2^{\text {a }}$ Cadeira da Vila, foi eleito entre 
os sujeitos mais influentes de Cotia naquele momento para ser o professor de seus filhos e tutelados, pois a maior parte destes estava matriculada na cadeira do Professor Marcolino.

A hipótese inicial da pesquisa era de que a presença dos filhos de escravas nas turmas refletia as características da sociedade, na qual os senhores e seus escravos conviviam por meio de relações mais estreitas do que em lugares mais abastados da Província e do Brasil. Verifiquei que dos quatro alunos filhos de escravas, dois eram filhos da escrava do Professor João José Coelho, este que também tinha seus filhos matriculados em sua cadeira, revelando que conviviam filhos de senhor e filhos de sua escrava na mesma turma, indicando que o ambiente escolar refletia o convívio desses sujeitos fora da escola. Ressaltou-se o fato de que a escola também era a casa deles.

Em outro caso, o menino "ingênuo" conviveu pouco com os netos do senhor de sua mãe na $2^{\text {a }}$ Cadeira da Vila (o senhor não tinha filhos na turma naquele momento), e foi matriculado posteriormente na $1^{\text {a }}$ Cadeira, a do Professor João José Coelho, podendo indicar uma rejeição da presença desse menino na escola pelos pais/mães/tutores e/ou pelo professor. O quarto menino, aluno da Cadeira do Bairro de Capitão Jerônimo, era filho da escrava de um homem que não tinha filhos matriculados nela, no entanto, ressaltou-se o fato de que estavam matriculados nessa turma seis filhos de um vereador de Cotia, indicando a diversidade social na composição da cadeira.

Dessa maneira, a presente pesquisa demonstrou que as escolas públicas de primeiras letras de Cotia não eram um privilégio dos mais abastados e nem existiam estritamente com o propósito de educar os pobres, mas eram constituídas de meninos e meninas de diversos estratos sociais. A presença de filhos de escravas apontou em direção ao que a historiografia da educação vem demonstrando como característica comum na escolarização das províncias, contudo, no caso de Cotia, ocorreu que os filhos do senhor estudavam na mesma turma que os filhos da escrava.

Ainda qua existissem algumas particularidades locais, processos assemelhados ocorreram em todo o Brasil, mesmo que em momentos diferentes entre eles, em decorrência, por exemplo, das variadas leis provinciais que, por sua vez, não se sobrepuseram de imediato às leis da praxis. Algumas características gerais do território nacional se evidenciaram na escolarização, e em Cotia não foi diferente: apesar de alguns núcleos urbanos, uns mais antigos e outros incipientes (como a Capital de São Paulo), no século XIX a maior parte do Brasil era rural. Este aspecto refletiu na falta de frequência dos alunos, pois muitos trabalhavam com seus pais na lavoura. A historiografia também tem apontado a diversidade na composição social e de cor, mas decerto, com muitas restrições de acordo com a sociedade 
escravista vigente. Contudo, apesar de leis educacionais homogeneizadoras sobre a heterogênea população brasileira ou mesmo provincial, o estudo dos locais e de suas singularidades trazem à tona as pluralidades do Brasil. Ao mesmo tempo, ao desvelar as especificidades locais, evidencia-se também o caráter geral da escolarização brasileira. 


\section{REFERÊNCIAS BIBLIOGRÁFICAS}

\section{Livros, capítulos, artigos:}

ABREU, M. Lei do Ventre Livre. In: VAINFAS, R. (Dir.). Dicionário do Brasil Imperial. Rio de Janeiro: Objetiva, 2002, p. 468-472.

ALMEIDA, J. R. P. Instrução pública no Brasil (1500-1889). Trad. Antonio Chizzoti. São Paulo: EDUC, 2000.

ANANIAS, M. A legislação da instrução pública primária na Província de São Paulo (1834-1868): fontes e historiografia. 2005. Tese (Doutorado em Educação) - Faculdade de Educação, Universidade de Campinas, Campinas, 2005.

ANDO, Z. Pioneirismo e cooperativismo: história da Cooperativa Agrícola de Cotia. São Paulo: Editora Sociologia e Politica/FESPSP (Fundação Escola de Sociologia e Política de São Paulo), 1961.

AZEVEDO MARQUES, M. E. Apontamentos históricos, geográficos, biográficos, estatísticos e noticiosos da Província de São Paulo, seguidos da cronologia dos acontecimentos mais notáveis desde a fundação da Capitania de S. Vicente até o ano de 1876. Tomo I e II. São Paulo: Livraria Martins, 1953.

BALZAN, D. As irmandades da Freguesia de Cotia. s/d. Disponível em $<$ http://www.portalviva.com.br/index.php?option=com_content\&view=article\&id=4644\%3A artigo-as-irmandades-da-freguesia-de-cotia\&catid=46\%3Amarcos-martinez\&Itemid=31> Acesso em: 5 mai. 2015.

—. Os sepultamentos na Freguesia de Cotia, s/d. Disponível em <http://www.cotiatododia.com.br/igreja-300-anos-sepultamentos-e-protetores/> Acesso em: 5 mai. 2015.

BARCELLOS, J. Cotia: uma história brasileira. São Paulo: Edicon, 2011.

BARRA, V. Briga de Vizinhos: um estudo dos processos de constituição da escola pública de instrução primária na província paulista (1853-1889). 2005. 286f. Tese (Doutorado em Educação) - Pontifícia Universidade Católica de São Paulo, São Paulo, 2005. 
BARROS, S. Negrinhos que por ahi andão: escolarização da população negra em São Paulo (1870-1920). 2005. Dissertação (Mestrado em Educação) - Faculdade de Educação, Universidade de São Paulo, 2005.

BASSANEZI, M. S. C. B. et al. São Paulo do passado: dados demográficos. Parte 3 (1872). Campinas: $\quad$ NEPO-UNICAMP, $1998 . \quad$ Disponível em <http://www.nepo.unicamp.br/publicacoes/censos/1872.pdf> Acesso em: 15 ago. 2015. São Paulo do passado: dados demográficos. Parte 4 (1886). Campinas: NEPOUNICAMP, $1998 . \quad$ Disponível em <http://www.nepo.unicamp.br/publicacoes/censos/1886.pdf> Acesso em: 15 ago. 2015.

BLAJ, I. A trama das tensões: o processo de mercantilização de São Paulo colonial (16811721). São Paulo: Humanitas/FFLCH/USP: Fapesp, 2002.

BLOCH, M. Para uma história comparada das sociedades europeias. In: História e historiadores: textos reunidos por Ėtienne Bloch. Tradução: Telma Costa. Lisboa: Teorema, 1998, p. 119-150.

BONTEMPI JR, B. Do vazio à forma escolar moderna. In: PORTA, P. (Org.). História da cidade de São Paulo: a cidade no Império. v.2. São Paulo: Paz e Terra, 2004.

BORBA, F. S. (Org.) Dicionário UNESP do Português Contemporâneo. São Paulo: Editora UNESP, 2004.

BORGES, A.; VIDAL, D. G. Racionalização da oferta e estratégias de distinção social: relações entre escola, cidade e família no Oitocentos (São Paulo e Rio de Janeiro). In: XI Congreso Iberoamericano de Historia de la Educación Latinoamericana (CIHELA), Toluca (México), 2014.

A urdidura do magistério primário na Corte Imperial: um professor na trama de relações e agências. 2014. 416f. Tese (Doutorado em Educação) - Faculdade de Educação, Universidade de São Paulo, São Paulo, 2014.

BORREGO, Maria Aparecida de Menezes. Laços familiares e aspectos materiais da dinâmica mercantil na cidade de São Paulo (séculos XVIII e XIX). An. mus. paul.[online]. v. 18, n. 1, p. 11-41, 2010.

BRASIL - IPHAN (Instituto do Patrimônio Histórico Artístico e Nacional)/MinC. Sítio Padre Ignácio, Roteiro de Visita. São Paulo: 9ª SR/IPHAN, 1996. 
BRASIL - IPHAN (Instituto do Patrimônio Histórico Artístico e Nacional)/MinC. Pesquisas em torno de um monumento. São Paulo: Prol editora e gráfica, 1997.

CANDIDO, A. Os parceiros do Rio Bonito: estudo sobre o caipira paulista e a transformação dos seus meios de vida. São Paulo: Editora 34, 2001 a.

CERTEAU, M. A invenção do cotidiano I: as artes de fazer. Petrópolis: Vozes, 1994.

CHAGAS, F. G.; PANIZZOLO, C. Álbum das Meninas (1898-1901): um estudo sobre a imagem da infância paulista na Primeira República. In: VII Simpósio Nacional de História Cultural, Universidade de São Paulo, São Paulo, 2014.

CHAPOULIE, J. M.; BRIAND, J. P. A instituição escolar e a escolarização: uma visão de conjunto. Educação e sociedade. Editora Papirus/CEDES, n. 47, ano XV, p. 11-60, abr/1994.

COSTA, E. V. Cotia e Itapecerica da Serra: subúrbios agrícolas. In: AZEVEDO, A (Coord.). A cidade de São Paulo: estudos de geografia urbana. Volume IV: Os subúrbios paulistanos. São Paulo: Cia. Editora Nacional, 1958, p. 109-152.

DAUNT, R. G. Diogo Antonio Feijó na tradição da família Camargo. Separata da Revista do Instituto Histórico e Geográfico de São Paulo, volume XLIII, São Paulo: Imprensa Oficial do Estado, 1945.

DIAS, A. Entre laranjas e letras: processos de escolarização no Distrito-Sede de Nova Iguaçu (1916-1950). 2012. 339 f. Tese (Doutorado em Educação) - Universidade Federal do Rio de Janeiro, Niterói, 2012.

ELLIS JR, A. O ciclo do muar. Revista de História. São Paulo, Departamento de História, Universidade de São Paulo, v. 1, n. 1, p. 73-81, 1950.

FARIA, J. R. O teatro na estante: estudos sobre dramaturgia brasileira e estrangeira. Cotia: Ateliê, 1998.

FARIA FILHO, L. M.; VIDAL, D. G. Os tempos e os espaços no processo de institucionalização da escola primária no Brasil. In: Revista Brasileira de Educação. São Paulo, n. 14, p.19-34, 2000.

Escolarização, culturas e práticas escolares no Brasil: elementos teóricometodológicos de um programa de pesquisa. In: LOPES, A. C.; MACEDO, E. (Orgs.). Disciplinas e integração curricular: história e políticas. Rio de Janeiro: DP\&A, 2002, p. 1336. 
História da educação e história regional: experiências, dúvidas e perspectivas. In: MENDONÇA, A. W. et al. (Orgs.). História da Educação: desafios teóricos e empíricos. Niterói: Editora da UFF, 2009, p. 57-67.

; BERTUCCI, L. M. Experiência e cultura: contribuições de E. P. Thompson para uma história social da escolarização. Currículo sem Fronteiras, v. 9, n. 1, p. 10-24, jan./jun. 2009.

Para fazer história da educação com E. P. Thompson: trajetórias de um aprendizado. In:__ (Org.). Pensadores sociais e história da educação. Belo Horizonte: Autêntica, 2011, p. 247-264.

FLEURY, R. S. O Padre Feijó. São Paulo: Melhoramentos, 1967.

FONSECA, M. V. Pretos, pardos, crioulos e cabras nas escolas mineiras do século XIX. 2007. 256f. Tese (Doutorado em Educação) - Faculdade de Educação, Universidade de São Paulo, São Paulo, 2007.

FREITAS, L. E. V. Folhetins e Máscaras: a obra de França Júnior. 2002. Dissertação (Mestrado em Ciências Sociais) - Pontifícia Universidade Católica de São Paulo, São Paulo, 2002.

GALLEGO, R. C. Tempo, temporalidades e ritmos nas escolas públicas primárias em São Paulo (1846-1890): heranças e negociações. 2008. 328f. Tese (Doutorado em Educação) - Faculdade de Educação, Universidade de São Paulo, São Paulo, 2008.

GAlvãO, M. (Org.) Casas do Patrimônio. Brasília: IPHAN, 2010. Disponível em <http://www.iphan.gov.br/baixaFcdAnexo.do?id=4206> Acesso em: 7 jan. 2015.

GERMANO, M. I., Um nome na areia. São Paulo: Editora Clube do livro, 1962.

GIGLIO, Celia Maria Benedicto. Uma genealogia de práticas educativas na Província de São Paulo: 1983-1876. 2 vol. 2001. Tese (Doutorado em Educação) - Faculdade de Educação, Universidade de São Paulo, São Paulo, 2001.

GIL, N. L. A produção dos números escolares (1871-1931): contribuições para uma abordagem crítica das fontes estatísticas em História da Educação. Rev. Bras. Hist., dez. 2009, v. 29, n.58, p. 341-358.

GINZBURG, C.; PONI, C. O nome e o como. In: GINZBURG, C; PONI, C.; CASTELNUOVO, E. A micro-história e outros ensaios. Lisboa: Diefel, 1991, p. 169-178. 
GOUVÊA, M. C. S. Os fios de Penélope: a mulher e a educação feminina no século XIX. In:

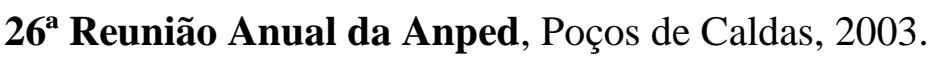

A escolarização da criança brasileira no século XIX: apontamentos para uma reescrita. Revista em questão. Natal, v. 28, n. 14, p. 121-146, jan-jun. 2007.

GRINBERG, K. O fiador dos brasileiros: cidadania, escravidão e direito civil no tempo de Antonio Pereira Rebouças. Rio de Janeiro: Civilização Brasileira, 2002.

GUEDES, R. Ofícios mecânicos e mobilidade social: Rio de Janeiro e São Paulo (séculos XII-XIX). Revista Topoi, Rio de Janeiro, v. 7, p. 379-422, 2006.

De ex-escravo à elite escravista: a trajetória de ascensão social do pardo alefres Joaquim Barbosa Neves (Porto Feliz, São Paulo, Século XIX). In: FRAGOSO, J. L. R.; ALMEIDA, C. M. C.; SAMPAIO, A. C. J. Conquistadores e negociantes: histórias de elites no Antigo Regime nos trópicos. América lusa, séculos XVI a XVIII. Rio de Janeiro: Civilização Brasileira, 2007.

Egressos do cativeiro: trabalho, família, aliança e mobilidade social (Porto Feliz, São Paulo, c.1798-c.1850). Rio de Janeiro: Mauad X: FAPERJ, 2008.

HILSDORF, M. L. S. Escolas Americanas de Confissão Protestante na Província de São Paulo: um estudo de suas origens. 1977. Dissertação (Mestrado em Educação) - Faculdade de Educação, Universidade de São Paulo, São Paulo, 1977.

Francisco Rangel Pestana: jornalista, político e educador. 1986. Tese (Doutorado em Educação) - Faculdade de Educação, Universidade de São Paulo, 1986.

Mestra Benedita ensina primeiras letras em São Paulo (1828-1858). In: Leitura e

Escrita em Portugal e no Brasil, 1500-1970. II vol. Porto: Sociedade Portuguesa de Ciências da Educação, 1998. p. 521-528.

Tempos de Escola: fontes para a presença feminina na educação de São Paulo século XIX, São Paulo: Ed. Plêiade, 1999.

Construindo a escolarização em São Paulo, 1820-1840. In: Prado, M. L. C.; Vidal, D.

G. (Org.). À Margem dos 500 anos: reflexões irreverentes. São Paulo: EDUSP, 2002.

História da educação brasileira: leituras. São Paulo: Pioneira Thomson, 2003a.

À Sombra da Escola Normal: achegas para uma outra história da profissão docente.

In: XXV ISCHE, International Standing Conference for the History of Education. São Paulo: Editora Plêiade, 2003b. 
HOLANDA, S. B. Caminhos e fronteiras. São Paulo: Companhia das Letras, 1994. Monções. São Paulo: Brasiliense, 2000.

INSTITUTO BRASILEIRO DE GEOGRAFIA E ESTATÍSTICA (IBGE). Documentação $\begin{array}{llllll}\text { territorial do } & \text { Brasil. } & \mathrm{s} / \mathrm{d} . & \text { Disponível } & \text { em }\end{array}$ <http://biblioteca.ibge.gov.br/visualizacao/dtbs/saopaulo/cotia.pdf> Acesso em: 10 jan. 2011. Cidades@. 2010. Disponível em <http://www.ibge.gov.br/cidadesat/painel/painel.php?codmun=351300\#> Acesso em: 10 jan. 2011.

INSTITUTO GEOGRÁFICO E CARTOGRÁFICO (IGC-São Paulo). Municípios e distritos do Estado de São Paulo. São Paulo: IGC, 1995. Disponível em <http://www.igc.sp.gov.br/produtos/arquivos/municipios_e_distritos.pdf > Acesso em: 8 jul. 2014.

LANGENBUCH, J. R. A estruturação da grande São Paulo: estudo de geografia urbana. Rio de Janeiro: Fundação IBGE, 1971.

LEMOS, A. I. G. Cotia e a sua participação no conjunto da faixa periférica da metrópole paulistana. 1972. Dissertação (Mestrado em Geografia) - Faculdade de Filosofia, Letras e Ciências Humanas, Universidade de São Paulo, 1972.

LIMA, D. R. P. Sinais do "desconforto" no exercício da docência pública em Recife e Olinda (1860-1880). 2014. 176 f. Dissertação (Mestrado em Educação) - Universidade Federal de Pernambuco, Recife, 2014.

LODI-CORREA, S. Anália Franco e sua ação socio-educacional na transição do Império para a República. 2009. Dissertação (Mestrado em Educação) - Universidade Estadual de Campinas, Campinas, 2009.

LOUZADA, C. Fundo de Emancipação e famílias escravas: o Município Neutro na lei de 1871. XXVI Simpósio Nacional de História - ANPUH: 50 anos. Universidade de São Paulo, São Paulo, 2011.

MARCÍliO, M. L. História da escola em São Paulo e no Brasil. São Paulo: Imprensa Oficial do Estado de São Paulo: Instituto Fernand Braudel, 2005.

MARCONDES, R. L.; MOTTA, J. F. A Família escrava em Lorena e Cruzeiro (1874). População e Família (USP), São Paulo, 2000, v.1, n.3, p.93-128. 
MARCOVITCH, J. Cotia: seis décadas de estratégia cooperativista. São Paulo: Editora CAC, 1989.

MATOS, T. F. L. Caseiras pentecostais: mulheres felizes. Trânsito religioso no município de Vargem Grande Paulista. 2007. 202f. Dissertação (Mestrado em Ciências da Religião) Pontifícia Universidade Católica de São Paulo, São Paulo, 2007.

MATTOS, H. Das cores do silêncio: os significados da liberdade no Sudeste escravista, Brasil século XIX. Rio de Janeiro: Nova Fronteira, 1998.

MONTEIRO, E. C. Anália Franco: a grande dama da educação brasileira. São Paulo: Madras, 2004.

MONTEIRO, J. Negros da terra: índios e bandeirantes nas origens de São Paulo. São Paulo: Companhia das Letras, 1994.

MUNHOZ, F. G. A experiência docente no século XIX: trajetórias de professores de primeiras letras da $5^{\mathrm{a}}$ Comarca da Província de São Paulo e da Província do Paraná. 2012. 215f. Dissertação (Mestrado em Educação) - Faculdade de Educação da Universidade de São Paulo, São Paulo, 2012.

; VIDAL, D. G. Experiência docente Oitocentista e transmissão familiar do magistério na $5^{\text {a }}$ Comarca da Província de São Paulo, In: X Congresso Luso-Brasileiro de História da Educação, Curitiba, 2014.

NASCIMENTO, C. V. Caminhos da docência: trajetórias de mulheres professoras em Sabará - Minas Gerais (1830-1904). 2011. Tese (Doutorado em Educação) - Faculdade de Educação, Universidade Federal de Minas Gerais, Belo Horizonte, 2011.

NÓBREGA, H. M. Batista Cepelos. Rio de Janeiro : Mandarino \& Molinari, 1937.

OLIVEIRA, E. C. Anália Franco e a Associação Feminina Beneficente e Instrutiva: idéias e práticas educativas para a criança e para a mulher (1870 - 1920). 2007. Dissertação (Mestrado em Educação) - Universidade São Francisco, Itatiba (SP), 2007.

PAiVA, C. A., GODOY, M. M., RODARTE, M. M. S., et al. Publicação Crítica do Recenseamento Geral do Império do Brasil de 1872. Belo Horizonte: Núcleo de Pesquisa em História Econômica e Demográfica, Cedeplar/Face/UFMG, 2012. Disponível em $<$ http://www.nphed.cedeplar.ufmg.br/wpcontent/uploads/2013/02/Relatorio_preliminar_1872_site_nphed.pdf> Acesso em 5 jul 2014. 
PENTEADO, A. R. Os subúrbios de São Paulo e suas funções. In: AZEVEDO, A (Coord.). A cidade de São Paulo: estudos de geografia urbana. São Paulo: Cia. Editora Nacional, 1958, p. 5-60.

PERES, E. T. "Templo de luz": os cursos noturnos masculinos de instrução primária da Biblioteca Pública Pelotense (1875-1915). Pelotas: Seiva Publicações, 2002.

PETRONE, P. Aldeamentos paulistas. São Paulo: EDUSP, 1995.

PORTELA, D. F. Iniciativas de atendimento para crianças negras na província de São Paulo (1871-1888). 2012. Dissertação (Mestrado em Educação) - Faculdade de Educação, Universidade de São Paulo, São Paulo, 2012.

PRADO, A.; CAMPOS, A.; DUARTE, A. História da cidade de São Paulo. Volume 1. São Paulo: Paz e Terra, 2004.

PRADO JUNIOR, C. O fator geográfico na formação e no desenvolvimento da cidade de São Paulo. In: Geografia, ano 1, n. 3, São Paulo, 1935.

RICCI, M. Assombrações de um padre regente: Diogo Antônio Feijó, 1784-1843. Campinas: Editora da UNICAMP, 2001.

RODARTE, M. M. S.; SANTOS JÚNIOR, J. M. A estrutura ocupacional revisitada: uma proposta de correção dos dados do Recenseamento Geral do Império de 1872. In: Encontro Nacional de Estudos Populacionais, 2008, Caxambú. Anais, Abep, 2008.

SÃO PAULO (Estado). Secretaria de Estado de Negócios Metropolitanos, Empresa Metropolitana de Planejamento da Grande São Paulo (EMPLASA). Memória urbana: A grande São Paulo até 1940. São Paulo: Imprensa Oficial, v. 2, 2001.

SCHLEUMER, F. Além de açoites e correntes: cativos e libertos em Cotia colonial (17901810). 1999. Dissertação (Mestrado em História) - Universidade de São Paulo, Faculdade de Filosofia, Letras e Ciências Humanas, São Paulo, 1999.

SEABRA, M. Vargem Grande: organização e transformações de um setor do cinturão-verde paulistano. Série Teses e Monografias, n. 4 - IGEOG-USP. São Paulo: Editora Instituto de Geografia da Universidade de São Paulo, 1971.

As cooperativas mistas do Estado de São Paulo: estudo de geografia econômica. Edição 30 da Série Teses e Monografias - IGEOG-USP. São Paulo: Editora Instituto de Geografia da Universidade de São Paulo, 1977. 
SILVA, A. M. P. Aprender com perfeição e sem coação: uma escola para meninos pretos e pardos na Corte. Brasília: Editora Plano, 2000.

. Processos de construção da escolarização em Pernambuco, em fins do século XVIII e primeira metade do século XIX. Recife: Editora Universitária da UFPE, 2007.

Notas para o estudo da instituição da obrigatoriedade da educação primária na província de Pernambuco. In: VIDAL, D. G.; SÁ, E. F.; SILVA, V. L. G. (Orgs.). Obrigatoriedade escolar no Brasil. Cuiabá: Ed. UFMT, 2013, v. 1, p. 209-226.

SILVA, E. M. Barueri: história revista e documentada (1560-1994). Osasco: ABC, 1995.

SILVA, D. L. E. Notas de historia ecclesiastica: Mogy das Cruzes e seus fundadores; Baruery-Parnahyba; Cutia. São Paulo: Ver. Tribunais, 1937.

SILVA, R. B. França Junior (1838-1890): um homem de letras do Segundo Império. Intellèctus (UERJ-Online), v. ano IX, p. 8, 2010. Disponível em <http://www.intellectus.uerj.br/Textos/Ano9n2/8artigoraquel.pdf> Acesso em: 10 out. 2014.

SOUZA, R. B. A história do município de Cotia, s/d.

SQUEFF, E. (Org.); FERREIRA H. P. (Consult.). A origem dos nomes dos municípios paulistas. São Paulo: Ed. Imprensa Oficial do Estado e Fundação Prefeito Faria Lima (CEPAM), 2003.

TALASSI, L. A doutrina do Padre Feijó e suas relações com a Sé Apostólica. Roma: Pontifícia Universidade Gregoriana, 1949.

THOMPSON, E. P. Costume, lei e direito comum. In: Costumes em comum: estudos sobre a cultura popular tradicional. São Paulo: Companhia das Letras, 1998, p. 86149.

VEIGA, C. G. Crianças negras e mestiças no processo de institucionalização da Instrução Elementar, Minas Gerais, século XIX. In: A Educação Escolar em Perspectiva Histórica. Anais do III Congresso Brasileiro de História da Educação (CBHE). Curitiba: UFU, 2004, Vol. $\quad$ III. Disponível em <http://www.sbhe.org.br/novo/congressos/cbhe3/Documentos/Coord/Eixo6/472.pdf> Acesso em 5 out. 2013. 
; RODRIGUES, M. G. Etnicidade e história da educação. In: MORAIS, C. C.; PORTES, E. A.; ARRUDA, M. A. (Orgs.). Historia da Educação: ensino e pesquisa. Belo Horizonte: Autêntica, 2006, p. 27-58.

. Escola pública para os negros e os pobres no Brasil: uma invenção imperial. In: Rev. Bras. Educ. [online]. 2008, v. 13, n. 39, p. 502-516. Disponível em <http://dx.doi.org/10.1590/S1413-24782008000300007> Acesso em 2 out. 2013.

Conflitos e tensões na produção da inclusão escolar de crianças pobres, negras e mestiças, Brasil, século XIX. In: Educ. Rev., Belo Horizonte, v. 26, n. 1, abr. 2010.

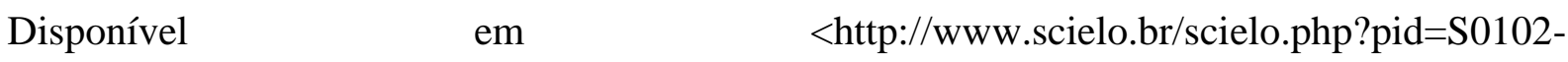
$46982010000100013 \&$ script=sci_arttext $>$ Acesso em: 2 out. 2013.

VIDAL, D. G. Mapas de frequência a escolas de Primeiras Letras: fontes para uma história da escolarização e do trabalho docente em São Paulo na primeira metade do século XIX. Revista Brasileira de História da Educação, v. 17, p. 41-67, 2008.

; BICCAS, M. S. As múltiplas estratégias de escolarização do social em São Paulo (1770-1970): cultura e prática escolares. In: VIDAL, D. G. (Org.). Educação e Reforma: o Rio de Janeiro nos anos 1920-1930. Belo Horizonte: Argvmentvm; São Paulo: CNPq: USP, Núcleo Interdisciplinar de Estudos e Pesquisas em História da Educação (NIEPHE), 2008, p. $19-44$.

A docência como uma experiência coletiva: questões para debate. In: DALBEN; DINIZ et al. (Orgs.). Convergências e tensões no campo da formação e do trabalho docente: didática, formação de professores, trabalho docente. Belo Horizonte: Autêntica, 2010, p. 711-734.

VINCENT, G.; LAHINE, B.; THIN, D. Sobre a história e a teoria da forma escolar. Educação em Revista. Belo Horizonte, n. 33, p. 7-47, jun. 2001.

WISSENBACH, M. C. Sonhos africanos, vivências ladinas: escravos e forros em São Paulo (1850-1888). São Paulo: Hucitec/História Social-USP, 1998.

ZINGG, P. Álbum do centenário de Cotia 1856-1956. São Paulo: Serviços Técnicos da Imprensa e Propaganda, 1956. Disponível na Biblioteca Digital Seade Disponível em $<$ http://produtos.seade.gov.br/produtos/bibliotecadigital/view/singlepage/index.php?pubcod=1 0013838\&parte=1> Acesso em: 5 mai. 2015. 


\section{Vídeo:}

CANDIDO, Antonio. Entrevista com o autor sobre os caipiras. In FERRAZ, Isa Grinspum (direção). Intérpretes do Brasil (Documentário/DVD duplo), 2001 b.

\section{FONTES}

\section{Legislação de Instrução Pública de São Paulo no Oitocentos e leis de criação das cadeiras de Cotia}

Disponíveis em:

Banco de dados do NIEPHE - Núcleo Interdisciplinar de Estudos e Pesquisas em História da Educação - Faculdade de Educação da Universidade de São Paulo - USP <www.niephe.usp.br>

Legislação on-line da Assembleia Legislativa de São Paulo <http://www.al.sp.gov.br>

Regulamento de 18 de abril de 1869 - Para Instrução Pública e particular da Província. São Paulo: Tipografia Correio Paulistano, 1874.

\section{Legislação, petições e ofícios diversos}

Lei $\mathrm{n}^{\mathrm{o}} 2.040$ de 28 de Setembro de 1871 (Lei do Ventre Livre). Disponível em <http://www2.camara.leg.br/legin/fed/lei/1824-1899/lei-2040-28-setembro-1871-538828publicacaooriginal-35591-pl.html>

Leis referentes a aposentadorias, petições e ofícios em geral relativos à escolarização em Cotia, a demarcação de fronteiras, a alteração de comarca, a construção da estrada Sorocabana e do ramal para Cotia, a artigos de posturas da Câmara Municipal de 1874 e 1886, a ofícios municipais sobre os casos de varíola. Disponíveis em:

Acervo Histórico da Assembleia Legislativa de São Paulo <http://www.al.sp.gov.br/acervohistorico/>

Legislação on-line da Assembleia Legislativa de São Paulo <http://www.al.sp.gov.br>

\section{Mapas cartográficos:}


LISBOA, J. M. R. Mappa da Província de São Paulo: Organisado no Escriptorio Tecnico da Companhia Mogyana sob a direcção do engenheiro em chefe Joaquim Miguel Ribeiro Lisboa. Rio de Janeiro: Lith. Paulo Robin, 1884. 1 mapa, col., 51,5 x 66,5 cm. Escala $1: 1.500 .000$. Disponível em: <http://objdigital.bn.br/objdigital2/acervo_digital/div_cartografia/cart515157/cart515157.jpg> PETRONE, P. O cinturão caipira de São Paulo e os aldeamentos - século XIX. In: Aldeamentos paulistas. São Paulo: EDUSP, 1995, p. 377.

SEADE - FUNDAÇÃO SISTEMA ESTADUAL DE ANÁLISE DE DADOS. Memória das

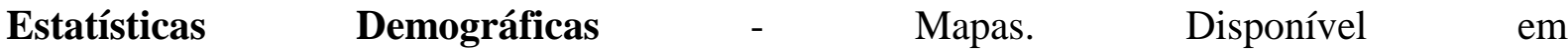
<http://www.seade.gov.br/produtos/500anos/index.php?tip=esta>

\section{Anais da Assembleia Provincial de São Paulo}

Disponíveis no Acervo Histórico da Assembleia Legislativa de São Paulo: <http://www.al.sp.gov.br/acervo-historico/base-de-dados/imperio/anaisImperio.htm>

\section{AESP - Série Instrução Pública (Manuscritos):}

Livro de registros de matrículas:

$1^{\text {a }}$ Cadeira Feminina da Vila de Cotia (1870-1885) - referências EO2230, EO3182.

$1^{\text {a }}$ Cadeira Masculina da Vila de Cotia - referências EO2234, EO3030.

$2^{\text {a }}$ Cadeira Masculina da Vila de Cotia - referência EO2918.

Cadeira Masculina do Bairro de Capitão Jerônimo - referências EO3116.

Ofícios de Instrução Pública:

Ofícios, relatórios de professores e mapas de escola, relatórios de inspetores locais e Inspetores Gerais da Instrução Pública de Cotia e outros municípios: referência CO5044.

Ofícios Diversos de Instrução Pública: referência CO4915.

\section{AESP - Série Ofícios Diversos}


Ofícios Diversos de Cotia: referências CO1007 e CO1008.

\section{Periódicos}

Imprensa brasileira. Coleção de periódicos oitocentistas (consultados jornais e almanaques). Disponíveis na Hemeroteca Digital da Biblioteca Nacional <www.hemerotecadigital.bn.br> Almanak da Província de São Paulo para 1873. Primeiro anno. LUNÉ, A. J. B. (Org.). Disponível no Acervo Digital da Brasilianas - Universidade de São Paulo. Disponível em <http://www.brasiliana.usp.br/bbd/handle/1918/00038100>

Almanach administrativo, commercial e industrial da Provincia de S. Paulo para o anno de 1885. São Paulo: Jorge Seckler, 1884.

HILSDORF, M. L. S., Tempos de escola: fontes para a presença feminina na educação de São Paulo - século XIX, São Paulo: Ed. Plêiade, 1999 - Informações de publicações de jornais extraídas pela autora e compiladas nesta obra.

\section{Lista de vereadores e de presidentes da Câmara entre 1870 e 1885}

Disponíveis em: 〈http://www.camaradecotia.sp.gov.br/presidentes.php> $<$ http://cotiatododia.com.br/retro/cotiatododia2007/guias_publicos/vereadores_guiasdecotia.ht $\mathrm{m}>$

\section{Relatórios e mapas estatísticos de governo}

Relatórios e mapas de Instrução Pública da Província de São Paulo referentes a 1870, 1871, 1879, 1880 e 1885. Disponíveis no site do Center for Research Libraries da Universidade de Chicago: $\quad<$ http://brazil.crl.edu/bsd/bsd/hartness/predpub.html> e <http://brazil.crl.edu/bsd/bsd/hartness/index.html>

SÃO PAUlO (Estado). Relatório apresentado ao Exmo. Sr. Presidente da Província de São Paulo pela Comissão Central de Estatística. São Paulo: Leroy King Typ., 1888. Disponível em <https://archive.org/details/relatorioaprese00paulgoog>

Estatistica Agricola e Zootechnica de Cotia no annoagricola de 1904-1905 1. districto. São Paulo: Secretaria da Agricultura, Commercio e Obras Publicas, 1907. 9 p. $\begin{array}{llll}\text { Disponível na } & \text { Biblioteca } & \text { Digital } & \text { Seade }\end{array}$ $<$ http://produtos.seade.gov.br/produtos/bibliotecadigital/view/singlepage/index.php?pubcod=1 $0011270 \&$ parte $=12>$ 


\section{Documentos eclesiásticos}

Registros de batismo e casamento. Disponíveis em FamilySearch: <https://familysearch.org/> Registro da fundação da segunda capela de Cotia: Termo de posse do Pe. Matheus de Laya de 9 de setembro de 1703. In: SILVA, D. L. E. Notas de historia ecclesiastica: Mogy das Cruzes e seus fundadores; Baruery-Parnahyba; Cutia. São Paulo: Ver. Tribunais, 1937, p. 96.

\section{Fotos, croquis e aerofotos}

DURSKI, J. W. Fotos da Parada de Cotia e da Estação São João de 1877 atribuídas a esse fotógrafo. In: GASPAR, Antonio Francisco Gaspar. Histórico do início, fundação, construcção e inauguração da Estrada de Ferro Sorocabana: 1870-1875. São Paulo: Estab. Gráfico Eugenio Cupolo, 1930.

INSTITUTO GEOGRÁFICO E CARTOGRÁFICO (IGC-São Paulo). Secretaria de Economia e Planejamento. Coordenadoria de Planejamento Regional. Croquis de $\begin{array}{lllll}\text { coordenadas } & \text { geográficas. } & 1941 . & \text { Disponível em }\end{array}$ <http://www.igc.sp.gov.br/produtos/galeria_croquis.aspx>

- Aerofotos Oblíquas 1939/1940. Disponível em
<http://www.igc.sp.gov.br/produtos/galeria_aerofotos.aspx>

LANGENBUCH, J. R. Foto da réplica da capela original de Bom Jesus do Itaqui, 1971. In: A estruturação da grande São Paulo: estudo de geografia urbana. Rio de Janeiro: Fundação IBGE, 1971.

\section{Poemas}

CEPELlOS, M. B. A derrubada. São Paulo: Typ. Riedel \& Lenni, 1896. . Os bandeirantes. São Paulo: Espindola \& Comp., 1908a. . Vaidades. São Paulo: Laemmert \& Comp., 1908 b.

\section{Peça de teatro}

FRANÇA JUNIOR, J. J. Tipos da atualidade. In: MENDES, I. França Junior: teatro completo. Poeteiro: São Paulo, 2014, p. 348-390.

\section{Crônica}


SALAMBÔ. Sobre o que vae pela Paulicéa - VII. In: Jornal Correio Paulistano de 27 de outubro de 1872 , p. 2.

\section{Relatos de viajantes}

ABREU, M. C. de A. Divertimento admirável para os historiadores observarem as maquinas do mundo reconhecidas nos sertões da navegação das minas de Cuiabá e Mato Grosso (1783). Capítulo XIII: Noticias particulares da Cidade de São Paulo. Da extensão da sua capitania, nome da povoação de negociações dos seus habitantes In: MOTA, O. C. Do rancho ao palácio: evolução da civilização paulista. São Paulo, Rio de Janeiro, Recife, Porto Alegre: Cia. Editora Nacional, 1941. Disponível em <http://www.brasiliana.com.br/obras/do-ranchoao-palacio-evolucao-da-civilizacao-paulista/pagina/170/texto>

PINTO, A. M. A cidade de S. Paulo em 1900: impressões de viagem. Rio de Janeiro: Imprensa Nacional, 1900. Disponível em <http://docvirt.noip.com/docreader.net/DocReader.aspx?bib=LIVROSSPMP\&PagFis=8535>

SAINT-HILAIRE, A.Viagem à Província de São Paulo: resumo das viagens ao Brasil, Província Cisplatina e Missões do Paraguai. Trad. Rubens Borba de Moraes. São Paulo: Livraria Martins/Empresa Gráfica da Revista dos Tribunais, 1940. Disponível em $<$ http://www.archive.org/stream/viagemprovinci00sainuoft/viagemprovinci00sainuoft_djvu.tx t>

SILVA, J. B. A., o Patriarca; ANDRADA, M. F. R. Viagem mineralógica na Província de S. Paulo. In: BOUBÉE, N. Geologia elementar applicada á agricultura e industria; com hum diccionario dos termos geologicos, ou, Manual de geologia [volume 1] / Traduzido da quarta edição. Rio de Janeiro: na Typ. Nacional, 1846. Disponível em $<$ http://docvirt.com/docreader.net/DocReader.aspx ?bib=LivrosSP\&PagFis=18565>

\section{Dados dos recenseamentos}

AZEVEDO MARQUES, M. E. Apontamentos históricos, geográficos, biográficos, estatísticos e noticiosos da Província de São Paulo, seguidos da cronologia dos acontecimentos mais notáveis desde a fundação da Capitania de S. Vicente até o ano de 1876. Tomo I e II. São Paulo: Livraria Martins, 1953.

BASSANEZI, M. S. C. B. et al. São Paulo do passado: dados demográficos. Parte 3 (1872). Campinas: $\quad$ NEPO-UNICAMP, $1998 . \quad$ Disponível em <http://www.nepo.unicamp.br/publicacoes/censos/1872.pdf> Acesso em: 15 ago. 2015. 
São Paulo do passado: dados demográficos. Parte 4 (1886). Campinas: NEPOUNICAMP, 1998.

Disponível

em

<http://www.nepo.unicamp.br/publicacoes/censos/1886.pdf>

BRASIL. Diretoria Geral de Estatística. IBGE. Recenseamento do Brazil de 1872 Província de São Paulo; Sexo, raça estado civil, nacionalidade, filiação, culto e analphabetismo da população recenseada em 31 de dezembro de 1872. Disponível em $<$ http://biblioteca.ibge.gov.br/visualizacao/monografias/GEBIS\%20-

\%20RJ/Recenseamento_do_Brazil_1872/Imperio\%20do\%20Brazil\%201872.pdf>

Synopse do recenseamento de 31 de dezembro de 1900. Rio de Janeiro: Typ. da

Estatistica, $1905 . \quad$ Disponível em

$<$ http://biblioteca.ibge.gov.br/visualizacao/monografias/GEBIS\%20-

\%20RJ/synopse_recenseamento_1900.pdf>

Recenseamento da Província de São Paulo referente a 1886. In: SÃO PAULO (Estado).

Relatório apresentado ao Exmo. Sr. Presidente da Província de São Paulo pela Comissão

Central de Estatística. São Paulo: Leroy King Typ., 1888. Disponível em <https://archive.org/details/relatorioaprese00paulgoog>

\section{Sermão proferido na Igreja Matriz de Cotia em 1871}

CARMELO, J. M. A Igreja e o Estado: sermão pregado na Matriz da Villa da Cutia, Termo da Cidade de São Paulo, Em 28 de maio do corrente anno pelo Dr. Joaquim de Monte Carmelo, Cônego da Sé da dita cidade. Rio de Janeiro: Typ. De Pinheiro \& C., 1871. 


\section{APÊNDICES}

Apêndice A:

ESCOLARIZAÇÃO EM COTIA NO SÉCULO XIX - PARTE I: 1838 a 1870

Professores responsáveis e outras informações

(Fontes: mapas de frequência e relatórios de professores e inspetores, AESP, ref. CO5044, CO4915 e CO1007; relatórios de governo; periódicos)

\begin{tabular}{|c|c|c|}
\hline $\begin{array}{c}\text { ANO E INFORMAÇOES } \\
\text { REFERENTES À INSPEÇÃO DE } \\
\text { DISTRITO }\end{array}$ & $\begin{array}{c}\text { CADEIRA DE PRIMEIRAS } \\
\text { LETTRAS DA FREGUESIA DA } \\
\text { CUTIA (ATÉ 01/04/1856) - } \\
\text { CADEIRA DE PRIMEIRAS } \\
\text { LETTRAS DA VILLA DA CUTIA } \\
\text { (A PARTIR DE 02/04/1856) }\end{array}$ & $\begin{array}{l}1^{\text {a }} \text { CADEIRA DE PRIMEIRAS } \\
\text { LETTRAS DO SEXO FEMININO }\end{array}$ \\
\hline 1838 & $\begin{array}{l}\text { Começa em } 1838 . \\
\text { Primeiro professor: Antonio Bandeira } \\
\text { Barreto de Gouvêa. } \\
36 \text { alunos matriculados, sendo um } \\
\text { aluno "exposto"; o professor pede as } \\
\text { Instruções, que ainda não tinham sido } \\
\text { enviadas a ele (15/12/1838). }\end{array}$ & \\
\hline 1839 & $\begin{array}{l}\text { Antonio Bandeira Barreto de Gouvêa } \\
40 \text { alunos matriculados (José Coelho } \\
\text { era um de seus alunos, possivelmente o } \\
\text { professor João José Coelho, então com } \\
7 \text { anos) }(28 / 08 / 39)\end{array}$ & \\
\hline $1841-1850$ & $\begin{array}{l}\text { Antonio Bandeira Barreto de Gouvêa } \\
\text { Em } 1841 \text { com } 44 \text { alunos; } \\
\text { Em 1842, } 17 \text { alunos; } \\
\text { Em 1843, } 17 \text { alunos, sendo um } \\
\text { "exposto" (José José Coelho - com } \\
\text { nome completo - era um de seus } \\
\text { alunos, o segundo da lista, então com } \\
13 \text { anos. O primeiro era seu irmão, } \\
\text { Jesuíno José Coelho); } \\
\text { Em } 1844,17 \text { alunos, sendo um } \\
\text { "exposto" (José José Coelho também } \\
\text { era um de seus alunos, o primeiro da } \\
\text { lista, então com } 14 \text { anos); } \\
\text { Em } 1845,20 \text { alunos (José José Coelho } \\
\text { era o primeiro da lista, então com } 14 \\
\text { anos); } \\
\text { Em } 1846,22 \text { alunos (José José Coelho } \\
\text { era o primeiro da lista, então com } 13 \\
\text { anos - apresenta confusão com relação } \\
\text { à idade dos alunos); } \\
\text { Em } 1848, \text { não tem número no relatório } \\
\text { de governo (não teve aula? Ou o } \\
\text { inspetor não mandou a relação?); } \\
\text { Em } 1849, \text { também não tem número de } \\
\text { alunos; } \\
1849: 19 \text { alunos matriculados (Manoel } \\
\text { de Moraes Pinto era um de seus alunos, } \\
\text { mas no mapa não informa a idade dos }\end{array}$ & \\
\hline
\end{tabular}




\begin{tabular}{|c|c|c|}
\hline & $\begin{array}{l}\text { alunos); } \\
\text { Em 50, } 19 \text { alunos. }\end{array}$ & \\
\hline $\begin{array}{l}1852 \\
\text { Torna-se inspetor o Vigário José } \\
\text { Manoel de Oliveira em maio }\end{array}$ & Antonio Bandeira Barreto de Gouvêa & \\
\hline $\begin{array}{l}1855 \\
\text { Vigário José Manoel de Oliveira } \\
\text { (inspetor de escolla) }\end{array}$ & $\begin{array}{l}\text { Antonio Bandeira Barreto de Gouvêa } \\
\text { Conforme mapa da instrução Pública } \\
\text { feito pelo inspetor de escolla referente } \\
\text { ao período de julho a setembro de } \\
\text { 1855, eram } 22 \text { alunos ( } 20 \text { brasileiros, } \\
\text { sendo } 2 \text { libertos), "alumnos aproveitão } \\
\text { o ensino", segundo o inspetor. }\end{array}$ & \\
\hline $\begin{array}{l}1856 \\
\text { Vigário José Manoel d"Oliveira } \\
\text { (inspetor de escolla) } \\
\text { Emancipação de Cotia. }\end{array}$ & $\begin{array}{l}\text { Antonio Bandeira Barreto de Gouvêa } \\
\text { Em relatório, o vigário-inspetor } \\
\text { informa que seu estado de saúde não o } \\
\text { permitiu fazer o mapa de frequência } \\
\text { dentro do prazo estabelecido, mas que } \\
\text { são } 22 \text { alunos matriculados e } 18 \\
\text { frequentes, sendo que a frequência } \\
\text { "algumas vezes" foi interrompida } \\
\text { "devido aos pais que no tempo da } \\
\text { lavoura os apartão para esse e outros } \\
\text { serviços". Pede "remessa de traslados } \\
\text { de livros e compêndios para o ensino. } \\
\text { Ao mesmo tempo torno a repetir que a } \\
\text { falta de uma salla própria para se dar } \\
\text { aula he a mais urgente sendo esse o } \\
\text { motivo de não ter podido provê-la de } \\
\text { tudo qto é mester e espero que V.S. } \\
\text { tomará as medidas precisas a esse } \\
\text { respeito" - No mapa (em anexo): } 22 \\
\text { alunos ( } 22 \text { brasileiros, zero libertos); e } \\
\text { a informação no campo sobre o } \\
\text { aproveitamento: "os alumnos tem } \\
\text { aproveitado o ensino" ( } 30 / 11 / 56) \text {. }\end{array}$ & \\
\hline $\begin{array}{l}1857 \\
\text { Vigário José Manoel d”Oliveira } \\
\text { (inspetor de instrucção pública) }\end{array}$ & $\begin{array}{l}\text { Antonio Bandeira Barreto de Gouvêa } \\
\text { O vigário-inspetor, em relatório, } \\
\text { informa que a frequência dos alunos é } \\
\text { irregular em decorrência do trabalho; } \\
\text { alunos são "distrahidos da instrucção } \\
\text { por occupa-los seus pais em diversos } \\
\text { serviços repetidas vezes e por muito } \\
\text { tempo"; apenas } 16 \text { a } 18 \text { são fequentes } \\
\text { (não há informação de quantos são } \\
\text { matriculados); todos com } \\
\text { comportamento regular. Pede } \\
\text { novamente um local próprio para as } \\
\text { aulas e "algum correctivo" para que os } \\
\text { alunos não deixem de ir à escola. O } \\
\text { professor escreve que os pais "desejão } \\
\text { mais entrega-los a lavoura do que } \\
\text { procurar-lhes o necessario ensino" } \\
\text { (14/10/57). }\end{array}$ & \\
\hline 1858 & $\begin{array}{l}\text { Antonio Bandeira Barreto se aposenta } \\
\left(\text { Lei } n^{\circ} 39 \text { de } 04 / 05 / 1858\right) \\
\text { Professor Interino Antonio Benedicto }\end{array}$ & $\begin{array}{l}\text { Criação Lei nº } 09 \text { de 11/03/1858 } \\
\text { Março - nomeação da educanda Rosa } \\
\text { Josefa de Jesus, mas não chegou a }\end{array}$ \\
\hline
\end{tabular}




\begin{tabular}{|c|c|c|}
\hline & $\begin{array}{l}\text { Gonçalves Gomide/ Professor Manoel } \\
\text { de Moraes Pinto (contratado). }\end{array}$ & $\begin{array}{l}\text { lecionar. } \\
\text { Junho - assume a cadeira a Professora } \\
\text { Maria Joanna do Sacramento, nomeada } \\
\text { em } 1^{\circ} \text { de junho e juramento prestado } \\
\text { perante a Câmara em } 30 \text { de junho. }\end{array}$ \\
\hline $\begin{array}{l}1859 \text { / } 1860 \\
\text { Inspetor de distrito: Vigário José } \\
\text { Manuel d"Oliveira }\end{array}$ & $\begin{array}{l}\text { Professor Interino Antonio Benedicto } \\
\text { Gonçalves Gomide / Professor João } \\
\text { José Coelho } \\
\text { 1859: } 52 \text { matriculados e } 28 \text { frequentes. }\end{array}$ & Maria Joanna do Sacramento \\
\hline $\begin{array}{l}1861 \\
(\text { Sem dados })\end{array}$ & 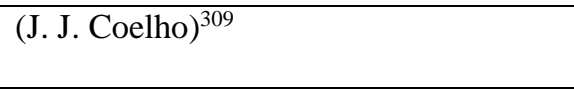 & (M. J. do Sacramento) \\
\hline $\begin{array}{l}1862 \\
\text { Vigário Jose Manoel de Oliveira } \\
\text { (inpetor de instrucção pública) } \\
\text { O inspetor informa que há uma escola } \\
\text { particular (Professor Antonio com } 2 \\
\text { alunos), além das escolas públicas, } \\
\text { também pede casa adequada para o } \\
\text { ensino e "utensis" próprios; diz que os } \\
\text { alunos são frequentes e têm "bastante } \\
\text { adiantamento". Com mapa. }\end{array}$ & $\begin{array}{l}\text { J. J. Coelho } \\
25 \text { alunos matriculados (todos } \\
\text { brasileiros, sendo } 6 \text { libertos). }\end{array}$ & $\begin{array}{l}\text { M. J. do Sacramento } \\
25 \text { alunas matriculadas (todas } \\
\text { brasileiras, sendo } 6 \text { libertas). }\end{array}$ \\
\hline $\begin{array}{l}1861 \text { a } 1865 \\
\text { (Sem dados) }\end{array}$ & (J. J. Coelho) & (M. J. do Sacramento) \\
\hline $\begin{array}{l}1866 \\
\text { Assume como inspetor interino de } \\
\text { distrito Manoel Joaquim da Luz (o } \\
\text { vigário morreu) - Em relatório comenta } \\
\text { da assiduidade dos professores, que } \\
\text { lecionam em "suas moradas, e que não } \\
\text { offerecem as precisas commodidades", } \\
\text { sendo } 2 \text { h30 de manhã e o mesmo à } \\
\text { tarde e que há "todo respeito". Há falta } \\
\text { de alunos e que soube que os pais } \\
\text { "applicão os filhos à lavoura, e mais se } \\
\text { demorão em seos Sítios levando-os em } \\
\text { sua companhia". Sem mapa. }\end{array}$ & J. J. Coelho & M. J. do Sacramento \\
\hline $\begin{array}{l}1867 \text { e } 1868 \\
\text { (Sem dados) }\end{array}$ & (J. J. Coelho) & (M. J. do Sacramento) \\
\hline $\begin{array}{l}1869 \\
\text { Inspetor de distrito Manoel Joaquim da } \\
\text { Luz menciona que as aulas são dadas } \\
\text { nas casas dos professores; alunos têm } \\
\text { adiantamento progressivo; há } \\
\text { assiduidade dos professores no ensino; } \\
\text { elogia os professores com relação à } \\
\text { "honesta conduta e regularidade de } \\
\text { vida com os que são conhecidos, } \\
\text { pública e particularmente". Pede uma } \\
\text { casa para cada cadeira para "formular } \\
\text { as classes de ensino" (comenta de } \\
\text { "utensis", mas está ilegível). Aulas } \\
\text { funcionam das } 8 \mathrm{~h} \text { às } 13 \mathrm{~h} \text {. Sem mapa. }\end{array}$ & $\begin{array}{l}\text { J. J. Coelho } \\
25 \text { alunos matriculados e } 25 \text { frequentes. }\end{array}$ & $\begin{array}{l}\text { M. J. do Sacramento } \\
24 \text { alunas matriculadas e } 20 \text { frequentes. } \\
\text { Maio - aprovada em exame para } \\
\text { receber } 200 \text { mil reis anuais, além do } \\
\text { ordenado (Jornal Correio Paulistano } \\
\text { de } 15 / 05 / 1869 \text { ). }\end{array}$ \\
\hline 1870 & J. J. Coelho & M. J. do Sacramento \\
\hline
\end{tabular}

${ }^{309}$ Os nomes de professores que estão dentro de parênteses se referem aos professores que possivelmente estavam à frente das respectivas cadeiras, mas que por não localizar nenhuma fonte referente ao professor e sua cadeira, recorri a esse recurso. 
Presidente de Província não aprova a criação da escola em Itaqui.

Em relatório do inspetor de distrito: Manoel Joaquim da Luz de 16/08/70 há a escusa de que os professores não entregaram os mapas e foram multados em 30 mil reis, mas não o fizeram porque não tinham o modelo do mapa para se basearem, aproveita para perguntar qual modelo usar .

Em outro relatório datado de 12/11/70 envia os mapas de instrução e informa a quantidade de alunos matriculados e frequentes, aponta que foram feitos exames no ano anterior aos alunos das duas cadeiras. Não aprenderam o sistema métrico; que os professores "gozam de grande estima, são aptos para o ensino, cumpridores de seus deveres, e de conducta irreprehensivel tanto civil, como moral". Não tem mapa.
30 alunos matriculados e 25 frequentes.

Relatório do inspetor: alunos "recebendo a instrucção necessária com aproveitamento segundo a capacidade intelectual de cada um". Aulas das 9 as $14 \mathrm{~h}$, na casa do professor.
25 alunas matriculadas e 22 frequentes.

Relatório do inspetor: "receberão a precisa instrucção, e com aproveitamento, aprendendo mais algumas as prendas domésticas como bordar, ?, e costurar". Aulas das 9 as $14 \mathrm{~h}$, na casa da professora. 
Apêndice B:

\begin{tabular}{|c|c|c|c|c|c|c|c|}
\hline \multicolumn{8}{|c|}{$\begin{array}{l}\text { ESCOLARIZAÇÃO EM COTIA NO SÉCULO XIX - PARTE II: de } 1871 \text { a } 1881 \\
\text { Professores responsáveis e outras informações } \\
\text { relatórios e ofícios de professores e inspetores, AESP, ref. CO5044, CO4915 e CO1007; livros de matrícula, } \\
\text { ESP, ref. EO2230, EO3182, EO2234, EO3030, EO2918 e EO3116; relatórios de governo; periódicos) }\end{array}$} \\
\hline $\begin{array}{l}\text { ANO E } \\
\text { INFORMAÇOES } \\
\text { REFERENTES À } \\
\text { INSPEÇÃO DE } \\
\text { DISTRITO }\end{array}$ & $\begin{array}{l}1^{\text {a }} \text { Cadeira } \\
\text { Masculina }\end{array}$ & $1^{\mathrm{a}}$ Cadeira Feminina & $\begin{array}{l}\text { Cadeira de Senhor } \\
\text { Bom Jesus do } \\
\text { Itaqui/Capitão } \\
\text { Jerônimo }\end{array}$ & $\begin{array}{c}\text { Cadeira de } \\
\text { Várzea-Grande }\end{array}$ & $\begin{array}{c}\text { Cadeira de } \\
\text { Sorocamirim }\end{array}$ & $\begin{array}{c}\text { Cadeira de } \\
\text { Carapicuíba }\end{array}$ & $\begin{array}{l}2^{\mathbf{a}} \text {.Cadeira } \\
\text { Masculina }\end{array}$ \\
\hline $\begin{array}{l}1871 \\
\text { Inspetor de distrito } \\
\text { desde agosto: Antonio } \\
\text { Bandeira Barreto de } \\
\text { Gouvêa } \\
\text { Ofício do Vigário } \\
\text { Manoel das Dores } \\
\text { Rocha solicita que } \\
\text { Antonio Barreto seja } \\
\text { o inspetor de 1as. } \\
\text { Letras - o anterior } \\
\text { pediu demissão. } \\
\text { Não há colégio nem } \\
\text { escola particular, } \\
\text { segundo Relatório de } \\
\text { Presidente da } \\
\text { Província referente a } \\
\text { 1871. }\end{array}$ & $\begin{array}{l}\text { J. J. Coelho } \\
\text { Relatório de governo: } \\
24 \text { matriculados e } 20 \\
\text { frequentes } \\
\text { No relatório de } \\
01 / 06 / 71 \text { o professor } \\
\text { informa que são } 22 \\
\text { alunos matriculados e } \\
\text { frequentes; que os } \\
\text { alunos recebem o } \\
\text { adiantamento "tal } \\
\text { qual é o talento, } \\
\text { applicação e boa } \\
\text { vontade de cada um } \\
\text { no desempenho de } \\
\text { seus deveres". Sobre } \\
\text { o ensino da gramática } \\
\text { nacional e do sistema } \\
\text { métrico, os alunos não } \\
\text { se aplicam e faltam } \\
\text { nas aulas; que no ano } \\
\text { anterior houve } \\
\text { aplicação de exame; } \\
\text { leciona em sua casa } \\
\text { das } 9 \text { às } 14 \text { h. }\end{array}$ & $\begin{array}{l}\text { M. J. do Sacramento } \\
\text { Relatório de governo: } \\
25 \text { matriculados e } 22 \\
\text { frequentes }\end{array}$ & $\begin{array}{l}\text { Criação Lei n }{ }^{\circ} 13 \\
\text { 09/03/1871 } \\
\text { Abril: aberto concurso } \\
\text { para esta cadeira } \\
\text { Relatório de governo: } \\
17 \text { matriculados e } 16 \\
\text { frequentes; neste } \\
\text { relatório aparece } \\
\text { Marcolino Pinto de } \\
\text { Queiroz como um dos } \\
\text { professores que se } \\
\text { removeram em 71: de } \\
\text { Pirapora para } \\
\text { S.B.Jesus do Itaqui. }\end{array}$ & $\begin{array}{l}\text { Criação Lei n }{ }^{\circ} 13 \\
09 / 03 / 1871 \\
\text { Abril: aberto concurso } \\
\text { para esta cadeira } \\
\text { Em junho João José } \\
\text { Pedroso é aprovado } \\
\text { como opositor em } \\
\text { exame para esta } \\
\text { cadeira (nos jornais } \\
\text { Correio Paulistano e } \\
\text { Diário de SP aparece } \\
\text { como professor de } \\
\text { Pirapora - Parnahyba) } \\
\text { Severiano José de } \\
\text { Ramos foi nomeado } \\
\text { professor desta } \\
\text { cadeira, porém sem } \\
\text { informações de } \\
\text { número de alunos } \\
\text { matriculados e } \\
\text { frequente; no relatório } \\
\text { de governo, Severiano } \\
\text { é um dos professores } \\
\text { nomeados neste ano. } \\
\text { Esta cadeira consta } \\
\text { entre as escolas cujo }\end{array}$ & $\begin{array}{l}\text { Criação Lei n } 70 \\
\text { 13/04/1871 } \\
\text { Agosto: aberto } \\
\text { concurso para esta } \\
\text { cadeira } \\
\text { José Custódio de } \\
\text { Queiroz foi nomeado } \\
\text { professor, porém sem } \\
\text { informações de } \\
\text { número de alunos } \\
\text { matriculados e } \\
\text { frequentes; no } \\
\text { relatório de governo, } \\
\text { J. Custódio é um dos } \\
\text { professores nomeados } \\
\text { neste ano. Esta } \\
\text { cadeira também } \\
\text { consta entre as } \\
\text { escolas cujo número } \\
\text { de alunos se ignora. }\end{array}$ & & \\
\hline
\end{tabular}




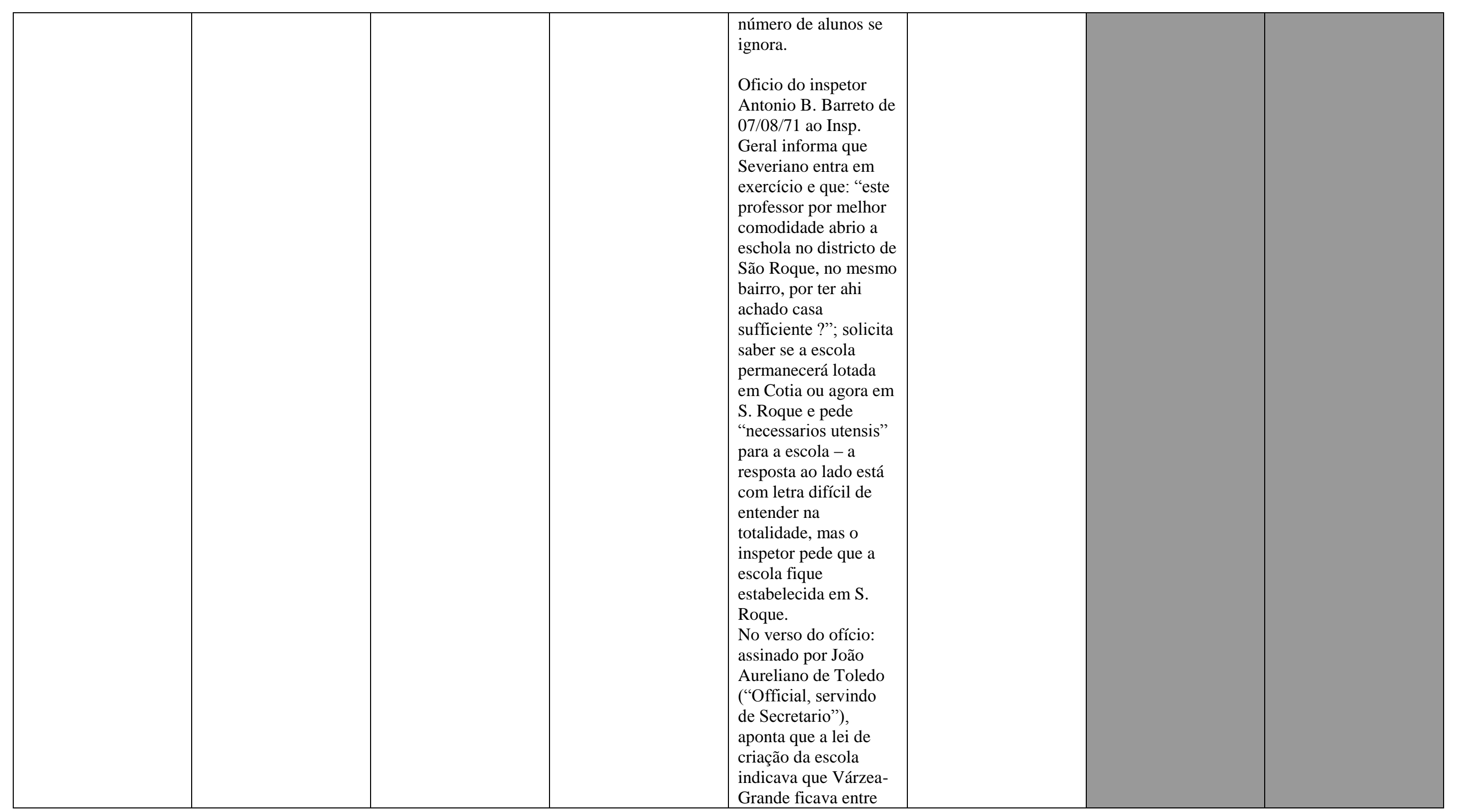




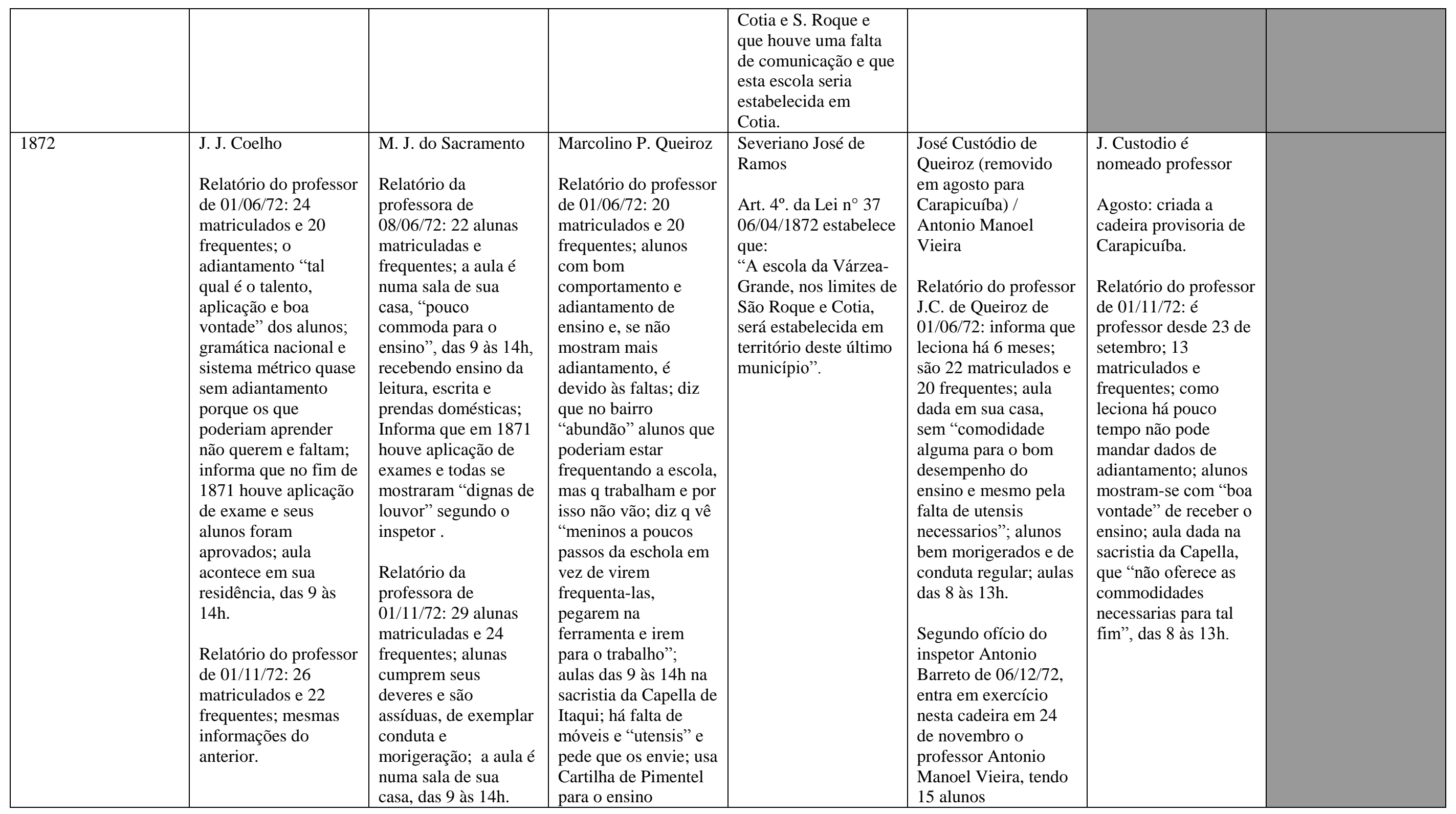




\begin{tabular}{|c|c|c|c|c|c|c|}
\hline & & & $\begin{array}{l}\text { religioso. } \\
\text { Relatorio do Prof. de } \\
01 / 11 / 72: 22 \\
\text { matriculadose } 20 \\
\text { frequentes; o mesmo } \\
\text { conteúdo com relação } \\
\text { ao trabalho dos alunos } \\
\text { e que para seus pais } \\
\text { "antes da instrucção } \\
\text { está o trabalho". Este } \\
\text { professor escreve } \\
\text { sobre Deus e religiao } \\
\text { em seus relatórios; } \\
\text { aulas em sua casa das } \\
9 \text { às } 14 \text { h; pede móveis } \\
\text { e "utensis"; para } \\
\text { ensino religioso usa a } \\
\text { Cartilha de Pimentel e } \\
\text { não foi possível } \\
\text { ensinar o sistema } \\
\text { métrico devido ao } \\
\text { "pouco conhecimento } \\
\text { dos alumnos para tal } \\
\text { fim". }\end{array}$ & & matriculados. & \\
\hline $\begin{array}{l}1873 \\
\text { Inspetor Antonio B. } \\
\text { Barreto; } \\
\text { Em ofício de } 16 / 11 / 73 \\
\text { ao Insp. Geral em } \\
\text { resposta a uma } \\
\text { circular do governo, } \\
\text { Antonio Barreto } \\
\text { informa haver } 6 \\
\text { escolas públicas, } \\
\text { sendo } 5 \text { do sexo } \\
\text { masculino e } 1 \text { do }\end{array}$ & $\begin{array}{l}\text { J. J. Coelho } \\
\text { No Almanak consta } \\
\text { esta cadeira } \\
\text { Livro de matrícula: } 32 \\
\text { matriculados. }\end{array}$ & $\begin{array}{l}\text { M. J. do Sacramento } \\
\text { No Almanak consta } \\
\text { esta cadeira } \\
\text { Relatório da } \\
\text { professora de } \\
\text { 02/06/73: informa sua } \\
\text { satisfação por ter o } \\
\text { inspetor geral } \\
\text { assumido o cargo } \\
\text { (Francisco Aurelio de } \\
\text { Souza Carvalho); } 32 \\
\text { matriculadas e } 25\end{array}$ & $\begin{array}{l}\text { Marcolino Pinto de } \\
\text { Queiroz } \\
\text { No Almanak consta } \\
\text { esta cadeira; } \\
\text { Relatório do professor } \\
\text { de 01/11/73: } 28 \\
\text { matriculados e } 21 \\
\text { frequentes (de junho a } \\
\text { outubro); } 4 \text { alunos } \\
\text { saíram ( } 2 \text { a mãe tirou, } \\
1 \text { se mudou e } 1 \text { sem } \\
\text { justificativa); no }\end{array}$ & $\begin{array}{l}\text { Severiano José de } \\
\text { Ramos } \\
\text { No Almanak consta } \\
\text { esta cadeira }\end{array}$ & $\begin{array}{l}\text { Antonio Manoel } \\
\text { Vieira } \\
\text { Requerimento do } \\
\text { inspetor Antonio } \\
\text { Barreto em 08/02/73 } \\
\text { ao Insp. Geral: pede } \\
\text { alguns móveis para } \\
\text { esta cadeira; no canto } \\
\text { do requerimento há } \\
\text { uma anotação onde } \\
\text { consta "toma-se nota" } \\
\text { (está ilegível) }\end{array}$ & $\begin{array}{l}\text { José Custódio de } \\
\text { Queiroz } \\
\text { No Almanak consta } \\
\text { esta cadeira }\end{array}$ \\
\hline
\end{tabular}




\begin{tabular}{|c|c|c|c|c|c|c|}
\hline $\begin{array}{l}\text { feminino; } 130 \\
\text { meninos matriculados } \\
\text { e } 110 \text { frequentes; } 28 \\
\text { meninas matriculadas } \\
\text { e } 24 \text { frequentes. }\end{array}$ & & $\begin{array}{l}\text { frequentes; aula das } 9 \\
\text { às } 14 ; \text { Cartilha de } \\
\text { Pimentel para ensino } \\
\text { religioso; } 7 \text { alumnas } \\
\text { eliminadas; }\end{array}$ & $\begin{array}{l}\text { momento que } \\
\text { mandava o relatório } \\
\text { eram } 24 \text { matriculados; } \\
\text { aula em sala de sua } \\
\text { casa das } 9 \text { às } 14 \mathrm{~h} \text {; ele } \\
\text { forneceu a maior } \\
\text { parte dos objetos } \\
\text { (penas, papel, tinta e } \\
\text { alguns livros); } \\
\text { "eschola em lugar } \\
\text { baldo de recursos"; } \\
\text { instrução religiosa } \\
\text { usando Cartilha de } \\
\text { Pimentel . }\end{array}$ & & $\begin{array}{l}\text { Nota de jornal } \\
\text { assinada por um } \\
\text { sorocamiriano } \\
\text { denunciando que esta } \\
\text { cadeira funcionava } \\
\text { em Caucaia. }\end{array}$ & \\
\hline $\begin{array}{l}1874 \\
\text { Inspetor Antonio B. } \\
\text { Barreto; } \\
\text { Em ofício ao Insp. } \\
\text { Geral de 19/01/74: } \\
\text { informa que João } \\
\text { Baptista Cepellos } \\
\text { abriu escola sem } \\
\text { proceder conforme } \\
\text { art. } 154 \text { do } \\
\text { Rgulamento de 69, } \\
\text { que ele não tem } \\
\text { nenhuma habilitação } \\
\text { para ensinar, que já } \\
\text { falou com Cepellos e } \\
\text { pede que Inspetor } \\
\text { Geral faça o que achar } \\
\text { melhor (está ilegível a } \\
\text { resposta do Inspetor } \\
\text { Geral no canto da } \\
\text { folha). } \\
\text { Oficio de Antonio }\end{array}$ & $\begin{array}{l}\text { J. J. Coelho } \\
\text { Relatório do professor } \\
\text { de } 01 / 06 / 74: 23 \\
\text { matriculados e } \\
\text { frequentes (de janeiro } \\
\text { a junho); recebendo } \\
\text { adiantamento "tal } \\
\text { qual é o talento, } \\
\text { applicação e boa } \\
\text { vontade de cada um"; } \\
\text { em } 73 \text { foram feitos } \\
\text { exames de todos, } \\
\text { sendo aprovados; } \\
\text { funciona das } 9 \text { às } 14 \mathrm{~h} \\
\text { em sala do lado de } \\
\text { fora de sua casa. } \\
\text { Relatório do professor } \\
\text { de } 01 / 11 / 74: 28 \\
\text { matriculados e } 23 \\
\text { frequentes; } \\
\text { adiantamento "tal } \\
\text { qual é o talento, } \\
\text { applicação e boa }\end{array}$ & $\begin{array}{l}\text { M. J. do Sacramento } \\
\text { Relatório da } \\
\text { professora de } \\
01 / 06 / 74 \text { : } \\
23 \text { matriculados e } \\
\text { frequentes, com maior } \\
\text { ou menor } \\
\text { aproveitamento e } \\
\text { "exemplar conducta e } \\
\text { morigeração"; aulas } \\
\text { na sala de sua casa } \\
\text { das } 9 \text { às } 14 \mathrm{~h} \text {; informa } \\
\text { que no fim de } 73 \\
\text { foram feitos exames e } \\
\text { todas aprovadas } \\
\text { Relatório da } \\
\text { professora de } \\
\text { 01/11/74: } 24 \\
\text { matriculados e } \\
\text { frequentes (junho a } \\
\text { outubro); } \\
\text { "adiantamento no } \\
\text { ensino e morigerada }\end{array}$ & $\begin{array}{l}\text { Marcolino Pinto de } \\
\text { Queiroz } \\
\text { Relatório do professor } \\
\text { de } 01 / 06 / 74 \text { : referente } \\
\text { a nov/73 a maio/74; } \\
25 \text { matriculados e } 21 \\
\text { frequentes; frequência } \\
\text { pouco regular, por } \\
\text { esse motivo não tem } \\
\text { "vantajoso resultado" } \\
\text { no aproveitamento; } 3 \\
\text { foram eliminados por } \\
\text { mudança (2 para } \\
\text { Tatuí e } 1 \text { para Aldeia } \\
\text { de Carapicuíba); } \\
\text { funciona em sua casa } \\
\text { das } 9 \text { às } 14 \mathrm{~h} \text {; Cartilha } \\
\text { de Pimentel para ens. } \\
\text { religioso; } \\
\text { Relatório do professor } \\
\text { de 01/11/74: de julho } \\
\text { a outubro; } 23 \\
\text { matriculados e } 20\end{array}$ & $\begin{array}{l}\text { Severiano José de } \\
\text { Ramos } \\
\text { Relatório do professor } \\
\text { de } 01 / 11 / 74 \text { : de junho } \\
\text { a outubro; } 28 \\
\text { matriculados; } \\
\text { comenta da } \\
\text { obrigatoriedade do } \\
\text { ensino; alunos } \\
\text { morigerados; ensino } \\
\text { ministrado é o } \\
\text { prescrito na lei } \\
54 / 1868 ; \text { das } 8 \text { às } 13 \mathrm{~h} ; \\
\text { informa que os alunos } \\
\text { moram longe, mas os } \\
\text { pais desejam que } \\
\text { frequentem as aulas; } \\
\text { pais e alunos pobres, } \\
\text { porém alunos “sempre } \\
\text { limpos em seus trajes } \\
\text { simples"; } 3 \text { foram } \\
\text { eliminados (1 pelo art. } \\
97 \text { do Regulamento - } \\
\text { abandono - e } 2 \\
\end{array}$ & $\begin{array}{l}\text { Antonio Manoel } \\
\text { Vieira } \\
\text { Relatório do professor } \\
\text { de } 01 / 06 / 74 \text { : de } \\
\text { nov/73 a maio/74; } 33 \\
\text { matriculados; neste } \\
\text { período } 10 \\
\text { eliminações (2 por } \\
\text { completarem o estudo } \\
\text { e } 8 \text { sem motivo) e em } \\
74 \text { entraram } 14 \text { alunos } \\
\text { (sendo } 1 \text { já eliminado) } \\
\text { - relatório bem } \\
\text { detalhado sobre o } \\
\text { adiantamento dos } \\
\text { alunos; professor } \\
\text { fornece material; } \\
\text { "alunos pobres" e } \\
\text { "bairro remoto"; } \\
\text { leciona na casa "que } \\
\text { servio o meu } \\
\text { antecessor, cuja } \\
\text { pertence a Antonio de } \\
\text { Oliveira Albuquerque, }\end{array}$ & $\begin{array}{l}\text { José Custódio de } \\
\text { Queiroz } \\
\text { Inspetor Antonio B. } \\
\text { Barreto em ofício de } \\
\text { 25/05/74: pede em } \\
\text { nome de J. C. Queiroz } \\
\text { (com o oficio do } \\
\text { mesmo incluso) que } \\
\text { sejam enviados } \\
\text { móveis e "utensis" } \\
\text { para a esta escola; o } \\
\text { ofício do professor ao } \\
\text { inspetor A. Barreto } \\
\text { data de 20/05/74. } \\
\text { Relatório do professor } \\
\text { de } 01 / 06 / 74: \text { de } \\
\text { nov/73 a maio/74; } 26 \\
\text { matriculados e } \\
\text { frequentes; } 4 \\
\text { eliminados (2 } \\
\text { mudaram-se e } 2 \text { os } \\
\text { pais retiraram da } \\
\text { escola); leciona em }\end{array}$ \\
\hline
\end{tabular}




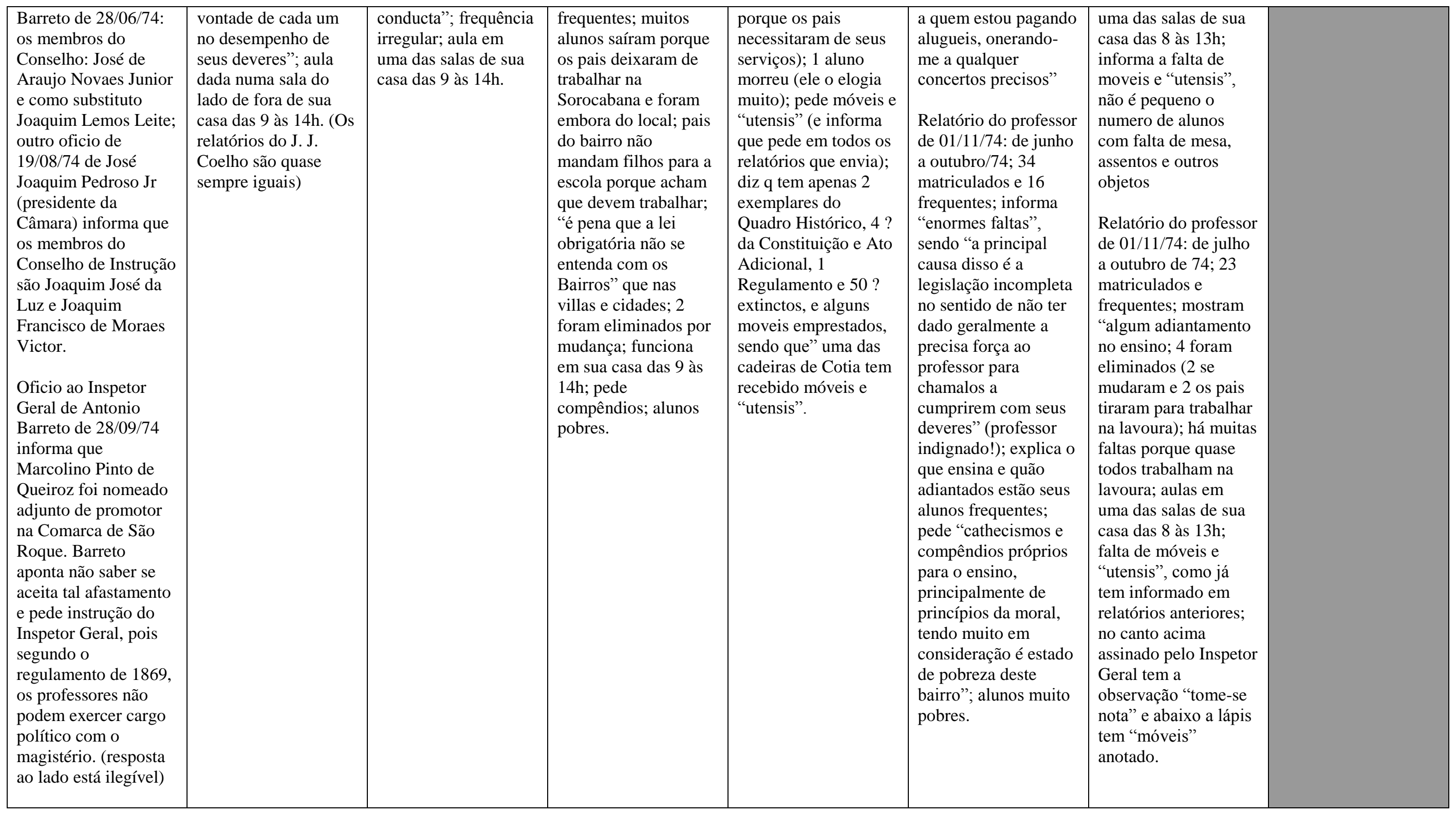




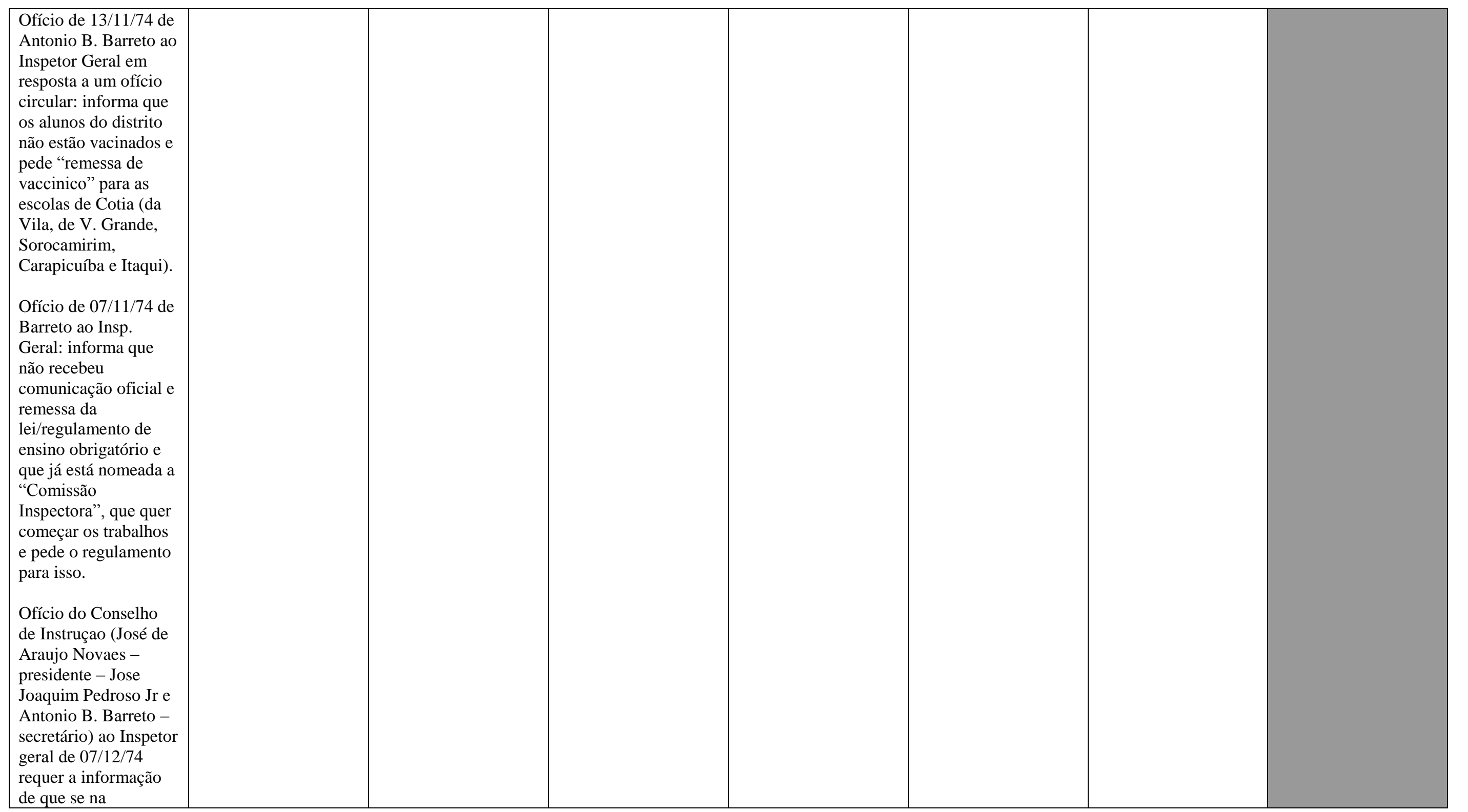




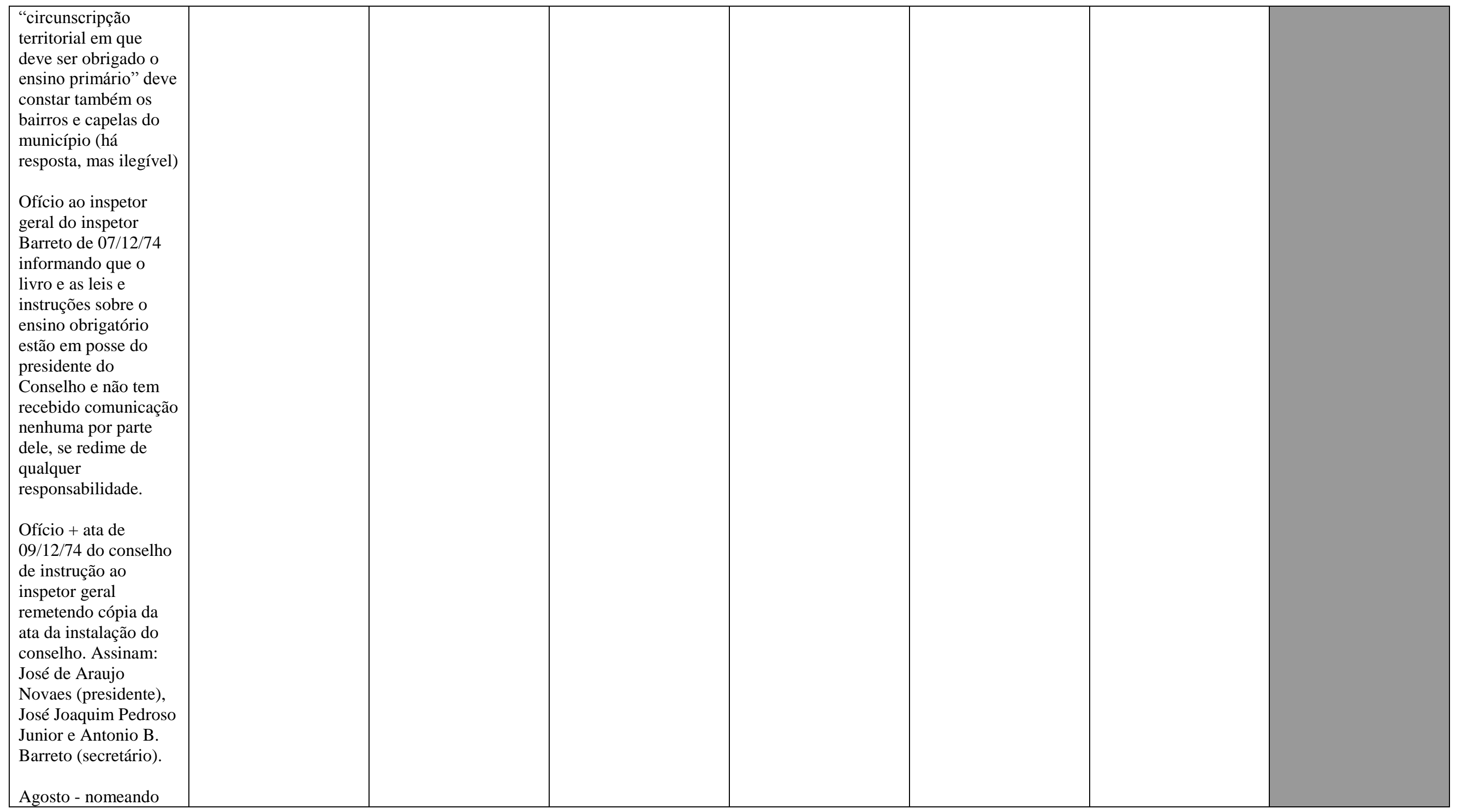




\begin{tabular}{|c|c|c|c|c|c|c|c|}
\hline $\begin{array}{l}\text { para Conselho de } \\
\text { Instr. Pública José de } \\
\text { Araujo de Novaes } \\
\text { Junior, substituto } \\
\text { Joaquim Lemos Leite. }\end{array}$ & & & & & & & \\
\hline $\begin{array}{l}1875 \\
\text { Outubro: nomeado } \\
\text { para inspetor de } \\
\text { distrito Joaquim de } \\
\text { Araujo Novaes e } \\
\text { exonerado o 3o } \\
\text { membro do Conselho } \\
\text { de I. P. do município } \\
\text { José de Araujo } \\
\text { Novaes. }\end{array}$ & $\begin{array}{l}\text { J. J. Coelho } \\
\text { Livro de matrícula: } 29 \\
\text { matriculados. }\end{array}$ & $\begin{array}{l}\text { M. J. do Sacramento } \\
\text { Livro de matrícula: } 29 \\
\text { matriculadas. }\end{array}$ & $\begin{array}{l}\text { (Marcolino Pinto de } \\
\text { Queiroz) } 310 / \text { ? } \\
\text { Julho de } 1875- \\
\text { concurso para a } \\
\text { cadeira de Itaqui. }\end{array}$ & $\begin{array}{l}\text { Severiano José de } \\
\text { Ramos } \\
\text { Em novembro } \\
\text { Severiano é } \\
\text { matriculado como } \\
\text { aluno-mestre na } \\
\text { Escola Normal da } \\
\text { Capital. }\end{array}$ & $?^{311}$ & $\begin{array}{l}\text { (José Custódio de } \\
\text { Queiroz?) } \\
\text { (varíola entre os } \\
\text { índios da aldeia de } \\
\text { Carapicuíba) } \\
\text { Julho: ofício do } \\
\text { inspetor de instrução } \\
\text { pública comunicando } \\
\text { o exercicio de cargo } \\
\text { do professor desta } \\
\text { cadeira }\end{array}$ & $\begin{array}{l}\text { Criação Lei n }{ }^{\circ} 27 \\
\text { 14/04/1875 } \\
\text { Marcolino Pinto de } \\
\text { Queiroz } \\
\text { Julho: Inspetor Geral } \\
\text { comunicando ao } \\
\text { Presidente do } \\
\text { exercicio de cargo do } \\
\text { professor. } \\
\text { Livro de matrícula: } 14 \\
\text { matriculados. }\end{array}$ \\
\hline 1876 & J. J. Coelho & M. J. do Sacramento & $\begin{array}{c}\text { Vaga } \\
\text { Agosto - aberto } \\
\text { concurso para } \\
\text { cadeiras esta cadeira. }\end{array}$ & $\begin{array}{l}\text { Severiano José de } \\
\text { Ramos } \\
\text { Junho - Severiano é } \\
\text { removido para cadeira } \\
\text { de Lageado (distrito } \\
\text { da Freguesia da Penha } \\
\text { de França, Capital) } \\
\text { Agosto - aberto } \\
\text { concurso para } \\
\text { cadeiras esta cadeira. }\end{array}$ & $\begin{array}{c}\text { Vaga } \\
\text { Agosto - aberto } \\
\text { concurso para } \\
\text { cadeiras esta cadeira. }\end{array}$ & $\begin{array}{l}\text { (José Custódio de } \\
\text { Queiroz) }\end{array}$ & $\begin{array}{l}\text { Marcolino Pinto de } \\
\text { Queiroz }\end{array}$ \\
\hline 1877 & $\begin{array}{l}\text { J. J. Coelho } \\
\text { Relatório do professor } \\
01 / 06 / 77 \text { : }\end{array}$ & M. J. do Sacramento & $\begin{array}{c}\text { Concurso para esta } \\
\text { cadeira }\end{array}$ & $\begin{array}{l}\text { Concurso para esta } \\
\text { cadeira }\end{array}$ & $\begin{array}{l}\text { Concurso para esta } \\
\text { cadeira }\end{array}$ & $\begin{array}{l}\text { José Custódio de } \\
\text { Queiroz } \\
\text { Julho: J. C. de }\end{array}$ & $\begin{array}{l}\text { Marcolino Pinto de } \\
\text { Queiroz }\end{array}$ \\
\hline
\end{tabular}

${ }^{310}$ Os nomes de professores que estão dentro de parênteses se referem aos professores que possivelmente estavam à frente das respectivas cadeiras, mas que por não localizar nenhuma fonte referente ao professor e sua cadeira, recorri a esse recurso.

${ }^{311}$ Sem fontes. 


\begin{tabular}{|c|c|c|c|c|c|c|c|}
\hline & $\begin{array}{l}20 \text { matriculados e } \\
\text { frequentes; em } 76 \\
\text { houve exames e todos } \\
\text { foram aprovados; aula } \\
\text { continua a ser dada } \\
\text { em uma sala do lado } \\
\text { de fora de sua } \\
\text { residência das } 9 \text { às } \\
14 \mathrm{~h} \text {. }\end{array}$ & & & & & $\begin{array}{l}\text { Queiroz pede } \\
\text { exoneração } \\
\text { Dezembro:edital de } \\
\text { concurso para cadeira } \\
\text { de Carapicuíba }\end{array}$ & \\
\hline 1878 & J. J. Coelho & M. J. do Sacramento & 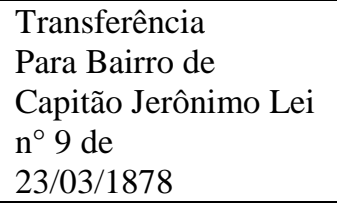 & $\begin{array}{c}\text { Concurso para esta } \\
\text { cadeira }\end{array}$ & $\begin{array}{c}\text { Concurso para esta } \\
\text { cadeira }\end{array}$ & $\begin{array}{l}\text { Transferência } \\
\text { Para Baruery Lei n }{ }^{\circ} 9 \\
\text { de 23/03/1878 }\end{array}$ & $\begin{array}{l}\text { Marcolino Pinto de } \\
\text { Queiroz }\end{array}$ \\
\hline $\begin{array}{l}1879 \\
\text { Relatorio de inspetor } \\
\text { de distrito Joaquim de } \\
\text { Araujo Novaes de } \\
03 / 01 / 79 \text { ao Insp. } \\
\text { Geral: informa que } \\
\text { havia em Cotia } 8 \\
\text { escolas, sendo } 7 \\
\text { públicas e } 1 \text { particular } \\
\text { para o sexo feminino; } \\
\text { informou apenas a } \\
\text { quantidade de alunos } \\
\text { das cadeiras da vila } \\
\text { (1 }{ }^{\text {a }} \text { e } 2^{\text {a }} \text {. masculinas e } \\
1^{\text {a }} \text { femnina), } \\
\text { respectivamente } 20,15 \\
\text { e } 18 . \\
\text { Conselho de Instrução } \\
\text { Pública, consta } \\
\text { Joaquim Lemos Leite } \\
\text { como substituto. } \\
\text { No relatório do }\end{array}$ & $\begin{array}{l}\text { J. J. Coelho } \\
\text { Relatório de governo: } \\
21 \text { matriculados e } 21 \\
\text { frequentes }\end{array}$ & $\begin{array}{l}\text { M. J. do Sacramento } \\
\text { Relatório de governo: } \\
20 \text { matriculados e } 20 \\
\text { frequentes }\end{array}$ & $\begin{array}{l}\text { João da Matta Luz/ } \\
\text { José Custódio de } \\
\text { Queiroz } \\
\text { Abril - nomeado } \\
\text { professor de Capitão } \\
\text { Jerônimo João da } \\
\text { Matta Luz; é } \\
\text { transferido para a } \\
\text { Cadeira do Bairro de } \\
\text { Canguára, São Roque, } \\
\text { em julho. } \\
\text { Julho - José Custódio } \\
\text { é nomeado professor } \\
\text { Relatório de governo: } \\
23 \text { matriculados e } 20 \\
\text { frequentes } \\
\text { Relatório do professor } \\
\text { de 25/09/79: resposta } \\
\text { a uma portaria, que } \\
\text { em principio já a tinha } \\
\text { enviado ao inspetor }\end{array}$ & Vaga & Vaga & $\begin{array}{l}\text { João Rodrigues de } \\
\text { Jesus - nomeado em } \\
\text { abril. } \\
\text { Relatório do professor } \\
\text { ao Insp. Geral de } \\
\text { maio (apesar da lei do } \\
\text { ano anterior): } \\
\text { comunica que desde } \\
\text { 19/05 abriu a escola } \\
\text { do sexo masculino } \\
\text { tendo } 17 \text { alunos } \\
\text { frequentes. }\end{array}$ & $\begin{array}{l}\text { M. Pinto de Queiroz } \\
\text { Relatório de governo: } \\
23 \text { matriculados e } 18 \\
\text { frequentes. }\end{array}$ \\
\hline
\end{tabular}




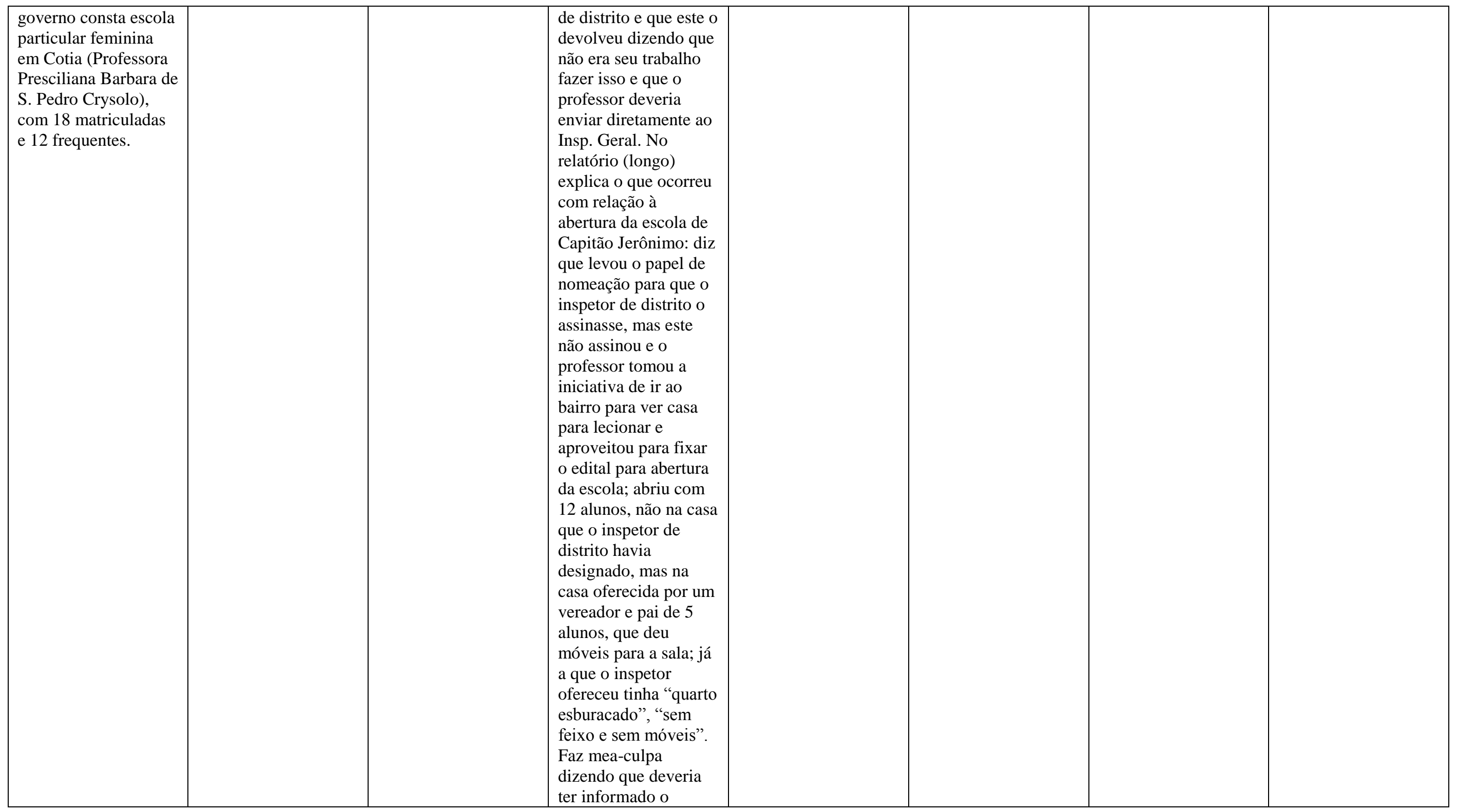




\begin{tabular}{|c|c|c|c|c|c|c|c|}
\hline & & & $\begin{array}{l}\text { inspetor, mas diz não } \\
\text { ter feito porque este } \\
\text { foi a Rio Novo e } \\
\text { voltou em 16/08. } \\
\text { Também diz que a } \\
\text { escola deveria ser } \\
\text { aberta em } 13 / 08, \text { mas } \\
\text { ele abriu em 12/08 } \\
\text { porque não tinha na } \\
\text { memória a data } \\
\text { correta; termina } \\
\text { dizendo que a escola } \\
\text { está num lugar melhor } \\
\text { para os alunos } \\
\text { moradores das } \\
\text { estradas de Una e } \\
\text { Sorocaba; aponta que } \\
\text { há } 23 \text { matriculados e } \\
20 \text { frequentes. }\end{array}$ & & & & \\
\hline $\begin{array}{l}1880 \\
\text { Inspetor de Distrito } \\
\text { Tenente Benedicto } \\
\text { José de Oliveira } \\
\text { Conselho da Instrução } \\
\text { Pública } \\
\text { Substituto: Joaquim } \\
\text { Lemos Leite } \\
\text { (não há } 3^{\circ} . \text { Membro) }\end{array}$ & $\begin{array}{l}\text { J. J. Coelho } \\
\text { Pede aposentadoria } \\
\text { Relatório de governo: } \\
20 \text { matriculados e } 20 \\
\text { frequentes } \\
\text { Relatório do professor } \\
\text { de 01/06/80: } 21 \\
\text { matriculados e } \\
\text { frequentes; } \\
\text { adiantamento é "tal } \\
\text { qual o talento, } \\
\text { applicação e boa } \\
\text { vontade de que são } \\
\text { dotados"; aula dada } \\
\text { numa sala do lado de } \\
\text { fora de sua casa das } 9 \\
\text { às } 14 \text { h. }\end{array}$ & $\begin{array}{l}\text { M. J. do Sacramento } \\
\text { Pede aposentadoria } \\
\text { Relatório de governo: } \\
\text { Sem alunas, porém } \\
\text { não está na relação de } \\
\text { cadeiras vagas } \\
\text { Ofício ao Insp. Geral } \\
\text { de } 03 / 02 / 80 \text { : envia o } \\
\text { livro de matrícula que } \\
\text { terminou em } 1879 \text {. } \\
\text { Relatório da } \\
\text { professora de } \\
\text { novembro: } 21 \\
\text { matriculadas e } \\
\text { frequentes; aula em } \\
\text { sala de sua casa das } 9 \\
\text { às } 14 \mathrm{~h} \text {. }\end{array}$ & $\begin{array}{l}\text { J. C. de Queiroz } \\
\text { Relatório de governo: } \\
29 \text { matriculados e } 23 \\
\text { frequentes } \\
\text { Relatório do professor } \\
\text { de 01/06/80: } 29 \\
\text { matriculados e } 23 \\
\text { frequentes; escola na } \\
\text { casa do cidadão } \\
\text { Jesuino Pereira Leite } \\
\text { das } 8 \text { às } 13 \text { h; informa } \\
\text { a falta de móveis e } \\
\text { "utensis"; usa cartilha } \\
\text { de Pimentel para o } \\
\text { ensino religioso. } \\
\text { Relatório do professor } \\
\text { de 01/11/80: informa }\end{array}$ & $\begin{array}{l}\text { Manoel de Moraes } \\
\text { Pinto } \\
\text { Relatório de governo: } \\
\text { Sem alunos, porém } \\
\text { não está na relação de } \\
\text { cadeiras vagas } \\
\text { Entre os professores } \\
\text { removidos neste ano } \\
\text { consta Manoel de } \\
\text { Moraes Pinto: da } \\
\text { cadeira da Villa de } \\
\text { Araçariguama para } \\
\text { Várzea-Grande } \\
\text { Relatório do professor } \\
\text { de 15/03/80: informa } \\
\text { que entrou em } \\
\text { exercício neste dia e }\end{array}$ & $\begin{array}{l}\text { João Cezar de Abreu } \\
\text { e Silva } \\
\text { No relatório de } 1880 \\
\text { não consta o } \\
\text { município, apenas } \\
\text { "Cadeira de } \\
\text { Sorocamirim", com o } \\
\text { Prof. João Cezar de } \\
\text { Abreu e Silva - sem } \\
\text { alunos } \\
\text { Em dezembro este } \\
\text { professor é nomeado } \\
\text { para Jundiaí }\end{array}$ & $\begin{array}{l}\text { João Rodrigues de } \\
\text { Jesus } \\
\text { Relatório do Inspetor } \\
\text { de distrito para Insp. } \\
\text { Geral de } 03 / 02 / 80, \\
\text { informa: o prof. João } \\
\text { Rodrigues de Jesus } \\
\text { mudou a escola para } \\
\text { uma “casa de } \\
\text { alambique, imprópria } \\
\text { para eschola pública, } \\
\text { ficando aquém da } \\
\text { Aldea, logar onde já } \\
\text { funcionou o seu } \\
\text { antecessor e onde o } \\
\text { mesmo lecionou até } \\
\text { dezembro, isto a seu } \\
\text { bello prazer, sem } \\
\text { sciencia minha”, diz } \\
\end{array}$ & $\begin{array}{l}\text { Marcolino Pinto de } \\
\text { Queiroz } \\
\text { Relatório de governo: } \\
24 \text { matriculados e } 18 \\
\text { frequentes }\end{array}$ \\
\hline
\end{tabular}




\begin{tabular}{|c|c|c|c|c|c|c|c|}
\hline & & & $\begin{array}{l}\text { que muitos alunos vão } \\
\text { trabalhar na lavoura } \\
\text { para ajudar seus pais, } \\
1 \text { aluno foi eliminado } \\
\text { por mudança e } \\
\text { matricularam-se 11; } \\
\text { são } 39 \text { matriculados e } \\
28 \text { frequentes; escola } \\
\text { continua na casa do } \\
\text { cidadão Jesuino } \\
\text { Pereira Leite das } 8 \text { às } \\
\text { 13h; usa cartilha de } \\
\text { Pimentel para o } \\
\text { ensino religioso }\end{array}$ & $\begin{array}{l}\text { que a escola tem } 10 \\
\text { alunos matriculados. } \\
\text { Ofício do inspetor de } \\
\text { distrito de 17/03/80: } \\
\text { informa o } \\
\text { funcionamento da } \\
\text { escola de Várzea- } \\
\text { Grande (a letra não é } \\
\text { do inspetor, que } \\
\text { assina abaixo, e } \\
\text { parece ser de J C de } \\
\text { Queiroz. Este inspetor } \\
\text { de distrito não } \\
\text { costuma escrever seus } \\
\text { documentos oficiais, } \\
\text { deixando a cargo de } \\
\text { outra pessoa, ele } \\
\text { apenas assina). }\end{array}$ & & $\begin{array}{l}\text { que a casa fica longe } \\
\text { dos alunos e em local } \\
\text { incomodo, que o prof. } \\
\text { deixa de dar aulas em } \\
\text { dias úteis para caçar. } \\
\text { Ainda, segundo o } \\
\text { inspetor, o prof. o } \\
\text { respondeu que ele tem } \\
\text { direito de dar aula às } \\
\text { quintas-feiras para } \\
\text { faltar em qualquer dia } \\
\text { útil e que deu aula na } \\
\text { casa do Alambique } \\
\text { mas agora o dono está } \\
\text { lá, porém, de acordo } \\
\text { com o inspetor, o } \\
\text { prof. continua } \\
\text { lecionando nesse } \\
\text { local. O inspetor } \\
\text { pergunta ao Insp. } \\
\text { Geral se o professor } \\
\text { pode fazer a mudança } \\
\text { sem a ciência dele e } \\
\text { se pode trocar as } \\
\text { quintas-feiras com } \\
\text { outros dias úteis. } \\
\text { Há uma resposta no } \\
\text { canto superior } \\
\text { esquerdo, que ao que } \\
\text { tudo indica o Inspetor } \\
\text { Geral dá razão ao } \\
\text { professor. }\end{array}$ & \\
\hline $\begin{array}{l}1881 \\
\text { Relatório do inspetor } \\
\text { de distrito Benedicto } \\
\text { José de Oliveira de } \\
\text { 24/07/81 em resposta } \\
\text { à circular de 27/06/81 }\end{array}$ & $\begin{array}{l}\text { J. J. Coelho } \\
\text { Relatório do professor } \\
\text { de } 01 / 06 / 81: 20 \\
\text { matriculados e } \\
\text { frequentes; no ano de } \\
80 \text { os alunos passaram }\end{array}$ & $\begin{array}{l}\text { M. J. do Sacramento } \\
\text { Relatório do professor } \\
\text { de } 01 / 11 / 81: 21 \\
\text { matriculadas, sendo } \\
\text { quase todas } \\
\text { frequentes; escola }\end{array}$ & $\begin{array}{l}\text { J.C. de Queiroz } \\
\text { Relatório do professor } \\
\text { de } 01 / 06 / 81: 45 \\
\text { matriculados e } 35 \\
\text { frequentes (neste } \\
\text { semestre } 3 \text { alunos se }\end{array}$ & $\begin{array}{l}\text { M. M. Pinto } \\
\text { Relatório do professor } \\
\text { de } 01 / 06 / 81: 16 \\
\text { matriculados e } 13 \\
\text { frequentes; aula dada } \\
\text { em uma sala de sua }\end{array}$ & ? & $\begin{array}{l}\text { Joao Rodrigues de } \\
\text { Jesus } \\
\text { Relatório do professor } \\
\text { de } 01 / 06 / 81: 18 \\
\text { matriculados e um } \\
\text { destes se eliminou }\end{array}$ & $\begin{array}{l}\text { M. P. de Queiroz } \\
\text { Relatório do professor } \\
\text { de } 01 / 06 / 81: 35 \\
\text { matriculados e } 25 \\
\text { frequentes, sendo } 15 \\
\text { matriculados e } 2\end{array}$ \\
\hline
\end{tabular}




\begin{tabular}{|c|c|c|c|c|c|c|}
\hline $\begin{array}{l}\text { ao Inspetor Geral, } \\
\text { informando que não } \\
\text { há bibliotecas, } \\
\text { museus e gabinetes de } \\
\text { leituras no distrito de } \\
\text { Cotia; há } 6 \text { aulas } \\
\text { públicas providas ( } 5 \\
\text { masculinas e } 1 \\
\text { feminina) e duas aulas } \\
\text { particulares, uma para } \\
\text { cada sexo. Nas } \\
\text { públicas do masculino } \\
\text { há } 131 \text { matriculados e } \\
105 \text { frequentes e no } \\
\text { feminino } 21 \\
\text { matriculadas e } 18 \\
\text { frequentes, ao todo } \\
152 \text { matriculados e } \\
123 \text { frequentes; nas } \\
\text { particulares } 22 \\
\text { matriculados e } \\
\text { frequentes; } 6 \text { no } \\
\text { masculino e } 16 \text { no } \\
\text { feminino. }\end{array}$ & $\begin{array}{l}\text { por exame presidido } \\
\text { pelo insp. de distrito, } \\
\text { sendo todos } \\
\text { aprovados nas } \\
\text { matérias que eles } \\
\text { mais se aplicaram; } \\
\text { aula continua em uma } \\
\text { sala para fora de sua } \\
\text { casa das } 9 \text { às } 14 \mathrm{~h} \text {. }\end{array}$ & $\begin{array}{l}\text { continua sendo na } \\
\text { sala de sua casa das } 9 \\
\text { às } 14 \mathrm{~h} \text {. }\end{array}$ & $\begin{array}{l}\text { matricularam); aula } \\
\text { na mesma casa das } 8 \\
\text { às 13h; ensino } \\
\text { religioso pela Cartilha } \\
\text { de Pimentel; pede } \\
\text { novamente móveis e } \\
\text { "utensis" pois tem } 35 \\
\text { alunos frequentes e, } \\
\text { destes, } 29 \text { já escrevem } \\
\text { e estão contando. } \\
\text { Relatório do professor } \\
\text { de 01/11/81: } 37 \\
\text { matriculados e } 28 \\
\text { frequentes; } 1 \text { aluno } \\
\text { matriculado no último } \\
\text { semestre e } 6 \\
\text { eliminados (1 com } \\
\text { autorização e } 4 \text { pelo } \\
\text { art } 97,2^{\circ} . \text { Parag. do } \\
\text { Regulamento de } 1869 \\
\text { - abandono); escola } \\
\text { na mesma casa e no } \\
\text { mesmo horário; } \\
\text { ensino religioso pela } \\
\text { Cartilha de Pimentel, } \\
\text { "visto não ter } \\
\text { Cathecismos da } \\
\text { Diocese" e pede q ele } \\
\text { mande } 12 \text { exemplares } \\
\text { destes. }\end{array}$ & $\begin{array}{l}\text { casa das } 9 \text { às } 14 \mathrm{~h} \text {; no } \\
\text { ano de } 80 \text { os alunos } \\
\text { passaram por exame } \\
\text { presidido pelo } \\
\text { inspetor de distrito, } \\
\text { sendo todos } \\
\text { aprovados nas } \\
\text { matérias que se } \\
\text { dedicaram. } \\
\text { Relatório do professor } \\
\text { de } 03 / 11 / 81: 20 \\
\text { matriculados e } 16 \\
\text { frequentes; aula em } \\
\text { uma sala de sua casa } \\
\text { das } 9 \text { às } 14 \mathrm{~h} \text {; “é } \\
\text { extraordinaria a falta } \\
\text { de utensis" e espera } \\
\text { ser atendido. }\end{array}$ & $\begin{array}{l}\text { "com a devida } \\
\text { autorização"; o } \\
\text { professor diz que tem } \\
\text { se "esforçado" em } \\
\text { ensinar "nos } 5 \\
\text { methodos de ensino } \\
\text { do Dr. Freire que me } \\
\text { forão fornecido por V. } \\
\text { Exa., porém como por } \\
\text { aqui não há mais } \\
\text { compêndios, luto com } \\
\text { grande difficuldade"; } \\
\text { que apesar da } \\
\text { dificuldade dos alunos } \\
\text { na escrita, arranjou } \\
\text { uma mesa para eles } \\
\text { escreverem q veio de } \\
\text { São Paulo; não tem } \\
\text { "Cathechismo", então } \\
\text { não se adiantaram na } \\
\text { "doutrina cristã"; } \\
\text { "sobre aritmética o } \\
\text { mesmo acontece pois } \\
\text { há grande falta de } \\
\text { pedras"; "as pedras e } \\
\text { o Cathechismo são de } \\
\text { uma necessidade } \\
\text { espantoza para o } \\
\text { adiantemento dos } \\
\text { alumnos". }\end{array}$ & $\begin{array}{l}\text { eliminados por } \\
\text { mudança (1 para } \\
\text { Capital e 1 para sitio); } \\
\text { diz-se feliz porque os } \\
\text { alunos estão } \\
\text { aprendendo, porque } \\
\text { há poucas faltas e os } \\
\text { pais estão mandando } \\
\text { os filhos para a } \\
\text { escola; "lutamos com } \\
\text { a acanhadez do lugar } \\
\text { para a escola e com a } \\
\text { falta de móveis e de } \\
\text { tudo que é necessário } \\
\text { para a sustentação do } \\
\text { ensino"; "do nosso } \\
\text { limitado ordenado } \\
\text { pagamos o aluguel" } \\
\text { (de onde mora e } \\
\text { funciona a escola) e } \\
\text { outros materiais, } \\
\text { porque alunos na } \\
\text { maior parte são } \\
\text { pobres; pede ajuda ao } \\
\text { Inspetor Geral; das } 9 \\
\text { às 104h; ensino } \\
\text { religioso é dado pelo } \\
\text { Cathecismo da } \\
\text { Diocese e para os q } \\
\text { não a possuem, o } \\
\text { prof. o dá oralmente } \\
\\
\text { Relatório do professor } \\
\text { de 01/11/81: } 31 \\
\text { matriculados e } 22 \\
\text { frequentes; no último } \\
\text { semestre } 5 \\
\text { matriculados e } 7 \\
\text { eliminações "por }\end{array}$ \\
\hline
\end{tabular}




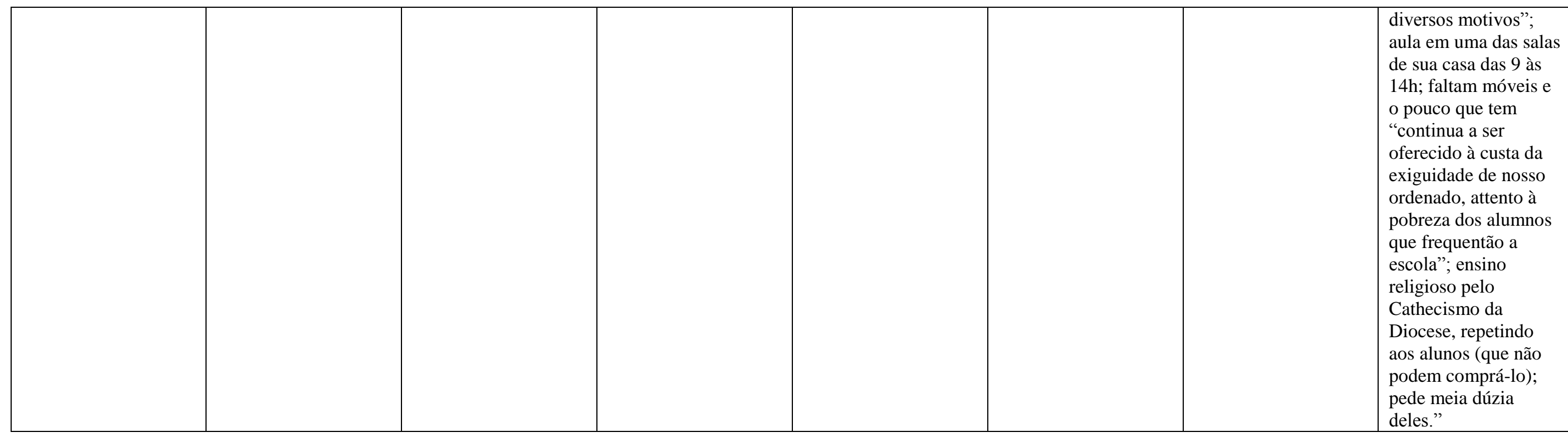

Apêndice C:

\begin{tabular}{|c|c|c|c|c|c|c|c|c|c|c|c|}
\hline \multicolumn{12}{|c|}{$\begin{array}{l}\text { ESCOLARIZAÇÃO EM COTIA NO SÉCULO XIX - PARTE III: de } 1882 \text { a } 1886 \\
\text { Professores responsáveis e outras informações } \\
\text { rios e ofícios de professores e inspetores, AESP, ref. CO5044, CO4915 e CO1007; livros de matrícula, } \\
\text { ef. EO2230, EO3182, EO2234, EO3030, EO2918 e EO3116; relatórios de governo; periódicos) }\end{array}$} \\
\hline $\begin{array}{l}\text { ANO E } \\
\text { INFORMA- } \\
\text { ÇOES } \\
\text { REFEREN- } \\
\text { TES À } \\
\text { INSPEÇÃO } \\
\text { DE } \\
\text { DISTRITO }\end{array}$ & $\begin{array}{l}1^{\text {a }} \text { Cadeira } \\
\text { Masculina }\end{array}$ & $\begin{array}{l}1^{\mathrm{a}} \text { Cadeira } \\
\text { Feminina }\end{array}$ & $\begin{array}{l}\text { Cadeira de } \\
\text { Senhor Bom } \\
\text { Jesus do } \\
\text { Itaqui// } \\
\text { Capitão } \\
\text { Jerônimo }\end{array}$ & $\begin{array}{l}\text { Cadeira de } \\
\text { Várzea- } \\
\text { Grande }\end{array}$ & $\begin{array}{l}\text { Cadeira de } \\
\text { Sorocami- } \\
\text { rim }\end{array}$ & $\begin{array}{l}\text { Cadeira de } \\
\text { Carapicuíba }\end{array}$ & $\begin{array}{l}2^{\mathrm{a}} \text { Cadeira } \\
\text { Masculina }\end{array}$ & $\begin{array}{l}\text { Escola da } \\
\text { Estação de } \\
\text { São João/ } \\
\text { Estrada } \\
\text { Sorocabana }\end{array}$ & $\begin{array}{l}2^{\mathrm{a}} \text { Cadeira } \\
\text { Feminina }\end{array}$ & \begin{tabular}{|l} 
Cadeira do \\
Bairro do \\
Lavapés
\end{tabular} & $\begin{array}{l}\text { Cadeira do } \\
\text { Bairro do } \\
\text { Rio Cotia }\end{array}$ \\
\hline
\end{tabular}




\begin{tabular}{|c|c|c|c|c|c|c|c|c|}
\hline 1882 & $\begin{array}{l}\text { J. J. Coelho } \\
\text { Relatório do } \\
\text { professor de } \\
\text { 01/11/82: } 20 \\
\text { matriculados } \\
\text { e "quasi } \\
\text { todos } \\
\text { frequentes"; } \\
\text { aula continua } \\
\text { em sala do } \\
\text { lado de fora } \\
\text { de sua casa } \\
\text { das } 9 \text { às } 14 \mathrm{~h} .\end{array}$ & $\begin{array}{l}\text { M. J. do } \\
\text { Sacramento } \\
\text { Relatório da } \\
\text { professora de } \\
\text { 01/06/82: } 24 \\
\text { matriculadas } \\
\text { e todas "mais } \\
\text { ou menos } \\
\text { frequentes"; } \\
\text { em } 81 \text { foram } \\
\text { feitos exames } \\
\text { e as alunas } \\
\text { foram } \\
\text { aprovadas nas } \\
\text { matérias que } \\
\text { se dedicaram; } \\
\text { aula em uma } \\
\text { sala de sua } \\
\text { casa das } 9 \text { às } \\
\text { 14h. } \\
\text { Relatório da } \\
\text { professora de } \\
\text { 01/11/82: } 24 \\
\text { matriculadas } \\
\text { e "quasi todas } \\
\text { frequentes"; } \\
\text { aula continua } \\
\text { em sala de } \\
\text { sua casa das } 9 \\
\text { às } 14 \mathrm{~h} .\end{array}$ & $\begin{array}{l}\text { J. C. de } \\
\text { Queiroz } \\
\text { Relatório do } \\
\text { professor de } \\
\text { 01/06/82: } 40 \\
\text { matriculados } \\
\text { e } 32 \\
\text { frequentes; } \\
\text { neste } \\
\text { semestre 1 se } \\
\text { eliminou e } 4 \\
\text { se } \\
\text { matricularam; } \\
\text { escola na } \\
\text { mesma casa e } \\
\text { no mesmo } \\
\text { horário; } \\
\text { ensino relig. } \\
\text { pela Cartilha } \\
\text { de Pimentel, } \\
\text { porque não } \\
\text { tem o } \\
\text { Cathecismo } \\
\text { da Diocese, } \\
\text { esperando o } \\
\text { que o } \\
\text { inspetor geral } \\
\text { pudesse } \\
\text { entregá-lo. } \\
\text { Relatório do } \\
\text { professor de } \\
01 / 11 / 82: 38 \\
\text { matriculados } \\
\text { e } 28 \\
\text { frequentes; } 2\end{array}$ & $\begin{array}{l}\text { M. M. Pinto } \\
\text { Relatório do } \\
\text { professor de } \\
\text { 01/06/82: } 15 \\
\text { matriculados } \\
\text { e } 12 \\
\text { frequentes; } \\
\text { aula em uma } \\
\text { sala de sua } \\
\text { casa das } 9 \text { às } \\
\text { 14h; no ano } \\
\text { de } 81 \text { os } \\
\text { alunos } \\
\text { passaram por } \\
\text { exame em } \\
\text { presença do } \\
\text { inspetor de } \\
\text { distrito e cada } \\
\text { um foi } \\
\text { "aprovado } \\
\text { nas materias } \\
\text { a que se } \\
\text { dedicarão". } \\
\text { Relatório do } \\
\text { professor de } \\
01 / 11 / 82: 17 \\
\text { matriculados } \\
\text { e } 14 \\
\text { frequentes; } \\
\text { aula em sala } \\
\text { de sua } \\
\text { residência das } \\
9 \text { às } 14 h \text { h. }\end{array}$ & $\begin{array}{l}\text { João Maria } \\
\text { Thomaz } \\
\text { Relatório do } \\
\text { professor de } \\
01 / 06 / 82: 22 \\
\text { matriculados } \\
\text { e } 16 \\
\text { frequentes; } \\
\text { detalha o } \\
\text { adiantamento } \\
\text { dos alunos; } \\
\text { tomou posse } \\
\text { da cadeira em } \\
\text { 17 de abril } \\
\text { então informa } \\
\text { que não há } \\
\text { como mostrar } \\
\text { mais } \\
\text { adiantamento } \\
\text {; a escola não } \\
\text { tem móveis e } \\
\text { "utensis". }\end{array}$ & $?^{312}$ & 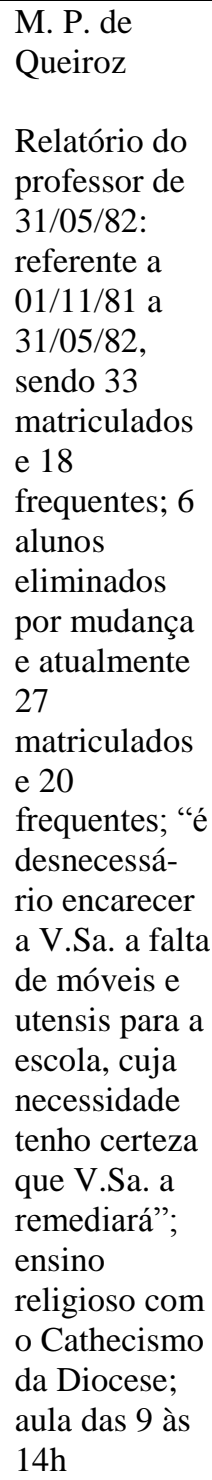 & $\begin{array}{l}\text { Criação Lei } \\
\text { n }^{\circ} 37 \\
30 / 03 / 1882 \\
\text { Joaquim } \\
\text { Chrispim de } \\
\text { Oliveira } \\
\text { Relatório do } \\
\text { professor de } \\
01 / 11 / 82 \text { : } \\
\text { informa que } \\
\text { abriu a escola } \\
\text { em 13 de } \\
\text { outubro; são } \\
\text { 16 } \\
\text { matriculados } \\
\text { e frequentes; } \\
\text { escola na } \\
\text { casa onde } \\
\text { mora das } 8 \text { às } \\
\text { 13h. }\end{array}$ \\
\hline
\end{tabular}




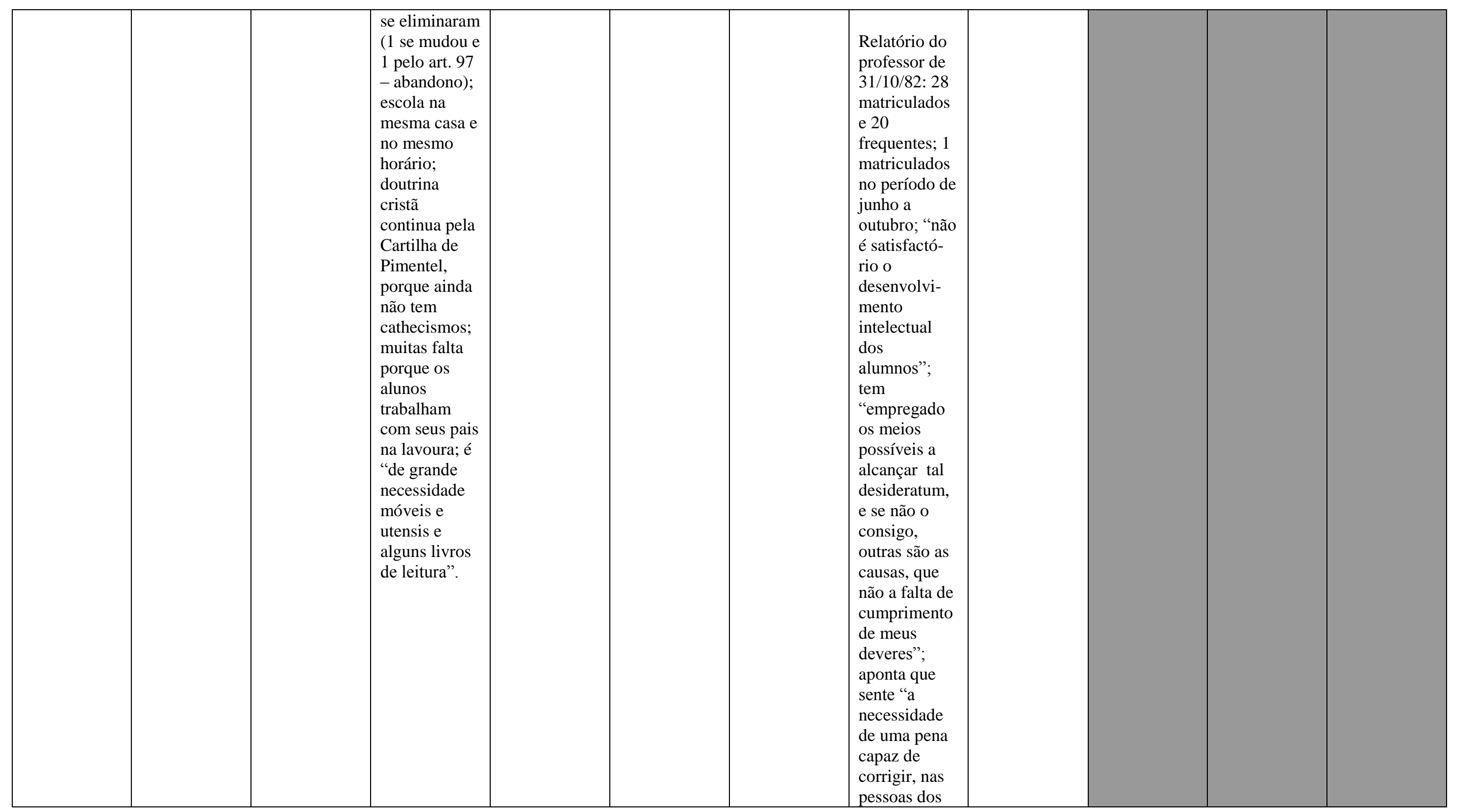




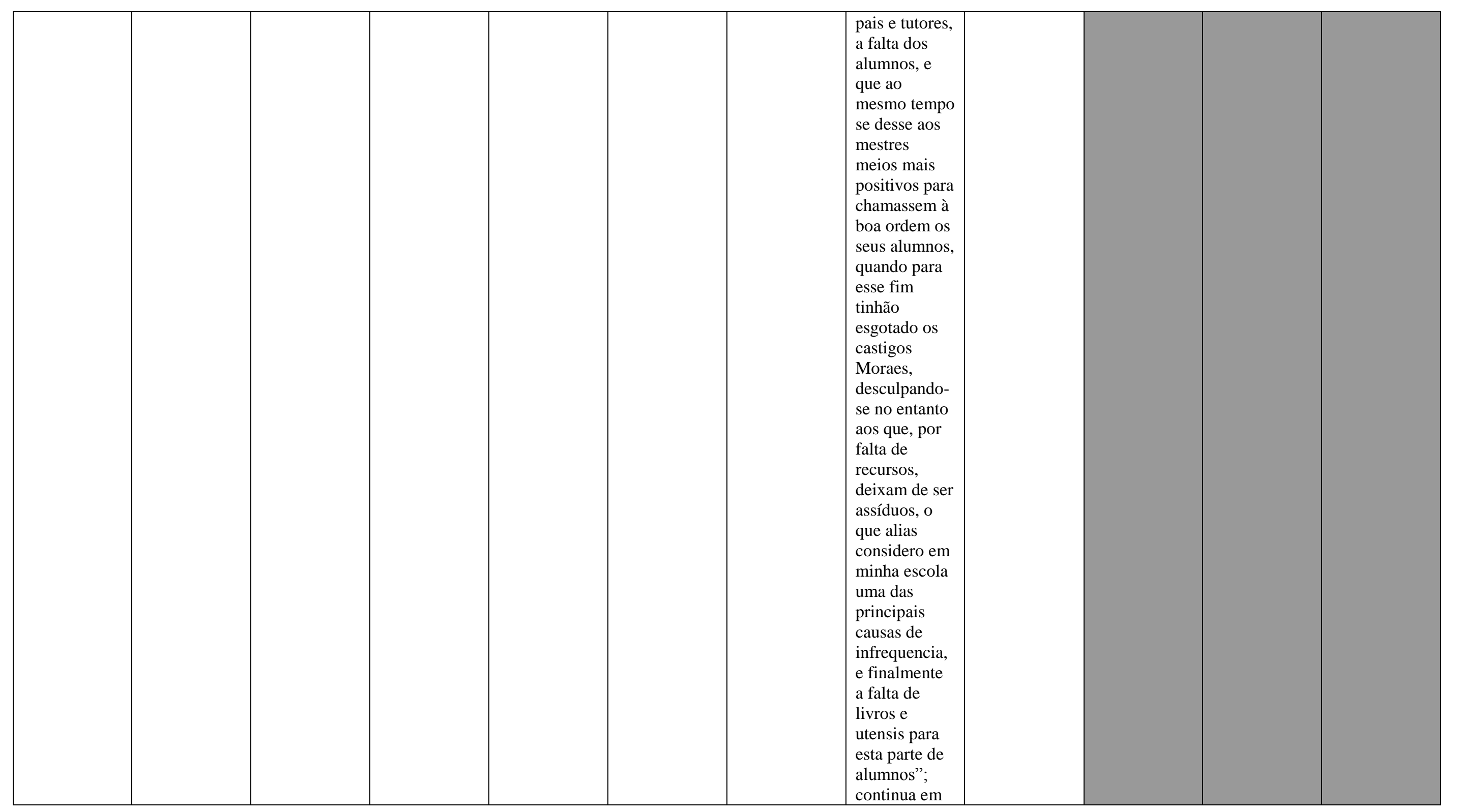




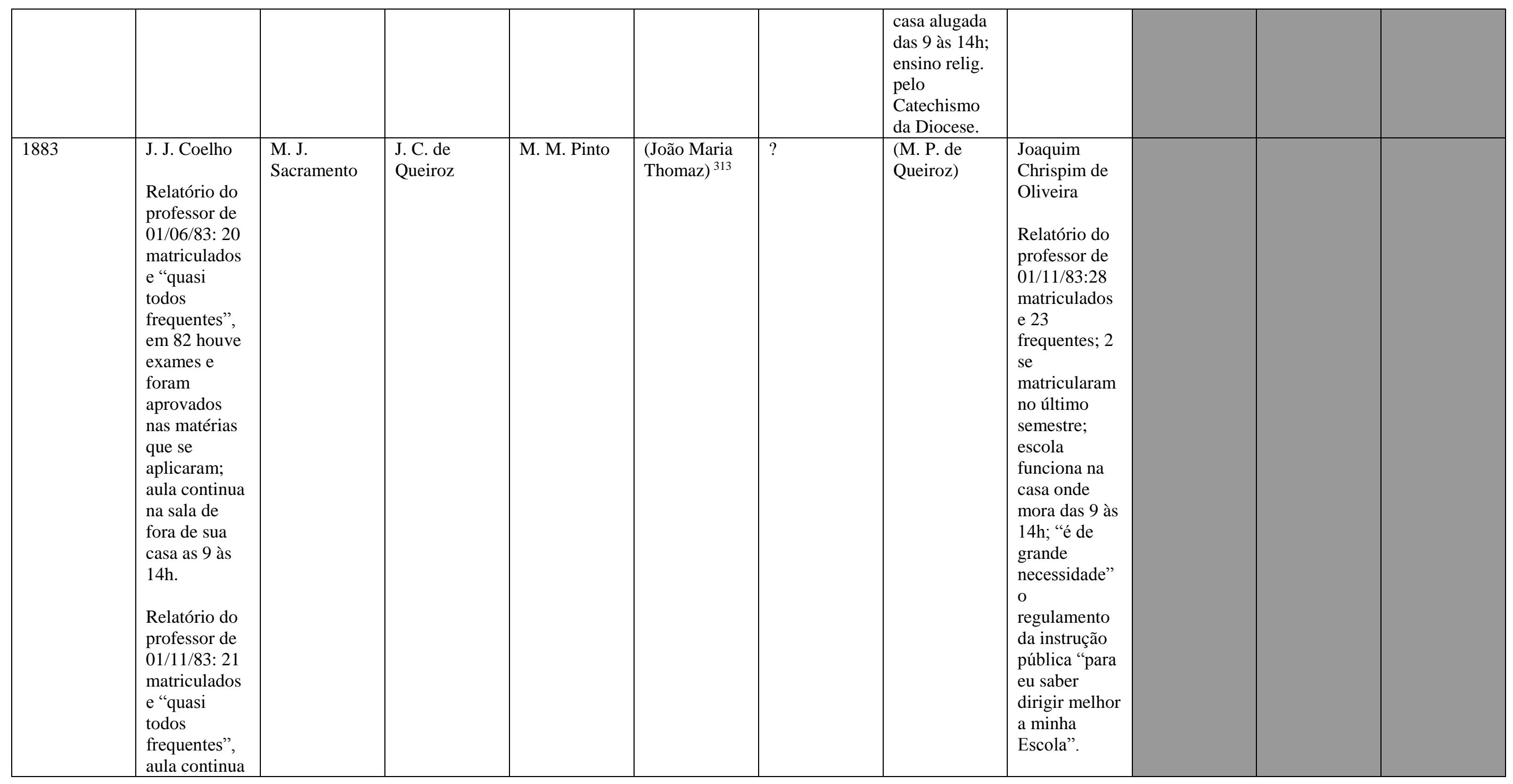

313 Os nomes de professores que estão dentro de parênteses se referem aos professores que possivelmente estavam à frente das respectivas cadeiras, mas que por não localizar nenhuma fonte referente ao professor e sua cadeira, recorri a esse recurso. 


\begin{tabular}{|c|c|c|c|c|c|c|c|c|c|c|c|}
\hline & $\begin{array}{l}\text { na sala de } \\
\text { fora de sua } \\
\text { casa as } 9 \text { às } \\
14 \mathrm{~h} .\end{array}$ & & & & & & & & & & \\
\hline $\begin{array}{l}1884 \\
\text { Inspetor } \\
\text { literário: } \\
\text { Benedito José } \\
\text { de Oliveira } \\
\text { Ofício de } \\
19 / 03 / 84 \text { do } \\
\text { inspetor } \\
\text { literário ao } \\
\text { inspetor } \\
\text { geral: } \\
\text { resposta ao } \\
\text { oficio de } \\
\text { dezembro, } \\
\text { mas que não } \\
\text { havia } \\
\text { respondido } \\
\text { por estar } \\
\text { doente. Nele } \\
\text { informa sobre } \\
\text { os exames: "é } \\
\text { satisfactório o } \\
\text { estado de } \\
\text { adiantamento } \\
\text { dos } \\
\text { alumnos”; } \\
\text { são } 6 \text { cadeiras } \\
\text { com } 147 \\
\text { alunos, dos } \\
\text { quais } 120 \\
\text { fizeram } \\
\text { exames; “ }\end{array}$ & $\begin{array}{l}\text { J. J. Coelho } \\
\text { Relatório do } \\
\text { professor de } \\
02 / 06 / 84: 22 \\
\text { matriculados } \\
\text { e todos "mais } \\
\text { ou menos } \\
\text { frequentes"; } \\
\text { em } 28 / 02 / 84 \\
\text { foram feitos } \\
\text { exames } \\
\text { presididos } \\
\text { pelo inspetor } \\
\text { de "fora do } \\
\text { tempo } \\
\text { competente"; } \\
\text { sendo os } \\
\text { alunos } \\
\text { aprovados } \\
\text { nas matérias } \\
\text { que se } \\
\text { aplicam; aula } \\
\text { continua na } \\
\text { sala do lado } \\
\text { de fora de sua } \\
\text { casa, das } 9 \text { às } \\
14 h \text {. }\end{array}$ & $\begin{array}{l}\text { M. J. } \\
\text { Sacramento }\end{array}$ & $\begin{array}{l}\text { Manoel de } \\
\text { Moraes Pinto } \\
\text { assume esta } \\
\text { cadeira (em } \\
\text { março) } \\
\text { transferido da } \\
\text { Cadeira de } \\
\text { V.Grande. } \\
\text { Relatório do } \\
\text { professor de } \\
02 / 06 / 84: 24 \\
\text { matriculados } \\
\text { e frequentes; } \\
\text { aula em sala } \\
\text { fora de sua } \\
\text { casa das } 9 \text { às } \\
14 \mathrm{~h} . \\
\text { Relatório do } \\
\text { professor de } \\
01 / 11 / 84: 28 \\
\text { matriculados } \\
\text { e } 20 \\
\text { frequentes; } \\
\text { aula dada em } \\
\text { sala do lado } \\
\text { de fora de sua } \\
\text { casa das } 9 \text { às } \\
14 h \text { h. }\end{array}$ & ? & $\begin{array}{l}\text { (João Maria } \\
\text { Thomaz) }\end{array}$ & ? & $\begin{array}{l}\text { (M.P. de } \\
\text { Queiroz) }\end{array}$ & $\begin{array}{l}\text { Joaquim } \\
\text { Chrispim de } \\
\text { Oliveira }\end{array}$ & $\begin{array}{l}\text { Criação } \\
\text { Lei n } 3 \\
05 / 02 / 1884 \\
\\
\text { Catharina } \\
\text { Etelvina } \\
\text { Pedroso } \\
\\
\text { Relatório da } \\
\text { professora de } \\
01 / 06 / 84: 22 \\
\text { matriculadas } \\
\text { e } 19 \\
\text { frequentes; } \\
\text { escola } \\
\text { funciona na } \\
\text { sala de sua } \\
\text { casa das } 9 \text { às } \\
14 h \text {; doutrina } \\
\text { cristã dada } \\
\text { pelo } \\
\text { Cathecismo } \\
\text { da Diocese de } \\
\text { SP, faltam } \\
\text { móveis e } \\
\text { "utensis" e os } \\
\text { pede. } \\
\text { Petição } \\
\text { enviada ao } \\
\text { Insp. Geral } \\
\text { por } \\
\text { intermédio do } \\
\text { inspetor }\end{array}$ & $\begin{array}{l}\text { Criação Lei } \\
\mathrm{n}^{\circ} 3 \\
05 / 02 / 1884 \\
\text { JC de } \\
\text { Queiroz } \\
\text { Ofício do } \\
\text { inspetor } \\
\text { literário de } \\
\text { 20/03/84: } \\
\text { informa que } \\
\text { José Custódio } \\
\text { de Queiroz } \\
\text { foi removido } \\
\text { para a cadeira } \\
\text { do Bairro de } \\
\text { Lavapés; } \\
\text { entrou em } \\
\text { exercício em } \\
\text { 15/03/84; } 14 \\
\text { alunos } \\
\text { matriculados } \\
\text { Relatório do } \\
\text { professor de } \\
\text { 01/06/84: } \\
\text { informa que } \\
\text { leciona por } \\
\text { pouco tempo; } \\
17 \text { se } \\
\text { matricularam } \\
\text { mas } 1 \text { se } \\
\text { eliminou por }\end{array}$ & $\begin{array}{l}\text { Criação Lei } \\
\mathrm{n}^{\circ} 8 \\
15 / 02 / 1884\end{array}$ \\
\hline
\end{tabular}




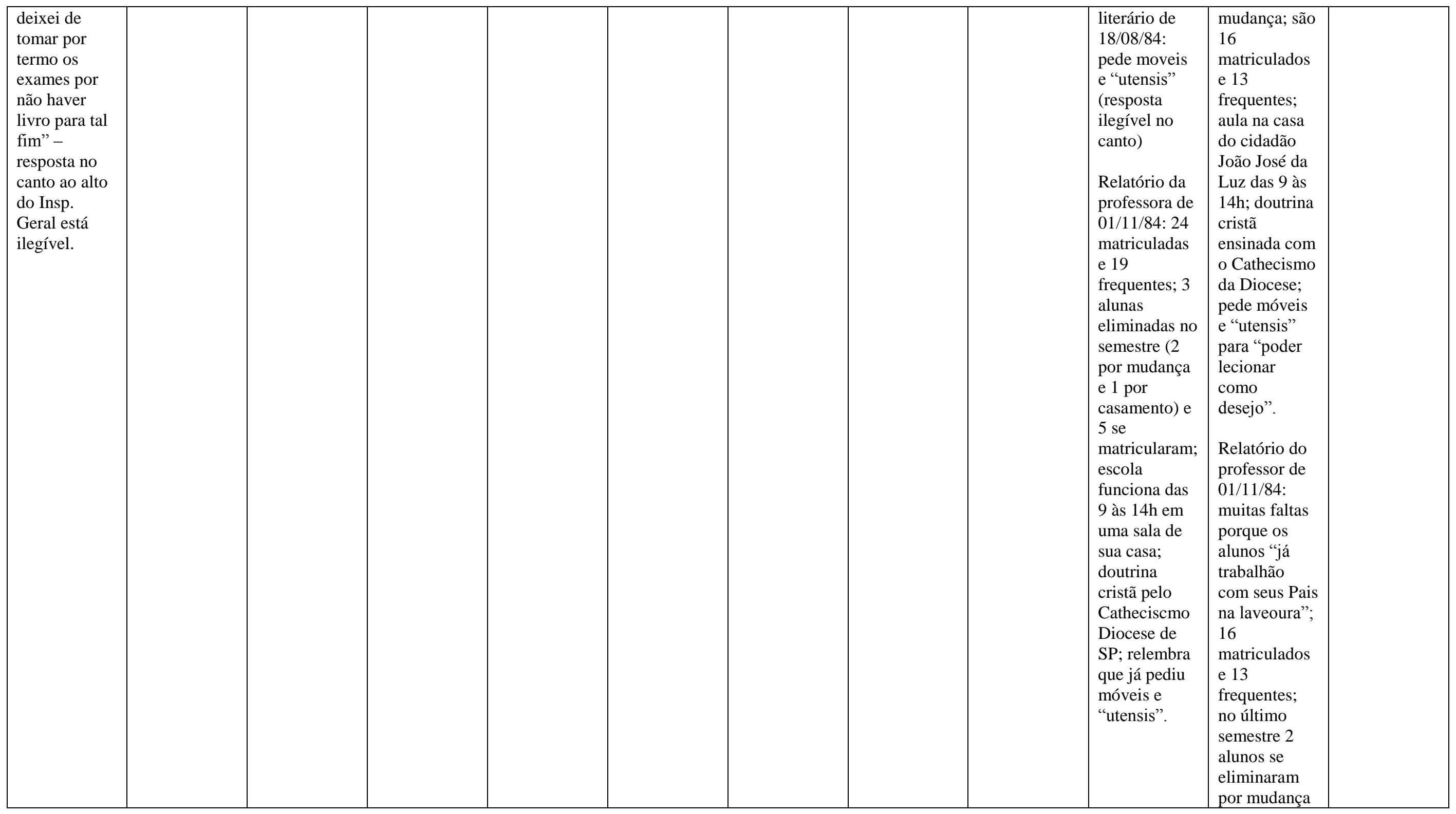




\begin{tabular}{|c|c|c|c|c|c|c|c|c|c|c|c|}
\hline & & & & & & & & & & $\begin{array}{l}\text { e } 2 \text { se } \\
\text { matricularam; } \\
\text { aula na casa } \\
\text { do cidadão } \\
\text { João José da } \\
\text { Luz; doutrina } \\
\text { cristã pelo } \\
\text { Cathecismo } \\
\text { da Diocese; } \\
\text { pede móveis } \\
\text { e "utensis" e } \\
\text { alguns livros } \\
\text { de leitura e } \\
\text { cathecismos. }\end{array}$ & \\
\hline $\begin{array}{l}1885 \\
\text { No decorrer } \\
\text { deste } \\
\text { assumem o } \\
\text { cargo de } \\
\text { Inspetor } \\
\text { Geral vários } \\
\text { nomes: } \\
\text { Francisco } \\
\text { Carvalho; } \\
\text { Luiz da } \\
\text { Fonseca } \\
\text { Moraes } \\
\text { Galvão; } \\
\text { Antonio } \\
\text { Carlos } \\
\text { Ribeiro de } \\
\text { Andrada } \\
\text { Machado e } \\
\text { Silva } \\
\text { (interino); } \\
\text { Arthur Cesar } \\
\text { Guimarães }\end{array}$ & $\begin{array}{l}\text { J. J. Coelho } \\
\text { se aposenta - } \\
\text { abril / José } \\
\text { Custódio de } \\
\text { Queiroz } \\
\text { Relatório de } \\
\text { governo: } \\
22 \\
\text { matriculadose } \\
20 \\
\text { frequentes. } \\
20 \\
\text { examinados, } \\
\text { "consta do } \\
\text { termo de } \\
\text { exame } \\
\text { regular } \\
\text { adiantamento } \\
\text { dos alunos". } \\
\text { Relatório do } \\
\text { professor de } \\
01 / 11 / 85:\end{array}$ & $\begin{array}{l}\text { M. J. } \\
\text { Sacramento } \\
\text { se aposenta - } \\
\text { abril / Analia } \\
\text { Emilia } \\
\text { Franco } \\
\text { Relatório de } \\
\text { governo: } 20 \\
\text { matriculadas, } \\
20 \text { frequentes } \\
\text { e } 20 \\
\text { examinadas, } \\
\text { "consta do } \\
\text { termo de } \\
\text { exame } \\
\text { regular } \\
\text { adiantamento } \\
\text { dos alunos". } \\
\text { Relatório da } \\
\text { professora de } \\
01 / 11 / 85: 20 \\
\text { matriculadas } \\
\text { e frequentes; }\end{array}$ & $\begin{array}{l}\text { M. M. Pinto } \\
\text { Relatório de } \\
\text { governo: } 30 \\
\text { matriculados, } \\
20 \text { frequentes } \\
\text { e } 20 \\
\text { examinados, } \\
\text { "consta do } \\
\text { termo de } \\
\text { exame } \\
\text { regular } \\
\text { adiantamento } \\
\text { dos alunos". } \\
\text { Relatório do } \\
\text { professor de } \\
\text { 01/06/85: } 28 \\
\text { matriculados } \\
\text { e } 20 \\
\text { frequentes; } \\
\text { aula das } 9 \text { às } \\
\text { 14h em sala } \\
\text { do lado de } \\
\text { fora de sua }\end{array}$ & $\begin{array}{l}\text { João Baptista } \\
\text { Cepellos } \\
\text { (removido em } \\
\text { outubro de } \\
\text { Tatuí para } \\
\text { Várzea- } \\
\text { Grande) } \\
\text { Relatório de } \\
\text { governo: } 20 \\
\text { matriculados, } \\
15 \text { frequentes } \\
\text { e } 15 \\
\text { examinados, } \\
\text { "consta do } \\
\text { termo de } \\
\text { exame } \\
\text { regular } \\
\text { adiantamento } \\
\text { dos alunos". }\end{array}$ & $\begin{array}{l}\text { João Maria } \\
\text { Thomaz } \\
\text { Relatório de } \\
\text { governo: } \\
\text { cadeira } \\
\text { pertence a } \\
\text { São Roque. } \\
\\
\text { Relatório do } \\
\text { professor de } \\
01 / 06 / 85: 23 \\
\text { matriculados } \\
\text { divididos em } \\
3 \text { classes; a } \\
1^{\text {a }} \text {, com } 7 \\
\text { alunos, estes } \\
\text { "estão no “2 } \\
\text { Livro de } \\
\text { Hilário } \\
\text { Ribeiro, } \\
\text { escrevem } \\
\text { bastardo, } \\
\text { sabem de cor }\end{array}$ & ? & $\begin{array}{l}\text { M. P. de } \\
\text { Queiroz } \\
\text { Relatório de } \\
\text { governo: } 26 \\
\text { matriculados, } \\
20 \\
\text { frequentes, } \\
20 \\
\text { examinados, } \\
\text { "consta do } \\
\text { termo de } \\
\text { exame } \\
\text { regular } \\
\text { adiantamento } \\
\text { dos alunos". } \\
\text { Relatório do } \\
\text { professor de } \\
\text { 01/06/85: } 21 \\
\text { matriculados } \\
\text { e 16-20 } \\
\text { frequentes; } \\
\text { matricularam } \\
\text {-se 5 alunos e }\end{array}$ & $\begin{array}{l}\text { Joaquim } \\
\text { Chrispim de } \\
\text { Oliveira } \\
\text { Relatório de } \\
\text { governo: } 30 \\
\text { matriculados, } \\
22 \text { frequentes } \\
\text { e } 22 \\
\text { examinados, } \\
\text { "consta do } \\
\text { termo de } \\
\text { exame } \\
\text { regular } \\
\text { adiantamento } \\
\text { dos alunos". } \\
\text { Cartilha de } \\
\text { Pimentel para } \\
\text { doutrina } \\
\text { cristã "visto } \\
\text { não ter } \\
\text { Cathecismos } \\
\text { da Diocese", } \\
\text { pede estes }\end{array}$ & $\begin{array}{l}\text { Catharina E. } \\
\text { Pedroso } \\
\text { Relatório de } \\
\text { governo: } 28 \\
\text { matriculados, } \\
20 \text { frequentes } \\
\text { e } 20 \\
\text { examinados } \\
\text { "consta do } \\
\text { termo de } \\
\text { exame } \\
\text { regular } \\
\text { adiantamento } \\
\text { dos alunos". } \\
\text { Relatório do } \\
\text { professor de } \\
01 / 11 / 85: 24 \\
\text { matriculados } \\
\text { e } 20 \\
\text { frequentes; } 4 \\
\text { se eliminaram } \\
\text { no semestre } \\
\text { (2 por }\end{array}$ & $\begin{array}{l}\text { J. C. de } \\
\text { Queiroz/ } \\
\text { Consta como } \\
\text { vaga no } \\
\text { relatório de } \\
\text { governo } \\
\text { Relatório do } \\
\text { professor de } \\
\text { 30/05/85: } \\
\text { alunos com } \\
\text { dificuldades } \\
\text { de } \\
\text { frequentarem } \\
\text { a escola } \\
\text { devido ao } \\
\text { trabalho na } \\
\text { lavoura com } \\
\text { seus pais; } 20 \\
\text { matriculados } \\
\text { e 16 } \\
\text { frequentes; } \\
\text { no ultimo } \\
\text { semestre } 6 \text { se } \\
\text { matricularam }\end{array}$ & $\begin{array}{l}\text { Consta como } \\
\text { vaga no } \\
\text { relatório de } \\
\text { governo. }\end{array}$ \\
\hline
\end{tabular}




\begin{tabular}{|c|c|c|c|c|c|c|c|c|}
\hline $\begin{array}{l}\text { Inspetor } \\
\text { Literário - } \\
\text { cargo vago } \\
\text { (Capitão Jos } \\
\text { Joaquim } \\
\text { Pedroso } \\
\text { exerceu este } \\
\text { cargo de } \\
\text { 24/09/85 a } \\
\text { 7/12/85 e } \\
\text { pediu } \\
\text { exoneração) }\end{array}$ & 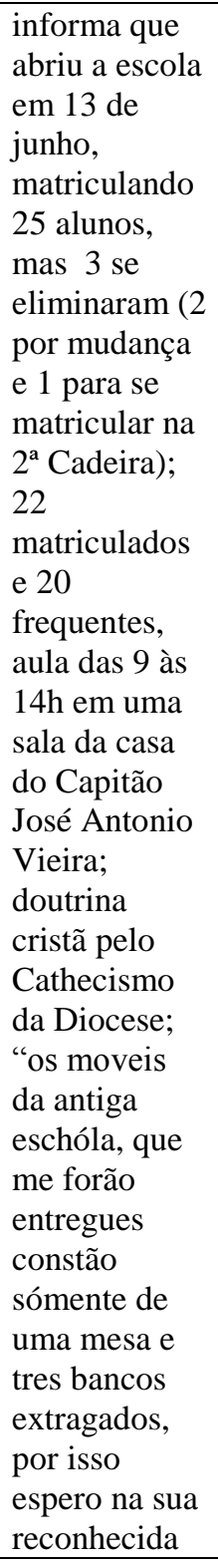 & $\begin{array}{l}\text { escola sem } \\
\text { móveis e } \\
\text { "utensis"; a } \\
\text { professora } \\
\text { ofereceu às } \\
\text { alunas "todos } \\
\text { os livros e } \\
\text { materiais } \\
\text { indispensá- } \\
\text { veis, visto } \\
\text { serem os paes } \\
\text { paupérrimos" } \\
\text {. No canto ao } \\
\text { alto, assinado } \\
\text { pelo Inspetor } \\
\text { Geral: } \\
\text { "tomadas as } \\
\text { notas } \\
\text { necessárias, } \\
\text { archiva-se, } \\
\text { SP, } 5 \text { de 9bro } \\
\text { de } 85 \text { ". }\end{array}$ & $\begin{array}{l}\text { casa; informa } \\
\text { que no ano de } \\
84 \text { houve } \\
\text { aplicação de } \\
\text { exame, cada } \\
\text { um deles } \\
\text { aprovados } \\
\text { nas matérias } \\
\text { que se } \\
\text { dedicaram. } \\
\text { Relatório do } \\
\text { professor de } \\
01 / 11 / 85: 31 \\
\text { matriculados } \\
\text { e } 20 \\
\text { frequentes; } \\
\text { aula das } 9 \text { às } \\
\text { 14h em sala } \\
\text { do lado de } \\
\text { fora de sua } \\
\text { casa. }\end{array}$ & $\begin{array}{l}\text { a Oração } \\
\text { Dominical e } \\
\text { saudação } \\
\text { Angelical, } \\
\text { somam, } \\
\text { diminuem e } \\
\text { multiplicam e } \\
\text { estão em } \\
\text { principio do } \\
\text { sistema } \\
\text { métrico; a } \\
\text { segunda que } \\
\text { consta de dez } \\
\text { estão no } \\
\text { terceiro livro } \\
\text { de Hilário, } \\
\text { escrevem } \\
\text { cursivo, } \\
\text { sabem várias } \\
\text { orações de } \\
\text { cor, estão na } \\
\text { segunda parte } \\
\text { do } \\
\text { catheciscmo, } \\
\text { fazem as } \\
\text { quatro } \\
\text { operações } \\
\text { fundamentais } \\
\text { e sabem de } \\
\text { cor o valor } \\
\text { das medidas } \\
\text { lineares e de } \\
\text { pesos; a } \\
\text { terceira que } \\
\text { consta de 6, } \\
\text { estão no } \\
\text { quarto livro } \\
\text { de Hilário, } \\
\text { escrevem }\end{array}$ & 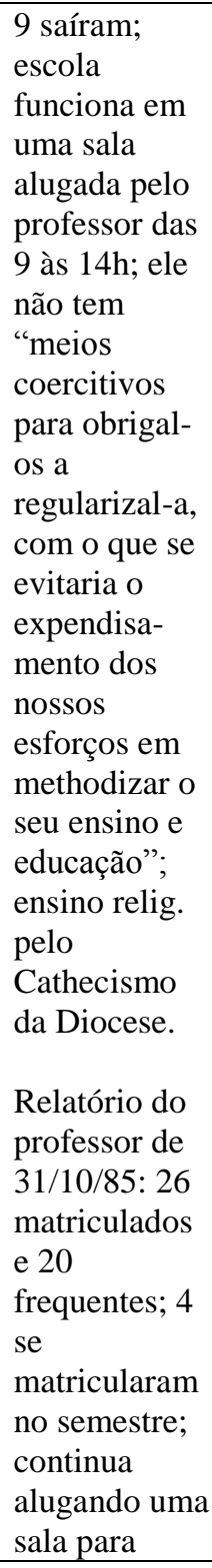 & $\begin{array}{l}\text { para o } \\
\text { Inspetor } \\
\text { Geral. } \\
\text { Relatório do } \\
\text { professor de } \\
\text { 01/06/85: } 27 \\
\text { matriculados } \\
\text { e 22 } \\
\text { frequentes; } 1 \\
\text { foi } \\
\text { matriculado e } \\
4 \text { eliminados } \\
4 \text { (3 por } \\
\text { mudança para } \\
\text { Parnahyba e } \\
1 \text { para S. } \\
\text { Roque); } \\
\text { escola } \\
\text { funciona em } \\
\text { sua casa das } 9 \\
\text { às } 14 h \text { h, } \\
\text { doutrina } \\
\text { cristã pelo } \\
\text { Cathecismo } \\
\text { da Diocese. } \\
\\
\text { Relatório do } \\
\text { professor de } \\
01 / 11 / 85: 29 \\
\text { matriculados } \\
\text { e } 22 \\
\text { frequentes; } 2 \\
\text { se } \\
\text { matricularam } \\
\text { no semestre; } \\
\text { escola } \\
\text { funciona em } \\
\text { sua casa das } 9 \\
\end{array}$ & 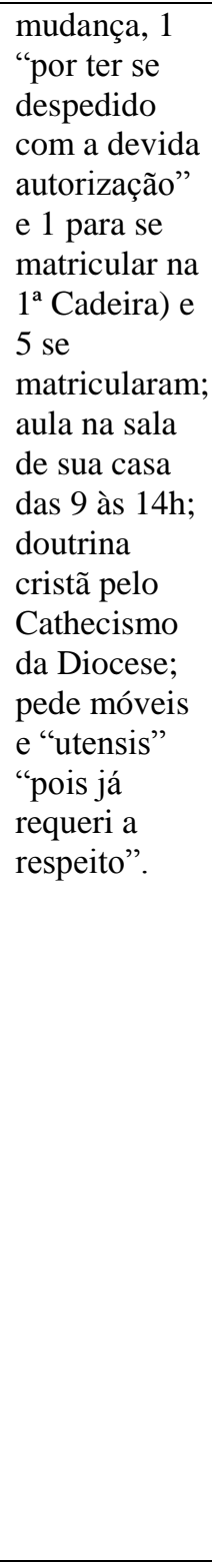 & $\begin{array}{l}\text { e } 2 \text { se } \\
\text { eliminara (1 } \\
\text { por mudança } \\
\text { e } 1 \text { pelo art. } \\
97) ; \text { aula das } \\
9 \text { as } 14 \text { na } \\
\text { casa do } \\
\text { cidadão João } \\
\text { José da Luz; } \\
\text { doutrina } \\
\text { cristã pelo } \\
\text { Cathecismo } \\
\text { da Diocese. }\end{array}$ \\
\hline
\end{tabular}




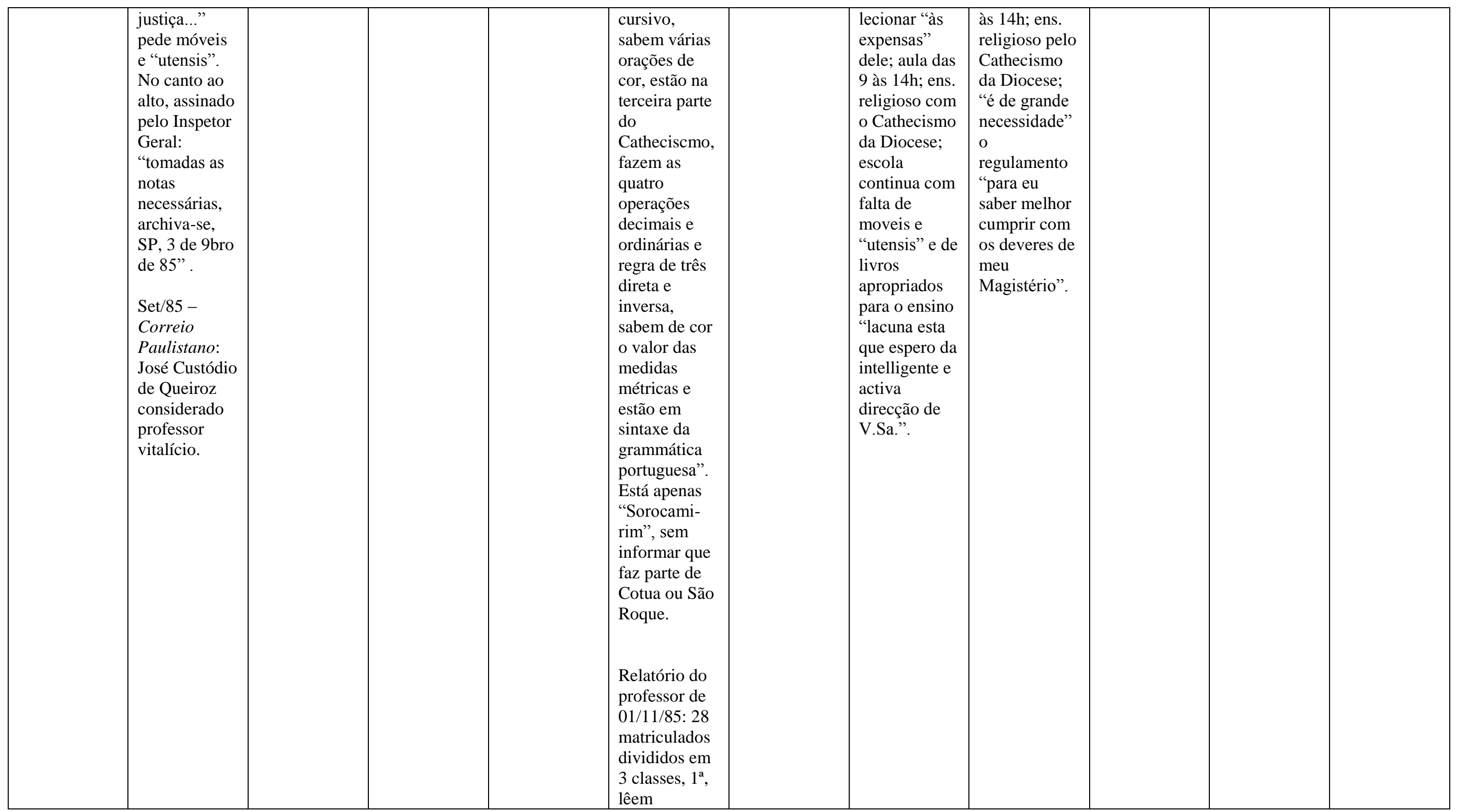




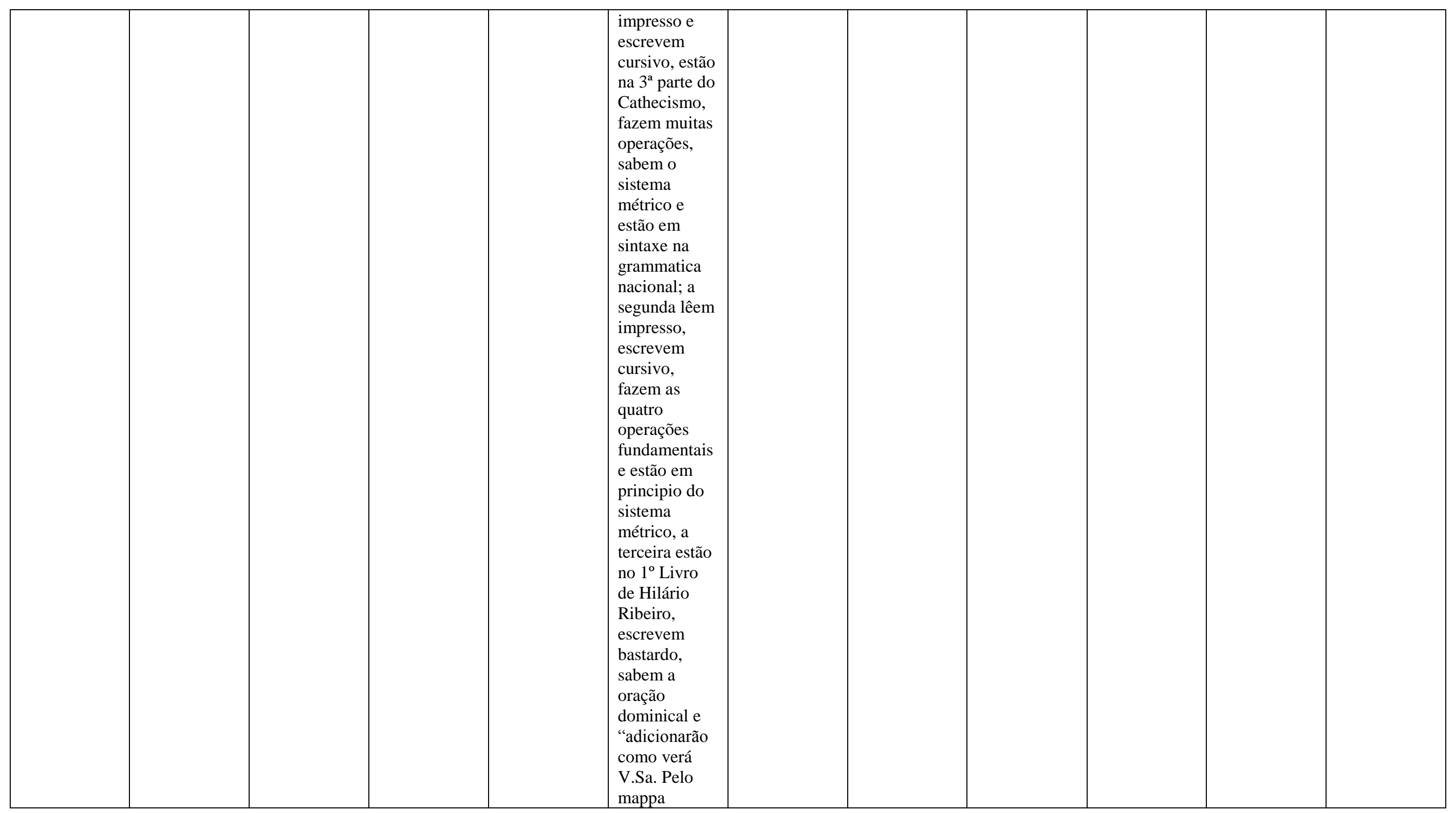




\begin{tabular}{|c|c|c|c|c|c|c|c|c|c|c|c|}
\hline & & & & & $\begin{array}{l}\text { junto". } \\
\text { Também está } \\
\text { apenas } \\
\text { "Sorocami- } \\
\text { rim". }\end{array}$ & & & & & & \\
\hline 1886 & $\begin{array}{l}\text { José Custodio } \\
\text { de Queiroz } \\
\text { Relatório de } \\
\text { governo: } 33 \\
\text { matriculados } \\
\text { e } 28 \\
\text { frequentes. } \\
\\
\text { Relatório do } \\
\text { professor de } \\
01 / 06 / 86: 35 \\
\text { matriculados } \\
\text { e } 30 \\
\text { frequentes; } \\
16 \\
\text { matriculados } \\
\text { no semestre e } \\
3 \text { eliminados } \\
\text { (1 com a } \\
\text { devida } \\
\text { autorização, } \\
\text { que por } \\
\text { mudança e } 1 \\
\text { para ir para a } \\
2^{\mathrm{a}} \text { Cadeira); } \\
\text { aula das 9 às } \\
14 \mathrm{~h} \text { em sala } \\
\text { da casa do } \\
\text { Capitão José } \\
\text { Antonio } \\
\text { Vieira; } \\
\text { doutrina }\end{array}$ & $\begin{array}{l}\text { Analia E. } \\
\text { Franco } \\
\text { Relatório de } \\
\text { governo: } \\
\text { obteve } \\
\text { licença "do } \\
\text { exmo. } \\
\text { Governo" } \\
\text { neste ano. } \\
\text { Relatório de } \\
\text { governo: } 29 \\
\text { matriculadas } \\
\text { e 25 } \\
\text { frequentes - } \\
\text { Analia } \\
\text { Franco } \\
\text { substituída } \\
\text { por Leonilbes } \\
\text { (?) C. de } \\
\text { Souza } \\
\text { Gouvêa. } \\
\\
\text { Ofício do } \\
\text { Inspetor } \\
\text { Geral da I. P. } \\
\text { para o } \\
\text { Presidente da } \\
\text { Província de } \\
21 / 08 / 86 \\
\text { (número } \\
707): \\
\text { requerimento }\end{array}$ & $\begin{array}{l}\text { M. M. Pinto } \\
\text { Relatório de } \\
\text { governo: } 26 \\
\text { matriculados } \\
\text { e } 16 \\
\text { frequentes. } \\
\text { Relatório do } \\
\text { professor de } \\
01 / 06 / 86: 20 \\
\text { matriculados } \\
\text { e } 16 \\
\text { frequentes; } \\
\text { aula em uma } \\
\text { sala de sua } \\
\text { casa das } 9 \text { às } \\
14 h \text {; exames } \\
\text { foram feitos } \\
\text { em } 85 \text { com a } \\
\text { presença do } \\
\text { inspetor de } \\
\text { distrito, no } \\
\text { qual os } \\
\text { alunos foram } \\
\text { aprovados } \\
\text { "nas matérias } \\
\text { a que se } \\
\text { dedicarão } \\
\text { durante o } \\
\text { anno lectivo" } \\
\text { Relatório do } \\
\text { professor de }\end{array}$ & $\begin{array}{l}\text { João Baptista } \\
\text { Cepellos } \\
\\
\text { Relatório de } \\
\text { governo: } 29 \\
\text { matriculados, } \\
26 \text { frequentes }\end{array}$ & $\begin{array}{l}\text { João Maria } \\
\text { Thomaz } \\
\text { No relatório } \\
\text { de governo } \\
\text { pertence a } \\
\text { São Roque. } \\
\\
\text { Relatório do } \\
\text { professor de } \\
\text { 01/06/86: } 26 \\
\text { alunos } \\
\text { divididos em } \\
3 \text { classes (a } \\
\text { primeira tem } \\
8, \text { "estão no } \\
\text { segundo livro } \\
\text { de Hilário } \\
\text { Ribeiro, } \\
\text { escrevem } \\
\text { bastardo, } \\
\text { sabem de cor } \\
\text { a orçãão } \\
\text { dominical e } \\
\text { saudação } \\
\text { angelical e } \\
\text { fazem duas } \\
\text { operações, } \\
\text { somar e } \\
\text { subtrahir; a } \\
\text { segunda de } 7 \\
\text { estão em } \\
\text { terceiro livro, }\end{array}$ & $?$ & $\begin{array}{l}\text { Marcolino } \\
\text { Pinto de } \\
\text { Queiroz } \\
\text { Relatório de } \\
\text { governo: } 29 \\
\text { matriculados, } \\
20 \\
\text { frequentes. } \\
\text { Relatório do } \\
\text { professor de } \\
01 / 06 / 86: \\
\text { semestre com } \\
4 \text { matrículas e } \\
1 \text { eliminação; } \\
30 \\
\text { matriculados } \\
\text { e } 20 \\
\text { frequentes, } \\
\text { chegando a } \\
\text { ser } \\
\text { frequentada } \\
\text { por } 27 \text {, mas } \\
\text { com muita } \\
\text { irregularidade } \\
\text {; aponta falta } \\
\text { de "casa } \\
\text { apropriada" e } \\
\text { que a escola } \\
\text { funciona em } \\
\text { sua casa das } 9 \\
\text { à } 14 \mathrm{~h} ; \text { ens. } \\
\text { religioso com }\end{array}$ & $\begin{array}{l}\text { Joaquim } \\
\text { Chrispim de } \\
\text { Oliveira } \\
\text { Relatório de } \\
\text { governo: } 22 \\
\text { matriculados, } \\
21 \\
\text { frequentes. } \\
\text { Relatório do } \\
\text { professor de } \\
01 / 06 / 86: 29 \\
\text { matriculados } \\
\text { e } 22 \\
\text { frequentes; } 1 \\
\text { matriculado e } \\
1 \text { eliminado } \\
\text { por mudar-se } \\
\text { pra S. Roque; } \\
\text { escola em sua } \\
\text { casa das } 9 \text { às } \\
14 h ; \text { doutrina } \\
\text { cristã pelo } \\
\text { Cathecismo } \\
\text { da Diocese. }\end{array}$ & $\begin{array}{l}\text { Catharina E. } \\
\text { Pedroso } \\
\text { Relatório de } \\
\text { governo: } 23 \\
\text { matriculados } \\
\text { e } 20 \\
\text { frequentes. } \\
\text { Relatório da } \\
\text { professora de } \\
01 / 06 / 86: 23 \\
\text { matriculadas } \\
\text { e 20 } \\
\text { frequentes; } 3 \\
\text { eliminadas } \\
\text { por mudança } \\
\text { e } 3 \text { se } \\
\text { matricularam; } \\
\text { aula em sala } \\
\text { de sua casa } \\
\text { das } 9 \text { às } 14 \mathrm{~h} ; \\
\text { doutrina } \\
\text { cristã pelo } \\
\text { Catheciscmo } \\
\text { da Diocese; } \\
\text { pede } \\
\text { novamente } \\
\text { móveis e } \\
\text { "utensis" } \\
\text { Relatório da } \\
\text { professora de } \\
01 / 11 / 86: 24 \\
\end{array}$ & 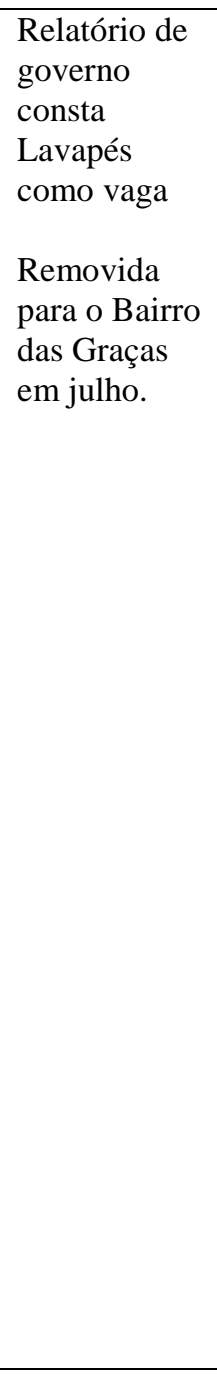 & $\begin{array}{l}\text { Relatório de } \\
\text { governo } \\
\text { consta Rio } \\
\text { Cotia como } \\
\text { vaga } \\
\text { Removida } \\
\text { para o Bairro } \\
\text { Caucaia em } \\
\text { julho. }\end{array}$ \\
\hline
\end{tabular}




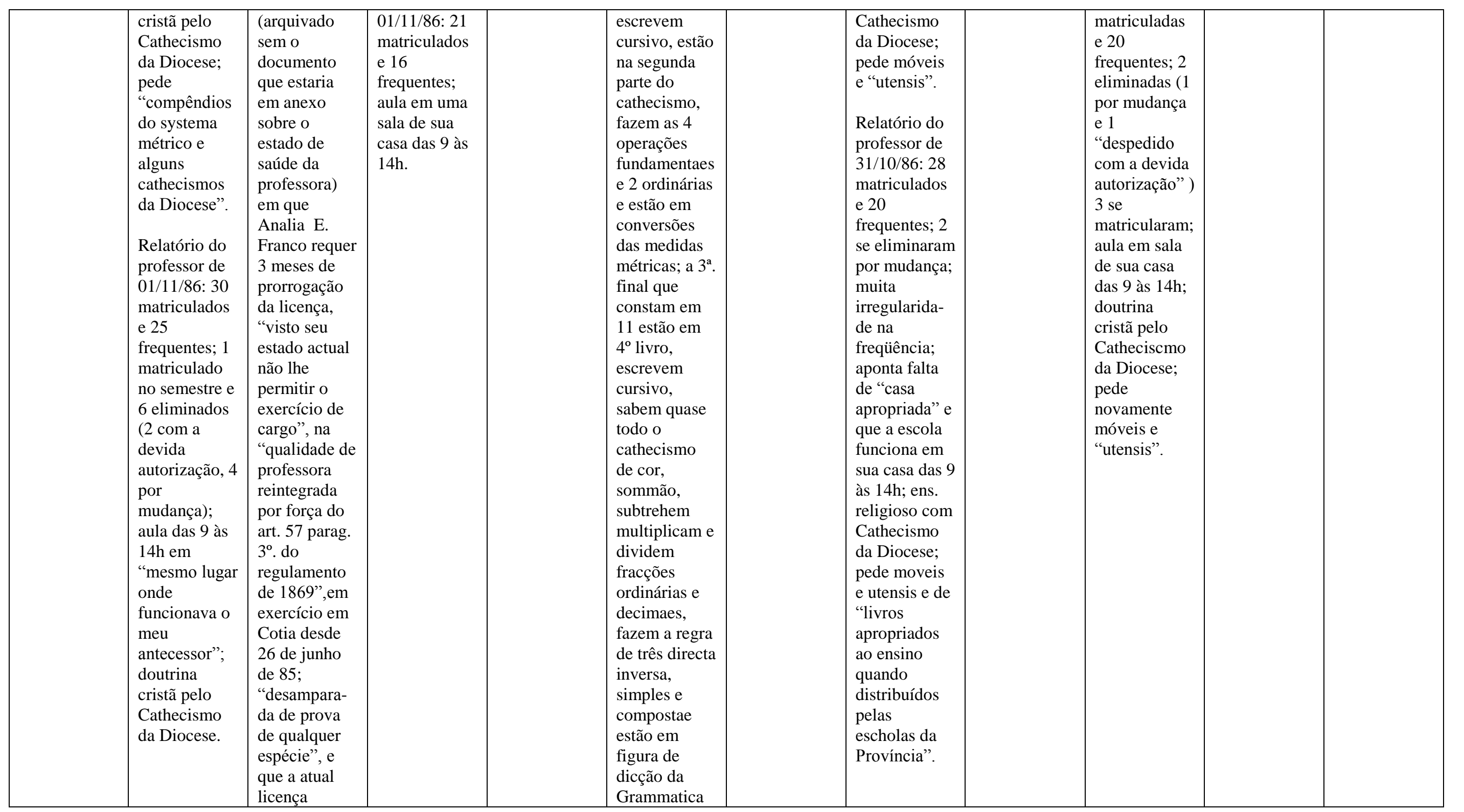




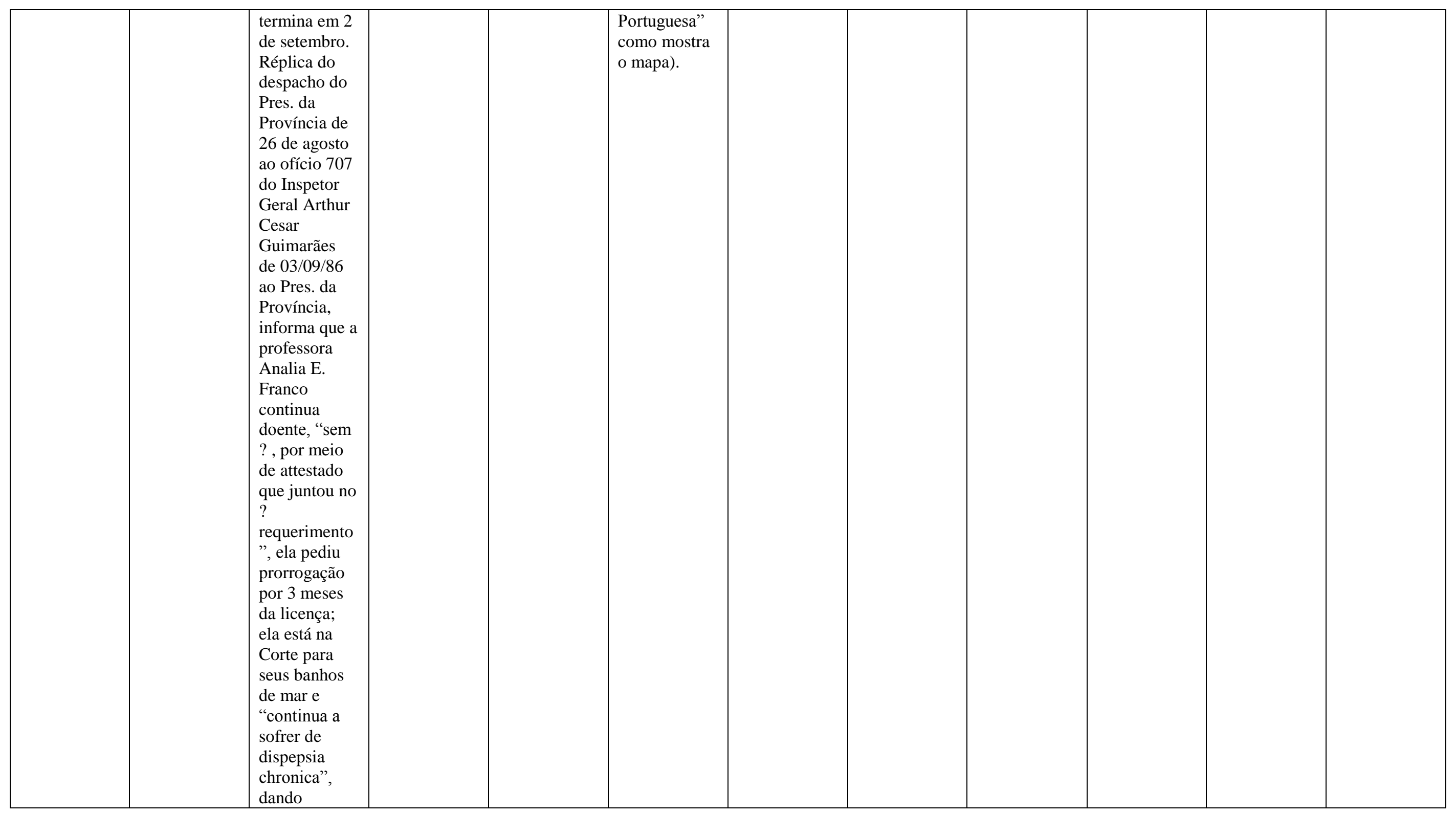




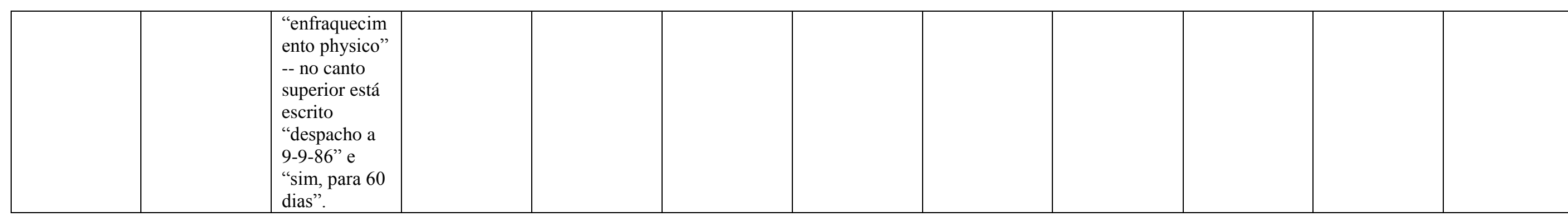


Apêndice D:

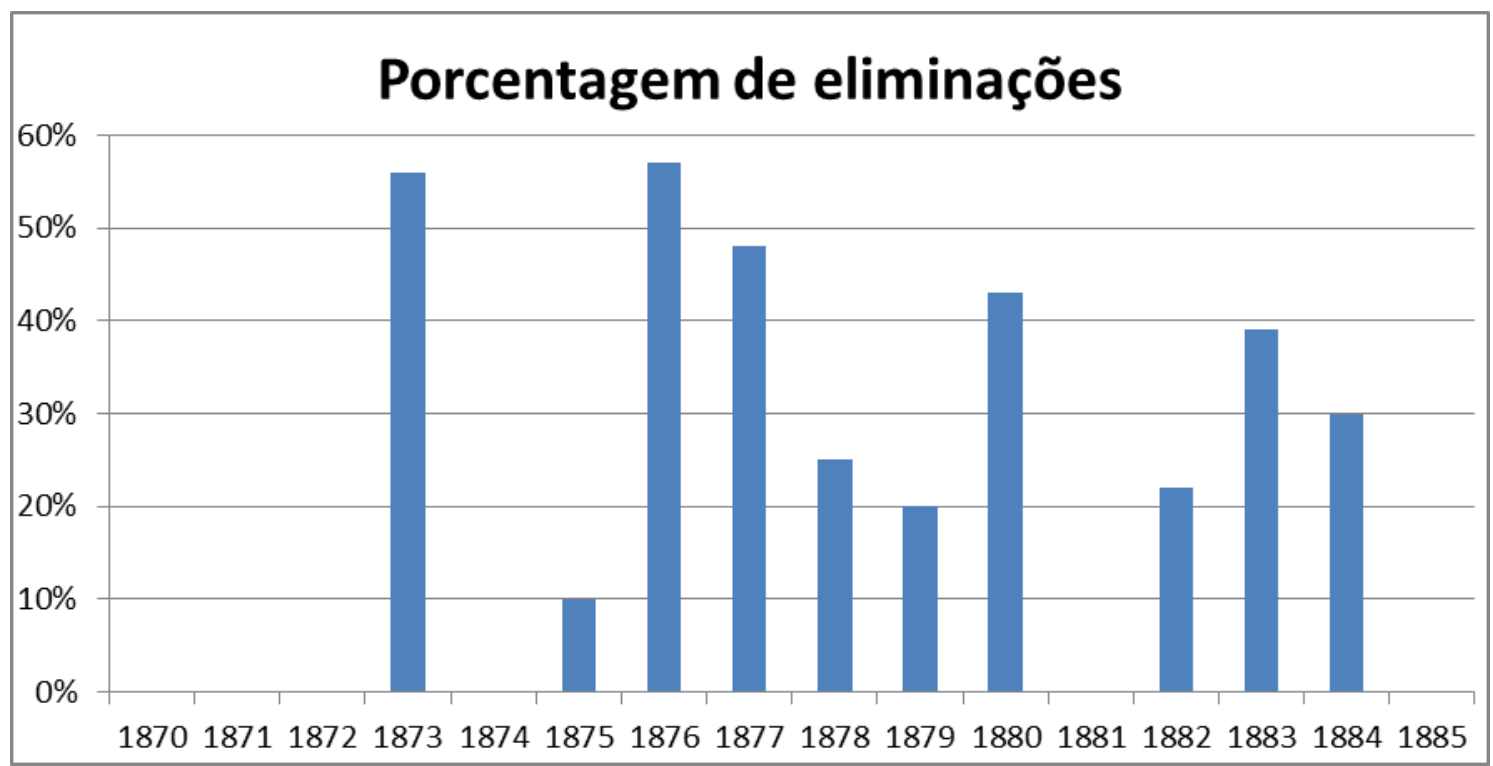

Quadro da porcentagem de eliminações da Cadeira Feminina da Vila - 1870-1885 (Fonte: AESP, ref. EO2230, EO3182).

Apêndice E:

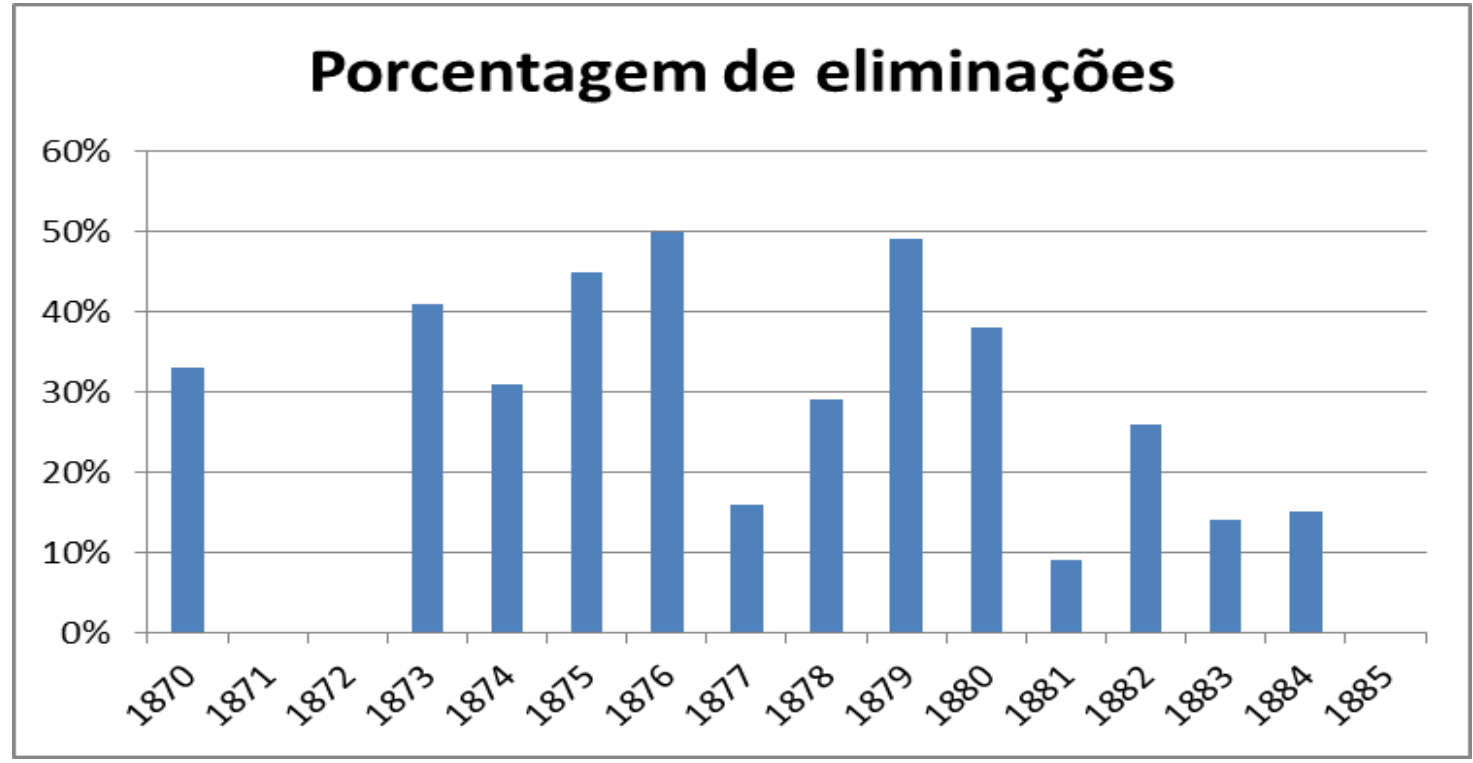

Quadro da porcentagem de eliminações da $1^{a}$ Cadeira Masculina da Vila - 1870-1885 (Fonte: AESP, ref. EO2234, EO3030). 
Apêndice F:

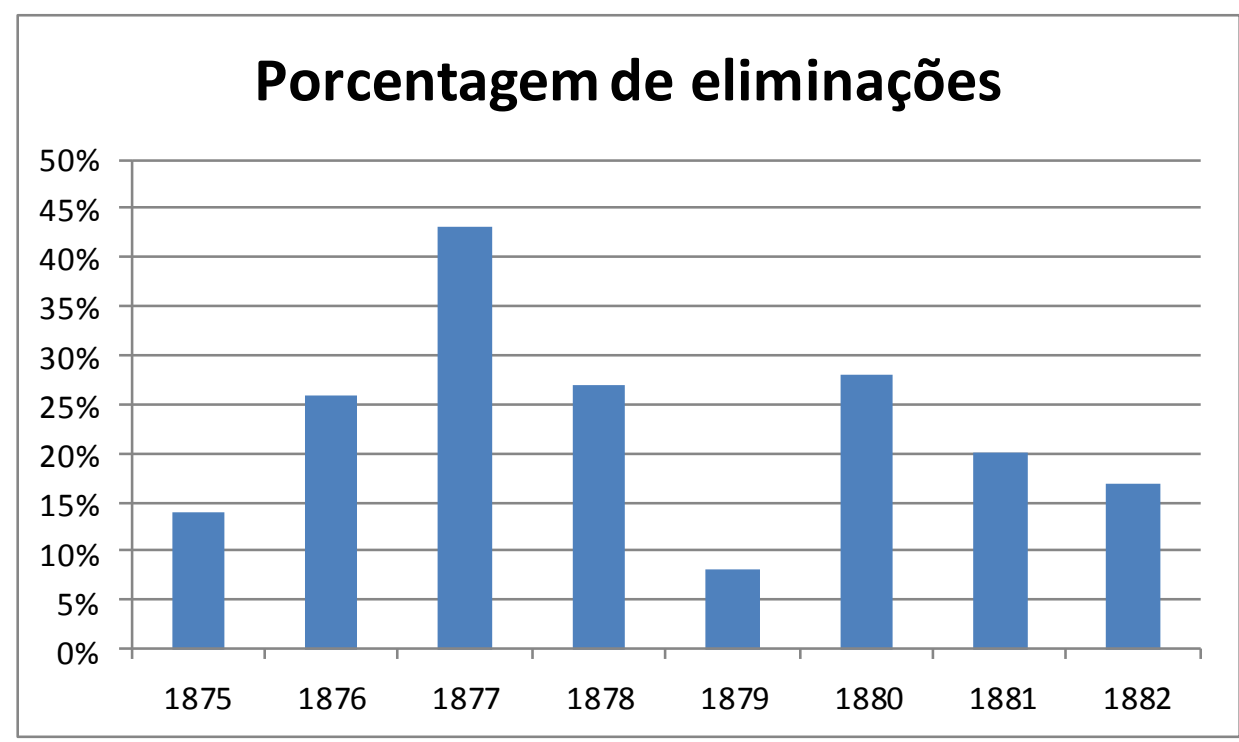

Quadro da porcentagem de eliminações da $2^{\mathrm{a}}$ Cadeira Masculina da Vila - 1875-1882 (Fonte: AESP, ref. EO2918).

Apêndice G:

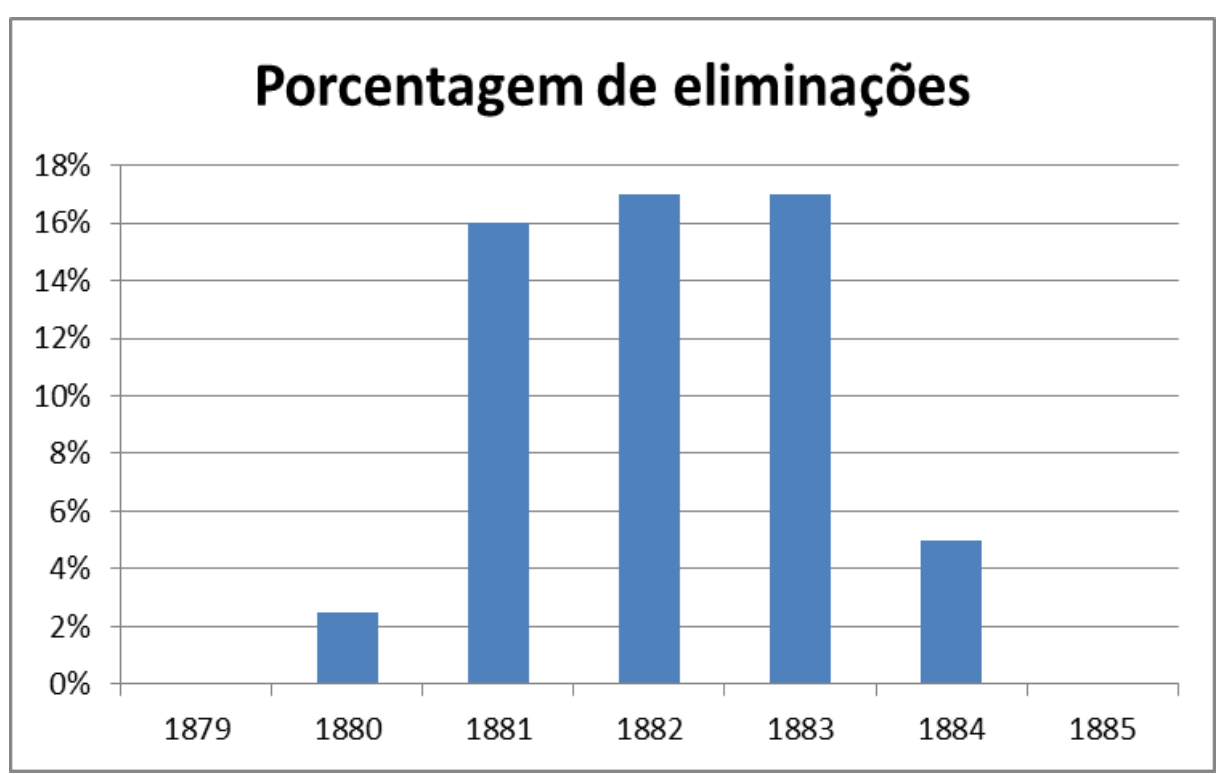

Quadro da porcentagem de eliminações da Cadeira de Capitão Jerônimo - 1879-1885 (Fonte: AESP, ref. EO3116). 